\title{
CARACTERIZAÇÃO PETROGENÉTICA DAS BORDAS NORÍTICAS E CHARNOQUITÓIDES DOS MACIÇOS DE VENDA NOVA E VÁRZEA ALEGRE-ES
}

\author{
Julio Cezar Mendes
}

Orientador: Prof. Dr. lan McReath

TESE DE DOUTORAMENTO

Programa de Pós-Graduação em Geoquímica e Geotectônica 


\title{
UNIVERSIDADE DE SÃO PAULO \\ INSTITUTO DE GEOCIENCIAS
}

\section{CARACTERIZAÇĀO PETROGENÉTICA DAS BORDAS NORÍTICAS E CHARNOQUITÓIDES DOS MACIÇOS DE VENDA NOVA E VÁRZEA ALEGRE-ES}

\author{
Julio Cezar Mendes
}

Orientador: Prof. Dr. lan McReath

TESE DE DOUTORAMENTO

COMISSÃO JULGADORA

nome

ass.

Presidente :

Examinadores:

\begin{tabular}{l} 
Ian McReath \\
Rômulo Machado \\
Valdecir de Assis Janasi \\
\hline Lauro Valentim Stoll Nardi \\
\hline Antonio Misson Godoy
\end{tabular}

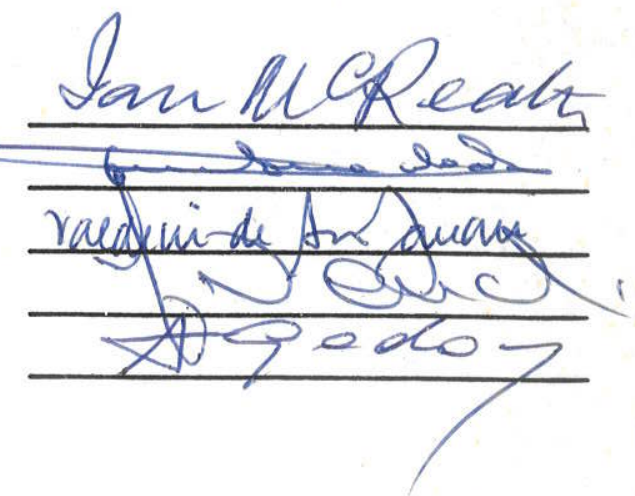




\section{UNIVERSIDADE DE SĀO PAULO \\ INSTITUTO DE GEOCIENCIAS}

\section{CARACTERIZAÇĀO PETROGENÉTICA DAS BORDAS NORÍTICAS E CHARNOQUITÓIDES DOS MACIÇOS DE VENDA NOVA E VÁRZEA ALEGRE-ES}

Julio Cezar Mendes

Orientador: Prof. Dr. lan McReath

TESE DE DOUTORAMENTO

Programa de Pós-Graduação em Geoquímica e Geotectônica

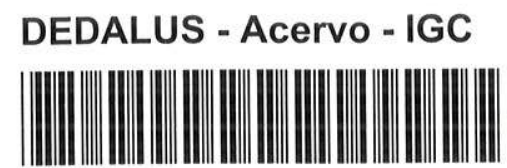

30900005200

SĀO PAULO

1996

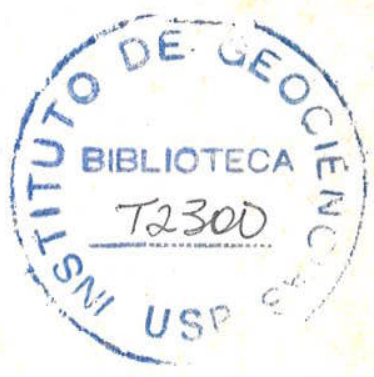




\section{INDICE DE TEMAS}

RESUMO XV

ABSTRACT XVIII

AGRADECIMEN'TOS XXI

\section{INTRODUÇÃO}

1.1 APRESENTAÇÃO E ENUNCIAÇÃO DO TEMA

1.2 LOCALIZAÇÃO E VIAS DE ACESSO

1.3 ASPECTOS FISIOGRÁFICOS DA REGIÃO 4

1.4 METODOLOGIA ADOTADA 5

- Procedimentos de campo 7

- Análises petrográficas 8

- Análises químicas de rochas

- Análises químicas de minerais

- Nomenclatura utilizada

2. A EVOLUÇÄO DO CONHECIMENTO DA GEOLOGIA REGIONAL

2.1 BREVE HISTÓRICO

2.2 ESTÁGIO ATUAL DAS PESQUISAS EM GEOLOGIA REGIONAL

3. GEOLOGIA LOCAL

3. 1. MACIÇO DE VENDA NOVA

- Trabalhos prévios 36

NORITOS E CHARNOQUITÓIDES DO MACIÇO DE VENDA NOVA 40

3.2 MACIÇO DE VÁRZEA ALEGRE 44

- Trabalhos prévios 44

CHARNOQUITÓIDES DA BORDA DO MACIÇO DE VÁRZEA ALEGRE 51

- Relações de contato 51

- Aspectos geológicos dos charnoquitóides 55 


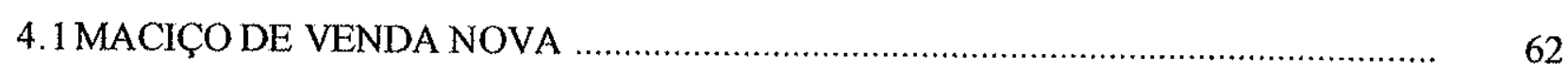

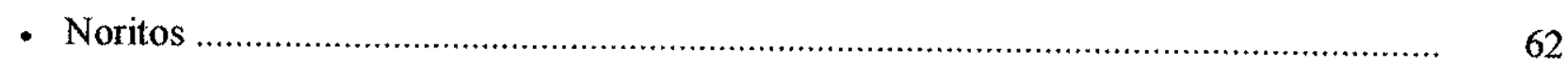

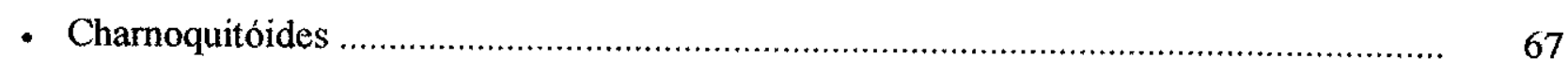

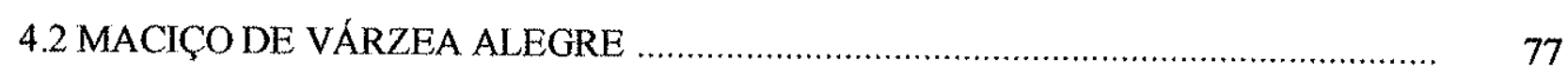

5. QUÍMICA DE ROCHAS …....................................................................... 88

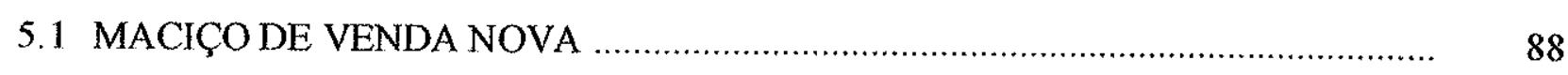

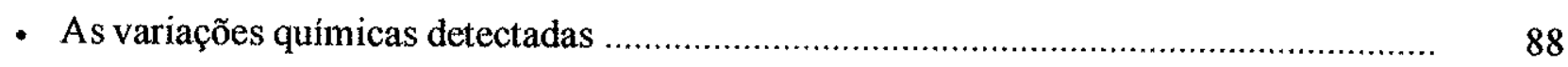

- Os diagramas de variação e suas possíveis correlações mineralógicas ........................... 96

- A caracterização do magmatismo …............................................................................ 100

- A classificação das rochas analisadas .................................................................... 103

- O comportamento dos elementos terras raras e os padrões de distribuição de elementos

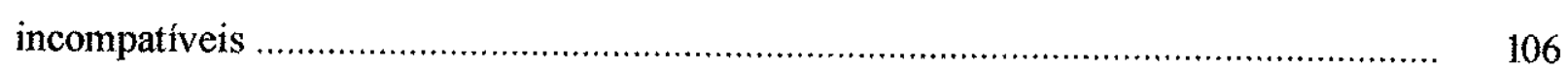

- Considerações sobre o ambiente tectônico a partir do quimismo das rochas .................. 109

5.2 MACIÇO DE VÁRZEA ALEGRE ........................................................................ 112

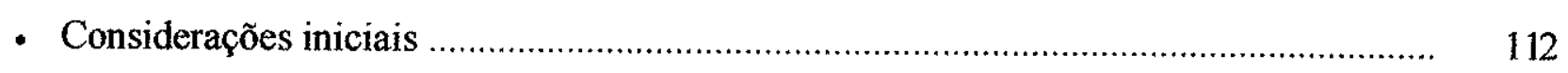

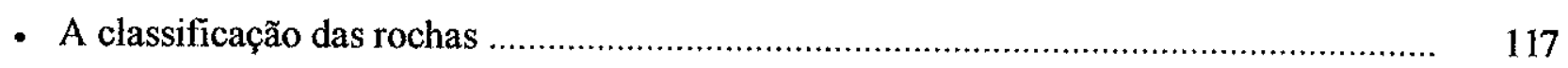

- O quimismo das rochas do domínio interno ….............................................................. 120

- As variações no quimismo das rochas charnoquitóides .............................................. 121

- O comportamento das rochas nos diagramas de variação ............................................. 123

- A caracterização do magmatismo ........................................................................... 127

- Os elementos terras raras e o padrão de distribuição dos elementos incompativeis

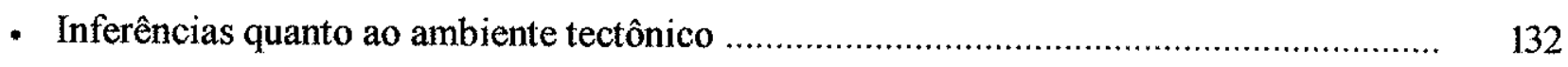

\section{QUIMICA MINERAL}

6.1 MACIÇO DE VENDA NOVA

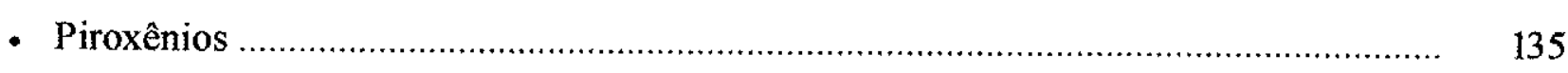

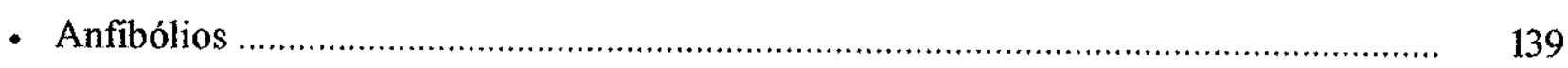

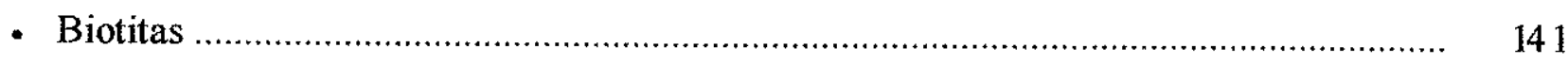

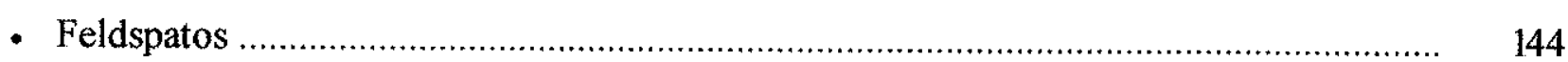


- Minerais Opacos ................................................................................................... 146

6.2 MACIÇO DE VÁRZEA ALEGRE ………............................................................ 161

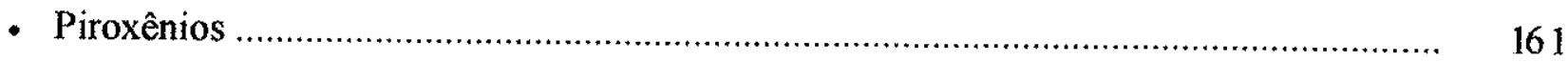

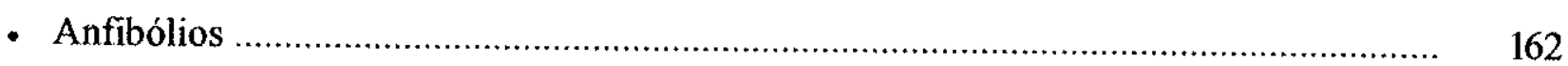

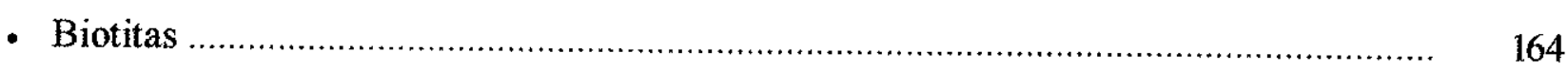

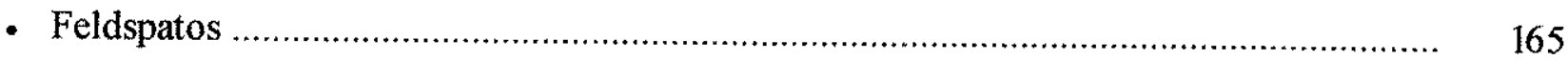

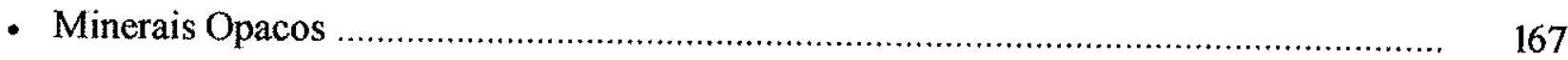

7. PETROGÊNESE dOS MACIÇOS DE VENDA NOVA E VÁRZEA ALEGRE ...... 179

7.1 MACIÇO DE VENDA NOVA ………………...................................................... 179

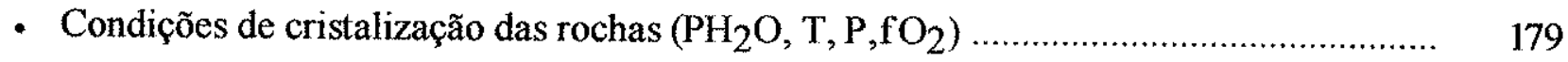

- Modelamentos geoquímicos e o estabelecimento do processo de diferenciação ............ 183

- A discussão a respeito do magma parental .................................................................. 191

7.2 MACIÇO DE VÁRZEA ALEGRE ........................................................................... 197

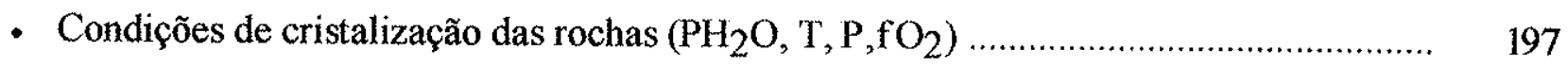

- Processos evolutivos e modelamentos geoquímicos ....................................................... 201

- Consideraç̃es a respeito do magma parental ............................................................... 216

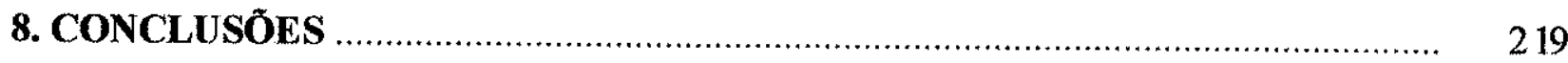

8.1 MACIÇO DE VENDA NOVA ............................................................................... 221

8.2 MACIÇO DE VÁRZEA ALEGRE ……................................................................. 225

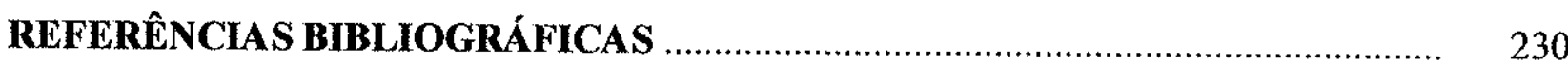

ANEXO 1 - MAPA DE PONTOS DO MACIÇO DE VÁRZEA ALEGRE ................... encarte 


\section{ÍNDICE DE FIGURAS}

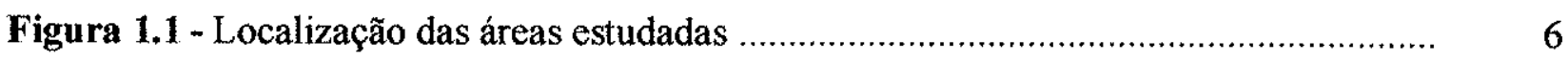

Figura 1.2 - Mapa de pontos do maciço intrusivo de Venda Nova .................................... $\quad 9$

Figura 2.1 - Mapa geológico do centro-sul do Espirito Santo ..................................... 31

Figura 3.1 - Mapa geológico do maciço intrusivo de Venda Nova ............................... 37

Figura 3.2 - Rocha enderbítica do ponto VN-13 cortada por diques e veios de sienomonzonito (em preto), que mostram relações de contato distintas, retilíneas e sinuosas (sin-intrusivos). Também ocorrem enclaves microgranulares básicos de formas irregulares (pontilhados)

Figura 3.3 - "Schlieren" de sienomonzonito no charnoquitóide do ponto VN-4. Observam-se xenocristais de feldspato isolados na matriz charnoquitóide

Figura 3.4 - Mapa geológico do maciço intrusivo de Várzea Alegre

Figura 3.5 - Charnoquitóide do ponto VA-298 exibindo o contato brusco entre um tipo textural onde predominam megacristais e outro no qual predomina a matriz

Figura 4.1 - Diagrama modal QAP para as rochas da borda do maciço de Venda Nova ....

Figura 4.2 - Diagrama modal Plagioclásio-OPX-CPX para as rochas gabróicas da borda do Maciço de Venda Nova

Figura 4.3 - Diagrama modal QAP para os charnoquitóides do maciço de Várzea Alegre

Figura 4.4 - Difratograma de feldspato alcalino do charnoquitóide de Várzea Alegre .......

Figura 5.1 - Diagramas de Harker para os noritos e charnoquitóides de Venda Nova

Figura 5.2 - Diagramas de variação $\mathrm{SiO}_{2} \times$ elementos traço para os noritos e charnoquitóides de Venda Nova

Figura 5.3 - Diagrama $\mathrm{SiO}_{2} \times \mathrm{Na}_{2} \mathrm{O}+\mathrm{K}_{2} \mathrm{O}$ para os noritos e charnoquitóides de Venda Nova

Figura 5.4 - Diagrama AFM para os noritos e charnoquitóides de Venda Nova

Figura 5.5 - Diagrama A/CNK x A/NK para as rochas da borda do maciço de Venda Nova 
Figura 5.6 - Diagrama B x A para as rochas da borda do maciço de Venda Nova

Figura 5.7 - Diagrama de Peacock mostrando o enriquecimento em cálcio nas rochas da borda do maciço de Venda Nova

Figura 5.8 - Diagrama Q x P para as rochas da borda do maciço de Venda Nova

Figura 5.9 - Diagrama $\mathrm{SiO}_{2} \times \mathrm{Na}_{2} \mathrm{O}+\mathrm{K}_{2} \mathrm{O}$ de Le Maitre (1989) para as rochas da borda do maciço de Venda Nova.

Figura 5.10 - Diagrama $\mathrm{Zr} / \mathrm{TiO}_{2} \times \mathrm{SiO}_{2}$ para as rochas da borda do maciço de Venda Nova

Figura 5.11 - Diagrama $\mathrm{SiO}_{2} \times \mathrm{Na}_{2} \mathrm{O}+\mathrm{K}_{2} \mathrm{O}$ de $\mathrm{Cox}$ et al. (1979) para as rochas da borda do maciço de Venda Nova.

Figura 5.12 - Diagrama QAP com a classificação mesonormativa de Le Maitre (1989) para as rochas da borda de Venda Nova

Figura 5.13 - Diagrama $\mathrm{Rb}$-Ba-Sr para as rochas da borda do maciço de Venda Nova

Figuras 5.14 e 5.15 - Padrões de elementos terras raras para as rochas da borda do maciço de Venda Nova.

Figura 5.16 - Diagramas de distribuição de elementos incompatíveis para os noritos da borda do maciço de Venda Nova

Figura 5.17 - Diagramas de distribuição de elementos incompatíveis para os charnoquitóides da borda do maciço de Venda Nova

Figura 5.18 - Diagrama $\mathrm{SiO}_{2} \times \log \left(\mathrm{CaO} / \mathrm{Na}_{2} \mathrm{O}+\mathrm{K}_{2} \mathrm{O}\right)$ para as rochas da borda do maciço de Venda Nova

Figura 5.19 - Diagrama R1 $\times$ R2 para as rochas da borda do maciço de Venda Nova

Figuras 5.20 e 5.21 - Diagramas $\mathrm{Y}+\mathrm{Nb}$ x Rb e $\mathrm{Y} \times \mathrm{Nb}$ de Pearce (1984) para as rochas da borda do maciço de Venda Nova

Figura 5.22- Diagrama $Q$ x $P$ para os charnoquitóides do maciço de Várzea Alegre .......

Figura 5.23 - Diagrama $\mathrm{SiO}_{2} \times \mathrm{Na}_{2} \mathrm{O}+\mathrm{K}_{2} \mathrm{O}$ de Le Maitre (1989) para os charnoquitóides do maciço de Várzea Alegre

Figura 5.24 - Diagrama $\mathrm{SiO}_{2} \times \mathrm{Na}_{2} \mathrm{O}+\mathrm{K}_{2} \mathrm{O}$ de Middlemost (1985) para os charnoquitóides do maciço de Várzea Alegre

Figura 5.25 - Diagrama $\mathrm{Zr} / \mathrm{TiO}_{2} \times \mathrm{SiO}_{2}$ para os charnoquitóides do maciço de Várzea Alegre 
Figura 5.26 - Diagrama $\mathrm{SiO}_{2} \times \mathrm{K}_{2} \mathrm{O}$ de $\mathrm{Cox}$ et al. (1979) para os charnoquitóides do maciço de Várzea Alegre

Figura 5.27 - Diagrama Q-A-P de Le Maitre (1989) para os charnoquitóides do maciço de Várzea Alegre

Figura 5.28 - Diagramas de Harker para os charnoquitóides do maciço de Várzea Alegre

Figura 5.29 - Diagramas $\mathrm{SiO}_{2} \times$ elementos traços para os charnoquitóides do maciço de Várzea Alegre

Figura 5.30 - Diagrama $\mathrm{SiO}_{2} \times \mathrm{Na}_{2} \mathrm{O}+\mathrm{K}_{2} \mathrm{O}$ para os charnoquitóides do maciço de Várzea Alegre

Figura 5.31 - Diagrama AFM para os charnoquitóides do maciço de Várzea Alegre

Figura 5.32- Diagrama $\mathrm{SiO}_{2} \times \mathrm{CaO}$ e $\mathrm{Na}_{2} \mathrm{O}+\mathrm{K}_{2} \mathrm{O}$ para os charnoquitóides do maciço de Várzea Alegre

Figura 5.33 - Diagrama $\mathrm{SiO}_{2} \times \log \left(\mathrm{CaO} / \mathrm{Na}_{2} \mathrm{O}+\mathrm{K}_{2} \mathrm{O}\right)$ para os charnoquitóides do maciço de Várzea Alegre

Figura 5.34 - Diagrama A/CNK x A/NK para os charnoquitóides do maciço de Várzea Alegre

Figura 5.35 - Padrões de elementos terras raras para os charnoquitóides do maciço de Várzea Alegre

Figura 5.36 - Padrões de elementos terras raras para amostras com composições extremas e intermediárias do maciço de Várzea Alegre

Figura 5.37 - Padrão de distribuição de elementos incompativeis para os charnoquitóides do maciço de Várzea Alegre

Figura 5.38 - Diagrama R 1 x R2 para os charnoquitóides do maciço de Várzea Alegre ....

Figuras 5.39 e 5.40 - Diagramas $\mathrm{Y}+\mathrm{Nb} \times \mathrm{Rb}$ e $\mathrm{Y} \times \mathrm{Nb}$ para os charnoquitóides do maciço de Várzea Alegre

Figura 6.1 - Diagrama $\mathrm{Al}_{2} \mathrm{O}_{3} \times \mathrm{MgO}+\mathrm{FeO}+\mathrm{Fe}_{2} \mathrm{O}_{3}$ com os campos para ortopiroxênios ígneos e metamórficos

Figura 6.2 - Diagrama Wo-En-Fs para as rochas da borda do maciço de Venda Nova

Figura 6.3 - Diagrama Wo-En-Fs com as "tie lines" para piroxênios coexistentes das rochas da borda do maciço de Venda Nova 
Figura 6.4 - Diagrama TSi x Mg/(Mg+Fe $\left.{ }^{+2}\right)$ de classificação de anfibólios cálcicos para as rochas da borda do maciço de Venda Nova

Figuras 6.5 e 6.6 - Diagramas onde estão correlacionados Al(total) x Aliv e Alvi para os anfibólios das rochas da borda do maciço de Venda Nova

Figuras 6.7 e 6.8 - Diagramas $\mathrm{Al}^{\mathrm{iv}} \times \mathrm{Al}^{\mathrm{i} \mathrm{i}} \mathrm{e}(\mathrm{Na}+\mathrm{K}) \mathrm{A} \times \mathrm{Al}$ iv para os anfibólios das rochas da borda do maciço de Venda Nova

Figura 6.9 - Variação composicional de flogopitas-biotitas para as rochas da borda do maciço de Venda Nova

Figuras 6.10 e 6.11 - Diagramas $\mathrm{Al}^{\mathrm{iv}} \times \mathrm{Ti} \mathrm{Al}^{\mathrm{iv}} \times \mathrm{Fe}^{+2}$ para biotitas das rochas da borda do maciço de Venda Nova

Figuras 6.12 e 6.13 - Diagramas $\mathrm{Mg} \times \mathrm{Cl}$ e Ti-Mg-Fe (prop. atômica) para biotitas das rochas da borda do maciço de Venda Nova

Figuras 6.14 e 6.15 - Diagramas Or-Ab-An exibindo as variações nas composições dos plagioclásios da matriz e megacristais/ microfenocristais, respectivamente, para os charnoquitóides e noritos do maciço de Venda Nova

Figura 6.16 - Diagrama Wo-En-Fs para os ortopiroxênios dos charnoquitóides de Várzea Alegre

Figura 6.17 - Diagrama $\mathrm{Al}_{2} \mathrm{O}_{3} \times \mathrm{MgO}+\mathrm{FeO}+\mathrm{Fe}_{2} \mathrm{O}_{3}$ para os ortopiroxênios dos charnoquitóides de Várzea Alegre

Figura 6.18 - Diagrama para classificação de anfibólios cálcicos (Leake, 1978 ) para os charnoquitóides de Várzea Alegre

Figuras 6.19 e 6.20 - Diagramas Altotal x Aliv e Alvi $x$ Aliv para os anfibólios dos charnoquitóides do maciço de Várzea Alegre

Figuras 6.21 e 6.22 - Diagramas $\mathrm{Al}^{\mathrm{iv}} \times \mathrm{Ti}$ e $(\mathrm{Na}+\mathrm{K}) \mathrm{A} \times \mathrm{Al}^{\mathrm{iv}}$ para os anfibólios dos charnoquitóides do maciço de Várzea Alegre

Figuras 6.23 e 6.24 - Diagramas $\mathrm{Fe} /(\mathrm{Fe}+\mathrm{Mg}) \times \mathrm{Aliv}$ e $\mathrm{Fe} 2 \times \mathrm{Ti}$ para as biotitas dos charnoquitóides de Várzea Alegre

Figuras 6.25 e 6.26 - Diagramas Alvi $x$ Ti e Alvi $x$ F para as biotitas dos charnoquitóides de Várzea Alegre

Figuras 6.27 e 6.28 - Composição dos plagioclásios da matriz e megacristais, respectivamente, dos charnoquitóides de Várzea Alegre 
Figuras 6.29 e 6.30 - Composição dos feldspatos alcalinos da matriz e megacristais, respectivamente, dos charnoquitóides de Várzea Alegre

Figura 7.1 - Diagramas $\log \left(\mathrm{K}_{2} \mathrm{O}\right) \times \log (\mathrm{V})$ e $\log (\mathrm{Zr}) \times \log (\mathrm{MgO})$ para os charnoquitóides de Venda Nova

Figura 7.2 - Padrões de elementos terras raras para o fracionamento da amostra VN-35 para a amostra $\mathrm{VN}-23$

Figura 7.3 - Padrões de elementos terras raras para o fracionamento da amostra VN-23 para a amostra $\mathrm{VN}-16$

Figura 7.4 - Padrões de elementos terras raras para o fracionamento da amostra VN-16 para a amostra $\mathrm{VN}-24$

Figura 7.5 - Padrões de elementos terras raras para o fracionamento da amostra VN-24 para a amostra VN-31

Figura 7.6 - Padrões de elementos terras raras para o fracionamento da amostra VN-24 para a amostra $\mathrm{VN}-27$

Figura 7.7 - Gráfico $\mathrm{M}(\mathrm{Na}+\mathrm{K}+2 \mathrm{Ca} / \mathrm{Si}$ x $\mathrm{Al})$ versus $\mathrm{Zr}$ para as rochas charnoquitóides do maciço de Várzea Alegre

Figura 7.8 - Gráfico $\mathrm{SiO}_{2} \times \mathrm{P}_{2} \mathrm{O}_{5}$ para as rochas charnoquitóides do maciço de Várzea Alegre

Figura 7.9 - Diagramas de variação que permitem a separação de dois grupos de rochas nos charnoquitóides da borda do Maciço de Várzea Alegre

Figura 7.10 - Padrões de elementos terras raras para o fracionamento da amostra VA261 para a amostra VA-56

Figura 7.11 - Padrões de elementos terras raras para o fracionamento da amostra VA- 56 para a amostra VA-249

Figura 7.12 - Padrões de elementos terras raras para o fracionamento da amostra VA249 para a amostra VA-252

Figura 7.13 - Padrões de elementos terras raras para o fracionamento da amostra VA252 para a amostra VA-42

Figura 7.14 - Padrões de elementos terras raras para o fracionamento da amostra VA261 para a amostra VA-253

Figura 7.15 - Padrões de elementos terras raras para o fracionamento da amostra VA-253 para a amostra VA-16. 


\section{ÍNDICE DE TABELAS}

Tabela 4.1 - Composição modal, a 1000 pontos, dos noritos do Maciço de Venda Nova ... 76

Tabela 4.2 - Composição modal, a 1000 pontos, dos charnoquitóides do Maciço de 76 Venda Nova

Tabela 4.3 - Composição modal das rochas do Maciço de Várzea Alegre

Tabela 5.1 - Análises químicas de elementos maiores, menores (\% em peso) e traço (em ppm) e parâmetros geoquímicos para os noritos da borda do Maciço de Venda Nova

Tabela 5.2 - Análises químicas de elementos maiores, menores (\% em peso) e traço (em ppm) e parâmetros geoquímicos para os charnoquitóides da borda do Maciço de Venda Nova.

Tabela 5.3 - Análises químicas de elementos terras raras (em ppm) para as rochas da borda do Maciço de Venda Nova.

Tabela 5.4 - Norma CIPW para os charnoquitóides do Maciço de Venda Nova

Tabela 5.5 - Análises químicas de elementos maiores, menores ( $\%$ em peso ) e traço ( em ppm ) e parâmetros geoquímicos para as rochas do Maciço de Várzea Alegre

Tabela 5.6 - Análises químicas de elementos terras raras (em ppm) das rochas do Maciço de Várzea Alegre

Tabela 5.7 - Norma CIPW para as rochas da borda do Maciço de Várzea Alegre

Tabela 6.1 - Análises químicas de ortopiroxênios das rochas da borda do Maciço de Venda Nova

Tabela 6.2 - Análises químicas de clinopiroxênios das rochas da borda do Maciço de Venda Nova

Tabela 6.3 - Análises químicas de anfibólios das rochas da borda do Maciço de Venda Nova

Tabela 6.4 - Análises químicas de biotitas das rochas da borda do Maciço de Venda Nova

Tabela 6.5 - Análises químicas de megacristais e microfenocristais de plagioclásio das rochas da borda do Maciço de Venda Nova 
Tabela 6.6 - Análises químicas de plagioclásios da matriz das rochas da borda do Maciço de Venda Nova

Tabela 6.7 - Análises químicas de feldspatos alcalinos das rochas da borda do Maciço de Venda Nova

Tabela 6.8 - Análises químicas de ilmenitas das rochas da borda do Maciço de Venda Nova

Tabela 6.9 - Análises químicas de magnetitas das rochas da borda do Maciço de Venda Nova

Tabela 6.10 - Análises químicas de ortopiroxênios das rochas charnoquitóides do Maciço de Várzea Alegre

Tabela 6.11 - Análises químicas de anfibólios das rochas charnoquitóides do Maciço de Várzea Alegre

Tabela 6.12 - Análises químicas de biotitas das rochas charnoquitóides do Maciço de Várzea Alegre

Tabela 6.13 - Análises químicas de megacristais de plagioclásio das rochas charnoquitóides do Maciço de Várzea Alegre

Tabela 6.14 - Análises químicas de plagioclásios da matriz das rochas charnoquitóides do Maciço de Várzea Alegre.

Tabela 6.15 - Análises químicas de megacristais de feldspato alcalino das rochas charnoquitóides do Maciço de Várzea Alegre

Tabela 6.16 - Análises químicas de feldspato alcalino da matriz das rochas charnoquitóides do Maciço de Várzea Alegre

Tabela 6.17 - Análises químicas de ilmenitas das rochas charnoquitóides do Maciço de Várzea Alegre

Tabela 6.18 - Análises químicas de magnetitas das rochas charnoquitóides do Maciço de Várzea Alegre

Tabela 7.1 - Temperaturas de équilibrio obtidas para pares de minerais dos noritos e charnoquitóides de Venda Nova

Tabela 7.2 - Determinações geobarométricas para anfibólios das rochas da borda do Maciço de Venda Nova 
Tabela 7. 3 - Composições químicas de rochas utilizadas nos modelamentos de fracionamento para elementos maiores, para os charnoquitóides do Maciço de Venda Nova

Tabela 7.4 - Composições químicas de minerais utilizados nos modelamentos de fracionamento para elementos maiores, para os charnoquitóides do Maciço de Venda Nova

Tabela 7.5 - Composição dos extratos obtidos no modelamento para elementos maiores para as rochas de Venda Nova

Tabela 7.6 - Proporção das fases extraídas no modelamento para elementos maiores para os charnoquitóides de Venda Nova

Tabela 7.7 - Coeficientes de partição (Kds) utilizados nos modelamentos para elementos terras raras e alguns outros traços

Tabela 7.8 - Resultados dos modelamentos para elementos terras raras e alguns outros traços para as rochas charnoquitóides do Maciço de Venda Nova, utilizando-se Kds para rochas básicas, intermediárias e félsicas

Tabela 7.9 - Determinações termobarométricas para os charnoquitóides do maciço de Várzea Alegre

Tabela 7.10 - Composições químicas de rochas utilizadas nos modelamentos de cristalização fracionada para rochas charnoquitóides do Maciço de Várzea Alegre

Tabela 7.11 - Composições químicas de minerais utilizados nos modelamentos de cristalização fracionada para rochas charnoquitóides do Maciço de Várzea Alegre

Tabela 7.12 - Composição dos extratos obtidos no modelamento para elementos maiores

Tabela 7.13 - Proporção das fases extraídas no modelamento para elementos maiores ....

Tabela 7.14 - Coeficientes de partição (Kds) utilizados nos modelamentos para elementos terras raras e alguns outros traços

Tabela 7.15 - Resultados dos modelamentos para elementos terras raras e alguns outros traços para as rochas charnoquitóides do Maciço de Várzea Alegre, utilizando-se Kds para rochas intermediárias e félsicas

Tabela 8.1 - Comparação entre as rochas da borda dos maciços de Venda Nova e Várzea Alegre 


\section{ÍNDICE DE FOTOGRAFIAS E FOTOMICROGRAFIAS}

Foto 3.1 - Contato entre o charnoquitóide e o quartzo-monzodiorito no ponto VA-74. Observa-se interdigitação entre os litotipos e xenocristais de feldspato no quartzomonzodiorito

Foto 3.2 - Contato brusco entre o charnoquitóide e o gnaisse encaixante no ponto VA-14. Os megacristais estão orientados e alguns deles truncam o contato

Foto 3.3 - Detalhe do contato entre o charnoquitóide e o quartzo-diorito. Nota-se uma forte interdigitação entre as rochas (assemelhando-se a uma estrutura gnáissica) e o desenvolvimento de pequenas dobras intrafoliais. Ponto VA-5

Foto 3.4 - A parte inferior da foto exibe a interdigitação entre o charnoquitóide e o quartzo-diorito do ponto VA-5, e na parte superior (onde está o martelo) a matriz diorítica contém xenocristais de feldspato

Foto 3.5 - Contato entre o charnoquitóide e o gabro do centro do maciço. Porções irregulares do charnoquitóide encontram-se em meio a rocha gabróica. Ponto VA-35 .......

Foto 3.6 - Xenólito de gnaisse kinzigítico, não assimilado, no charnoquitóide. Bloco explodido no ponto VA-242

Foto 3.7 - Dique de microdiorito sin-intrusivo cortando o charnoquitóide no ponto VA299. Destaque para shilieren de rocha charnoquitóide e xenocristais de feldspato na matriz diorítica

Foto 3.8 - Detalhe do contato entre xenólito de gnaisse e o charnoquitóide do ponto VA-289

Foto 3.9 - Contato entre o charnoquitóide de cor verde e uma pequena borda descharnoquitizada pela presença de veio pegmatóide. Bloco explodido no ponto VA-4 ...

Foto 3.10 - Restito de enclave xenolítico observado no ponto VA-274. Na parte inferior da foto tem-se material félsico segregado e concentração de granadas (canto esquerdo da foto). Há a formação de discreta zona de cisalhamento dúctil no charnoquitóide

Fotomicrografia 4.1 - Textura hipidiomórfica granular a localmente intergranular em norito. O campo vazado da escala mede $0,8 \mathrm{~mm}$. Nx. Amostra VN-11 
Fotomicrografia 4.2 - Microfenocristal de plagioclásio parcialmente corroído no norito.

$\mathrm{O}$ campo vazado da escala mede $0,8 \mathrm{~mm}$. Nx. Amostra VN-26

Fotomicrografia 4.3 - Estrutura de fluxo em norito. A orientação é conferida pelas ripas de plagioclásio e pelos cristais de hornblenda. O campo vazado da escala mede $0,8 \mathrm{~mm}$. Nx. Amostra VN-5

Fotomicrografia 4.4 - Cristal poiquilítico de hornblenda em norito. As inclusões são de plagioclásio, OPX, apatita e minerais opacos. O campo vazado da escala mede $0,8 \mathrm{~mm}$. Nx. Amostra VN-14

Fotomicrografia 4.5 - Textura inequigranular hipidiomórfica em charnoquitóide. $O$ campo vazado da escala mede $1,6 \mathrm{~mm}$. Nx. Amostra VN-23

Fotomicrografia 4.6 - Glomérulo máfico com apatita e minerais opacos em charnoquitóide. Piroxênios exsolvem opacos e são substituídos por hornblenda e biotita. O campo vazado da escala é de cerca de $1,6 \mathrm{~mm}$. N//. Amostra VN-18

Fotomicrografia 4.7 - Cristal de plagioclásio zonado contendo um grande número de minúsculas inclusões de vários minerais. O campo vazado da escala mede $0,8 \mathrm{~mm}$. Nx. Amostra VN-18

Fotomicrografia 4.8 - Cristal de plagioclásio com inúmeras inclusões prismáticas a arredondadas de uma fase incolor e com cor de interferência cinza (feldspato alcalino?). O campo vazado da escala mede $0,1 \mathrm{~mm}$. Nx. Amostra VN-15

Fotomicrografia 4.9 - Contato entre orto e clinopiroxênio, que estão exsolvendo minerais opacos e são substituídos por anfibólio e biotita. O campo vazado da escala mede $0,2 \mathrm{~mm}$. N//. Amostra VN-20

Fotomicrografia 4.10 - Intercrescimento entre magnetita e ilmenita com lamelas de exsolução de hematita, no charnoquitóide. O campo vazado da escala mede $0,1 \mathrm{~mm}$. Amostra VN-17

Fotomicrografia 4.11 - Detalhe textural do charnoquitóide, onde pode-se observar que a matriz é mais fina quando está apertada entre os megacristais, como também o contato bastante irregular (corroído) do megacristal de ortoclásio (a esquerda). O campo vazado da escala mede $2,5 \mathrm{~mm}$. Nx. Amostra VA-264

Fotomicrografia 4.12 - Megacristal de ortoclásio pertítico apresentando restos de plagioclásio xenomórfico no seu interior. O campo vazado da escala mede $1,25 \mathrm{~mm}$. Nx. Amostra VA-264 
Fotomicrografia 4.13 - Detalhe do contato entre megacristais de plagioclásio e quartzo xenomórfico. O plagioclásio exibe borda corroída por quartzo. O campo vazado da escala mede $0,8 \mathrm{~mm}$. Nx. Amostra VA-182

Fotomicrografia 4.14 - Ortopiroxênios muito alterados para material de cor ocre sendo substituídos por anfibólio e biotita, com exsolução de minerais opacos. O campo vazado da escala mede $0,63 \mathrm{~mm}$. N//. Amostra VA- 16

Fotomicrografia 4.15 - Cristais de ortopiroxênio aglutinados e intimamente associados a biotita e minerais opacos (que tanto estão exsolvidos quanto substituindo os OPX). $\mathrm{O}$ campo vazado da escala mede $1,0 \mathrm{~mm}$. N//. Amostra VA-182

Fotomicrografia 4.16 - Cristal de ilmenita sendo substituído por magnetita, que está bordẹ ando quase todo o grão de ilmenita. $O$ campo vazado da escala mede $0,1 \mathrm{~mm}$. Amostra VA-246 


\section{RESUMO}

Os maciços intrusivos de Venda Nova e Várzea Alegre localizam-se na região centro-sul do Estado do Espírito Santo e são representantes do magmatismo tardi a pós-tectônico associado ao desenvolvimento do arco magmático de idade Brasiliana nessa região. Ambos possuem forma circunscrita e são inversamente zonados; além disto, têm em comum uma auréola de rochas noríticas e charnoquitóides distintamente desenvolvida em cada um deles. A porção aflorante nos dois maciços corresponde a raiz dos plutons, e eles estão encaixados em gnaisses orto e paraderivados de grau metamórfico anfibolito a anfibolito alto (maciço de Venda Nova) e anfibolito alto a granulito (maciço de Várzea Alegre).

Na parte interna do maciço de Venda Nova encontram-se gabros e monzogabros que estão totalmente envolvidos por sienomonzonitos e monzonitos. Entre os gabros e os sienomonzonitos desenvolveu-se uma zona mista destes litotipos. Um estreito e irregular anel de rochas noríticas e charnoquitóides circunda todo o conj unto nos seus bordos oeste, sul e sudeste. Porções sieníticas irregulares localmente aparecem em meio ao domínio charnoquitóide.

São escassos os afloramentos dos noritos e dos charnoquitóides. Eles são rochas de estrutura maciça e homogênea, mas localmente a foliação de fluxo é mais desenvolvida. Nos charnoquitóides ocorrem discretas zonas de cisalhamento dúctil, associadas a penetração de veios e diques pegmatóides. Exibem também enclaves microgranulares básicos e veios máficos sin-intrusivos, possivelmente de noritos, o que comprova o seu posicionamento simultâneo.

Os noritos são rochas cumuláticas com granulação fina e textura que varia de hipidiomórfica granular a intergranular, sendo localmente microporfiríticos. A sua mineralogia é plagioclásio (An54 a An85), hornblenda, OPX, CPX, ilmenita, magnetita, apatita, zircão e rara biotita. $O$ anfibólio e a magnetita são predominantemente secundários. Os charnoquitóides são classificados em enderbitos, OPX-quartzo-dioritos, opdalitos e jotunitos. São rochas de granulação média, leucocráticas a mesocráticas e que possuem textura granular hipidiomórfica a porfirítica. Compõem-se de plagioclásio (An30 a An45), quartzo, biotita, OPX, CPX, hornblenda, feldspato alcalino, ilmenita, magnetita, pirita, apatita e zircão. Zoneamentos mais significativos foram detectados nos plagioclásios dos noritos. Texturas de desequilibrio mineral geradas em estado subsolidus foram identificadas nos noritos e nos charnoquitóides. Os piroxênios são substituídos por anfibólios e biotitas, exsolvendo minerais opacos, e magnetita substitui ilmenita e piroxênios. Observam-se feições de deformação incipiente no estado dúctil.

Os Mg\# dos minerais máficos dos noritos são inferiores aos dos charnoquitóides, ao contrário dos valores obtidos para as rochas, que mostram $\mathrm{Mg \#} \mathrm{na} \mathrm{mesma} \mathrm{ordem} \mathrm{de} \mathrm{grandeza}$ para as duas seqüências, apesar deles serem bem menores que os dos minerais. As "tie lines" traçadas para os piroxênios evidenciam cristalização em equilíbrio. As composicões dos anfibólios e das biotitas variam muito pouco, dificultando a identificação de possíveis cristais primários. Os KdsF e-Mg próximos de 1 indicam cristalização em equilíbrio para ambas as fases. 
A utilização do geotermômetro OPX-CPX forneceu temperaturas de equilíbrio da ordem de $920^{\circ} \mathrm{C}$ nos noritos e de $970^{\circ} \mathrm{C}$ nos charnoquitóides. As prováveis temperaturas de subsolidus, calculadas por meio do par ilmenita-magnetita, foram de cerca de $600^{\circ} \mathrm{C}$ e o valor da $\mathrm{fO}_{2}$ obtida indica um ambiente redutor na geração dessas rochas. As pressões estimadas para o final da cristalização das rochas se situam em torno de $5,5 \mathrm{a} 6 \mathrm{~Kb}$.

A química de rocha separa duas seqüências: uma básica, com características toleíticas, que corresponde aos cumulatos noríticos e outra intermediária, Ca-alcalina de médio $\mathrm{K}$, compreendendo os charnoquitóides. Diferem completamente do quimismo apresentado pelas rochas da porção interna do maciço de Venda Nova, que possem tendência alcalina.

As duas seqüências apresentam características químicas gerais similares: caráter metaluminoso, enriquecimento em $\mathrm{Ca}, \mathrm{Fe}$ e $\mathrm{Al}$ e valores moderados a baixos de elementos incompativeis, $\mathrm{Mg \#} \mathrm{com} \mathrm{a} \mathrm{mesma} \mathrm{ordem} \mathrm{de} \mathrm{grandeza} \mathrm{e} \mathrm{semelhança} \mathrm{nos} \mathrm{padrões} \mathrm{de} \mathrm{terras} \mathrm{raras.}$ Os "sp idergrams" das duas seqüências exibem anomalias negativas de elementos $\mathrm{HFS}(\mathrm{Nb}, \mathrm{P}$, Ti e $\mathrm{Zr}$ ), comprovando que a origem das rochas está associada a processos de subduccão, como indicam os diagramas de discriminação tectônica.

Os diagramas de variação mostram "trends" lineares para os charnoquitóides, que foram interpretados como refletindo uma evolução por cristalização fracionada a partir de um magma básico, em condições anidras e redutoras, e controlada por plagioclásio, OPX, CPX e ilmenita. Modelamentos efetuados indicam ser provável tal hipótese. Quanto aos noritos, parecem corresponder a cumulatos do mesmo magma parental que evoluiu para a sequência charnoquitóide, mas também podem estar vinculados a um magma basáltico de afinidade toleítica. Ambas as sequências tiveram significativa contribuição de um manto normal ou empobrecido, e granada deve ter sido fase residual quando da fusão mantélica, haja visto os teores de ETRP dos noritos e charnoquitóides.

O maciço de Várzea Alegre mostra no centro gabros que são envolvidos por dioritos/quartzo-dioritos-monzodioritos e granitos megaporfiríticos. Granito a titanita ocorre como um pequeno stock próximo dos gabros e também na forma de diques que cortam os demais litotipos. Todo este conjunto é circundado por uma extensa e irregular auréola de rochas charnoquitóides, que estão representadas num grande número de afloramentos. Enquanto nos bordos sul e oeste esse anel é estreito, a leste e a norte ele é largo e forma serras de cotas elevadas com amplos laj edos e encostas. Entre os granitos megaporfiríticos e os gabros/dioritos ocorre uma ampla zona mista onde são vistas estruturas em rede com feições típicas de mistura de magmas, além de litotipos com composições intermediárias.

Os charnoquitóides são rochas megaporfiríticas, de cor verde escura, que exibem foliação bem desenvolvida próximo aos contatos e uma estrutura maciça quando distante dos mesmos. Exibem algumas heterogeneidades tais como: variação na quantidade de megacristais, às vezes num mesmo afloramento; presença de diques de provável composição diorítica e de enclaves microgranulares básicos com ou sem xenocristais de feldspato; veios pegmatóides que 
provocam descharnoquitização localizada e xenólitos das rochas encaixantes variavelmente assimilados. Quando afloram, os contatos com os gnaisses são bruscos e paralelos à foliação, enquanto que com os litotipos do domínio interno eles são normalmente interdigitados.

A composição mineralógica dos charnoquitóides é: plagiclásio (An32 a An40), álcali-feldspato pertítico/mesopertita, OPX , biotita, hornblenda, ilmenita, magnetita, pirita, apatita, zircão e rara allanita. A textura é porfirítica, com megacristais de feldspato alcalino, plagioclásio e quartzo, que podem atingir até $6 \mathrm{~cm}$ de tamanho. A matriz tem granulação média a grossa e quando está apertada entre os megacristais é mais fina e parcialmente recristalizada. São observados efeitos de deformação incipiente no estado dúctil. Os cristais de OPX encontram-se parcialmente substituídos por biotita, anfibólio e minerais opacos e estão bem alterados. Biotitas e anfibólios primários podem ocorrer, mas a análise por microssonda não detectou variações nas suas composições. São observados cristais de feldspato alcalino substituindo plagioclásio e consideráveis variações nas concentrações de suas lamelas pertíticas. Os OPX são bem ricos em $\mathrm{Fe}$, mas possuem Mg\# superior aos das rochas que os contém, o que também foi constatado para os anfibólios e biotitas. As biotitas são ricas em Ti e Ba e o álcalifeldspato tem até $2,3 \% \mathrm{BaO}$.

Estimativas da temperatura de cristalização do magma através da saturação de $\mathrm{Zr}$ e $\mathrm{P}_{2} \mathrm{O}_{5}$ resultou em valores da ordem de $950^{\circ} \mathrm{C}$. As temperaturas de reequilibro subsolidus calculadas através dos termômetros ilmenita-magnetita e plagioclásio-feldspato alcalino deram próximas a $550^{\circ} \mathrm{C}$ para o primeiro par e de $630^{\circ} \mathrm{C}$ para os feldspatos. $\mathrm{A} \mathrm{fO}_{2}$ calculada através do par ilmenita-magnetita resulta em valores compativeis com um ambiente fortemente redutor, corroborado pelos baixos $\mathrm{Mg \#} \mathrm{das} \mathrm{rochas.} \mathrm{As} \mathrm{pressões} \mathrm{de} \mathrm{consolidação} \mathrm{estimadas} \mathrm{para} \mathrm{os}$ vários litotipos da borda do maciço de Várzea Alegre são de $6,5 \mathrm{a} 7 \mathrm{~Kb}$.

Os charnoquitóides de Várzea Alegre são quimicamente classificados em OPXquartzo-dioritos, opdalitos, jotunitos e quartzo-mangeritos. São rochas ricas em elementos incompatíveis, inclusive terras raras e elementos HFS, como $\mathrm{Zr}$ e Nb. Os padrões de ETR são bem fracionados e exibem discretas anomalias positivas de Eu. Possuem quimismo álcali-cálcico e no aranhograma apresentam anomalias negativas de Ti e P, comprovando origem associada a fenômenos de subducção.

Nos diagramas de variação convencionais pôde-se verificar uma possível acumulação de feldspatos em algumas amostras. Através de gráficos de elementos incompatíveis versus elementos compatíveis foram separados dois grupos de rochas com diferentes comportamentos: um evoluiu principalmente por cristalização fracionada de um magma intermediário e o outro por mistura de magmas, em condições anidras e num ambiente redutor; modelamentos geoquímicos indicam ser possível esta hipótese. A fusão parcial da crosta inferior, induzida por residência de um magma basáltico, deve ter possibilitado tal mistura de magmas. O magma básico provavelmente se formou pela fusão parcial de um manto previamente enriquecido em elementos incompatíveis, inclusive alguns HFS. 


\section{ABSTRACT}

The intrusive massifs of Venda Nova and Varzea Alegre are situated in the central-southern portion of the Espirito Santo State. They are examples of the late to posttectonic magmatic activity related to the development of the Brasiliano magmatic arc in this region. They constitute inversely zoned plutons with an almost circular shape. Both of these structures are surrounded by a distinctly developed ring of noritic and charnockitic rocks. The lithotypes that now outcrop in the massifs reveal the roots of the plutons. Their host rocks are ortho and paragneisses of amphibolite/high-amphibolite metamorphic grade (Venda Nova pluton) and high-amphibolite/granulite metamorphic grade (Várzea Alegre pluton).

The inner part of the Venda Nova massif comprises gabbros and monzogabbros completely surrounded by syenomonzonites and monzonites. An irregular and narrow ring of charnockites and norites involves these rocks in the west, south and southeast borders of the massif. Gabbros and syenomonzonites interfinger in a mixing zone. Locally small and irregulars syenitic schlieren occur in the charnockitic types.

The norites and charnockites rarely crop out. They have an homogeneous and massive structure, and the foliation is only locally well marked. Small ductile shear zones are observed in the charnockites, associated with the intrusion of pegmatitic veins and dykes. The presence of basic microgranular enclaves as well as mafic, probably noritic, syn-intrusive veins in this lithology is proof of their simultaneous emplacement.

The norites are fine grained cumulatic rocks with granular hypidiomorphic to intergranular texture. They are locally microporphyritic. Their mineralogical composition is plagioclase (An54 to An85), hornblende, OPX, CPX, ilmenite, magnetite, apatite, zircon and scarce biotite. The amphibole and the magnetite are predominantly of secondary origin. The charnockites comprise enderbites, OPX-quartz-diorites, opdalites and jotunites. They are medium grained and leucocratic to mesocratic rocks, with granular hypidiomorphic to porphyritic texture. Their mineralogy is plagioclase (An30 to An45), quartz, biotite, OPX, CPX, hornblende, alkali feldspar, ilmenite, magnetite, pyrite, apatite and zircon. Zoned plagioclases are mainly observed in the norites. Textures of subsolidus mineral disequilibrium occur in the charnockites and norites. The pyroxenes are replaced by amphiboles and biotites, with exsolution of opaque minerals, and the magnetite replaces ilmenite and pyroxenes. Features of weak ductile deformation are observed.

The $\mathrm{Mg} /(\mathrm{Mg}+\mathrm{Fe})$ ratios of the mafic minerals of the norites are lower than those of the charnockites. In the rocks, these ratios are similar for the norites and charnockites, and lower than in the minerals. The tie lines of coexisting pyroxenes indicate crystallization in equilibrium. The chemistry composition of the amphiboles and biotites are almost constant and their $\mathrm{KdFe}-\mathrm{Mg}$ are close to 1,0 , pointing to equilibrium crystallization. The pyroxene geotermometers yielded temperatures of approximately $920^{\circ} \mathrm{C}$ for the norites and $970^{\circ} \mathrm{C}$ for the 
charnockites. Subsolidus temperatures of near $600^{\circ} \mathrm{C}$ were obtained using the pair ilmenitemagnetite. The low values of $\mathrm{fO}_{2}$ indicate reducing conditions during the formation of these rocks. The pressures estimated for their crystallization range from 5,5 to $6 \mathrm{~Kb}$.

The whole rock chemistry separates two different sequences: a basic one, with tholeiitic affinities corresponding to the noritic cumulates, and an intermediary one, medium $\mathrm{K}$ calc-alkalic comprising the charnockites. They show clearly different chemistry signatures when compared to the rocks of alkaline affinity of the inner domain of the pluton.

Both the sequences have similar geochemical characteristics: they are metaluminous, enriched in $\mathrm{Ca}, \mathrm{Fe}$ and $\mathrm{Al}$, and have low to moderate contents of incompatible elements. The $\mathrm{Mg} /(\mathrm{Mg}+\mathrm{Fe})$ ratios are so close and the REE patterns are similar. Negative anomalies of HFS elements in the spidergrams point to an origin related to subduction process, as indicated by the tectonic discriminant diagrams used.

In the charnockitic sequence the variation diagrams exhibits linear trends. These trends are interpreted as resulting from fractional crystallization of a basic magma controled by plagioclase, OPX, CPX and ilmenite, under anydrous and reducing conditions. Geochemistry modelling confirms such hypothesis. The norites may be cumulates from the same parental magma that evolved towards the charnockitic sequence. Nevertheless, they might also be associated to a tholeitic basaltic magma. An expressive contribution of normal or depleted mantle is inferred for both sequences, and garnet probably were residual phase during mantle partial melting, indicated by the low contents of HREE.

The Várzea Alegre massif has at its center gabbros completely sourrounded by diorites/quartz-diorites-monzodiorites and megaporphyritic granites. A finer-grained titanite granite occurs as a stock close to the gabbros and as dykes cutting all the lithotypes. All these rocks are involved by a large and irregular ring of charnockitic rocks, which crop out extensively. While in the south and west borders of the massif such ring is narrow, in the east and north borders it is very broad. A mixed zone marked by the presence of net veined structures with typical magma mixing features as well as the presence of hybrid rocks highlights the contact between the megaporphyritic granites and the gabbros/diorites.

The charnockites are dark green megaporphyritic rocks. They show a well developed foliation close to the contacts and a massive structure away from them. They also show some heterogeneities, like: variable amount of megacrysts, sometimes in the same outcrop; dykes of probable dioritic composition and basic microgranular enclaves with or without feldspar xenocrysts; pegmatitic veins that cause decharnockitization and xenoliths of gneisses variably assimilated. The contacts with the enclosed rocks are sharp and parallel to the foliation, and with the rocks of the inner domain they are generally interfingered.

The mineralogycal composition of the charnockites is: plagiclase (An32 a An40), perthitic alkali feldspar/mesoperthite, OPX, biotite, hornblende, ilmenite, magnetite, pyrite, apatite, zircon and rare allanite. The texture is porphyritic with megacrysts of alkali feldspar, 
plagioclase and quartz. The matrix is medium to coarse grained and it may be finer-grained when compressed and partially recrystalized among the megacrysts. The OPX are partly replaced by biotite, amphibole and opaque minerals. Primary biotites and amphiboles may also occur, but the microprobe analysis didn't detect variations in the compositions of these minerals. Alkali felsdspar replaces plagioclase and the concentration of the perthitic lamella is very variable. The composition of the OPX presents discrete variation. The mafic minerals are Fe rich and they have higher $\mathrm{Mg} /(\mathrm{Mg}+\mathrm{Fe})$ ratios than the rocks. The biotites are rich in $\mathrm{Ba}$ and the alkali feldspar has up to $4,2 \%$ of the celsian component.

The $\mathrm{Zr}$ and $\mathrm{P}_{2} \mathrm{O}_{5}$ saturation level indicates crystallizations temperatures of about $950^{\circ} \mathrm{C}$. The subsolidus temperatures obtained for the pairs ilmenite-magnetite and plagioclasealkali feldspar were close to $550^{\circ} \mathrm{C}$ and $630^{\circ} \mathrm{C}$ respectively. The values calculated for the $\mathrm{fO}_{2}$ are consistent with highly reducing conditions, which is confirmed by the low $\mathrm{Mg} /(\mathrm{Mg}+\mathrm{Fe})$ ratios of the rocks. Estimates of the pressure of crystallization range from 6,5 to $7 \mathrm{~Kb}$.

The charnockitic rocks of the Várzea Alegre massif have the following chemical classification: OPX-quartz-diorites, opdalites, jotunites and quartz-mangerites. They are rich in incompatible elements, including REE and HFS elementes, such as $\mathrm{Zr}$ and $\mathrm{Nb}$. The REE patterns are fracionated and show small positive Eu anomalies. The chemical signature of the rocks is alkali-calcic, and in the spidergrams they present negative Ti and $\mathrm{P}$ anomalies, revealing an origin related to subduction process.

A possible acumulation of feldspars in some samples was inferred from the variation diagrams. Two groups of rocks were geochemically separated by means of incompatible versus compatible elements diagrams. One of these groups evolved mainly by fractional crystallization of a intermediate magma and the other one by magma mixing under anydrous and reducing conditions. Geochemical modelling confirmes this hypothesis. The mixing probably ocurred after the partial melting of the lower crust, induced by underplating of a basaltic magma. The formation of such basic magma is probably related to partial melting of a previously enriched mantle source, including the HFS elements. 


\section{AGRADECIMENTOS}

A finalização desta tese só foi possível devido ao irrestrito apoio recebido de Bernadete, que me poupou ao máximo da função de pai e assumiu quase integralmente nossos filhos. A eles devo grande parte do estímulo e dedicação necessários nesta empreitada.

Aos meus pais e irmãos agradeço pelo apoio recebido. Em especial agradeço a Ana Mendes, que me acolheu em São Paulo e teve participação essencial na edição e artefinalização deste trabalho.

A Ian McReath por ter me aceito como orientando já na etapa final, com preciosas idéias e sugestões.

A Cristina Wiedemann pelo incentivo constante, pelas discussões e sugestões e pelas palavras que serviram para levantar o astral em momentos importantes.

A Isabel Ludka (que assumiu minhas funções quando necessário) e Silvia Medeiros pelas discussões e sugestões e companheirismo constante, inclusive nas etapas de campo.

A Ariadne Fonseca pelas proveitosas discussões e incentivo.

A Valdecir Janasi pelas sugestões e colaboração em vários momentos. A Rômulo Machado pelas sugestões bem aproveitadas.

A Cristopher Töpfner pelas análises por XRF em Munique e ao Marcos pela aj uda nas análises por microssonda. A Luis Ferro pelos cuidadosos desenhos e ao Tarcísio pela confecção das lâminas delgadas.

A Cláudia Valladares, Beatriz Duarte, Ismar Carvalho, Diana Ragakti e Gorki Mariano pela amizade e interesse constantes.

A participação de várias instituições foi de essencial importância neste trabalho: primeiramente, o Departamento de Geologia da UFRJ pelo uso das instalações e liberação, quando foi necessário, para dedicar-me à tese; ao Instituto de Geociências da USP pela infraestrutura institucional; ao $\mathrm{CNPq}$ pela concessão de bolsa de estudos; a FINEP pelo financiamento às pesquisas deste trabalho, através do convênio PADCT/UFRJ n ${ }^{\circ}$ 65.91.0304.00; às unversidades de Munique e Utrecht (por intermédio de Cristina Wiedemann) e a CPRM pelas análises químicas de rocha.

Finalmente, deixo registrada a minha homenagem e meus agradecimentos a Mário Figueiredo, que tão precocemente nos deixou. 


\section{CAPítulo 1 \\ INTRODUÇÃO}

\subsection{APRESENTAÇÃO E ENUNCIAÇÃO DO TEMA}

A presente tese está inserida em um projeto de pesquisa bem consolidado, desenvolvido por pesquisadores do Departamento de Geologia da Universidade Federal do Rio de Janeiro há cerca de 16 anos, sob a coordenação da Prof ${ }^{\mathfrak{a}}$ Dra $^{\mathfrak{a}}$ Cristina Wiedemann. Durante muitos anos foi realizado em convênio com a Universidade de Munique, Alemanha, resultando em vários trabalhos de graduação e teses de mestrado e doutorado defendidas tanto naquela universidade quanto na UFRJ. Atualmente, tal parceria científica é celebrada com a Universidade de Utrech, na Holanda.

A referida linha de pesquisa tem como enfoque o estudo da geologia do centro-sul do Estado do Espírito Santo, especialmente dos diversos corpos intrusivos de posicionamento sin a pós tectônicos. Esses apresentam grandes variações composicionais (sienomonzonitos a gabros, com toda a sorte de composições intermediárias), químicas (alcalinas a toleíticas) e de estruturação interna (zonação inversa, camadas sub-horizontais a verticais, estruturas de fluxo monótonas a caóticas e turbulentas, enxame de enclaves localizados e meso a mega estruturas em rede, delimitando zonas mistas mapeáveis, mega xenólitos/roof pendants, etc).

Ao longo da Faixa Ribeira (Cordani, 1971; Almeida et al., 1973) podem ser identificadas rochas de fácies granulito dentro de, pelo menos, três diferentes contextos geológicos: o primeiro, onde tais tipos rochosos são encontrados em maior abundância, corresponde a faixas alongadas (com até mais de $250 \mathrm{Km}$ e larguras variáveis) de rochas metamórficas de alto grau, representadas por granulitos deformados associados a gnaisses e migmatitos; a segunda ocorrência se dá na forma de granitóides intrusivos com hiperstênio (charnoquitóides), comumente pouco deformados e/ou recristalizados; o último tipo aparece como intercalações, na forma de lentes, pequenas camadas ou bolsões, de rochas charnoquíticas em gnaisses, migmatitos ou anfibolitos da estruturação regional. Na presente tese as rochas estudadas são relacionadas ao segundo tipo descrito.

O tema desenvolvido nesta tese foi idealizado a partir da constatação de que havia uma carência de conhecimento mais detalhado das rochas charnoquitóides que ocorrem como domínio externo de alguns maciços intrusivos da região. Em mapa elas têm forma de um anel, 
que pode estar mais ou menos desenvolvido, circundando grande parte do domínio interno do maciço (e.g. Maciço de Várzea Alegre) ou uma porção restrita do mesmo (e.g. Maciço de Venda Nova). Adicionalmente a estes dois corpos, rochas de composição similar aflorando como envoltório externo são também encontradas nos maciços de Ibituba, Itapina, Aimorés e Lagoa Preta (Tuller, 1993; Vieira, 1993) e no de Conceição de Muqui (Wiedemann, comunicação pessoal).

Os maciços de Várzea Alegre e Venda Nova foram escolhidos como áreas de estudo porque $\mathrm{j} a$ a haviam sido feitos trabalhos de detalhe nos seus domínios internos (Medeiros, 1993 e Tuller, op.cit.; Petrick, 1987) e porque o domínio externo de Várzea Alegre é abordado superficialmente em Tuller (op. cit.) e o de Venda Nova é tema do trabalho de graduação de Töpfner (1987). Além disto, são áreas de fácil acesso e próximas a locais de razoável infraestrutura. Sendo assim, optou-se por não se mapear em detalhe essas bordas dos corpos intrusivos e sim checar as informações dos mapas existentes e fazer as mudanças que porventura seriam observadas durante as etapas de campo.

Com o intuito de justificar e facilitar o desenvolvimento do tema, algumas questões primordiais foram levantadas antes e no início dos trabalhos. Dentre elas, podemos destacar: -teriam as rochas dos domínios externos contatos nitidamente intrusivos? -qual o seu grau de deformação (i.e., teriam foliação gnáissica ou a textura ígnea preservada) e qual as relações de contato com os litotipos do domínio interno? -regime tectônico dominante quando do seu posicionamento? -e quanto à variação composicional, seria ela similar à encontrada nos litotipos internos, apesar de tratar-se de seqüências cristalizadas sob diferentes razões $\mathrm{P}_{\mathrm{H} 2 \mathrm{O}} \mathrm{P} \mathrm{PO}_{2}$ ? -e sua afinidade geoquímica, seria correlacionável ao do domínio interno ou teriam um quimismo diferenciado? Com o avanço das pesquisas outras dúvidas foram surgindo. $\mathrm{Na}$ medida do possível, esta tese tem a resposta para várias questões, mas muitas outras foram deixadas de lado, e ficarão em aberto, em função da falta de dados ou porque um maior aprofundamento iria ampliar sobremaneira os objetivos propostos e inviabilizaria o término dentro do prazo institucional.

Finalmente, dentro das limitações para o desenvolvimento da tese (dificuldades de verba, atividades profissionais paralelas e prazo de entrega) optou-se por fazer uma caracterização petrogenética dos corpos charnoquitóides/noríticos, com uma descrição sucinta da geologia e detalhando sua petrografia, química de rochas e de minerais. Com estas ferramentas foi possível tecer considerações petrológicas/genéticas e sugerir prováveis mecanismos para a 
diversificação litológica encontrada nas bordas dos dois corpos intrusivos, além de se determinar valores teóricos para as temperaturas de cristalização de algumas fases minerais encontradas.

No anel externo do maciço de Venda Nova pôde-se separar facilmente, através de um mapeamento litofaciológico, duas seqüências bem distintas: uma gabróica e outra charnoquitóide. Os litofácies que estão delimitados no mapa geológico foram determinados com o auxílio dos dados petrográficos. Por outro lado, não foi possível separar em mapa geológico as variações composicionais dos charnoquitóides de Várzea Alegre, por se tratarem de rochas megaporfiríticas que aparentam grande homogeneidade nos afloramentos e com classificação petrográfica por vezes não coerente com os dados da química de rochas.

\subsection{LOCALIZAÇÃO E VIAS dE ACESSO}

As áreas aqui enfocadas situam-se no centro-sul do Estado do Espírito Santo, estando compreendidas entre os paralelos $19^{\circ} 49^{\prime} 38^{\prime \prime}$ e $20^{\circ} 20^{\prime}$ de latitude sul e os meridianos $41^{\circ} 14^{\prime}$ e $40^{\circ} 45^{\prime} 24^{\prime \prime}$ de longitude oeste (cf. Figura 1.1). O Maciço Intrusivo de Venda Nova, com cerca de $80 \mathrm{Km}^{2}$ (o anel externo não possui mais do que $10 \mathrm{Km}^{2}$ de área), está localizado mais ao sul do Estado, em sua maior parte dentro dos municípios de Venda Nova do Imigrante e Conceição de Castelo, e uma menor porção no município de Afonso Cláudio. Geograficamente, está posicionado entre os paralelos $20^{\circ} 15^{\prime} 37^{\prime \prime}$ e $20^{\circ} 20^{\prime}$ de latitude sul e os meridianos $41^{\circ} 14^{\prime}$ e $41^{\circ} 08^{\prime} 40^{\prime \prime}$ de longitude oeste. O Maciço Intrusivo de Várzea Alegre situa-se mais ao norte, entre os paralelos $19^{\circ} 49^{\prime} 38^{\prime \prime}$ e $19^{\circ} 55^{\prime} 03^{\prime \prime}$ de latitude sul e os meridianos $40^{\circ} 50^{\prime} 37^{\prime \prime}$ e $40^{\circ} 45^{\prime} 24^{\prime \prime}$ de longitude oeste. Abrange uma área de aproximadamente $140 \mathrm{Km}^{2}$ nos municípios de Itarana, Itaguaçu e Santa Teresa. $O$ anel externo do maciço tem aproximadamente $70 \mathrm{Km}^{2}$.

A cidade de Venda Nova do Imigrante está a 102 quilômetros de Vitória e a 460 quilômetros do Rio de Janeiro. Partindo-se desta última cidade, o acesso é feito pela rodovia BR101 até o município de Cachoeiro de Itapemirim, de onde se chega a Venda Nova pela estrada estadual ES-166. Através da BR-262 e da ES-165 e de acessos secundários chega-se ao anel externo do maciço.

Os principais acessos ao maciço de Várzea Alegre correspondem a estradas secundárias dos municípios de Itarana e Itaguaçu e do distrito de Praça Oito. Para se chegar nestas cidades deve-se seguir pela rodovia BR-101 até o município de Fundão, 58 quilômetros acima de Vitória, e daí continuar pela estrada estadual ES-259 de onde se alcança as localidades 
de Santa Teresa, Itarana e finalmente Itaguaçu. Elas estão a aproximadamente 142 quilômetros de Vitória e 660 quilômetros do Rio de Janeiro.

\subsection{ASPECTOS FISIOGRÁ FICOS DA REGIÃO}

A região estudada caracteriza-se por um relevo montanhoso que faz parte de um sistema maior definido como Mantiqueira Setentrional (Proj eto Radambrasil, 1983). O sistema Mantiqueira representa o relevo de maior importância do sudeste brasileiro, estendendo-se desde São Paulo até o vale do rio Doce, no centro do Espírito Santo.

A área nas proximidades do maciço de Venda Nova está inserida geomorfologicamente na Unidade do Planalto (Signorelli, 1993). Caracteriza-se por cotas elevadas, entre 800 e 1000 metros em média, sem cursos fluviais de grande porte e com drenagens de baixo gradiente. Exceção são os maciços intrusivos de Venda Nova, Pedra Azul e Castelo, bastante próximos entre si. No maciço de Venda Nova ocorre entre a porção externa (noritos/enderbitos) e o centro gabróico, arrasado, uma grande extensão de altas montanhas de sienomonzonitos/monzosienitos com drenagens mais abundantes e de maior gradiente. Contrastando com tal morfologia, tem-se os morrotes de paragnaisses e as altas cadeias montanhosas dos ortognaisses encaixantes. Nas unidades de rochas intrusivas observa-se variações de relevo, com quedas bruscas e vales encaixados.

A vegetação predominante corresponde a gramíneas e pinus, encontrando-se localmente matas de maior porte (tipo floresta latifoliada tropical), algumas nativas, como é o caso do Parque Estadual de Pedra Azul, distante cerca de $15 \mathrm{Km}$ de Venda Nova. A cultura intensiva de hortifrutigranj eiros e de café está gradativamente substituindo o que ainda resta de floresta. O clima é do tipo tropical úmido; temperado nas cotas mais elevadas. Via de regra o verão é a estação chuvosa (com maior índice nas maiores altitudes) e tem-se uma estação seca de maio a outubro.

Na região central do Estado do Espírito Santo, onde está localizado o maciço de Várzea Alegre, observa-se a predominância de um relevo aplainado, com forte ação erosiva, dando lugar a formas abauladas, com altitudes variando de 250 a 450 metros. Em meio a tal morfologia encontram-se vários maciços intrusivos (e.g. Várzea Alegre, Itapina e Ibituba) que possuem picos que atingem por vezes mais de 1000 metros, com desníveis acentuados, vales profundos, uma profusão de afloramentos rochosos e drenagens de maior gradiente. 
Algumas áreas se destacam por altiplanos cuja as cotas oscilam entre 900 e 1000 metros, mostrando drenagens alongadas e de baixo gradiente. Isto ocorre na região ao norte do maciço de Várzea Alegre (Alto Santa Julia), a noroeste de Itaguaçu, junto ao corpo de Ibituba (Alto Lage) e na região de Santa Teresa (Tuller, 1993). Uma grande queda de relevo pode ser observada quando se vai de Santa Teresa para Itarana.

O clima na região é tropical, com estações de seca (entre maio e outubro) e de chuva (novembro a abril) bem definidas. A temperatura chega a $40^{\circ} \mathrm{C}$ no verão e $20^{\circ} \mathrm{C}$ no inverno, com exceção dos lugares mais altos, onde no inverno a temperatura pode vir a menos de $10^{\circ} \mathrm{C}$. A vegetação já está muito devastada, com amplas áreas de pastagem para gado ou utilizadas para agricultura, delineando em alguns locais uma paisagem do tipo caatinga. Pode-se encontrar florestas preservadas apenas nas áreas mais elevadas, como na Reserva Biológica de Nova Lombardia, em Santa Teresa. A produção de hortigranjeiros é bem desenvolvida, principalmente em Santa Maria do Jetibá (sudeste da intrusão de Várzea Alegre) e em Várzea Alegre, distrito situado numa planície de aluvião no centro do corpo intrusivo. A rede hidrográfica é bastante vasta, formada por afluentes e subafluentes do rio Doce, tais como os rios Santa Maria, Santa Joana, Santa Julia e Perdido.

\subsection{METODOLOGIA ADOTADA}

Os trabalhos tiveram início com um levantamento geral sobre o que havia disponível em relação a mapas e à geologia das áreas escolhidas. Da parte externa do maciço de Venda Nova, as informações foram encontradas no trabalho de Töpfner (op. cit.) e no mapa geológico do plúton elaborado por ele e três colaboradores. Do anel externo do maciço de Várzea Alegre, um esboço da geologia e escassos dados químicos foram encontrados no relatório preliminar do Programa Levantamentos Geológicos Básicos do Brasil (PLGBB), da CPRM, e na prévia da dissertação de mestrado de Medeiros (op. cit.). 


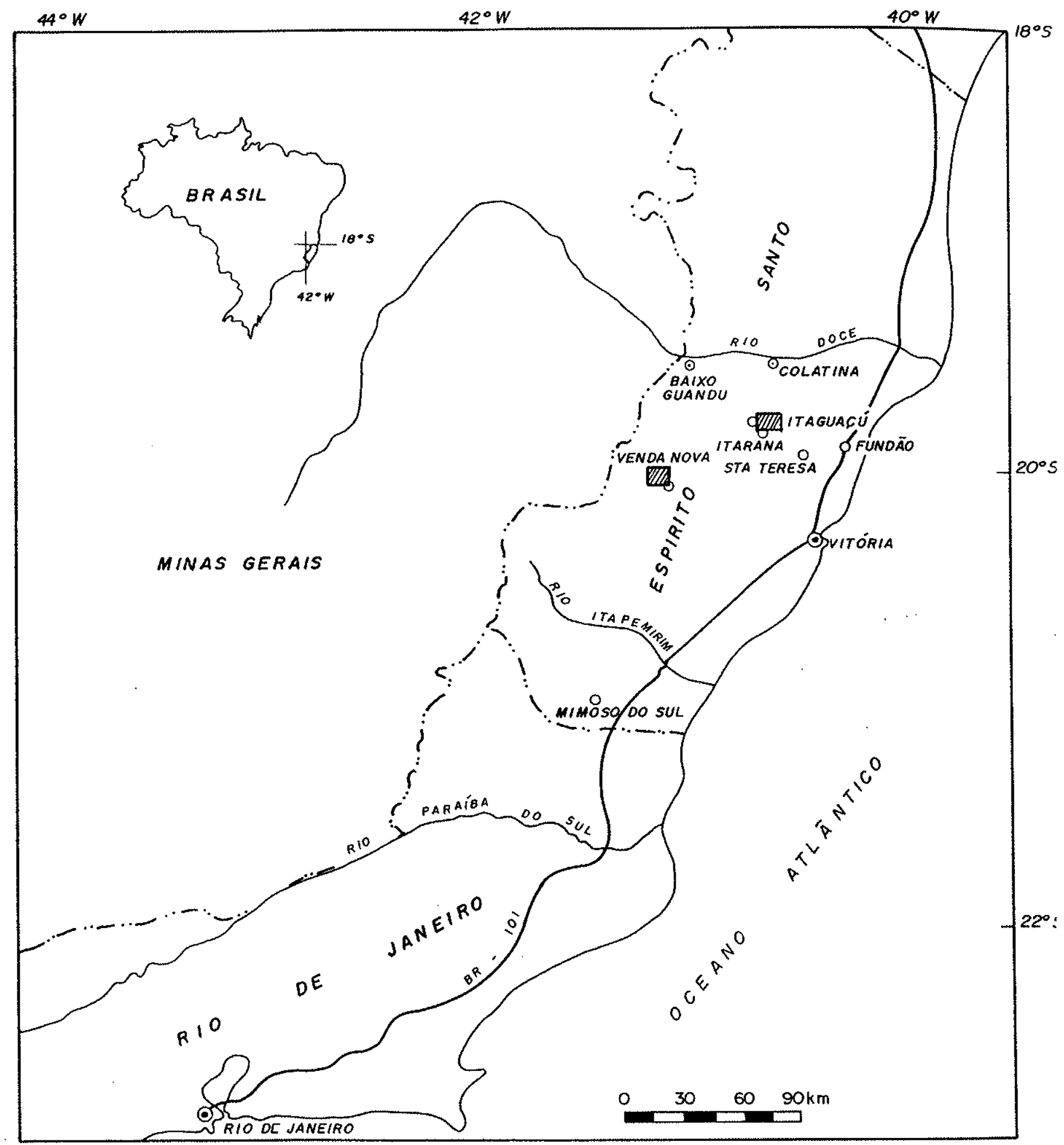

Figura 1.1 - Localização das áreas estudadas 
Após uma avaliação do que já era conhecido, pôde-se formular algumas questões iniciais a serem respondidas com os trabalhos de campo, como por exemplo a relação com as encaixantes e com o domínio interno, o grau de deformação das rochas e o tipo de interação entre os litotipos. A partir disto, um levantamento bibliográfico mais esmiuçado sobre a geologia regional deu maior suporte para o desenvolvimento das etapas posteriores.

No intervalo entre as atividades de campo deu-se andamento, dentro do possível, aos trabalhos de petrografia, de pesquisa e revisão bibliográfica e de preparação de amostras para análises químicas, além de atividades de escritório como confecção de mapas preliminares e avaliação dos dados existentes. As etapas de campo tiveram início em meados de 1992 e foram finalizadas no início de 1994. Compreenderam quatro curtas viagens, com períodos entre nove e dez dias de duração.

\section{Procedimentos de campo}

A base topográfica utilizada para os trabalhos na região de Venda Nova foi a folha Conceição do Castelo, SF24V-A-II-4 do IBGE, escala 1:50.000. No Maciço de Várzea Alegre foi usada uma base ampliada, para a escala 1:50.000, da folha Colatina 1:100.000 (SE.24Y-C-VI) do IBGE, uma vez que não existem folhas topográficas em escalas maiores para a região.

Como explicado anteriormente, em função de se ter uma base geológica prévia, optou-se por não realizar um mapeamento sistemático. Em Várzea Alegre foram feitos vários perfis para o reconhecimento e observação da geologia e para a coleta de amostras, do mesmo modo que os contatos com os gnaisses encaixantes foram checados em toda sua extensão, o que implicou em modificações consideráveis no traçado do mesmo, reduzindo a área do bordo externo. Por se tratar de uma área pequena, o bordo do maciço de Venda Nova foi percorrido quase que em sua totalidade, excetuando apenas os locais de dificil acesso pela densidade da cobertura vegetal. Com isto foi possível verificar uma escassez de afloramentos, recorrendo-se muitas vezes a observações e coleta de amostras em blocos rolados de vários tamanhos.

O procedimento adotado nos trabalhos de campo foi: reconhecimento dos afloramentos e descrição dos mesmos, medida de elementos estruturais, localização e marcação dos pontos nas bases topográficas e coleta de amostras.

Inicialmente as principais estradas foram percorridas com o intuito de se fazer um levantamento preliminar e verificar os contatos externos dos maciços. Isto possibilitou uma 
avaliação dos locais que poderiam requerer um detalhamento da geologia e de pontos adequados para coleta de amostras. Em Várzea Alegre as amostras para análises químicas foram retiradas principalmente de blocos estourados, ali encontrados com muita freqüência. Alguns pontos foram aproveitados do trabalho de Medeiros (op. cit.) e, em função disto, uma seqüência ordenada dos mesmos não foi estabelecida. Foram visitados e descritos um total de 83 pontos em Várzea Alegre, e trinta e oito (38) em Venda Nova (cf. Mapa de pontos do Maciço intrusivo de Venda Nova-Figura 1.2 e Mapa de pontos do Maciço intrusivo de Várzea Alegre-anexo 1).

\section{Análises petrográficas}

Foram confeccionadas 54 lâminas delgadas para a intrusão de Venda Nova e 70 para Várzea Alegre. Foram observadas com detalhe, através de luz transmitida, 40 seções de cada maciço, dentre norito-charnoquitóides (a grande maioria) e gnaisses encaixantes. Um total de vinte lâminas foram polidas visando a identificação e observação das relações entre as fases opacas, e quinze delas foram utilizadas nas análises de minerais por microssonda eletrônica. Os estudos petrográficos foram realizados com o auxílio de um microscópio Axioplan da Zeiss. Esta etapa permitiu o estabelecimento e compreensão das variações composicionais e texturais das rochas dos maciços, sendo de grande importância para a escolha das amostras para análise química e dos minerais posteriormente analisados na microssonda, e, de uma forma mais geral, para considerações e interpretações petrogenéticas posteriores.

Com o intuito de obter uma classificação confiável para os litotipos descritos, procedeu-se uma contagem modal em lâmina, utilizando-se para isto um contador de pontos automático e um vernier convencional com espaçamento padrão de $0,3 \mathrm{~mm}$ para as rochas de Venda Nova e $0,5 \mathrm{~mm}$ para os charnoquitóides porfiríticos de Várzea Alegre. Nestes últimos, nas amostras mais grossas, megaporfiríticas, para tentar minimizar os erros decorrentes de análise modal em rochas com esta granulação, foram feitas três lâminas por amostra, em cortes ortogonais, como sugerido por Chayes (1949). A contagem separada de megacristais, com o auxílio de uma malha quadrada, não foi realizada porque não é possível separar, a olho nu, plagioclásios de feldspatos alcalinos, pois ambos são verdes.

Depois de efetuada a contagem foi calculada a média das três lâminas para a apresentação dos resultados e classificação das rochas. Ao se comparar com as análises químicas ficou claro que os dados modais não eram de todo representativos (provavelmente em função do tamanho da lâmina delgada, que teria que ser 4 vezes maior). Em função disto, optouse pela classificação química na denominação dos litotipos do maciço de Várzea Alegre. 


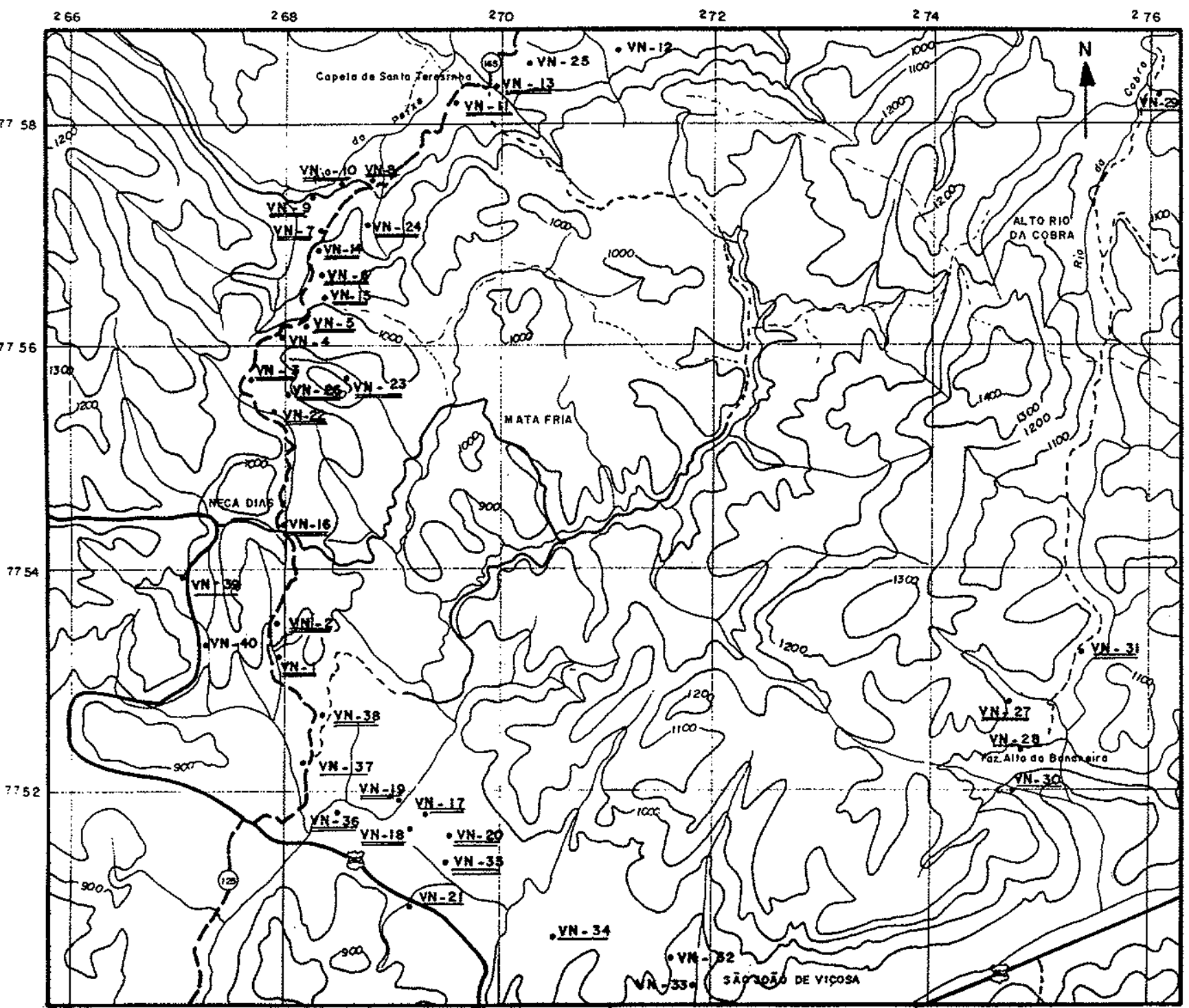

Figura 1.2

- MAPA DE PONTOS -

MACICO DE VENDA NOVA

\section{LEGENDA}

- vn.iz ponto descrito e amostrado

- YN-34 PONTO COM ANÁl.LSE PETROgRÁFICA

- vN-24 PONTO COM ANÁLISE PETROGRÁFICA E GEOQUIMICA

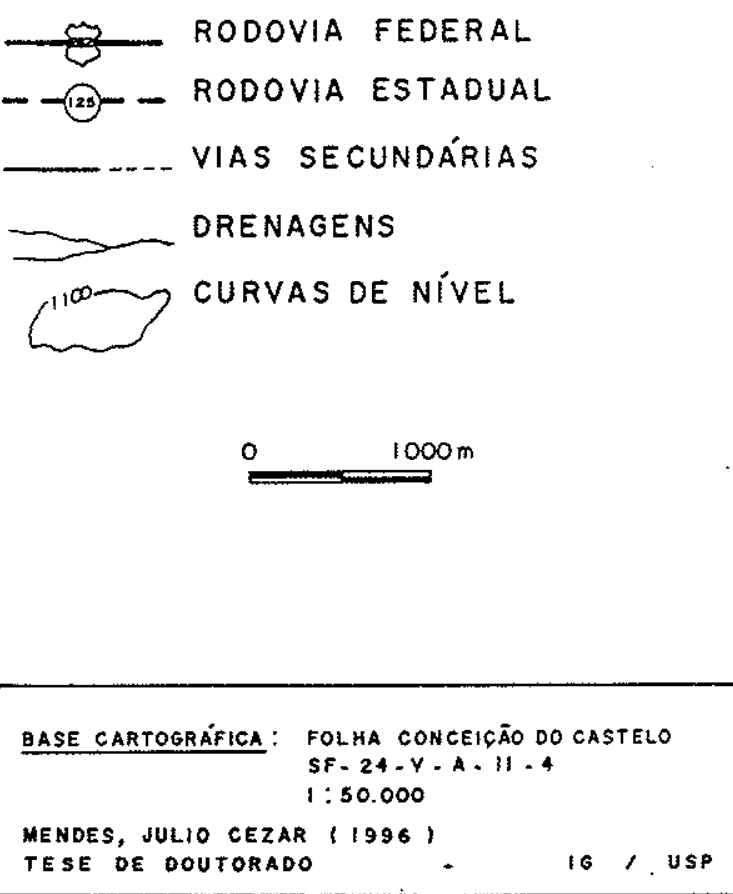




\section{Análises químicas de rochas}

Para o desenvolvimento desta tese foram feitas análises químicas em 24 amostras dos charnoquitóides do maciço de Várzea Alegre e em 27 amostras dos noritos e charnoquitóides do maciço de Venda Nova. Além dessas análises, são utilizados os dados de cinco amostras de Várzea Alegre extraídas do relatório preliminar do PLGBB da CPRM.

A coleta de rochas para a viabilização desta etapa seguiu o critério da utilização única de amostras frescas e possuindo um tamanho que fosse representativo de todas as fases componentes, de maneira geral dez vezes maior que o maior cristal da rocha (estimativa visual). A capa de alteração das amostras foi retirada na serra para se dar andamento à preparação. Seguiu-se o método convencional de preparação, triturando-as em um britador de mandíbulas de aço, quarteando os fragmentos até se obter cerca de $100 \mathrm{~g}$ que foram moídos em moinho de tungstênio. Cuidado especial foi tomado na preparação das rochas megaporfiríticas de Várzea Alegre, na coleta de um volume representativo e para que não fossem pulverizados apenas megacristais.

As determinações para as rochas de Venda Nova foram realizadas no Laboratório de fluorescência de raios-X do Departamento de Geologia da Universidade de Munique, Alemanha, o mesmo ocorrendo para a maior parte das rochas do maciço de Várzea Alegre. As exceções são as amostras VA-42, VA-125, VA-16, VA-90 e VA-164, que foram analisadas na CPRM (elementos maiores e menores) e na Universidade de Utrecht, Holanda (elementos traços, inclusive terras raras). A dosagem dos elementos terras raras se deu nos laboratórios da GEOLAB, em Belo Horizonte, excetuando as amostras citadas acima.

Para o cálculo da norma CIPW foi utilizado o programa Newpet (opção $\mathrm{NewClPW})$ e a razão $\mathrm{FeO} /\left(\mathrm{FeO}+\mathrm{Fe}_{2} \mathrm{O}_{3}\right)$ adotada para as amostras de ambos os maciços foi de 0,6 , por ser a que apresentou os resultados mais compatíveis com a análise modal. A norma dos noritos de Venda Nova não é apresentada e não será utilizada, uma vez que a grande quantidade de hornblenda que eles possuem faz resultar em valores normativos irreais.

Os métodos e alguns dos padrões utilizados para as dosagens nos diferentes laboratórios são os seguintes:

-Universidade de Munique: todos elementos analisados por XRF. O padrão interno usado para as rochas ácidas e intermediárias foi o sienito STM-1 e para as rochas básicas foi o basalto BIR-1. -Universidade de Utrecht: determinação de elementos traços, menos Th e Hf - fluorescência de raios-X; determinação de $\mathrm{Th}$, Hf e terras raras - ativação neutrônica 
-CPRM: determinação de $\mathrm{SiO}_{2}$ e $\mathrm{P}_{2} \mathrm{O}_{5}$ por espectrometria de absorção molecular (colorimetria); de $\mathrm{Fe}_{2} \mathrm{O}_{3}, \mathrm{FeO}$ e $\mathrm{CaO}$ por volumetria; de $\mathrm{Al}_{2} \mathrm{O}_{3}, \mathrm{TiO}_{2}, \mathrm{MnO}, \mathrm{Na}_{2} \mathrm{O}$ e $\mathrm{K}_{2} \mathrm{O}$ por espectrometria de absorção atômica e para a determinação da $\mathrm{H}_{2} \mathrm{O}^{+}$e PF foi utilizado o método da gravimetria. -GEOLAB: análise de elementos terras raras por ICP (detalhes analíticos quanto à metodologia $\mathrm{e}$ limites de deteç̧ão estão descritos em Dutra, 1986 e Dutra et al., 1988)

\section{Análises químicas de minerais}

Visando estabelecer a composição e fórmula estrutural de várias fases minerais presentes nos litotipos estudados e obter subsídios para cálculos geotermométricos e modelamentos geoquímicos, cerca de 400 análises, em 15 amostras, foram realizadas nas dependências do Laboratório de Microssonda eletrônica do DMP/IG da Universidade de São Paulo. O equipamento usado foi uma JEOL Superprobe JXA-8600, com sistemas WDS e EDS acoplado (microanalisador Tracor), dotado de cinco espectrômetros, com um par de cristais em cada. As condições de operação foram: potencial de aceleração igual a $15 \mathrm{KV}$, corrente do feixe $20.12 \mathrm{nA}$ e tempo de contagem variando de 5 a 10 segundos, dependendo da fase analisada.

Os minerais analisados foram: orto e clinopiroxênios, anfibólios, plagioclásios, feldspatos alcalinos, biotitas, ilmenitas e magnetitas. Das análises obtidas, foi feita uma seleção criteriosa e nesta tese são utilizados 104 pontos para o maciço de Várzea Alegre e 163 para o maciço de Venda Nova. Há que se ressaltar que alguns pontos correspondem à média de duas análises. Segue abaixo os elementos analisados por grupos de minerais:

Piroxênios e minerais opacos: $\mathrm{Si}, \mathrm{Ti}, \mathrm{Al}, \mathrm{Cr}, \mathrm{Fe}, \mathrm{Mn}, \mathrm{Mg}, \mathrm{Ni}, \mathrm{Ca}, \mathrm{Na}, \mathrm{K}$ e Ba.

Anfibólios e biotitas: $\mathrm{Si}, \mathrm{Ti}, \mathrm{Al}, \mathrm{Cr}, \mathrm{Fe}, \mathrm{Mn}, \mathrm{Mg}, \mathrm{Ca}, \mathrm{Na}, \mathrm{K}, \mathrm{F}$ e Cl .

Feldspatos: $\mathrm{Si}, \mathrm{Al}, \mathrm{Fe}, \mathrm{Ca}, \mathrm{Na}, \mathrm{K}, \mathrm{Ba}$ e $\mathrm{Sr}$.

O laboratório utiliza programas de padronização de acordo com a fase analisada (programas desenvolvidos internamente), e as composições dos padrões usados podem ser verificadas nas dependências do mesmo. $O$ equipamento possui sof twares desenvolvidos para transformar os valores percentuais de elementos em óxidos e para fazer as correções analíticas necessárias numa análise por microssonda (número atômico, absorção de massa, fluorescência secundária). 


\section{Nomenclatura utilizada}

Por se tratar de litotipos com textura ígnea preservada, apesar de mostrarem localmente um maior ou menor grau de deformação, sem evidências de metamorfismo superimposto, a nomenclatura das rochas aqui adotada é aquela sugerida por Streckeisen (1976) para os litotipos da série charnockítica, isto é, rochas com ortopiroxênio modal e geralmente de cor esverdeada (e.g. enderbitos, jotunitos, opdalitos, mangeritos). A denominação de enderbito é usada nesta tese para as amostras de composição tonalítica; as porções enderbíticas mais básicas são tratadas como OPX-quartzo-diorito. Como já esclarecido anteriormente, a denominação dos charnoquitóides do maciço de Várzea Alegre é baseada na classificação química.

O termo foliação ou estrutura de fluxo ígneo é empregado para descrever a orientação preferencial de algumas fases, sobretudo megacristais de feldspatos e minerais planares, eventualmente de glomérulos de minerais máficos. Usa-se foliação metamórf ica para indicar orientação paralela, penetrativa, de minerais planares ou alongados (deformados) imposta por deformação de cunho regional.

A conceituação de enclave empregada neste trabalho corresponde ao que foi definido por Didier (1987):

- enclaves xenolíticos: fragmentos das rochas encaixantes incorporados pelo magma quando do seu posicionamento.

- enclaves microgranulares: porções de rochas magmáticas microgranulares envolvidas e em contato brusco ou difuso com a rocha hospedeira, também magmática.

- enclaves supermicáceos: são os restitos, isto é, os resíduos de rochas metamórficas que sobram numa fusão parcial.

Os limites granulométricos usados na descrição das rochas no presente trabalho são:

- granulação muito fina: $<0,4 \mathrm{~mm}$

- granulação fina: 0,4 a $1,0 \mathrm{~mm}$

- granulação média: 1,0 a $4,0 \mathrm{~mm}$

- granulação grossa: 4,0 a $10,0 \mathrm{~mm}$

- rochas porfiriticas: megacristais $>8,0 \mathrm{~mm}$ (as megaporfiríticas possuem megacristais maior ou igual a $3 \mathrm{~cm}$ ); microfenocristais: 2,5 a $4,0 \mathrm{~mm}$. 


\section{CAPÍtULO 2 \\ A EVOLUÇÃO DO CONHECIMENTO DA GEOLOGIA REGIONAL}

\subsection{BREVE HISTÓRICO}

Apesar de serem reportados estudos geológicos no Estado do Espírito Santo desde meados do século passado, somente no ano de 1942 a Companhia Central Brasileira de Força Elétrica de Vitória publicou o primeiro mapa para o estado, elaborado por Horace Williams e Luciano Jacques de Moraes, que separaram os sedimentos Barreiras das planícies costeiras quaternárias. Abreu (1943) abordou aspectos tectônicos e mostrou os prováveis sistemas de falhas que deram origem às serras litorâneas e fossas transversais a linha da costa. Fez ainda referências às ocorrências de areias monazíticas e ilmeníticas e à possível existência de petróleo no norte do estado. Lamego (1949) escreveu sobre a fisiografia da região costeira, apontando também alguns tópicos petrográficos, estratigráficos e de recursos minerais. Apresentou um mapa no qual delimitou as restingas e os aluviões, posicionando-as no Holoceno; os sedimentos da Formação Barreiras foram posicionados no Mioceno e os granitos e gnaisses no PréCambriano.

Num trabalho mais geral, Brajnikov (1955) abordou a petrografia do PréCambriano do Espírito Santo e, baseado na mesma, elaborou uma carta geológica do estado na escala 1:400.000 e interpretou a evolução geológica da área. Utilizando-se de material coletado por esse autor, Guimarães (1956) descreveu a petrografia e sugeriu proposições genéticas do que ele designa genericamente de "charnockitos". As amostras estudadas são de vários locais do sul do estado; correspondem, segundo o autor, a discretas ocorrências de rochas via de regra gnaissificadas, por vezes miloníticas, que são interpretadas como sendo o resultado de produto de metamorfismo atuante em protólitos ígneos. Muitas vezes possuem granada, k-feldspato bem desenvolvido é raro e as seguintes feições texturais são freqüentes: presença de minerais deformados e de plagioclásio antipertítico, a substituição de orto e clinopiroxênio por hornblenda e biotita (sobrando quartzo) e de ilmenita/magnetita por titanita. A presença sistemática de antipertita, quartzo e titanita e a substituição localizada de plagioclásio por kfeldspato é associada a discretos fenômenos de granitização que em geral ocorrem, segundo o autor, devido a percolação de soluções silicosas durante processos retrometamórficos. Ele sugere que os charnoquitos sẹjam derivados de intrusão gabro norítica do proterozóico, passando por 
um primeiro evento metamórfico no início desta era e um último no final da mesma; situa os gnaisses regionais encaixantes no arqueano.

Os trabalhos de Rosier (1957 e 1965) nos Estados do Rio de Janeiro, Minas Gerais e Espírito Santo foram os primeiros a separar as rochas pré-cambrianas em unidades geológicas individualizadas. Na publicação de 1965, sugeriu um modelo geossinclinal para a evolução da região. Às seqüências supracrustais ele deu o nome de Série Paraíba-Desengano, e aos gnaisses granitóides chamou de Série Serra dos Órgãos. Ebert (1967) denominou a primeira de Grupo Paraíba (Paraibides), que se estenderia de São Paulo ao Espírito Santo. Almeida (1967) propôs idade Brasiliana para esta faixa.

A extensa faixa móvel da costa do sudeste brasileiro foi denominada de Cinturão Orogenético Ribeira por Cordani (1971) e Almeida et al. (1973), considerado de idade Brasiliana. Cordani et al. (1973), fazendo uso de dados geológicos e geocronológicos de rochas aflorantes nas regiões limítrofes de Rio de Janeiro e Minas Gerais, próximas ao sul do Espírito Santo, propuseram a existência da duas orogenias superpostas no Cinturão Ribeira: a primeira de idade Transamazônica $(2.000 \mathrm{Ma})$ representada por granulitos bandados e a mais nova, brasiliana, com $620 \mathrm{Ma}$, envolvendo gnaisses migmatíticos e granitóides. Obtiveram idade de $540 \pm 60$ Ma para corpos pós-tectônicos. Em trabalho posterior, Cordani \& Brito Neves (1982) chamaram de Cinturão Móvel Ribeira e Dom Feliciano à extensa faixa dobrada paralela a costa e que vai do sul da Bahia ao Rio Grande do Sul.

Os resultados de levantamentos aeromagnéticos realizados pelo Convênio Geofísico Brasil-Alemanha (Bosum, 1973) nos estados de Minas Gerais e Espírito Santo, revelaram diversas anomalias de forma circular, que foram associadas a fenômenos de magmatismo relativamente recente.

Silva e Ferrari (1976), propuseram quatro divisões para as rochas da Faixa Ribeira no Espírito Santo: Associação Paraíba do Sul, representada por gnaisses e migmatitos aluminosos com intercalações de quartzitos, mármores, anfibolitos, gonditos, charnoquitos e rochas cálcio-silicatadas; Complexo Charnoquítico, que engloba os charnoquitos e metamorfitos de composição intermediária a básica; Complexo Migmatítico, compreendendo rochas granitóides e diatexitos e Maciços Intrusivos, no qual eles descreveram alguns corpos com forma elíptica a circular que ocorrem no sul do estado.

Estudando imagens Landsat e Radar, junto a observações de campo, Meneses e Paradella (1978) definiram para o centro-sul do Espírito Santo três unidades de mapeamento 
caracterizadas por associações de rochas metamórficas e migmatíticas de médio e alto grau: gnaisses/migmatitos bandados, charnoquitos/granulitos e diatexitos. Também foram delimitados vários corpos intrusivos. A segunda unidade apresenta tipos texturais e composicionais diversos: rochas charno-enderbíticas de aparência plutônica, ou com texturas homófonas a miloníticas que não mostram limites definidos entre si e com as rochas circundantes.

Fonseca et al. (1979) descreveram de maneira geral a estruturação das rochas no Espírito Santo e em partes vizinhas dos estados de Minas Gerais e Rio de Janeiro. Comentam sobre a direção preferencial NE-SW e NNE-SSW das estruturas e sobre grandes falhamentos inversos para NW que aí ocorrem e que confere um estilo regional em escamas. Tal disposição é confirmada tanto por macroestruturas como por pequenas dobras com planos axiais mergulhando para SE e vergência para o interior, atestando que os esforços compressivos foram no sentido sudeste para noroeste e de leste para oeste, em direção ao cráton do São Francisco. Algumas estruturas de maior porte são descritas, como por exemplo a serra do Caparaó e o Lineamento de Guaçuí.

Estudando os maciços charnoquíticos/granulíticos de Aimorés, Itapina, Itaguaçu e Itanhomi, Pinheiro et al. (1978) relacionaram a paragênese destes corpos a metamorfismo de fácies granulito atuante sobre os mesmos. Desta forma, as rochas foram interpretadas como metamorfitos, apesar dos autores se referirem a texturas ígneas preservadas. Os estudos realizados nesta tese não confirmam tal teoria, e as rochas de Itaguaçu são aqui tratadas como tipicamente magmáticas.

Utilizando-se de dados radiométricos $\mathrm{Rb}-\mathrm{Sr}, \mathrm{K}-\mathrm{Ar}$ e U-Pb de rochas granulíticas, gnáissicas-migmatíticas e graníticas da porção setentrional da Faixa Ribeira, Siga Jr. et al. (1982) também separaram na região duas províncias de idades superpostas, uma Transamazônica e a outra Brasiliana.

O Proj eto Radambrasil (1983 e 1987) traçou considerações sobre o Complexo Paraíba do Sul, que compõe, segundo os autores, o embasamento do Cinturão Móvel Atlântico. Dividiram-no em quatro diferentes unidades: unidade indivisa (gnaisses bandados e migmatitos com lentes de quartzitos, cálcio-silicatadas, mármores, anfibolitos e metabasitos), gnaisses granitóides, rochas enderbíticas a charnoquíticas e gnaisses granatíferos e kinzigitos. Com relação aos maciços intrusivos, agruparam os mesmos em três suítes: 
a. Suíte Espírito Santo - inclui os corpos de composição granítica a granodiorítica do sul do estado, de caráter sin a pós-tectônico ao ciclo Brasiliano, exemplificados pelas intrusões de Iconha, Castelo, Aracê, Laj inha e Conceição de Muqui.

b. Suíte Santa Angélica - caracterizada por corpos diferenciados básicos a ácidos, incluindo rochas intermediárias e, secundariamente, alcalinas; incluem-se aí os maciços de Afonso Cláudio, Venda Nova, Santa Angélica e Jacutinga-Torre.

c. Suite Aimorés - inclui corpos de dimensões até batolíticas que ocorrem numa extensa área compreendendo a porção centro-norte do Espírito Santo e norte-nordeste de Minas Gerais. Correspondem a ortopiroxênios granitóides porfiróides e noritos associados com estrutura maciça ou apresentando foliação de incipiente a cataclástica. A composição varia de granitotonalito a norito, destacando-se os megacristais esverdeados de feldspato; possuem raros enclaves xenolíticos e microgranulares. São citados no Estado do Espírito Santo os maciços de Barra de São Francisco, Itapina, Itarana (posteriormente batizado de Maciço de Várzea Alegre nos trabalhos da CPRM), Aimorés e Fundão. Os autores sugeriram tratar-se de um conjunto alóctone, de posicionamento sin a tardi-tectônico ao ciclo Brasiliano, podendo estar relacionado a anatexia de rochas dos Complexos Juiz de Fora e Pocrane em condições catazonais. A presença de biotita nessas rochas denota, segundo eles, um evento retrometamórfico posterior que causou a desestabilização de algumas fases como o hiperstênio. Acenaram também com a possibilidade desses corpos terem a mesma origem que os granitóides porfiróides do Complexo Medina, porém em diferentes níveis crustais, em função de sua íntima relação de campo (mostram contatos gradacionais) e datações isotópicas similares. Admitiram que este material teve longa residência crustal, com base em isócrona $\mathrm{Rb}-\mathrm{Sr}$ calculada para quatro amostras do maciço de Itarana, que revelou idade de $600 \mathrm{Ma}$ e razão inicial de 0,708 . Ressaltaram que foram coletadas várias amostras, de diferentes localidades, para efetuar datação, mas a grande homogeneidade e as baixas relações $\mathrm{Rb}-\mathrm{Sr}$ dificultaram as determinações.

Trabalhos de detalhe realizados posteriormente no maciço de Várzea Alegre (Tuller, 1993 e Medeiros, 1993) revelaram que o mesmo não compõe-se unicamente de rochas noríticas e charnoquíticas, mas trata-se de uma intrusão inversamente zonada, com gabros no centro circundados por quartzo-dioritos e granitos, com um envoltório externo charnoquitóide. Não deve-se descartar a hipótese de que outros maciços citados pelos autores possuam uma estrutura mais complexa, como é o caso do de Itarana. 
A partir da década de 80 o conhecimento da geologia da região centro-sul do Espírito Santo foi impulsionado por vários projetos de cartografação geológica de detalhe e semi-detalhe, visando principalmente estudos geoquímicos, estruturais, isotópicos e tectônicos. Merecem destaque os trabalhos desenvolvidos por pesquisadores da UFRJ e da Universidade de Munique, mas também houve significativas contribuições através de levantamentos em escalas menores ou de cunho regional realizados pela CPRM e por pesquisadores da USP. No próximo item tais trabalhos serão abordados e, na medida do possível, será feita ưma análise crítica de alguns deles.

\subsection{ESTÁGIO ATUAL DAS PESQUISAS EM GEOLOGIA REGIONAL.}

Após alguns anos de trabalhos preliminares, Bayer et al. (1986) e Wiedemann et al. (1986) publicaram artigos nos quais descreveram a estruturação geral das rochas no sul do Espírito Santo e detalharam aspectos petrográficos e geoquímicos de quatro maciços intrusivos. Identificaram na região três complexos metamórficos paralelos a costa, Complexos Juiz de Fora, Alegre e Costeiro. O Complexo Juiz de Fora foi identificado nas cercanias da serra do Caparaó, compreendendo granulitos e charnoquitos com intercalações de metassedimentos. No Complexo Costeiro afloram migmatitos e gnaisses facoidais junto a linha de costa e charnoquitos no centro. O Complexo Alegre é separado de ambas as unidades por zonas de cisalhamento ductil, compondo-se de rochas supracrustais dobradas de provável idade brasiliana.

As estruturas exibem um "trend" geral NE-SW a NNW-SSE e o estilo de deformação e metamorfismo aponta, segundo os autores, para um provável cavalgamento de leste para oeste, em direção ao cráton. A zona de contato do empurrão do Complexo Juiz de Fora sobre o Alegre deve ter sido obliterada pelo lineamento de Guaçuí, um expressivo cisalhamento ductil posterior. Corpos diapíricos tardi a pós-orogênicos ao ciclo brasiliano intrudiram todas as seqüências. Para explicar as feições encontradas e o plutonismo pós-tectônico, de caráter cálcioalcalino, associado a granitóides sin-tectônicos, os autores propuseram um mecanismo de subducção para leste, provocado por colisão continente-continente, envolvendo uma placa paleoafricana, onde estariam os complexos Costeiro e Juiz de Fora e a oeste uma placa subductada com o complexo Alegre em sua extremidade. Tal modelo foi colocado em dúvida no próprio artigo de Wiedemann et al. (op. cit.), já acenando com o caimento da placa para oeste, o que foi confirmado nos estudos posteriores. A descrição do Complexo Alegre é similar ao que outros 
autores denominaram de Associação (Complexo) Paraíba do Sul, tratando-se provavelmente da mesma unidade.

Os maciços intrusivos reportados são os de Santa Angélica, Jacutinga-Torre, Castelo e Venda Nova. Enfatizaram que o atual nível de exposição deve corresponder às raízes dos plutons e fazem detalhadas descrições de campo e petrográficas, principalmente para os dois primeiros corpos. São descritas variadas feições evidenciando fenômenos de mistura magmática, tanto micro quanto megascópicas, sobretudo para Santa Angélica. No geral, possuem composição que varia desde granitos e sienomonzonitos até gabros, e sua geoquímica exibe um caráter cálcio-alcalino que tende a alcalino nas rochas de Torre e Venda Nova.

O tratamento geoquímico dado é pouco elucidativo, exceto quanto às afinidades químicas, visto que nos diagramas de variação estão representados variados litotipos de todos os maciços, o que dificulta as interpretações dos possíveis mecanismos responsáveis pela diversificação litológica encontrada. Apesar disto, as considerações quanto a complexidade dos processos responsáveis por tal diversidade, envolvendo desde fusão parcial de rochas mantélicas, cristalização fracionada, assimilação e fusão crustal, devem corresponder à realidade, assim como quanto a profundidade de geração dos corpos.

Wiedemann et al. (1987) fizeram uma comparação de alguns maciços intrusivos do Espírito Santo e Rio de Janeiro. Sugeriram que as diferenças de composição e de estrutura observadas estẹ am relacionadas a desiguais niveis de erosão. Quanto ao arcabouço regional, afirmaram tratar-se de material antigo, retrabalhado e predominantemente siálico que sofreu metamorfismo e deformação junto com as rochas supracrustais mais novas. Todo este conj unto foi intrudido por vários pulsos de rochas básicas a intermediárias e parcialmente fundido para formar os batólitos pré a sin-tectônicos. No final do ciclo orogênico, vários corpos elípticos a arredondados penetraram todas as unidades. Fazem alusão especial aos ortognaisses, descrevendo-os como batólitos de até $500 \mathrm{~km}^{2}$, de composição tonalítica a granodiorítica, granulação média a grossa, textura localmente tipo "augen" e de posicionamento pré a sintectônico.

Numa abordagem bastante regional, baseando-se em perfil estrutural da costa até o Estado de Minas Gerais, Lammerer (1987) observou as variações no padrão estrutural de oeste para leste. $\mathrm{Na}$ porção mais ocidental (correspondente ao Complexo Juiz de Fora) descreveu dobras de grandes dimensões, um anticlinal com o núcleo charnoquítico recoberto por "augen" gnaisses e metassedimentos. Uma zona de cisalhamento separa-o da parte central, que é afetada 
por intrusões sin, tardi e pós-tectônicas. O Complexo Costeiro, a leste, mostra similaridades petrológicas e estruturais com a porção oeste.

Em sua tese de doutoramento, Bayer (1987) estudou a geologia estrutural dos gnaisses orto e paraderivados adjacentes a intrusão de Santa Angélica. Abordou diversos eventos deformacionais, metamórficos e plutônicos e discutiu um modelo de intrusionamento para o referido maciço. Elaborou um quadro no qual correlaciona metamorfismo e magmatismo com as fases de deformação. Soa a exagero a proposição de nove fases de deformação, mas deve-se ressaltar que o autor não considerou somente estruturas maiores, relacionadas a esforços regionais, mas também estruturas subliminares e localizadas, como as decorrentes do posicionamento do pluton de Santa Angélica.

Através dos métodos $\mathrm{Rb}-\mathrm{Sr}$ em rocha total e U-Pb em zircões, Söllner et al. (1987) dataram rochas metassedimentares e ortognáissicas do Complexo Alegre. Concluíram que o pico do metamorfismo e anatexia se deu a 590+2-4 Ma; os núcleos dos zircões dos metassedimentos foram datados em $2100 \mathrm{Ma}$ (idade provável da rocha fonte) e os ortognaisses intrudiram próximo ao auge do metamorfismo regional, a 580+20-6 Ma. O granito de borda da intrusão de Santa Angélica forneceu idade de $513 \pm 8 \mathrm{Ma}$. Estes dados são muito relevantes por concordarem com várias determinações já realizadas em rochas semelhantes de outras regiões do Espírito Santo, Rio de Janeiro e Minas Gerais (Cordani et al., op. cit.; Siga Jr. et al., op. cit.; Fonseca, 1986; Batista, 1984).

Ao estudarem as rochas do Complexo Costeiro que afloram nas proximidades de Guarapari, Sluitner \& Weber-Diefenbach (1989) atestaram a predominância de dois litotipos, que estão intimamente associados: granulitos charnoenderbíticos e gnaisses anfibolíticos contendo granada e biotita. Ocorrem também biotita gnaisses, leptinitos e gnaisses kinzigíticos. Os granulitos e gnaisses anfibolíticos mostram às vezes passagens gradativas entre si, assim como são observadas porções esverdeadas nestes gnaisses com contatos difusos. Possuem granulação média a grossa e textura granoblástica; algumas amostras guardam características ígneas reliquiares, como textura ofítica e piroxênios exsolvidos. A composição varia de granodioritos a quartzo-monzonitos, e não foram encontradas rochas com teor de sílica menor do que $52 \%$. Os teores de elementos LIL são uniformes tanto para os granulitos quanto para os gnaisses; exibem padrões de ETR muito similares (além de proximidade nos valores totais e idênticas anomalias de $\mathrm{Eu}$ ), apesar da seqüência como um todo exibir mais de um padrão de terras raras, com anomalias tanto negativas quanto positivas. 
Os autores concluíram que ambas as seqüências têm a mesma origem, haj a visto os aspectos resumidos acima, tendo sido determinante a composição da fase fluida durante o metamorfismo $\left(\mathrm{CO}_{2} / \mathrm{H}_{2} \mathrm{O}\right)$ na cristalização de fases secas ou hidratadas, o que parece muito coerente e acertado. Tendo como base as razões $\mathrm{K} / \mathrm{Rb}$ próximas da crosta continental, a razão $\mathrm{Rb} / \mathrm{Sr}$ característica de rochas supracrustais e a similaridade dos padrões de ETR com aqueles de folhelhos e grauvacas da literatura, os autores propuseram que as rochas sejam derivadas de fusão parcial de grauvacas, tendo posteriormente se metamorfoseado sob condições de 5,3 a 6,9 $\mathrm{Kb}$ e 620 a $750^{\circ} \mathrm{C}$.

Não foi discutida a probabilidade de um protólito magmático, apesar de relatarem características ígneas herdadas. A possibilidade de fusão parcial de granodiorito para se obter os padrões apresentados é aventada, mas descartaram-na pela falta, segundo eles, de indicativo de crosta granítica no Complexo Costeiro no sul do Espírito Santo. Talvez com um maior detalhamento da petrografia e utilização do comportamento de outros elementos traços, por exemplo os HFS, tal conclusão poderia ficar mais solidificada ou abriria espaço para diferentes interpretações.

Utilizando-se de amostras dos charnoenderbitos descritos acima, Söllner et al. (1989) obtiveram uma idade U-Pb em zircão (cristais globulares e multifacetados) de $558 \pm 2 \mathrm{Ma}$ para o auge do metamorfismo granulítico na área. Idade aproximadamente $10 \mathrm{Ma}$ mais velha alcançada para diferente população de zircões (prismas alongados) foi interpretada como refletindo anatexia precedente ao evento metamórfico. Também foram calculadas as razões iniciais ${ }^{87} \mathrm{Sr} /{ }^{86} \mathrm{Sr}$ para composições charnoquíticas e enderbíticas, resultando em $0,7132 \mathrm{e}$ 0,7127 respectivamente. Como valores próximos foram obtidos para migmatitos do Complexo Alegre (Söllner et al., 1987), os autores acenaram para uma origem supracrustal comum para as seqüências.

Utilizando-se tanto de dados próprios como da literatura (e.g. Machado Filho et al., 1983; Barbosa \& Sad, 1983; Batista, op. cit.; Rêgo, 1989, etc.), Campos Neto e Figueiredo (1990) escreveram um abrangente artigo no qual propõem uma complexa evolução geológica para a região sul do Espírito Santo e norte fluminense. Para cumprir com tal objetivo eles fizeram uma proposição sobre a compartimentação estratigráfica-tectônica da área, com esmiuçadas descrições das variações litológicas e estruturais encontradas, e também com base em consistentes caracterizações geoquímicas, junto a determinações geocronológicas obtidas na literatura. Um resumo é apresentado a seguir. 
Dividiram a região em três domínios distintos: uma faixa ocidental, de características infracrustais, originalmente denominada de Série Juiz de Fora por Ebert (1955) e redimensionada por Barbosa \& Sad (1983); uma faixa supracrustal metassedimentar que engloba, em núcleos de nappes anticlinais ou em fatias de cavalgamento, ortomigmatitos mais antigos, correspondendo ao Complexo Paraíba do Sul, definido por Rosier (1957) e, numa faixa oriental, o Domínio Costeiro, que constitui um cinturão metamórfico de baixa pressão (apud Campos Neto e Figueiredo, op. cit.). Um plutonismo granitóide/charnoquitóide do final do Proterozóico/Cambriano intrude essas unidades crustais e marca os estágios finais de um ciclo tectônico (Figueiredo et al., 1989).

Quanto ao Domínio Juiz de Fora, concluem que o mesmo é composto por duas associações litológicas: 1-associação magmática cálcio-alcalina, compreendendo ortogranulitos e ortognaisses (charnoquitóides, granitóides cinzentos gnaissificados e migmatizados) com enclaves de rochas calciossilicáticas e lentes, pinçadas tectonicamente, de quartzitos miloníticos recristalizados, mostrando foliação regional de terceira geração; 2-associação de granitos diatexíticos e gnaisses granatíferos com foliação regional primária e que exibe localmente faixas descharnoquitizadas. Na associação l separaram uma série charnoquítica e outra ortognáissica, geoquimicamente idênticas, co-genéticas, cálciomalcalinas, distinguindo-se nelas uma seqüência TTG típica e outra enriquecida em elementos LIL, às quais associaram a granitóides de arco magmático pré-colisionais com origem ligada a plutonismo de subduccão de crosta oceânica.

O Complexo Paraíba do Sul corresponde, segundo os autores, a uma seqüência supracrustal com incompatibilidade metamórfica com os terrenos adjacentes, preservada na região por zonas de cisalhamento verticais e sob extenso cavalgamento do domínio infracrustal Costeiro. Agrupa uma seqüência metassedimentar com diques e "sills" de metavulcânicas básicas e uma seqüência gnáissico-migmatítica mais antiga; na seqüência metassedimentar os autores identificaram três unidades: psamítica, grauváquica e carbonática. Compreende ampla gama de tipos rochosos, entre eles quartzitos, quartzo-xistos, anfibolitos, gnaisses calciossilicáticos, kinzigitos, biotita-gnaisses, gnaisses bandados, migmatitos e mármores.

No tocante ao Domínio Costeiro afirmaram que se trata um cinturão metamórfico de grau alto e do tipo baixa pressão, a cordierita, com profusa anatexia e granitogênese, estando completamente alóctone sobre o Complexo Paraíba do Sul. Compreende migmatitos peraluminosos com charnoquitóides e granitóides intrusivos, subdividido em um segmento 
granulito-granito-migmatito e outro gnáissico-migmatítico. No primeiro, predominam migmatitos diatexíticos com biotita, granada, sillimanita, cordierita e eventualmente grafita. Rochas plutônicas intrusivas ocorrem em corpos pequenos a batolíticos, e representam suítes enderbito-charnoenderbíticas e/ou tonalito-granodioríticas. O segmento gnáissico-migmatítico é constituído principalmente por migmatitos estromáticos peraluminosos, a granada e/ou cordierita. São comuns nessas rochas lentes de quartzitos e calciossilicáticas. Determinações geotermobarométricas indicaram condições de cerca de $720^{\circ} \mathrm{C}$ e $6 \mathrm{~Kb}$ na formação dos migmatitos e charno-enderbitos.

Além dos domínios descritos acima, os autores discorreram também sobre o amplo e volumoso magmatismo cálcio-alcalino sob a forma de forma de grandes batólitos ou plutons isolados, de caráter pré a tardi-orogênicos ao brasiliano, que intrude nos diversos domínios crustais da região, configurando segundo eles um plutonismo de margem continental ativa. Possuem composição variando de tonalitos a granitos, inclusive com termos charnoenderbíticos. A maior parte mostra um quimismo predominantemente cálcio-alcalino (Bela Joana, Angelim, Muniz Freire, Guarapari), mas alguns tendem a álcali-cálcico (Serra dos Órgãos). Os autores discordam de Sluitner \& Weber-Diefenbach (op. cit.) com relação a origem sedimentar dos charno-enderbitos do Complexo Costeiro.

Os autores propuseram um modelo no qual consideram que os três domínios crustais (Juiz de Fora, Paraíba do Sul e Costeiro) correspondem a dois terrenos suspeitos acoplados durante a evolução de uma microplaca continental no Cambriano. Os terrenos retrabalhados do Domínio Juiz de Fora provavelmente consolidaram durante o Proterozóico Inferior. O outro terreno suspeito compreende as rochas migmatíticas do Domínio Costeiro e as supracrustais do Complexo Paraíba do Sul, depositadas provavelmente no Proterozóico Superior. De acordo com o modelo, o terreno evoluiu, no limite com o Cambriano, para uma margem continental ativa com subducção de crosta oceânica, estabelecendo-se um arco magmático continental. A sutura desses terrenos no Eo-Cambriano (fechamento de oceano e subducção tipo A), originou uma microplaca que empurrou o cráton do São Francisco. Seguiu-se então um plutonismo que marcou o final do ciclo tectônico. Atualmente o Domínio Juiz de Fora está cavalgado sobre a borda retrabalhada do cráton do São Francisco, e, por sua vez, é cavalgado por um terreno suspeito oriental, os Complexos Paraíba do Sul e Costeiro.

As divisões propostas pelos autores nos três domínios é bastante interessante e válida no seu todo. No entanto, a faixa mais ocidental do Complexo Costeiro (que se situa entre 
o Juiz de Fora e o Paraíba do Sul) não pode ser uma porção de um dos dois outros domínios? (faltam dados geoquímicos e geocronológicos nesta faixa para se ter uma resposta). Talvez trabalhos de campo em escalas maiores solucionem muitas dúvidas. O modelo propõe uma subducção de crosta oceânica, mas não estão claras as evidências quanto a presença da mesma.

Num complemento das idéias propostas para a região, e estendendo a teoria para áreas mais ao sul, no Estado de São Paulo, Campos Neto \& Figueiredo (1992) propuseram dois eventos orogênicos: Orogenia Brasiliana e Orogenia Rio Doce. Segundo eles, o primeiro episódio iniciou-se a cerca de 900 Ma com subdução de crosta oceânica e formação de um arco magmático com plutonismo cálcio-alcalino; novo arco magmático foi constituído há $650 \mathrm{Ma}$ resultando num magmatismo sin a tardi-colisional e, para finalizar o ciclo, estabeleceu-se um plutonismo tipo-I Caledoniano (tardi a pós-tectônico) associado a rochas sub-alcalinas (anorogênico) entre 610 e $585 \mathrm{Ma}$.

Quanto à Orogenia Rio Doce, eles vinculam seu início paralelamente a estabilização do domínio brasiliano, envolvendo a subducção de uma placa oceânica que originou um arco magmático cálcio-alcalino, com a intrusão de massas batolíticas nos domínios Costeiro (Bela Joana, Angelim, Serra dos Órgãos, Muniz Freire) e Juiz de Fora (Serra do Valentim, luna, Galiléia). Situam tal fenômeno entre 600 e $585 \mathrm{Ma}$, coincidindo com os picos metamórficos para ambos os segmentos. Segundo os autores, a microplaca Rio Doce se amalgamou à Faixa Araçuaí e à microplaca Brasiliana durante a colisão, quando se deu novo pulso metamórfico com o surgimento de granitóides metaluminosos tardi-orogênicos encontrados sobretudo no norte do cinturão. Antes do magmatismo pós-tectônico (Cambriano superior), bimodal cálcio-alcalino a alcalino, deu-se um novo metamorfismo de grau médio, junto com deformação, associado a granitos peraluminosos.

A proposta feita pelos autores foi uma prévia de trabalhos posteriores nos quais forneceram dados com as devidas referências (nesse trabalho não há citações) e dão mais embasamento à teoria. Nesse resumo eles parecem situar e comprovar a orogenia Brasiliana apenas nas cercanias do Estado de São Paulo e a Rio Doce nas regiões do Rio de Janeiro e Espírito Santo, apesar de estendê-las por toda esta área da faixa móvel.

Prosseguindo com tais estudos, Figueiredo \& Campos Neto (1993) reafirmaram a existência da microplaca Serra do Mar e consequentemente da Orogenia Rio Doce e detalharam a geoquímica de rochas agrupadas nos períodos pré, sin e tardi a pós-orogênico que ocorrem no norte do Estado do Rio de Janeiro e no centro-sul do Espírito Santo. Segundo eles, a 
microplaca Serra do Mar é constituída por rochas de alto grau metamórfico com gnaisses supracrustais subordinados, compostos principalmente por migmatitos peraluminosos. Ela evoluiu a partir de uma subducção de placa oceânica ("residual oceanic space") para noroeste originando um plutonismo cálcio-alcalino pré-colisional (590 a $570 \mathrm{Ma}$ ) seguido por extensiva anatexia crustal e magmatismo tipo S nas raízes do arco (560 a $530 \mathrm{Ma}$ ), culminando com a colisão e espessamento crustal. Grandes empurrões para NW afetaram tanto esta microplaca como as unidades consolidadas na orogenia Brasiliana. O episódio encerrou-se com o plutonismo pós-tectônico $(520$ a $480 \mathrm{Ma}$ ) do Cambriano superior/Ordoviciano inferior. Os parágrafos abaixo trazem uma síntese das características geoquímicas das três fases, como foi abordado pelos autores.

O magmatismo pré-colisional é representado por corpos batolíticos básicosintermediários-ácidos, alguns deles charnoquitizados, com quimismo cálcio-alcalino, de alto $\mathrm{Al}$, sobretudo metaluminosos e com volumes variáveis de rochas básicas associadas. Possuem razão inicial de 0,708 e conteúdo de terras raras é inversamente proporcional ao teor de $\mathrm{SiO}_{2}$, com anomalia de Eu variável. Isto é interpretado como resultado de um provável equilíbrio cristallíquido do protólito, sẹja por fusão parcial de uma fonte máfica (mais esperado para os corpos com pouco material básico, como Angelim e Guarapari) ou cristalização fracionada (controlada por fracionamento de piroxênio-hornblenda-plagioclásio) de um magma básico, processo que seria mais viável para os batólitos com maior volume de rochas básicas, como Muniz Freire e Bela Joana.

Os autores chamam a atenção para o grande enriquecimento nos elementos LIL e para as anomalias negativas de $\mathrm{Nb}, \mathrm{P}$ e Ti reveladas pelo "spidergram", considerando-as como característica geoquímica de zona de subducção. Uma subducção para NW é confirmada, segundo eles, pelo zoneamento químico observado no norte do Rio de Janeiro, onde ocorre para W-NW um aumento no teor de elementos incompatíveis (maturação do arco). As seqüências charnoquitizadas (e.g. Bela Joana e Guarapari) são consideradas geradas a partir de protólitos ígneos cuj a fase fluida apresentava pressão de $\mathrm{CO}_{2}$ maior que a pressão de $\mathrm{H}_{2} \mathrm{O}$.

As seqüências de características pré a sin-colisionais são constituídas por granitos tipo S (norte do Rio de Janeiro e do Espírito Santo), migmatitos estromáticos/ diatexitos peraluminosos (norte do Rio de Janeiro e sul do Espírito Santo) e biotita granitos leucocráticos (tipo I) de Muniz Freire, ES. Possuem composição granítica-granodiorítica e são relacionados a fusão crustal. As suas razões iniciais variam de 0,706 a 0,711 (pré-colisionais) e de 0,709 a 0,715 
(sin-colisionais). As diferenças encontradas nos padrões de terras raras são relacionadas às variações da mineralogia residual durante a anatexia. $O$ aranhograma destas seqüências revela um padrão similar ao dos batólitos cálcio-alcalinos, com maior enriquecimento em elementos LIL e pronunciadas anomalias negativas de $\mathrm{P}$ e Ti.

O plutonismo pós-tectônico é exemplificado por alguns plutons (e.g. Garrafão, Aracê, Iconha e Rio Novo do Sul) e diques ácidos/intermediários (Itaipavas, Domingos Martins e Piuma) de caráter álcali-cálcico (seqüências monzoníticas expandidas) que ocorrem nos estados do Espírito Santo e Rio de Janeiro (exemplificado apenas pelos diques da pedreira Itaipavas em São Fidélis).

Possuem composição predominantemente intermediária a ácida e são muito enriquecidos em elementos incompatíveis, até mesmo nas porções básicas que ocorrem em alguns deles. Isto sugere uma origem a partir de um manto enriquecido, o que é reforçado pela marcante presença dos componentes de subducção (anomalias negativas de $\mathrm{Nb}, \mathrm{P}$ e Ti), o que indica um metassomatismo mantélico associado à subducção. Os padrões de terras raras são muito fracionados com pequenas anomalias negativas de Eu, e indicam, segundo os autores, uma forte participação de equilíbrio cristal-líquido na sua diferenciação, com participação de granada ou anfibólio residual na área fonte. Fazem referências às evidências de mistura magmática encontradas em alguns corpos pós-orogênicos do Espírito Santo e Rio de Janeiro, mas com relação à geração das seqüências por eles estudadas assumem uma preponderância de processos de cristalização fracionada de magmas básicosjá enriquecidos

É importante ressaltar que os autores não apresentaram dados de vários plutons tardi a pós-orogênicos com assinatura geoquímica tipicamente cálcio-alcalina, e que as intrusões de Garrafão e Aracê não possuem um mapa geológico detalhado. O maciço de Iconha-Alfredo Chaves mostra variação composicional de 73,00 a 49,60\% de $\mathrm{SiO}_{2}$ (Wiedemann, 1993).

Campos Neto \& Figueiredo (1995), num trabalho amplo e bem elaborado, mas polêmico, consideraram o Ciclo Brasiliano/ Panafricano como sendo o resultado de um amalgamento, isto é, uma conj unção orogênica de microcontinentes, arcos de ilha, complexos acrecionários, etc. Neste contexto, sugeriram que o sudeste brasileiro seja constituído de diversos sistemas orogênicos, onde a Orogenia Rio Doce, representada pela microplaca Serra do Mar, é o mais novo componente de tal sistema. A orogenia anterior é denominada Sistema Orogênico Brasiliano I e é separada da orogenia Rio Doce pelo magmatismo, de caráter extensional de acordo com os autores, do Cinturão Itu, no Estado de São Paulo. 
O Sistema Orogênico Brasiliano I é exemplificado no sudeste brasileiro por faixas dobradas de margem passiva (Araçuai-Rio Pardo), pelas microplacas Guanhães, Apiaí-Guaxupé e Curitiba, pelo Cinturão de cavalgamento Juiz de Fora e pelos Terrenos acrecionários Embu. Acreditam os autores que o primeiro evento associado a esta orogenia pode ter ocorrido no atual domínio da Faixa Araçuaí, após um magmatismo toleí́tico tipo MORB de aproximadamente 850 Ma . De acordo com eles, o Cinturão Juiz de Fora evoluiu a partir de uma série de empurrões em direção ao cráton, possivelmente relacionados a uma subducção NNW, e compreende fragmentos crustais (granulitos e gnaisses dos complexos Mantiqueira e Juiz de Fora e gnaisses/migmatitos do Complexo Paraíba do Sul) que devem corresponder a porções de uma margem continental ativa associados a um plutonismo cálcio-alcalino/álcali-cálcico de arco magmático. Na microplaca Apiaí-Guaxupé a orogênese Brasiliano I é por eles associada aos terrenos exóticos da Nappe de empurrão Socorro-Guaxupé e às seqüências de baixo grau do Cinturão Apiaí. Um arco magmático caracterizado por batólitos granitóides cálcio-alcalinos de alto $\mathrm{K}$ (670-650 Ma, U-Pb em zircão) é relacionado a subducção. Idade de $630 \mathrm{Ma}$ para uma série mangerítica é vinculada a um metamorfismo de alto grau ou ao fím do ciclo. O final do evento é exemplificado por um magmatismo tardi-orogênico de $610 \mathrm{Ma}$ que grada a granitos rapakivi pós-orogênicos (600-580 Ma) no Cinturão Itu.

Com relação a microplaca Serra do Mar (Orogenia Rio Doce), os autores forneceram características estruturais e geoquímicas visando comprovar tal episódio orogênico. Pouco difere do que está descrito acima em Campos Neto e Figueiredo (1993), apenas contendo maior ênfase nos aspectos macro e microestruturais e em interpretações geotectônicas mais elaboradas.

Também neste trabalho não está clara a atuação da Orogenia Brasiliano I nas regiões dos estados do Rio de Janeiro e Espírito Santo. Mesmo não sendo o escopo principal do artigo, a precariedade de informações referentes ao estabelecimento de arcos magmáticos pré e pós-colisional no Sistema Juiz de Fora, e até mesmo os poucos dados apresentados com relação a Microplaca Apiaí-Guaxupé, aponta serem necessários trabalhos de detalhe (a começar por mapas em maior escala) para melhor definir e comprovar tal domínio orogênico.

No tocante à Orogenia Rio Doce, ela foi definida levando-se em conta aspectos bem gerais, sem detalhamentos de campo ou petrográficos. Está embasada em dados colhidos quase que exclusivamente em rochas do Espírito Santo e norte do Rio de Janeiro. A caracterização geoquímica do episódio pós-tectônico é baseada em apenas quatro maciços 
intrusivos e na região ocorrem vários deles, com quimismo variando de toleítico/cálcico/cálcioalcalino a cálcio-alcalino de alto $\mathrm{K} /$ alcalino. A separação de granitóides pré-colisionais dos sincolisionais não está muito clara e parece necessitar de mais apoio petrográfico e geocronológico. Alguns dados geocronológicos encontrados na literatura situam a idade de aproximadamente $600 \mathrm{Ma}$ como a do auge do metamorfismo, correspondendo a um evento de colisão (Söllner, 1987 e 1991 ) e não de pré-colisão. Idades maiores que $600 \mathrm{Ma}$ para rochas ortoderivadas do batólito Serra dos Órgãos e da cidade do Rio de Janeiro (Fonseca, 1986) não coadunam com a teoria. O mesmo ocorre no Complexo Granitóide de Medina, onde Siga Jr. et al. (op. cit.) obtiveram três possíveis intervalos de formação para rochas ortoderivadas: 650-550 Ma para granitóides de caráter sin a tardi-tectônico; 550-500 Ma para granitóides de caráter tardi a póstectônico e 500 a 450 Ma para granitóides pós-tectônicos a anorogênicos.

Pelo que foi exposto acima, parece provável que as dúvidas quanto à existência ou não das orogenias propostas só serão solucionadas com o avanço de pesquisas multidisciplinares na região. Em vista disto, nesta tese somente será utilizada a denominação consagrada de ciclo Brasiliano, correspondendo a um longo período de quase $400 \mathrm{Ma}$ de duração, cujo pico metamórfico na região (Espírito Santo e adjacências ) se deu há cerca de $590 \mathrm{Ma}$.

Wiedemann (1992) publicou um resumo no qual reforça a presença de três domínios crustais, de idade brasiliana, no Estado do Espírito Santo: Domínio Costeiro (gnaisses charnoenderbíticos e anfibolíticos com intrusões bimodais); Domínio Alegre (seqüências supracrustais cortadas por um grande número de corpos batolíticos sintectônicos e diápiros zonados tardi a pós-tectônicos) e um terceiro domínio constituído por sequências orto e paraderivadas charnoquitizadas próximo de $590 \mathrm{Ma}$, correlacionável ao Complexo Juiz de Fora. Traça considerações sobre os maciços intrusivos pós-tectônicos, reafirmando os fenômenos de mistura mecânica e química entre magmas contrastantes e a presença de duas suítes, uma cálcioalcalina normal com magma básico de caráter toleiítico e outra de alto $\mathrm{K}$, revelando a maturação do arco.

Num artigo no qual propôs a evolução do arco magmático e a divisão do plutonismo tardi a pós-orogênico em três séries, Wiedemann (1993) fez um abrangente apanhado de numerosos dados acumulados em mais de uma década de variados trabalhos na região. Fez uso de interpretações e conclusões anteriores, assim como sugeriu novas interpretações, 
principalmente quanto à divisão proposta e à petrogênese dos magmatitos. Na Figura 2.1 encontra-se o mapa geológico proposto para a região centro-sul do Estado do Espírito Santo.

A autora parte de um modelo de evolução de uma placa tectônica ensiálica (Fritzer, 1991) com subducção para oeste, resultando em uma colisão continente-continente; sugeriu um alto ângulo de mergulho da placa, uma vez que ocorre íntima associação espacial entre as séries magmáticas. Neste contexto, segundo ela, os grandes batólitos ortognáissicos (e.g. Muniz Freire, Galiléia, Angelim, Serra dos Órgãos) e alguns corpos menores charnoquitizados, de composição granítica a norítica, cristalizaram-se durante a fase colisional, a cerca de $600 \mathrm{Ma}$, e sofreram metamorfismo de fácies anfibolito (provável arco magmático sin-colisional). Seguiuse a este espessamento crustal uma segunda fase (retro)metamórfica, em torno de $520 \mathrm{Ma}$ atrás, que afetou todo o pacote e culminou com o início de uma nova atividade magmática, de caráter tardi-tectônica, originando (meta)gabros da Série Toleiítica. Sugere a formação de um arco magmático intracontinental que teve continuidade com a intrusão de rochas cálcio-alcalinas normais (Série cálcio-alcalina de médio a alto $\mathrm{K}$ ) e álcali-cálcicas/alcalinas (Série de alto potássio), resultando no fechamento da orogenia de idade Brasiliana.

Contrastando com a subdivisão proposta pelo Proj eto Radambrasil (op. cit.) as séries foram definidas levando-se em conta aspectos abrangentes, como campo, petrografia e química de rochas e minerais. Eis a descrição das mesmas, segundo Wiedemann (1993):

-A Série Toleítica é caracterizada por gabros coroníticos formados por olivina, bronzita, pargasita e bytownita primários e diopsídio, salita, biotita e oligoclásio como paragênese secundária, retrometamórfica. Mostram algumas evidências de contaminação tais como razões iniciais 0.708 e heterogêneo enriquecimento em elementos incompativeis, principalmente $\mathrm{K}, \mathrm{Rb}$ e Zr. Deve-se ressaltar que a borda norítica de Venda Nova, tema desta tese e incluída nesta série, não possui olivina e sua paragênese secundária é hornblenda e magnetita.

-A Série Cálcio-alcalina de médio a alto $\mathrm{K}$ corresponde ao principal magmatismo desse arco, correspondendo a diversos plutons que penetraram as seqüências dos Domínios Alegre e Costeiro. Podem ser separados quimicamente em uma série de médio K e noutra de médio a alto K. A possibilidade dessas duas séries terem se originado a partir de cristalização fracionada de um álcali basalto é contestada, tanto pela mineralogia (hiperstênio modal e normativo) quanto pela afinidade química e composição dos piroxênios, pobres em $\mathrm{Al}_{2} \mathrm{O}_{3}$, sendo mais indicado uma origem a partir de um magma toleítico a subalcalino. Alguns aspectos geoquímicos de 
caráter alcalino podem, segundo a autora, estar relacionados com os fenômenos posteriores de mistura magmática.

-A Série de alto $\mathrm{K}$ inclui os corpos com quimismo alcalino (shoshonítico?) que possuem nefelina e leucita normativa e não têm hiperstênio modal ou normativo. As rochas mais básicas mostram às vezes mineralogia compatível com rochas cálcio-alcalinas, contrastando com um quimismo alcalino; isto pode também ser conseqüência de processos de mistura magmática. A possibilidade das rochas desta série terem como magma parental um basalto alcalino é aventada pela autora.

Seidensticker e Wiedemann (1993) estudaram geoquimicamente granulitos da região da Serra do Caparaó, ES, inserida no Complexo Juiz de Fora. A partir de um mapeamento detalhado, obtiveram composições granodioríticas a tonalito-trondhjemíticas (uma seqüência TTG, assim como descrito por Campos Neto \& Figueiredo, op. cit. para área mais a sudeste) e uma química de tendência calcio-alcalina. Por outro lado, através de dados de campo (e.g. rochas bandadas de granulometria muito fina, intercalação de camadas grafitosas, contatos gradacionais entre os migmatitos e quartzitos e kinzigitos) e químicos (diagramas de classificação, razões entre alguns óxidos, padrões de terras raras, alto teor de corindon normativo, etc.) os autores creditaram uma origem predominantemente sedimentar para estas rochas.

A partir dos teores de $\mathrm{K}_{2} \mathrm{O}, \mathrm{Rb}$ e $\mathrm{Sr}$ classificaram as rochas como granulitos não empobrecidos ("undepleted" granulites). Dados geobarométricos e geotermométricos (pressões da ordem de 8 a $10 \mathrm{~Kb}$ e temperatura de cerca de $700^{\circ} \mathrm{C}$ para a fácies granulito), juntamente com a razão $\mathrm{K} / \mathrm{Rb}$ (varia de 100 a 500 ), permitiram posicionar tais rochas como granulitos de média pressão, gerados provavelmente em crosta inferior.

Portanto, os autores atribuem uma origem complexa para os granulitos estudados: formaram-se a partir de metamorfismo de alto grau, de idade Brasiliana ( $586 \pm 2 \mathrm{Ma}, \mathrm{U}-\mathrm{Pb}$ em zircões, Söllner, 1991), sobre seqüências metassedimentares, que por sua vez se originaram a partir de uma fonte bimodal de natureza cálcio-alcalina, do Proterozóico Inferior.

Traçando um panorama geral da evolução geológica do Estado do Espírito Santo, Wiedemann et al. (1995) publicaram um resumo no qual reforçam a incidência de duas orogenias superpostas, que culminou com a formação de um cinturão móvel de idade transamazônica e outro de idade brasilana. Os limites destas faixas é marcado pela existência de duas descontinuidades: Abre Campo, correspondendo à borda do craton e Manhuaçu, que marca 
o limite do cinturão acrescido no Proterozóico Superior. A colisão entre os cratons do São Francisco e Congo-Angolano foi, de acordo com os autores, o evento propulsor para o desenvolvimento deste cinturão.

A intrusão de massas batolíticas se deu durante o período pré a sin-colisional coincidindo com o auge do metamorfismo ocorrido há cerca de $600 \mathrm{Ma}$. Os autores sugerem o aporte contemporâneo de magmas de origem crustal e mantélica durante o auge tectonometamórfico brasiliano. Citam a ocorrência de pequenos corpos de flogopita peridotitos associados a estruturas antiformais, que poderiam representar resquícios de uma zona de sutura, embora não hả a indícios de crosta oceânica.

No final do ciclo tectônico todas as unidades metamórficas foram intrudidas por diápiros tardi a pós-tectônicos de estruturação complexa e larga variação composicional. Fazem referência a uma segunda fase metamórfica de características retrógradas, que propiciou o crescimento de biotita e o desenvolvimento de simplectitos nos granulitos/charnoquitos.

Tomando como base o mapeamento geológico em escala 1:100.000 realizado pela CPRM (PLGBB), Vieira et al. (1993) traçaram considerações quanto à estruturação regional da porção sul do Estado do Espírito Santo. Identificaram quatro domínios estruturais, limitados por zonas de cisalhamento dúcteis transcorrentes: Domínio central (Domínio do arco magmático), Domínio oriental (DOR), Domínio ocidental (DOC) e Domínio litorâneo (fragmento de crosta inferior). Detectaram a existência de pelo menos três fases de deformação: uma fase precoce, uma tangencial e uma transcorrente.

Encontraram rochas supracrustais nos domínios ocidental e oriental; no domínio ocidental definiram a unidade chamada de Complexo Ipanema, correspondendo a uma associação plutono-vulcanosedimentar com corpos de metamáficas/ultramáficas que foram interpretadas como possível evidência de crosta oceânica. Trata-se na realidade de charnoquitóides da Serra do Valentim (ortognaisses de composição norítica a charnoquítica) anteriormente estudados por Fritzer (op. cit.) e Figueiredo et al. (1992). A outra unidade supracrustal, de amplo predomínio, é formada pelas rochas do Complexo Paraíba do Sul, aflorantes no DOC, no DOR e no dominio central. Nela foram individualizadas três associações litológicas: gnaisses aluminosos, gnaisses kinzigíticos e associação metavulcano sedimentar. Foram também cartografados corpos granitóides que ocupam cerca de $50 \%$ da área e que mostram características de pré a pós-colisionais. Dentre eles foram identificadas cinco suítes, separadas principalmente por composição, estrutura e relação com as rochas encaixantes. 


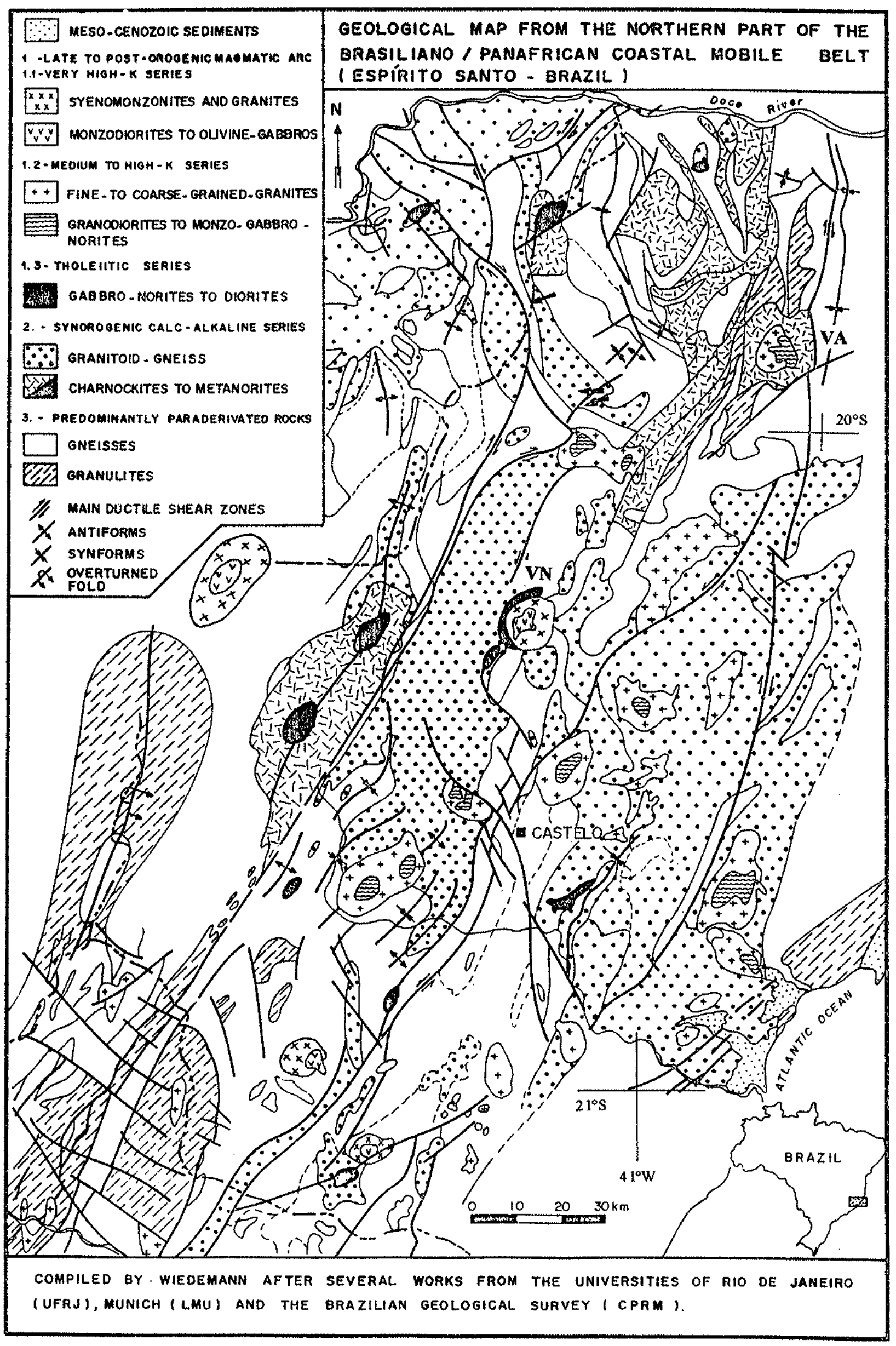

Figura 2.1 - Mapa Geológico Regional 
O domínio litorâneo, gnáissico-granulítico, é interpretado como sendo ortoderivado e relacionado a um arco magmático de idade provável Transamazônica, com rẹ uvenescimento Brasiliano. Segundo os autores este terreno deve representar, juntamente com os gnaisses/migmatitos/granulitos do Complexo Juiz de Fora, a infraestrutura desse segmento do Cinturão Móvel Ribeira.

As divisões propostas com denominações novas para seqüências anteriormente estabelecidas por vezes podem complicar a compreensão e uma integração da geologia da região. Dentre as unidades do Complexo Paraíba do Sul, as associações de gnaisses aluminosos e a dos kinzigitos parecem não apresentar muitas diferenças, podendo talvez serem agrupadas. Quanto à separação proposta para os granitóides, parece ser possível juntar algumas suítes, de características muito similares e que não possuem suficientes determinações geocronológicas. A descrição da suíte $\gamma 1$ muito se assemelha aos ortognaisses Muniz Freire e Estrela (Campos Neto \& Figueiredo, 1990; Wiedemann et al., 1986), cuja idade do metamorfismo é de 590 Ma. Poderia ser agrupada com as suítes $\gamma 3 \mathrm{~b}$ e $\gamma 3 \mathrm{c}$. Outra maneira para tornar mais simples e mais adequado, à luz do atual nível de conhecimento, seria considerar os granitóides de características pré e sin-tectônicas num grupo e os outros tardi a pós-tectônicos noutro.

Signorelli (1993) elaborou o texto explicativo da carta geologica da folha Afonso Cláudio (SF .24-V-A-II)- PLGBB/CPRM, onde está situado o Maciço de Venda Nova. Em termos regionais, o corpo intrusivo está contido em unidades metassedimentares do Complexo Paraíba do Sul (Unidades Pps 1, Pps3, Pps5) e em gnaisses ortoderivados.

A unidade Pps 1 corresponde a uma larga faixa de gnaisses aluminosos que se estende para o norte, caracterizando-se pela predominância de grafita-cordierita-granadasillimanita-biotita gnaisse bandado, de granulometria média e localmente dobrado. Mais raramente intercalam-se a anfibolitos, quartzitos e rochas cálcio-silicatadas, e sua composição é tonalítica. A unidade Pps3 é representada nesta folha somente por uma faixa que continua para o sul. Compreende intercalações de biotita-anfibólio gnaisses e quartzitos, associados a rochas cálcio-silicáticas, mármores e anfibolitos. $O$ gnaisse tem estrutura bandada a fitada, muito dobrada com marcante foliação de transposição, textura granoblástica e sua composição é granítica. Compreendendo bandas (centimétricas a decimétricas) intercaladas de anfibóliobiotita gnaisse fino e biotita-microclina-gnaisse médio a grosso, as rochas da unidade Pps5 são representadas numa pequena área a nordeste do maciço de Venda Nova. Ambas são bem foliadas e a textura é lepidoblástica e granoblástica. 
Os ortognaisses da borda do pluton de Venda Nova são divididos em três unidades: P $\gamma$ la-Muniz Freire, $P \gamma$ lb-Alto Guandu e P $\gamma$ 1c-São Benedito. De acordo com o que está descrito, elas são muito semelhantes e estão separadas devido a variações texturais e mineralógicas localizadas. A unidade $\mathrm{P} \gamma \mathrm{lb}$ é a única que apresenta composição mais básica, tonalítica a diorítica, composta essencialmente por plagioclásio, anfibólio, biotita e quartzo. $\mathrm{O}$ autor atribui sua origem a partir da anatexia dos gnaisses aluminosos da unidade Pps5. A textura destas rochas é granolepidoblástica a porfiroblástica e porfíroclástica/milonítica nas proximidades de contatos com zonas de cisalhamento, que é o caso dos gnaisses do batólito de Muniz Freire nas adjacências dos lineamentos de Guaçuí e Piracema. A composição predominante é granítica, com gradações a tonalitos e granodioritos, e a granulação é média a grossa. Estes gnaisses exibem feições ígneas preservadas, como também enclaves xenolíticos de paragnaisses.

O Complexo intrusivo de Várzea Alegre está inserido nos domínios da folha topográfica Colatina (SE.24-Y-C-VI), cujo mapa geológico e o respectivo texto explicativo encontram-se em Tuller (1993). Está envolvido por gnaisses aluminos da unidade Pps1 do Complexo Paraíba do Sul e por ortognaisses tipo Colatina e granulitos (gnaisse enderbítico) tipo Santa Tereza.

Os kinzigitos da unidade Pps1 bordejam todo o flanco leste, num grande segmento que continua a norte e a sul da folha, e parte do flanco oeste do corpo de Várzea Alegre. Segundo o autor, estão comumente migmatizados e mostram estrutura bandada, com alternância de bandas félsicas e máficas milimétricas a centimétricas geralmente descontínuas. Associados a eles observam-se pequenas lentes ou níveis de rochas calcissilicáticas, deformadas ou não, como também, localmente, discretos bancos de quartzito. São bastante dobrados, com foliação transposta, tendo sido identificadas até 4 fases de deformação. Possuem granulometria média e localmente são aparentemente homogêneas, confundindo-se com os ortognaisses. Sua composição é granítica e, dentre os minerais aluminosos, a cordierita predomina e pode formar glomérulos, ocorrendo o mesmo com a granada. Segundo o autor, os contatos com os ortognaisses são comumente difusos, em função de processos anatéticos; na zona de contato com os granulitos, a granada diminui e desaparecem a cordierita e a sillimanita, surgindo o hiperstênio e a rocha adquire tom esverdeado.

Os gnaisses enderbíticos Santa Tereza afloram em dois segmentos, a norte e a sul do maciço de Várzea Alegre, o que indica um truncamento quando do posicionamento do 
mesmo. São descritos como tendo composição dominante quartzo-feldspato-biotita-hiperstênio e granulação variando de média a grossa; sua foliação pode ser incipiente a bem pronunciada. Mostram-se afetados tanto pelo cisalhamento de baixo ângulo quanto de alto ângulo, e é comum exibirem evidências de blastese, com crescimento de porfiroblastos de feldspato. Os contatos com os ortognaisses tonalíticos (Colatina e Jequitibá) são transicionais, com a passagem de um tipo para o outro através do aparecimento de hiperstênio e da mudança na cor da rocha. $O$ autor atribui para este conjunto um caráter ortoderivado, com a incidência de processos metassomáticos posteriores.

Do mesmo modo que o granulito Santa Tereza, o ortognaisse tipo Colatina aparece em duas faixas alongadas ao norte e ao sul do pluton de Várzea Alegre, dando continuidade geográfica aos segmentos dos granulitos. Está descrito como uma rocha de granulação média a grossa, de foliação incipiente a bem marcada, que sofreu cisalhamento (de alto ou baixo ângulo) tanto ruptil quanto ductil. Sua composição é tonalítica e possui granada em abundância; localmente observa-se cordierita como restito da fusão dos kinzigitos, uma vez serem freqüentes os xenólitos de paragnaisse. Também podem estar associadas a lentes cálcissilicáticas e a gnaisse enderbítico. Os contatos com os paragnaisses são normalmente difusos, em função de anatexia local, e são gradacionais com os granulitos. 


\section{CAPÍTULO 3 \\ GEOLOGIA LOCAL}

A estruturação dos maciços intrusivos de Venda Nova e Várzea Alegre, suas rochas encaixantes de alto grau metamórfico e a considerável extensão de rochas básicas aflorantes são fatores que indicam que o que está atualmente exposto corresponde às raizes dos plutons. Neste capítulo serão descritas as estruturas megascópicas observadas nas áreas em estudo, com maior nível de detalhe para aquelas encontradas nos charnoquitóides do Maciço de Várzea Alegre, uma vez que neste os afloramentos são abundantes, ao contrário de Venda Nova.

A proposição de uma seqüência estratigráfica para ambos os maciços aqui estudados é dificultada pelas feições de interação mecânica observadas entre as diversas rochas aflorantes. Isto é, enquanto que em alguns locais um determinado litotipo aparece envolvendo ou cortando (como dique ou veio) um outro, em outros pontos a relação entre eles pode estar invertida. Tal interação indica que houve intrusão simultânea (magmatismo bimodal) e/ou que o posicionamento se deu num espaço de tempo geologicamente desprezível. No entanto, a partir das observações de campo e de descrições encontradas na literatura foi possível montar uma estratigrafia que parece ser a mais correta para os dois maciços.

Antes da descrição da geologia das bordas charnoquitóides de cada maciço será feito um resumo de vários trabalhos encontrados na literatura que têm como enfoque as rochas de ambos os maciços, dando assim subsídios para uma melhor compreensão dos aspectos geológicos das áreas estudadas.

\subsection{MACIÇO DE VENDA NOVA}

$\mathrm{O}$ conjunto de informações da literatura juntamente com os dados de campo coletados para esta tese possibilitaram o estabelecimento de uma seqüência estratigráfica mais provável para o maciço de Venda Nova, que é a seguinte:

\begin{tabular}{|l|l|}
\hline $4^{\circ}$ pulso & titanita granitos \\
\hline $2^{\circ} / 3^{\circ}$ pulso & sienomonzonitos e monzonitos \\
\hline $2^{\circ}$ pulso & gabros do centro do pluton \\
\hline $1^{\circ}$ pulso & noritos e charnoquitóides da borda \\
\hline
\end{tabular}


Os noritos e charnoquitóides da borda correspondem certamente a um primeiro pulso pois são encontrados como enclaves nos sienomonzonitos. Por outro lado, algumas feições de campo, descritas abaixo, indicam que o posicionamento de ambos os litotipos tenha ocorrido num intervalo temporal muito restrito. As relações entre os gabros e os sienomonzonitos sugere que eles tenham se posicionado simultaneamente, originando uma região de contato (zonas mistas) tipo "frozen-in" caracterizada por enclaves gabróicos na matriz sienomonzonítica e viceversa. Para efeito de coluna estratigráfica, os gabros estão abaixo por se cristalizarem antes (atingem primeiramente o solidus). Os titanita granitos aparecem cortando os demais litotipos, assim como mostram enclaves dos mesmos, caracterizando-se como um pulso final. $O$ mapa geológico do maciço intrusivo de Venda Nova encontra-se na Figura 3.1.

\section{Trabalhos prévios}

A primeira publicação em que se encontra um relato mais detalhado sobre as rochas da intrusão de Venda Nova é a de Wiedemann et al. (1986). Como rochas encaixantes são citados migmatitos, ortognaisses e gnaisses melanocráticos. No centro do maciço afloram dioritos e gabros intrudindo preferencialmente ao longo de fraturas e uma zona mista composta por enclaves dioríticos numa matriz sienomonzonítica. De acordo com os autores, tais enclaves estão alinhados com a direção do fluxo magmático e são cada vez mais frequuentes ao se aproximar do contato com as rochas máficas. Sienomonzonitos com variações locais para tonalitos e granitos (estes por vezes como "schlieren") representam o maior volume de rochas, e envolvem os litotipos internos. O contato dos sienomonzonitos com o migmatito foi observado num único ponto, mostrando-se "lit par lit". A borda norítica/charnoquitóide não foi descrita ou apresentada no mapa.

Estruturalmente destacam-se um sistema radial de juntas de resfriamento, fraturas NW-SE e NE-SW e megacristais de feldspato orientados nos sienomonzonitos, que na parte mais externa do corpo exibe uma conspícua foliação de borda. Estruturas de fluxo, comuns nos domínios félsicos, são pouco observadas nas rochas mais máficas. 


\section{MAPA GEOLÓGICO DO MACICO INTRUSIVO DE VENDA NOVA - ES}

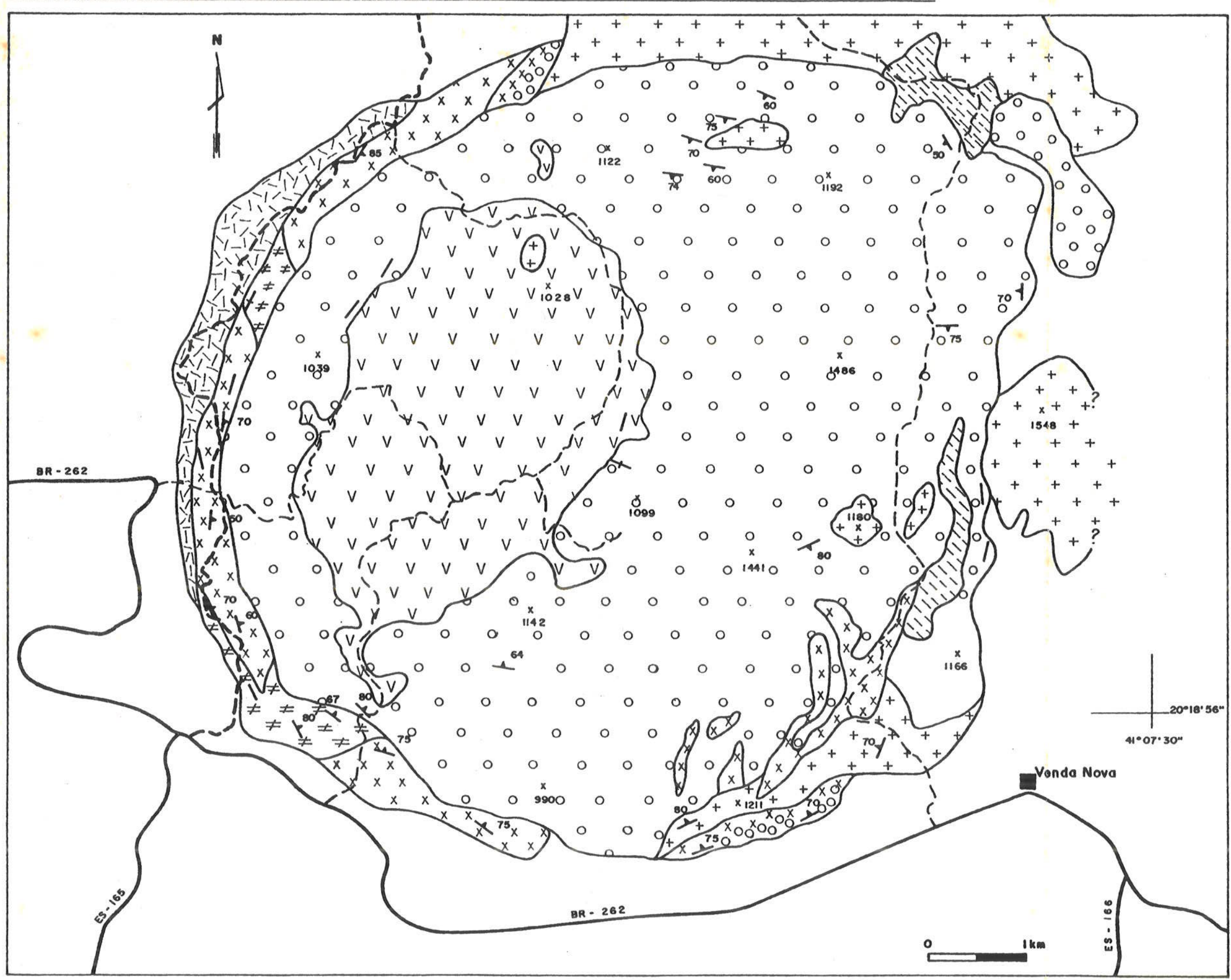

\section{- LEGENDA -}

\section{+++ GRANITOS}

OOOO SIENOMONZONITOS, QUARTZO-MONZONITOS

$\mathrm{V}_{\mathrm{V}}^{\mathrm{V}}$ GABROS, MONZO-GABROS I DIORITOS

监是过 NORITOS

$\mathrm{x} \times \mathrm{x}$ ENDERBITOS

F OPX-QUARTZO-DIORITO, OPDALITOS E JOTUNITOS

\begin{tabular}{lll}
\hline$x$ & $X$ \\
0 & 0 \\
0
\end{tabular}

EIIN ANFIBOLITOS

$\square$ GNAISSES E QUARTZITOS ENCAIXANTES

_ CONTATOS GEOLÓGICOS

$\lambda_{\text {bo foliagẽo de fluXo }}$

- RODOVIAS PRINCIPAIS

- - ESTRAdas secundárias

$\underset{1441}{x} \quad$ PICOS

MODIFICADO POR MENDES, J.C. DE TÖPFNER, C.; PETRICK, F, JAFFÉ, P. NEUMANN, R. (1986).

TESE DE DOUTORADO - IG / USP - (1996) 
Os autores fornecem também um breve relato da petrografia: os megacristais são microclina micropertítica e plagioclásio (oligoclásio/andesina) e a matriz compõe-se de hiperstênio, clinopiroxênio, hornblenda hastingsítica, Ti-biotita e plagioclásio com a mesma composição. Os minerais acessórios são magnetita, apatita, titanita e zircão. Em direção à borda, o piroxênio é substituído por anfibólio e a biotita se torna mais rica em ferro, com cores mais esverdeadas. Feições de deformação como plagioclásios com lamelas de geminação recurvadas, sub-grãos de feldspato e quartzo, biotitas com clivagens irregulares e cristais fraturados são comuns e aumentam nas proximidades da porção externa do corpo.

No texto explicativo do PLGBB, Signorelli (op.cit.) descreve o maciço de Venda Nova como sendo formado por um domínio externo de sienitos (sienomonzonitos) e quartzomonzonitos porfiríticos, com megacristais de feldspato e matriz média a grossa, com granitos e granodioritos grossos a porfiríticos e dioritos subordinados, e por um núcleo de gabros; em todo o bordo sul e oeste aflora uma faixa contínua de rocha charnoquítica, com largura média de 400 metros. Está encaixado em ortognaisses sin a tardi-tangenciais e paragnaisses do Complexo Paraíba do Sul. Tanto as rochas encaixantes quanto aquelas da porção externa do maciço exibem foliações com mergulhos para o interior do corpo.

Segundo os autores, o sienito possui textura inequigranular xenomórfica e seus minerais essenciais são ortoclásio, oligoclásio, quartzo, biotita, augita sódica e hornblenda. $\mathrm{O}$ diorito tem granulação fina a média e os principais minerais são plagioclásio e biotita. $O$ gabro possui granulação média e compõe-se de andesina, diopsídio, hiperstênio, biotita, ortoclásio, quartzo, apatita, epidoto, opacos e titanita, mostrando fluxo ígneo ao microscópio.

Com relação ao charnoquito, ele é descrito como uma rocha de cor cinza escura a esverdeada e granulação média a grossa, ligeiramente orientado com foliação mergulhando para o interior do maciço. Constitui-se de plagioclásio, quartzo, biotita, hornblenda, hiperstênio, opacos e apatita.

Wiedemann e Mendes (1993) salientaram que as condições tectônicas de menor compressão regional, quando do posicionamento da intrusão de Venda Nova, propiciaram uma menor interação entre os magmas, fazendo com que feições de mistura magmática sejam bem menos freqüentes que em outros maciços vizinhos, como Castelo e Santa Angélica. Descrevem um núcleo gabro-diorítico envolvido por um anel monzonítico a quartzo-sienomonzonítico com típico fraturamento sub-horizontal, e na zona de contato entre eles ocorrendo estruturas tipo "pillow". Os autores também fizeram menção e apresentaram em mapa o anel charnoquítico 
externo da porção oeste/sudoeste, com cerca de $1 \mathrm{Km}$ de largura e composto por hornblendacpx-metanoritos, opx-metadioritos e enderbitos (apud Töpfner, op.cit.). Os charnoquitóides exibem enclaves microgranulares e são cortados por diques de sienomonzonito.

Num trabalho específico sobre a geologia da zona mista entre gabros e sienomonzonitos do maciço de Venda Nova, Petrick (1987) descreveu a mesma como sendo caracterizada por algumas regiões de predomínio de "schlieren" de sienomonzonito numa matriz máfica e fina e outras onde ocorrem porções irregulares do material básico na matriz sienomonzonítica. Cita a presença de xenocristais de feldspatos nos gabros e de piroxênios nas rochas félsicas, caracterizando assim processos de mistura mecânica entre os magmas contrastantes. Petrograficamente, esta íntima interação é confirmada por estruturas de desequilíbrio mineral, obsevadas sobretudo dentre os fenocristais. São descritos diversos estados de reabsorção nos feldspato alcalinos (texturas tipo "finger-print"), plagioclásios com zoneamento complexo (inverso, "patchy zoning") e piroxênios irregularmente transformados em biotita, quartzo, opacos e hornblenda.

Töpfner (1987) estudou os noritos e charnoquitóides da borda externa da intrusão de Venda Nova. Menciona a existência dessas rochas ao sul, oeste e a norte do maciço, correspondendo a um anel com largura variando de 250 a $750 \mathrm{~m}$ e cita a sua ocorrência como enclaves e estruturas tipo "schollen" nos sienomonzonitos e titanita granitos da porção leste/sudeste. Segundo ele, a composição varia de hornblenda-clinopiroxênio norito, hiperstênio diorito, hiperstênio-quartzo diorito e enderbito. Este autor descreveu uma larga zona de contatos agmáticos com o titanita granito a leste, com intercalação de blocos dos dois litotipos e contatos angulosos a sinuosos. Também neste bordo, próximo da Fazenda Alto da Bananeira, relatou a ocorrência, principalmente em blocos, de contatos bruscos e discordantes da foliação com sienomonzonitos/quartzo monzonitos, observando-se porções tipo "schollen" do enderbito nos mesmos, com borda de reação de 3 a $5 \mathrm{~cm}$.

As rochas são descritas como tipos homogêneos, maciços, verde escuro a negros e de granulação variando de fina a grossa. Possuem poucos xenólitos máficos lenticulares que junto com os contatos intrusivos apontam uma origem magmática, o que foi comprovado pela petrografia e geoquímica. Os estudos petrográficos indicam transição entre texturas ígneas e estruturas de recristalização granoblásticas; observações texturais sugerem cristalização segundo a série de Bowen (Töpfner, op.cit.). 
Mendes et al. (1994) publicaram um resumo que contém uma visão geral da geologia e petrografia dos hiperstênio gabros e enderbitos. São relatados como aparecendo na forma de um estreito anel nas bordas oeste e sul e como porções isoladas na parte sudeste do maciço. Afloram em pequenos lajedos, tendo estrutura maciça e com foliação de fluxo incipiente a localmente desenvolvida. Nos enderbitos observam-se enclaves microgranulares básicos arredondados e lenticulares paralelos à foliação da rocha e zonas de interação com material possivelmente sienomonzonítico, que se acha sob a forma de "schlieren" e veios sinintrusivos.

Os litotipos da seqüência enderbítica são descritos como sendo leucocráticos a mesocráticos, com granulação média e textura ígnea bem preservada, predominantemente hipidiomórfica granular; sua composição varia de tonalitos a quartzo-dioritos, com raros jotunitos e granodioritos, e sua mineralogia é andesina, quartzo, biotita, hiperstênio, augita, hornblenda, magnetita, ilmenita, feldspato alcalino, apatita e zircão. Os hiperstênio gabros possuem granulação fina e textura hipidiomórfica granular, localmente microporfiríticos; compõem-se de labradorita, hornblenda, OPX, CPX, magnetita, ilmenita, apatita, zircão e rara biotita.

\section{NORITOS E CHARNOQUTTÓIDES DO MACIÇO DE VENDA NOVA}

Estas rochas estão posicionadas na forma de um estreito e irregular anel que envolve os litotipos de tendência alcalina (gabros/monzogabros e sienomonzonitos/monzonitos) a oeste, noroeste, sul e em porções isoladas no sudeste da intrusão de Venda Nova (cf. Mapa Geológico - Fig. 3.1). Afloram em poucos locais, e isto dificulta sobremaneira a observação e descrição dos aspectos geológicos. Aparecem também isoladamente na região do Alto Rio Cobra, ao norte, como diques sin-intrusivos, de tamanhos variados, no quartzo-sienomonzonito. Suas rochas encaixantes são ortognaisses graníticos a tonalíticos em toda a borda oeste e gnaisses kinzigíticos do Complexo Paraíba do Sul a noroeste e a sul, como foi descrito no item 2.2 desta tese.

São raros os afloramentos dos noritos, aparecendo principalmente na forma de discretos blocos rolados, alguns deles estourados nas encostas das estradas. Os charnoquitóides, que têm composição variando entre enderbitos, opdalitos, jotunitos e OPX-quartzo-dioritos, afloram sobretudo na forma de pequenos lajedos ou menos comumente em drenagens. 
Destacam-se na maior parte dos pontos como blocos rolados de dimensões bastante variadas, chegando a enormes matacões, que muitas vezes apresentam grandes caneluras, denotando uma típica feição intempérica.

Os noritos possuem coloração verde muito escura a negra, granulação fina a muito fina, localmente microporfiríticos, e em amostra de mão identifica-se apenas o feldspato e os minerais máficos. Sua estrutura é maciça e homogênea, mas em determinados pontos, como VN-5 e VN-22, mostram uma foliação bem desenvolvida. As rochas charnoquitóides têm granulação média, coloração cinza esverdeada a verde oliva, mesocráticas, e os minerais identificados a olho nu são feldspato, quartzo, biotita e piroxênio/anfíbólio. Trata-se também de uma rocha isotrópica, mas com orientação das fases minerais (sobretudo máficas) variando bastante, desde vestigial, como nos pontos VN-15 e 20 até bem marcada, caso dos pontos VN-13 e 38. Quando mostram orientação, a direção é paralela aos contatos com as rochas encaixantes e com os domínios internos.

A presença de enclaves microgranulares básicos é muito freqüente nos enderbitos. Possuem formas e tamanhos diversos, arredondados a lenticulares e centimétricos a decimétricos. Quando lenticulares estão via de regra orientados, paralelamente ou fazendo pequenos ângulos com a foliação da rocha, como no caso dos pontos $\mathrm{VN}-24$ e 13. Neste último ponto, ocorre um grande número desses enclaves alongados numa direção preferencial N-S e observa-se também vários diques, veios e bolsões de material feldspático, de provável composição sienomonzonítica. Estes mostram diferentes tipos de relação de contato com o enderbito, como por exemplo: diques de contatos bruscos ou diques sin-intrusivos, com pequeno halo de reação; veios sinuosos interligados; material quartzo-feldspático disperso, assemelhandose a "schlieren" na matriz enderbítica e, finalmente, concentrações localizadas de quartzo ou feldspato (Figura 3.2). Diques pegmatóides ocorrem tanto cortando a foliação (e os enclaves) quanto intrudindo paralelamente a mesma, evidenciando aporte desse material em mais de um estágio da historia evolutiva do enderbito.

Localmente verifica-se a ocorrência nos charnoquitóides de diques e veios sinintrusivos de material máfico muito fino, similar ao norito, originando uma borda de reação félsica que corta o norito ("back veining"). A relação entre as rochas, com contatos bem irregulares, indica um posicionamento simultâneo para ambas. Caso houvesse um maior número de afloramentos na área tal interação entre os litotipos com certeza se repetiria, o que 
indiscutivelmente confirmaria a hipótese de sin-intrusionamento. Töpfner (op. cit.) citou a ocorrência de contato gradacional entre os noritos e os charnoquitóides.

Um fenômeno que é visto em alguns blocos e afloramentos (e.g. VN-13 e VN-4) é a interdigitação irregular entre os charnoquitóides e uma rocha porfirítica, que certamente tratase do sienomonzonito do interior do maciço (não é possível ser amostrado). No ponto VN-4 aflora na encosta uma rocha félsica porfirítica, levemente alterada, e mais abaixo, onde corre uma drenagem junto da estrada, aparece um pequeno laj edo em que se vê o charnoquitóide intimamente associado com porções irregulares do sienomonzonito, mostrando contatos bem plásticos e alguns xenocristais de feldspato isolados no charnoquitóide (Figura 3.3). É bem possível que o contato entre estes litotipos se dê, por toda ou grande parte de sua extensão, sob a forma de zonas mistas, que foram apontadas por Töpfner (op. cit.) em diversos locais e individualizadas no seu mapa geológico. No ponto $\mathrm{VN}-23$ tem-se um afloramento de charnoquitóide ligeiramente foliado e relativamente homogêneo; no entanto, ocorre uma grande quantidade de blocos rolados de enderbitos (mais claros e foliados), de noritos e de sienomonzonitos, e muitos deles exibem duas rochas (norito ou enderbito e sienomonzonito) associadas de uma forma irregular, em contato plástico. Nas cotas mais elevadas vê-se pequenas porções do sienomonzonito em contatos irregulares com o charnoquitóide.

Em termos de estrutura, as rochas charnoquitóides não exibem grandes variações. Além das pequenas mudanças observadas na sua foliação de fluxo, já citadas anteriormente, são verificados fraturamentos sem direções preferenciais e pequenas zonas de cisalhamento dúctil desenvolvidas nas proximidades dos contatos. Uma delas, no ponto $\mathrm{VN}-23$, mostra duas superfícies de cisalhamento sub-horizontais, fazendo cerca de 80 a $100^{\circ}$ entre si, associadas com recristalização de quartzo e feldspato. Diques pegmatóides cortam a foliação e os enclaves máficos, mas acompanham a superfície cisalhada, o que indica terem sido posicionados contemporaneamente ao cisalhamento. Um dique de sienomonzonito corta todas as estruturas, sugerindo ser mais jovem, mas, como ele mostra evidências de penetração num estado não completamente cristalizado (ainda um "mush"?), a afirmação categótica da sua idade relativa de intrusionamento torna-se pouco precisa.

Nas investigações de campo para o desenvolvimento desta tese, os contatos com as rochas encaixantes não foram observados. No entanto, Töpfner (op. cit.) descreveu intrusão de charnoquitóide na superfície de foliação do paragnaisse e um contato intrusivo, brusco, entre o norito e o gnaisse (por ele denominado de Santa Teresinha) nas imediações do rio do Peixe 
(bordo noroeste do maciço). Com relação ao contato entre o para e o ortognaisse, o autor afirmou que o mesmo se dá com o desenvolvimento de uma borda migmatítica.

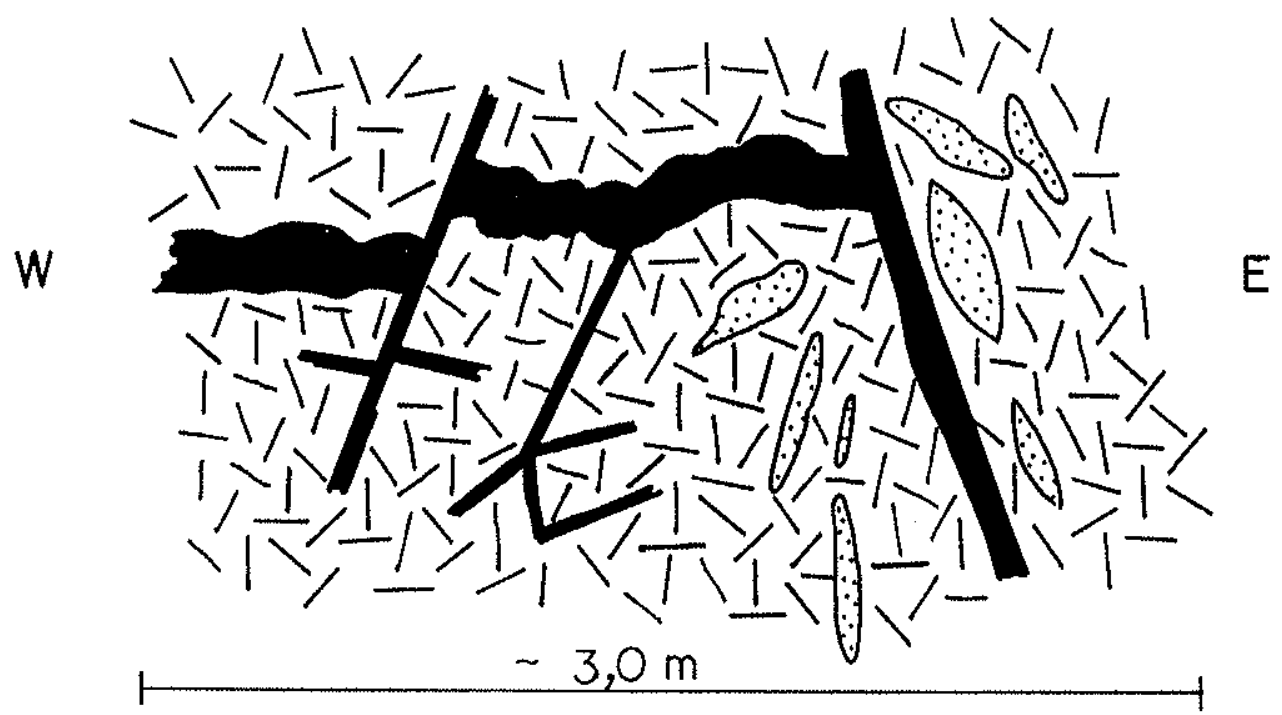

Figura 3.2 - Rocha enderbítica do ponto VN-13 cortada por diques e veios de sienomonzonito (em preto), que mostram relações de contato distintas, retilíneas e sinuosas (sin-intrusivos). Também ocorrem enclaves microgranulares básicos de formas irregulares (pontilhados).

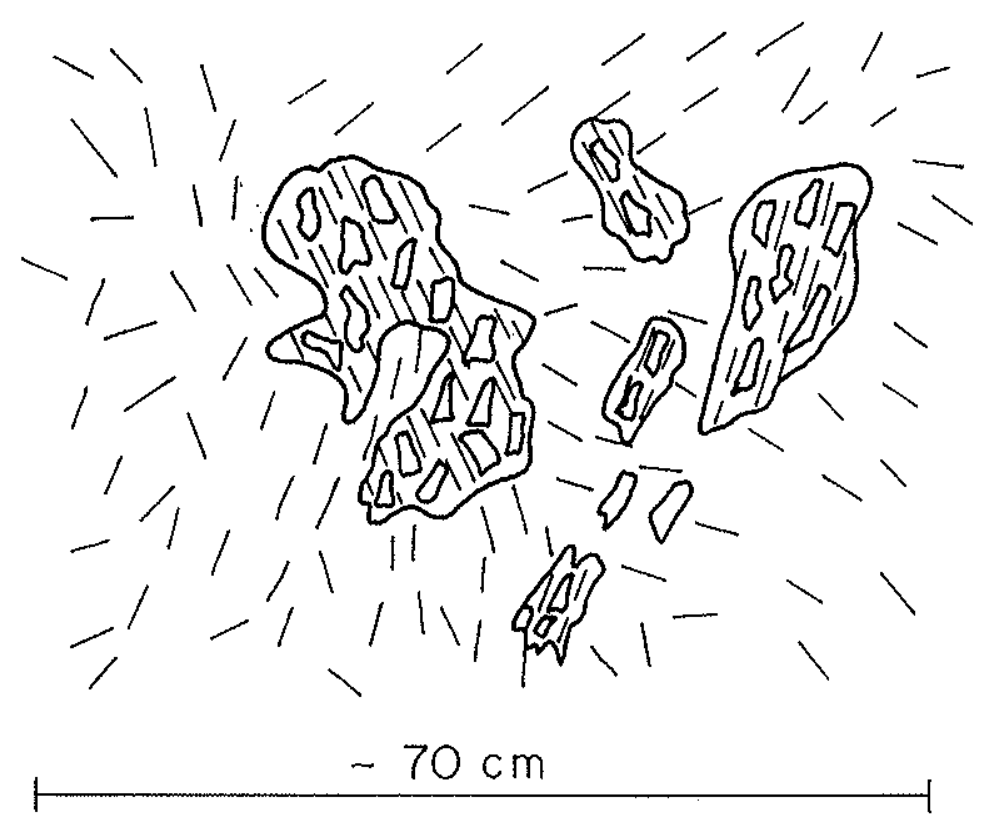

Figura 3.3 - Schlieren de sienomonzonito no charnoquitóide do ponto VN-4. Observam-se xenocristais de feldspato isolados na matriz charnoquitóide. 


\subsection{MACIÇO DE VÁRZEA ALEGRE}

Assim como ocorre no maciço de Venda Nova, os litotipos presentes em Várzea Alegre comumente exibem evidências de interação mecânica entre si, sobretudo os dioritos e granitos. Tal fenômeno dificulta o estabelecimento da estratigrafia do maciço, mas neste trabalho, baseando-se nas observações de campo e em dados da literatura, a seguinte seqüência estratigráfica é assumida:

\begin{tabular}{|l|l|}
\hline $5^{\circ}$ pulso & Titanita-granito (quartzo-monzonito) \\
\hline $4^{\circ}$ pulso & Granito megaporfirítico \\
\hline $2^{\circ} / 3^{\circ}$ pulso & Dioritos/quartzo-dioritos \\
\hline $2^{\circ}$ pulso & Gabros/dioritos \\
\hline $1^{\circ}$ pulso & Charnoquitóides \\
\hline
\end{tabular}

O lapso temporal decorrido no posicionamento dos litotipos presentes foi certamente muito curto, e os gabros/(quartzo)dioritos e o granito megaporfirítico correspondem provavelmente a um episódio magmático bimodal (intrusionamento simultâneo). Os dioritos devem corresponder a uma evolução do magma gabróico (provavelmente por cristalização fracionada) que se misturou com o magma granítico originando quartzo-dioritos e quartzomonzodioritos. Uma posição definitiva quanto às relações genéticas entre essas rochas será dada com a finalização da tese de doutoramento de Medeiros (em preparação).

O mapa geológico do maciço intrusivo de Várzea Alegre está na Figura 3.4.

\section{Trabalhos prévios}

No texto explicativo do PLGBB, Tuller (op. cit.) descreve o Maciço Várzea Alegre como um polidiápiro concêntrico de morfologia montanhosa nas bordas e centro arrasado. Não observou grandes deformações, a não ser no bordo oeste, onde o hiperstênio granito foi afetado por uma zona de cisalhamento de alto ângulo e no centro, com a foliação exibida pelo titanita granito. Cita os seguintes litotipos: hiperstênio-granito porfirítico, microclina-granito porfirítico, tonalito/hornblenda-tonalito, norito, titanita-granito e diorito. Abaixo seguem as características destas rochas conforme relatado no trabalho. 


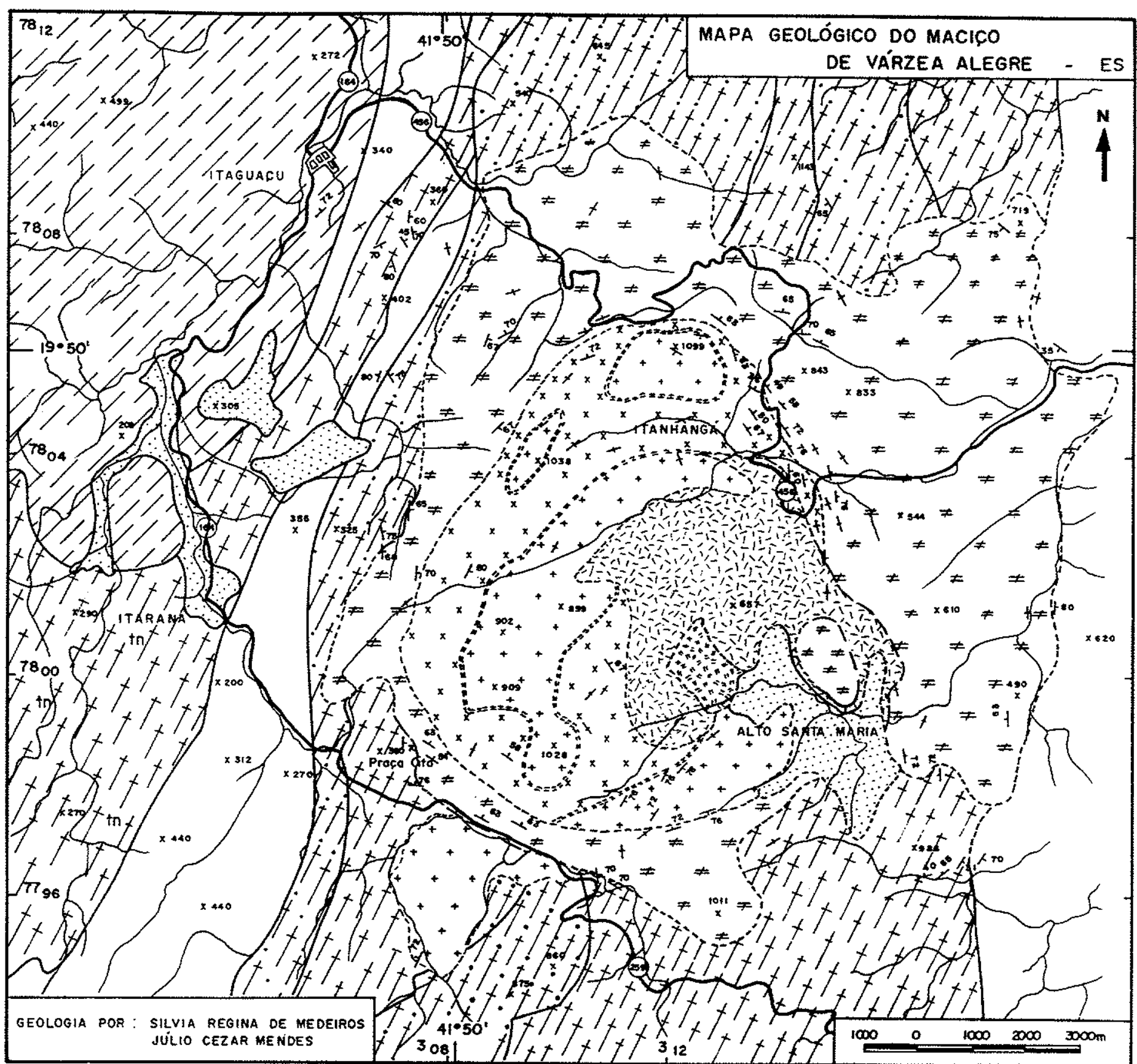

\section{- LEGENDA -}

SEOIMENTOS CENOZÖICOS

\section{COMPLEXO INTRUSIVO}

DOMINHOS INTERNOS

ESEN - QUARTZO-SIENITO FINO

+4 - GRANITO MEGAPORFIRITICO

[Xxx] - QUARTZO-DIORITO, OUARTZO - MONZODIORITO, MONZONITO

WII. OPX - GABRO

\section{DOMINIO EXTERNO}

FED - CHARNOQUITÓIDES

SEQUENNCIAS ENCAIXANTES REGIONAIS

\section{IfD - ORTOGNAISSE}

WIITH - GRANULITO FINO

$\not \supset A$ - GNAISSE ENDERBITICO

D - KINZIGITO

tin 7 - ORTOGNAISSE TONALITICO

$\angle$ - CONTATO OBSERVADO

$[--$ - CONTATO INFERIDO

$E=$ - CONTATO GRADACIONAL

$\square$ - CONTATO EXTRAído do MAPA ElaBorado PELA CPRM CONTATO EXTRAIDO DO MAPA ELABORAD
(PROJETO-ES) PARA A FOLHA COLATINA

$X$ - FOLIASÁO COM MERGULHO SUb - VERTICAL

CH - FOLIACÃO COM MERGULHO INCLINADO

- ES- ESTRADA PRINCIPAL

- DRENAGEM

$x=10$ - PICO

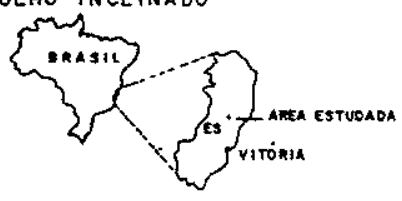

FIGURA 3.4 
O hiperstênio-granito aflora nạ parte externa do maciço em serras abauladas e exibe megacristais de feldspato bem formados e aleatoriamente distribuídos; possui cor cinza escuro esverdeada e é isotrópico, pouco deformado, e seus contatos com as encaixantes são geralmente bruscos. Compõe-se de andesina/labradorita, microclina, quartzo, hiperstênio, biotita, anfibólio, opacos, apatita e zircão.

A área de predominância do microclina-granito porfírítico está nas porções intermediárias, comumente em cotas mais elevadas. Trata-se de uma rocha rica em megacristais de feldspato alcalino centimétricos com pouca ou nenhuma deformação e com xenólitos de gnaisses aluminosos. Sua mineralogia é microclina, quartzo, oligoclásio, muscovita, opacos, apatita, zircão e epidoto.

$O$ hornblenda tonalito situa-se principalmente na parte central do maciço, em regiões bem arrasadas. Sua cor é cinza-médio, a textura é hipidiomórfico granular rica em megacristais de feldspato e constitui-se de andesina, biotita, quartzo, hornblenda, diopsídio e acessórios (opacos, apatita, allanita e epidoto). Ocorre associado um quartzo-diorito cinza escuro a verde, foliado, de granulação média e textura sub-ofítica, rico em enclaves microdioríticos, que tem a seguinte mineralogia: andesina, biotita, olivina, hornblenda, quartzo, ortoclásio, minerais opacos, titanita e apatita.

O norito ocorre no centro da intrusão, de aspecto homogêneo, possuindo granulação média e textura hipidiomórfico granular, cortado por muitos diques de granito porfíritico. Sua composição é andesina, biotita, augita, hiperstênio, quartzo, feldspato alcalino, hornblenda, minerais opacos e apatita.

Também no centro do corpo aparece, sob a forma de laj edos e matacões, o titanita granito fino de textura granolepidoblástica, cor cinza clara e com foliação de fluxo. Compõe-se de microclina, quartzo, plagioclásio, biotita, titanita e minerais acessórios.

O quartzo-diorito encontra-se na porção central e intermediária do maciço, em regiões geralmente arrasadas, sob a forma de lajedos e matacões com esfoliação esferoidal. Possui granulação fina, cor cinza escura, constituída por andesina, diopsídio, hornblenda biotita, hiperstênio, quartzo e minerais acessórios.

Uma abordagem detalhada da geologia, petrografia e geoquímica do Maciço de Várzea Alegre encontra-se na dissertação de mestrado de Medeiros (op. cit.), que teve como enfoque principal os litotipos do domínio interno e suas variadas interações. O domínio externo charnoquitóide foi sumariamente relatado. É signiticativa a diferença em relação ao exposto por 
Tuller (op. cit.), tanto a nível de geologia (mapa geológico e descrição) quanto a petrografia, geoquímica e petrogênese. Como o nível de detalhe e interpretação é muito superior, nesta tese serão utilizados preferencialmente, quando necessário, os dados, descrições e aspectos conclusivos do trabalho de Medeiros (op. cit.).

A autora salienta a forma circunscrita do maciço, com gabros-norito no centro circundados por quartzo-dioritos, quartzo-monzodioritos, quartzo-monzonitos e granitos megaporfiríticos, caracterizando um diápiro de zoneamento inverso. Um pequeno corpo de titanita granito fino aflora junto aos gabros. Todo este conj unto é circundado por um largo anel charnoquítico. Os diversos litotipos do domínio interno exibem estruturas de fluxo (que têm como principais minerais marcadores as biotitas e feldspatos) e com forte mergulho que são mais proeminentes próximas ao contato com o domínio externo. Os charnoquitóides são tratados como rochas com foliação metamórfica penetrativa.

Fenômeno bastante realçado e explorado no trabalho é o da interação e mistura mecânica entre magmas contrastantes, sobretudo do granito megaporfirítico com o diorito, e raramente com o gabro; tais mecanismos de mistura originaram feições típicas como estruturas em rede, enxame de enclaves máficos em matriz félsica, megacristais de feldspato manteados e grãos de quartzo corroídos embainhados por minerais máficos nas rochas de composição intermediária. Os parágrafos que se seguem trazem uma rápida descrição dos tipos litológicos do maciço, transcrita de Medeiros (op. cit.).

O sub-domínio gabro-norítico aflora no centro arrasado da intrusão, em laj edos e morrotes. São rochas de granulação média a grossa, com indice de cor de aproximadamente $50 \%$, cinza-médio e que são freqüentemente cortadas por diques simples ou compostos (leucocráticos a melanocráticos) que exibem diferentes graus de plasticidade. Possui raros enclaves e o contato com o charnoquito foi observado no bordo leste, aparentemente gradacional; por outro lado, com o granito megaporfirítico observou-se uma zona de contato numa estrutura em rede. Compõe-se de: plagioclásio An50-65 que mostra evidentes sinais de deformação (lamelas recurvadas, extinção ondulante e muito fraturamento) e recristalização localizada que pode estar associada a "stress" posterior a cristalização da rocha; OPX (com lamelas de exsolução de CPX e de minerais opacos, intercrescimento simplectítico e deformação gerando cristais falhados e fraturados, kink-bands e recristalização nos bordos); augita/salita poiquilítica que formam coronas de reação com hornblenda e que possuem lamelas de exsolução de OPX; hornblenda substituindo os piroxênios e envolvendo-os nas coronas; biotitas pardas em 
ripas e castanho escuras como megacristais, substituindo piroxênios e anfibólios ou em glomérulos máficos; minerais opacos (ilmenita, magnetita, pirita e rara calcopirita) e acessórios (até 3\% de apatita, algumas bem desenvolvidas, quartzo e zircão). As estruturas de desequilíbrio mineral observadas são relacionadas a reações em estado subsolidus.

O subdomínio de rochas intermediárias (quartzo-dioritos, quartzo-monzodioritos e quartzo-monzonitos) compreende tipos cinza claros a escuros e esverdeados quando muito finos; o índice de cor varia de 40 a $70 \%$ e a textura é equigranular. Foi delimitado numa região que vai de norte a oeste e numa porção mais interna do corpo, aflorando ao longo de paredões, em meias encostas e em lajedos, além de serem comuns blocos rolados. Seus contatos com o granito megaporfirítico se dão na forma de espetaculares estruturas em rede de tamanhos diversos, decimétricas a métricas, que tendem a acompanhar a forma da intrusão. Caracterizam-se por zonas de "schlieren" graníticos numa massa quartzo-diorítica que por vezes fica isolada na forma de enclaves arredondados a lenticulares. Tal faixa de interação (sólido-líquido ou "mushmush") mostra um volume cada vez maior de granito à medida que se aproxima do sub-domínio desta rocha. $O$ contato dos litotipos intermediários com o gabro-norito não aflora, mas foi definido como gradativo em função de mudanças de textura e índice de cor. Localmente são cortadas por diques e bolsões de granitos pegmatóides e por espessos diques de titanita granito. Trata-se de um grupo bem heterogêneo, com grande variação na proporção das fases minerais. A mineralogia básica é: plagioclásio oligoclásio-andesina por vezes com geminação recurvada e antipertíticos, ricos em micro-inclusões e raramente como megacristais ou zonados; feldspato alcalino localmente pertítico, geminado e/ou poiquilítico, assim como mesopertíticos nos quartzo-monzodioríticos; quartzo amebóide com extinção ondulante e originando sub-grãos, ocorrendo também nos intercrescimentos simplectíticos (com plagioclásio, biotita e hornblenda); salita/augita e hiperstênio/ferro-hiperstênio hipidiomórficos a xenomórficos que em muitos casos estão associados nos glomérulos máficos e são substituídos por hornblenda; biotita como cristais maiores hipidiomórficos ou pequenas ripas dispersas, sendo bem limpas ou com muitas inclusões de apatita e zircão; hornblenda rica em $\mathrm{Fe}$ ou $\mathrm{Mg}$ de tamanhos e formas variadas; minerais opacos e apatita e zircão como minerais acessórios.

O granito megaporfirítico ocorre principalmente nas partes medianas do complexo, e numa menor área nas bordas e próximo do centro, ocupando as cotas mais elevadas como na Pedra Alegre, Pedra da Onça e Pedra Paulista, o pico mais alto da região. Possui tom cinza a rosado e sua textura é porfirítica, com megacristais centimétricos de feldspato alcalino 
tabulares, normalmente orientados, e matriz fina a média. Trata-se de uma rocha bem homogênea, com esparsos enclaves surmicáceos de poucos centímetros de tamanho e estrutura de fluxo pronunciada marcada pela orientação do eixo maior dos megacristais de feldspato. Aparece como "schlieren" nos termos intermediários e mais raramente no gabro, como foi descrito no parágrafo anterior. Localmente observam-se porções irregulares de quartzo-diorito no granito, apresentando contatos dúcteis. A sua composição é: microclina predominantemente como megacristais tabulares de até $3 \mathrm{~cm}$, com bordos irregulares e muitas inclusões, e menos freqüente na matriz. Certas lâminas possuem megacristais de mesopertita corroídos, oligoclásio bem alterado, localmente todo saussuritizado, quartzo xenomórfico e alguns grãos com contorno corroído, extinção ondulante e fraturados, podendo ser megacristais; biotita como máfico principal, exibindo inclusões de apatita e minerais opacos; apatita é a fase acessória mais freqüente, seguida por zircão e allanita que são raros.

O granito fino a titanita aflora numa pequena área no centro do maciço, sendo também comum ocorrer sob a forma de matacões e diques que cortam os litotipos do domínio interno. É foliado e possui granulação fina, cor cinza claro, textura hipidiomórfica granular e xenólitos microgranulares máficos angulosos. Apresenta microclina corroída como o mineral mais abundante, seguida por plagioclásio hipidiomórfico alterado, quartzo xenomórfico e embainhado, ripas de biotita hipidiomórficas dispersas na rocha, titanita substituindo ilmenita e minerais opacos, apatita, zircão e allanita como acessórios.

O domínio externo é formado por rochas charnoquíticas que afloram numa larga faixa nos bordos norte e leste e estreita nos bordos sul e oeste da intrusão. Apresentam grande homogeneidade composicional e textural e uma observação mais detalhada é prẹjudicada por espessa camada de alteração. Segundo a autora, trata-se de uma rocha de matriz grossa e com porfiroblastos de feldspato que podem chegar a $8 \mathrm{~cm}$ de eixo maior. Sua foliação metamórfica é realçada pelos megacristais ocelares de feldspato alcalino envolvidos por cristais menores, e torna-se mais pronunciada próxima ao contato com o domínio interno, acompanhando o contorno do mesmo. A matriz é composta por plagioclásio, feldspato alcalino, quartzo, biotita OPX, anfibólio, minerais opacos, apatita, zircão e allanita.

Suas relações de contato com as rochas do domínio interno são preferencialmente interdigitadas com os quartzo-dioritos e de assimilação com o gabro. Ela detalha uma estreita faixa de contato (com cerca de $2 \mathrm{~m}$ de largura) que ocorre no norte da área, na base da Pedra Paulista (ponto VA-74). Aí o charnoquitóide e o quartzo-monzodiorito estão interdigitados, 
assemelhando-se a uma estrutura migmatítica (Foto 3.1). Os contatos entre eles são bruscos ou em borda de reação com assimilação de megacristais de feldspato pela rocha quartzomonzodiorítica. Estas feições se repetem em alguns locais do bordo oeste, até as proximidades do ponto VA-205.

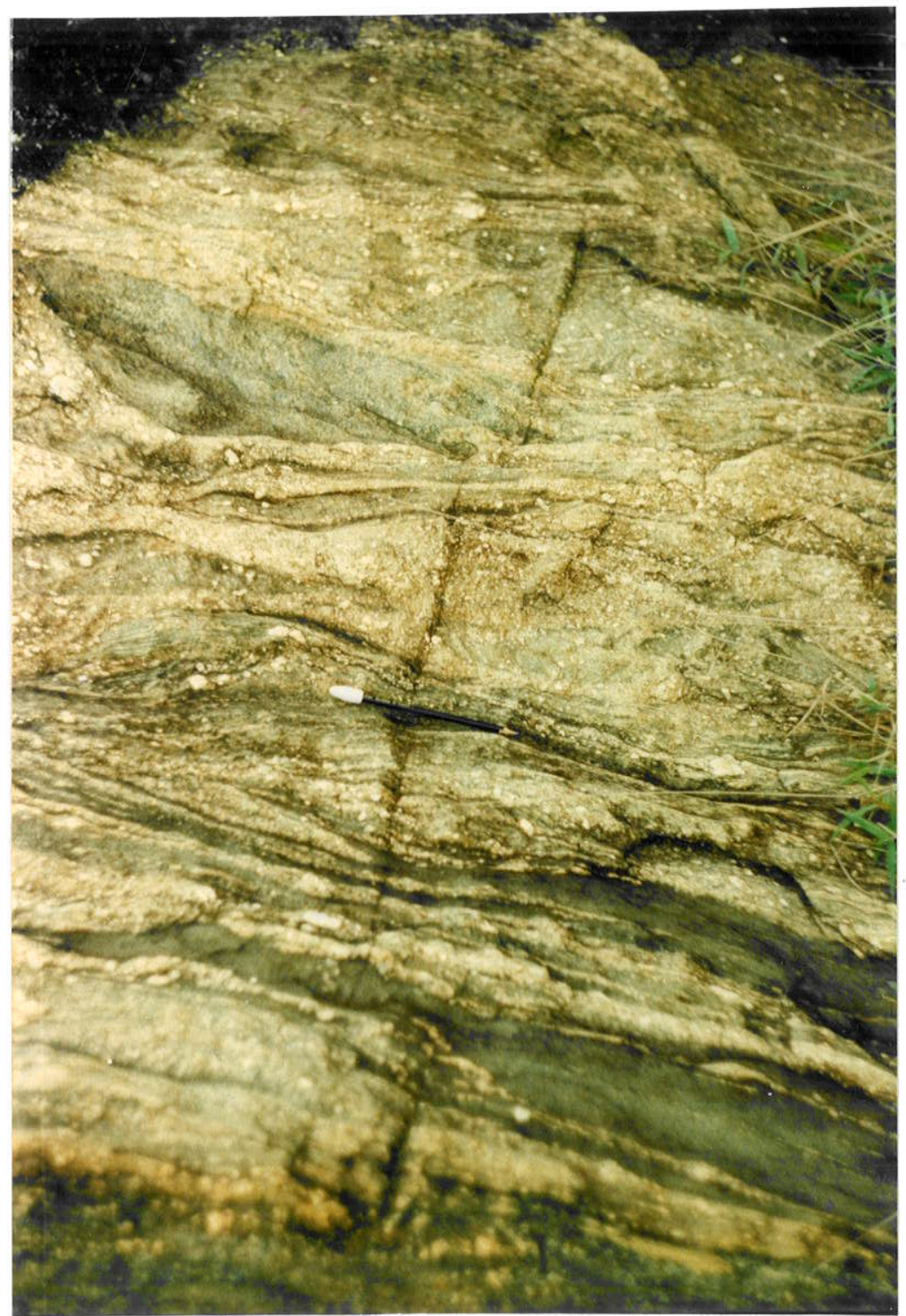

Foto 3.1 - Contato entre o charnoquitóide e o quartzo-monzodiorito no ponto VA-74. Observa-se interdigitação entre os litotipos e xenocristais de feldspato no quartzo-monzodiorito.

Medeiros et al. (1994) publicaram um resumo que traz as principais características geológicas e petrográficas do Maciço de Várzea Alegre. Foram individualizados dois domínios: um interno, consistindo de hiperstênio-gabro, quartzo-diorito a quartzomonzodiorito e granito megaporfirítico; e outro externo formado por charnoquitóides. Todo o conjunto está encaixado nas faixas gnáissico-granulíticas regionais, delimitadas por Tuller 
(op.cit.). A descrição do domínio interno é muito semelhante àquela dos parágrafos acima e em função disto apenas o domínio externo será aqui relatado.

Os charnoquitóides correspondem ao litotipo de maior área aflorante. No bordo oeste formam serras de cotas inferiores àquelas do domínio interno, e nos bordos norte e leste as elevações são expressivas. São rochas porfiríticas, de coloração verde escura e com foliação ígnea bem desenvolvida, concordante com os contatos do maciço. A quantidade dos megacristais de feldspato varia bastante, conferindo localmente à rocha mudanças texturais e composicionais. Trata-se de um domínio isotrópico com raros enclaves e diques de grande porte. Os charnoquitóides variam composicionalmente entre enderbitos (quartzo-dioritos), jotunitos (quartzo-monzodioritos) e quartzo-monzonitos (mangeritos).

\section{CHARNOQUITÓIDES DA BORDA DO MACIÇO DE VÁRZEA ALEGRE}

São rochas megaporfiriticas que ocorrem bordejando as litologias do domínio interno do corpo, na forma de um anel irregular que é bem largo a leste e a norte e se estreita a oeste e a sul, estando interrompido a sudeste, onde não são observados afloramentos desta porção externa (cf. Mapa Geológico - Fig. 3.4). Estão encaixadas nos gnaisses kinzigíticos do Complexo Paraíba do Sul em toda a borda leste e num pequeno segmento do flanco sudoeste, nos ortognaisses tipo Colatina ao sul e em pequenas faixas no norte e finalmente nos ortognaisses enderbíticos tipo Santa Tereza a sudeste, em todo flanco oeste e ao norte, conforme encontra-se em Tuller (op. cit.) e foi detalhado no final do item 2.2 desta tese.

\section{Relações de contato}

Os contatos com os orto e paragnaisses regionais são observados em poucos afloramentos, apresentando-se de forma brusca, confirmando o caráter intrusivo da seqüência charnoquitóide. Na maioria das vezes, o que ocorre é um mascaramento dos mesmos por capa de alteração espessada ou pela formação de solo na zona de contato. Tal processo é freqüente no bordo leste, onde se tem numa encosta da estrada que vai do lugarẹ o de Caldeirão de Baixo para São João de Petrópolis afloramentos do gnaisse aluminoso e na outra encosta aflora o charnoquitóide. Entre elas existe solo residual, ou corre o rio Santa Maria, de leito arenoso, não sendo portanto possível observar o contato. Na porção norte, região de Alto Santa Julia, acontece fenômeno similar, isto é, afloramentos de charnoquitóide (como os do leito do Córrego Frio) e 
de ortognaisse Santa Tereza bem perto um do outro, não observando-se, no entanto, a zona de contato. Aí tem-se o agravante que a rocha encaixante também possui cor esverdeada, por se tratar de um granulito, mas sua granulação mais fina e a presença de granada possibilita diferenciá-la. Nos pontos VA-72 (no leito de uma drenagem) e 295, próximos daí, ocorre o contato brusco entre os dois litotipos, mostrando-se paralelo à xistosidade do gnaisse e à orientação dos megacristais de feldspato do charnoquitóide (pela localização dos pontos, trata-se provavelmente de mega xenólito de gnaisse).

Uma bela exposição do contato entre os charnoquitóides e os granulitos pode ser vista no bordo oeste, na localidade denominada Triunfo. No ponto VA-14 observa-se o contato brusco entre as rochas, com a xistosidade do gnaisse exibindo uma maior ondulação e pequenas dobras intrafoliais, e alguns megacristais de feldspato do charnoquitóide truncando o contato. Tais megacristais são predominantemente tabulares e orientados e o gnaisse possui foliação marcante, mergulhando para o interior do maciço, paralela àquela da rocha intrusiva, e por sua vez também paralela ao contato (Foto 3.2). Esta feição pode ser vista em outros pontos onde aflora o contato com as encaixantes, em qualquer borda do corpo.

Nos pontos VA-177 e VA-273, no leito e margem do córrego Limoeiro dos Carvalhos, novamente pode-se observar a zona de contato com o gnaisse Santa Tereza. É também brusco, mas localmente ocorre interdigitação entre os litotipos.

$\mathrm{Na}$ parte sudoeste do complexo, as rochas do domínio charnoquitóide estão em contato com um pequeno corpo de granito megaporfirítico. A região de contato, ao longo do leito do córrego Limoeiro dos Carvalhos, é bastante complexa, por ser difícil a separação das duas litologias na superfície alterada e por aparecer também um gnaisse mesocrático muito foliado e com granada intercalado com as rochas porfiríticas. Num perfil entre os pontos VA178 e VA-271 observa-se que no ponto VA-178 aflora o charnoquitóide homogêneo, com megacristais tabulares orientados, localmente ocelares; dirigindo-se ao ponto VA-272 sua foliação se torna muito irregular, caótica. Neste ponto ele está irregularmente intercalado ao gnaisse, exibindo xenólitos do mesmo.

O charnoquitóide assimila granada do gnaisse, da mesma forma que o granito porfirítico, que aflora na encosta da margem esquerda do rio exibindo um contato brusco com o gnaisse e com muitos xenólitos do mesmo. No ponto VA-271 ocorre o charnoquitóide em contato brusco com uma rocha mesocrática, de foliação conspícua, e com pequenos megacristais idiomórficos de feldspato, tratando-se provavelmente de uma variação textural do gnaisse. 
Com relação ao contato das rochas charnoquitóides com os litotipos do domínio interno, eles são observados em vários locais de forma diferenciada.

No leito do córrego Limoeiro, no ponto VA-5, tem-se o contato entre o charnoquitóide e o quartzo-diorito. Ele ocorre numa pequena zona de cisalhamento dúctil, o que propicia uma forte interação mecânica entre as duas rochas, que estão intensamente intercaladas resultando num aspecto gnáissico.

$\mathrm{Na}$ parte inferior da drenagem aflora o charnoquitóide bem foliado em contato irregular (plástico) com o quartzo-diorito. À medida que se sobe, a interação mecânica torna-se acentuada e a foliação é mais pronunciada, com pequenas dobras intrafoliais (Foto 3.3). Tal associação propicia um pequeno grau de assimilação do charnoquitóide pelo quartzo-diorito, o que provoca, localmente, o isolamento de megacristais de feldspato na matriz quartzo-diorítica (Foto 3.4). Nas cotas mais altas pode-se observar o contato irregular do quartzo-diorito com o granito megaporfirítico.

O contato dos charnoquitóides com o gabro-norito no bordo leste é observado ao longo dos pontos VA-141, VA-142 e VA-35, ocorrendo tanto de forma brusca como numa estreita faixa de reação a meia encosta, onde o material básico envolve porções da rocha charnoquitóide e isola megacristais da mesma (Foto 3.5).

No bordo sul, a relação de contato entre o charnoquitóide e o granito megaporfirítico do domínio interno não foi observada, podendo estar aflorando em cotas mais elevadas e de difícil acesso. Na porção nordeste da área, o contato com o quartzo-diorito não aflora, observando-se apenas solo nessas regiões. Como tal aspecto é verificado em diversos locais, tanto em contatos com as litologias do domínio interno quanto externo, optou-se nestes casos por inferir o contato tomando-se como referência os afloramentos mais próximos.

Assim como ocorre com os gnaisses encaixantes, a foliação dos charnoquitóides torna-se mais pronunciada junto aos contatos com os litotipos do domínio interno do complexo, acompanhando o contorno dos mesmos. 


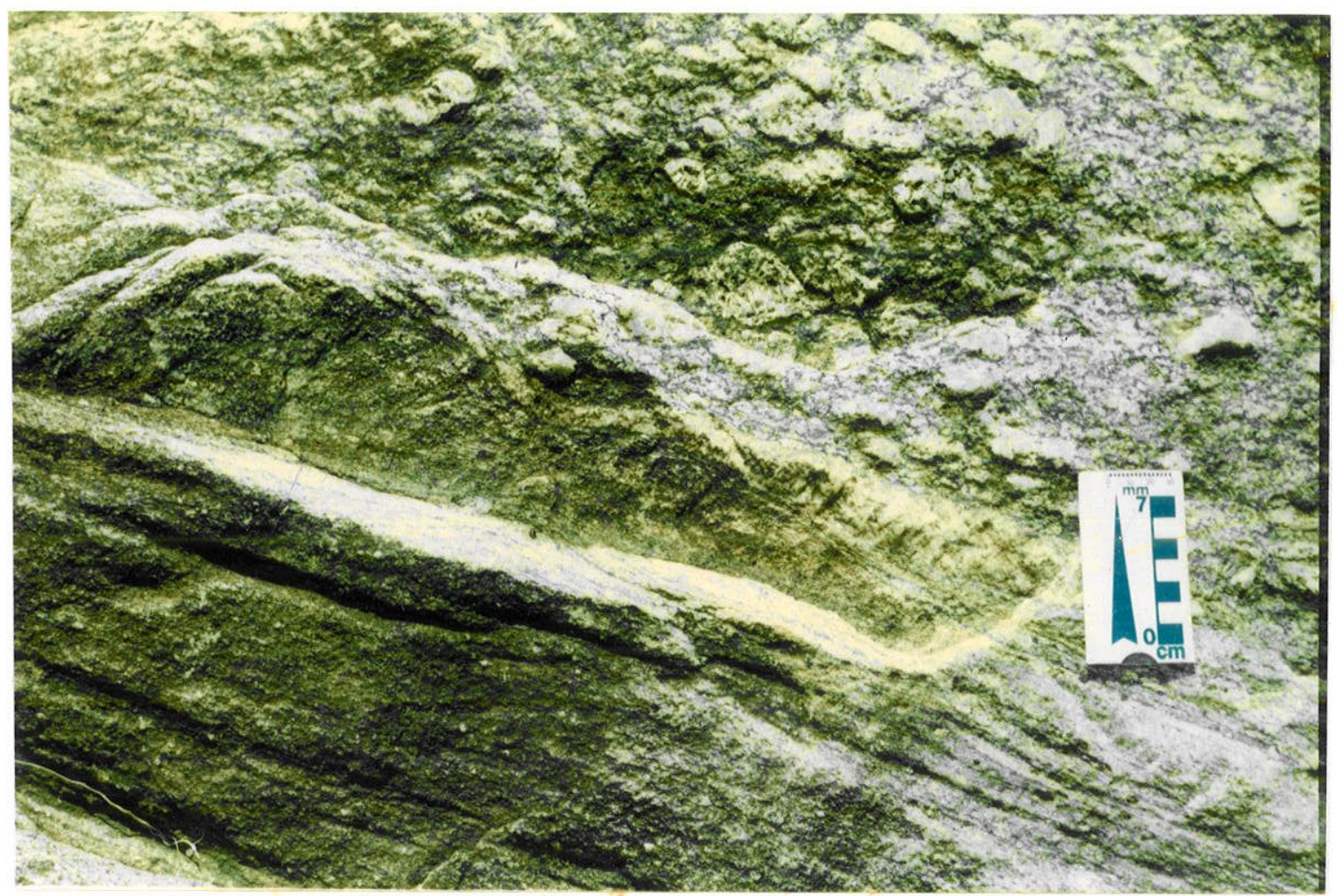

Foto 3.2 - Contato brusco entre o charnoquitóide e o gnaisse encaixante no ponto VA-14. Os megacristais estão orientados e alguns deles truncam o contato.

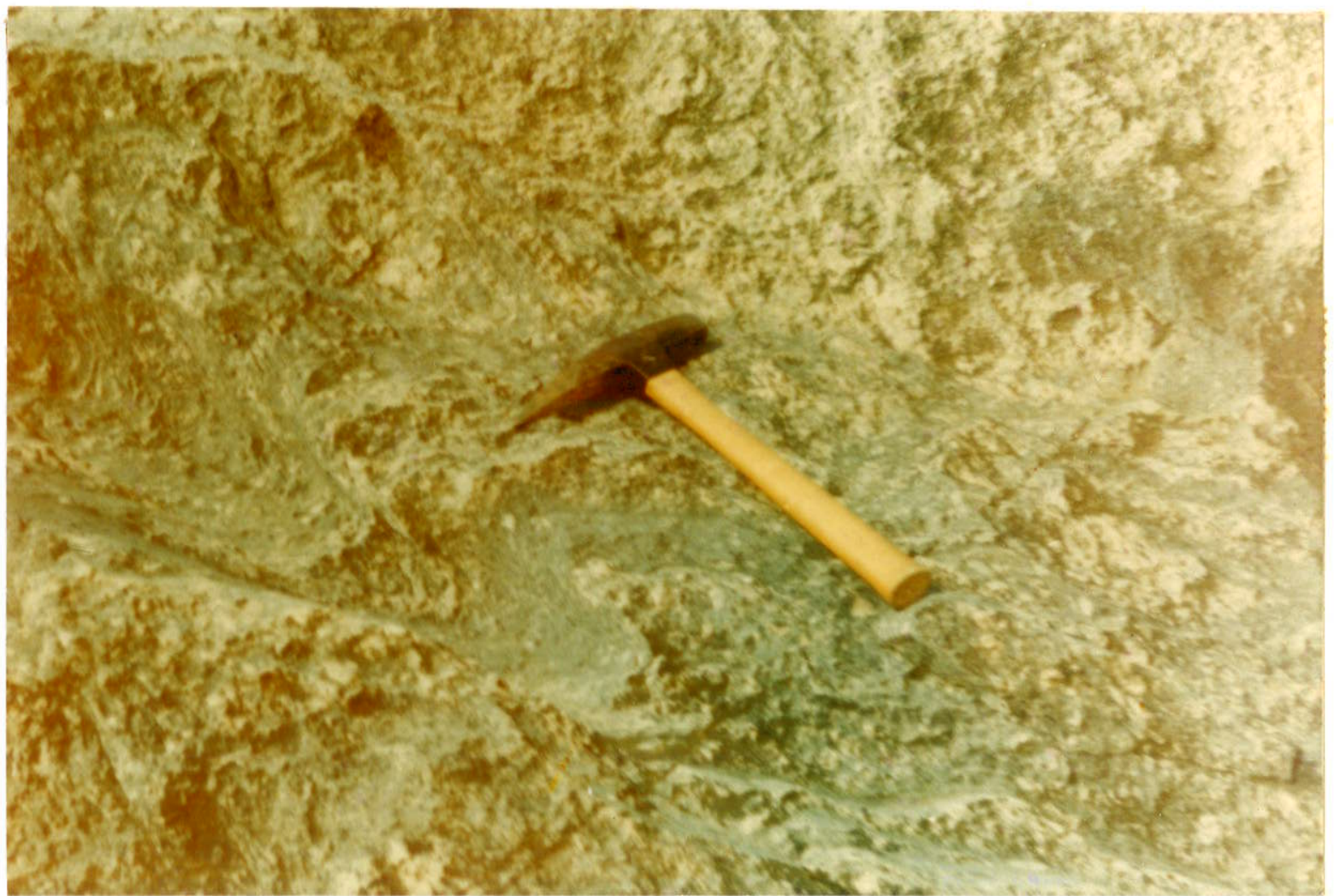

Foto 3.3 - Detalhe do contato entre o charnoquitóide e o quartzo-diorito. Nota-se uma forte interdigitação entre as rochas (assemelhando-se a uma estrutura gnáissica) e o desenvolvimento de pequenas dobras intrafoliais.

Ponto VA-5. 


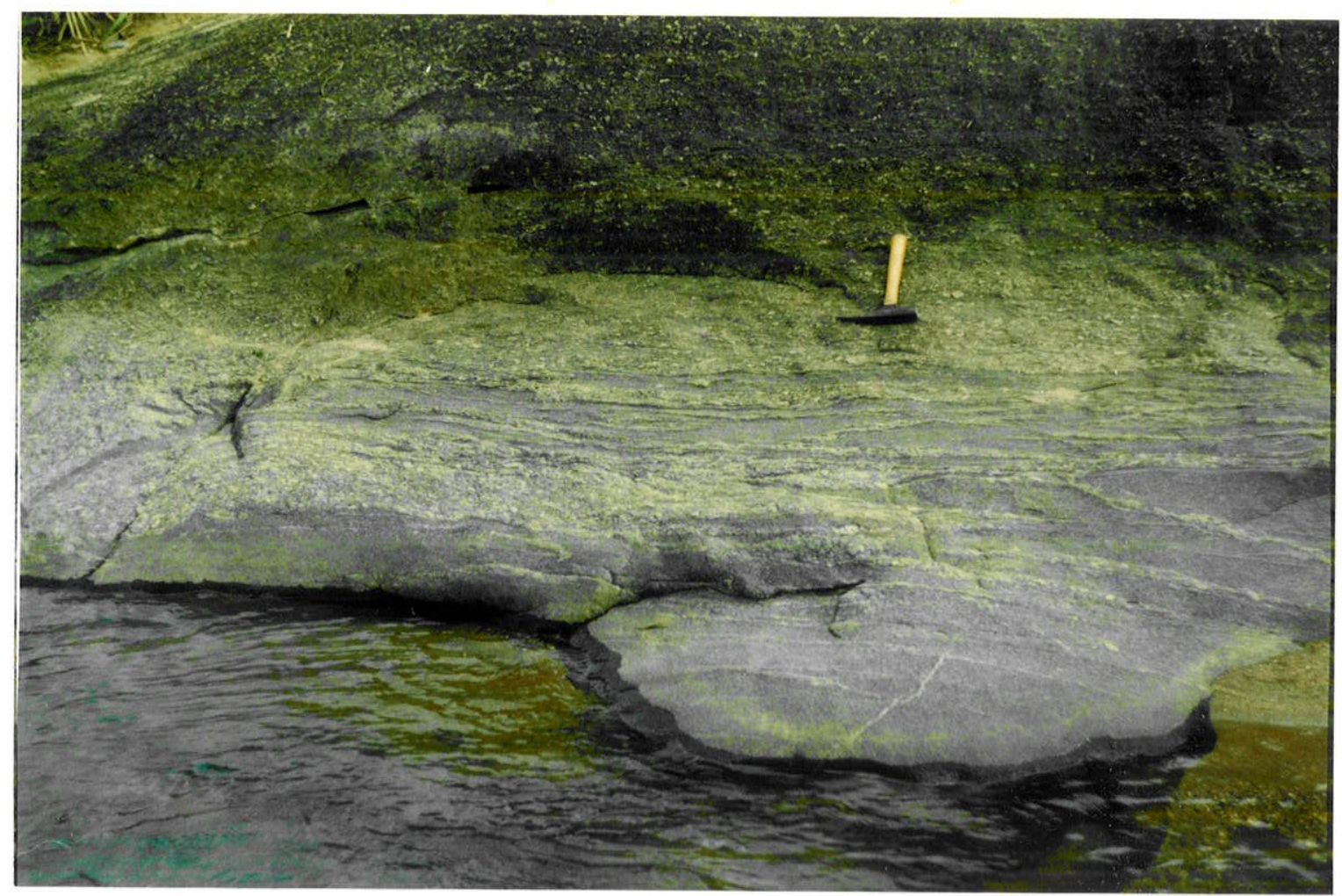

Foto 3.4 - A parte inferior da foto exibe a interdigitação entre o charnoquitóide e o quartzo-diorito do ponto VA-5, e na parte superior (onde está o martelo) a matriz diorítica contém xenocristais de feldspato.

\section{Aspectos geológicos dos charnoquitóides}

As rochas charnoquitóides do Maciço de Várzea Alegre têm como característica marcante sua textura porfirítica com megacristais, de até $6 \mathrm{~cm}$ de tamanho, de feldspatos com superfícies hexagonais ou tabulares (orientados ou não) e matriz de granulação média a grossa que varia de leucocrática a mesocrática, e com uma típica cor verde escura quando fresca e acastanhada a marrom quando alterada. A proporção entre megacristais e matriz muda razoavelmente num mesmo afloramento e pode variar bastante de um afloramento para outro, e em amostra de mão a matriz é composta por feldspato, quartzo, biotita e piroxênio/anfibólio.

A separação faciológica destas rochas em mapa não foi realizada pelas seguintes razões: por se tratar de uma litologia de granulação muito grossa, seria necessário um mapeamento numa escala bem maior do que a adotada no presente trabalho para possibilitar a delimitação em área dos fácies, já que ocorre variação da composição em pequenas distâncias (mudança na proporção megacristais/matriz); pela dificuldade de classificação dos litotipos, que por serem megaporfiríticos dão margem a consideráveis erros numa contagem modal, mesmo tendo se optado, para as rochas mais grossas, por três cortes ortogonais numa mesma amostra, como foi explicado no item 1.4 e, finalmente, pela dificuldade de amostragem na grande maioria 
dos muitos afloramentos da região, onde predominam amplos laj edos em encostas e drenagens, com superfícies muito aplainadas e/ou com camada de alteração.

Como descrito acima, as rochas charnoquitóides afloram maciçamente na área, tanto nas encostas como em extensos laj edos na parte superior e base dos morros, nas superfícies planas e nas drenagens. Encontram-se com freqüência em elevações do tipo meia-laranja. No norte e leste/nordeste do maciço a extensão areal de afloramentos é muito expressiva, observando-se aí serras com cotas bem significativas. Já nos bordos sul e oeste formam pequenas serras de cotas inferiores àquelas do domínio interno. Blocos de dimensões métricas são vistos espalhados por todo o domínio e na zona de contato com a porção interna, principalmente nas encostas e fundo de vales, muitos deles explodidos para exploração ou abertura de estradas, o que possibilitou e favoreceu uma boa coleta de amostras para análises químicas.

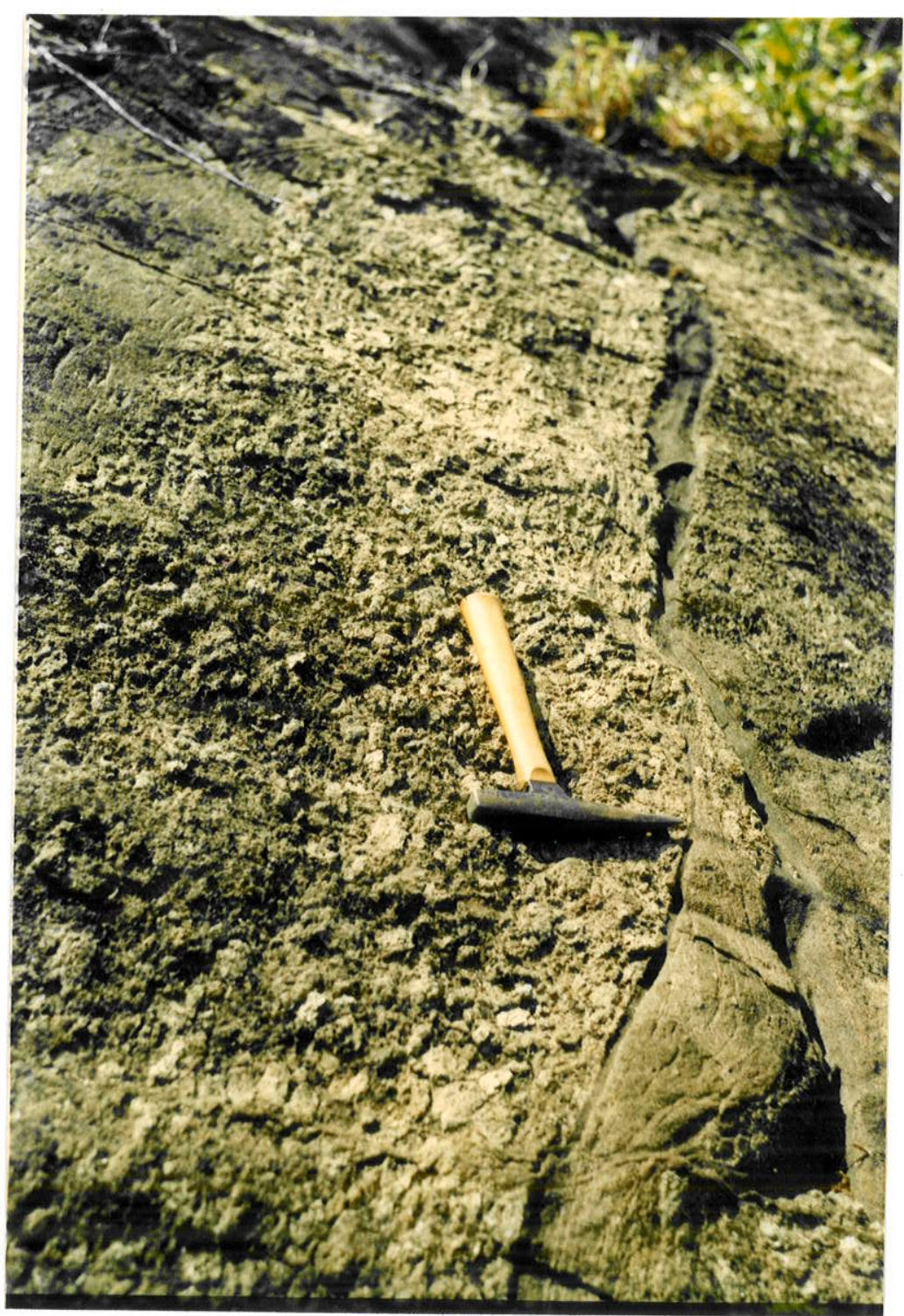

Foto 3.5 - Contato entre o charnoquitóide e o gabro do centro do maciço. Porções irregulares do charnoquitóide encontram-se em meio a rocha gabróica. Ponto VA-35. 
$\mathrm{Na}$ maior parte dos afloramentos e blocos observados e descritos os charnoquitóides apresentam-se como rochas homogêneas, maciças quando distante dos contatos mas com considerável foliação quando próximos aos mesmos. Tal foliação não é penetrativa, podendo corresponder a uma combinação do fluxo ígneo primário com esforços relacionados ao seu posicionamento $\mathrm{e}$ ao das rochas do domínio interno. Localmente são observados megacristais de feldspato ocelares bem orientados, concentração de megacristais e matriz mais máfica espremida entre os megacristais. Em muitos dos afloramentos que correspondem a extensos laj edos, a observação da rocha é deveras dificultada por uma capa de alteração (com até $15 \mathrm{~cm}$ de espessura) que deixa a rocha com uma superfície esbranquiçada, ressaltando os megacristais.

No entanto, ocorrem heterogeneidades tais como: variação na quantidade de megacristais; presença de diques de provável composição diorítica (raramente granítica) e de enclaves microgranulares básicos com ou sem xenocristais de feldspato; veios pegmatóides e xenólitos das encaixantes variavelmente assimilados (Foto 3.6). A contaminação com granada junto dos contatos com os gnaisses encaixantes ou resultante da assimilação de xenólitos dos mesmos é outro fenômeno que foi verificado. Nos próximos parágrafos são relatados alguns pontos onde algumas destas peculiariedades foram encontradas.

A ocorrência de pequenos diques predominantemente dioríticos e variação brusca na granulação pode ser observada nos pontos VA-298 e 299, na margem e leito do rio Santa Maria (região leste da intrusão). Verifica-se a existência de dois tipos texturais de charnoquitóide: um tem granulação grossa e megacristais dispersos de feldspato com foliação bem marcada pelos minerais máficos; o outro é porfirítico, com megacristais bastante orientados e matriz de granulação média. A direção da foliação é a mesma para os dois tipos e não ocorre um aumento gradativo de megacristais, sugerindo um contato brusco (Fig. 3.5). O fácies porfirítico é cortado por um dique de micro-diorito que mostra borda de reação e engloba pedaços de charnoquitóide, isolando xenocristais de feldspato (Foto 3.7).

Nos pontos VA-182 e VA-292 ocorre consideráveis variações na granulação e quantidade de megacristais, sendo que em VA-292 vê-se uma gradação de um tipo porfirítico para outro de granulação grossa com megacristais isolados.

Num perfil entre os pontos VA-287 e VA-250 constata-se mudanças texturais e a presença de vários enclaves. No ponto VA-287 aflora na drenagem um gnaisse de granulação média e cor verde escura. Descendo pela mesma encontra-se o gnaisse menos foliado e um 
pouco alterado e mais abaixo, no ponto VA-289, ocorre uma rocha mesocrática, de granulação grossa com megacristais de feldspato isolados, com pouco quartzo e matriz rica em minerais máficos, representando provavelmente um fácies menos porfirítico dos charnoquitóides. Possui xenólitos de paragnaisse e pequenos enclaves microgranulares básicos alongados (Foto 3.8). Continuando a descer em direção ao ponto VA-250 observa-se diques de diorito com xenocristais de feldspato cortando o charnoquitóide, além de um maior número de enclaves microgranulares básicos e xenolíticos (de paragnaisses e gnaisses enderbíticos). Nas proximidades de VA-250 observa-se a transição gradacional entre a rocha grossa com megacristais isolados (igual ao de VA-289) e o charnoquitóide porfirítico.

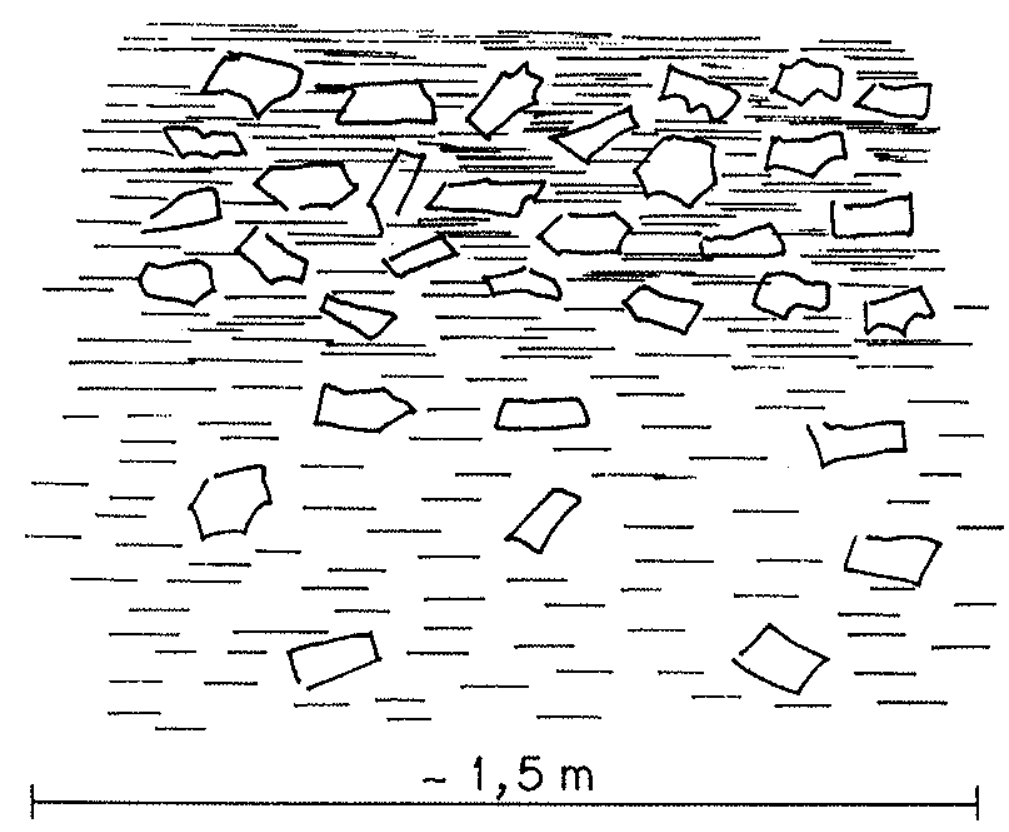

Figura 3.5 - Charnoquitóide do ponto VA-298 exibindo o contato brusco entre um tipo textural onde predominam megacristais e outro no qual predomina a matriz.

A presença de bolsões e veios pegmatóides irregulares é observada em alguns locais, mas no ponto VA-4 verifica-se um contraste bastante singular entre eles e o charnoquitóide. Aí os megacristais estão orientados e o veio, formado principalmente por grandes cristais de feldspato, está paralelo a foliação. É interessante notar que junto do contato os megacristais de feldspato não estão verdes, tornando-se à medida que se afasta do mesmo, conferindo uma borda de descharnoquitização de alguns centímetros induzida provavelmente por fluidos relacionados ao material pegmatítico (Foto 3.9). 
Ao longo do ponto VA-274, que está localizado num amplo laj edo no alto da drenagem de VA-14 (onde está o contato com o gnaisse), aflora o charnoquitóide localmente foliado contendo enclaves xenolíticos estirados e bem assimilados. Próximo destes xenólitos a foliação do charnoquitóide torna-se muito irregular, originando pequenas zonas de cisalhamento dúctil. Concentrações localizadas de granada são formadas junto dessas feições, assim como porções pegmatóides félsicas (Foto 3.10).

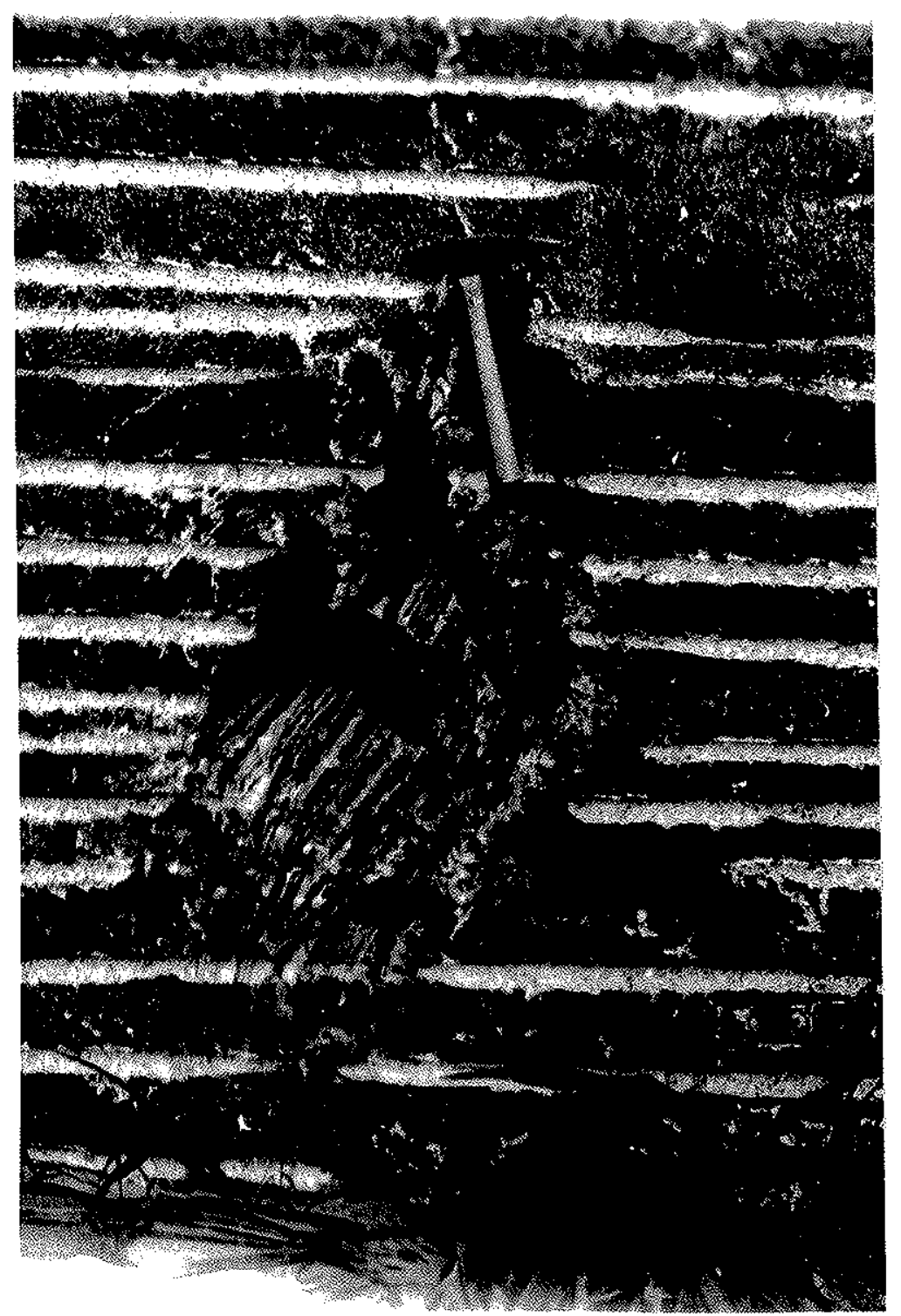

Foto 3.6 - Xenólito de gnaisse kinzigítico, não assimilado, no charnoquitóide. Bloco explodido no ponto VA-242. 


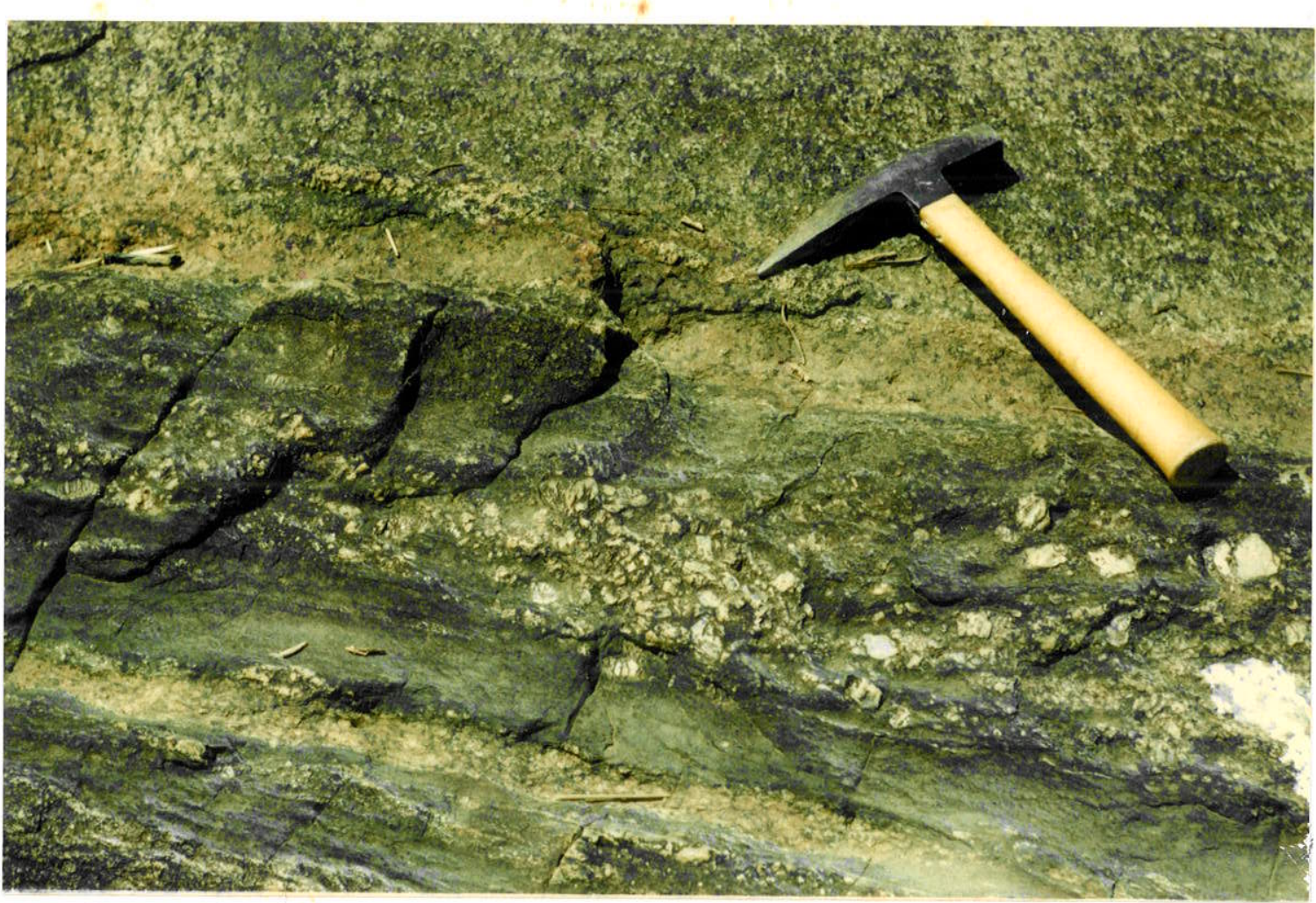

Foto 3.7 - Dique de microdiorito sin-intrusivo cortando o charnoquitóide no ponto VA-299. Destaque para shilieren de rocha charnoquitóide e xenocristais de feldspato na matriz diorítica.

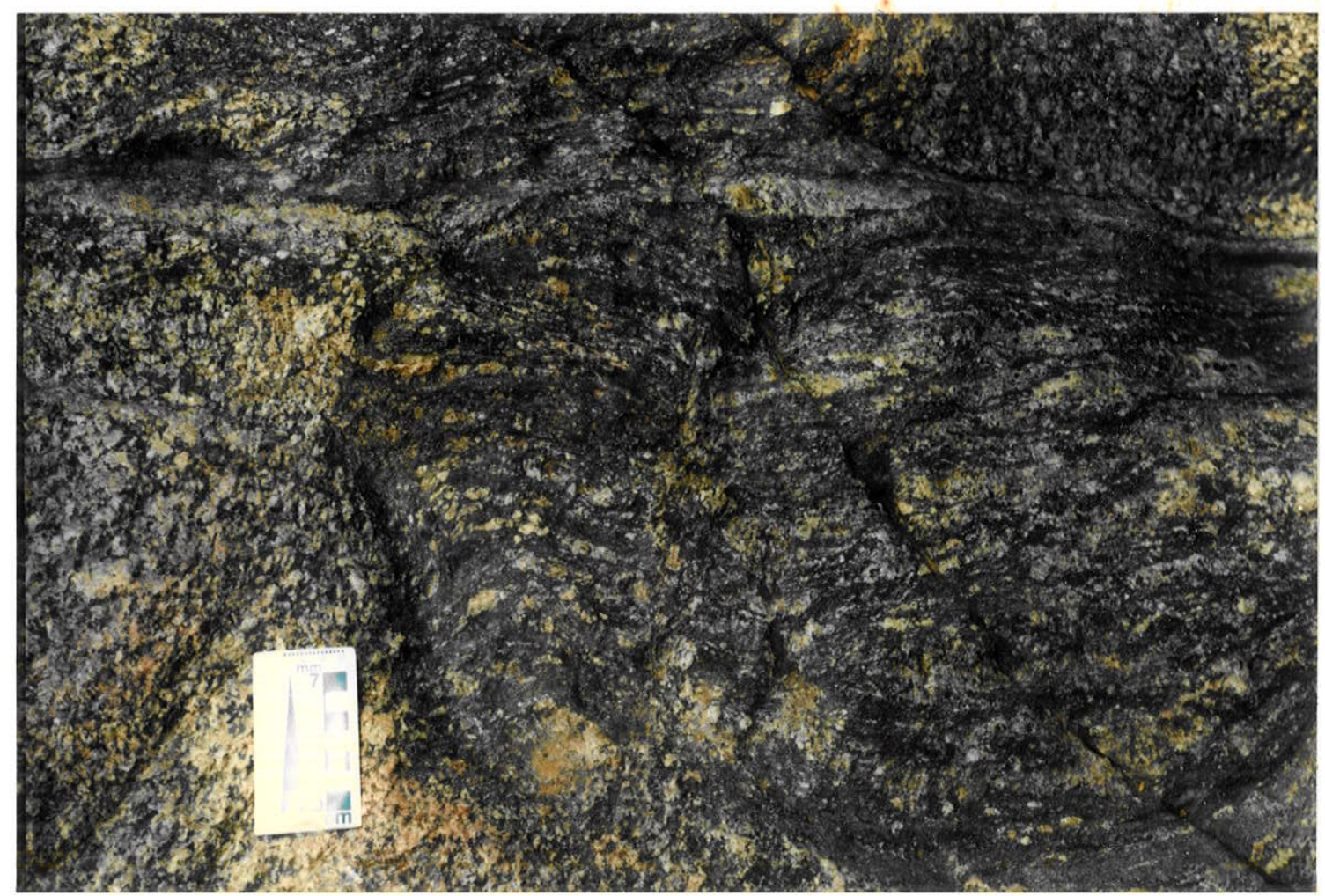

Foto 3.8 - Detalhe do contato entre xenólito de gnaisse e o charnoquitóide do ponto VA-289 


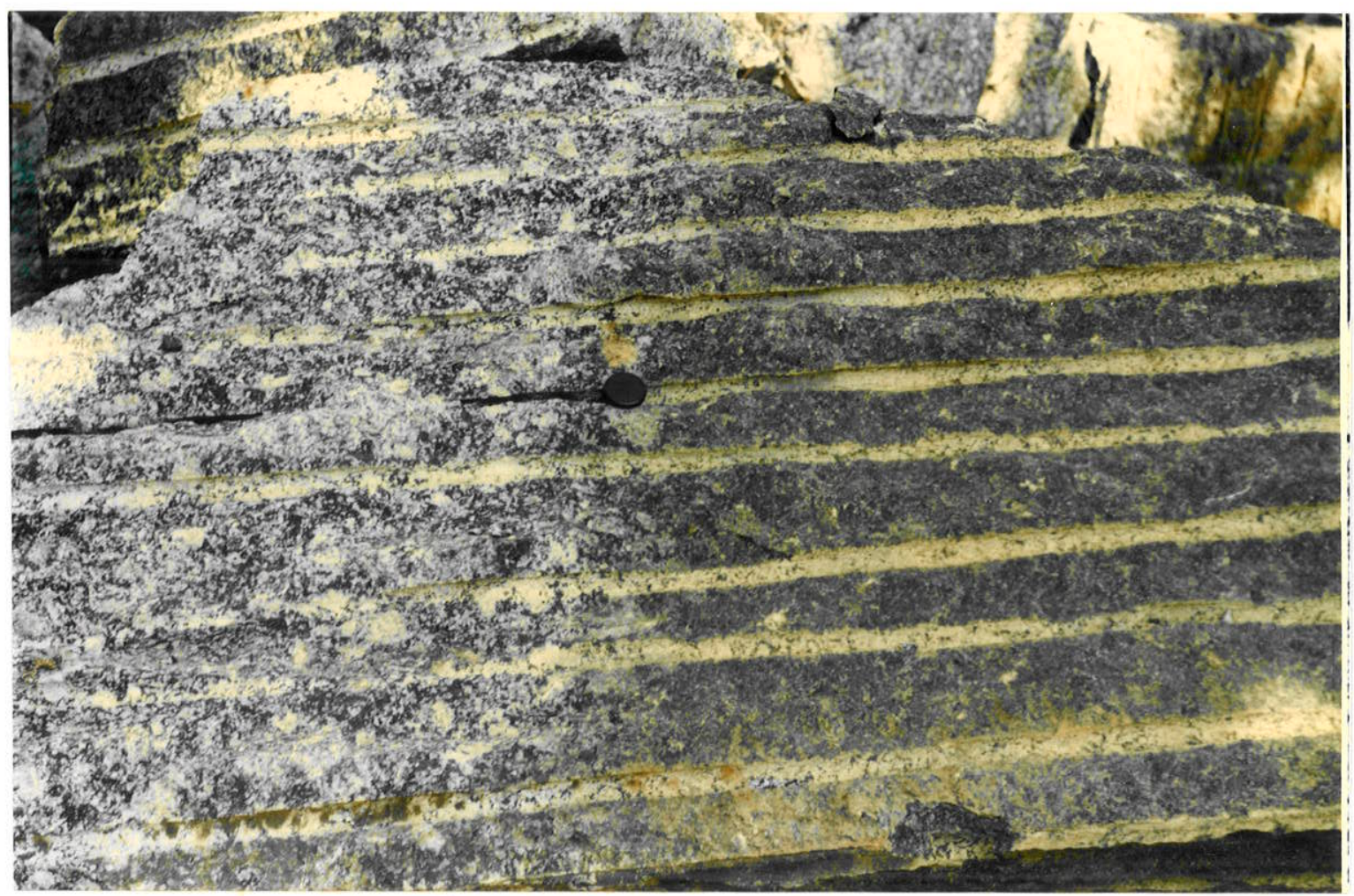

Foto 3.9 - Contato entre o charnoquitóide de cor verde e uma pequena borda descharnoquitizada pela presença de veio pegmatóide. Bloco explodido no ponto VA-4.

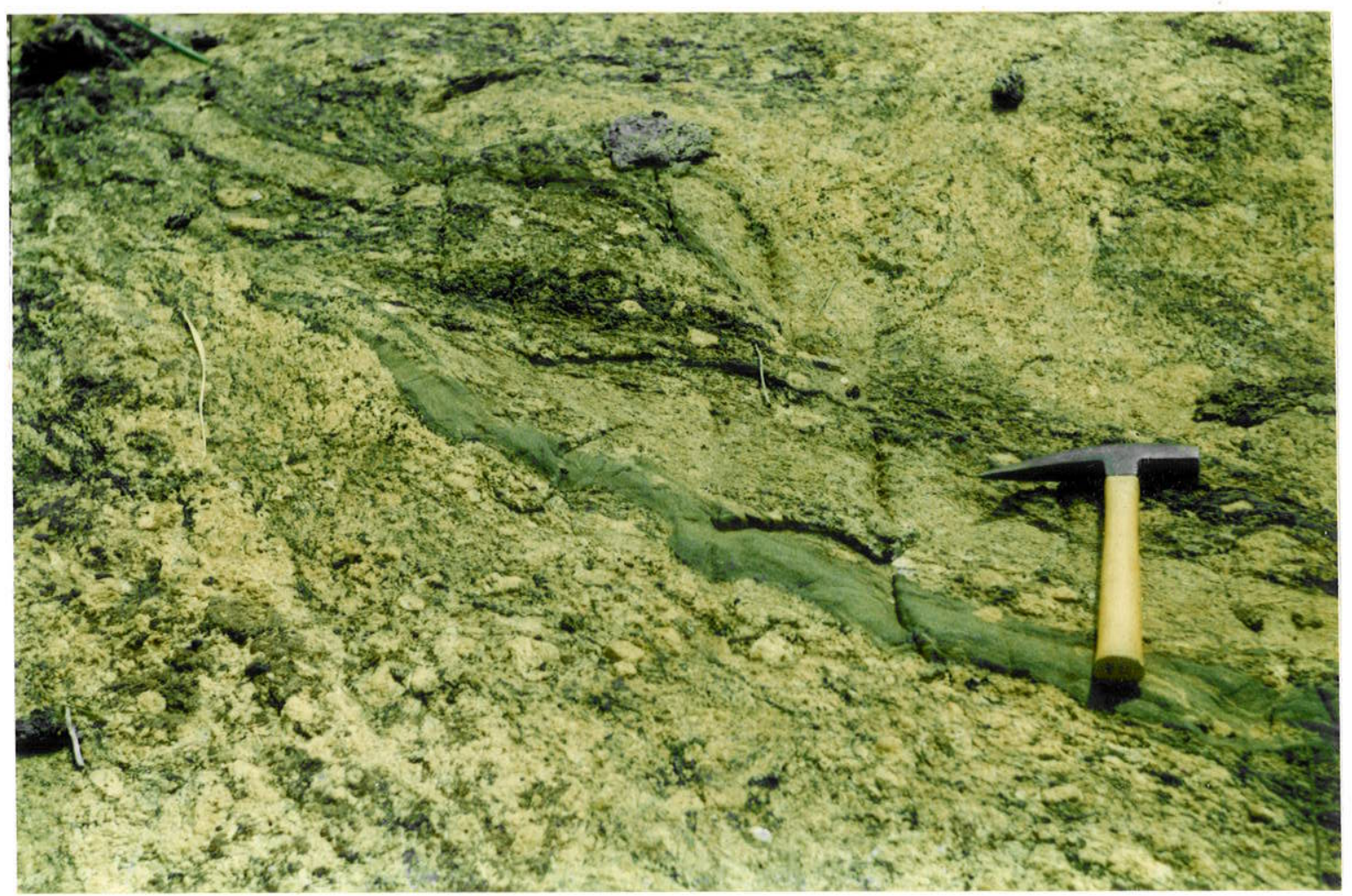

Foto 3.10 - Restito de enclave xenolítico observado no ponto VA-274. Na parte inferior da foto tem-se material félsico segregado e concentração de granadas (canto esquerdo da foto). Há a formação de discreta zona de cisalhamento dúctil no charnoquitóide. 


\section{CAPÍtulo 4 \\ PETROGRAFIA}

Neste capítulo serão descritos os diferentes aspectos texturais, as fases minerais e suas formas de ocorrência e as relações de transformações mineralógicas encontradas nas rochas estudadas em ambos os maciços. É feita também uma proposição da possível ordem de cristalização das fases tomando-se como base as suas interrelações.

As composições dos minerais essenciais foram de início grosseiramente estimadas por métodos óticos e posteriormente verificadas com precisão através de análises por microssonda eletrônica. No capítulo 6 encontram-se as tabelas contendo as suas composições químicas pormenorizadas e respectivas fórmulas estruturais.

\subsection{MACIÇO DE VENDA NOVA}

\section{Noritos}

Os noritos são rochas de granulação fina (cristais com $0,8 \mathrm{~mm}$ em média), com índice de cor variando entre 44 e 54\%, textura variando de hipidiomórfica granular a intergranular, com o espaço entre as ripas de plagioclásio sendo preenchido por piroxênios e minerais opacos (Fotomicrografia 4.1). Alguns são microporfiríticos, com microfenocristais de plagioclásio e raros de anfíbólio e piroxênio de até $4 \mathrm{~mm}$, muitas vezes corroídos por cristais da matriz, representando de 15 a $25 \%$ do volume da rocha (Fotomicrografia 4.2). Em algumas amostras observa-se forte orientação das ripas de plagioclásio e dos anfibólios, enquanto que em outras não são observadas evidências de estrutura de fluxo (Fotomicrografia 4.3). Determinados traços de deformação incipiente em estado dúctil, tais como cristais de plagioclásio com extinção ondulante e recristalização da matriz (plagioclásios com contatos poligonais), são verificados em várias lâminas. Tanto nos noritos quanto nos charnoquitóides são comuns glomérulos máficos, onde estão intimamente associados piroxênios, anfibólios, biotitas, minerais opacos e apatita. Nas rochas que exibem foliação de fluxo ígneo mais intensa tais glomérulos podem estar orientados.

A análise petrográfica deixa claro que se trata de um litotipo muito rico em anfibólio e piroxênios (cf. Tabela 4.1). No diagrama modal QAP quase todas as rochas analisadas plotam no vértice "plagioclásio" do mesmo (Fig. 4.1). Em função disto, utiliza-se o 
diagrama modal ternário plagioclásio-OPX-CPX (Streckeisen, 1976) recomendado pela IUGS para classificação de rochas gabróicas. Nele pode-se verificar que a maior parte das amostras cai no campo dos noritos, restando algumas nos limites dos CPX-noritos (Fig 4.2). Devido a quantidade de anfibólio que elas possuem podem ser classificadas como hornblenda-noritos e hornblenda-CPX noritos. A sua mineralogia é: plagioclásio An54 a An87, anfibólio (Mghornblenda / Mg-hornblenda hastingsítica e Fe-hornblenda pargasítica), OPX, CPX, magnetita, ilmenita, pirita, apatita, zircão e raros biotita e quartzo.

Os cristais de plagioclásio são hipidiomórficos a xenomórficos, em sua maioria tabulares, com poucas e microscópicas a submicroscópicas inclusões de minerais opacos, apatita, piroxênios, anfibólio e raras de zircão e biotita. Os seus contatos são retos e sinuosos, são bem preservados e os cristais maiores mostram-se mais zonados e com geminação menos desenvolvida. A análise por microssonda revelou microfenocristais zonados com núcleos com aproximadamente $77 \%, 70 \%$ e $67 \%$ de molécula de anortita e bordos com $54 \%, 63 \%$ e $63 \%$ de anortita, respectivamente. Quando microfenocristais atingem até $3 \mathrm{~mm}$, estando por vezes corroídos. Em algumas amostras são vistos cristais de plagioclásio poligonais localizados, que devem refletir uma recristalização incipiente.

A hornblenda tem amplo predomínio dentre os máficos, estando disseminadas na rocha, mostrando-se tanto isoladas (primárias?, não pode-se afirmar com conviç̧ão) como substituindo os piroxênios ou associando-se a outras fases máficas em glomérulos. Variam de idiomórficas a xenomórficas, com pleocroísmo castanho-verde claro-verde musgo e substituem os piroxênios tanto pelas bordas quanto nas clivagens e fraturas dos mesmos; muitas vezes eles ficam como restos no interior dos anfibólios. Ocorrem cristais de hornblenda poiquilítica, com inúmeras inclusões de apatita e minerais opacos. A amostra $\mathrm{VN}-14$ apresenta um grão poiquilítico de quase $1 \mathrm{~cm}$ com inúmeras inclusões de opacos e apatita, além de OPX e plagioclásio que na realidade são restos muito corroídos, evidenciando a reação destes dois minerais para formar o anfibólio (Fotomicrografia 4.4).

Os ortopiroxêniọ mostram pleocroísmo castanho-verde-rosa, estando disseminados ou em associação com as outras fases máficas presentes. São hipidiomórficos a xenomórficos, fraturados, muitos deles arredondados, com as arestas corroídas, e comumente substituídos por hornblenda e menos por CPX, biotita e alterados para um material de cor ocre. Possuem inclusões de apatita e minerais opacos, sendo que estes últimos são muitas vezes produtos de exsolução. A lâmina VN-14 exibe vários cristais de OPX com pequenas lamelas de 
biotita paralelas à clivagem e exsolvendo minerais opacos. Os clinopiroxênios estão em menor quantidade que os OPX, estando intimamente associados. São hipidiomórficos a xenomórficos, de pleocroísmo incolor a verde claro (quando presente), substituídos por hornblenda e também exsolvendo minerais opacos. Possuem inclusões de apatita, zircão e opacos.

Os piroxênios podem se apresentar como agregados que em determinadas amostras estão orientados paralelamente à foliação da rocha.

Quando aparece, a biotita tem a forma de lamelas com pleocroísmo variando de castanho a marrom escuro, muitas delas em substituição ao OPX. Possuem inclusões de apatita e minerais opacos.

Os minerais opacos encontram-se principalmente como grãos xenomórficos associados às outras fases máficas, mas ocorrem também cristais isolados bem desenvolvidos e pequenas inclusões nos outros minerais essenciais. Dentre eles observa-se o intercrescimento de ilmenita e magnetita e a substituição de ilmenita por magnetita. Os cristais de ilmenita geralmente apresentam lamelas de exsolução bem finas de uma outra fase opaca, provavelmente hematita.

A apatita é o principal mineral acessório e ocorre tanto como pequenas inclusões hipidiomórficas quanto em cristais maiores frequentemente associados com os máficos. $\mathrm{O}$ zircão é raro e apresenta-se na forma de pequenas inclusões idiomórficas a xenomórficas.

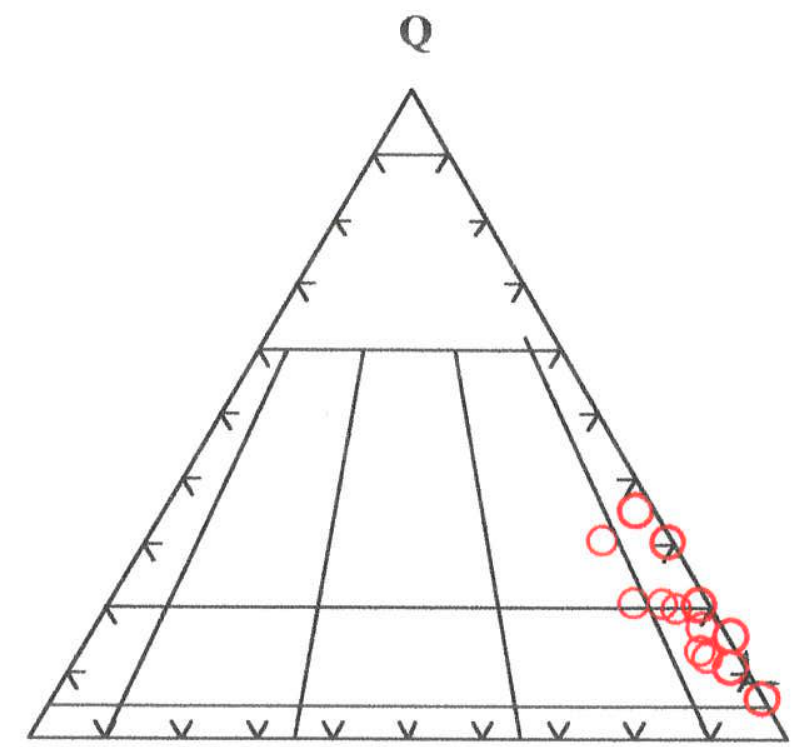

A $\mathbf{P}$

Figura 4.1 - Diagrama modal QAP para classificação das rochas da borda do maciço de Venda Nova. 


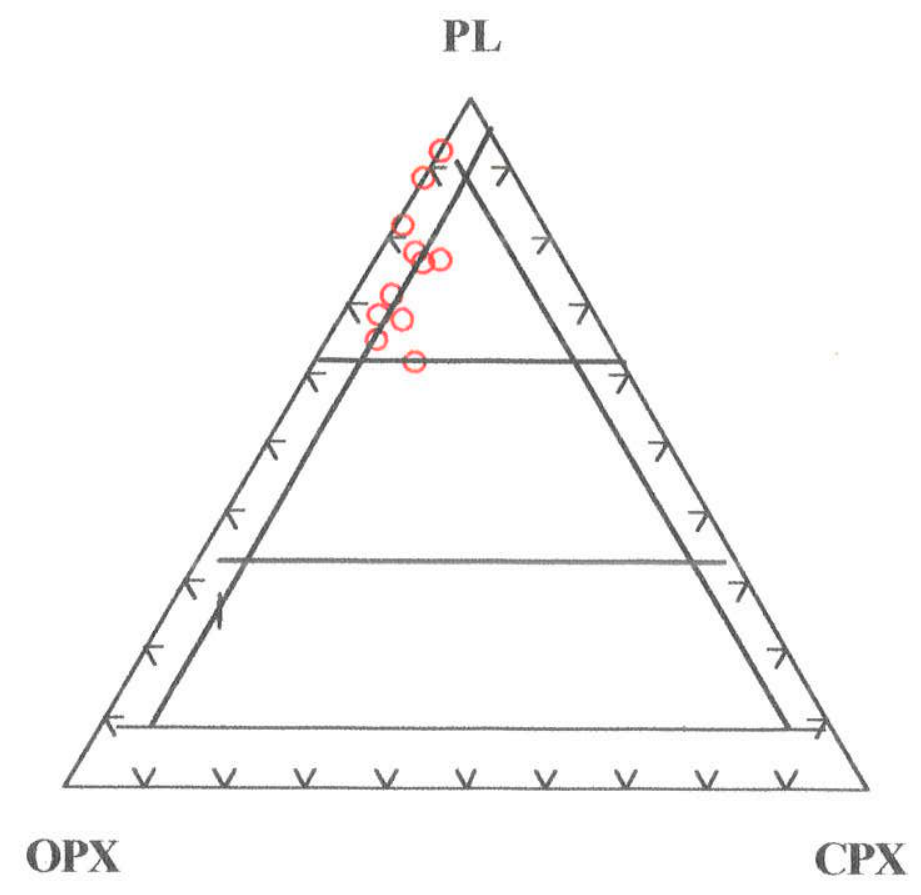

Figura 4.2 - Diagrama modal Plagioclásio-OPX-CPX para classificação das rochas gabróicas da borda do Maciço de Venda Nova.

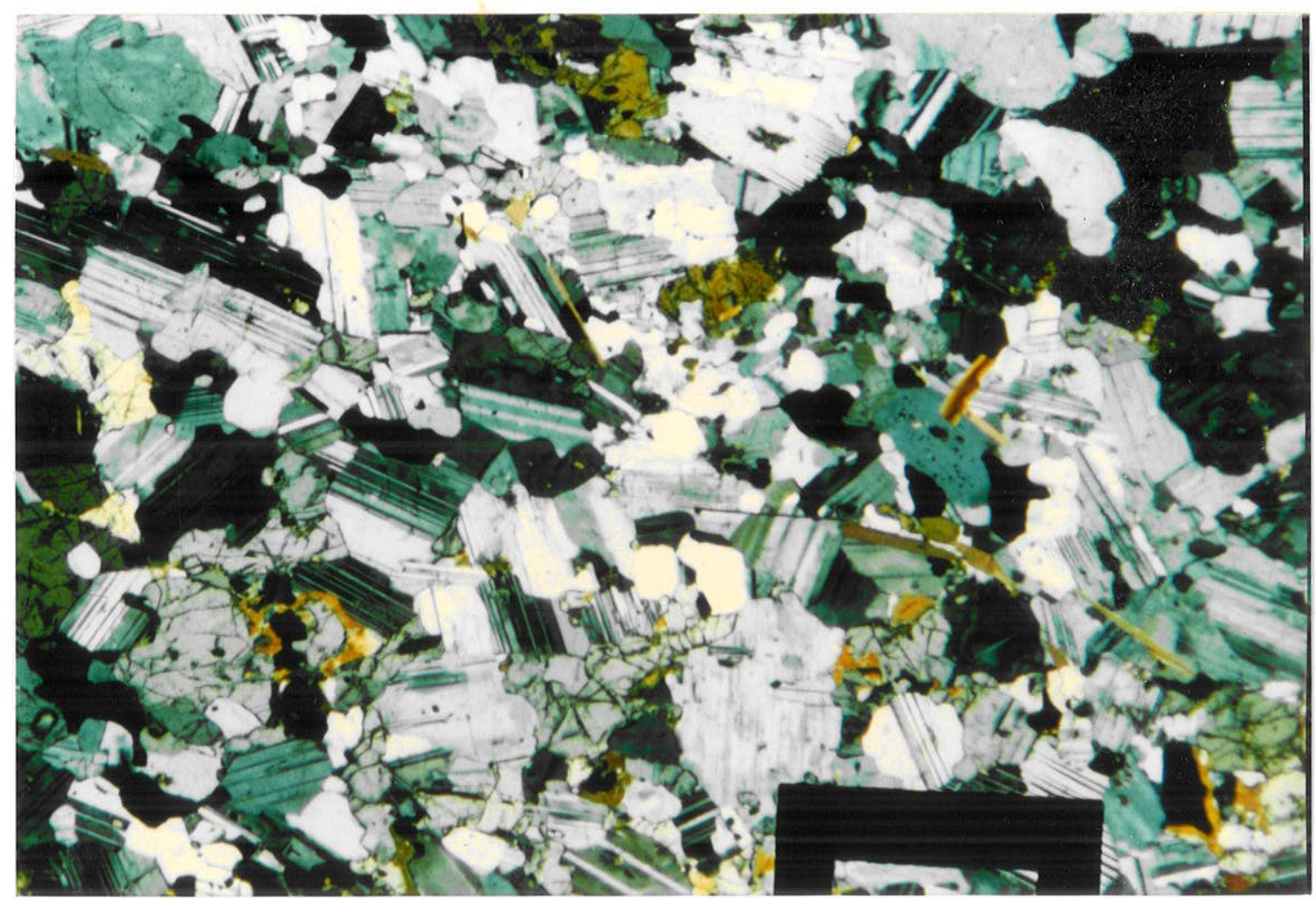

Fotomicrografia 4.1 - Textura hipidiomórfica granular a localmente intergranular em norito. O campo vazado da escala mede $0,8 \mathrm{~mm}$. Nx. Amostra VN-11 


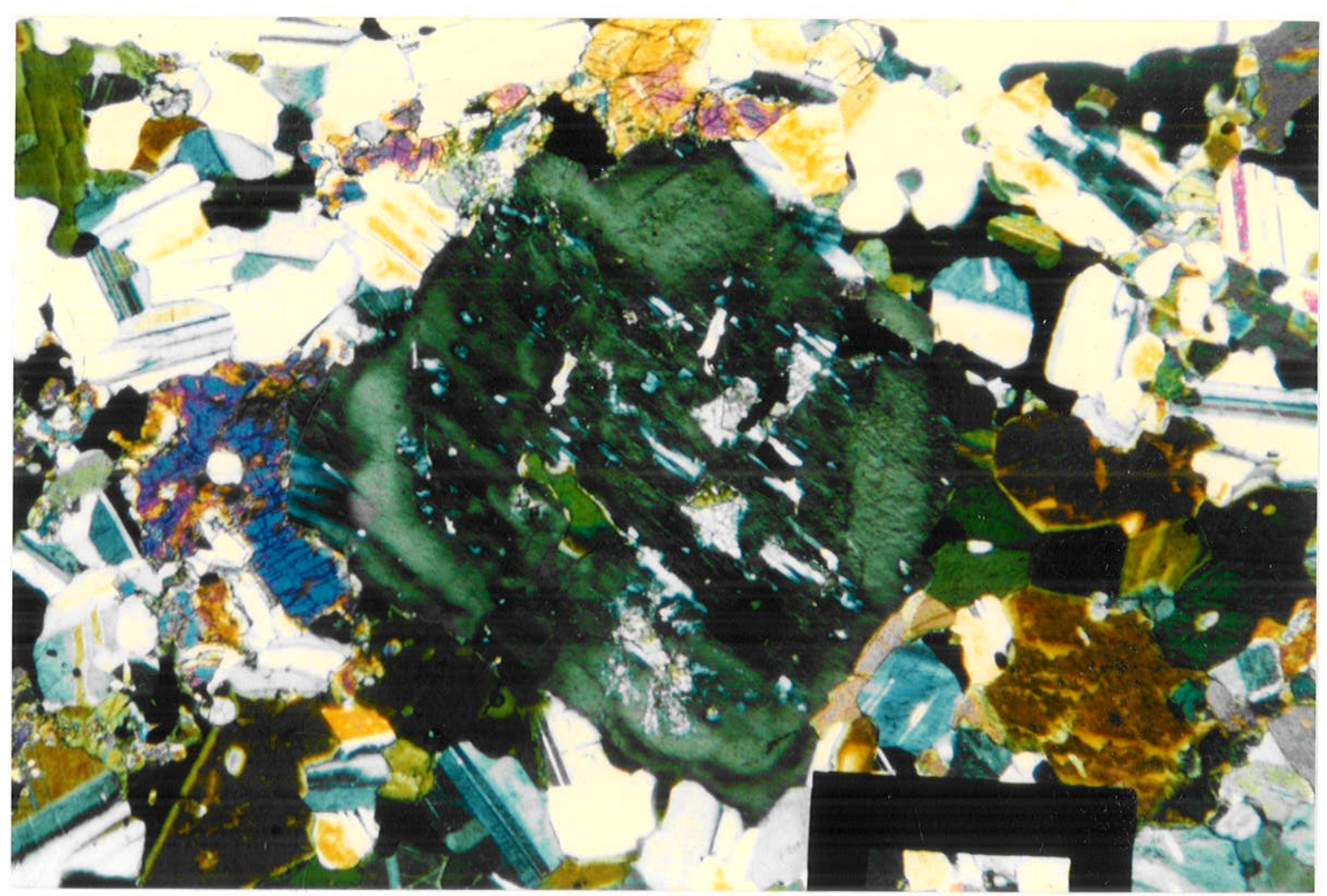

Fotomicrografia 4.2 - Microfenocristal de plagioclásio parcialmente corroído no norito. O campo vazado da escala mede 0,8 mm. Nx. Amostra VN-26

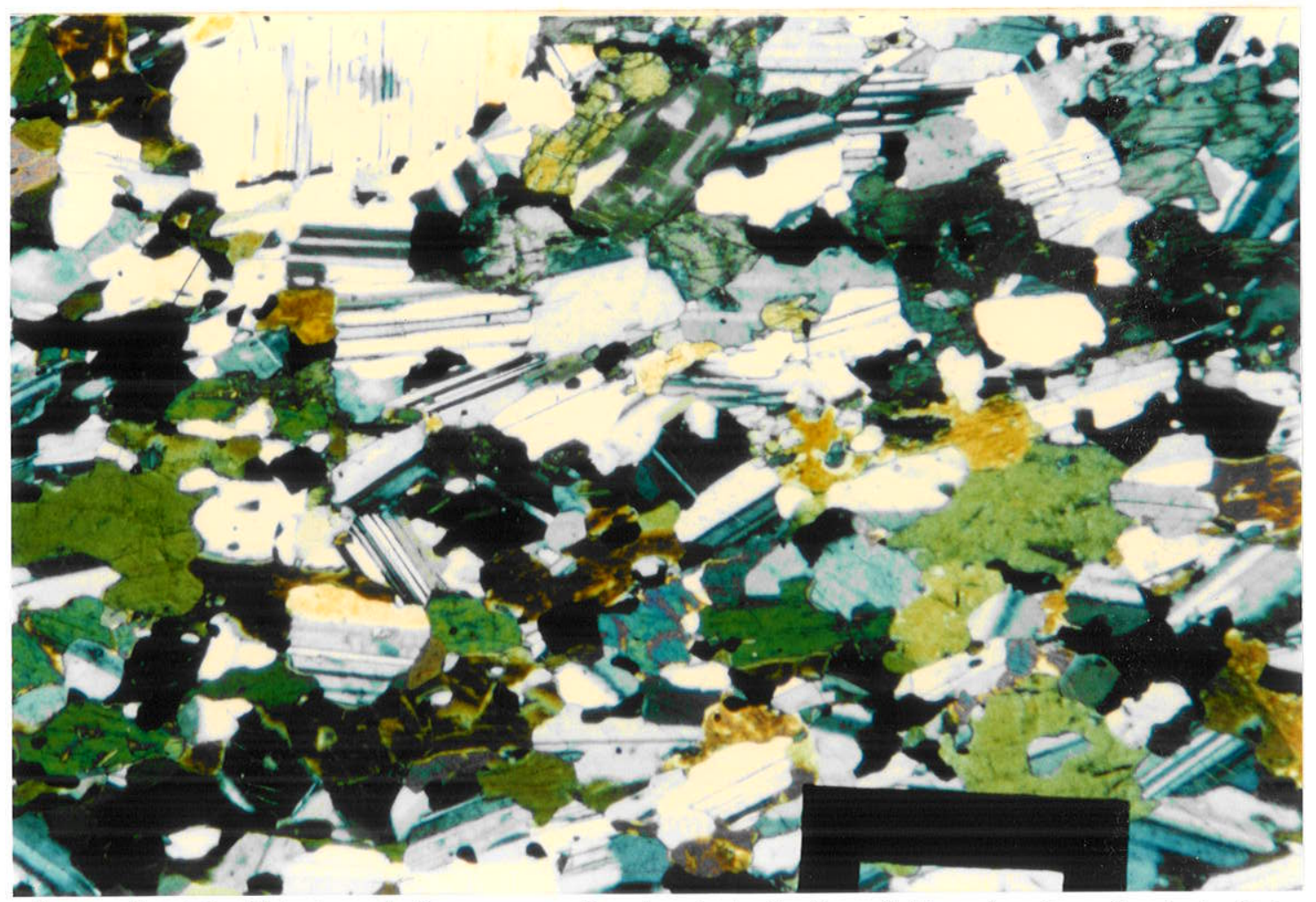

Fotomicrografia 4.3 - Estrutura de fluxo em norito. A orientação é conferida pelas ripas de plagioclásio e pelos cristais de hornblenda. O campo vazado da escala mede $0,8 \mathrm{~mm}$. Nx. Amostra VN-5 


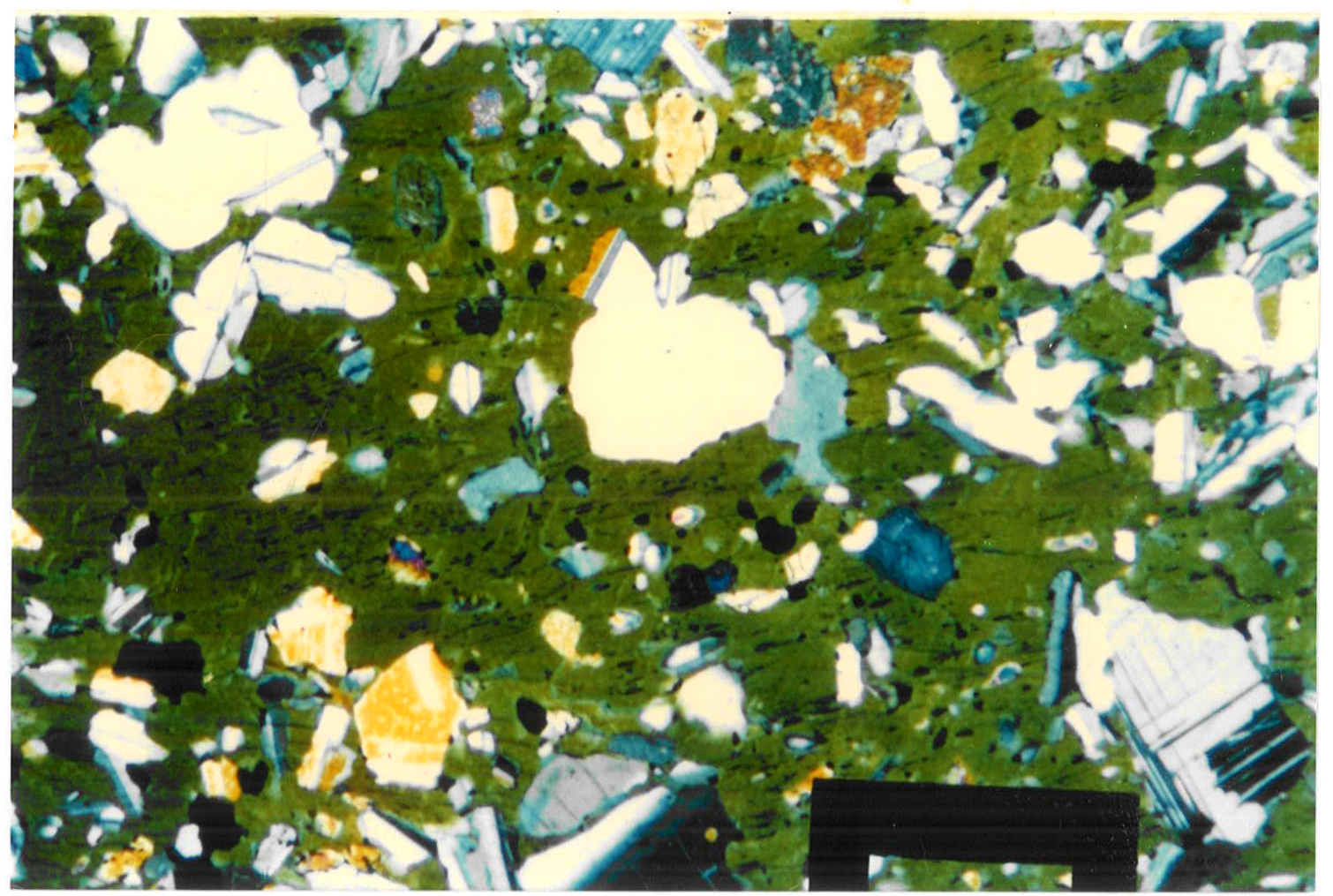

Fotomicrografia 4.4 - Cristal poiquilítico de hornblenda em norito. As inclusões são de plagioclásio, OPX, apatita e minerais opacos. O campo vazado da escala mede $0,8 \mathrm{~mm}$. Nx. Amostra VN-14.

\section{Charnoquitóides}

As rochas da seqüência charnoquitóide são leucocráticas a mesocráticas (possuem índice de cor até 39\%), com textura hipidiomórfica granular/inequigranular de granulação média (os cristais variam de 0,2 a 3,0 mm) e megacristais isolados de plagioclásio ou porfíítica, com megacristais de plagioclásio tabulares de até $1,0 \mathrm{~cm}$ de tamanho e raramente de quartzo e piroxênio (Fotomicrografia 4.5). A matriz tem granulação média e perfaz cerca de $70 \%$ do total da rocha; em certas amostras (e.g. VN-2 e VN-35) os megacristais variam bastante de tamanho, assemelhando-se a uma textura porfirítica seriada. Uma orientação preferencial dos cristais maiores de feldspato e das biotitas é observada em várias das lâminas estudadas.

Algumas amostras, principalmente as porfiriticas, mostram sinais de recristalização da matriz, que pode estar apertada entre megacristais: plagioclásios poligonais em contatos tríplices e grãos de quartzo deformados, alguns originando sub-grãos (bem exemplificado pelas amostras VN-20 e 38). Feições de deformação incipiente no estado dúctil como extinção ondulante em grãos de quartzo, feldspato e biotita e lamelas de geminação de plagioclásio e biotitas recurvadas são verificadas em determinados pontos. Em muitas das lâminas estudadas ocorrem glomérulos máficos com apatita associada que atingem até $0,9 \mathrm{~cm}$ e 
em algumas delas, tais como VN-17, VN-18 e VN-20 chegam a constituir uma textura glomeroporfirítica (Fotomicrografia 4.6).

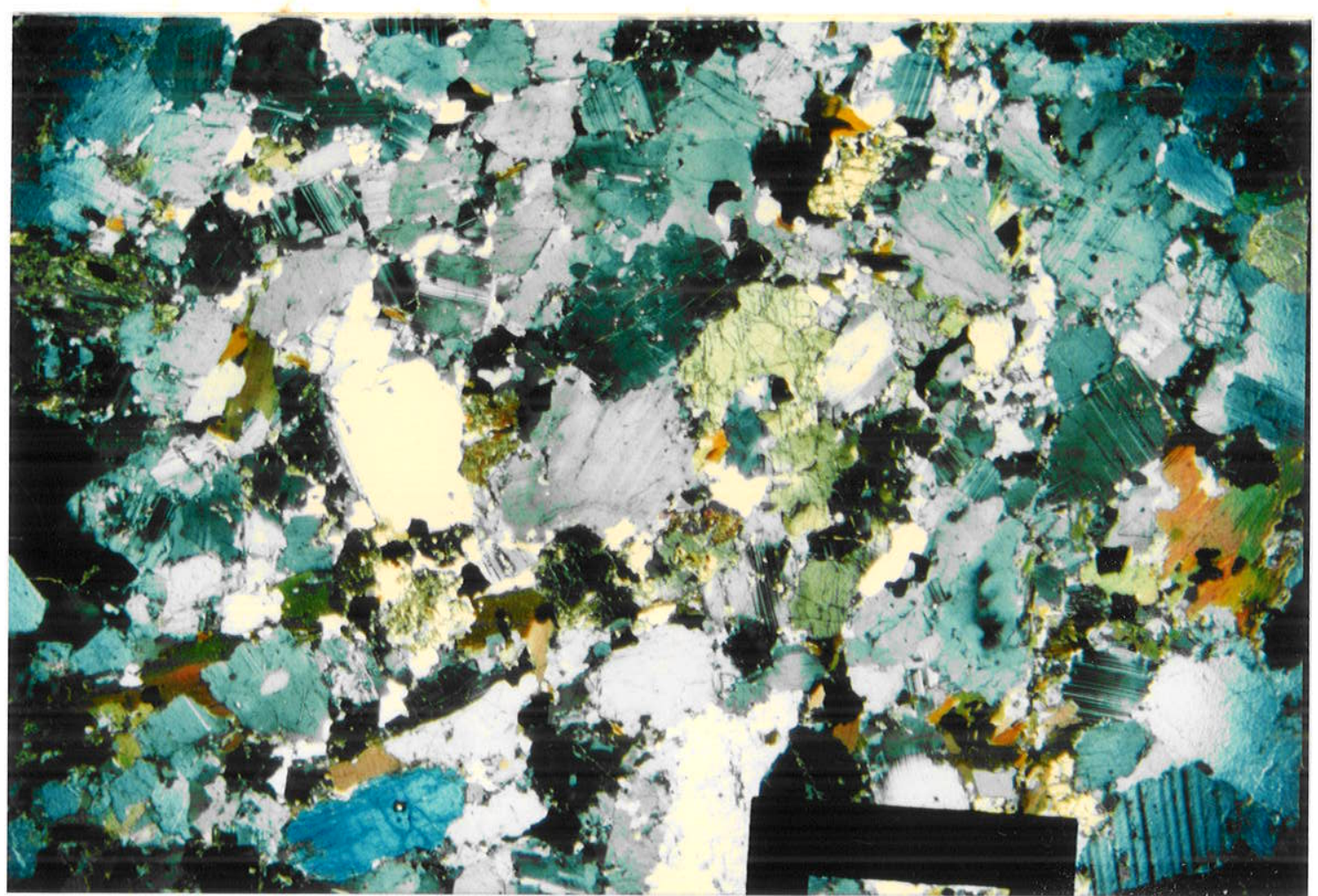

Fotomicrografia 4.5 - Textura inequigranular hipidiomórfica em charnoquitóide. O campo vazado da escala mede $1,6 \mathrm{~mm}$. Nx. Amostra VN-23.

A análise modal destas rochas (cf. Tabela 4.2) permite classificá-las como enderbitos, OPX-quartzo-dioritos e raros opdalitos e jotunitos, como está exposto no diagrama QAP da Figura 4.1.

Compõem-se de plagioclásio (An30 a An45), quartzo, biotita, OPX, CPX, anfibólio (Mg-hornblenda/Mg-hornblenda hastingsítica e Fe-hornblenda pargasítica), feldspato alcalino, ilmenita, magnetita, pirita, apatita e zircão.

O plagioclásio, com composição variando de andesina sódica a andesina cálcica, ocorre de três formas diferentes, indicando no mínimo duas gerações:

- Um é hipidiomórfico, na maioria das vezes com geminação polissintética bem desenvolvida, mais limpos (somente pequenas inclusões de apatita, opacos e zircão), com contatos retos, côncavos e convexos e pouco fraturados e alterados.

- O segundo corresponde a cristais maiores, xenomórficos, de hábito tendendo a tabular, de contatos irregulares e serrilhados com biotita. São mais fraturados, alterados (principalmente 
para sericita/muscovita e calcita) e zonados, possuindo geminação mal desenvolvida e várias inclusões: apatita, zircão, minerais opacos, biotita, OPX, anfibólio, agulhas submicroscópicas (rutilo?) e muitas minúsculas inclusões alinhadas ou não, tanto sólidas quanto fluidas, que podem dar um aspecto empoeirado ao cristal (Fotomicrografia 4.7). Localmente são vistos grãos poiquilíticos com inclusões de biotita lamelar e minerais opacos idiomórficos a arredondados, além de CPX, hornblenda, apatita e zircão. Na amostra VN-2 ocorre coalescência de pequenos cristais geminados na borda de um megacristal (recristalização de borda ou syneusys?). Dificilmente fazem contato entre si, porque quase sempre cristalizaram-se grãos da matriz entre eles ou, o que é menos comum, porque se limitam com megacristais de quartzo. Raros cristais encontram-se totalmente envolvidos por pequenos cristais de minerais máficos, sobretudo biotita.

- O terceiro tipo compreende cristais pequenos, bem formados e que não exibem maclas de geminação. São muito limpos, com contatos poligonais, provavelmente relacionados a recristalização incipiente.

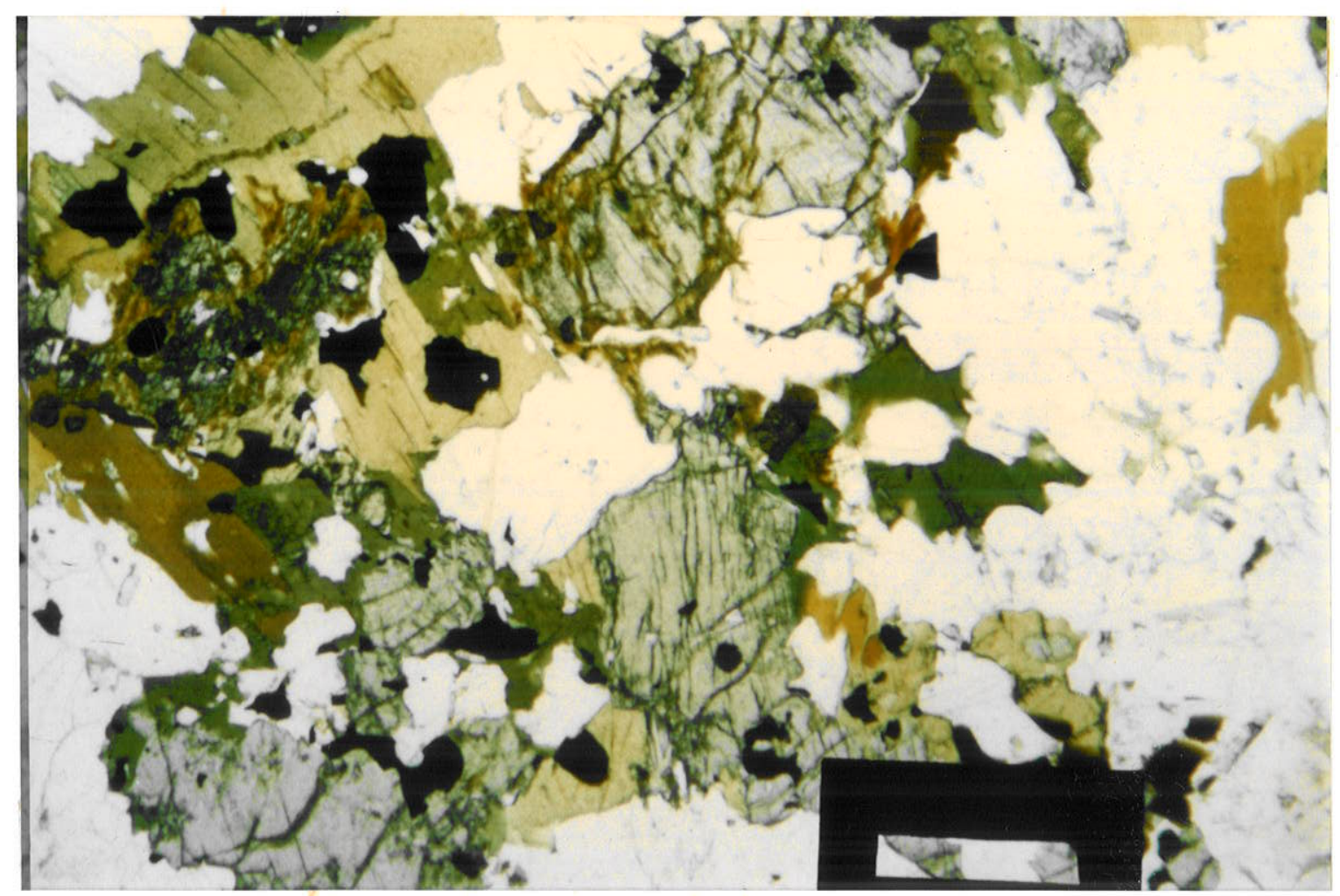

Fotomicrografia 4.6 - Glomérulo máfico com apatita e minerais opacos em charnoquitóide. Piroxênios exsolvem opacos e são substituídos por hornblenda e biotita. O campo vazado da escala é de cerca de $1,6 \mathrm{~mm}$. N//. Amostra $\mathrm{VN}-18$. 


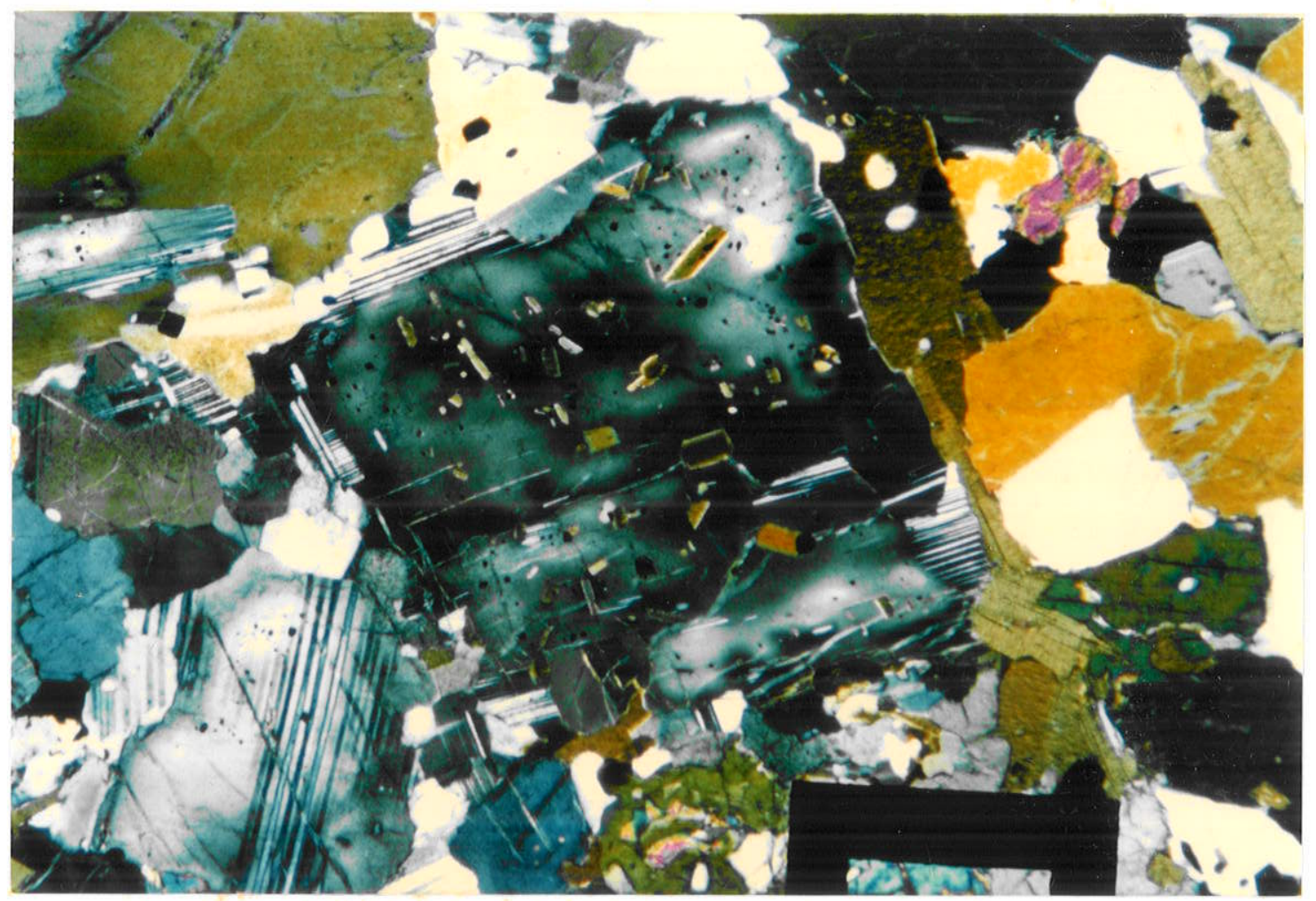

Fotomicrografia 4.7 - Cristal de plagioclásio zonado contendo um grande número de minúsculas inclu sões de vários minerais. O campo vazado da escala mede $0,8 \mathrm{~mm}$. Nx. Amostra VN-18.

Observam-se cristais embainhados por quartzo, sobretudo naqueles que pertencem ao segundo grupo, que por sua vez estão muitas vezes corroídos por cristais da matriz ou por megacristais de quartzo. Algumas amostras, como VN-2 e VN-13, têm cristais com lamelas de geminação interrompidas, isto é, sendo visíveis somente na borda ou no centro dos mesmos.

Vários cristais de plagioclásio, tanto megacristais quanto da matriz, mostram intercrescimento de um material incolor, de relevo baixo, cor de interferência cinza e sinal ótico biaxial negativo, que não foi possível ser determinado por microssonda, mas trata-se provavelmente, pelas características óticas, de feldspato alcalino (anti-pertitas?). Este mineral possui formas variadas, desde pequenos prismas quadráticos ou retangulares até lamelas vermiculares (Fotomicrografia 4.8). Nas lâminas que apresentam álcali-feldspato muitos cristais de plagioclásio exibem franjas de mirmequita xenomórfica, com tamanhos variados, em determinados pontos ocupando todo o cristal.

A composição química dos plagioclásios, megacristais e da matriz, encontra-se nas tabelas 6.5 e 6.6 no capítulo 6. Pode-se verificar a presença de megacristais zonados de composição An39 e An45 no núcleo e bordo correspondendo, respectivamente, a An30 e An39, assim como de cristais zonados na matriz com a seguinte composição: núcleo An37 e An45, bordo An30 e An40, respectivamente. 
Os cristais de quartzo são via de regra xenomórficos, limpos (inclusões, em maior quantidade nos cristais maiores, de zircão, apatita, biotita, minerais opacos, anfibólio e fluidas alinhadas), fraturados ou não e invariavelmente intersticiais. Em algumas amostras eles são megacristais de contatos côncavos e convexos, por vezes amebóides. Quando ocorre recristalização na matriz eles podem exibir contatos retos. Observam-se cristais com forte extinção ondulante, iniciando um processo de recuperação.

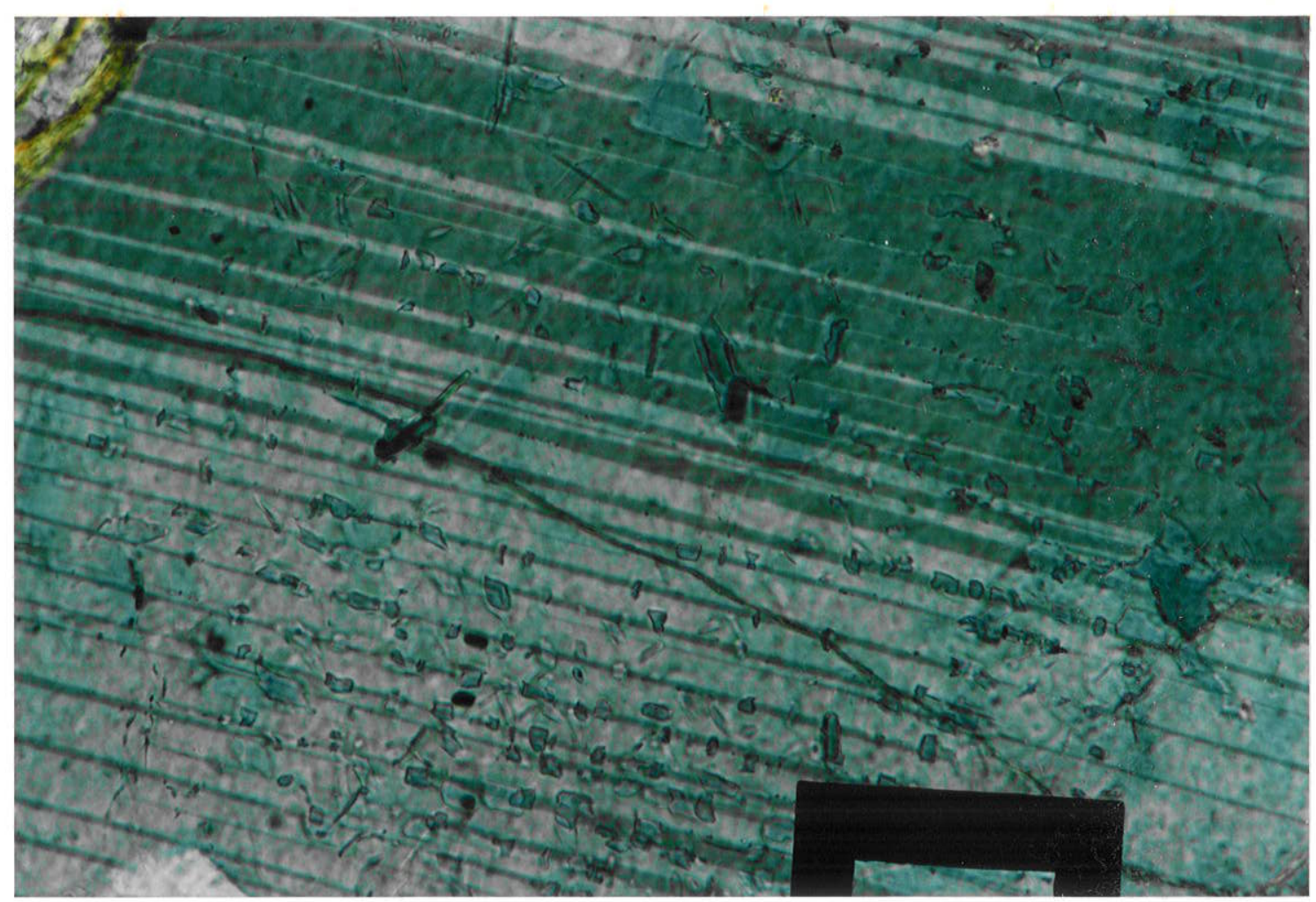

Fotomicrografia 4.8 - Cristal de plagioclásio com inúmeras inclusões prismáticas a arredondadas de uma fase incolor e com cor de interferência cinza (feldspato alcalino?). O campo vazado da escala mede 0,1 mm. Nx. Amostra VN-15.

O ortopiroxênio tem pleocroísmo típico castanho- verde- rosa, é hipidiomórfico a xenomórfico, bem fraturado e ocorre tanto como cristais individuais disseminados na rocha como em agregados ou nos glomérulos máficos. Alguns cristais mostram arestas arredondadas que são provavelmente associadas a corrosão magmática.

Altera-se, principalmente nas fraturas, para um material de cor ocre ou marrom escuro e para clorita. É comumente substituído por biotita e hornblenda a partir das bordas, nas clivagens e fraturas e está muitas vezes associado a estas fases mais CPX, opacos e apatita nos glomérulos máficos. Exsolvem minerais opacos e alguns cristais são totalmente envolvidos por 
CPX, anfibólio ou material de alteração (Fotomicrografia 4.9). Apresenta inclusões de apatita, zircão e minerais opacos.

O clinopiroxênio é predominantemente xenomórfico, menos fraturado que o OPX, seu pleocroísmo quando presente é incolor a verde claro, de ângulo $2 \mathrm{~V}$ alto $\left(>=60^{\circ}\right) \mathrm{e}$ muito substituído por anfibólio, biotita e clorita (pelas bordas, clivagens ou fraturas), exsolvendo minerais opacos (cf. Fotomicrografia 4.9). Estão disseminados ou associados a outras fases máficas. Em algumas amostras são observados cristais envolvendo completamente o OPX, que fica como resto no centro. Também ocorrem cristais com tendência ao arredondamento. Possuem inclusões de apatita, zircão e minerais opacos.

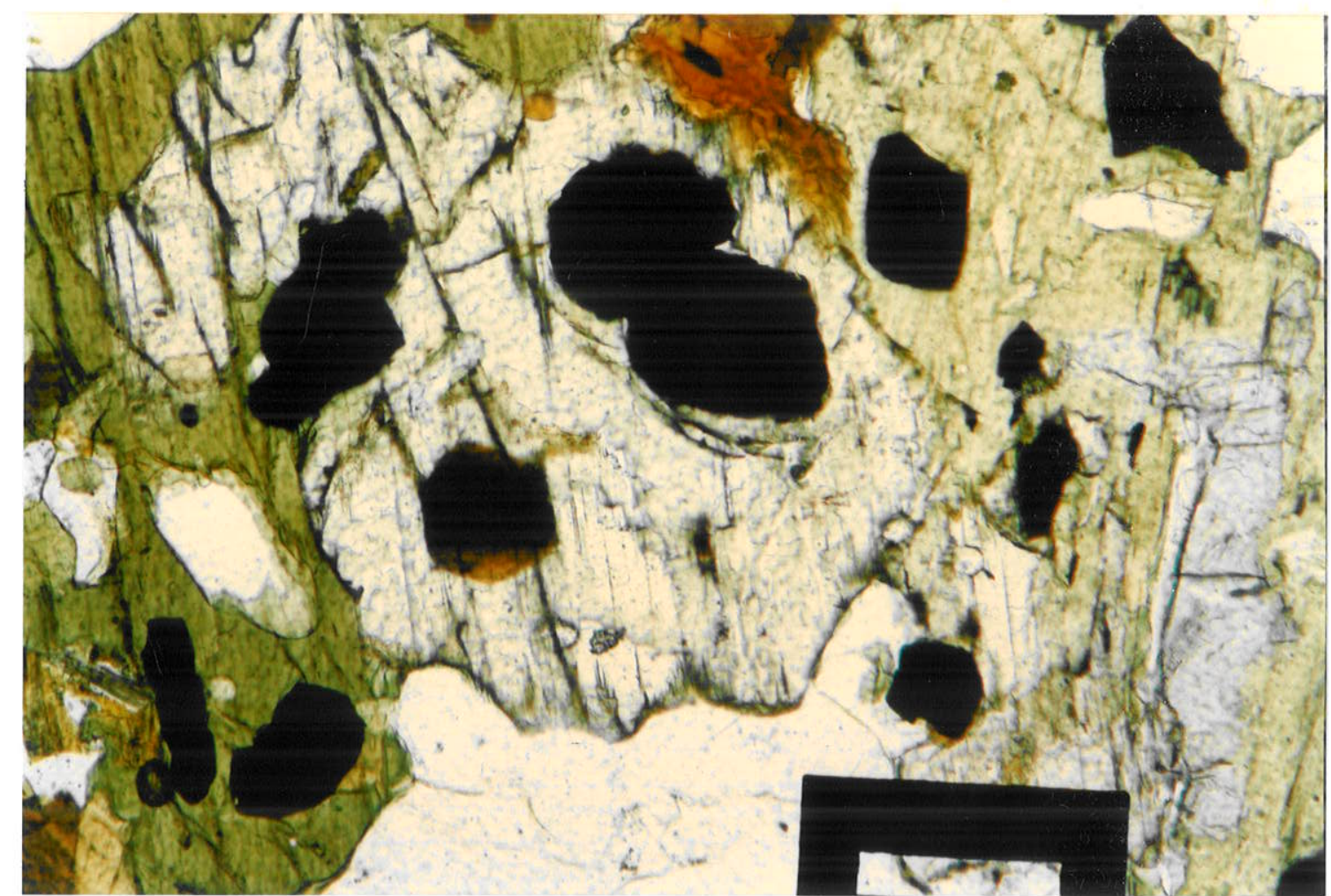

Fotomicrografia 4.9 - Contato entre orto e clinopiroxênio, que estão exsolvendo minerais opacos e são substituídos por anfibólio e biotita. O campo vazado da escala mede 0,2 mm. N//. Amostra VN-20.

A biotita ocorre substituindo piroxênios e anfibólios, nos glomérulos máficos (sobretudo na forma de lamelas com pleocroísmo castanho pálido- marrom claro- marrom escuro) e também em cristais isolados, normalmente xenomórficos (primários?, não se pode precisar pois são cristais que geralmente não estão associados a outras fases, mas por outro lado não possuem formas definidas), pouco ou nada pleocróicos e com uma cor marrom tijolo. A análise por microssonda não detectou diferenças sigmificativas entre elas, tão somente pequenas 
variações na razão Fe/Mg. Apenas a amostra VN-27 possui biotitas de outra composição, mais ricas em $\mathrm{Fe}$, mas seus piroxênios e anfibólios também possuem tal enriquecimento (cf. Tabela 6.4 no capítulo 6 ).

Ambos os tipos possuem inclusões de apatita, minerais opacos e zircão, que são mais comuns nas variedades xenomórficas. São observadas lamelas recurvadas e com extinção ondulante. $\mathrm{Na}$ amostra VN-36 ocorre intercrescimento simplectítico com feldspato e na VN-17 com quartzo. Quando altera-se o faz principalmente para clorita.

Os anfibólios são hipidiomórficos a xenomórficos e freqüentemente substituem os piroxênios, sobretudo $\mathrm{CPX}$, mas também aparecem nos glomérulos máficos e poucos como fases individualizadas. Da mesma forma que a biotita, estas últimas podem ser primárias, principalmente porque algumas são idiomórficas, mas não há como precisar pois são de mesma composição química (cf. Tabela 6.3 no Cap. 6). O pleocroísmo é castanho-verde claro-verde musgo, diferenciando-se em alguns cristais isolados. Possuem inclusões de apatita, minerais opacos e zircão e são substituídos por biotita.

Os cristais de álcali-feldspato são xenomórficos, de contatos côncavos e convexos, variavelmente fraturados e em sua maioria micropertíticos. Não exibem maclas de geminação e à primeira vista é facilmente confundido com plagioclásio. Possuem poucas inclusões de apatita, minerais opacos, biotita, zircão e fluidas alinhadas. Alguns grãos têm inclusões de plagioclásio e são frequentes as bordas de reação com o mesmo, formando mirmequita.

Os minerais opacos são predominantemente xenomórficos e apresentam-se disseminados nas rochas, associados às outras fases máficas (a maior parte) ou em cristais isolados e como pequenas inclusões de formas variadas em outros minerais, sendo exsolvido pelos piroxênios. $O$ exame em luz refletida deixa claro o intercrescimento lamelar entre ilmenita e magnetita e a substituição da primeira pela última (Fotomicrografia 4. 10). É frequente a presença de lamelas de exsolução na ilmenita, provavelmente de hematita.

Os minerais acessórios são representados por apatita e zircão; allanita foi observada somente em duas amostras. Os cristais de apatita estão tanto isolados como associados aos máficos e em pequenas inclusões. Suas formas são variadas, mas os grãos individuais e os dos glomérulos máficos tendem a ser idiomórficos a hipidiomórficos. $\mathrm{O}$ zircão encontra-se em sua maior parte como inclusões arredondadas a idiomórficas nas fases principais. 


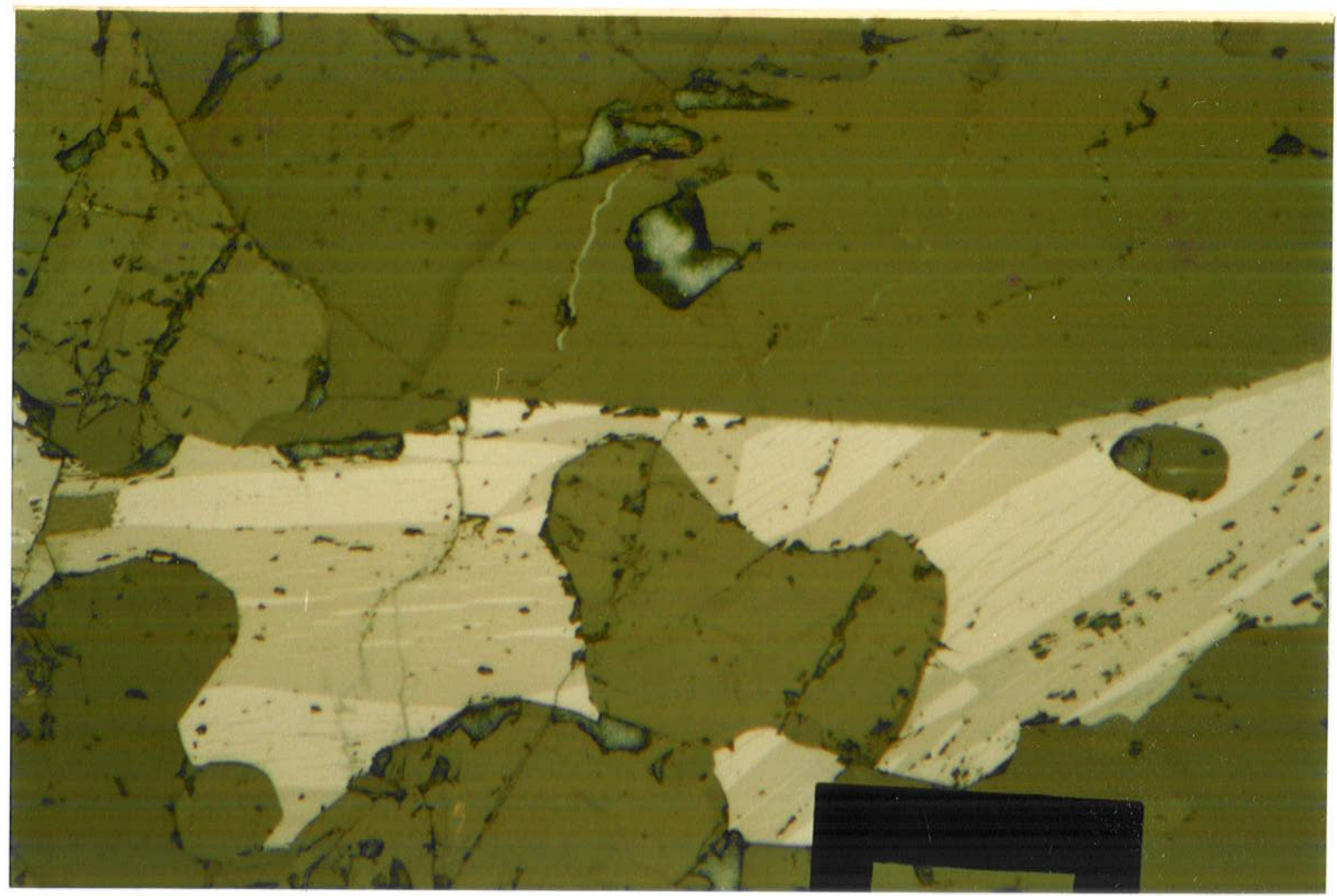

Fotomicrografia 4.10 - Intercrescimento entre magnetita e ilmenita com lamelas de exsolução de hematita, no charnoquitóide. O campo vazado da escala mede $0,1 \mathrm{~mm}$. Amostra VN-17.

Uma possível ordem de cristalização dos minerais, baseada somente nas relações entre eles e nos prováveis eventos tardi-magmáticos e secundários identificados pela petrografia, é aqui proposta.

A maior parte dos minerais acesssórios (zircão e apatita) estão inclusos em quase todas as fases e, juntamente com os minerais opacos também inclusos, devem ter sido os primeiros a se formarem.

Os ortopiroxênios e clinopiroxênios nuclearam e cristalizaram-se contemporaneamente a pouco depois dos minerais acessórios, já que exibem algumas inclusões dos mesmos. Os CPX podem ter tido um intervalo de cristalização ligeiramente mais amplo que os OPX, uma vez que ocorrem cristais dos primeiros envolvendo totalmente os últimos.

Muitos dos cristais de plagioclásio dos noritos se formaram ao mesmo tempo que os piroxênios, dada a sua composição muito rica em cálcio, enquanto que poucos deles possuem inclusões de piroxênios, indicando serem posteriores. Dentre os plagioclásios dos charnoquitóides, podem ter ocorrido três gerações: a mais antiga, contemporânea (ou quase) ao ortopiroxênio, sendo hipidiomórfica e contendo poucas inclusões, principalmente de apatita e zircão; os cristais maiores, xenomórficos e por vezes corroídos, contêm um grande número de 
inclusões, inclusive de piroxênios e biotita, e devem ter iniciado a sua cristalização pouco tempo após os anteriores; os pequenos cristais da matriz com evidências de recristalização correspondem a última geração de plagioclásio.

As biotitas são, em sua maioria, de origem secundária, substituindo piroxênios e anfibólios em uma fase tardi-magmática, provavelmente em condições de subsolidus. $O$ mesmo ocorre com os anfibólios, que substituem maciçamente os piroxênios, sobretudo CPX. Nestas reações ocorre a liberação de óxidos de ferro, que são portanto fases opacas secundárias, assim como cristais de magnetita que crescem às expensas da ilmenita. No entanto, inclusões de biotita e anfibólio em plagioclásio e a presença destes cristais individualizados, já descritos acima, indicam uma formação primária para tais fases, que parecem ter se cristalizado ao mesmo tempo que os plagioclásios da "segunda" geração. O álcali-feldspato formou-se numa fase final de cristalização, em função de sua forma, das inclusões e de apresentarem restos de plagioclásio no seu interior (feição observada em pouquíssimas amostras). O quartzo está, via de regra, preenchendo espaços entre os outros minerais, xenomórficos, o que indica que se trata da última fase cristalizada.

No contato entre feldspato potássico e plagioclásio formou-se mirmequita, possivelmente num período tardio da evolução magmática.

Finalmente, fluidos hidrotermais, ou até mesmo meteóricos, alteraram os piroxênios, feldspatos e biotitas, gerando mineral de cor ocre ou marrom (descritos acima), cloritas, muscovitas/sericitas e calcitas. 
Tabela 4.1 - Composição modal, a 1000 pontos, dos noritos do Maciço de Venda Nova

\begin{tabular}{|c|c|c|c|c|c|c|c|c|c|c|c|}
\hline Amostras & VN11 & VN9 & VN3 & VN8 & VN10 & VN26 & VN14 & VN22 & VN5 & VN7 & VN6 \\
\hline Plagioclásio & 53,6 & 45,5 & 55,5 & 52,9 & 52,4 & 51,2 & 43,8 & 51,6 & 47,8 & 48,8 & 47,4 \\
\hline Anfibólio & 5,3 & 39,3 & 15,4 & 26,7 & 24,9 & 33,8 & 28,7 & 26,3 & 40,4 & 18,3 & 22,1 \\
\hline OPX & 22,5 & 6,0 & 18,3 & 10,6 & 12,2 & 11,0 & 15,7 & 11,9 & 3,8 & 21,9 & 18,5 \\
\hline $\mathrm{CPX}$ & 10,8 & - & 3,7 & 5,7 & 4,1 & 0,5 & 5,1 & 3,0 & - & 4,5 & 3,0 \\
\hline Opacos & 4,1 & 8,4 & 6,3 & 3,6 & 6,2 & 3,3 & 6,0 & 6,3 & 7,2 & 6,4 & 8,6 \\
\hline Apatita & 0,2 & 0,3 & 0,8 & 0,3 & 0,2 & 0,1 & 0,7 & 0,9 & 0,8 & 0,1 & 0,4 \\
\hline Biotita & 3,1 & -- & -- & - & - & - & $\operatorname{tr}$ & - & $\cdots$ & $-\cdots$ & -- \\
\hline Quartzo & 0,4 & 0,5 & -- & 0,2 & -- & 0,1 & - & -- & - & -. & $\ldots$ \\
\hline Zircão & tr & -- & $\mathrm{tr}$ & $\operatorname{tr}$ & $\ldots$ & tr & $\ldots$ & - & $\operatorname{tr}$ & -- & $\mathrm{tr}$ \\
\hline
\end{tabular}

Tabela 4.2 - Composição modal, a 1000 pontos, dos charnoquitóides do Maciço de Venda Nova

\begin{tabular}{|c|c|c|c|c|c|c|c|c|c|c|c|c|c|c|c|c|}
\hline Amostras & VN17 & VN19 & VN16 & VN13 & VN15 & VN31 & VN24 & VN35 & VN23 & VN38 & VN1 & VN20 & VN2 & VN36 & VN18 & VN27 \\
\hline Plagioclásio & 53,9 & 61,5 & 60,1 & 47,5 & 51,20 & 58,5 & 59,9 & 58,5 & 61,9 & 64,9 & 52,9 & 60,8 & 51,0 & 57,4 & 57,6 & 49,1 \\
\hline Quartzo & 6,5 & 6,1 & 10,1 & 22,1 & 11,5 & 19,5 & 20,7 & 12,5 & 16,5 & 14,4 & 7,9 & 14,6 & 27,5 & 11,3 & 11,2 & 24,5 \\
\hline Biotita & 5,6 & 8,9 & 10,0 & 22,0 & 9,5 & 8,0 & 8,9 & 8,3 & 7,5 & 13,0 & 16,2 & 5,6 & 11,5 & 9,9 & 12,2 & 11,2 \\
\hline Anfibólio & 2,6 & 1,6 & tr & -- & -- & 0,1 & 3,0 & 5,8 & 0,1 & 1,4 & $\operatorname{tr}$ & 7,3 & 0,4 & 5,9 & 5,5 & 1,2 \\
\hline OPX & 15,8 & 10,6 & 3,3 & 3,6 & 5,2 & 2,3 & 4,0 & 5,7 & 1,6 & 3,2 & 1,8 & 6,0 & 0,3 & 6,9 & 5,2 & 0,2 \\
\hline $\mathrm{CPX}$ & 10,4 & 7,9 & 5,3 & - & 6,6 & 1,2 & 2,0 & 2,9 & 2,3 & 0,7 & 6,5 & 2,8 & 0,2 & 4,3 & 4,2 & 0,8 \\
\hline $\begin{array}{l}\text { Feldspato } \\
\text { alcalino }\end{array}$ & - & - & 3,6 & - & 6,4 & 8,6 & - & 2,1 & 3,9 & $\mathrm{tr}$ & 2,8 & - & -- & - & - & 8,4 \\
\hline Opacos & 5,2 & 3,2 & 2,7 & 1,2 & 3,5 & 1,4 & 1,3 & 3,4 & 1,3 & 2,0 & 3,8 & 2,7 & 2,9 & 2,6 & 3,6 & 0,4 \\
\hline Mirmequita & -- & -- & 0,5 & - & 0,8 & 0,4 & - & $\ldots$ & - & $\ldots$ & 1,3 & - & - & - & - & $\operatorname{tr}$ \\
\hline Apatita & $\mathrm{tr}$ & 0,1 & 0,1 & 0,6 & 0,1 & $\mathrm{tr}$ & 0,2 & 0,6 & 0,4 & 0,4 & 0,3 & 0,2 & 0,6 & 0,2 & 0,5 & 0,2 \\
\hline Zircão & $\mathrm{tr}$ & 0,1 & tr & 0,2 & $\mathrm{tr}$ & $\mathrm{tr}$ & $\mathrm{tr}$ & 0,2 & tr & $\mathrm{tr}$ & $\mathrm{tr}$ & tr & 0,2 & $\mathrm{tr}$ & $\mathrm{tr}$ & tr \\
\hline Allanita & - & - & -- & -- & 0,1 & - & - & tr & -- & -- & -- & - & -- & -- & $m$ & -- \\
\hline $\begin{array}{l}\text { Alteração } \\
\text { plagioclásio }\end{array}$ & -- & $-m$ & 1,0 & 2,8 & 1,8 & -- & - & $-\cdots$ & - & -- & 0,5 & - & 0,6 & 0,7 & -- & - \\
\hline $\begin{array}{l}\text { Alteração } \\
\text { de OPX }\end{array}$ & - & - & 3,3 & -- & 3,3 & - & -- & -- & 4,5 & - & 6,0 & - & 4,8 & 0,8 & - & 4,0 \\
\hline
\end{tabular}

$\mathrm{tr}=$ tracos (fases observadas mas não contadas) 


\subsection{MACIÇO DE VÁRZEA ALEGRE}

Será realizada uma descrição petrográfica única para os diferentes tipos litológicos do domínio externo do maciço de Várzea Alegre, uma vez que se trata de rochas de mesmo aspecto textural, bem homogêneas, variando somente a proporção entre os minerais constituintes, fornecendo assim as quatro denominações adotadas.

Os charnoquitóides do Complexo intrusivo de Várzea Alegre são rochas de textura porfirítica a megaporfirítica, com megacristais de ortoclásio, plagioclásio andesina, mesopertita e raros de quartzo, com tamanho variando de cerca de 0,7 a 6 centímetros. A proporção megacristais/matriz destas rochas varia bastante, mas de maneira geral predomina a matriz. Ela é inequigranular hipidiomórfica, tem granulação média a grossa, mas os seus cristais são menores quando estão apertados entre os megacristais (Fotomocrografia 4.11). Compõe-se de andesina, quartzo, álcali-felsdspato, biotita, OPX, anfibólio (Mg-hastingsita e hastingsita magnesiana), ilmenita, magnetita, pirita, apatita, zircão e allanita.

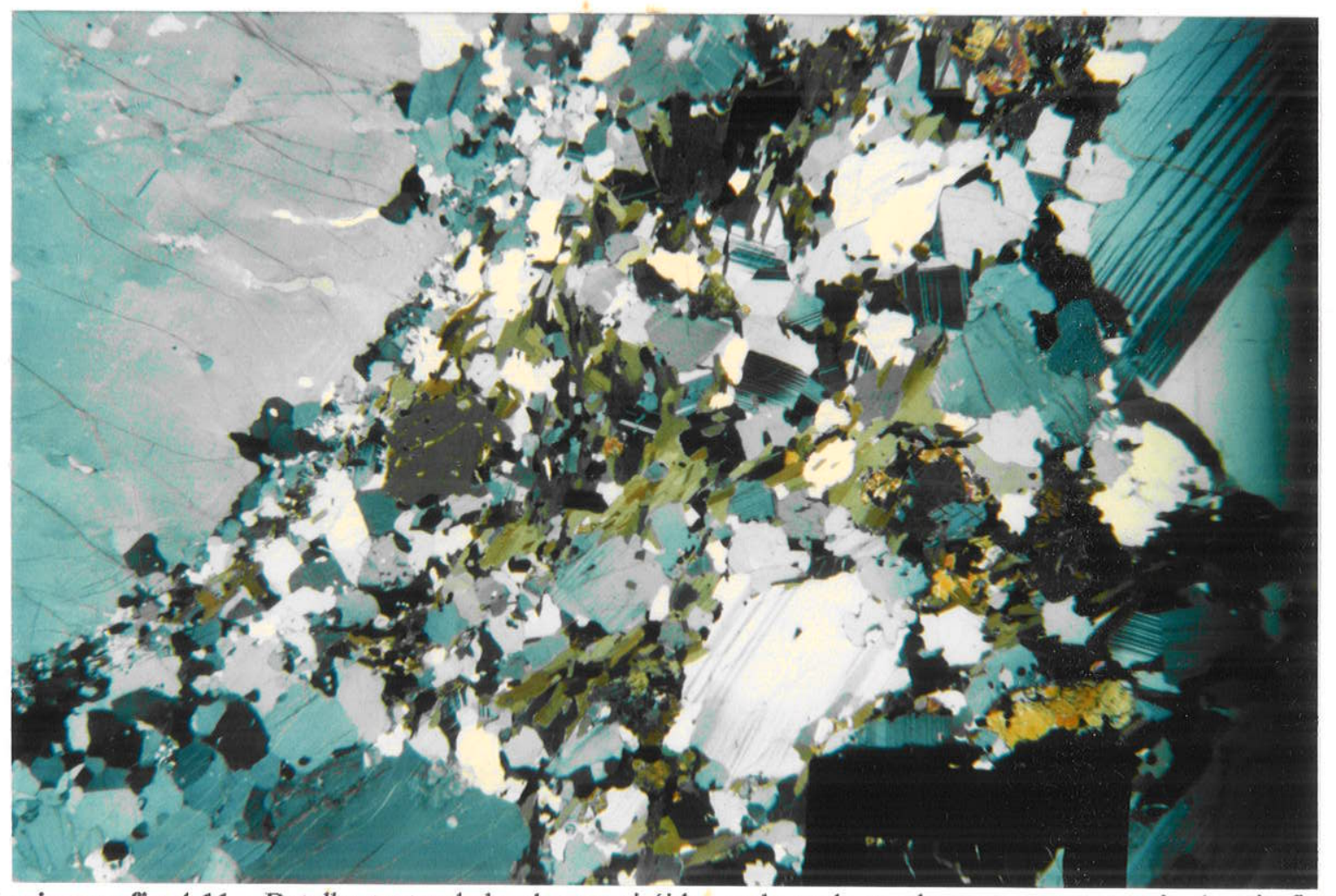

Fotomicrografia 4.11 - Detalhe textural do charnoquitóide, onde pode-se observar que a matriz é mais fina quando está apertada entre os megacristais, como também o contato bastante irregular (corroído) do megacristal de ortoclásio (a esquerda). O campo vazado da escala mede 2,5 mm. Nx. Amostra VA-264. 
Interessantes feições texturais e micro-estruturais são observadas em algumas das amostras estudadas, dentre elas: orientação do eixo maior dos feldspatos e biotitas, extinção ondulante incipiente a muito pronunciada, gerando sub grãos (principalmente entre os megacristais), lamelas de geminação dos plagioclásios e planos de clivagem de biotitas recurvadas, recristalização localizada da matriz, principalmente quando está espremida entre os megacristais e glomérulos máficos com apatita associada, por vezes orientados, que localmente caracterizam uma textura glomeroporfiritica. No entanto, a principal forma de ocorrência dos minerais máficos são pequenos agregados onde duas fases estão associadas, sendo OPX e biotita as mais comuns. Em algumas amostras observam-se megacristais de feldspato (ou cristais maiores da matriz) totalmente envolvidos por pequenos cristais máficos, notadamente piroxênio e biotita.

Como já explicado no ítem 1.4, foi realizada uma análise modal diferenciada para as rochas de granulação mais grossa, contando-se um maior número de pontos através de três cortes perpendiculares por amostra. Apesar de ter chegado a conclusão que esta contagem não é representativa, em função da granulação da rocha, o resultado da mesma encontra-se na Tabela 4.3, e o diagrama QAP correspondente está na Figura 4.3, classificando as rochas estudadas em OPX-quartzo-dioritos, jotunitos e quartzo-mangeritos. A classificação química, adotada na nomenclatura destas rochas, é a seguinte: OPX-quartzo-dioritos, jotunitos, opdalitos e quartzo-mangeritos, sendo abordada no próximo capítulo.

Os megacristais de feldspato alcalino são hipidiomórficos a xenomórficos, de diversos tamanhos $(0,7$ a $6 \mathrm{~cm})$ e variavelmente pertíticos (são observadas mesopertitas e megacristais que possuem concentrações pertíticas localizadas, chegando a formar zonas mesopertíticas no seu interior). Foram feitas análises por difração de raios-X em alguns cristais de feldspato alcalino, e os difratogramas exibem raias com picos característicos de ortoclásio de bário (Figura 4.4).

Estão pouco alterados, apesar de fraturados, não mostram geminação e possuem contatos sinuosos e irregulares e poucas inclusões, entre elas biotita, plagioclásio, OPX, apatita, zircão e minerais opacos; ocorrem cristais poiquilíticos que envolvem praticamente todos estes minerais. Vários megacristais apresentam inclusões de plagioclásio nitidamente corroídos (às vezes com lamelas de geminação bem formadas), como "restos" que caracterizam um nítido processo de substituição (Fotomicrografia 4.12). É muito frequente a presença de mirmequita nos contatos com plagioclásio. 


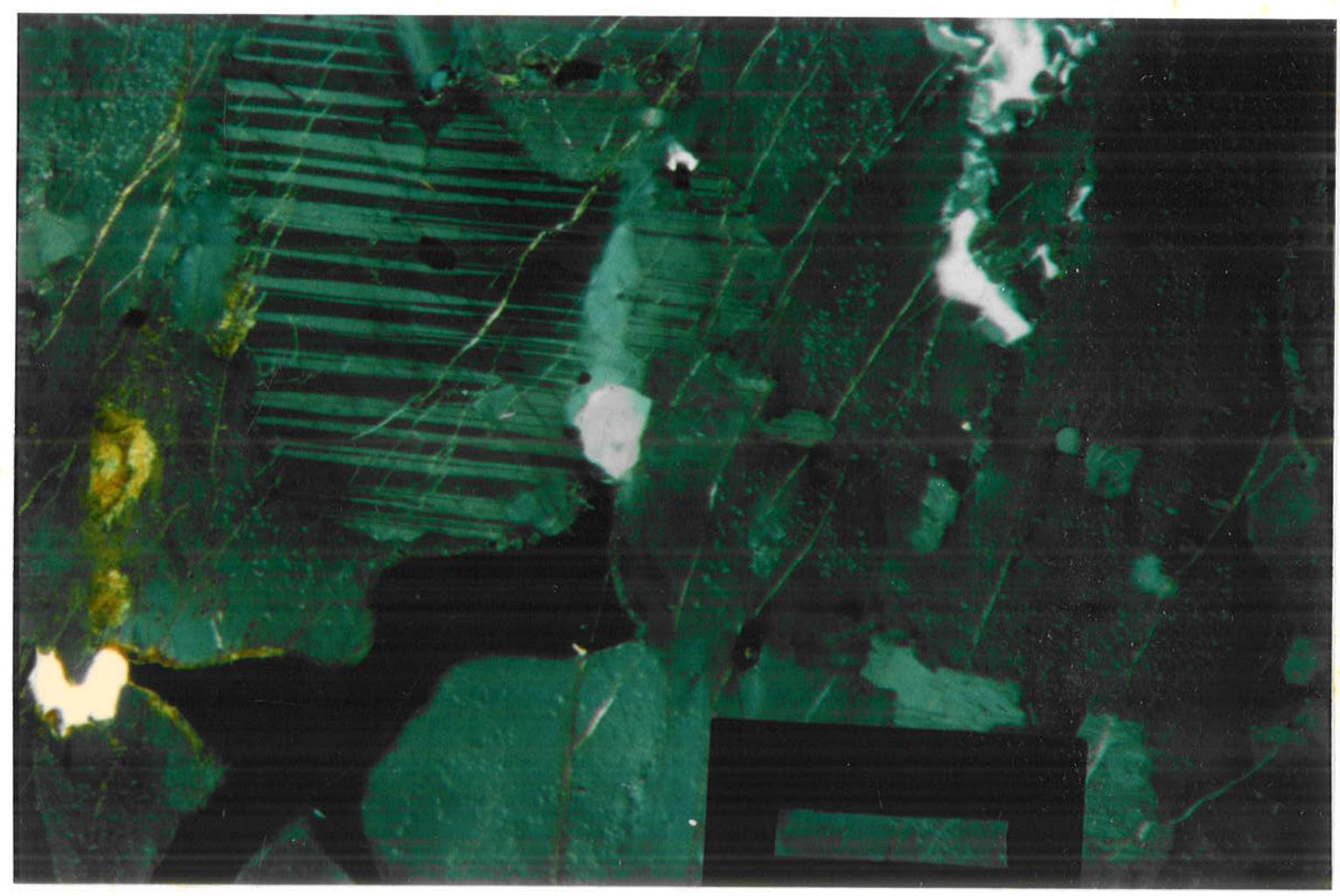

Fotomicrografia 4.12 - Megacristal de ortoclásio pertítico apresentando restos de plagioclásio xenomórfico no seu interior. O campo vazado da escala mede 1,25 mm. Nx. Amostra VA-264.

Na matriz o feldspato alcalino é mais limpo, xenomórfico, e alguns grãos não exibem lamelas pertíticas, o que dificulta a sua identificação. Assim como acontece com os megacristais, ocorrem cristais com bordas muito irregulares, o que pode estar associado ao frequente contato em reação com plagioclásio, formando muita mirmequita. Tanto os cristais da matriz quanto os megacristais podem apresentar evidências de deformação incipiente, tais como extinção ondulante variando de fraca a acentuada e recristalização evidenciada por cristais com contatos retilíneos (cf. Fotomicrografia 4.11).

Os megacristais de plagioclásio são xenomórficos, de tendência tabular, com bordas irregulares, às vezes corroídos e embainhados por quartzo. No geral, são menores que os megacristais de ortoclásio e em sua maioria possuem lamelas de geminação mal desenvolvida (é comum ocorrerem cristais com lamelas de geminação interrompida) e muitas inclusões de apatita, biotita, zircão, OPX e minerais opacos (inclusive nuvens de opacos e inclusões fluidas alinhadas). Exibe algumas inclusões irregulares (lamelares, prismáticas ou esqueléticas, posicionadas aleatoriamente ou paralelas ao eixo c) de um mineral incolor, de relevo baixo, biaxial negativo e com cor de birrefringência cinza, possivelmente álcalifeldspato (não foi possível analisar na microssonda), podendo tratar-se portanto de anti-pertita 
São variavelmente fraturados e pouco alterados, e raros são zonados. Mostram lamelas de geminação recurvadas, extinção ondulante e largas franjas de mirmequita e têm composição variando de An32 a An40 (cf. Tabela 6.13 no Cap. 6). Os minerais de alteração identificados foram sericita, calcita e rara clinozoisita.

$\mathrm{Na}$ matriz o plagioclásio é hipidiomórfico a xenomórfico com dimensões variadas, possuindo menos inclusões que os megacristais e localmente com contatos poligonais ou extinção ondulante; algumas amostras, e.g. VA-56, apresentam uma matriz muito recristalizada e apertada entre os megacristais, com vários cristais de feldspato aglutinados, poligonizados e não mostrando geminação. A variação composicional é similar àquela encontrada nos megacristais e possuem bordas de mirmequita de tamanhos diversos, por vezes tomando todo o cristal. Os grãos maiores da matriz às vezes também exibem as inclusões do mineral incolor descrito nos megacristais.

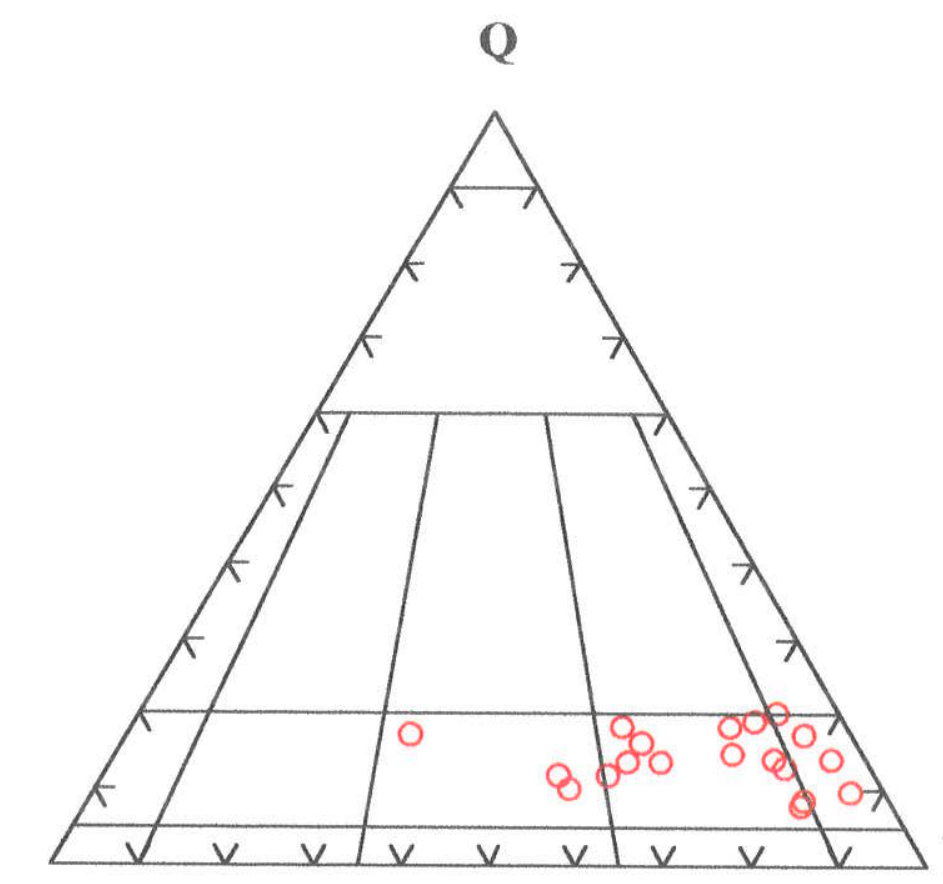

A

P

Figura 4.3 - Diagrama modal QAP para os charnoquitóides do maciço de Várzea Alegre 


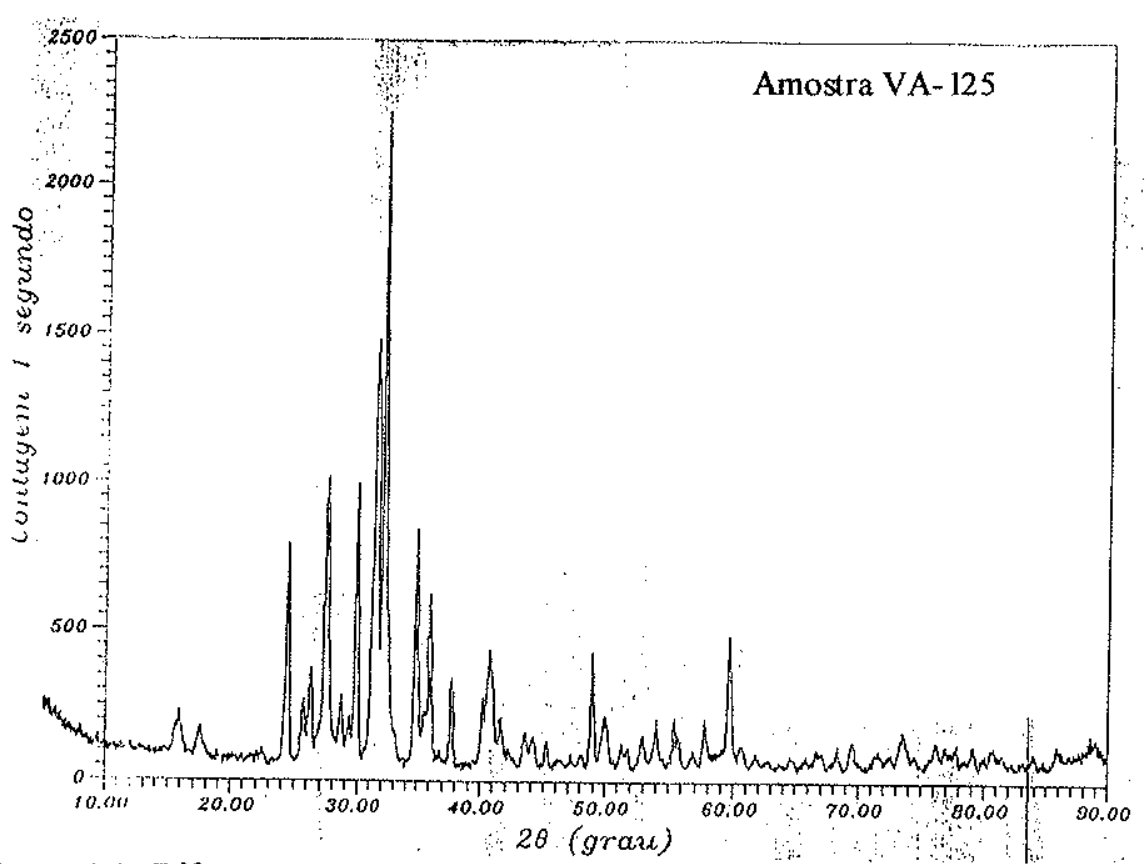

Figura 4.4 - Difratograma de feldspato alcalino do charnoquitóide de Várzea Alegre.

Os cristais de quartzo predominam na matriz como grãos xenomórficos, pouco fraturados, limpos e intersticiais; dentre os megacristais exibem formas muito irregulares, arredondados a amebóides, corroendo e embainhando os cristais maiores de plagioclásio (Fotomicrografia 4.13), mas mostram um número maior de inclusões de apatita, zircão, biotita, minerais opacos, raro OPX e micro-inclusões sólidas e líquidas alinhadas. É comum apresentarem extinção ondulante e localmente alguns grãos estão alongados paralelamente à foliação da rocha.

Os ortopiroxênios são hipidiomórficos a xenomórficos, com pleocroísmo típico, fraturados (alguns bem quebrados e com arestas arredondadas), substituídos principalmente por biotita e menos por anfibólio. Alteram-se para material de cor ocre e marrom e por clorita (principalmente nas fraturas e clivagens) que muitas vezes penetra nas fraturas dos megacristais; em algumas lâminas os cristais estão quase totalmente alterados (Fotomicrografia 4.14). Exsolvem frequentemente minerais opacos e alguns estão uralitizados; na amostra VA-261 ocorre um grande número de lamelas de exsolução de opacos colocados paralelamente à face (100). Estão tanto na forma de grãos isolados como em agregados associados ou não às outras fases máficas, que podem exibir uma orientação paralela à dos megacristais de feldspato (Fotomicrografia 4.15). Possuem inclusões de apatita, zircão e minerais opacos. A determinação por microssonda eletrônica deixou claro o enriquecimento em $\mathrm{Fe}$ destes piroxênios, que por estarem muito alterados não apresentaram, na maior parte dos pontos analisados, um fechamento adequado, próximo de $100 \%$ (cf. Tabela 6.10 no Cap. 6). 


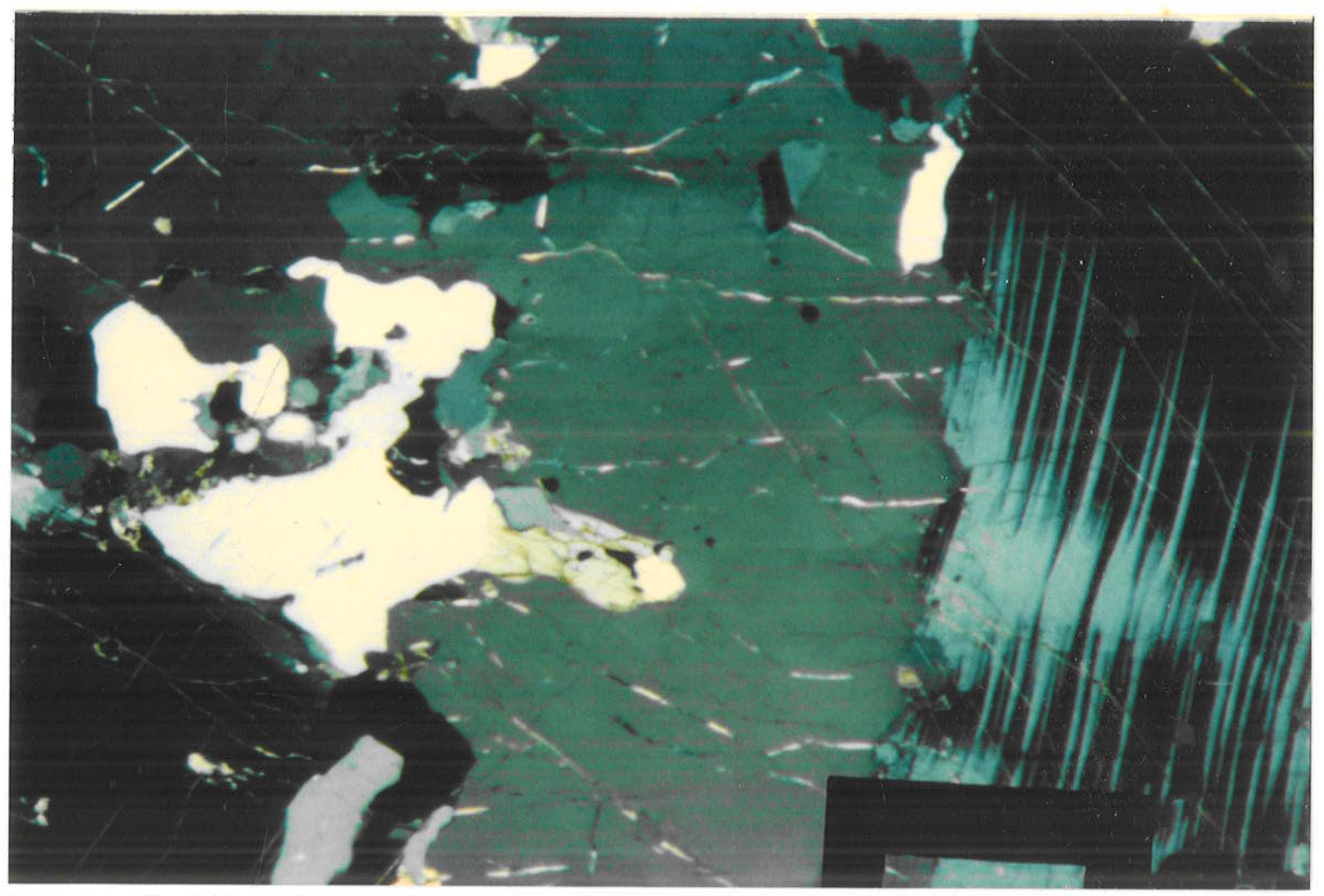

Fotomicrografia 4.13 - Detalhe do contato entre megacristais de plagioclásio e quartzo xenomórfico. O plagioclásio exibe borda corroída por quartzo. O campo vazado da escala mede $0,8 \mathrm{~mm}$. Nx. Amostra VA- 182 .

Os cristais de biotita apresentam-se como lamelas isoladas, em agregados ou substituindo piroxênio e anfibólio (pleocroísmo castanho claro a marrom escuro) ou como cristais maiores xenomórficos, isolados, de cor marrom escuro e não pleocróicos (que podem ser primários), alguns deles poiquilíticos. Estão pouco alteradas, mas algumas transformam-se em clorita e muscovita. Associam-se frequentemente a OPX, minerais opacos, hornblenda e apatita e localmente contornam outras fases, principalmente megacristais. São muitas as inclusões de zircão e apatita, e menos de OPX e minerais opacos. São observados cristais de biotita com planos de clivagem recurvados.

O anfibólio, quando presente, tem pleocroísmo castanho-verde claro-verde musgo, apresentando-se na forma de cristais maiores isolados (por vezes poiquilíticos, com inclusões de apatita, zircão, opacos e restos corroídos de OPX) ou agregados hipidiomórfícos a xenomórficos muitas vezes substituindo OPX. Integram os glomérulos máficos e são substituídos por biotita. 


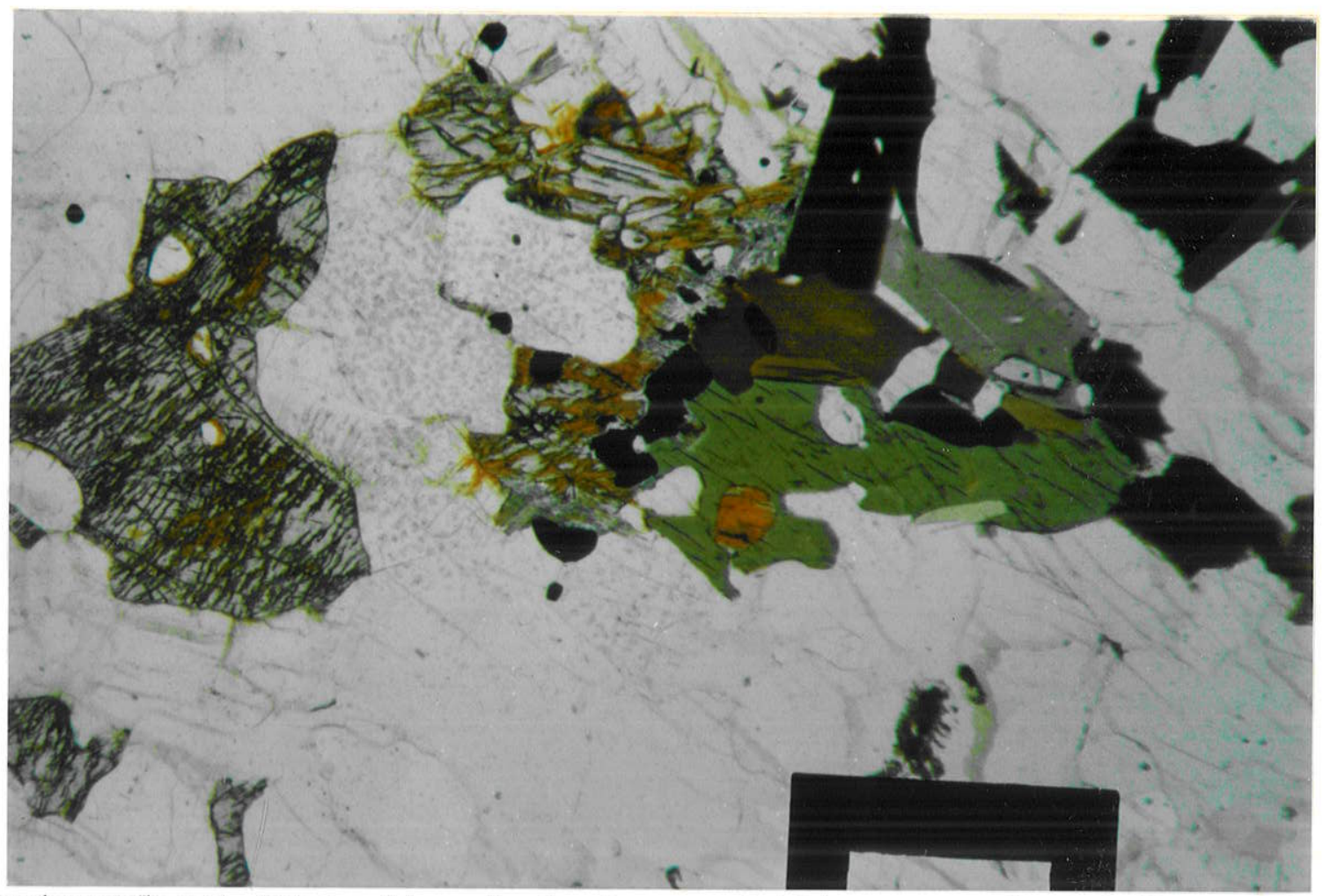

Fotomicrografia 4.14 - Ortopiroxênios muito alterados para material de cor ocre sendo substituídos por anfibólio e biotita, com exsolução de minerais opacos. O campo vazado da escala mede 0,63 mm. N//. Amostra VA- 16 .

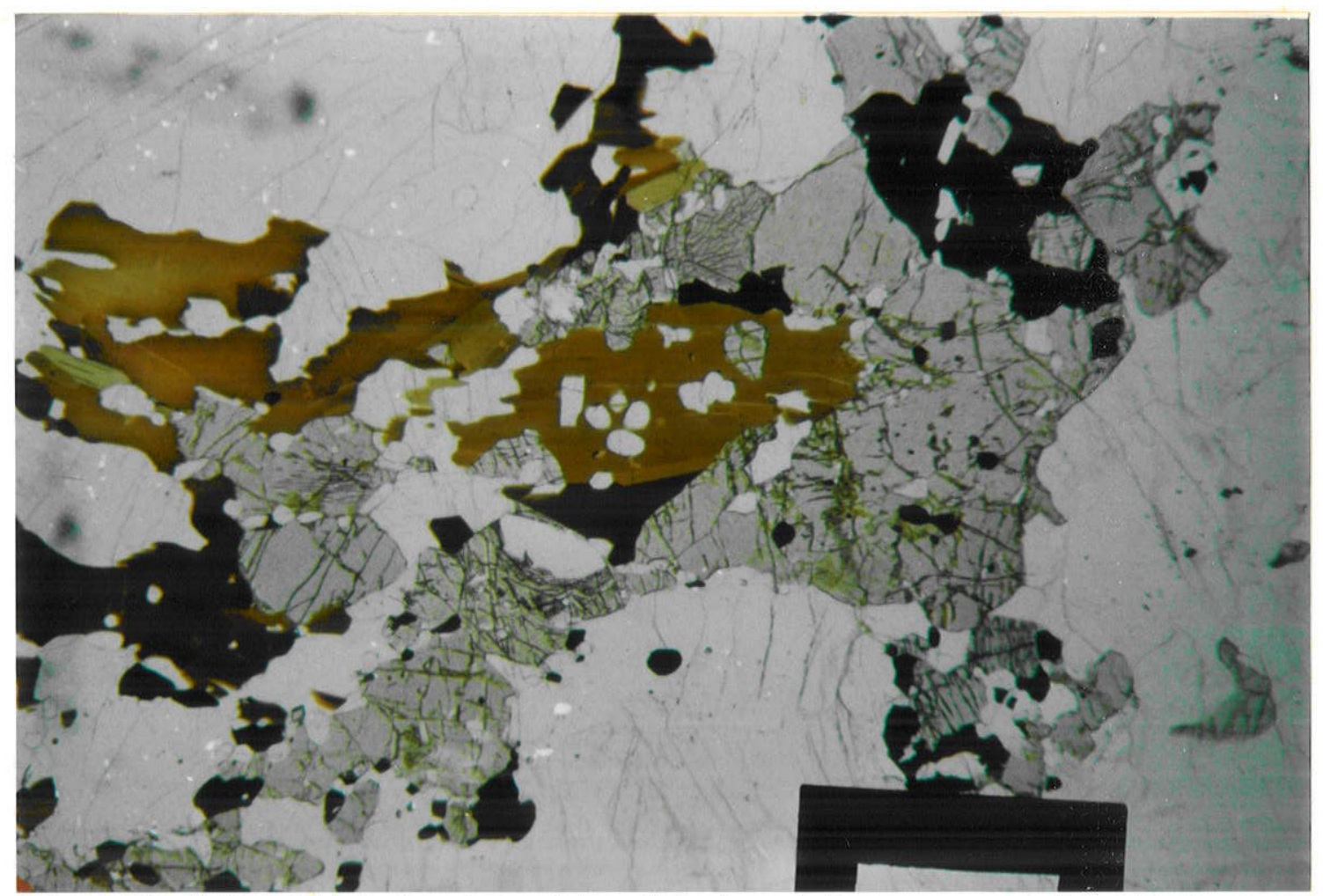

Fotomicrografia 4.15 - Cristais de ortopiroxênio aglutinados e intimamente associados a biotita e minerais opacos (que tanto estão exsolvidos quanto substituindo os OPX). O campo vazado da escala mede $1,0 \mathrm{~mm}$. N//. Amostra VA- 182. 
Dentre as fases opacas, há um considerável predomínio de grãos de ilmenita sobre magnetita e pirita. Ocorrem cristais de ilmenita sendo substituída por magnetita e também intercrescimento entre as duas fases (Fotomicrografia 4.16). Lamelas de exsolução de hematita na ilmenita são menos frequentes do que nos charnoquitóides da intrusão de Venda Nova. Predominantemente estão associados a minerais máficos, sendo xenomórficos, e como pequenas inclusões idiomórficas a xenomórficas em vários minerais. Por vezes estão bordej ando OPX, sugerindo substituição.

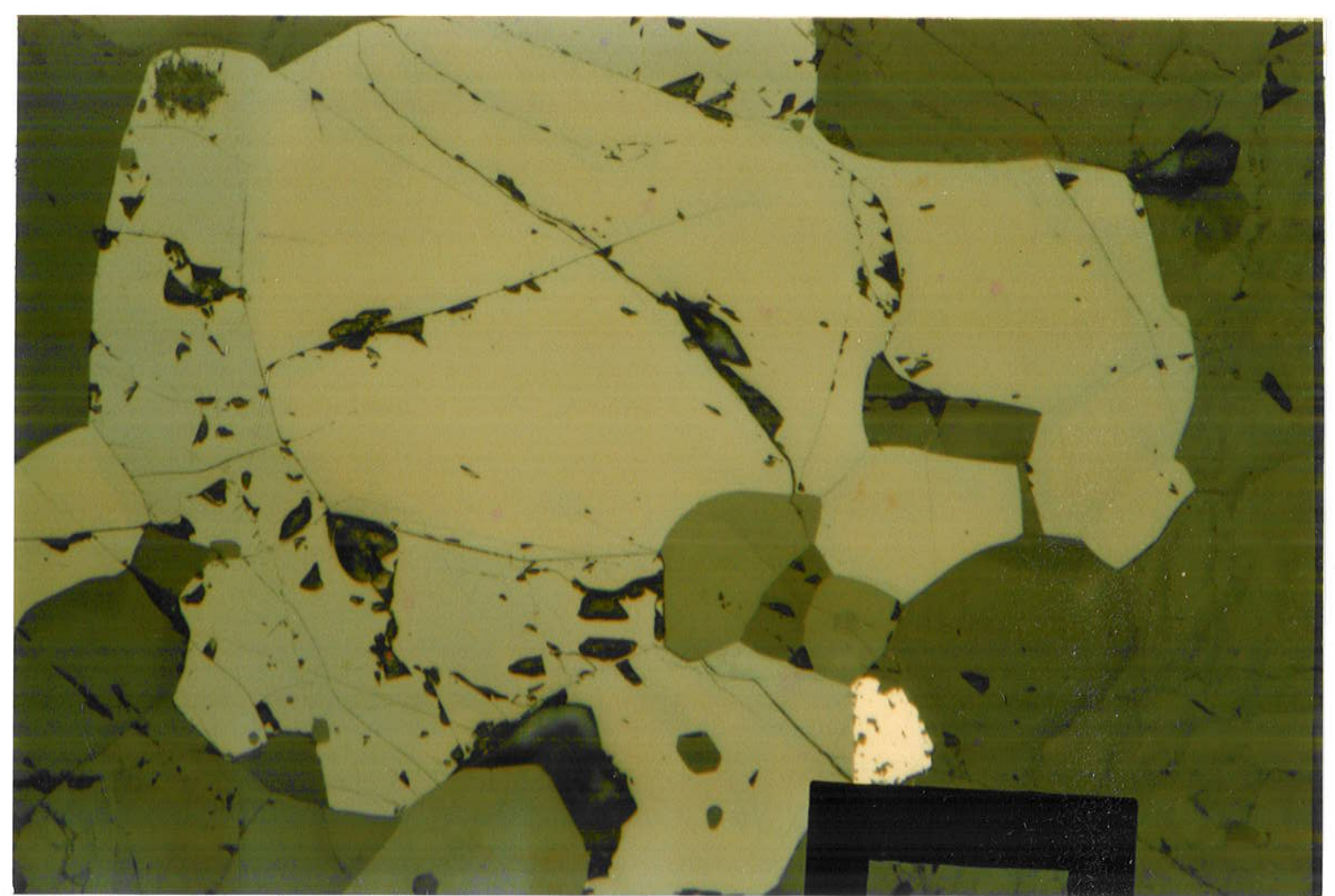

Fotomicrografia 4.16 - Cristal de ilmenita sendo substituído por magnetita, que está bordej ando quase todo o grão de ilmenita. O campo vazado da escala mede $0,1 \mathrm{~mm}$. Amostra VA-246.

Somente na amostra VA-263 foi observada granada. Apresenta-se xenomórfica, tendendo ao arredondamento, em frequente associação com os glomérulos máficos ou nas proximidades dos mesmos. Possui inclusões de apatita e quartzo e não mostra contatos de reação com qualquer fase.

Os principais minerais acessórios são apatita e zircão. Ambos aparecem como inclusões de formas e hábitos variados assim como em cristais individualizados. Ocorrem grãos de apatita hipidiomórfica bem desenvolvidos, sobretudo quando associados às fases máficas. Em algumas lâminas são observadas concentrações de zircão xenomórficos normalmente orientados. A allanita foi identificada em poucas amostras, aparecendo 
principalmente como inclusões, mas cresceram também alguns cristais isolados. Nas lâminas VA-56, VA-237 e VA-250 ocorre inclusões de diminutos cristais idiomórficos, tendendo a losangular, de relevo alto e birrefringência anômala, provavelmente titanita.

Dentre os minerais de alteração de ortopiroxênio, plagioclásio e biotita foram identificados o material de cor ocre ou marrom, clorita, sericita, muscovita, calcita e clinozoisita.

A sugestão de uma ordem de cristalização para os minerais das rochas do domínio externo do maciço de Várzea Alegre é dificultada pela presença de grandes cristais de fases diferentes. Isto muitas vezes é um fator complicador no estabelecimento da relação entre eles, em função do limite de área que pode ser observada no microscópio ótico. Apesar disto, são encontrados alguns megacristais de feldspato alcalino com restos de plagioclásio no seu interior, tornando clara a substituição ocorrida. Com relação ao quartzo, muitos deles possuem formas extremamente irregulares e/ou corroem outros megacristais, sugerindo serem posteriores.

As primeiras fases cristalizadas foram, muito provavelmente, zircão, apatita e as pequenas inclusões de minerais opacos. Com relação a allanita e titanita identificadas, não pode-se afirmar com total segurança pois foram muito poucos os cristais observados, mas devem estar relacionadas ao início de cristalização do magma, uma vez que também aparecem como inclusões.

O ortopiroxênio veio logo a seguir, tendo inclusões de acessórios e aparecendo como inclusão nos plagioclásios, principalmente os megacristais. Em sequência, vieram estes últimos; talvez os grãos da matriz tenham iniciado antes a sua cristalização (quase simultaneamente ao OPX, dada a composição dos dois minerais), em função de serem mais limpos e com formas mais definidas. No entanto, se os megagacristais de plagioclásio se cristalizaram depois seria de se esperar que eles tivessem inclusões ou "restos" dos plagioclásios da matriz no seu interior, o que não ocorre. Além do que, todos eles têm a mesma variação composicional. Os cristais da matriz que são produtos de recristalização caracterizam, sem dúvida alguma, a última geração de plagioclásios.

As biotitas que podem ser consideradas primárias (e talvez também os anfibólios xenomórficos isolados) cristalizaram-se provavelmente ao mesmo tempo que os plagioclásios, apesar destes últimos possuírem algumas poucas inclusões de biotita, mas estas podem ser produto de substituição de OPX. As biotitas e anfibólios secundários, advindas de 
ortopiroxênio, assim como os óxidos de ferro exsolvidos pelo mesmo e a magnetita formada às expensas da ilmenita, devem ter se formado numa fase tardi-magmática, provavelmente em estado subsolidus, tendo em vista os fenômenos de desestabilização mineral observados.

Por ocorrerem megacristais de álcali-feldspato bem formados, quase euédricos, o crescimento desta fase (incluindo as mesopertitas) deve ter se iniciado num período relativamente cedo na evolução do magma, talvez pouco depois dos plagioclásios já que vários cristais de feldspato alcalino nitidamente os substituem. Seu intervalo de cristalização pode ter sido longo, pois na matriz eles são totalmente xenomórficos e localmente espremidos entre os megacristais, sugerindo terem preenchido, durante o seu crescimento, espaços que sobraram.

Os cristais de quartzo, tanto os megacristais quanto os da matriz, correspondem a última fase cristalizada, tendo em vista serem extremamente xenomórficos e claramente preencherem os espaços deixados.

A grande quantidade de mirmequita observada formou-se provavelmente numa fase tardia da evolução magmática.

Finalmente, fluidos hidrotermais, ou até mesmo meteóricos, alteraram os piroxênios, feldspatos e biotitas, formando o mineral de cor ocre ou marrom descrito acima, cloritas, muscovitas/sericitas, calcitas e clinozoisitas. 
Tabela 4.3 - Composição modal das rochas do Maciço de Várzea Alegre

\begin{tabular}{|c|c|c|c|c|c|c|c|c|c|c|c|c|}
\hline Amostras & VA262 & VA263 & VA264 & VA244 & VA249 & VA242 & VA125 & VA252 & VA257 & VA241 & VA.56 & VA42 \\
\hline Plagioclásio & 51,8 & 22,5 & 48,6 & 48,5 & 58,3 & 52,6 & 49,6 & 51,5 & 48,5 & 40,8 & 60,0 & 46,0 \\
\hline Quartzo & 11,1 & 15,2 & 14,5 & 9,9 & 9,8 & 11,0 & 11,3 & 14 & 10,4 & 9,2 & 5,9 & 14,9 \\
\hline $\begin{array}{l}\text { Feldspato } \\
\text { alcalino }\end{array}$ & 19,5 & 38,4 & 5,4 & 25,5 & 7,5 & 11,3 & 21,0 & 21,5 & 18,3 & 28,3 & 7,7 & 20,9 \\
\hline Mesopertita & -- & 12,3 & 10,7 & -- & -- & -- & 4,0 & -- & -. & - & .. & -. \\
\hline Biotita & 6,4 & 6,8 & 13,6 & 8,5 & 13,3 & 10,5 & 5,5 & 4,5 & 6,9 & 6,8 & 1,6 & 7,5 \\
\hline OPX & 5,4 & 0,9 & 2,9 & 4,7 & 4,8 & 10,6 & 5,2 & 4,0 & 7,1 & 9,2 & 16,0 & 1,6 \\
\hline Anfibólio & 3,1 & -. & 2,0 & - & 3,3 & - & tr & 0,1 & 3,9 & 0,3 & 3,5 & 1,5 \\
\hline Opacos & 1,7 & 0,7 & 1,3 & 4,7 & 1,5 & 2,7 & 1,5 & 1,1 & 2,5 & 2,2 & 4,0 & 0,8 \\
\hline Mirmequita & 0,2 & 1,5 & $-n$ & 1,2 & 0,7 & 0,2 & 0,9 & 1,5 & 1,0 & 2,4 & .- & 1,3 \\
\hline Apatita & 0,5 & 0,3 & 0,9 & 0,6 & 0,7 & 0,9 & 0,6 & 0,3 & 1,2 & 0,8 & 1,3 & 1,3 \\
\hline Zựcão & ts & tr & $t 5$ & tr & - & $\operatorname{tr}$ & tr & 0,1 & 0,2 & $t$ & - & tr \\
\hline Allanita & 0,1 & - & - & - & 0,1 & 0,2 & - & -. & - & - & -- & -. \\
\hline Granada & $n$ & 1,1 & - & $\ldots$ & $\ldots$ & $\ldots$ & - & - & .. & - & . & - \\
\hline $\begin{array}{l}\text { Alteração } \\
\text { de OPX }\end{array}$ & 0,1 & 0,3 & -- & - & -- & - & 0,4 & 0,3 & -- & - & -- & 1,0 \\
\hline $\begin{array}{l}\text { Alteração } \\
\text { de plagiocl. }\end{array}$ & 0,1 & - & 0,1 & -. & - & - & -- & 1,2 & -- & - & -- & 3,2 \\
\hline $\begin{array}{l}\text { Total de } \\
\text { pontos }\end{array}$ & 3.000 & 3.000 & 3.000 & 3.000 & 3.000 & 3.000 & 3.000 & 3.000 & 3.000 & 3.000 & 3.000 & 3.000 \\
\hline
\end{tabular}

tr $=$ traços (fases observadas mas não contadas)

\begin{tabular}{|c|c|c|c|c|c|c|c|c|c|c|c|}
\hline Amostras & VA256 & VA254 & VA250 & VA237 & VA90 & VA182 & VA260 & VA16 & VA261 & VA246 & $\overline{\text { VA253 }}$ \\
\hline Plagioclásio & 54,0 & 35,9 & 61,6 & 56,9 & 57,9 & 66,0 & 43,8 & 59,1 & 62,3 & 56,6 & 62,6 \\
\hline Quartzo & 24,2 & 41,8 & 16,5 & $\{2,7$ & 12,0 & 7,4 & 8,1 & 16,2 & 10,7 & 10,5 & 6,6 \\
\hline $\begin{array}{l}\text { Feldspato } \\
\text { alcalino }\end{array}$ & 11,5 & 7,8 & 9,1 & 4,0 & -- & 2,9 & 28,9 & -- & 3,1 & 7,9 & 7,6 \\
\hline Mesopertita & $\cdots$ & - & -- & -- & -- & -- & - & 11,6 & - & -. & $\cdots$ \\
\hline Biotita & 4,4 & 3,5 & 3,9 & 9,7 & 17 & 3,5 & 7,5 & 6,4 & 3,7 & 12,1 & 1,4 \\
\hline OPX & 0.1 & 0,2 & 5,7 & 10,4 & 8,8 & 14,7 & 7,3 & 0.2 & 15,2 & 6,8 & 14,7 \\
\hline Anfibólio & .- & .. & 1,4 & 2,3 & 0,8 & 0,3 & tr & 5,8 & tr & 3,3 & 2,5 \\
\hline Opacos & 0,8 & 0,2 & 1,2 & 2,6 & 2,7 & 3,8 & 0,9 & 0,6 & 3,7 & 2,2 & 3,2 \\
\hline Mirmequita & - & 0,5 & - & 0,5 & - & -. & 2,7 & $\ldots$ & $\ldots$ & -. & 0,3 \\
\hline Apatita & 0,3 & 0,1 & 0,5 & 0,9 & 0,8 & 1,4 & 0,6 & 0,1 & 1,1 & 0,6 & 1,1 \\
\hline Zícão & $\mathrm{tr}$ & $\mathrm{tr}$ & ts & tr & ts & tr & 0,2 & tr & 0,2 & tr & tr \\
\hline Granada & 4,7 & 10 & -. & -. & -. & .. & .- & .. & -- & . & - \\
\hline $\begin{array}{l}\text { Total de } \\
\text { pontos }\end{array}$ & 1.000 & 1.000 & 1.000 & 1.000 & 1.000 & 1.000 & 1.000 & 1.000 & 1.000 & 1.000 & 1.000 \\
\hline
\end{tabular}

tr = traços (fases observadas mas não contad̉as) 


\section{CAPÍtULO 5 QUIMICA DE ROCHAS}

A maior parte das publicações com dados químicos de rochas charnoquitizadas são referentes a faixas antigas e extensas (arqueanas e proterozóico inferior principalmente) metamorfoseadas em fácies granulito, como é o caso dos granulitos do sul da Índia (Condie et al., 1982; Allen et al., 1985), do Complexo Lewisian, Escócia (Drury, 1973; Tarney \& Weaver, 1987), do Cinturão Lapland, Finlândia (Barbey \& Cuney, 1982), entre outros, e no Brasil dos granulitos do sul da Bahia (Figueiredo, 1982) e do Complexo Juiz de Fora.

São relativamente escassos os trabalhos de cunho geoquímico em maciços charnoquitóides com características ígneas preservadas (alguns mais e outros menos preservados), independente do grau de deformação e da idade, como é o caso dos maciços de Venda Nova e Várzea Alegre. Tal problemática encontra-se bem explorada por Field et al. (1980) estudando os gnaisses charnoquíticos do sul da Noruega, por Petersen (1980) nas intrusões de Farsund e Kleivan, sudoeste da Noruega, por Hubbard \& Whittley (1979) nos charnoquitos do sudeste da Suécia, por Ormaasen (1977) em intrusões mangeríticascharnoquíticas do norte da Noruega, por Kaiyi et al. (1985) em gnaisses charnoquíticos do norte da China e preliminarmente por Kerr et al. (1987) em charnoquitóides do sudeste da África. No Brasil, Gasparini \& Mantovani (1979) estudaram a geoquímica dos charnoquitos de Ubatuba, São Paulo, Campos Neto et al. (1988) a seqüência mangerítica de São José do Rio Pardo, SP, Rêgo (1989) trabalhou detalhadamente os noritos e charnoquitóides do maciço de Bela Joana, norte do Rio de Janeiro e Janasi (1992) o maciço charnoquítico-mangerítico de São Pedro de Caldas, sul de Minas Gerais, todos eles através de um enfoque dominantemente magmático.

\subsection{MACIÇO DE VENDA NOVA}

\section{As variações químicas detectadas}

Com o propósito de traçar considerações petroquímicas sobre as rochas da borda da intrusão de Venda Nova, foram utilizadas 27 análises químicas de elementos maiores, menores e traços (sendo onze análises para elementos terras raras). Os resultados obtidos encontram-se nas tabelas 5.1, 5.2 e 5.3 . 
Praticamente todos os dados alcançados estão apresentados, mas alguns elementos apontam teores que não devem corresponder a realidade, provavelmente em função de estarem abaixo do limite de detecção para o método utilizado ou por problemas inerentes a própria análise em si (calibração não aj ustada, padronizão inadequada, etc.). São dignas de nota as quantidades relativamente altas de $\mathrm{Pb}$ para todas as amostras, sobretudo dentre os noritos, e os teores obtidos para os elementos terras raras da amostra $\mathrm{VN}-19$, muito aquém das outras determinações. Com relação aos resultados desta amostra, eles são utilizados já que o seu padrão de terras raras é compativel com as outras (ele é paralelo), só que em concentrações bem menores. Poderia ter sido utilizado um fator de multiplicação, mas tal procedimento poderia acarretar em erro sobretudo para os elementos com baixas concentrações. Alguns valores encontrados para $\mathrm{Nb}$ e $\mathrm{Hf}$ podem não refletir a realidade. Com relação ao Hf, dosado por XRF, a limitação do método é a causa das distorções, pois a metodologia ideal para a dosagem deste elemento é a ativação neutrônica.

A análise química de elementos maiores, menores e traços indica a presença de duas sequências: uma de composição básica, correspondendo aos noritos e CPX-noritos, e outra de composição intermediária, onde incluem-se as rochas charnoquitóides. Estão separadas por uma considerável lacuna composicional (de cerca de 49 a $54 \% \mathrm{SiO}_{2}$ ), que pode ser observada tanto nas tabelas como nos diagramas de variação utilizados mais adiante.

Com relação aos noritos e CPX-noritos, eles exibem um comportamento geoquímico que os caracterizam como rochas cumuláticas, como será visto mais à frente. Tratam-se de rochas enriquecidas em $\mathrm{Fe}, \mathrm{Ca}, \mathrm{Al}$ e $\mathrm{V}$ e relativamente pobres em $\mathrm{K}, \mathrm{Mg}, \mathrm{Na}, \mathrm{Cr}$ e Ni quando comparada com banco de dados para rochas ígneas disponiveis na literatura (e.g. Nockolds, 1978; Sial \& McReath, 1984; Wilson, 1991). Dentre os elementos terras raras, observam-se valores moderados (teor de La até 70 vezes o condrito) com um maior fracionamento de terras raras intermediárias e pesadas.

Os charnoquitóides mostram-se ligeiramente mais ricos em Fe e Ca, têm valores moderados de Ti, P e ETR e são empobrecidos em $\mathrm{K}$ e Rb quando se compara com os dados da literatura. O padrão de distribuição dos elementos terras raras revela um fracionamento bem mais acentuado nos ETRL e os teores de La não chegam a 100 vezes o condrito. Poucas amostras possuem Mg\# superior a 0,50 (cf. tabelas de análises químicas de rochas), confirmando a tendência de enriquecimento em ferro de toda a seqüência. Os baixos teores de elementos LIL contrasta com a maioria dos dados disponiveis para corpos intrusivos do Espírito Santo, sendo 
tal característica comum para vários terrenos granulíticos do planeta, tal como apontado por Weaver \& Tarney (1983). As razões $\mathrm{K} / \mathrm{Rb}$ variam pouco e são comparáveis com aquelas encontradas para os granulitos do sul da Índia (Weaver, 1980; Condie et al., op. cit.). Por outro lado, as razões $\mathrm{Rb} / \mathrm{Sr}$ mostram maiores discrepâncias e são significativamente superiores nos chamoquitóides.

Comparando-se com os dados da Série Cálcio-alcalina definida por Wiedemann (1993) para o Estado do Espírito Santo e com os da suíte pós-orogênica do norte do Rio de Janeiro e sul do Espírito Santo utilizados por Figueiredo e Campos Neto (1993), verifica-se que os charnoquitóides de Venda Nova, ao contrário daqueles, não são enriquecidos em elementos incompatíveis e não apresentam anomalias de $\mathrm{Sr}$ e Ba. As rochas básicas revelam maiores concentrações de $\mathrm{Ti}, \mathrm{V}$ e $\mathrm{Sr}$ e menores teores de $\mathrm{Mg}, \mathrm{K}, \mathrm{Rb}$ e $\mathrm{Ba}$ nas rochas do maciço de Venda Nova quando comparada com outros corpos da Série Toleiítica de Wiedemann (op. cit.).

$O$ quimismo dos noritos e charnoquitóides de Venda Nova, com seu conspícuo enriquecimento em $\mathrm{Ca}, \mathrm{Fe}$, e Al e os moderados a baixos teores de elementos LIL (sobretudo $\mathrm{K} \mathrm{e}$ $\mathrm{Rb}$ ) e HFS (principalmente $\mathrm{P}$ e $\mathrm{Zr}$ ) só encontra algum paralelo com as rochas charnoquitizadas da unidade Bela Joana (mais ou menos gnaissificadas) na região de São Fidélis, RJ (Rêgo, op. cit.) e com os gnaisses charnoquíticos do norte da China (Kaiyi, op. cit.). As primeiras têm idade brasiliana e compreendem litotipos maciços ou bandados de composição predominantemente intermediária e ácida, com enclaves gabróicos; os gnaisses da China são do Proterozóico inferior e se encontram, segundo os autores, pouco deformados e com texturas ígneas preservadas.

As rochas básicas do Bela Joana, que mostram um restrito intervalo composicional, de 48 a $54 \% \mathrm{SiO}_{2}$, possuem conteúdos inferiores de $\mathrm{Fe}, \mathrm{Ca}$ e $\mathrm{Mg}$ e significativamente superiores de $\mathrm{K}, \mathrm{Rb}, \mathrm{Ba}, \mathrm{Na}, \mathrm{Ti}, \mathrm{P}$ e $\mathrm{Zr}$ com relação aos noritos de Venda Nova. Os teores totais de elementos terras raras são também maiores, com destaque para os elementos leves. Dentre os charnoquitóides existe uma maior semelhança, apesar dos maiores valores de $\mathrm{Fe}, \mathrm{Ca}, \mathrm{Mg}$ e $\mathrm{V}$ e ligeiramente menores de $\mathrm{K}, \mathrm{Rb}$ e $\mathrm{Zr}$ das rochas estudadas nesta tese. As rochas enderbíticas do Bela Joana apresentam maiores teores de elementos terras raras, mas a diferença não é tão significativa como a que se observa dentre os litotipos básicos.

Os gnaisses charnoquíticos do norte da China correspondem a uma seqüencia expandida, com os teores de sílica variando de 48 a $71 \%$, mostrando em seus litotipos básicos um acentuado enriquecimento em $\mathrm{Fe}, \mathrm{Na}, \mathrm{K}, \mathrm{Cr}, \mathrm{Ni}$, $\mathrm{Sr}$ e ETRL comparativamente com as rochas de similar teor de $\mathrm{SiO}_{2}$ dos noritos de Venda Nova. Por outro lado, estes últimos exibem 
quantidades significativamente maiores de $\mathrm{Al}$, e ligeiramente superiores de $\mathrm{Ca}$ e $\mathrm{Ba}$. As razões $\mathrm{K} / \mathrm{Rb}$ são bem maiores nos gnaisses da China, ao contrário dos valores de $\mathrm{Rb} / \mathrm{Sr}$. Dentre os charnoquitóides, as rochas de Venda Nova são bem mais ricas em Al e Ca, sendo mais pobres em $\mathrm{K}, \mathrm{Rb}, \mathrm{Ba}, \mathrm{Cr}$, $\mathrm{Ni}$ e nas terras raras como um todo. As razões $\mathrm{K} / \mathrm{Rb}$ se eqüivalem e $\mathrm{Rb} / \mathrm{Sr}$ são bastante superiores nos gnaisses chineses.

Antes de dar prosseguimento às considerações petroquímicas, abrangendo aí evidências e hipóteses baseadas na geoquímica, além da classificação das rochas, é necessário esclarecer que, assim como a petrografia, o quimismo das rochas da borda nada tem a ver com o dos litotipos da porção interna do corpo intrusivo de Venda Nova (e.g. Horn \& Weber Diefenbach, 1987). Estes últimos possuem nítida afinidade alcalina, com teores de $\mathrm{K}_{2} \mathrm{O}$ variando de cerca de 2 a 5\%, Rb, Ba e $\mathrm{Sr}$ elevados e $\mathrm{CaO}$ não ultrapassando $8 \%$ (mesmo nas rochas com concentração de sílica em torno de $48 \%$ ). Fica claro, portanto, que as rochas dos dois domínios têm afinidades químicas adversas e se cristalizaram a partir de diferentes magmas progenitores. 
Tabela 5.1 - Análises químicas de elementos maiores, menores (\% em peso) e traços (em ppm) e parâmetros geoquímicos para os noritos da borda do Maciço de Venda Nova

\begin{tabular}{|c|c|c|c|c|c|c|c|c|c|c|c|}
\hline Amostras & VN5 & VN22 & $\mathrm{VN10}$ & VN9 & VN7 & VN3 & VN26 & VN8 & VN6 & VN14 & VN11 \\
\hline $\mathrm{SiO} 2$ & 42,17 & 42,41 & 43,29 & 43,38 & 43,84 & 43,88 & 44,95 & 45,27 & 46,45 & 46,57 & 48,88 \\
\hline $\mathrm{TiO}_{2}$ & 2,46 & 1,99 & 1,65 & 2,31 & 1,53 & 2,15 & 1,42 & 1,47 & 1,69 & 0,99 & 1,19 \\
\hline $\mathrm{Al} 2 \mathrm{O} 3$ & 18,69 & 18,64 & 18,81 & 18,25 & 18,29 & 18,19 & 19,04 & 18,21 & 19,16 & 18,44 & 17,69 \\
\hline $\mathrm{Fe} 2 \mathrm{O} 3$ & 15,68 & 15,38 & 13,97 & 14,91 & 13,66 & 14,53 & 12,21 & 13,04 & 13,37 & 10,91 & 12,97 \\
\hline $\mathrm{MnO}$ & 0,21 & 0,24 & 0,19 & 0,21 & 0,21 & 0,21 & 0,19 & 0,19 & 0,21 & 0,18 & 0,22 \\
\hline $\mathrm{MgO}$ & 5,42 & 5,95 & 6,49 & 5,75 & 6,80 & 5,67 & 7,11 & 6,46 & 4,86 & 7,79 & 5,85 \\
\hline $\mathrm{CaO}$ & 12,61 & 12,41 & 13,38 & 12,75 & 13,36 & 11,98 & 12,76 & 12,72 & 10,80 & 13,28 & 10,20 \\
\hline $\mathrm{Na} 2 \mathrm{O}$ & 1,34 & 1,21 & 0,72 & 0,74 & 0,67 & 1,67 & 1,04 & 1,19 & 2,25 & 0,66 & 1,56 \\
\hline $\mathrm{K} 2 \mathrm{O}$ & 0,28 & 0,29 & 0,11 & 0,14 & 0,11 & 0,27 & 0,22 & 0,18 & 0,28 & 0,13 & 0,43 \\
\hline $\mathrm{P} 205$ & 0,81 & 0,70 & 0,35 & 0,64 & 0,39 & 0,76 & 0,27 & 0,30 & 0,48 & 0,16 & 0,32 \\
\hline PF. & 0,17 & 0,47 & 0,35 & 0,29 & 0,41 & 0,28 & 0,52 & 0,14 & 0,39 & 0,51 & 0,26 \\
\hline Total & 99,84 & 99,69 & 99,31 & 99,37 & 99,27 & 99,59 & 99,73 & 99,17 & 99,94 & 99,62 & 99,57 \\
\hline $\mathrm{Cr}$ & 24 & 19 & 7 & 29 & 22 & 30 & 19 & 14 & 11 & 24 & 33 \\
\hline $\mathrm{Ni}$ & 20 & 14 & 11 & 18 & 29 & 26 & 21 & 19 & 18 & 22 & 23 \\
\hline $\mathrm{Co}$ & 63 & 68 & 72 & 86 & 71 & 51 & 61 & 84 & 61 & 53 & 59 \\
\hline $\mathrm{Sc}$ & 43 & 27 & 36 & 36 & 37 & 38 & 41 & 41 & 33 & 38 & 36 \\
\hline $\mathrm{V}$ & 323 & 290 & 447 & 452 & 377 & 297 & 330 & 381 & 278 & 292 & 240 \\
\hline $\mathrm{Pb}$ & 31 & 62 & 33 & 20 & 37 & 23 & 54 & 24 & 26 & 32 & 19 \\
\hline $\mathrm{Zn}$ & 128 & 131 & 99 & 109 & 104 & 130 & 82 & 90 & 108 & 76 & 112 \\
\hline $\mathrm{Rb}$ & $\mathrm{ND}$ & ND. & ND. & ND. & ND. & ND. & ND. & ND. & $\mathrm{ND}$ & ND. & 10 \\
\hline $\mathrm{Ba}$ & 88 & 64 & 53 & 29 & 35 & 130 & 53 & 89 & 159 & 62 & 284 \\
\hline Sr & 479 & 475 & 454 & 435 & 439 & 481 & 419 & 418 & 554 & 391 & 453 \\
\hline $\mathrm{Ga}$ & 24 & 21 & 21 & 22 & 21 & 22 & 19 & 20 & 21 & 17 & 23 \\
\hline $\mathrm{Nb}$ & 15 & 9 & 5,4 & 8,6 & 6 & 13,7 & 8,10 & 8,2 & 12,2 & 6 & 9,4 \\
\hline $\mathrm{Hf}$ & 4,5 & 3,9 & 3,7 & 4,2 & 3,6 & 5,5 & 4,4 & 4,5 & 5,9 & 3,7 & 5,6 \\
\hline $\mathrm{Zr}$ & 106 & 57 & 46 & 76 & 39 & 154 & 71 & 97 & 149 & 38 & 139 \\
\hline $\mathrm{Y}$ & 41 & 22 & 13 & 16 & 12 & 34 & 21 & 26 & 31 & 11 & 22 \\
\hline ACNK & 0,73 & 0,75 & 0,73 & 0,74 & 0,72 & 0,73 & 0,76 & 0,72 & 0,81 & 0,73 & 0,82 \\
\hline $\mathrm{Mg \#}$ & 0,41 & 0,43 & 0,48 & 0,43 & 0,50 & 0,44 & 0,54 & 0,49 & 0,42 & 0,59 & 0,47 \\
\hline $\mathrm{K} / \mathrm{Rb}$ & $m$ & -. & - & - & -. & -.. & 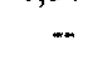 & -- & - & - & 356,8 \\
\hline $\mathrm{Rb} / \mathrm{Sr}$ & - & - & + & -- & - & -- & - & -. & -- & $\ldots$ & 0,022 \\
\hline
\end{tabular}


Tabela 5.2 - Análises químicas de elementos maiores, menores (\% em peso) e traços (em ppm) e parâmetros geoquímicos para os charnoquitóides da borda do Maciço de Venda Nova

\begin{tabular}{|c|c|c|c|c|c|c|c|c|c|c|c|c|c|c|c|c|}
\hline Amostras & VN38 & VN35 & VN17 & VN36 & VN20 & VN23 & VN15 & VN19 & VN18 & VN1 & VN16 & VN13 & VN24 & VN2 & VN27 & VN31 \\
\hline $\mathrm{SiO} 2$ & 54,46 & 54,96 & 55,24 & 56,31 & 56,37 & 56,77 & 57,40 & 57,43 & 57,47 & 58,41 & 59,06 & 61,13 & 62,45 & 65,17 & 66,24 & 67,12 \\
\hline $\mathrm{TiO} 2$ & 0,89 & 0,87 & 0,88 & 0,87 & 0,84 & 0,89 & 0,84 & 0,81 & 0,80 & 0,79 & 0,77 & 0,90 & 0,76 & 0,71 & 0,53 & 0,50 \\
\hline $\mathrm{A} 12 \mathrm{O} 3$ & 18,03 & 17,49 & 17,79 & 17,45 & 17,41 & 16,28 & 17,72 & 17,23 & 17,12 & 16,74 & 16,59 & 16,92 & 16,18 & 15,67 & 15,64 & 15,49 \\
\hline $\mathrm{Fe} 2 \mathrm{O} 3$ & 8,57 & 9,19 & 8,79 & 8,41 & 8,28 & 8,84 & 8,23 & 8,15 & 8,16 & 7,83 & 7,50 & 7,15 & 6,87 & 6,77 & 5,21 & 4,81 \\
\hline $\mathrm{MnO}$ & 0,21 & 0,17 & 0,16 & 0,16 & 0,15 & 0,15 & 0,14 & 0,14 & 0,14 & 0,12 & 0,13 & 0,14 & 0,14 & 0,13 & 0,12 & 0,12 \\
\hline $\mathrm{MgO}$ & 4,27 & 4,23 & 4,08 & 3,96 & 3,98 & 4,21 & 3,23 & 3,94 & 3,75 & 3,64 & 3,34 & 2,44 & 2,47 & 1,34 & 1,28 & 1,22 \\
\hline $\mathrm{CaO}$ & 8,01 & 7,75 & 7,92 & 7,39 & 7,67 & 7,53 & 7,35 & 6,99 & 7,09 & 6,95 & 6,80 & 5,26 & 5,35 & 5,80 & 4,47 & 3,79 \\
\hline $\mathrm{Na} 2 \mathrm{O}$ & 3,67 & 3,28 & 3,36 & 3,38 & 3,61 & 3,02 & 3,43 & 3,29 & 3,39 & 3,12 & 3,06 & 3,72 & 3,64 & 2,73 & 3,96 & 3,88 \\
\hline $\mathrm{K} 2 \mathrm{O}$ & 1,00 & 1,23 & 0,66 & 0,91 & 0,87 & 0,96 & 0,71 & 0,96 & 1,14 & 1,52 & 1,59 & 1,43 & 1,17 & 0,76 & 1,35 & 1,85 \\
\hline $\mathrm{P} 2 \mathrm{O} 5$ & 0,22 & 0,21 & 0,22 & 0,21 & 0,21 & 0,23 & 0,22 & 0,20 & 0,20 & 0,19 & 0,19 & 0,27 & 0,23 & 0,22 & 0,21 & 0,20 \\
\hline P.F. & 0,61 & 0,53 & 0,23 & 0,76 & 0,51 & 1,09 & 0,55 & 0,35 & 0,51 & 1,13 & 0,86 & 0,56 & 0,80 & 0,39 & 0,37 & 0,49 \\
\hline Total & 99,94 & 99,91 & 99,33 & 99,81 & 99,90 & 99,97 & 99,82 & 99,49 & 99,77 & 100,44 & 99,89 & 99,92 & 100,06 & 99,69 & 99,38 & 99,47 \\
\hline $\mathrm{Cr}$ & 41 & 27 & 38 & 38 & 34 & 42 & 31 & 41 & 35 & 26 & 26 & 20 & 18 & 29 & 71 & 60 \\
\hline $\mathrm{Ni}$ & 41 & 27 & 33 & 31 & 32 & 34 & 23 & 31 & 45 & 27 & 28 & 20 & 21 & 18 & 41 & 31 \\
\hline $\mathrm{Co}$ & 36 & 40 & 44 & 49 & 39 & 41 & 32 & 47 & 37 & 40 & 40 & 33 & 31 & 39 & 18 & 12 \\
\hline Sc & 26 & 33 & 24 & 28 & 26 & 28 & 22 & 27 & 26 & 25 & 30 & 21 & 28 & 21 & 17 & 14 \\
\hline V & 202 & 198 & 188 & 182 & 183 & 189 & 162 & 165 & 176 & 157 & 154 & 113 & 110 & 46 & 55 & 46 \\
\hline $\mathrm{Pb}$ & 81 & 76 & 71 & 52 & 27 & 45 & 30 & 75 & 97 & 38 & 27 & $3 I$ & 78 & 25 & 48 & 41 \\
\hline $\mathrm{Zn}$ & 113 & 88 & 86 & 77 & 81 & 78 & 84 & 69 & 78 & 72 & 72 & 82 & 73 & 60 & 64 & 63 \\
\hline $\mathrm{Rb}$ & 19 & 29 & 17 & 19 & 22 & 26 & 21 & 26 & 36 & 53 & 62 & 37 & 25 & 20 & 34 & 50 \\
\hline $\mathrm{Ba}$ & 436 & 382 & 338 & 356 & 417 & 428 & 429 & 554 & 282 & 458 & 445 & 883 & 581 & 196 & 849 & 679 \\
\hline $\mathrm{Sr}$ & 561 & 459 & 557 & 464 & 506 & 495 & 489 & 513 & 467 & 454 & 436 & 371 & 380 & 533 & 358 & 315 \\
\hline $\mathrm{Ga}$ & 21 & 21 & 20 & 20 & 21 & 19 & 19 & 20 & 20 & 19 & 19 & 20 & 17 & 20 & 18 & 17 \\
\hline $\mathrm{Nb}$ & 16,4 & 14,8 & 9,5 & 9,1 & 9,2 & 9 & 8,5 & 9,9 & 11,7 & 9,3 & 9,4 & 11 & 9,9 & 10,7 & 14 & 10,5 \\
\hline Hf & 6,3 & 5,8 & 5,9 & 5,6 & 5,9 & 6,5 & 6,5 & 6,4 & 6,2 & 6,4 & 6,5 & 8,4 & 8,1 & 12,1 & 8,8 & 8,2 \\
\hline $\mathrm{Zr}$ & 144 & 99 & 113 & 94 & 114 & 125 & 154 & 126 & 111 & 124 & 121 & 210 & 178 & 377 & 196 & 158 \\
\hline $\mathrm{Y}$ & 22 & 25 & 21 & 22 & 20 & 20 & 19 & 19 & 28 & 23 & 24 & 19 & 24 & 12 & 15 & 20 \\
\hline $\mathrm{ACNK}$ & 0,83 & 0,84 & 0,86 & 0,87 & 0,84 & 0,83 & 0,90 & 0,90 & 0,87 & 0,86 & 0,87 & 0,98 & 0,95 & 0,99 & 0,97 & 1,01 \\
\hline Mg\# & 0,50 & 0,48 & 0,48 & 0,48 & 0,49 & 0,48 & 0,44 & 0,49 & 0,48 & 0,48 & 0,47 & 0,40 & 0,42 & 0,28 & 0,33 & 0,33 \\
\hline $\mathrm{K} / \mathrm{Rb}$ & 436,7 & 351,9 & 322,1 & 397,4 & 328,1 & 306,4 & 280,5 & 306,4 & 262,7 & 238 & 212,8 & 320,7 & 388,3 & 315,3 & 329,4 & 307 \\
\hline $\mathrm{Rb} / \mathrm{Sr}$ & 0,034 & 0,063 & 0,030 & 0,041 & 0,043 & 0,052 & 0,043 & 0,051 & 0,077 & 0,12 & 0,14 & 0,10 & 0,066 & 0,037 & 0,095 & 0,16 \\
\hline
\end{tabular}


Tabela 5.3 - Análises químicas de elementos terras raras (em ppm) para as rochas da borda do Maciço de Venda Nova

\begin{tabular}{lccccccccccc}
\hline Amostras & VN27 & VN13 & VN16 & VN19 & VN23 & VN17 & VN38 & VN6 & VN26 & VN7 & VN22 \\
\hline La & 18,47 & 16,06 & 19,21 & 3,68 & 29,09 & 16,44 & 18,98 & 8,44 & 11,18 & 8,71 & 18,15 \\
Ce & 39,27 & 35,12 & 45,44 & 8,17 & 69,90 & 39,23 & 40,95 & 23,12 & 29,41 & 22,13 & 49,89 \\
Nd & 17,03 & 16,62 & 21,22 & 3,16 & 30,13 & 19,44 & 18,85 & 15,40 & 18,14 & 13,33 & 28,95 \\
$\mathrm{Sm}$ & 3,19 & 3,37 & 4,26 & 0,64 & 5,24 & 3,62 & 3,60 & 3,64 & 4,05 & 2,94 & 5,51 \\
Eu & 0,88 & 0,99 & 0,93 & 0,17 & 1,13 & 0,94 & 0,88 & 1,06 & 1,02 & 0,89 & 1,54 \\
Gd & 2,73 & 2,65 & 3,36 & 0,47 & 3,77 & 2,71 & 2,80 & 3,06 & 3,03 & 2,39 & 3,91 \\
Dy & 2,84 & 2,16 & 3,65 & 0,54 & 3,95 & 2,78 & 2,41 & 2,70 & 2,59 & 2,22 & 2,91 \\
Ho & 0,57 & 0,40 & 0,76 & 0,10 & 0,80 & 0,55 & 0,46 & 0,49 & 0,48 & 0,43 & 0,55 \\
Er & 1,57 & 0,93 & 2,19 & 0,24 & 2,21 & 1,48 & 1,13 & 1,06 & 1,08 & 1,05 & 1,31 \\
Yb & 1,44 & 0,67 & 1,96 & 0,25 & 2,02 & 1,32 & 0,93 & 0,76 & 0,76 & 0,80 & 0,99 \\
Lu & 0,19 & 0,11 & 0,25 & 0,04 & 0,25 & 0,18 & 0,12 & 0,09 & 0,09 & 0,10 & 0,12 \\
Total & 88,18 & 79,08 & 103,23 & 17,46 & 148,49 & 88,69 & 91,11 & 59,82 & 71,83 & 54,99 & 113,83 \\
Ce/YbN & 7,05 & 13,56 & 6,00 & 8,45 & 8,95 & 7,69 & 11,39 & 7,87 & 10,01 & 7,16 & 13,03 \\
Dy/YbN & 1,28 & 2,09 & 1,21 & 1,40 & 1,27 & 1,37 & 1,68 & 2,31 & 2,21 & 1,80 & 1,91 \\
Eu/Eu*N & 0,89 & 0,98 & 0,73 & 0,91 & 0,74 & 0,88 & 0,82 & 0,95 & 0,85 & 1,00 & 0,97 \\
& & & & & & & & & & \\
\hline SiO2 & 66,24 & 61,13 & 59,06 & 57,43 & 56,77 & 55,24 & 54,46 & 46,45 & 44,95 & 43,84 & 42,41 \\
\hline
\end{tabular}


Tabela 5.4 - Norma CIPW para os charnoquitóides do Maciço de Venda Nova

\begin{tabular}{|c|c|c|c|c|c|c|c|c|c|c|c|c|c|c|c|c|}
\hline Amostras & VN31 & VN27 & VN2 & VN24 & VN13 & VN16 & VN1 & VN18 & VN19 & VN15 & VN23 & VN20 & VN36 & VN17 & VN35 & VN38 \\
\hline Quartzo & 27,15 & 26,11 & 31,18 & 21,00 & 18,32 & 15,74 & 14,19 & 12,52 & 13,32 & 13,82 & 13,49 & 10,03 & 11,30 & 10,06 & 8,29 & 6,13 \\
\hline Corindon & 0,61 & 0,00 & 0,26 & 0,00 & 0,23 & 0,00 & 0,00 & 0,00 & 0,00 & 0,00 & 0,00 & 0,00 & 0,00 & 0,00 & 0,00 & 0,00 \\
\hline Ortoclásio & 11,10 & 8,10 & 4,55 & 7,01 & 8,56 & 9,56 & 9,11 & 6,84 & 5,76 & 4,26 & 5,78 & 5,21 & 5,47 & 3,96 & 7,37 & 5,99 \\
\hline Albita & 33,26 & 33,95 & 23,36 & 31,16 & 31,81 & 26,26 & 26,71 & 29,04 & 28,22 & 29,38 & 25,98 & 30,89 & 29,02 & 28,84 & 28,08 & 31,42 \\
\hline Anortita & 18,03 & 21,26 & 27,90 & 24,70 & 24,97 & 27,26 & 27,54 & 28,52 & 29,87 & 31,29 & 28,55 & 29,10 & 30,24 & 32,01 & 29,76 & 30,18 \\
\hline Diopsidio & 0,00 & 0,15 & 0,00 & 0,76 & 0,00 & 4,84 & 5,16 & 4,87 & 3,47 & 3,63 & 6,63 & 6,70 & 4,72 & 5,41 & 6,50 & 7,19 \\
\hline Hiperstênio & 5,69 & 5,99 & 6,97 & 9,45 & 9,69 & 10,10 & 10,84 & 11,51 & 12,66 & 10,76 & 12,21 & 11,22 & 12,23 & 12,43 & 12,55 & 11,95 \\
\hline Magnetita & 2,83 & 3,06 & 3,97 & 4,03 & 4,19 & 4,41 & 4,59 & 4,79 & 4,79 & 4,83 & 5,21 & 4,86 & 4,95 & 5,17 & 5,39 & 5,03 \\
\hline Cromita & 0,01 & 0,02 & 0,01 & 0,00 & 0,00 & 0,01 & 0,01 & 0,01 & 0,01 & 0,01 & 0,01 & 0,01 & 0,01 & 0,01 & 0,01 & 0,01 \\
\hline Ilmenita & 0,96 & 1,02 & 1,36 & 1,46 & 1,73 & 1,48 & 1,52 & 1,54 & 1,56 & 1,61 & 1,72 & 1,61 & 1,68 & 1,70 & 1,67 & 1,71 \\
\hline Apatita & 0,48 & 0,51 & 0,53 & 0,55 & 0,65 & 0,46 & 0,46 & 0,48 & 0,48 & 0,53 & 0,56 & 0,51 & 0,51 & 0,53 & 0,51 & 0,53 \\
\hline Zircão & 0,03 & 0,04 & 0,08 & 0,04 & 0,04 & 0,02 & 0,03 & 0,02 & 0,03 & 0,03 & 0,03 & 0,02 & 0,02 & 0,02 & 0,02 & 0,03 \\
\hline Total & 100,17 & 100,20 & 100,16 & 100,16 & 100,20 & 100,15 & 100,15 & 100,13 & 100,17 & 100,15 & 100,16 & 100,15 & 100,14 & 100,15 & 100,14 & 100,17 \\
\hline ID. & 71,51 & 68,16 & 59,09 & 59,17 & 58,69 & 51,56 & 50,01 & 48,40 & 47,30 & 47,46 & 45,25 & 46,13 & 45,79 & 42,86 & 43,74 & 43,54 \\
\hline
\end{tabular}




\section{Os diagramas de variação e suas possíveis correlações mineralógicas}

A fim de ilustrar o comportamento dos vários elementos, nas duas seqüências identificadas, são utilizados diagramas de variação, que se encontram nas figuras 5.1 e 5.2 . O índice de diferenciação que melhor retrata as oscilações químicas existentes é $\mathrm{SiO}_{2}$, que é plotado contra vários dos óxidos e elementos analisados.

Observa-se que ocorre um clara separação entre os noritos e os charnoquitóides. Enquanto as amostras dos noritos tendem a se concentrar, formando um "cluster" em diversos gráficos, as amostras da sequência charnoquitóide apresentam-se bem alinhadas em quase todos os diagramas. Apesar da tendência a aglomeração, os noritos chegam a delinear um trend nos gráficos $\mathrm{SiO}_{2}$ versus $\mathrm{TiO}_{2}, \mathrm{Fe}_{2} \mathrm{O}_{3}, \mathrm{Sr}, \mathrm{Ni}$ e V. Estas características das rochas da seqüência norítica, seus conteúdos muito altos de $\mathrm{Ca}$ e Fe, associada a composição muito básica dos seus plagioclásios (cf. Cap. 6) levam a crer que elas correspondam a cumulatos, e serão tratadas como tal nesta tese.

A boa correlação existente entre a silica e os diversos óxidos e elementos traços dos charnoquitóides evidencia que eles correspondem a uma seqüência magmática cogenética, cư a evolução se deu no intervalo de $54 \%$ a $67 \% \mathrm{SiO}_{2}$. As amostras VN-2, VN-27 e VN-31 possuem mais que $65 \% \mathrm{SiO}_{2}$ e destacam-se do restante, o que também é verificado pelos seus menores valores de $\mathrm{Mg \# ;} \mathrm{o} \mathrm{pequeno} \mathrm{"gap"} \mathrm{composicional} \mathrm{que} \mathrm{desta} \mathrm{forma} \mathrm{se} \mathrm{insitui} \mathrm{deve} \mathrm{ser}$ consequência da restrita área de amostragem dessas rochas.

Algumas amostras distanciam-se do grupo principal em determinados gráficos apresentados. A amostra $\mathrm{VN}$ - 14 está ligeiramente deslocada nos gráficos do $\mathrm{Fe}, \mathrm{Mg}, \mathrm{Ca}$ e Ti em função da composição dos seus OPX (são os de maiores Mg\# entre os noritos, vide Cap. 6), plagioclásios (até $87 \%$ anortita) e ilmenitas, com menores teores de $\mathrm{TiO}_{2}$. Por outro lado, a amostra $\mathrm{VN}-11$ possui menores concentrações de $\mathrm{CaO}$, relacionadas a composição do plagioclásio e a menor quantidade de anfibólio modal, e maiores de $\mathrm{Fe}_{2} \mathrm{O}_{3}$ associadas provavelmente a quantidade modal e composição dos seus piroxênios. Dentre os charnoquitóides destaca-se a amostra $\mathrm{VN}-2$ por estar nitidamente empobrecida em álcalis e ligeiramente enriquecida em $\mathrm{Fe}$ e $\mathrm{Ca}$, podendo estar associado a fenômenos de transformações tardi ou pós magmáticas. É pouco provável que não se trate de amostra cogenética, haja visto suas características petrográficas semelhantes às da sequência charnoquitóide. As amostras VN-27 e 31 correspondem ao extremo da seqüência e estão sempre associadas, mas não deslocadas e sim alinhadas nos diversos "trends".

Os "trends" lineares definidos pelas rochas charnoquitóides, nos diagramas de variação utilizados, exibem em sua maioria, a grosso modo, continuidade em direção ao grupo definido pelos noritos. Isto, a princípio, faz com que se suspeite que ambas as sequências evoluíram a partir de um mesmo magma parental, isto é, que os noritos venham a ser cumulatos do líquido que se diferenciou e cristalizou os litotipos da sequência charnoquitóide. No entanto, o comportamento do Sr e pricipalmente do $\mathrm{Ni}$ (cujos teores são mais baixos dentre os noritos) 
nos diagramas de variação suscita dúvidas quanto a validade desta hipótese. Outro ponto que serve de restrição a tal hipótese é que os minerais máficos dos charnoquitóides possuem $\mathrm{Mg \#}$ superior aos das rochas noríticas (exceto a amostra VN-27), como será visto no capítulo 6. Por outro lado, a química global das duas sequências é bem semelhante, sendo caracterizada pelo enriquecimento em $\mathrm{Ca}$ e $\mathrm{Fe}$ e baixos conteúdos de elementos incompativeis, além das similaridades dos padrões de ETR.

Cox et al. (1979), com base nas composições de rochas vulcânicas (elas correspondem, com maior probabilidade, à composição do liquidus), consideram que "trends" com tendência retilínea devem refletir processos de mistura magmática ou cristalização fracionada na qual as fases extraidas foram as mesmas durante toda a evolução da sequêencia. Quando há inflexões, a "quebra" da tendência está associada com a extração, do líquido, de uma nova fase ou então a uma brusca diminuição no fracionamento de determinado mineral. Rollinson (1993) exemplifica tal situação com basaltos do Hawaii e chama a atenção para o fato de que em rochas cálcio-alcalinas o número de fases extraídas é grande e por vezes o fracionamento de um mineral não afeta a composição geral do líquido, não provocando mudanças bruscas no "trend".

As tendências lineares obtidas para os charnoquitóides de Venda Nova são compativeis, portanto, tanto com mecanismos de cristalização fracionada quanto com mistura de magmas. Imaginando-se que houve predomínio de cristalização fracionada, deduz-se pelos diagramas de variação que a mesma deve ter sido controlada por extração de plagioclásio, OPX, CPX e ilmenita (magnetita?). No capítulo 7 será dada ênfase à caracterização do modelo genético-evolutivo, auxiliada por testes quantitativos através de modelamentos geoquímicos. 

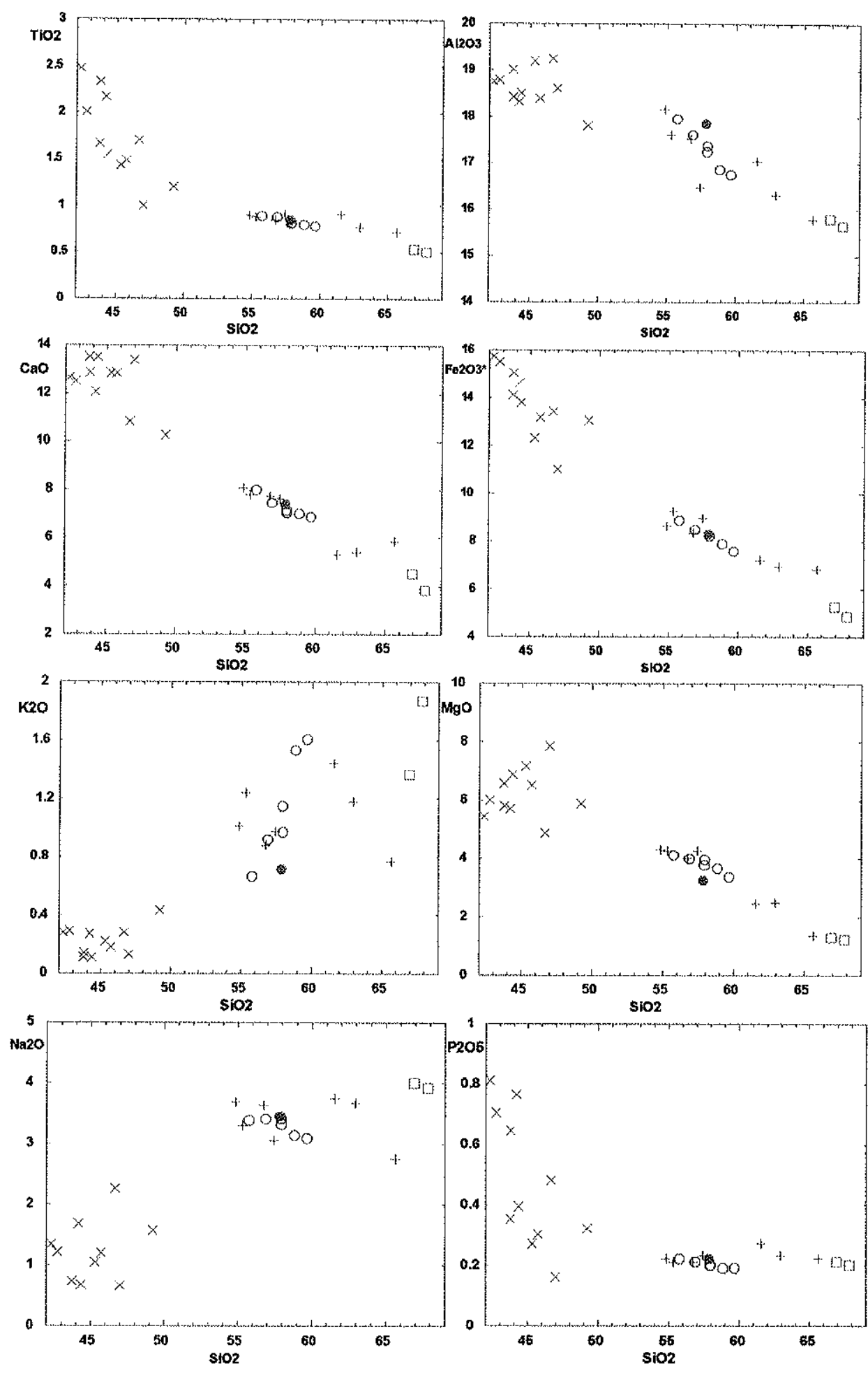

Figura 5.1 - Diagramas de Harker para os noritos e charnoquitóides de Venda Nova. Símbolos: $x$ Noritos; $1 .$. Opdalitos; O OPX-Quartzo-dioritos; + Enderbitos; * Quartzo-mangerito 

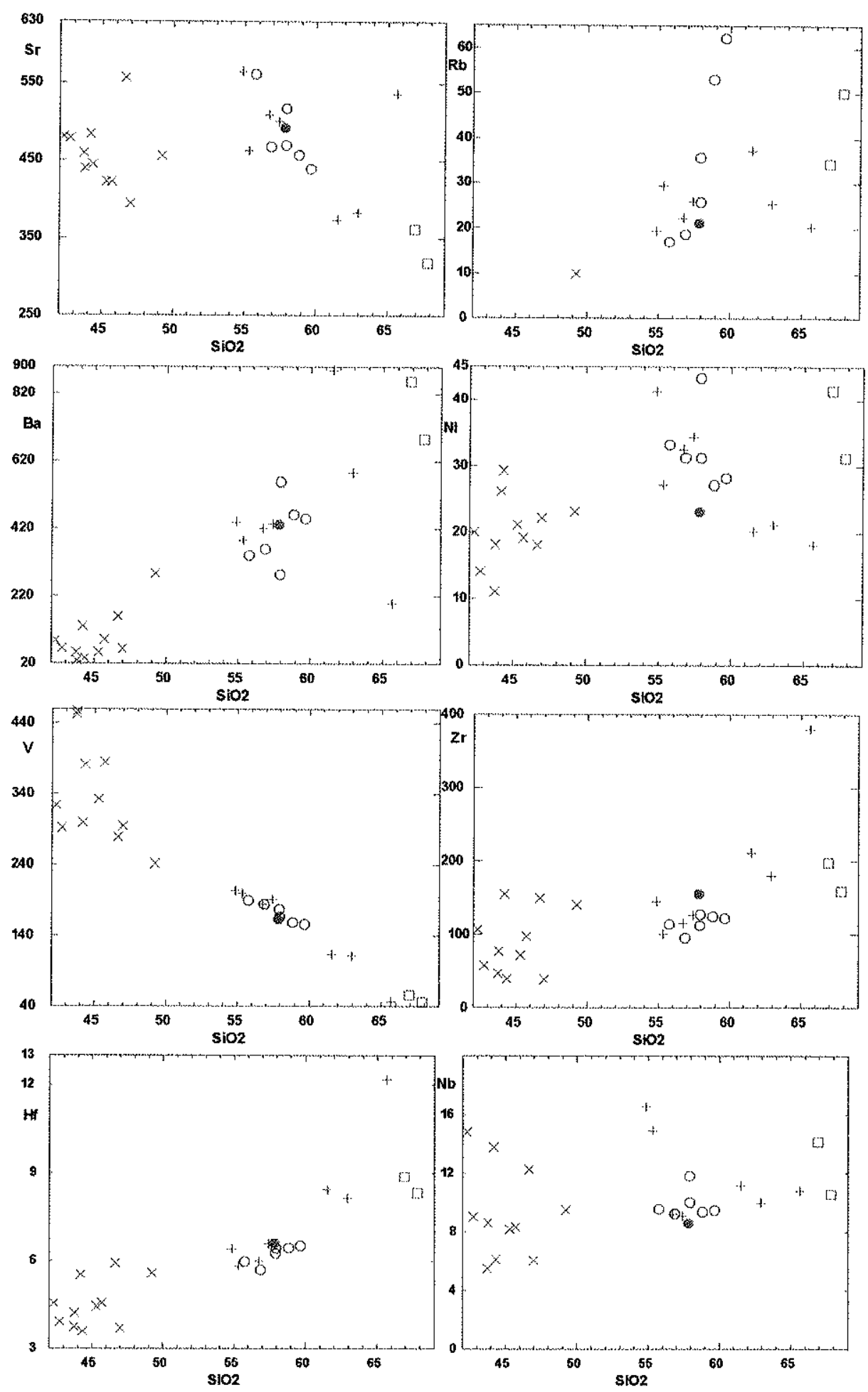

Figura 5.2 - Diagramas de variação $\mathrm{SiO}_{2} \times$ elementos traço para os noritos e charnoquitóides de Venda Nova. Símbolos: X Noritos; $\ldots$ Opdalitos; O OPX-Quartzo-dioritos; + Enderbitos; $\otimes$ Quartzo-mangerito 


\section{A caracterização do magmatismo}

Apesar das análises químicas já apontarem a presença de duas seqüências distintas (uma básica e outra intermediária), é necessário lançar mão de algumas outras ferramentas para uma melhor caracterização do magmatismo.

Irvine \& Baragar (1971) utilizaram o diagrama $\mathrm{SiO}_{2} \times \mathrm{Na}_{2} \mathrm{O}+\mathrm{K}_{2} \mathrm{O}$ para separar seqüências vulcânicas alcalinas e sub-alcalinas (toleíticas e Ca-alcalinas). Fazendo uso do mesmo, as rochas plutônicas de Venda Nova posicionam-se francamente no campo sub-alcalino, com nítida separação dos grupos básico e intermediário, conforme está exposto na figura 5.3.

No gráfico triangular AFM da figura 5.4, criados pelos mesmos autores, fíca claro que um grupo de rochas, representado pelos noritos, agrupa-se numa área correspondente a suítes toleiíticas, mas que as amostras não configuram um "trend" toleiítico típico (que evolui desde os termos ricos em $\mathrm{Mg}$, passando por alto Fe chegando a composições com maiores teores de álcalis). Os charnoquitóides traçam um "trend" Ca-alcalino um pouco deslocado para o vértice FeO. Tanto nesse gráfico como no anterior a amostra $\mathrm{VN}-2$ está totalmente deslocada, em função de sua provável perda de álcalis e enriquecimento em $\mathrm{Fe}$. Comparando-se com o que foi obtido por Rêgo (op. cit.) no maciço de Bela Joana, nota-se grande semelhança no posicionamento das rochas intermediárias.

Analisando-se a norma dos charnoquitóides (a dos noritos não está apresentada, conforme foi esclarecido no Cap. 1), que se encontra na tabela 5.4, observa-se algumas características típicas de rochas cálcio-alcalinas, como a presença de quartzo e hiperstênio normativos e a diminuição dos valores de diopsídio e hiperstênio normativos com a diferenciação junto a um progressivo acréscimo de quartzo. $O$ cálculo dos óxidos normativos não concorda com os dados modais, já que ao microscópio não se constata um grande predomínio de magnetita sobre ilmenita.

Apenas três amostras apresentam corindon normativo, o que sugere um caráter metaluminoso para as rochas. Tal caráter dos charnoquitóides é evidenciado no diagrama $\mathrm{A} / \mathrm{CNK} \times \mathrm{A} / \mathrm{NK}$ de Maniar \& Picolli (1989), apresentado na figura 5.5, com praticamente todas as amostras posicionadas no campo metaluminoso, algumas $\mathrm{junto}$ do limite de peraluminosidade.

As razões $\mathrm{A} / \mathrm{CNK}$ foram calculadas e encontram-se nas tabelas de análises químicas, podendo-se observar que os noritos mostram os menores valores, possuindo portanto caráter fortemente metaluminoso. No diagrama $\mathrm{B}(\mathrm{Fe}+\mathrm{Mg}+\mathrm{Ti})$ x $\mathrm{A}(\mathrm{Al}-\mathrm{K}+\mathrm{Na}+2 \mathrm{Ca})$ de Debon $\&$ Le Fort todas as rochas plotam no campo metaluminoso IV (rochas com biotita, hornblenda, OPX, CPX, epidoto e titanita), como está ilustrado na figura 5.6. As amostras mais ácidas da seqüência estão junto do limite com o campo peraluminoso III (rochas a biotita). 


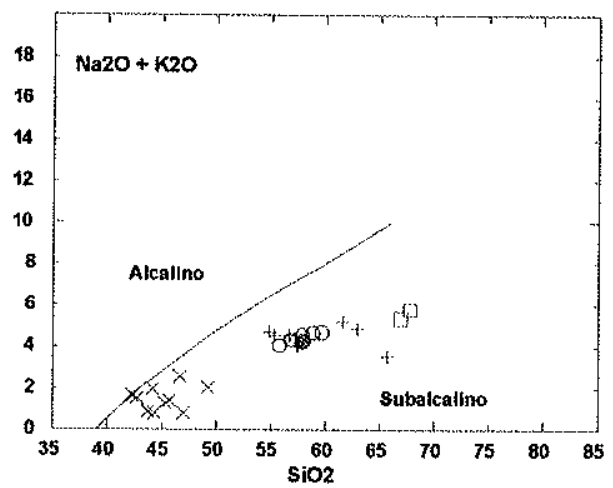

Figura 5.3 - Diagrama $\mathrm{SiO}_{2} \times \mathrm{Na}_{2} \mathrm{O}+\mathrm{K}_{2} \mathrm{O}$ para os noritos e charnoquitóides de Venda Nova. Símbolos: $x$ Noritos; $\square$ Opdalitos; O OPX-Quartzo-dioritos; + Enderbitos; • Quartzo-mangerito

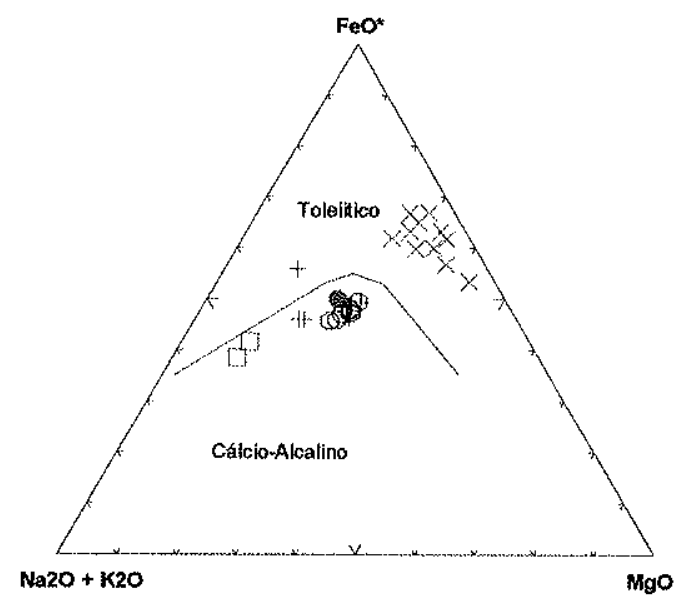

Figura 5.4 - Diagrama AFM para os noritos e charnoquitóides de Venda Nova Símbolos: $x$ Noritos; [.] Opdalitos; O OPX-Quartzo-dioritos; + Enderbitos; * Quartzo-mangerito

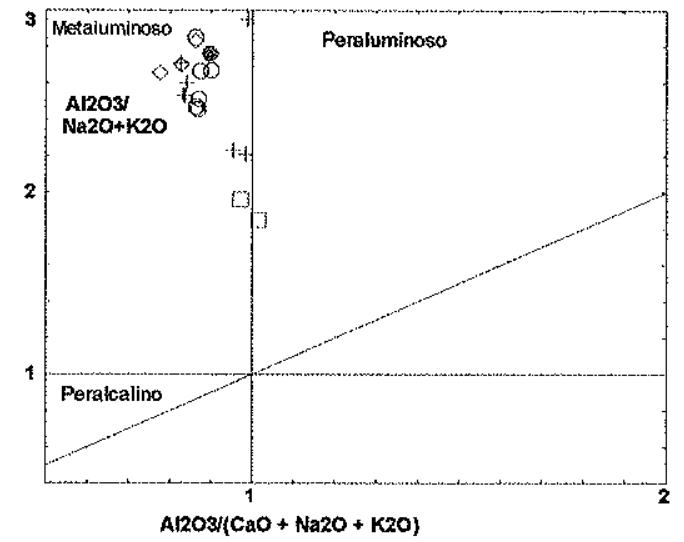

Figura 5.5 - Diagrama A/CNK $\times$ A/NK para as rochas da borda do maciço de Venda Nova. Símbolos: 1.$]$ Opdalitos; O OPX-Quartzo-dionitos; + Enderbitos; * Quartzo-mangerito 


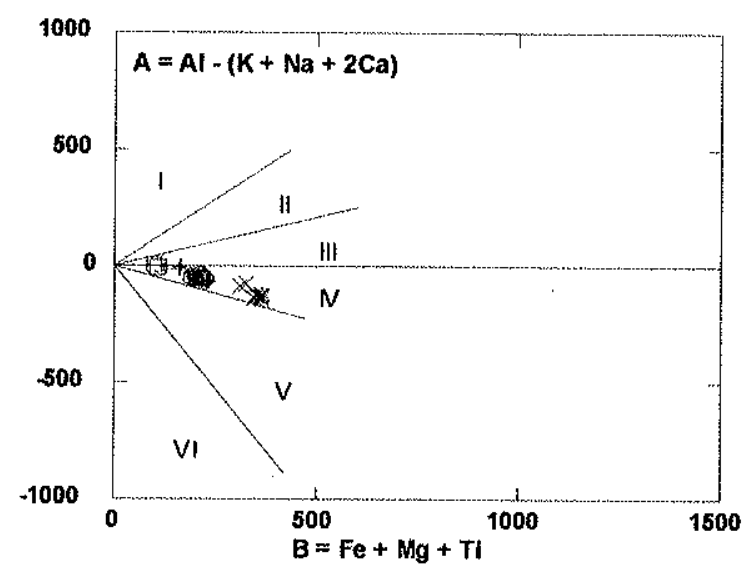

Figura 5.6 - Diagrama B x A para as rochas da borda do maciço de Venda Nova.

Símbolos: $\mathrm{x}$ Noritos; Opdalitos; O OPX-Quartzo-dioritos; + Enderbitos; Quartzo-mangerito

O índice álcali-cálcico de Peacock (1931) para os charnoquitóides da borda da intrusão de Venda Nova é próximo de $60 \% \mathrm{SiO}_{2}$, que é o limite entre os campos de granitóides Ca-alcalinos e cálcicos, ficando então evidente o considerável enriquecimento em cálcio da seqüência. O diagrama que ilustra tal situação encontra-se na figura 5.7.

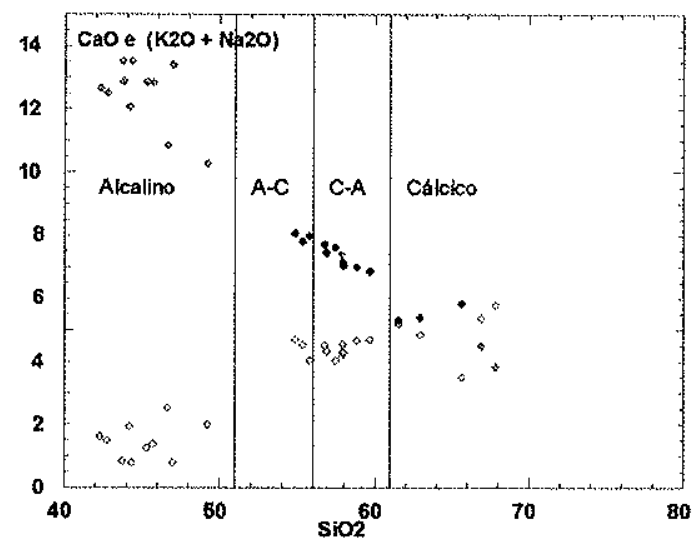

Figura 5.7 - Diagrama de Peacock mostrando o enriquecimento em cálcio nas rochas da borda do maciço de Venda Nova.

Com a finalidade de caracterizar e separar seqüências vulcânicas cálcio-alcalinas dos Andes, Wilson (op. cit.) utilizou o diagrama $\mathrm{SiO}_{2} \times \mathrm{K}_{2} \mathrm{O}$ dividido em campos que separam rochas de baixo, médio e alto $\mathrm{K}$ (apud Pecerillo \& Taylor, 1976). Os charnoquitóides de Venda Nova posicionam-se preferencialmente dentro dos limites de seqüências Ca-alcalinas de médio $\mathrm{K}$, e apenas a amostra $\mathrm{VN}-2$ fica no campo de baixo $\mathrm{K}$. A autora atenta para o fato de que a ocorrência de uma maior dispersão dos dados neste diagrama está possivelmente associada a contaminação crustal, fenômeno menos comum em seqüências de arco de ilha, que normalmente exibem "trends" retilíneos. Constata-se moderada dispersão das amostras no gráfico $\mathrm{SiO}_{2} \times \mathrm{K}_{2} \mathrm{O}$ para as rochas aqui estudadas (cf. Figura 5.1). 
Do mesmo modo, quando se compara o comportamento das amostras dos charnoquitóides no diagrama modal QAP (Fig. 4.1) com os "trends" para rochas cálcio-alcalinas definidos por Lameyre \& Bowden (1982) a partir deste diagrama, observa-se que elas tendem a acompanhar o traçado idealizado para rochas Ca-alcalinas de médio $\mathrm{K}$, geradas preferencialmente em ambientes compressionais.

\section{A classificação das rochas analisadas}

Existe na literatura muitas proposições para classificação de rochas ígneas baseadas em parâmetros químicos. Quase todas elas levam em conta interrelações entre os elementos maiores (na forma de óxido ou elemento) ou entre minerais normativos. Os principais elementos utilizados são $\mathrm{Si}, \mathrm{Al}, \mathrm{Ca}, \mathrm{Na}$ e $\mathrm{K}$, logicamente por serem comuns nos mais diversos tipos rochosos e, consequentemente, nas classificações baseadas em normas usa-se preferencialmente quartzo, ortoclásio, albita, anortita, nefelina e leucita. Portanto, análises com teores incorretos podem fornecer classificações distorcidas, mas uma comparação com a composição e classificação modal é de suma importância na avaliação dos resultados. Os termos plutônicos utilizados pelos diversos autores não correspondem a nomenclatura de rochas charnoquitóides, adotada neste trabalho. Visto isto, a denominação charnoquitóide equivalente será também referenciada.

Fazendo-se uso do diagrama Q x P de Debon \& Le Fort (1983), que está na figura 5.8 , percebe-se que as rochas de Venda Nova posicionam-se continuamente, definindo uma tendência, nos campos 12 (gabro/norito), 8 (quartzo-diorito/OPX-quartzo-diorito) e 4 (tonalito/enderbito). Algumas amostras classificadas modalmente como norito plotam no campo 8, o que deve ocorrer em função dos menores teores de Ca e de álcalis das mesmas. O mesmo deve se dar com os OPX-quartzo-dioritos posicionados no campo 4, enquanto que as amostras VN-27 e 31 (opdalitos modais) também estão deslocadas para o mesmo campo em função dos seus teores de $\mathrm{Ca}$ e álcalis relativamente maiores.

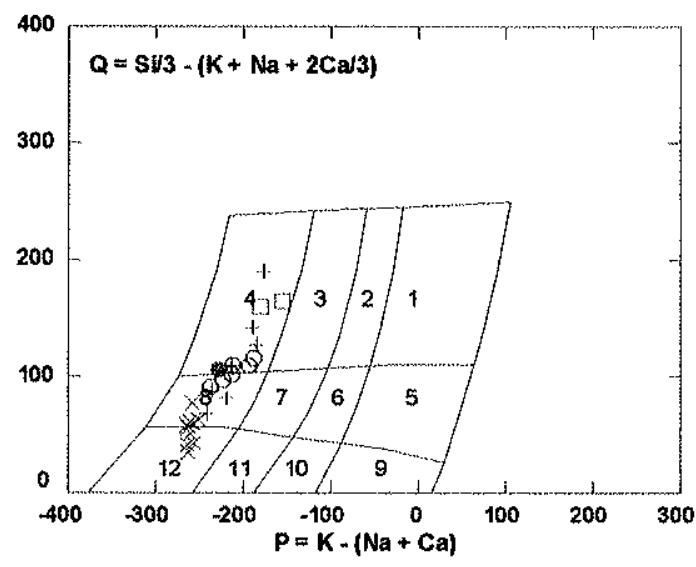

Figura 5.8 - Diagrama $Q \times P$ para as rochas da borda do maciço de Venda Nova. Símbolos: $\mathrm{x}$ Noritos; $\square$ Opdalitos; O OPX-Quartzo-dioritos; + Enderbitos; Q Quartzo-mangerito 
Ao se utilizar diagramas originalmente definidos para rochas vulcânicas, verificase que as rochas da borda do maciço de Venda Nova posicionam-se em campos vulcânicos correlacionados a equivalentes plutônicos que concordam, de maneira geral, com a classificação modal das rochas.

$\mathrm{Na}$ figura 5.9 o gráfico $\mathrm{SiO}_{2} \times \mathrm{Na}_{2} \mathrm{O}+\mathrm{K}_{2} \mathrm{O}$ de Le Maitre (1989) apresenta limites composicionais para classificação de rochas vulcânicas. As amostras de Venda Nova plotam nos campos $\mathrm{Pc}$ e $\mathrm{B}$ (picrobasaltos e basaltos), $\mathrm{O} 1$ e $\mathrm{O} 2$ (andesitos basálticos e andesitos) e $\mathrm{O} 3$ (dacitos). Pode-se notar que ocorre uma excelente correlação com a classificação plutônica.

Winchester \& Floyd (1977) fazendo uso de outros elementos, tais como Ti, Zr, Y e $\mathrm{Nb}$ propuseram diagramas para classificar rochas vulcânicas. $\mathrm{Na}$ figura 5.10 as amostras da intrusão de Venda Nova encontram-se nos campos dos basaltos sub-alcalinos, andesitos e dacitos/riodacitos, mantendo a coerência salientada na figura anterior.

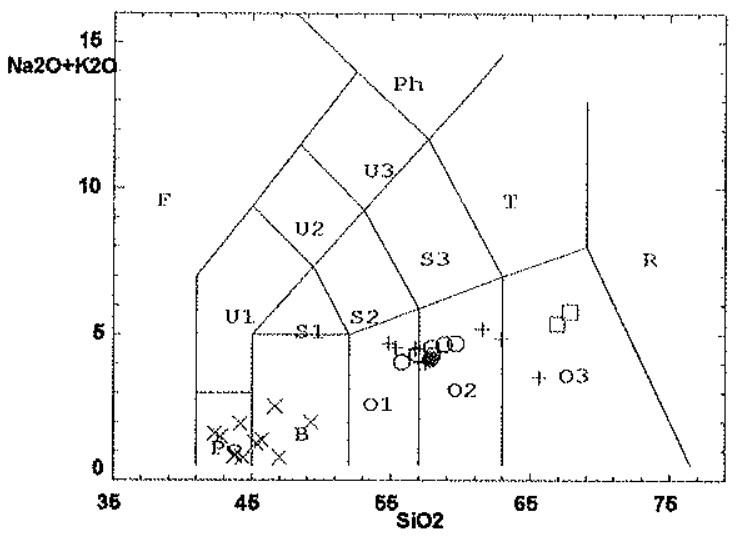

Figura 5.9 - Diagrama $\mathrm{SiO}_{2} \times \mathrm{Na}_{2} \mathrm{O}+\mathrm{K}_{2} \mathrm{O}$ de Le Maitre (1989) para as rochas da borda do maciço de Venda Nova posicionadas nos campos originalmente definidos para rochas vulcânicas.

Símbolos: x Noritos; 1 Opdalitos; O OPX-Quartzo-dioritos; + Enderbitos; $・$ Quartzo-mangerito

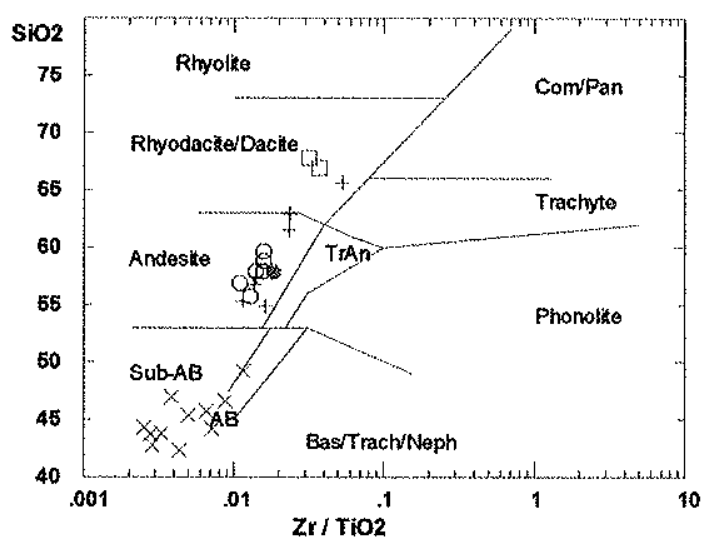

Figura 5.10 - Diagrama $\mathrm{Z} r / \mathrm{TiO}_{2} \times \mathrm{SiO}_{2}$ para as rochas da borda do maciço de Venda Nova.

Símbolos: x Noritos; Opdalitos; O OPX-Quartzo-dioritos; + Enderbitos; * Quartzo-mangerito 
No gráfico $\mathrm{SiO}_{2} \times \mathrm{Na}_{2} \mathrm{O}+\mathrm{K}_{2} \mathrm{O}$ de Cox et al. (1979), na figura 5.11, as rochas de Venda Nova também caem nos campos dos basaltos, andesitos basálticos e andesitos e dacitos, correspondendo a gabros (noritos), dioritos (OPX-dioritos), quartzo-dioritos (OPX-quartzodioritos) e granodioritos (opdalitos) segundo Wilson (op. cit.).

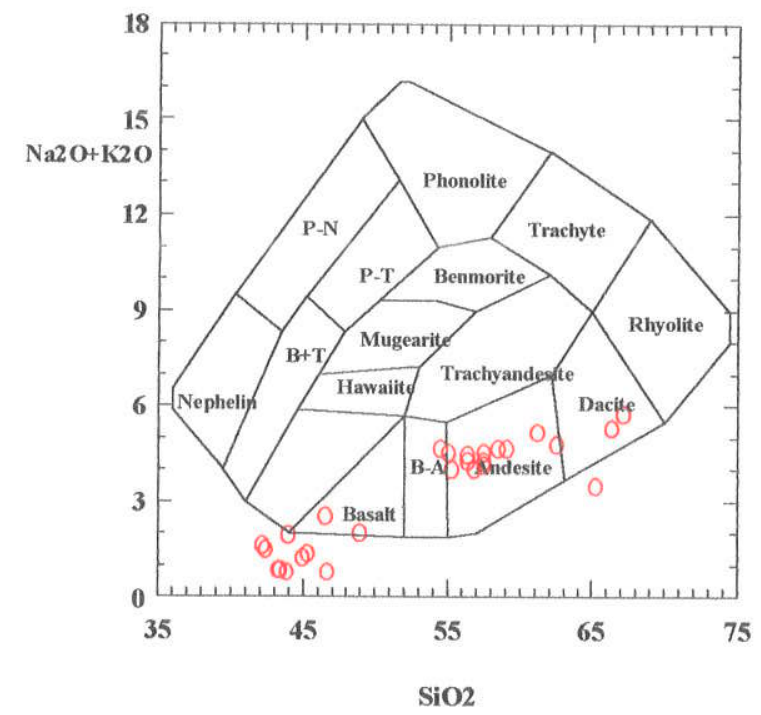

Figura 5.11 - Diagrama $\mathrm{SiO}_{2} \times \mathrm{Na}_{2} \mathrm{O}+\mathrm{K}_{2} \mathrm{O}$ de Cox et al. (1979) para as rochas da borda do maciço de Venda Nova.

A classificação de rochas ígneas usando parâmetros normativos exibe por vezes algumas distorções em função da composição modal da rocha. Rochas possuindo grande quantidade de minerais hidratados (biotitas e anfibólios) tendem a fornecer normas contendo maiores proporções de minerais ricos em Ca e K (anortita, diopsído, ortoclásio). Isto ocorre com algumas das amostras de Venda Nova, notadamente os noritos ricos em hornblenda. Na figura 5.12 tem-se o gráfico QAP de Le Maitre (op. cit.) que fornece uma classificação mesonormativa. Observa-se que os tipos litológicos de Venda Nova classificam-se em gabros (noritos), monzodioritos e quartzo-monzodioritos (jotunitos), quartzo-dioritos (OPX-quartzo-dioritos), tonalitos (enderbitos) e granodioritos (opdalitos). Nota-se, portanto, que a classificação deslocase para termos levemente mais ricos em álcalis, em função da concentração de hornblenda e biotita das rochas. 


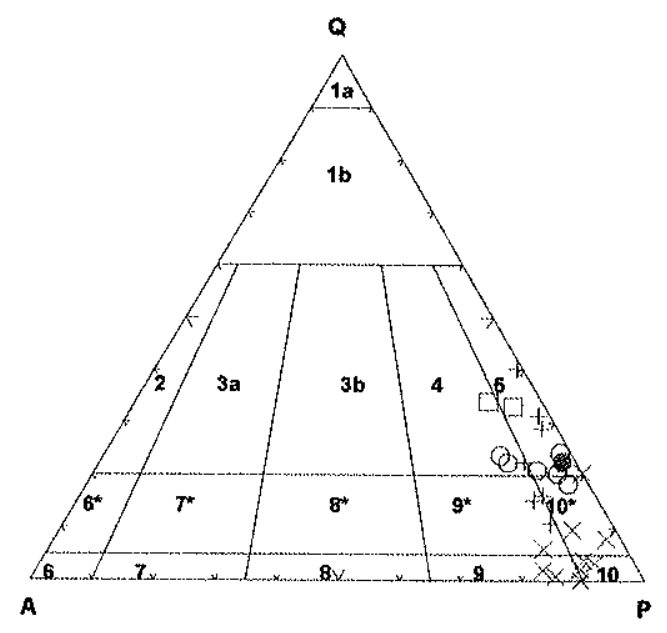

Figura 5.12 - Diagrama QAP com a classificação mesonormativa de Le Maitre (1989) para as rochas da borda de Venda Nova.

Símbolos: $\mathrm{x}$ Noritos; $\square$ Opdalitos; O OPX-Quartzo-dioritos; + Enderbitos; Quartzo-mangerito

Utilizando-se dos elementos traços Rb, Ba e Sr, El Bouseily \& El Sokkary (1975) propuseram uma classificação baseada nas variações das concentrações dos mesmos. Na figura 5.13 encontra-se o gráfico ternário criado por eles, onde pode-se observar que as rochas charnoquitóides da intrusão de Venda Nova situam-se preferencialmente entre os campos dos (OPX)quartzo-dioritos e dioritos, secundariamente nos granodioritos (opdalitos). Nestes campos é nítido o aumento de $\mathrm{Sr}$ e $\mathrm{Ba}$ em detrimento de $\mathrm{Rb}$, como os autores destacam no artigo.

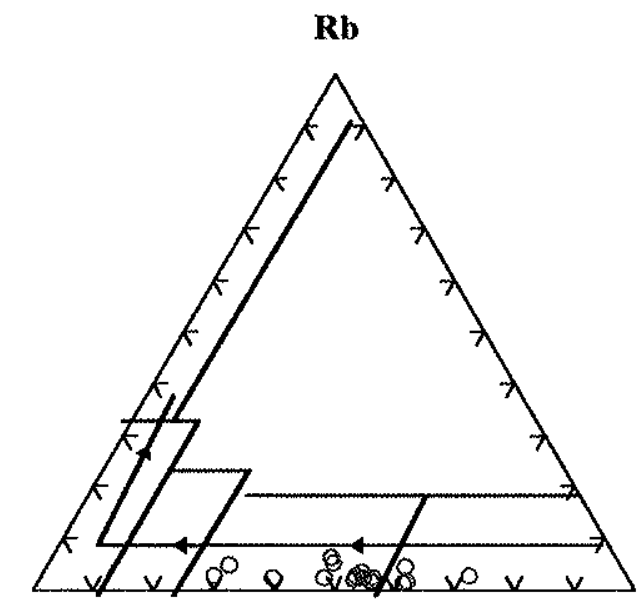

Ba

Sr

Figura 5.13 - Diagrama Rb-Ba-Sr para as rochas da borda do maciço de Venda Nova.

O comportamento dos elementos terras raras e os padrões de distribuição de elementos incompatíveis

De maneira geral, as rochas da borda do maciço de Venda Nova não possuem teores muito discrepantes de elementos terras raras, não caracterizando seqüencias pobres ou enriquecidas, como pode-se verificar na tabela 5.3. Existe uma tendência das rochas noríticas apresentarem, num todo, concentrações menores de elementos TRP. Nas duas seqüências 
observa-se variação nos teores totais, mas em direção aos termos mais diferenciados ocorre um sutil e irregular decréscimo dos mesmos. Tais características em suítes cálcio-alcalinas têm sido normalmente associadas a equilibrio cristal-líquido na rocha fonte, seja por cristalização fracionada de magmas básicos ou por fusão parcial de fonte máfica (Condie et al., op. cit.; Cullers \& Graf, 1984). A amostra VN-19 possui teores muito inferiores devido a provável problema analítico, mas observa-se uma proporção que está mais ou menos mantida dentre os diversos elementos, i. e., as concentrações são aproximadamente cinco vezes menores.

Os charnoquitóides são um pouco mais ricos em ETRL do que os noritos, com os teores de La chegando a 100 vezes o condrito dentre os primeiros e 70 vezes nos noritos. Assim como no total de ETR, as concentrações de Eu tendem a diminuir em direção aos litotipos mais ácidos, ao contrário da razão $\mathrm{Sm} / \mathrm{Eu}$, que tende a aumentar. Ormaasen (1977) aponta tal característica como uma resposta ao fracionamento de feldspato durante a evolução de uma seqüência magmática.

Os padrões de elementos terras raras são bem semelhantes para as duas seqüências, como pode ser visto nas figuras 5.14 e 5.15. Eles são homogêneos (o padrão da amostra VN-19 é paralelo, apesar das concentrações bem inferiores), exibindo um fracionamento moderado, com razões $(\mathrm{Ce} / \mathrm{Yb})_{\mathrm{N}}$ um pouco maiores nos charnoquitóides (varia de 6 a 13,56, enquanto que nos tipos básicos a variação é de 7,16 a 13,03). As razões (Dy/Yb) são maiores nos noritos, estando claro no gráfico o comportamento mais fracionado das terras raras intermediárias e pesadas nestas rochas.

A seqüência Ca-alcalina mostra um maior fracionamento nas terras raras leves, apresentando discretas anomalias negativas de $\mathrm{Eu}\left(\mathrm{razões}\left(\mathrm{Eu} / \mathrm{Eu}^{*}\right)_{\mathrm{N}}\right.$ variam de 0,73 a 0,98$)$. A amostra VN-16 é a que possui a anomalia negativa mais acentuada, apesar de ter teor de $\mathrm{CaO}$ superior aos das amostras $\mathrm{VN}-13$ e 27, que são mais ácidas e com razões (Eu/Eu*) $\mathrm{N}$ maiores. Nos noritos tais razões são próximas de 1 , não se configurando anomalias de Eu.

Os teores relativamente baixos de ETRP das rochas podem estar relacionados a cristalização fracionada do magma parental controlada por hornblenda (é descartado, pois as rochas se cristalizaram em condições anidras) ou, o que parece mais plausível, pela presença de granada ou hornblenda residual na sua área fonte, gerando um magma parental já empobrecido. A amostra $\mathrm{VN}-13$ possui os mais baixos teores de terras raras pesadas, apesar dos teores de ETR leves e intermediários serem coerentes com o resto da sequência.

As rochas do batólito Bela Joana possuem padrões bem diferentes, mais fracionados (razões $\mathrm{Ce} / \mathrm{Yb}$ chegam a 41) e com anomalias variadas e acentuadas de Eu. Do mesmo modo, as rochas charnoquíticas do norte da China são bem mais enriquecidas em terras raras e exibem padrões bem fracionados e com anomalias positivas e negativas de $\mathrm{Eu}$, principalmente os termos mais ácidos. 


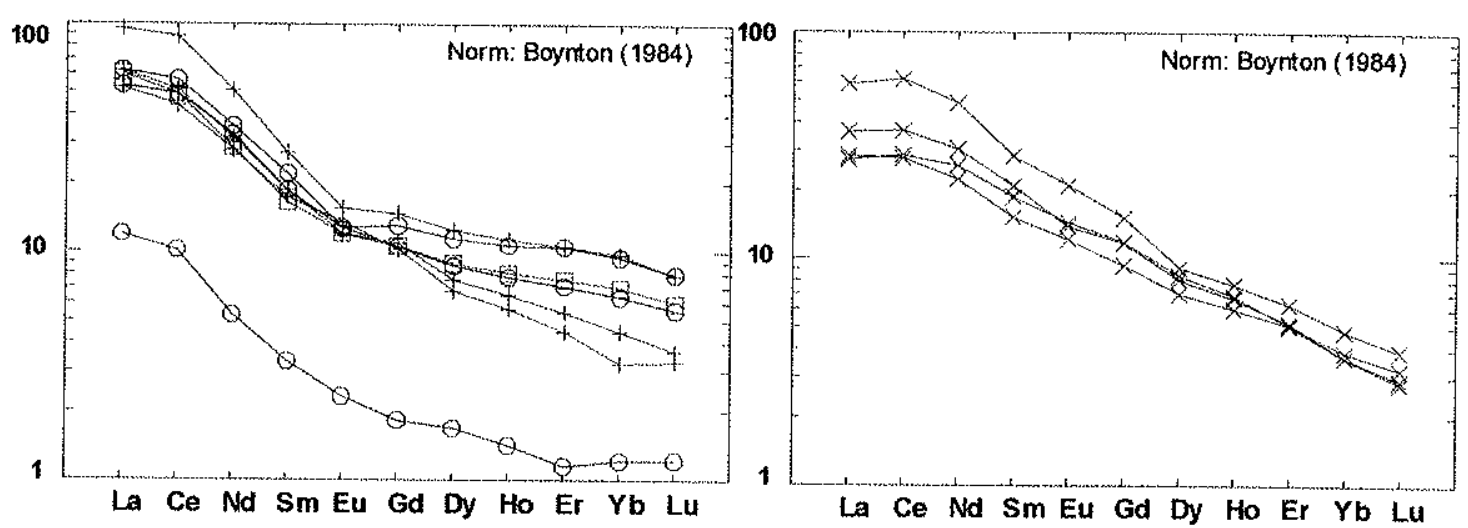

Figuras 5.14 e 5.15 - Padrões de elementos terras raras para as rochas da borda do maciço de Venda Nova.

Simbolos: $x$ Noritos;.$]$ Opdalitos; O OPX-Quartzo-dioritos; + Enderbitos; Quartzo-mangerito

As figuras 5.16 e 5.17 exibem os gráficos de distribuição de elementos incompatíveis, com duas diferentes normalizações, para as rochas da borda do maciço de Venda Nova.

O padrão para ambos os grupos de rochas é bem similar, com a diminuição relativa dos teores em direção aos elementos menos incompativeis. Chama a atenção a pequena variação de teores que ocorre dentre os elementos da seqüência Ca-alcalina, resultando num padrão muito homogêneo para todas as amostras plotadas. Já na seqüência "toleiítica" observase uma maior variação, sobretudo entre os mais incompatíveis, que são os primeiros da série. Ambas as normalizações utilizadas são para NMORB, e algumas anomalias ficam por vezes melhor caracterizadas com uma delas, como é o caso do $\mathrm{K}, \mathrm{Zr}$ e Ti.

Os charnoquitóides exibem discretas anomalias positivas de $\mathrm{Ba}, \mathrm{Ce}, \mathrm{Y}$ e $\mathrm{Zr}$ e fortemente negativas de $\mathrm{Nb}$, $\mathrm{Ti}$ e $\mathrm{P}$, estas últimas típicas de granitóides cálcio-alcalinos (cf. Pearce et al., 1984). Os noritos têm sutis anomalias positivas de Sr, Y e Sm e negativas de K e $\mathrm{Zr}$, esta última bem acentuada.
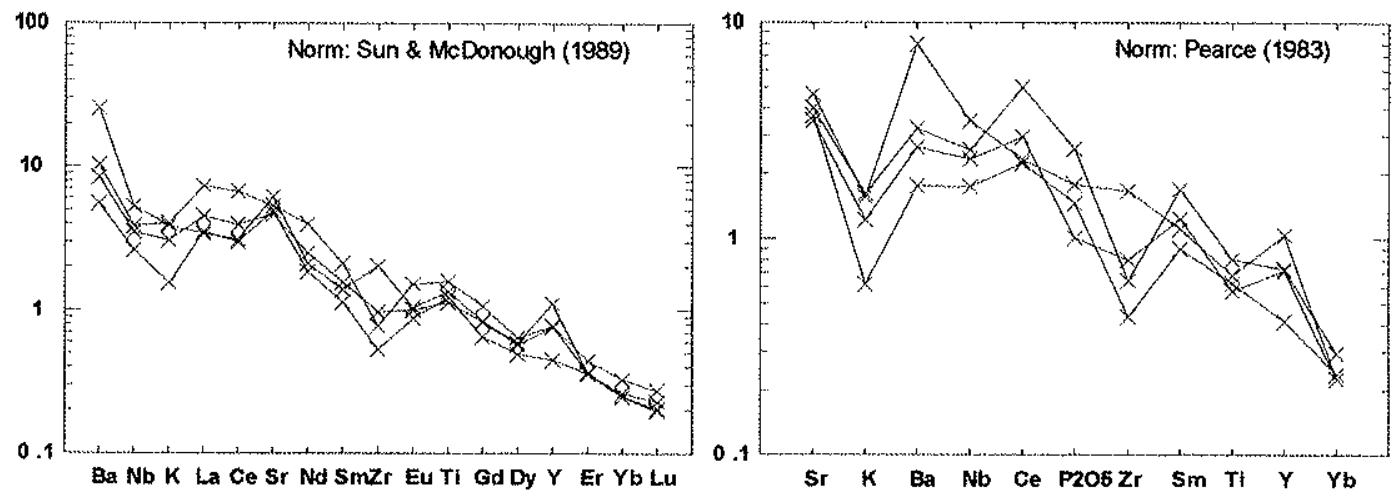

Figura 5.16 - Diagramas de distribuição de elementos incompatíveis para os noritos da borda do maciço de Venda Nova. 

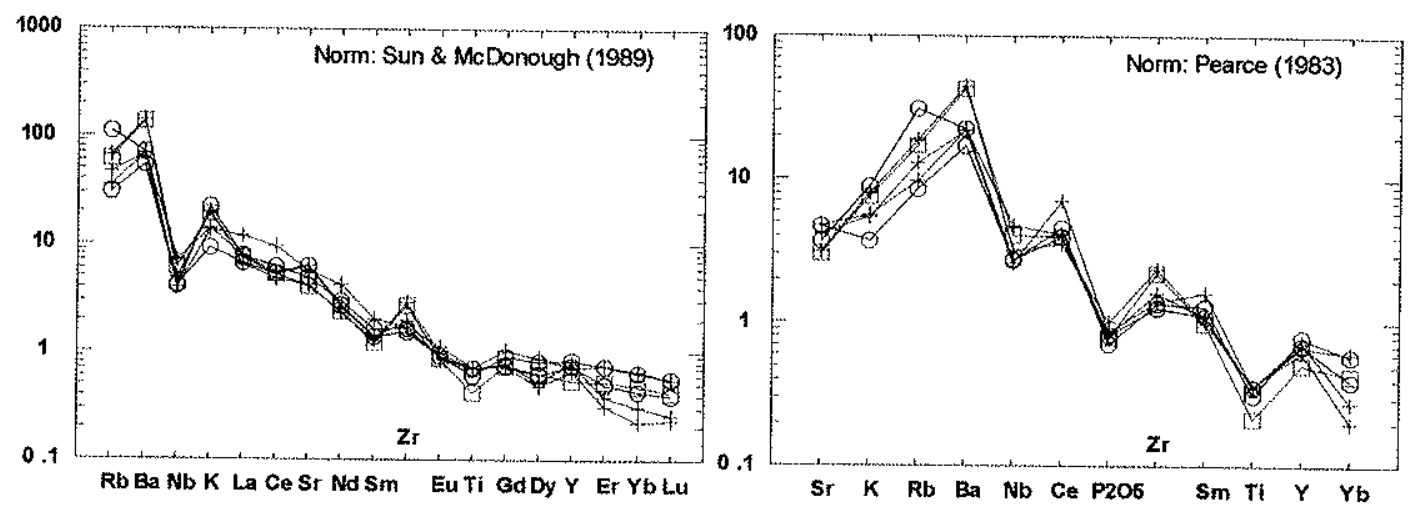

Figura 5.17 Diagramas de distribuição de elementos incompatíveis para os charnoquitóides da borda do maciço de Venda Nova.

Símbolos: [] Opdalitos; O OPX-Quartzo-dioritos; + Enderbitos

\section{Considerações sobre o ambiente tectônico a partir do quimismo das rochas}

Os noritos e charnoquitóides do maciço de Venda Nova não exibem evidências de terem sido impostos a eventos deformacionais significativos. A foliação observada não é penetrativa, tendo se desenvolvido provavelmente devido a uma combinação de fluxo primário com esforços decorrentes do seu "emplacement" e/ou de um estágio final de compressão regional. As feições de deformação incipiente observadas ao microscópio, já descritas no capítulo 4, devem também estar relacionadas a tais esforços. A aparência mega e microscópica relativamente isotrópica e sua associação espacial com os sienomonzonitos (diques sinintrusivos e estruturas tipo "schilieren"), relatada no capítulo 3, levam a crer que essas rochas tenham possivelmente se posicionado num intervalo temporal de final de compressão a início de relaxamento crustal, i.e., num período tardi a pós-orogênico, com relação ao ciclo Brasiliano.

Petro et al. (1979) fizeram um apanhado geral de algumas características geoquímicas que auxiliam na distinção de suítes plutônicas extensionais e compressionais. Extrapolando-as para as rochas charnoquitóides de Venda Nova observa-se nas mesmas um nítido predomínio de pontos comuns a suítes compressionais.

São diversos os diagramas disponíveis na literatura que discriminam tectonicamente suítes magmáticas. Aqui serão utilizados alguns mais consagrados e que fornecem respostas mais coerentes para as rochas estudadas.

Brown (1982) utilizou o diagrama $\mathrm{SiO}_{2} \times \log \left(\mathrm{CaO} / \mathrm{Na}_{2} \mathrm{O}+\mathrm{K}_{2} \mathrm{O}\right)$ para distinguir e comparar um variado número de seqüências vulcânicas e plutônicas amplamente conhecidas, abrangendo uma larga faixa de idade. Separa suítes magmáticas de diferentes características e ambientes tectônicos de formação. Na figura 5.18 as amostras dos charnoquitóides de Venda Nova apresentam uma distribuição que tende a acompanhar os "trends" de batólitos Ca-alcalinos formados em ambientes compressionais, que é o caso dos tonalitos do sudoeste da Finlândia (SWF) e do batólito de Ben Ghnema, Líbia (BG), ambos proterozóicos. 


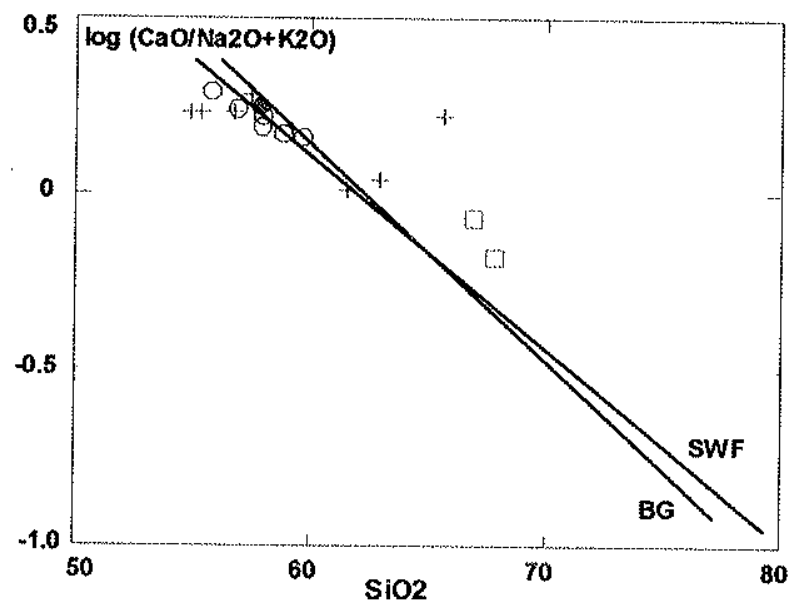

Figura 5.18 - Diagrama $\mathrm{SiO}_{2} \times \log \left(\mathrm{CaO} / \mathrm{Na}_{2} \mathrm{O}+\mathrm{K}_{2} \mathrm{O}\right)$ para as rochas da borda do maciço de Venda Nova Símbolos: [] Opdalitos; O OPX-Quartzo-dioritos; + Enderbitos; Quartzo-mangerito

O diagrama multicatiônico R 1 x R2 de De La Roche, adaptado por Batchelor \& Bowden (1985), apresenta diversas divisões que separam as suítes magmáticas e seus respectivos ambientes de formação, isto é, ele propicia uma representação da variação das composições de rochas através de um ciclo orogênico.

Observa-se na figura 5.19 que os noritos caem no campo 1 (toleí́tico/fracionados do manto), com várias amostras deslocadas em função dos seus altos teores de Ca e Al. As rochas charnoquitóides posicionam-se no campo 2, que é correspondente a suites Ca-alcalinas e trondhj emíticas geradas em ambiente pré-colisional. Os baixos teores de álcalis das amostras são provavelmente os responsáveis por tal posicionamento, e devem refletir características herdadas da área fonte. A amostra $\mathrm{VN}-2$, com sua maior deficiência em álcalis, está totalmente deslocada, fora dos limites traçados.

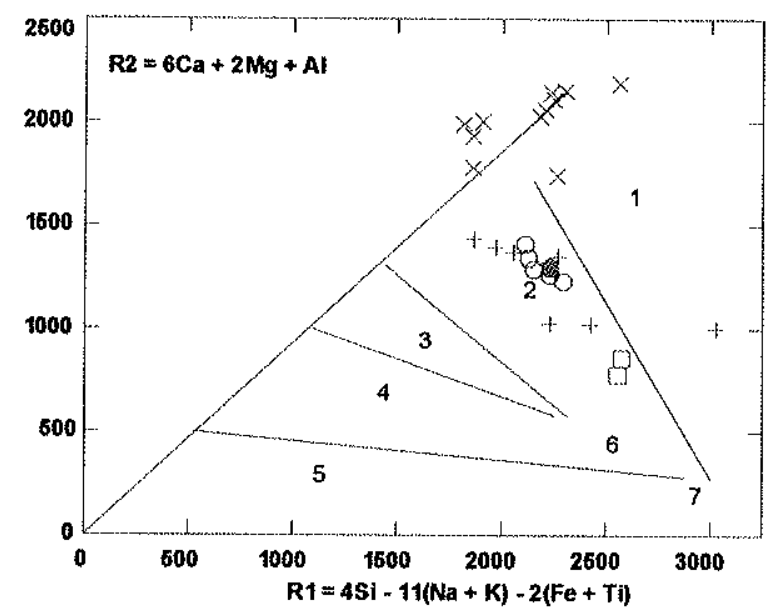

Figura 5.19 - Diagrama R1 $\mathrm{R} 2$ para as rochas da borda do maciço de Venda Nova. Símbolos: $x$ Noritos; $[$ Opdalitos; O OPX-Quartzo-dioritos; + Enderbitos; * Quartzo-mangerito 
Os gráficos de discriminação tectônica de Pearce et al. (op. cit.), apresentados nas figuras 5.20 e 5.21 são baseados nos elementos traços $\mathrm{Rb}, \mathrm{Y}$ e Nb. Mesmo considerando-se possíveis problemas analíticos com o $\mathrm{Nb}$, todas as amostras de Venda Nova plotam nos campos dos granitos de arco vulcânico (VAG). Vale destacar que as rochas do batólito Bela Joana (Rêgo, op. cit.) comportam-se de maneira similar nesses diagramas.

As anomalias negativas de HFSE, mostradas acima nos aranhogramas, têm sido apontadas na literatura como um típico componente geoquímico de zona de subducão (Pearce, 1983; Pearce et al., op. cit.).
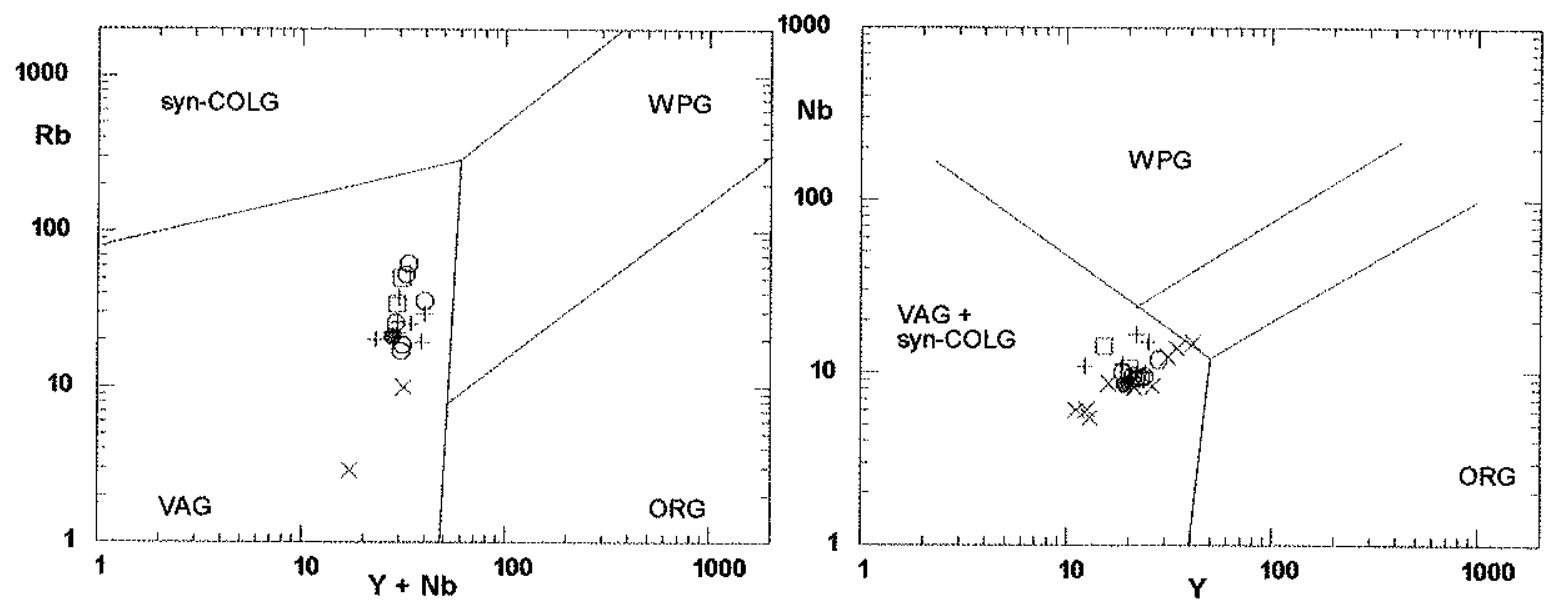

Figuras 5.20 e 5.21 - Diagramas $\mathrm{Y}+\mathrm{Nb} \times \mathrm{Rb}$ e $\mathrm{Y} \times \mathrm{Nb}$ de Pearce (1984) para as rochas da borda do maciço de Venda Nova.

Símbolos: x Noritos; O Opdalitos; O OPX-Quartzo-dioritos; + Enderbitos; Quartzo-mangerito 


\subsection{MACIÇO DE VÁRZEA ALEGRE}

\section{Considerações iniciais}

Foram utilizadas 32 análises químicas de rocha total (elementos maiores, menores e traços, incluindo 16 análises de elementos terras raras) para a caracterização química dos charnoquitóides do maciço de Várzea Alegre. Como foi relatado no capítulo 1, item 1.4, algumas destas análises foram dosadas em laboratórios diferentes, o que por vezes pode resultar em problemas na interpretação, em função de algumas disparidades de dados. As amostras referenciadas como "MP" e "HR" foram extraídas do relatório preliminar do "PLGBB" da CPRM. Os dados estão nas tabelas 5.5 e 5.6.

Como foi relatado no item anterior, as concentrações de alguns elementos podem não corresponder a realidade, por problemas analíticos ou de limite de detecção dos mesmos. Destaca-se alguns baixos valores de $\mathrm{Cr}, \mathrm{Ni}$ e $\mathrm{Sc}$, provavelmente próximos dos seus limites de deteç̧̃a para o método utilizado, e determinados teores de $\mathrm{Pb}$, aparentemente elevados para esses tipos de rocha. As concentrações de $\mathrm{Al}_{2} \mathrm{O}_{3}$ são bastante variáveis em amostras de composição semelhante (e.g., de 15,37 a 16,58), o que pode estar associado a problemas na dosagem ou refletirem variações das proporções plagioclásio/álcali-feldspato da rocha. Uma homogeneização inadequada do material (dos grãos quarteados ou do pó de rocha) poderia também causar distorções, devido ao tamanho dos megacristais de feldspato, mas isto não parece provável porque os teores de $\mathrm{CaO}$ e $\mathrm{K}_{2} \mathrm{O}$ variam de forma coerente com o aumento dos valores de $\mathrm{SiO}_{2}$.

Para cinco amostras analisadas na Holanda não foi feita a determinação dos elementos terras raras intermediários, implicando portanto numa lacuna no padrão de ETR. As amostras VA-256 e VA-254 correspondem a gnaisses enderbíticos encaixantes (ortognaisse Santa Tereza) e foram analisadas a título de comparação com os charnoquitóides. 
Tabela 5.5 - Análises químicas de elementos maiores, menores (\% em peso ) e traço ( em ppm ) e parâmetros geoquímicos para as rochas do Maciço de Várzea Alegre

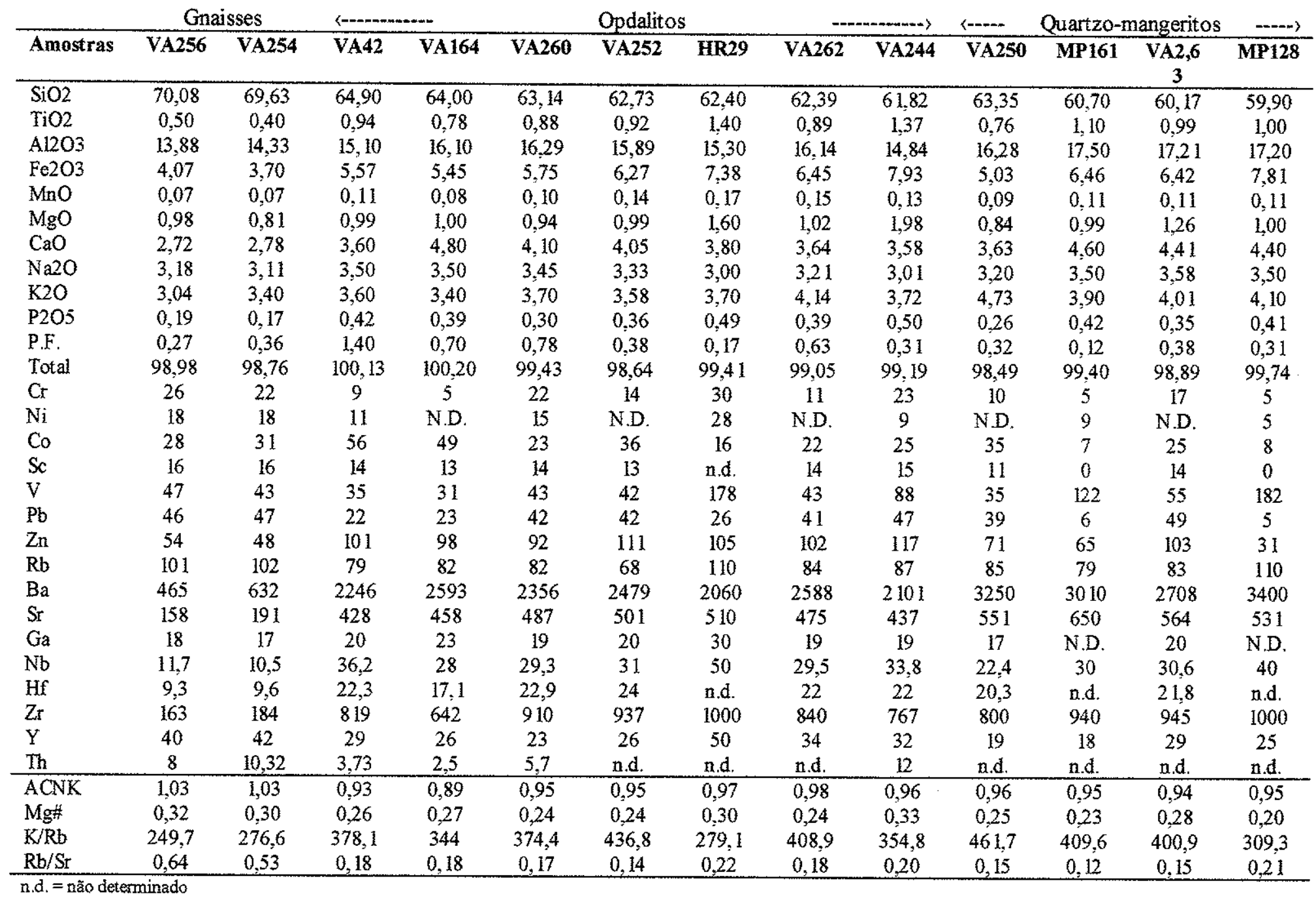

$\mathrm{ND}$. = nẫo detectado 
Tabela 5.5 - Continuação

\begin{tabular}{|c|c|c|c|c|c|c|c|c|c|c|c|c|c|c|c|c|}
\hline \multirow[b]{2}{*}{ Amostras } & \multicolumn{3}{|c|}{ (2) } & \multicolumn{6}{|c|}{ Jotunitos } & \multicolumn{3}{|c|}{ 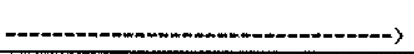 } & \multicolumn{4}{|c|}{ (-...... OPX-Quartzo-Dioritos -.-.) } \\
\hline & VA125 & VA16 & VA241 & VA249 & VA90 & VA242 & VA264 & VA253 & VA246 & VA237 & VA56 & VA257 & VA182 & VA261 & MP718 & MP173 \\
\hline $\mathrm{SiO} 2$ & 61,00 & 61,00 & 60,01 & 59,51 & 59,00 & 58,71 & 57,43 & 57,34 & 56,98 & 56,81 & 56,46 & 56,22 & 55,23 & 53,99 & 54,40 & 53,10 \\
\hline $\mathrm{TiO} 2$ & 1,10 & 1,30 & 1,49 & 1,16 & 1,50 & 1,70 & 1,58 & 1,65 & 1,66 & 1,78 & 1,40 & 1,74 & 1,95 & 1,97 & 1,90 & 1,90 \\
\hline $\mathrm{Al} 2 \mathrm{O} 3$ & 16,10 & 16,10 & 14,84 & 16,78 & 15,10 & 14,86 & 15,89 & 15,71 & 15,82 & 14,68 & 16,37 & 15,37 & 15,55 & 16,58 & 17,10 & 16.20 \\
\hline $\mathrm{Fe} 2 \mathrm{O} 3$ & 6,75 & 7,08 & 8,64 & 7,38 & 9,30 & 10,09 & 9,52 & 9,76 & 9,74 & 11,14 & 8,43 & 10,43 & 11,61 & 11,28 & 11.20 & 9,60 \\
\hline $\mathrm{MnO}$ & 0,10 & 0,12 & 0,14 & 0,15 & 0,14 & 0,16 & 0,16 & 0,15 & 0,16 & 0,18 & 0,14 & 0,17 & 0,18 & 0,18 & 0,18 & 0,15 \\
\hline $\mathrm{MgO}$ & 2,60 & 1,70 & 2,14 & 1,55 & 1,80 & 2,58 & 2,29 & 2,36 & 2,39 & 2,57 & 1,90 & 2,47 & 2,83 & 2,76 & 1,80 & 3,70 \\
\hline $\mathrm{CaO}$ & 3,90 & 4,50 & 4,16 & 4,92 & 5,00 & 4,41 & 4,99 & 5,19 & 4,87 & 5,00 & 5,28 & 5,39 & 5,39 & 6,22 & 6,60 & 7,90 \\
\hline $\mathrm{Na} 2 \mathrm{O}$ & 3,20 & 3,50 & 2,99 & 3,45 & 3,50 & 2,95 & 3,39 & 3,09 & 3,16 & 3,09 & 3,41 & 3,32 & 3,18 & 3,28 & 3,00 & 3,20 \\
\hline $\mathrm{K} 2 \mathrm{O}$ & 3,60 & 3,10 & 3,41 & 3,23 & 3,40 & 2,94 & 2,84 & 2,78 & 3,33 & 2,46 & 3,49 & 2,62 & 2,39 & 2,02 & 2,40 & 2,30 \\
\hline $\mathrm{P} 205$ & 0,53 & 0,44 & 0,62 & 0,46 & 0,66 & 0,72 & 0,73 & 0,76 & 0,77 & 0,90 & 0,60 & 0,84 & 0,96 & 0,95 & 0,86 & 0,77 \\
\hline P.F. & 0,90 & 1,20 & 0,37 & 0,34 & 0,60 & 0,26 & 0,29 & 0,17 & 0,27 & 0.26 & 0,65 & 0,41 & 0,15 & 0,21 & 0,35 & 0,68 \\
\hline Total & 99,78 & 100,04 & 98,81 & 98,93 & 100,00 & 99,38 & 99,11 & 98,96 & 99,15 & 98,87 & 98,13 & 98,98 & 99,42 & 99,44 & 99,79 & 99,50 \\
\hline $\mathrm{Cr}$ & 13 & 14 & 24 & 20 & 16 & 40 & 33 & 48 & 35 & 35 & 24 & 47 & 31 & 40 & 17 & 62 \\
\hline $\mathrm{Ni}$ & 12 & 12 & 9 & 9 & 14 & 17 & 14 & 27 & 15 & 30 & N.D. & 26 & 10 & 17 & 32 & 74 \\
\hline $\mathrm{Co}$ & 63 & 69 & 33 & 33 & 61 & 36 & 28 & 33 & 38 & 43 & 26 & 28 & 38 & 31 & 22 & 50 \\
\hline $\mathrm{Sc}$ & 14 & 16 & 16 & 16 & 17 & 18 & 18 & 18 & 19 & 16 & 16 & 22 & 20 & 24 & n.d. & n.d. \\
\hline $\mathrm{V}$ & 67 & 57 & 93 & 69 & 125 & 111 & 106 & 108 & 107 & 117 & 85 & 112 & 122 & 121 & 160 & 216 \\
\hline $\mathrm{Pb}$ & 24 & 19 & 58 & 50 & 21 & 25 & 37 & 28 & 34 & 28 & 85 & 40 & 36 & 47 & 26 & 28 \\
\hline $\mathrm{Zn}$ & 126 & 130 & 121 & 110 & 134 & 142 & 135 & 135 & 128 & 163 & 107 & 149 & 165 & 169 & 58 & 85 \\
\hline $\mathrm{Rb}$ & 91 & 72 & 74 & 61 & 64 & 60 & 62 & 56 & 58 & 60 & 50 & 46 & 47 & 36 & 38 & 67 \\
\hline $\mathrm{Ba}$ & 3043 & 2594 & 2317 & 2526 & 2727 & 2160 & 2154 & 2136 & 2779 & 1744 & 3389 & 2063 & 1982 & 1746 & 2030 & 1070 \\
\hline $\mathrm{Sr}$ & 518 & 534 & 498 & 621 & 579 & 505 & 581 & 614 & 614 & 515 & 702 & 594 & 577 & 677 & 760 & 890 \\
\hline $\mathrm{Ga}$ & 23 & 22 & 20 & 21 & 21 & 19 & 21 & 21 & 20 & 22 & 20 & 21 & 21 & 21 & 30 & 28 \\
\hline $\mathrm{Nb}$ & 33,2 & 33,4 & 33,8 & 32,2 & 35,2 & 39,5 & 38,6 & 36,8 & 35,8 & 43,5 & 30,3 & 41,5 & 45 & 46 & 64 & 26 \\
\hline $\mathrm{Hf}$ & 22,9 & 21,8 & 22,2 & 23 & 18,3 & 24,1 & 20,5 & 21,7 & 20,7 & 23,7 & 23,1 & 21,8 & 22 & 23 & n.d. & n.d. \\
\hline $\mathrm{Zr}$ & 915 & 860 & 819 & 980 & 724 & 929 & 828 & 894 & 841 & 917 & 1049 & 913 & 932 & 1084 & 1760 & 600 \\
\hline$Y$ & 32 & 32 & 32 & 31 & 36 & 37 & 36 & 37 & 35 & 41 & 25 & 35 & 40 & 36 & 70 & 54 \\
\hline Th & 4,63 & 6,14 & 4 & n.d. & 2,41 & nd. & n.d. & n.d. & 5,27 & 6,80 & n.d. & n.d. & 4 & n.d. & n.d. & n.d. \\
\hline $\mathrm{ACNK}$ & 0,99 & 0,93 & 0,92 & 0,93 & 0,81 & 0,93 & 0,90 & 0,90 & 0,87 & 0,87 & 0,86 & 0,86 & 0,88 & 0,88 & 0,88 & 0,73 \\
\hline $\mathrm{Mg} \#$ & 0,43 & 0,32 & 0,33 & 0,29 & 0,28 & 0,34 & 0,32 & 0,32 & 0,33 & 0,31 & 0,31 & 0,32 & 0,33 & 0,33 & 0,24 & 0,43 \\
\hline $\mathrm{K} / \mathrm{Rb}$ & 328,2 & 357,2 & 382,3 & 439,3 & 440,8 & 406,6 & 380 & 411,9 & 476,4 & 340,2 & 579,1 & 472,6 & 421,9 & 465,6 & 524 & 284,8 \\
\hline $\mathrm{Rb} / \mathrm{Sr}$ & 0,18 & 0,13 & 0,15 & 0,10 & 0.11 & 0,12 & 0,11 & 0,09 & 0,09 & 0,12 & 0,07 & 0,08 & 0,08 & 0,05 & 0,05 & 0,07 \\
\hline
\end{tabular}


Tabela 5.6 - Análises químicas de elementos terras raras (em ppm) das rochas do Maciço de Várzea Alegre

\begin{tabular}{|c|c|c|c|c|c|c|c|c|c|c|c|c|c|c|c|c|}
\hline \multirow{2}{*}{ Amostras } & \multicolumn{2}{|c|}{ Gnaissse } & \multirow{2}{*}{ VA164 } & \multicolumn{2}{|c|}{ Opdalitos } & \multirow{2}{*}{ VA244 } & \multicolumn{2}{|c|}{ 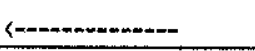 } & \multicolumn{3}{|c|}{ Jotunitos } & \multicolumn{2}{|c|}{ 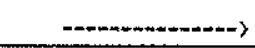 } & \multicolumn{3}{|c|}{ (- OPX-Quartzo-dioritos -) } \\
\hline & VA256 & VA42 & & HR29 & VA262 & & VA125 & VA16 & MP161 & MP128 & VA90 & VA264 & VA56 & VA261 & MP718 & MP173 \\
\hline $\mathrm{La}$ & 28,38 & 41,30 & 30,05 & 111,30 & 56,18 & 100,90 & 70,83 & 71,51 & 50,07 & 49,41 & 80,19 & 67,15 & 58,44 & 70,38 & 71,36 & 56,93 \\
\hline $\mathrm{Ce}$ & 63,54 & 111,00 & 94,10 & 190,70 & 126,90 & 212,80 & 144,00 & 156,00 & 89,96 & 96,47 & 155,00 & 153,00 & 126,20 & 159,70 & 140,10 & 110,80 \\
\hline Nd & 28,84 & 67,00 & 65,20 & 88,61 & 57,67 & 93,94 & 74,20 & 79,70 & 48,98 & 58,44 & 92,00 & 79,22 & 64,60 & 82,61 & 84,96 & 61,71 \\
\hline $\mathrm{Sm}$ & 6,20 & 10,90 & 9,83 & 12,10 & 10,50 & 15,28 & 12,20 & 13,00 & 8,10 & 10,90 & 13,20 & 14,10 & 10,73 & 14,08 & 13,60 & 9,70 \\
\hline $\mathrm{Eu}$ & 1,06 & 4,75 & 4,98 & 3,19 & 3,54 & 3,26 & 5,24 & 5,17 & 3,80 & 4,09 & 4,84 & 3,73 & 4,30 & 3,46 & 4,32 & 2,73 \\
\hline $\mathrm{Gd}$ & 5,22 & n.d. & n.d. & 8,43 & 7,21 & 9,69 & n.d. & nid. & 6,15 & 8,02 & n.d. & 9.75 & 7,16 & 9,67 & 10,19 & 7,03 \\
\hline Dy & 5,45 & n.d. & n.d. & 4,23 & 5,04 & 5,91 & n.d. & n.d. & 3,80 & 4,95 & n.d. & 6,95 & 5,07 & 6,77 & 6,16 & 4,49 \\
\hline Ho & 1,05 & n.d. & n.d. & 0,78 & 0,94 & 1,06 & n.d. & n.d. & 0,66 & 0,93 & n.d. & 1,32 & 0,94 & 1,27 & 1,15 & 0,81 \\
\hline Er & 2,67 & n.d. & n.d. & 1,57 & 2,21 & 2,24 & n.d. & n.d. & 1,60 & 2,52 & n.d. & 3,20 & 2,18 & 3,03 & 2,74 & 1,95 \\
\hline $\mathrm{Yb}$ & 1,99 & 2,19 & 2,11 & 1,03 & 1,48 & 1,33 & 2,14 & 2,43 & 1,38 & 1,91 & 2,52 & 2,28 & 1,54 & 2,14 & 2,19 & 1,47 \\
\hline $\mathrm{Lu}$ & 0,24 & 0,30 & 0,33 & 0,13 & 0,19 & 0,15 & 0,38 & 0,41 & 0,18 & 0,26 & 0,46 & 0,27 & 0.20 & 0,29 & 0,28 & 0,18 \\
\hline Total & 144,64 & 237,44 & 206,60 & 422,07 & 271,86 & 446,56 & 308,99 & 328,22 & 214,68 & 237,90 & 348,21 & 340,97 & 281,36 & 353,40 & 337,05 & 257,80 \\
\hline $\mathrm{Ce} / \mathrm{YbN}$ & 8,26 & 13,11 & 11,53 & 47,90 & 22,18 & 41,39 & 17,40 & 16,61 & 16,86 & 13,06 & 15,91 & 17,36 & 21,20 & 19,30 & 16,55 & 19,50 \\
\hline $\mathrm{Dy} / \mathrm{YbN}$ & 1,78 & $\cdots$ & $\ldots$ & 2,66 & 2,21 & 2,88 &.- & $m$ & 1,79 & 1,68 & -..- & 1,98 & 2,14 & 2,05 & 1.83 & 1.98 \\
\hline $\mathrm{Eu} / \mathrm{Eu} * \mathrm{~N}$ & 0,55 & $\cdots$ & $\cdots$ & 0,92 & 1,18 & 0,77 & -- & $\ldots$ & 1,58 & 1,28 & $\ldots$ & 0,92 & 1,42 & 0,86 & 1,08 & 0.97 \\
\hline $\mathrm{SiO} 2$ & 70,08 & 64,90 & 64,00 & 62,40 & 62,39 & 61,82 & 61,00 & 61,00 & 60,70 & 59,90 & 59,00 & 57,43 & 56,46 & 53,99 & 54,40 & 53,10 \\
\hline
\end{tabular}


Tabela 5.7 - Norma CIPW para as rochas da borda do Maciço de Várzea Alegre

\begin{tabular}{|c|c|c|c|c|c|c|c|c|c|c|c|c|c|c|c|}
\hline Amostras & VA182 & VA261 & VA42 & VA164 & VA125 & VA16 & VA90 & VA256 & VA254 & VA250 & VA260 & VA252 & VA262 & VA244 & VA263 \\
\hline Quartzo & 12,19 & 10,35 & 21,90 & 19,45 & 16,41 & 16,71 & 13,32 & 32,69 & 31,42 & 17,48 & 18,61 & 19,37 & 18,23 & 19,42 & 12,48 \\
\hline Corindon & 0,02 & 0,00 & 0,00 & 0,00 & 0,84 & 0,00 & 0,00 & 0,82 & 0,83 & 0,00 & 0,00 & 0,00 & 0,44 & 0,35 & 0,00 \\
\hline Ortoclásio & 14,33 & 12,11 & 21,65 & 20,29 & 21,64 & 18,65 & 20,36 & 18,28 & 20,50 & 28,59 & 22,25 & 21,63 & 25,01 & 22,37 & 24,20 \\
\hline Albita & 27,29 & 28,14 & 30,10 & 29,86 & 27,49 & 30,09 & 29,96 & 27,30 & 26,80 & 27,68 & 29,72 & 28,82 & 27,71 & 25,85 & 30,89 \\
\hline Anortita & 21,50 & 25,07 & 15,24 & 18,48 & 17,13 & 19,54 & 15,76 & 12,66 & 13,18 & 16,65 & 18,50 & 18,39 & 16,70 & 15,45 & 19,57 \\
\hline Diopsidio & 0,00 & 0,50 & 0,73 & 3,17 & 0,00 & 0,91 & 4,88 & 0,00 & 0,00 & 0,91 & 0,85 & 0,51 & 0,00 & 0,00 & 1,08 \\
\hline Hiperstênio & 12,02 & 11,53 & 4,54 & 3,45 & 9,47 & 6,68 & 6,15 & 4,52 & 4,02 & 3,99 & 4,53 & 5,21 & 5,74 & 8.29 & 5,53 \\
\hline Magnetita & 6,83 & 6,64 & 3,28 & 3,19 & 3,98 & 4,17 & 5,46 & 2,40 & 2,18 & 2,98 & 3,39 & 3,71 & 3,82 & 4,67 & 3,79 \\
\hline Cromita & 0,01 & 0,01 & 0,00 & 0,00 & 0,00 & 0,00 & 0,00 & 0,01 & 0,00 & 0,00 & 0,00 & 0,00 & 0,00 & 0,00 & 0,00 \\
\hline llmenita & 3,76 & 3,80 & 1.81 & 1,49 & 2,12 & 2,51 & 2,88 & 0,97 & 0,77 & 1,47 & 1,71 & 1,79 & 1,72 & 2,64 & 1,92 \\
\hline Apatita & 2,35 & 2,32 & 1,04 & 0,95 & 1,32 & 1,09 & 1,62 & 0,46 & 0,41 & 0,65 & 0,74 & 0,89 & 0,97 & 1.24 & 0,88 \\
\hline Zircão & 0,19 & 0,22 & 0,17 & 0,13 & 0,19 & 0,18 & 0,15 & 0,03 & 0,04 & 0,16 & 0,19 & 0,19 & 0,17 & 0,16 & 0,19 \\
\hline Total & 100,49 & 100,49 & 100,46 & 100,47 & 100,58 & 100,52 & 100,53 & 100,12 & 100,15 & 100,58 & 100,48 & 100,51 & 100,50 & 100,44 & 100,54 \\
\hline I.D. & 53,81 & 50,60 & 73,65 & 69,60 & 65,54 & 65,45 & 63,64 & 78,27 & 78,72 & 73.75 & 70,58 & 69.82 & 70,95 & 67,64 & 67,57 \\
\hline
\end{tabular}

\begin{tabular}{|c|c|c|c|c|c|c|c|c|c|c|c|c|c|c|}
\hline Amostras & VA241 & VA249 & VA242 & VA264 & VA253 & VA246 & VA237 & VA56 & VA257 & MP161 & MP128 & HR-29 & MP718 & MP173 \\
\hline Quartzo & 17,74 & 14,20 & 17,05 & 13,08 & 14,46 & 12,14 & 15,39 & 9,91 & 12,38 & 14,59 & 13,85 & 22,59 & 13,46 & 8.24 \\
\hline Corindon & 0,00 & 0,00 & 0,30 & 0,00 & 0,00 & 0,00 & 0,00 & 0,00 & 0,00 & 0,55 & 0,94 & 1,69 & 0,64 & 0,00 \\
\hline Ortoclásio & 20,60 & 19,48 & 17,67 & 17,12 & 16,75 & 20,06 & 14,86 & 21.30 & 15,80 & 23,34 & 24,69 & 22,54 & 14,70 & 14,25 \\
\hline Albita & 25,80 & 29,77 & 25,34 & 29,17 & 26,61 & 27,23 & 26,70 & 29.79 & 28,60 & 29,94 & 30,12 & 26,11 & 26,27 & 28,32 \\
\hline Anortita & 17,54 & 21,30 & 18,20 & 20,26 & 21,33 & 19,64 & 19,43 & 19.83 & 20,37 & 19,43 & 17,08 & 13,34 & 25,42 & 24,18 \\
\hline Diopsídio & 0,15 & 1,16 & 0,00 & 0,72 & 0,52 & 0,68 & 0,43 & 3,56 & 1,69 & 0,00 & 0,00 & 0,00 & 0,00 & 5,90 \\
\hline Hiperstênio & 8,94 & 6,67 & 10,75 & 9,50 & 9,81 & 9,79 & 11,19 & 6,77 & 9,88 & 5,18 & 5,85 & 5,91 & 7,84 & 8,59 \\
\hline Magnetita & 5,12 & 4,36 & 5,94 & 5,62 & 5,76 & 5,74 & 6,60 & 5,04 & 6,16 & 3,79 & 4,20 & 3,39 & 5,34 & 4,12 \\
\hline Cromita & 0,01 & 0,00 & 0,01 & 0,01 & 0,01 & 0,01 & 0,01 & 0,01 & 0,01 & 0,00 & 0,00 & 0,01 & 0,00 & 0,01 \\
\hline Ilmenita & 2,90 & 2,25 & 3,28 & 3,05 & 3,19 & 3,21 & 3,46 & 2,74 & 3,36 & 2,11 & 1,93 & 2,73 & 3,73 & 3,77 \\
\hline Apatita & 1,54 & 1,14 & 1,76 & 1,79 & 1,87 & 1,89 & 2,21 & 1,51 & 2,06 & 1,04 & 1,02 & 1,22 & 2,14 & 1,92 \\
\hline Calcita & 0,00 & 0,00 & 0,00 & 0,00 & 0,00 & 0,00 & 0,00 & 0,00 & 0,00 & 0,70 & 1.29 & 1,28 & 1,27 & 1,72 \\
\hline Zircão & 0,17 & 0,20 & 0,19 & 0,17 & 0,18 & 0,17 & 0,19 & 0,22 & 0,19 & 0,19 & 0,20 & 0,21 & 0,37 & 0,13 \\
\hline Total & 100,49 & 100,54 & 100,49 & 100,48 & 100,50 & 100,56 & 100,46 & 100,67 & 100,50 & 100,88 & 101,17 & 101,04 & 101,18 & 101,15 \\
\hline I.D. & 63,45 & 63,45 & 60,06 & 59,37 & 57,82 & 59,43 & 56,95 & 61,00 & 56,78 & 67,87 & 68,66 & 71,24 & 54,43 & 50,81 \\
\hline
\end{tabular}




\section{A classificação das rochas}

Haj a visto as dificuldades, limitações e imprecisões na classificação modal destas rochas, já discutidas anteriormente, a que tem como base a composição química ganhou maior importância por servir de referência para as amostras estudadas. Em função disto, vários diagramas classificatórios serão aqui utilizados para justificar a classificação adotada para tais amostras .

As classificações modal e química concordam em determinados diagramas classificatórios, enquanto que em outros isto não ocorre. Na figura 5.22 tem-se o diagrama de Debon \& Le Fort (op. cit.). Neste gráfico o que se observa é que ocorre, de maneira geral, um ligeiro deslocamento para composições mais ricas em álcalis e quartzo ao se comparar com a moda das rochas. As amostras posicionam-se nos campos 11 (monzodiorito/j otunito), 7 (quartzomonzodiorito/j otunito), 6 (quartzo-monzonito/quartzo-mangerito), 3 (granodiorito/opdalito) e 2 (adamelito/charnoquito). Observa-se uma tendência a concentração dos pontos, ocorrendo uma maior densidade nos jotunitos. As amostras dos gnaisses enderbíticos destacam-se das demais, em função dos maiores teores de $\mathrm{SiO}_{2}$.

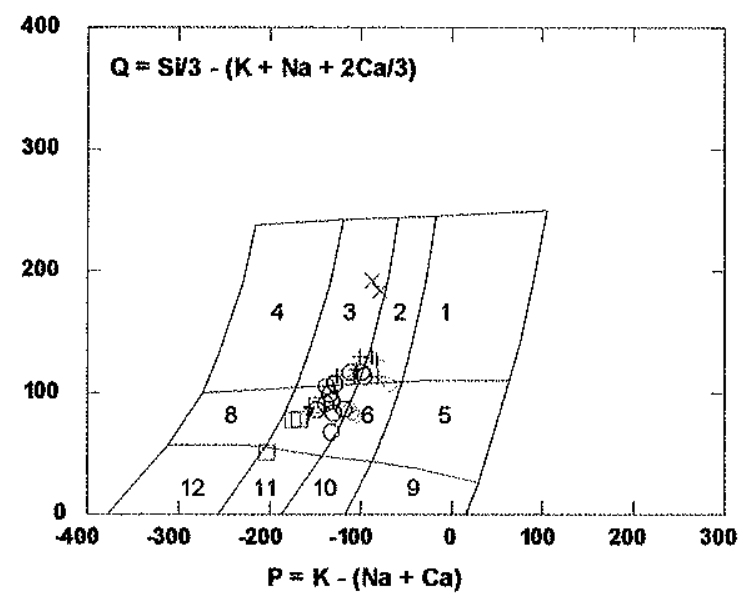

Figura 5.22- Diagrama $Q \times P$ para os charnoquitóides do maciço de Várzea Alegre.

Símbolos: [ OPX-Quartzo-dioritos; O Jotunitos; + Opdalitos; $\diamond$ Quartzo-mangeritos; $\mathrm{x}$ Gnaisse enderbítico

No gráfico $\mathrm{SiO}_{2} \times \mathrm{Na} 2 \mathrm{O}+\mathrm{K}_{2} \mathrm{O}$ de Le Maitre (1989), na figura 5.23, originalmente concebido para classificação de rochas vulcânicas, as rochas do maciço de Várzea Alegre caem nos campos $\mathrm{O} 1, \mathrm{O} 2$ (andesito basáltico e andesito), $\mathrm{S} 2, \mathrm{~S} 3$ (traquiandesito basáltico e traquiandesito), $\mathrm{T}$ (traquito) e $\mathrm{O} 3$ (dacito). Os gnaisses estão no campo dos riolitos. Neste diagrama fica claro o deslocamento das amostras para composições mais ricas em álcalis. 


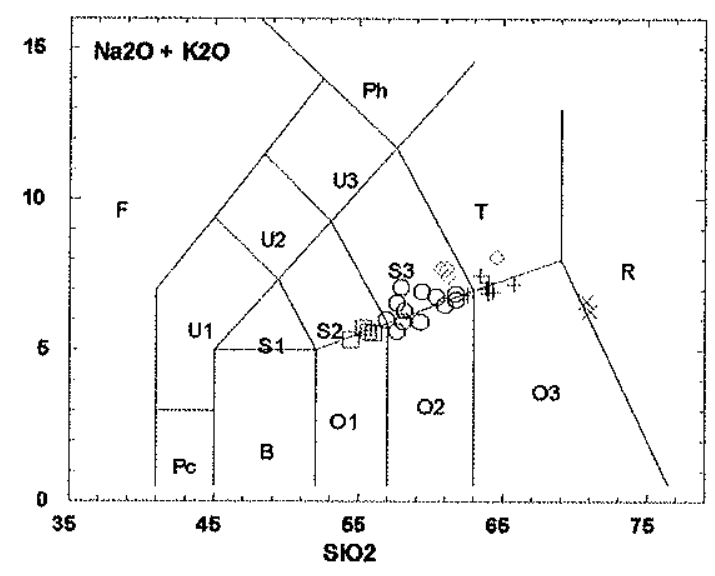

Figura 5.23 - Diagrama $\mathrm{SiO}_{2} \times \mathrm{Na}_{2} \mathrm{O}+\mathrm{K}_{2} \mathrm{O}$ de Le Maitre (1989) para os charnoquitóides do maciço de Várzea Alegre.

Símbolos: [] OPX-Quartzo-dioritos; O Jotunitos; + Opdalitos; $\diamond$ Quartzo-mangeritos; $x$ Gnaisse enderbítico

$\mathrm{O}$ diagrama $\mathrm{SiO}_{2} \times \mathrm{Na}_{2} \mathrm{O}+\mathrm{K}_{2} \mathrm{O}$ com os campos para classificação de rochas plutônicas delimitados por Middlemost (1985) exibe um menor deslocamento para composições mais alcalinas. Ele pode ser visto na figura 5.24, onde observa-se que as amostras analisadas caem nos campos 10 (quartzo-monzodioritos/jotunitos), 11 (granodioritos/opdalitos) e 8 (quartzo-monzonitos/quartzo-mangeritos).

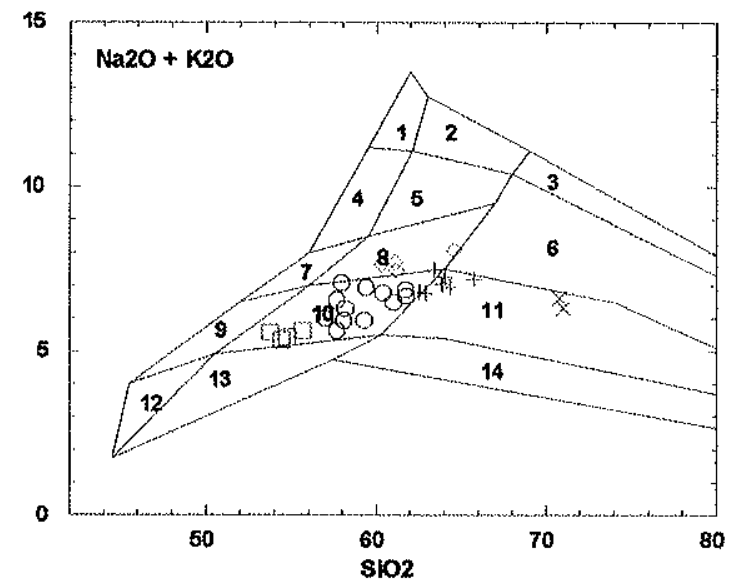

Figura 5.24 - Diagrama $\mathrm{SiO}_{2} \times \mathrm{Na}_{2} \mathrm{O}+\mathrm{K}_{2} \mathrm{O}$ de Middlemost (1985) para os charnoquitóides do maciço de Várzea Alegre.

Símbolos: 1 OPX-Quartzo-dioritos; O Jotunitos; + Opdalitos; $\vartheta$ Quartzo-mangeritos; $x$ Gnaisse enderbítico

Fazendo-se uso do diagrama $\mathrm{Zr} / \mathrm{TiO}_{2} \times \mathrm{SiO}_{2}$ de Winchester \& Floyd (op. cit.), que está na figura 5.25, os altos teores de $\mathrm{Zr}$ dos charnoquitóides de Várzea Alegre fazem com que as amostras plotem em campos de rochas vulcânicas ainda mais alcalinas, chegando a 
fonolitos. Além de ter sido definido para rochas vulcânicas, o resultado alcançado evidencia que tal gráfico não é recomendado para classificação dos litotipos aqui estudados.

Um diagrama consagrado na classificação de rochas vulcânicas é o de Cox et al. (1979). Wilson (1991) adaptou a nomenclatura dos campos delimitados nesse diagrama para rochas plutônicas. Ele pode ser visto na figura 5.26, onde as amostras do maciço de Várzea Alegre estão posicionadas nos campos dos traquiandesitos, andesitos basálticos, andesitos e dacitos, equivalentes a quartzo-monzodioritos $f$ otunitos e quartzo-monzonitos/quartzomangeritos, dioritos/OPX-dioritos e quartzo-dioritos/OPX-quartzo-dioritos e granodioritos/opdalitos. Os gnaisses enderbíticos caem no campo dos riolitos.

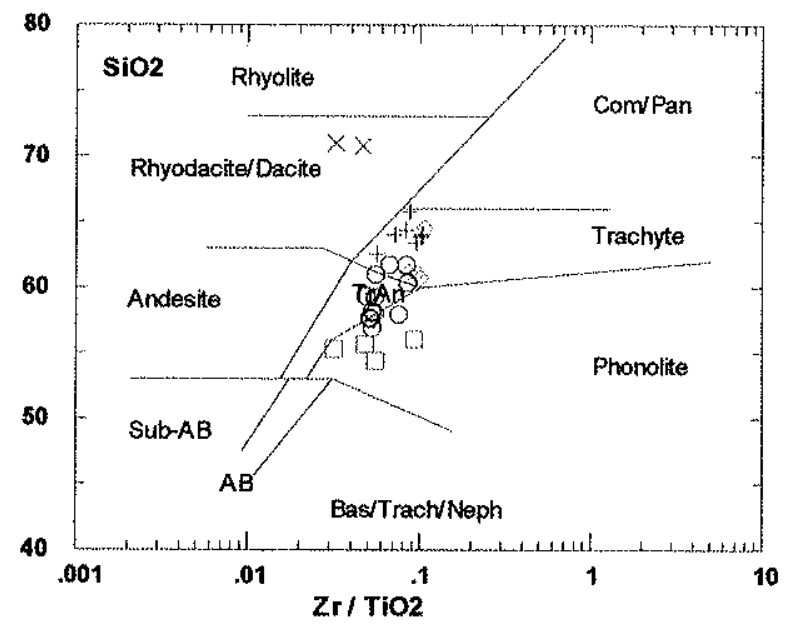

Figura 5.25 - Diagrama $\mathrm{Zr} / \mathrm{TiO}_{2} \times \mathrm{SiO}_{2}$ para os charnoquitóides do maciço de Várzea Alegre.

Símbolos: $\square$ OPX-Quartzo-dioritos; O Jotunitos; + Opdalitos; $\diamond$ Quartzo-mangeritos; $\mathrm{x}$ Gnaisse enderbítico

Pela classificação mesonormativa de Le Maitre (op. cit.), cuj o gráfico se encontra na figura 5.27, os charnoquitóides de Várzea Alegre situam-se nos campos $8^{*}, 9^{*}, 4$ e 5 , que correspondem a quartzo-monzonito/quartzo-mangerito, quartzo-monzodiorito/j otunito, granodiorito/opdalito e tonalito/enderbito. Com relação às classificações modal e química observa-se que a mesonorma implica num deslocamento em direção a composições mais ácidas e, no geral, ligeiramente mais alcalinas. 


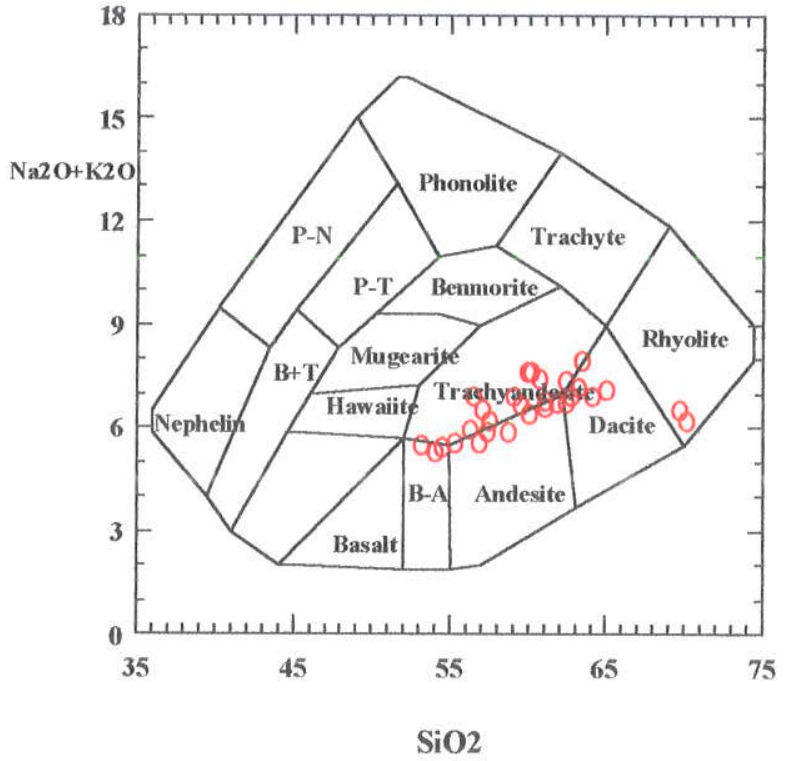

Figura 5.26 - Diagrama $\mathrm{SiO}_{2} \times \mathrm{Na}_{2} \mathrm{O}+\mathrm{K}_{2} \mathrm{O}$ de Cox et al. (1979) para os charnoquitóides do maciço de Várzea Alegre.

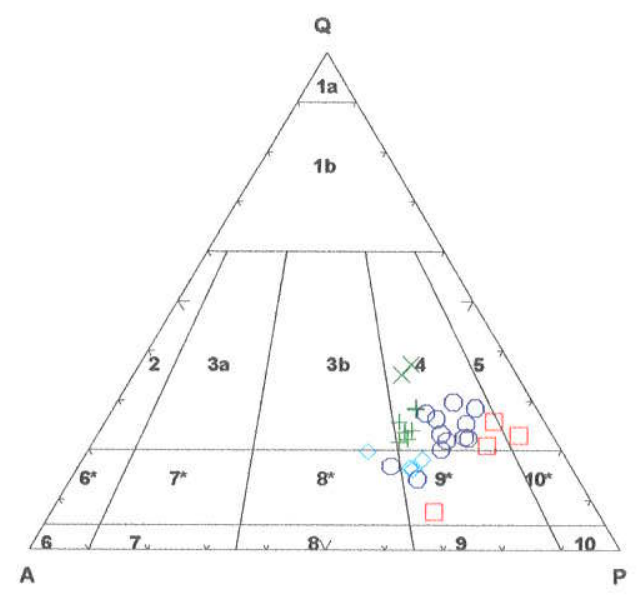

Figura 5.27 - Diagrama Q-A-P de Le Maitre (1989) para os charnoquitóides do maciço de Várzea Alegre. Símbolos: [ OPX-Quartzo-dioritos; O Jotunitos; + Opdalitos; $\diamond$ Quartzo-mangeritos; $\mathrm{x}$ Gnaisse enderbítico

\section{O quimismo das rochas do domínio interno}

Antes de iniciar as discussões quanto ao comportamento geoquímico dos charnoquitóides da intrusão de Várzea Alegre, será feita uma rápida explanação das principais características químicas das rochas do domínio interno do maciço, baseada em Medeiros (1993). Correspondem a rochas com teor de sílica muito variado, de 47 a $72 \% \mathrm{SiO}_{2}$, oscilando entre gabros e granitos. São enriquecidas em $\mathrm{Ba}$ e $\mathrm{Sr}$, ligeiramente enriquecidas em $\mathrm{Al}_{2} \mathrm{O}_{3}, \mathrm{TiO}_{2}$, 
$\mathrm{P}_{2} \mathrm{O}_{5}$ e $\mathrm{K}_{2} \mathrm{O}$ nos termos mais ácidos e levemente empobrecidas em $\mathrm{Rb}$, ao se comparar com rochas semelhantes de bancos de dados de rochas ígneas (Nockolds et al., op. cit.). Existe uma nítida lacuna composicional entre os termos ácidos e os básicos/intermediários.

Representam um plutonismo cálcio-alcalino de médio $\mathrm{K}$, ligeiramente enriquecido em $\mathrm{Fe}$, correlacionável ao tipo I Caledoniano de Pitcher (1982). São rochas metaluminosas, raramente com corindon normativo, e que exibem nos muitos diagramas apresentados pela autora uma nítida separação, com "trends" independentes, das composições mais básicas (gabros e dioritos) para as mais ácidas (granitos), ficando claro a não cogeneticidade entre elas.

\section{As variações no quimismo das rochas charnoquitóides}

Os charnoquitóides do maciço de Várzea Alegre representam uma seqüência pouco expandida, possuindo teores de $\mathrm{SiO}_{2}$ variando de 54 a $65 \%$, compatíveis com termos intermediários/intermediários-ácidos. Compreendem rochas ricas em $\mathrm{Ti}, \mathrm{P}, \mathrm{Zr}, \mathrm{Ba}$ e ETR, ligeiramente enriquecidas em $\mathrm{Fe}$ e $\mathrm{K}$, e pobres em $\mathrm{Mg}, \mathrm{Al}$ e $\mathrm{V}$, sendo variavelmente empobrecidas em $\mathrm{Ca}$, quando se compara com rochas de composição similar encontradas na literatura. O padrão de ETR é bem fracionado com suaves anomalias positivas de Eu. Possuem algumas características comparáveis a rochas da série mangerítica, como os baixos teores de $\mathrm{MgO}$, concentrações elevadas de elementos HFS e Fe\# relativamente altos (que mantém valores aproximadamente similares nos piroxênios, anfibólios e biotitas, como pode ser visto nas tabelas de análises de minerais no capítulo 6). Por outro lado, suas concentrações mais altas de Ca e $\mathrm{Sr}$ e mais baixas de $\mathrm{K}$ e $\mathrm{Rb}$ (além das razões $\mathrm{K} / \mathrm{Rb}$ e $\mathrm{Rb} / \mathrm{Sr}$ bem inferiores) não permitem que sẹ am geoquimicamente associadas às rochas de tal série. Deve-se ressaltar que os mangeritos típicos são gerados em ambientes anorogênicos comumente associados a anortositos e granitos rapakivi (Emslie, 1991; Philpotts, 1966).

Dentre as rochas dos complexos anortosito-mangerito-granitos rapakivi da Escandinávia e Finlândia encontram-se algumas associações litológicas com composição química que grosseiramente se assemelha aos charnoquitóides de Várzea Alegre. Dentre elas destacam-se os gnaisses charnoquíticos da região de Varberg, sudoeste da Suécia ( Hubbard \& Whittley, op. cit.) e o maciço mangerito-charnoquítico de Hopen, norte da Noruega (Ormaasen, 1977), ambos constituídos por rochas de composições predominantemente mais ácidas que aquelas de Várzea Alegre. No Brasil, pode-se comparar com os charnoquitos de Ubatuba (com 
litotipos consideravelmente mais ácidos), os chamoquitos e mangeritos São Pedro de Caldas (Janasi, op. cit.) e com os mangeritos de São José do Rio Pardo (Campos Neto et al., op. cit.). Na maioria destes casos, os litotipos constituintes são mais ricos em $\mathrm{Fe}, \mathrm{Na}$ e alguns elementos LIL (notadamente $\mathrm{K}, \mathrm{Rb}$ e ETRP), e mais pobres em $\mathrm{Ca}, \mathrm{Sr}, \mathrm{Ba}$ e elementos HFS (Ti, $\mathrm{P}$ e $\mathrm{Zr}$ ) comparativamente com as rochas da borda do maciço de Várzea Alegre.

As rochas mangeríticas do norte da Noruega exibem, segundo Ormaasen (op. cit.), texturas e estruturas bem preservadas (chegam a exibir acamamento magmático), são pouco deformadas e/ou afetadas por metamorfismo, sendo localmente descharnoquitizadas (feição geralmente associada aos tipos foliados); a mineralogia metamórfica é biotita, anfibólio, granada, microclina, epidoto e titanita. Variam entre termos com $59 \%$ a $72 \% \mathrm{SiO}_{2}$, e o autor divide os litotipos entre os de alto Fe\# $(>0,8)$ e os de baixo Fe\# $(<0,8)$. São nitidamente mais ricos em $\mathrm{K}, \mathrm{Na}$ e $\mathrm{Al}$ e mais pobres em $\mathrm{Ti}, \mathrm{Mg}, \mathrm{Ca}, \mathrm{P}, \mathrm{Sr}$ e ETR e as razões $\mathrm{K} / \mathrm{Rb}$ e $\mathrm{Rb} / \mathrm{Sr}$ são bem superiores quando comparadas aos charnoquitóides de Várzea Alegre. Os padrões de ETR são bem menos fracionados que os de Várzea Alegre, com anomalias de Eu variáveis, mas positivas nas rochas de composição intermediária.

Os mangeritos do maciço São Pedro de Caldas, MG representam rochas variavelmente deformadas, bastante modificadas por metamorfismo (localmente descharnoquitizadas) e com texturas primárias bem obliteradas (Janasi, op. cit.). São conspicuamente mais ricos em $\mathrm{K}$ e $\mathrm{Na}$, ligeiramente enriquecidos em $\mathrm{Rb}, \mathrm{Zr}$ e ETR (sobretudo os pesados) e mais pobres em $\mathrm{Ca}, \mathrm{Sr}, \mathrm{Ti}, \mathrm{Mg}, \mathrm{P}$ e $\mathrm{Ba}$ (destacadamente os dois primeiros elementos) com relação aos charnoquitóides do maciço de Várzea Alegre. Os padrões de terras raras são semelhantes aos encontrados em Várzea Alegre, com anomalias de Eu correlacionáveis, mas de maneira geral são menos fracionados. Os $\mathrm{Mg \#} \mathrm{das} \mathrm{rochas} \mathrm{do} \mathrm{maciço} \mathrm{de}$ São Pedro de Caldas são bem inferiores aos de Várzea Alegre (o mesmo ocorre para os minerais máficos).

Quando se compara com as análises químicas, em rochas com a mesma variação de $\mathrm{SiO}_{2}$, das Séries $\mathrm{Ca}$-alcalina e Ca-alcalina de alto $\mathrm{K} /$ alcalina definidas por Wiedemann (1993) para o Estado do Espírito Santo, observa-se que os charnoquitóides de Várzea Alegre possuem concentrações que se aproximam nas duas séries, i.e., alguns óxidos/elementos estão mais próximos dos teores das rochas cálcio-alcalinas enquanto outros da série alcalina. Destacam-se os valores bem superiores de $\mathrm{Fe}_{2} \mathrm{O}_{3}, \mathrm{CaO}, \mathrm{P}_{2} \mathrm{O}_{5}$ e $\mathrm{Sr}$ nas duas séries, os altos teores de $\mathrm{Zr}$ e $\mathrm{Ba}$ em Várzea Alegre e as concentrações de $\mathrm{K}_{2} \mathrm{O}$, que são ligeiramente superiores 
nas rochas aqui estudadas. Ao se comparar com os dados utilizados por Figueiredo e Campos Neto (1993) para maciços pré, sin e pós-colisionais da região limítrofe RJ/ES, observa-se que só ocorre alguma semelhança com alguns corpos pós-tectônicos, notadamente o de Rio Novo do Sul.

Poucas são as rochas do domínio interno da intrusão de Várzea Alegre que se situam no mesmo intervalo composicional dos charnoquitóides, como pode ser observado em Medeiros (op. cit.). Dentre essas, observa-se que ocorrem consideráveis semelhanças com os granitos a titanita, que modalmente classificam-se como quartzo-monzonitos e quartzo-sienitos. Eles são descritos como rochas de granulação fina, levemente foliadas, com enclaves microgranulares básicos e que aparecem num pequeno corpo no centro da intrusão, em matacões e cortando, sob a forma de diques, os demais litotipos do domínio interno. São apontados como representantes de evento magmático tardio na evolução do maciço. As diferenças mais significativas detectadas estão nos maiores teores de $\mathrm{K}_{2} \mathrm{O}, \mathrm{Rb}$ e La (o único ETR dosado) dos "granitos", evidenciando uma maior concentração de elementos mais incompatíveis que pode estar associada a sua origem ou a contaminação crustal.

\section{O comportamento das rochas nos diagramas de variação}

Assim como nas rochas da intrusão de Venda Nova, o melhor indicador de diferenciação para os charnoquitóides de Várzea Alegre é o $\mathrm{SiO}_{2}$, resultando em boas correlações. Nas figuras 5.28 e 5.29 acham-se os diversos diagramas de variação que serão utilizados neste item. A boa correlação observada na maior parte deles sugere tratar-se de uma seqüência magmática cogenética, que deve ter evoluído nos limites do restrito intervalo composicional obtido.

Dentre os diagramas de Harker da figura 5.28, somente aquele do $\mathrm{Al}_{2} \mathrm{O}_{3}$ resultou em "nuvem", isto devido a acentuada dispersão dos dados, que não guardam uma relação direta com a sílica. $\mathrm{O}$ gráfico do $\mathrm{Na}_{2} \mathrm{O}$ também apresenta uma maior dispersão, mas neste caso pode-se observar que ocorre, na média, um gradual aumento dos teores em direção aos termos mais ácidos. Para os outros óxidos tem-se "trends" razoavelmente bem definidos, com discreto espalhamento, e coerentes com o indice de diferenciação utilizado. O mesmo ocorre para a maior parte dos gráficos de $\mathrm{SiO}_{2} \times$ elementos traços, onde apenas o gráfico do $\mathrm{Ba}$ exibe acentuada dispersão (cf. Fig. 5.29). 
Numa análise prévia dos diagramas de variação apresentados observa-se que algumas amostras deslocam-se consideravelmente das tendências obtidas. As amostras MP-718 e MP- 173 possuem teores mais elevados de $\mathrm{Al}_{2} \mathrm{O}_{3}, \mathrm{CaO}$ e $\mathrm{Sr}$ e estão nitidamente deslocadas em vários dos gráficos. Tais características sugerem que estas amostras possam corresponder a cumulatos, sendo o plagioclásio a principal fase cumulática. As amostras VA-250, VA-263, MP- 161 e MP- 128 possuem concentrações mais altas de $\mathrm{Al}_{2} \mathrm{O}_{3}$ e $\mathrm{K}_{2} \mathrm{O}$ e destacam-se nesses gráficos e no do $\mathrm{SiO}_{2} \times \mathrm{Ba}$, sugerindo que elas podem estar relacionadas a processos de acumulação de feldspato potássico. Em função do tamanho dos megacristais destas rochas é dificil identificar ao microscópio tais feições de acumulação.

A amostra VA-42, a mais diferenciada da seqüência, está na maior parte dos gráficos fora do "trend" principal. No entanto, sua composição coerente com as outras rochas e seu idêntico aspecto textural não deixam dúvidas que se trata de amostra cogenética.

Considerando-se os "trends" predominantemente lineares obtidos nos diversos diagramas suspeita-se que mecanismos de diferenciação por cristalização fracionada e/ou mistura de magmas tenham sido os responsáveis pela evolução da sequência. Em se tratando de cristalização fracionada, os gráficos sugerem, à primeira vista, que a diferenciação magmática da sequência se deu principalmente pela extração de plagioclásio, ortopiroxênio, apatita e ilmenita ( \pm magnetita). No entanto, levando-se em conta a dispersão das amostras (em maior ou menor grau) verificada em alguns gráficos e o efeito de soma constante ao se utilizar a sílica como índice de diferenciação, fica claro ser necessário lançar mão de outros diagramas para uma melhor caracterização dos processos atuantes. Mais adiante, no capitulo 7 , tal aspecto será discutido novamente, a partir de gráficos de elementos compatíveis versus elementos incompatíveis e com o apoio de modelamentos geoquímicos. 

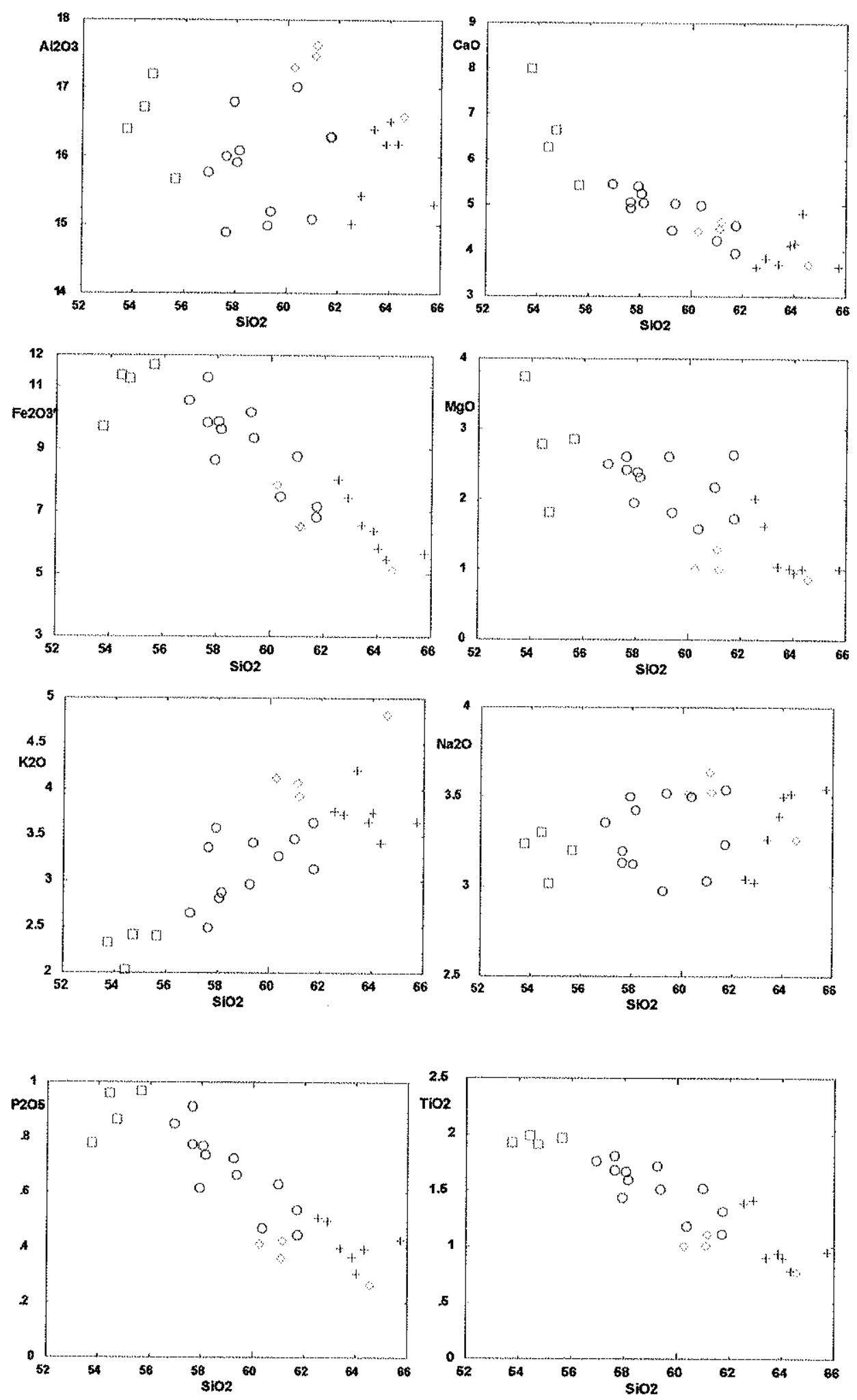

Figura 5.28 - Diagramas de Harker para os charnoquitóides do maciço de Várzea Alegre. Símbolos: OPX-Quartzo-dioritos; O Jotunitos; + Opdalitos; $\diamond$ Quartzo-mangeritos 

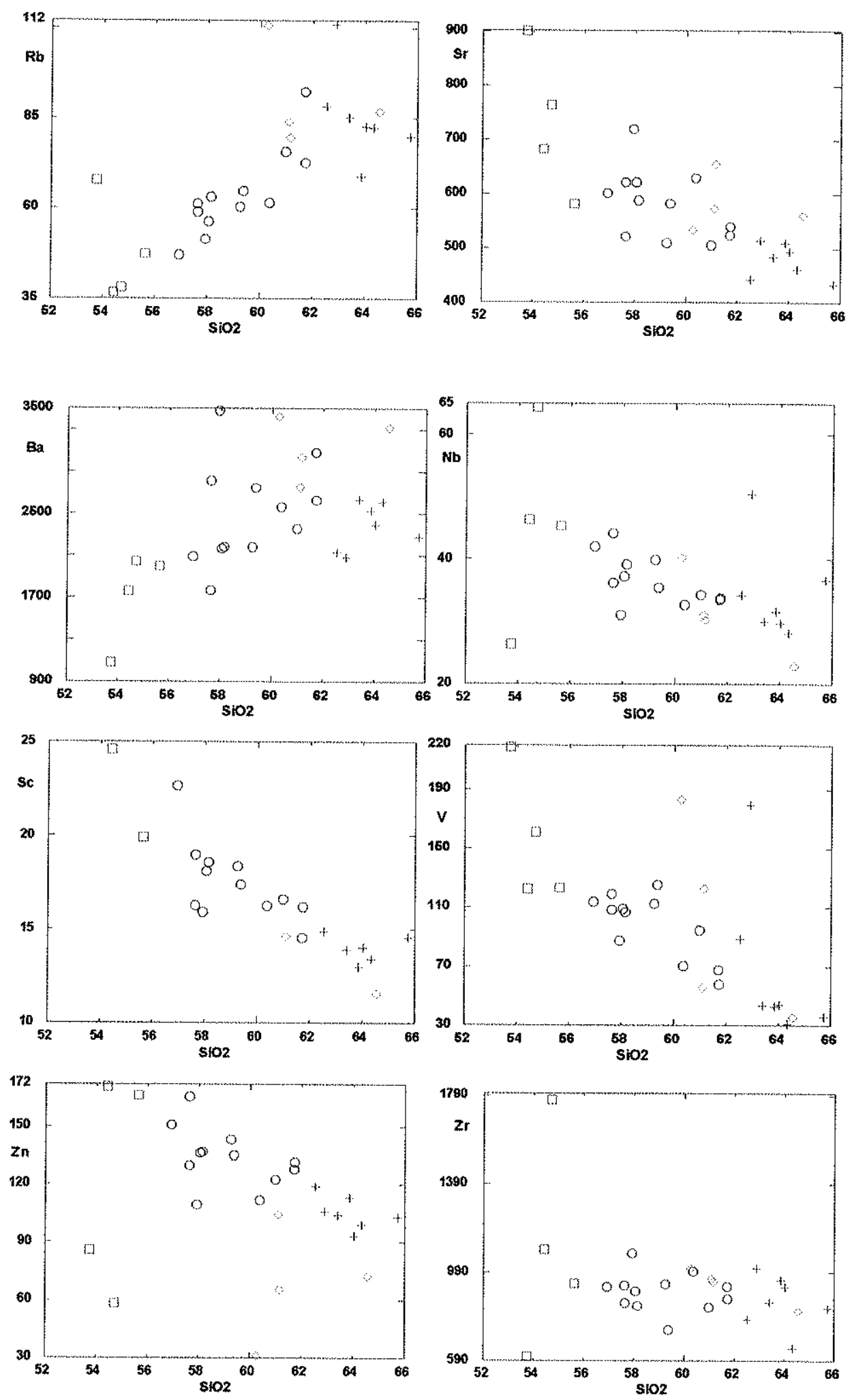

Figura 5.29 - Diagramas $\mathrm{SiO}_{2} \times$ elementos traços para os charnoquitóides do maciço de Várzea Alegre. Símbolos: [] OPX-Quartzo-dioritos; O Jotunitos; + Opdalitos; $\diamond$ Quartzo-mangeritos 


\section{A caracterização do magmatismo}

Com o auxílio de alguns diagramas e de parâmetros geoquímicos diversos é possível avaliar a mais provável assinatura geoquímica das rochas da borda do maciço de Várzea Alegre.

No gráfico $\mathrm{SiO}_{2} \times \mathrm{Na}_{2} \mathrm{O}+\mathrm{K}_{2} \mathrm{O}$ de Irvine \& Baragar (1971) as amostras dos charnoquitóides do maciço de Várzea Alegre posicionam-se no campo sub-alcalino próximo da linha divisória com o campo alcalino, como pode ser visto na figura 5.30.

No diagrama AFM da figura 5.31 os litotipos de Várzea Alegre apresentam um comportamento que se assemelha ao de suítes Ca-alcalinas, mas com tendência ao enriquecimento em Fe. Janasi (op. cit.) obteve para as rochas do maciço São Pedro de Caldas um "trend" paralelo e próximo do lado AF do triângulo, em função do enriquecimento em álcalis, feição esta associada a rochas alcalinas por Petro et al., 1979 (apud Janasi, op. cit.).

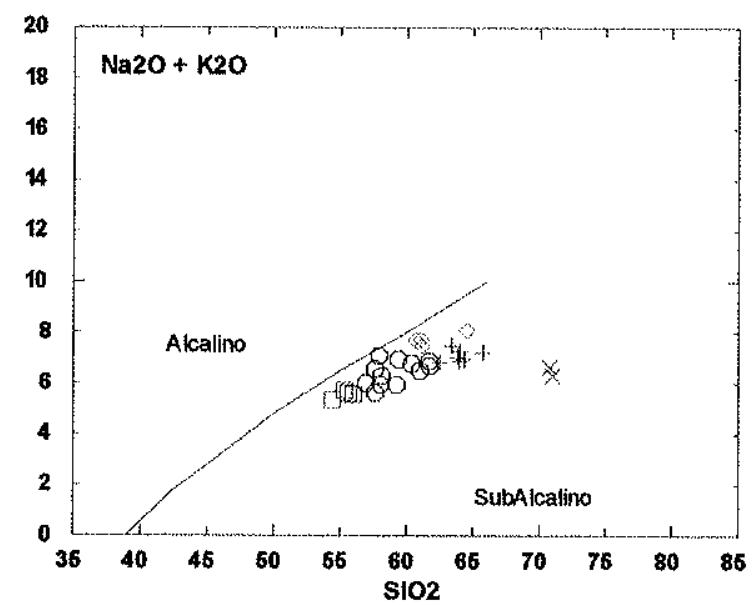

Figura 5.30 - Diagrama $\mathrm{SiO} 2 \times \mathrm{Na} 2 \mathrm{O}+\mathrm{K} 2 \mathrm{O}$ para os charnoquitóides do maciço de Várzea Alegre. Símbolos: 0 OPX-Quartzo-dioritos; O Jotunitos; + Opdalitos; $\diamond$ Quartzo-mangeritos; $x$ Gnaisse enderbítico

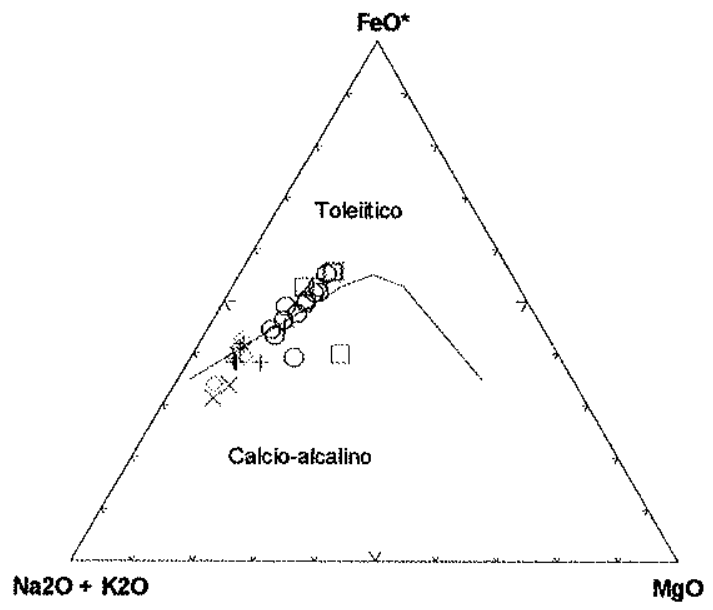

Figura 5.31 - Diagrama AFM para os charnoquitóides do maciço de Várzea Alegre.

Símbolos: $L$ OPX-Quartzo-dioritos; $O$ Jotunitos; + Opdalitos; $\diamond$ Quartzo-mangeritos; $x$ Gnaisse enderbítico 
No diagrama de Peacock (1931), na figura 5.32, os charnoquitóides de Várzea Alegre exibem um índice álcali-cálcico de aproximadamente $56 \%$, que é o valor limite entre suítes álcali-cálcicas e Ca-alcalinas.

Brown et al. (1982) compilou dados de várias suítes geoquimicamente bem estudadas e de posicionamento tectônico conhecido, de diferentes regiões da Terra, para delimitar os "trends" que as mesmas definem no diagrama $\mathrm{SiO}_{2} \times \log \left(\mathrm{CaO} / \mathrm{Na}_{2} \mathrm{O}+\mathrm{K}_{2} \mathrm{O}\right) . \mathrm{Na}$ figura 5.33 as amostras de Várzea Alegre estão posicionadas neste gráfico, onde os "trends" de três complexos ígneos estão traçados: NYG são granitos jovens da Nigéria, HEB são granitos terciários da Grã-Bretanha e FSR são granitos rapakivi da Escandinávia e Finlândia, de idade proterozóica. Todos eles são álcali-cálcicos e gerados em ambiente extensional. Os charnoquitóides de Várzea Alegre estão localizados de forma tal que tende a acompanhar os "trends" apresentados, sobretudo FSR e NYG.

Portanto, pode-se afirmar que os charnoquitóides do maciço de Várzea Alegre possuem uma assinatura álcali-cálcica com enriquecimento em álcalis e ferro.

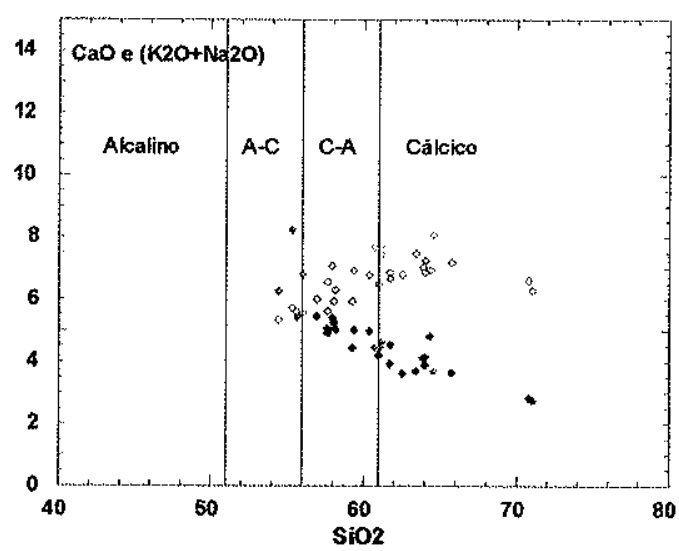

Figura 5.32- Diagrama $\mathrm{SiO}_{2} \times \mathrm{CaO}$ e $\mathrm{Na}_{2} \mathrm{O}+\mathrm{K}_{2} \mathrm{O}$ para os charnoquitóides do maciço de Várzea Alegre.

Analisando-se os dados da norma CIPW dos charnoquitóides, que estão na tabela 5.7, verifica tratar-se de uma seqüência super saturada em sílica, com quartzo e hiperstênio normativos. Tais características juntamente com a presença de anortita normativa sugerem uma afinidade Ca-alcalina para as rochas mas, o comportamento aleatório do hiperstênio e do diopsídio com respeito a diferenciação não corrobora com tal conclusão. $O$ cálculo da norma extrapola significativamente as concentrações de minerais opacos, principalmente de ilmenita. 


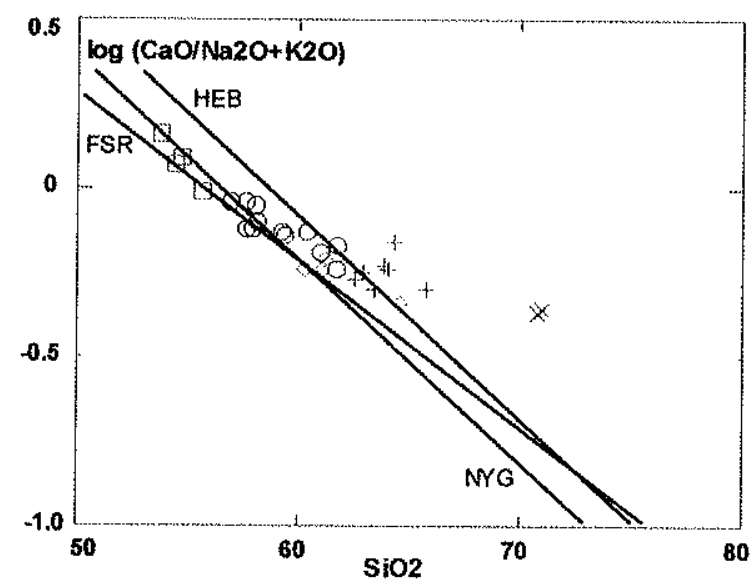

Figura 5.33 - Diagrama $\mathrm{SiO}_{2} \times \log \left(\mathrm{CaO} / \mathrm{Na}_{2} \mathrm{O}+\mathrm{K}_{2} \mathrm{O}\right)$ para os charnoquitóides do maciço de Várzea Alegre. Símbolos: OPX-Quartzo-dioritos; O Jotunitos; + Opdalitos; $\diamond$ Quartzo-mangeritos; $x$ Gnaisse enderbítico

A presença de pequena quantidade de corindon normativo em poucas amostras e as baixas concentrações de diopsídio espelham o caráter metaluminoso das rochas. No diagrama A/CNK x A/NK de Maniar \& Picolli (1989) da figura 5.34 todas as amostras plotam no campo metaluminoso, com exceção do gnaisse enderbítico, algumas delas junto da linha divisória com o campo peraluminoso. As razões A/CNK são próximas de 1, como pode-se ver na tabela 5.5 .

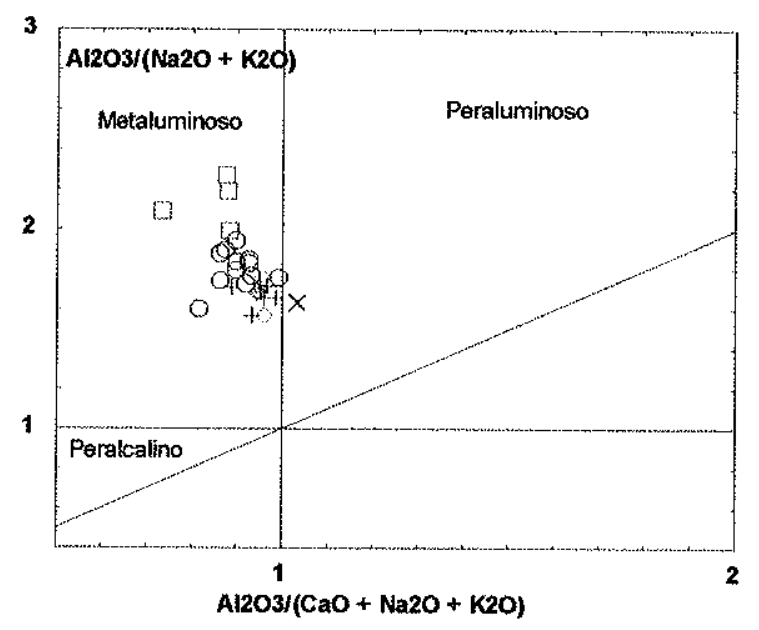

Figura 5.34 - Diagrama A/CNK x A/NK para os charnoquitóides do maciço de Várzea Alegre.

Símbolos: OPX-Quartzo-dioritos; $O$ Jotunitos; + Opdalitos; $\diamond$ Quartzo-mangeritos; $x$ Gnaisse enderbítico

\section{Os elementos terras raras e o padrão de distribuição dos elementos incompativeis}

Os charnoquitóides da intrusão de Várzea Alegre possuem teores altos de elementos terras raras, sobretudo de elementos leves. As concentrações variam bastante, com os valores de La oscilando entre cerca de 150 a 300 vezes o condrito, como pode ser visto na figura 
5.35. Pode-se observar na tabela 5.6 que os valores totais variam muito, e as duas amostras mais ácidas são as que exibem os menores teores em toda a seqüência. Como foi apontado para o maciço de Venda Nova, tais irregularidades na distribuição de ETR têm sido associadas a processos de equilíbrio cristal-líquido na fonte. A amostra VA-256 corresponde ao gnaisse enderbítico, que foi analisado com o intuito de ser comparada com as outras.

Os padrões de terras raras mostram-se, no geral, moderadamente fracionados, mas as razões $(\mathrm{Ce} / \mathrm{Yb})_{\mathrm{N}}$ oscilam bastante, entre 11,53 e 47,90. No entanto, somente em 2 amostras, VA-244 e HR-29, ocorre uma disparidade, com valores superiores a 41 . O padrão é homogêneo na maioria das amostras analisadas, não existindo grandes diferenças de fracionamento nos diferentes segmentos (por exemplo, as razões $\mathrm{Dy} / \mathrm{Yb}$ variam muito pouco). Eles são comparáveis aos padrões obtidos por Figueiredo \& Campos Neto (1993) para os diques pós-tectônicos da pedreira Itaipavas, norte do RJ; no entanto, estes últimos praticamente não exibem anomalias de Eu. Trata-se também de padrões similares aos dos magmatitos presentes em segmentos anômalos das cadeias mesoceânicas e basanitos, provavelmente oriundos de um manto enriquecido (Frey, 1984).

Não se observam variações significativas na razão $\left(\mathrm{Eu} / \mathrm{Eu}^{*}\right) \mathrm{N}$, predominando pequenas anomalias positivas, que estão mais realçadas em função das anomalias ligeiramente negativas de $\mathrm{Sm}$. Os teores de Eu e as razões $\mathrm{Sm} / \mathrm{Eu}$ não exibem uma relação direta com os teores de $\mathrm{SiO}_{2}$, como seria de se esperar em uma seqüência na qual o fracionamento de plagioclásio pode ter exercido um importante papel. É interessante notar que o padrão do gnaisse enderbítico tende a acompanhar o dos charnoquitóides, mas seus teores bem inferiores de terras raras leves e sua significativa anomalia negativa de Eu indica que se trata de material com origem distinta.

A figura 5.36 permite uma comparação dos padrões dos termos extremos da seqüência, i.e., dos mais e dos menos ácidos (VA-42 e VA-164; VA-261 e MP-173) e de amostras com composições situadas entre eles (VA-90 e MP-128). Observa-se uma coerência dos tipos de padrão, que só mostram diferenças nas anomalias de Eu e Sm, não apresentadas pelas rochas menos ácidas, e pelo leve enriquecimento em ETRP da amostra VA-90. Fica também destacado que não deve ter ocorrido significativo fracionamento de elementos terras raras nos diversos intervalos composicionais, e, se houve, as evidências podem ter sido mascaradas por processos de mistura de magmas ou contaminação crustal. 
É importante ressaltar que os padrões de ETR para os charnoquitóides são muito semelhantes aos dos gabros e dioritos do domínio interno da intrusão de Várzea Alegre, apresentado por Wiedemann et al. (1994). Por outro lado, os autores comentam que "a ausência de uma evolução para anomalias negativas de Eu traz dúvidas quanto à consanguinidade desses magmas; os padrões de ETR pouco expandidos e com pequenas anomalias positivas de Eu podem tanto ser indicativos de uma fusão parcial de crosta inferior, quanto da cristalização a partir do mesmo magma que gerou a série gabro-diorítica, sob condições redutoras".

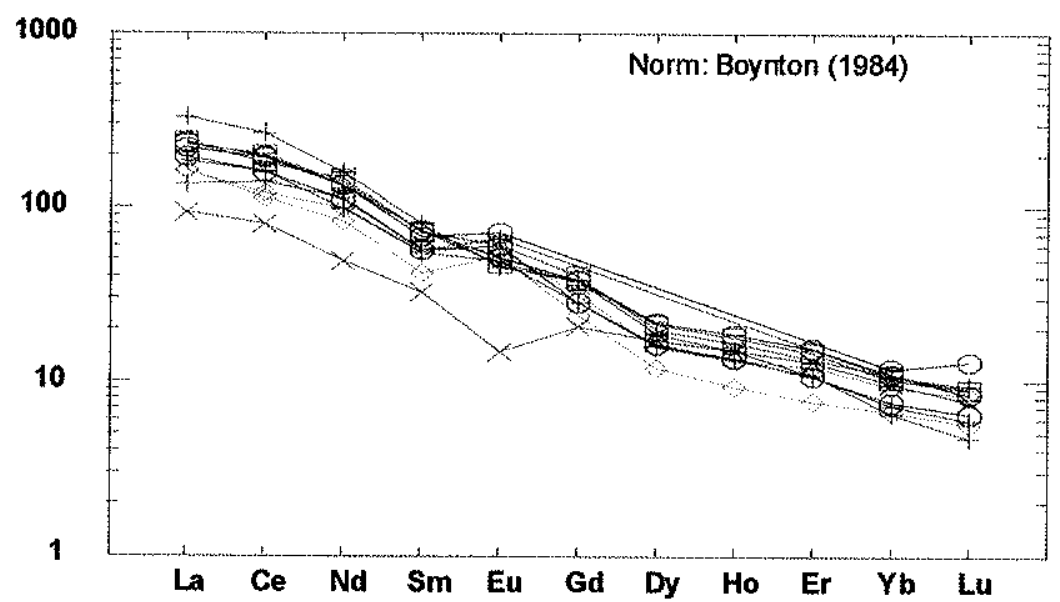

Figura 5.35 - Padrões de elementos terras raras para os charnoquitóides do maciço de Várzea Alegre. Símbolos: $[$ OPX-Quartzo-dioritos; O Jotunitos; + Opdalitos; $\diamond$ Quartzo-mangeritos; $x$ Gnaisse enderbítico

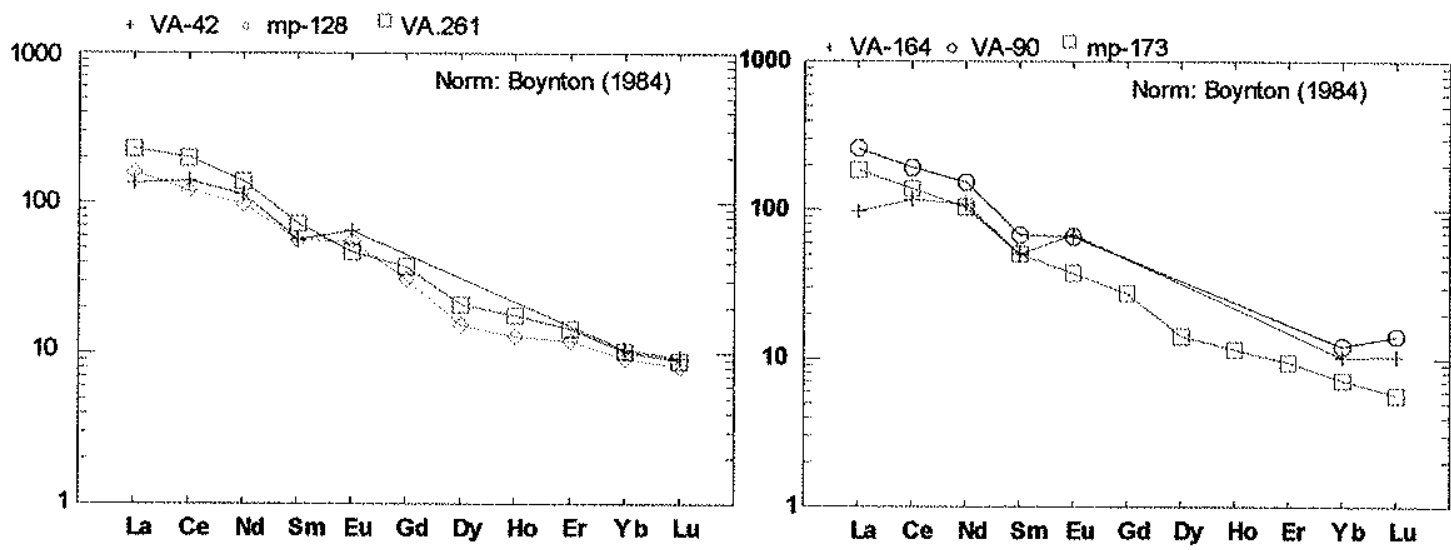

Figura 5.36 - Padrões de elementos terras raras para amostras com composições extremas e intermediárias do maciço de Várzea Alegre.

O padrão de distribuição de elementos incompatíveis para estas rochas encontrase na figura 5.37, onde se tem duas diferentes normalizações para NMORB. Pode-se constatar uma grande homogeneidade no mesmo, com uma sensível diminuição relativa dos elementos 
menos incompatíveis, mais realçado pela normalização de Sun \& McDonough (1989), relacionado a um considerável enriquecimento dos mais incompatíveis, sobretudo $\mathrm{Ba}$, seguido por $\mathrm{Rb}$ e K.

De modo geral, a normalização de Pearce (1983) acentua mais as anomalias para as rochas estudadas. Estão destacadas as anomalias positivas de $\mathrm{Ba}$ e $\mathrm{Zr}$ e as anomalias negativas de Ti, P, Nb e \pm Sm e Sr. Novamente o padrão apresentado pelo ortognaisse enderbítico é semelhante, mas com teores bastante inferiores e sem as anomalias positivas de $\mathrm{Ba}$ e $\mathrm{Zr}$.

Figueiredo \& Campos Neto (1993) obtiveram padrões similares para as intrusões pós-tectônicas álcali-cálcicas do sul do Estado do Espírito Santo, com a diferença de que elas não possuem comparáveis anomalias de $\mathrm{Ba}$ e que os seus teores de Rb e K são bem superiores aos de Várzea Alegre. Janasi (op. cit.) utilizou a normalização por condrito para aos mangeritos do maciço de São Pedro de Caldas, obtendo anomalias negativas mais acentuadas de P, Ti e Sr e positiva de Zr. Comparando-se com o padrão apresentado por Wiedemann et al. (1994) para os dioritos e gabros do domínio interno do complexo intrusivo de Várzea Alegre, observa-se considerável diferença no comportamento da maioria dos elementos: merece destaque as anomalias negativas de $\mathrm{Zr}$ e $\mathrm{Hf}$, o não desenvolvimento de anomalias de $\mathrm{Ti}$, $\mathrm{Sm}$ e $\mathrm{Sr}$ e os menores teores de $\mathrm{Ba}$.

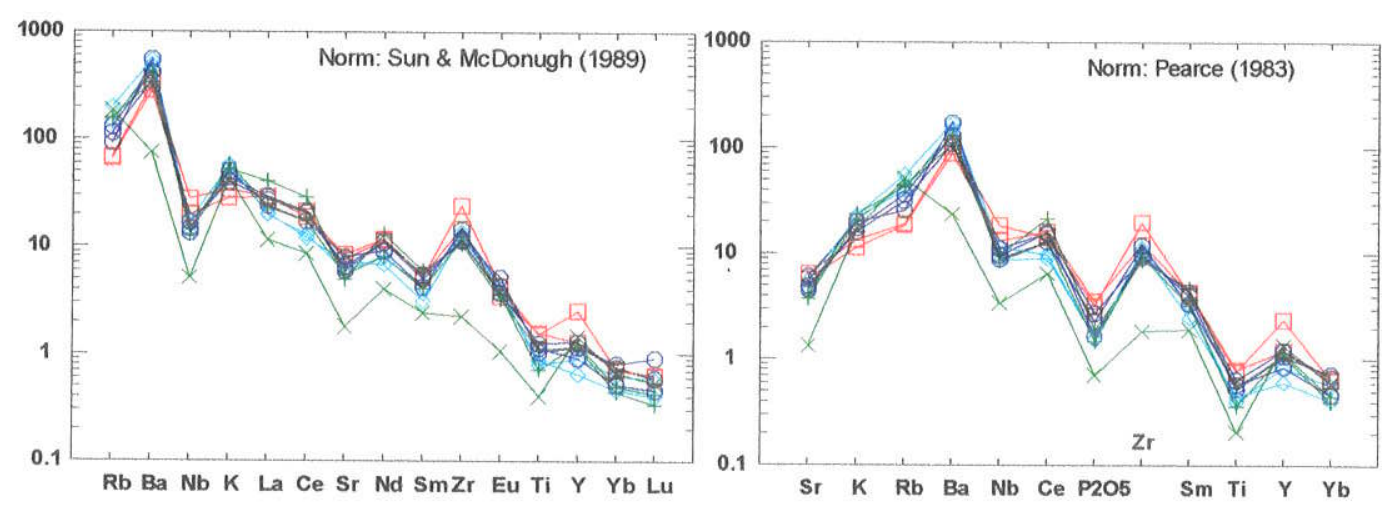

Figura 5.37 - Padrão de distribuição de elementos incompatíveis para os charnoquitóides do maciço de Várzea Alegre.

Símbolos: $\square$ OPX-Quartzo-dioritos; O Jotunitos; + Opdalitos; $\diamond$ Quartzo-mangeritos; x Gnaisse enderbítico

\section{Inferências quanto ao ambiente tectônico}

As rochas charnoquitóides do maciço de Várzea Alegre não estão muito deformadas, exibindo uma foliação mais pronunciada próximo dos contatos. Esta orientação não 
é penetrativa, não caracterizando uma estrutura gnáissica. Algumas feições localizadas indicam que elas sofreram esforços que geraram uma maior orientação e deformação dos megacristais, que por sua vez pressionaram os cristais da matriz provocando sua recristalização, em alguns pontos bem intensa.

Distanciando-se das regiões de contato pode-se encontrar amostras bem isotrópicas, não deformadas. Há que se considerar também que rochas de granulação muito grossa respondem de forma diferente aos esforços, sej am estes relacionados ao "emplacement" do corpo ou a compressão regional. No entanto, se os charnoquitóides foram submetidos a tais esforços compressivos os mesmos devem estar relacionados a um estágio orogênico final, transpressivo, pouco antes de ter inicio o relaxamento crustal.

No diagrama R1 x R2 de Batchelor \& Bowden (op. cit.) os charnoquitóides de Várzea Alegre posicionam-se preferencialmente no campo 3, típico de granitóides cálcioalcalinos de alto $\mathrm{K}$ pós-tectônicos, como pode ser visto na figura 5.38 .

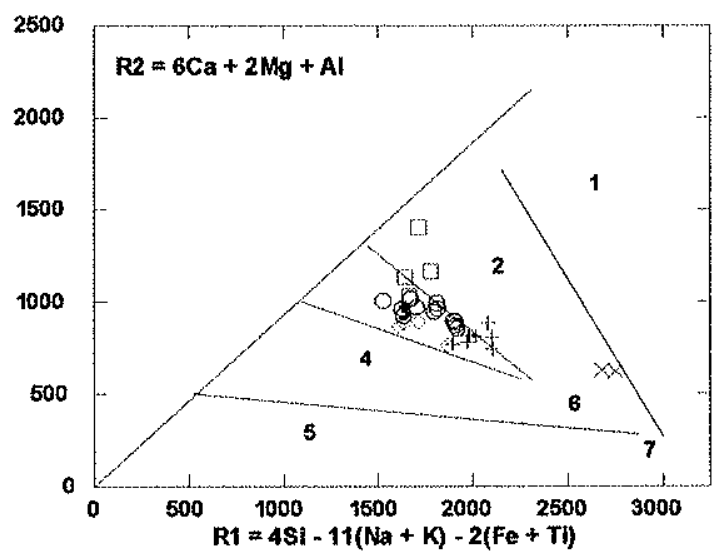

Figura 5.38 - Diagrama R 1 x R2 para os charnoquitóides do maciço de Várzea Alegre.

Símbolos: [] OPX-Quartzo-dioritos; O Jotunitos; + Opdalitos; $\gg$ Quartzo-mangeritos; x Gnaisse enderbítico

Ao se plotar as amostras de Várzea Alegre nos diagramas $\mathrm{Y}+\mathrm{Nb} \times \mathrm{Rb}$ e $\mathrm{Y} \times \mathrm{Nb}$ de Pearce et al. (1984) para discriminação de ambiente tectônico, vemos que elas se situam preferencialmente no campo dos granitos intra-placa (WPG) e poucas amostras nos limites dos granitos de arco vulcânico (VAG), que seria o posicionamento mais esperado para estas rochas. Este resultado, ilustrado nas figuras 5.39 e 5.40, contrasta com uma origem certamente associada ao arco magmático estabelecido na região durante o final do ciclo Brasiliano. O que está claro nos gráficos é que os teores de $\mathrm{Y}$ e/ou $\mathrm{Nb}$ são superiores àqueles esperados para granitóides de arco vulcânico. Isto pode se dar por motivos tais como o enriquecimento prévio da rocha fonte 
no(s) elemento(s) ou por problemas analíticos quando da dosagem dos elementos. Tem sido freqüente a associação de teores mais elevados em determinados elementos HFS (Nb, Hf, Zr) a anomalias geradas por metassomatismo do manto (Pearce, 1983; McCulloch \& Gamble, 1991). Há que se considerar que as rochas de Várzea Alegre não são enriquecidas em Ti e P.

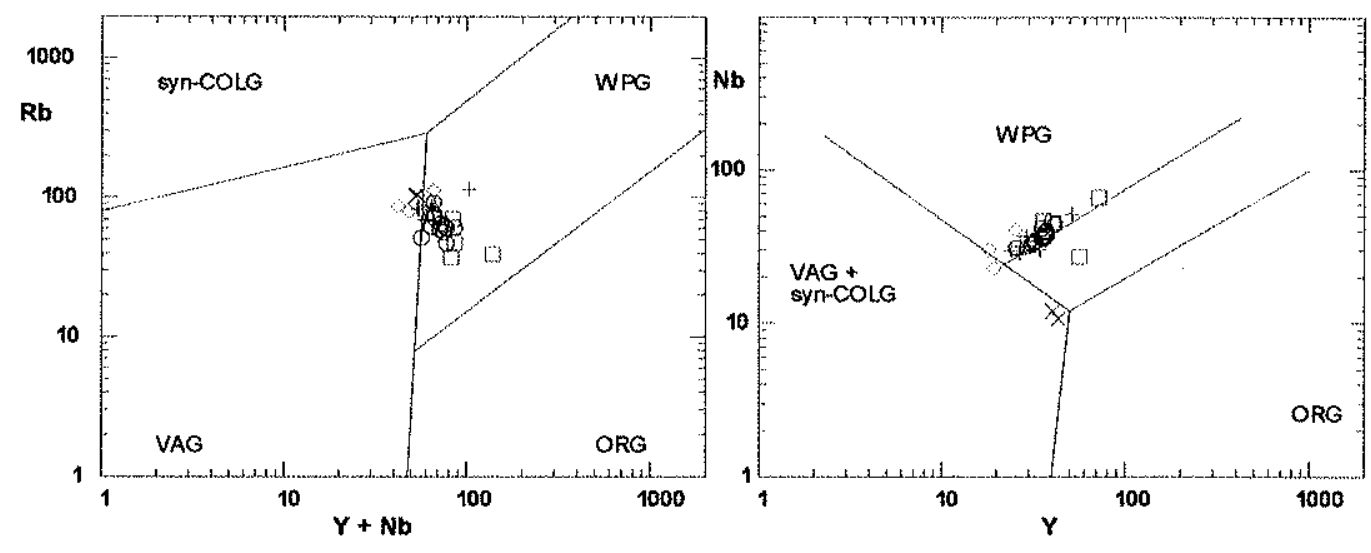

Figuras 5.39 e 5.40 - Diagramas $\mathrm{Y}+\mathrm{Nb} \times \mathrm{Rb}$ e $\mathrm{Y} \times \mathrm{Nb}$ para os charnoquitóides do maciço de Várzea Alegre. Símbolos: $]$ OPX-Quartzo-dioritos; O Jotunitos; + Opdalitos; $\diamond$ Quartzo-mangeritos; $x$ Gnaisse enderbítico

As anomalias negativas de $\mathrm{Ti}, \mathrm{P}$ e $\mathrm{Nb}$, relativas a $\mathrm{NMORB}$, observadas nos "spidergrams" da figura 5.37 corroboram com a hipótese de uma origem associada a um ambiente de arco magmático, pois tais anomalias têm sido apontadas na literatura como uma característica geoquímica de zona de subducção (Pearce, op. cit.; Pearce et al., op. cit.). Janasi (op. cit.) discute o fato de que tais anomalias em rochas de natureza alcalina não obrigatoriamente indicam uma geração contemporânea a subduç̧ão, podendo ser o reflexo de eventos de subducção prévios.

Utilizando-se os parâmetros apresentados por Petro et al. (1979) para distinção de suítes magmáticas compressionais e extensionais tem-se o seguinte quadro para os charnoquitóides de Várzea Alegre: freqüência de distribuição do índice de diferenciação bimodal e índice álcali-cálcico igual a 56 são características de ambiente extensional; freqüência de distribuição de plagioclásio normativo unimodal e uma distribuição das amostras no diagrama AFM comparável com suítes compressionais, são características de geração em ambiente compressional. O caráter metaluminoso das rochas de Várzea Alegre é associado pelos autores a ambas as suítes. Tal resultado reforça a teoria da formação destas rochas num ambiente de transição, no qual a crosta ainda estava submetida a algum esforço de compressão, talvez contemporaneamente a um início de relaxamento em áreas adjacentes. 


\section{CAPÍtULO 6 QUÍMICA MINERAL}

Foram realizadas análises por microssonda eletrônica em quinze lâminas polidas, sendo oito delas do maciço de Venda Nova (três de noritos e cinco de charnoquitóides) e sete do Maciço de Várzea Alegre. As fases analisadas foram: OPX, CPX, plagioclásio, feldspato alcalino, bitotita, anfibólio, ilmenita e magnetita. As fórmulas estruturais foram obtidas por meio do software MINPET (Richard, 1995).

\subsection{MACICO DE VENDA NOVA}

\section{Piroxênios}

Foram analisados pares de orto e clinopiroxênios coexistentes tanto nos noritos como nos charnoquitóides. As análises de ortopiroxênios estão na tabela 6.1 e as de clinopiroxênios encontram-se na tabela 6.2. Como pode ser observado, as concentrações dos vários elementos são bastante homogêneas nos pontos de cada amostra analisada, confirmando a não existência de zoneamentos significativos, comojá atestado ao microscópio ótico.

Os OPX dos noritos correspondem grosseiramente a soluções sólidas de $\mathrm{FeO}$ $(24,2 \%$ a $29,06 \%)-\mathrm{MgO}(17,63 \%$ a $21,11 \%)-\mathrm{Al}_{2} \mathrm{O}_{3}(0,86 \%$ a $1,11 \%)-\mathrm{SiO}_{2}(50,06 \%$ a $51,88 \%$ ), com conteúdos de $\mathrm{CaO}$ variando de $0,4 \%$ a $1,15 \%$ e de $\mathrm{MnO}$ de $0,53 \%$ a $0,79 \%$, complementando com infimas quantidades de $\mathrm{TiO}_{2}, \mathrm{Cr}_{2} \mathrm{O}_{3}, \mathrm{NiO}, \mathrm{Na}_{2} \mathrm{O}$ e $\mathrm{K}_{2} \mathrm{O} . \mathrm{O} \mathrm{Fe}_{2} \mathrm{O}_{3}$ calculado estequiométricamente é no geral bem baixo, menos do que $5 \%$ de $\mathrm{FeO}$, mas chega até próximo a $15 \%$ em um ponto analisado. Em suma, a composição deles varia de Wo0,81 a Wo2,37, En50,57 a En59,58 e Fs39, 16 a Fs47,63.

Os Mg\# variam pouco, mostrando valores moderados que coincidem com aqueles da rocha total para a amostra VN-14, mas são ligeiramente superiores nas amostras VN-3 e VN11. As variações dos teores de $\mathrm{CaO}$ e $\mathrm{MnO}$ dos $\mathrm{OPX}$ não refletem as oscilações destes óxidos nas análises de rocha total destas amostras.

A variação composicional dos ortopiroxênios dos charnoquitóides é similar a dos noritos, com maiores concentrações de $\mathrm{MgO}$, com o Mg\# alcançando até 0,66 (Wo 1,17 a Wo3,28, En58,94 a En64,62 e Fs33,34 a Fs39,62), com exceção da amostra VN-27 que é bem mais rica em Fe (Wo 1,63En4 1,38Fs56,99). Correspondem a soluções sólidas de $\mathrm{FeO}(20,94 \%$ a 
$24,81 \%)$ - $\mathrm{MgO}(20,72 \%$ a $23,44 \%)-\mathrm{Al}_{2} \mathrm{O}_{3}(0,83 \%$ a $1,01 \%)$ - $\mathrm{CaO}(0,58 \%$ a $1,5 \%)-\mathrm{MnO}$ $(0,61 \%$ a $1,1 \%)-\mathrm{SiO}_{2}$. A amostra $\mathrm{VN}-27$ possui maiores teores de $\mathrm{FeO}$ (32\% em média) e $\mathrm{MnO}(2,5 \%)$ e, em contrapartida, menores conteúdos de $\mathrm{MgO}$ (cerca de $14 \%$ ) e $\mathrm{Al}_{2} \mathrm{O}_{3}(0,64 \%)$,

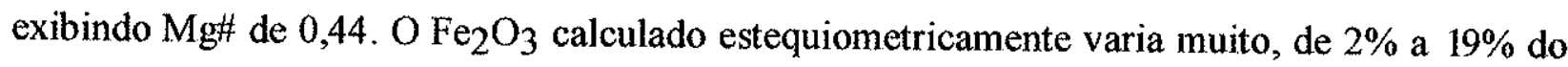
$\mathrm{FeO}$.

Assim como dentre os noritos, os Mg\# dos OPX são bem superiores aos da rocha total correspondente, e as variações das concentrações de $\mathrm{CaO}$ e $\mathrm{MnO}$ também não mostram correspondência.

Comparando-se com os ortopiroxênios do maciço Bela Joana (Rêgo, op. cit.) verifica-se que os OPX de Venda Nova são, no geral, mais ricos em MgO (no Bela Joana o Mg\# é 0,5 em média) e $\mathrm{CaO}$, principalmente entre os charnoquitóides.

A figura 6.1 traz o gráfico $\mathrm{Al}_{2} \mathrm{O}_{3} \times \mathrm{MgO}+\mathrm{FeO}+\mathrm{Fe}_{2} \mathrm{O}_{3}$, proposto por Bhattacharyya (1971) e modificado por Rietmeji er (1983) para distinção entre OPX ígneos e metamórficos. As amostras de Venda Nova estão preferencialmente posicionadas na zona de transição, onde se superpõem os piroxênios de origem ígnea e metamórfica segundo Rietmeij er (op. cit.). Este autor pondera que as composições dos piroxênios ígneos podem se modificar e deslocarem-se para o campo metamórfico, refletindo reequilíbrios em condições de metamorfismo de alto grau.

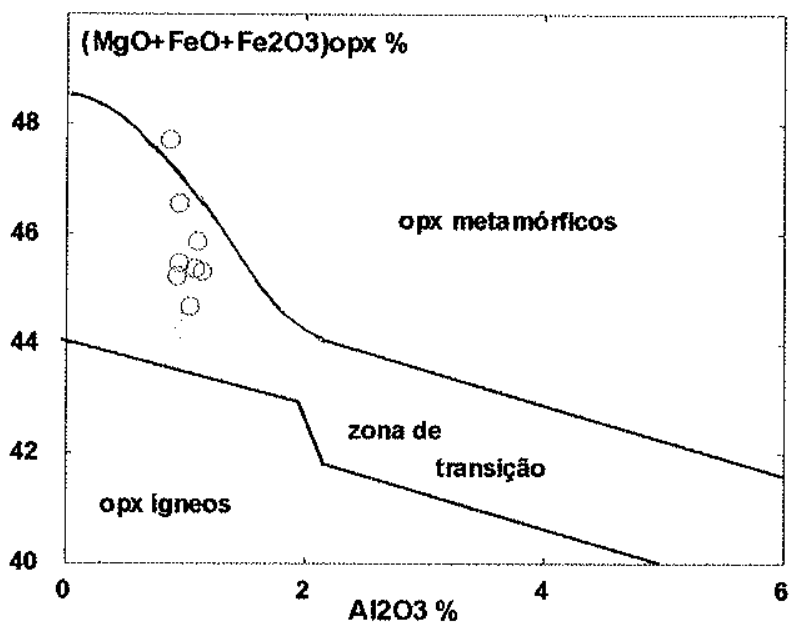

Figura 6.1 - Diagrama $\mathrm{Al}_{2} \mathrm{O}_{3} \times \mathrm{MgO}+\mathrm{FeO}+\mathrm{Fe}_{2} \mathrm{O}_{3}$ com os campos para ortopiroxênios ígneos e metamórficos. Símboles: ONonitos; Charnoquitóides

Os clinopiroxênios dos noritos e dos charnoquitóides possuem $\mathrm{Mg \#} \mathrm{superiores} \mathrm{aos}$ OPX coexistentes, e consequentemente maiores que os das rochas correspondentes, como pode 
ser visto na tabela 6.2. Novamente dentre os noritos os teores de $\mathrm{MgO}$ são inferiores,

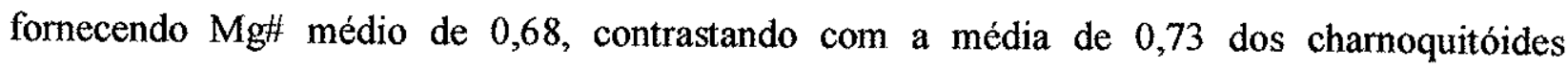
(excetuando a amostra VN-27, com Mg\# de 0,56). Oscilam composicionalmente entre Wo44,07 a Wo48,97, En34,44 a En40,53 e Fs 12,93 a Fs 19,26, com exceção da amostra VN-27 que possui composição média Wo46,3En29,2Fs24,4. Os teores de $\mathrm{CaO}$ variam de $21,94 \%$ a $23,93 \%$, de $\mathrm{FeO}$ entre $7,86 \%$ e $11,97 \%$ e de $\mathrm{MgO}$ de $12,04 \%$ a $14,66 \%$ (a amostra $\mathrm{VN}-27$ é bem mais rica em $\mathrm{FeO}$, com conteúdo igual a $14 \%$ ).

Verifica-se grande variação no $\mathrm{Fe}_{2} \mathrm{O}_{3}$ calculado estequiométricamente, de 2 a $19 \% \mathrm{FeO}$. As concentrações de $\mathrm{Al}_{2} \mathrm{O}_{3}$ são de $1,5 \%$ em média, e ocorre uma tendência geral de aumento dos teores de Fe com a diminuição de $\mathrm{Ca}$, conforme apontado por Lindsley (1983). Ao se comparar com os clinopiroxênios do maciço Bela Joana nota-se que eles são mais pobres em $\mathrm{Ca}$ e $\mathrm{Mg}$ e bem mais ricos em Fe e Al que os de Venda Nova.

Os teores de $\mathrm{CaO}$ e $\mathrm{MnO}$ dos $\mathrm{CPX}$ não mostram qualquer relação de proporcionalidade com aqueles da rocha total correspondente, nem mesmo para a amostra VN27, cujos conteúdos de $\mathrm{CaO}$ de rocha total são bem menores que os das outras amostras analisadas.

O diagrama para classificação de piroxênios da figura 6.2 ilustra a tendência de um leve enriquecimento em $\mathrm{Mg}$ dentre os charnoquitóides com relação aos noritos, ao mesmo tempo que mostra haver superposição composicional em vários pontos analisados. Verifica-se que os CPX dos noritos tendem a ficar mais ricos em Fe com teores de Ca praticamente constantes, enquanto que os dos charnoquitóides exibem ligeira diminuição dos mesmos. Dentre os OPX praticamente não há oscilação do Ca. Fica também nítida a pequena variação composicional dos CPX e um intervalo um pouco superior para os OPX. A amostra VN-27 destaca-se das demais em função dos maiores conteúdos de Fe.

$\mathrm{Na}$ figura 6.3 tem-se o diagrama para classificação de piroxênios onde foram plotados alguns pares de OPX-CPX coexistentes. Ligando-se os pares obtém-se "tie lines" muito próximas umas das outras mas que não se cruzam, evidenciando cristalização em condições de equilíbrio. As pequenas variações nas proporções $\mathrm{CaFe} \mathrm{Mg}$ dos piroxênios podem indicar um "solvus" restrito, evidenciando equilíbrio em condições ígneas. Brown (1961) afirmou que em pares de piroxênios ígneos coexistentes, o ortopiroxênio possui normalmente menores valores de

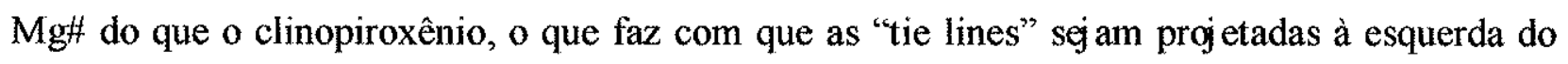
vértice Wo no diagrama triangular. 
Com a finalidade de separar piroxênios ígneos e metamórficos e para estimar as temperaturas de (re)cristalização dos mesmos Kretz $(1961,1963)$ usou o coeficiente de partição de $\mathrm{Mg}$ e Fe entre piroxênios coexistentes. Concluiu que valores de $\mathrm{KdMg}-\mathrm{F}$ e entre 0,86 e 0,65 são típicos de rochas ígneas e valores entre 0,65 e 0,51 são de rochas metamórficas. $O$ valor de Kd médio para os piroxênios coexistentes dos noritos é de aproximadamente 0,61 e para os charnoquitóides é superior a 0,67 ; a amostra VN-27 possui Kd de 0,61. Os baixos valores de Kd obtidos para os noritos devem estar vinculados a sua provável origem por acumulação de plagioclásio e piroxênios, o que pode provocar desequilíbrios nas trocas químicas (Kretz, 1963). Quanto a amostra VN-27, seus baixos $\mathrm{Kds}$ podem ser o reflexo de reequilíbrios químicos ocorridos provavelmente em condições de subsolidus.
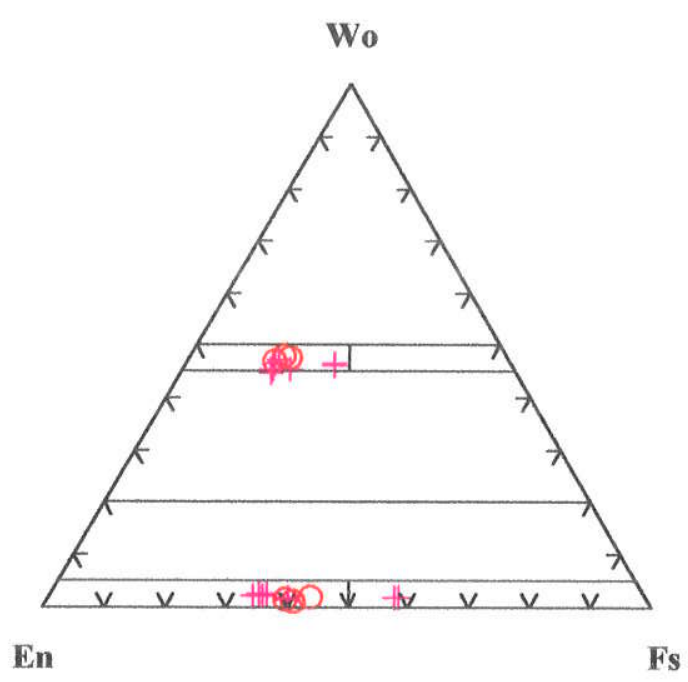

Figura 6.2 - Diagrama Wo-En-Fs para as rochas da borda do maciço de Venda Nova. Símbolos: O Noritos; + Charnoquitóides Wo

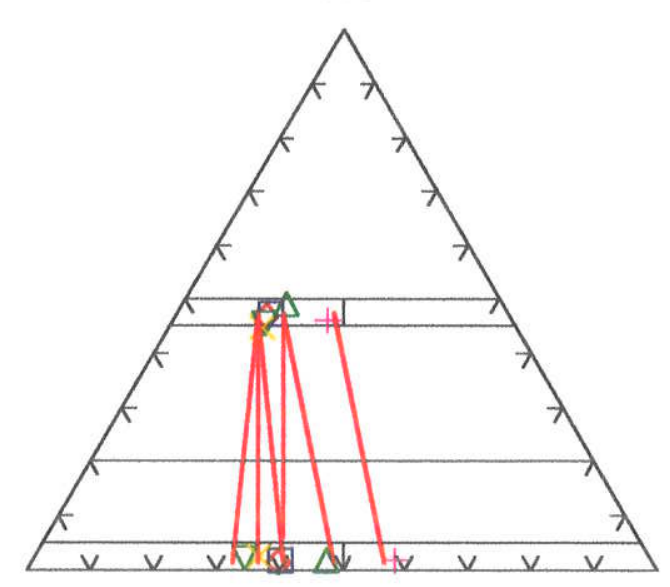

En

Fs

Figura 6.3 - Diagrama Wo-En-Fs com as "tie lines" para piroxênios coexistentes das rochas da borda do maciço de Venda Nova.

Símbolos: $\triangle$ VN-3; $\diamond \mathrm{VN}-14 ; \mathrm{x}$ VN-23; $\nabla$ VN-16; $\square \mathrm{VN}-18 ;+\mathrm{VN}-27$. 


\section{Anfibólios}

Foram analisados anfibólios em cinco amostras da borda do maciço de Venda Nova, sendo duas delas de noritos e três de charnoquitóides. Os dados obtidos e as respectivas fórmulas estruturais encontram-se na tabela 6.3. Para o seu cálculo o teor de ferro adotado foi o ponto médio entre o máximo e o mínimo possível de $\mathrm{Fe}^{+3}$.

Apesar de ser possivel distinguir em lâmina delgada a provável existência de mais de uma fase de anfibólio (primário e secundário?), as análises de cristais nas mesmas amostras resultaram em composições muito próximas, sem variaçôes significativas nas razões Fe/Mg. Os

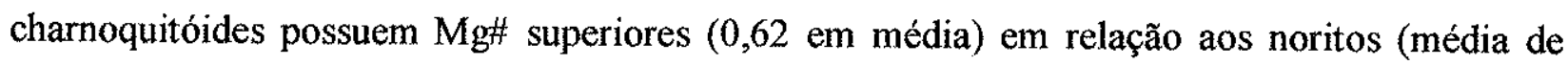
0,55), com exceção dos anfibólios da amostra VN-27 que são mais ricos em Fe e têm Mg\# por

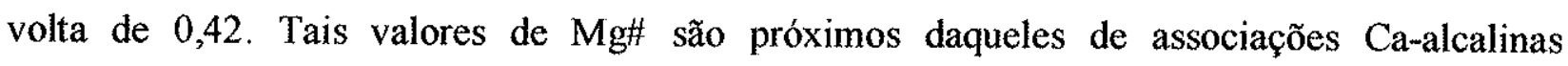
(Czamanske et al., 1981).

Os anfibólios possuem composição cálcica e a classificação da maioria das amostras (segundo Leake, 1978) é Mg-hornblenda, com $\mathrm{Si}=6,28$ a 6,6 átomos/fórmula, como pode ser visto na figura 6.4. No entanto, as amostras $\mathrm{VN}-27$ e $\mathrm{VN}-11$, por possuírem $\mathrm{ANa}+\mathrm{AK}>0,5$ classificam-se em Mg-hornblenda hastingsítica $\left(\mathrm{Fe}^{+3}>\mathrm{Al}{ }^{\mathrm{V}}\right)$ e Fe-hornblenda pargasítica $\left(\mathrm{Fe}^{+3}<\mathrm{Alvi}\right)$.

As figuras 6.5 e 6.6 exibem a boa correlação existente entre o Al(total), Aliv e Alvi. As amostras VN-27 e VN-35 destacam-se devido ao seu maior conteúdo de Al (total). Quando se correlaciona Aliv $\times$ Alvi, como está apresentado na Figura 6.7, verifica-se que, para a maioria das amostras, pequenas variações nos teores de $\mathrm{Al}$ iv correspondem a oscilações relativamente maiores de Alvi.

Os teores de $\mathrm{Ca}$ e $\mathrm{Na}$ exibem pequenas variações, enquanto que o $\mathrm{K}$ oscila consideravelmente, sendo maior nas amostras VN-11 e VN-27, onde se tem a maior ocupação do sítio A. Na figura 6.8 constata-se que existe uma boa correlação entre o conteúdo de Aliv e a ocupação do sítio A. O posicionamento observado é compatível com composições hastingsíticas, que resultam de combinações de substituições edeníticas e tchermackíticas; no entanto, a influência das substituições tchermackíticas é relativamente maior nas composições desses anfibólios (Deer et al., 1966).

A amostra VN-27 possui as maiores concentrações de Mn, em função do seu Feł\# superior, proporcionalidade esta que no geral se mantém nas demais amostras. Os teores de Al(total) mostram uma relação inversa com os $\mathrm{Mg \# ,} \mathrm{sendo} \mathrm{portanto} \mathrm{inferiores} \mathrm{dentre} \mathrm{os}$ 
charnoquitóides. Os conteúdos de $\mathrm{F}$ e Cl são ínfimos, sobretudo deste último. Os anfíbólios do maciço Bela Joana são consistentemente mais ricos em $\mathrm{Fe}$ e $\mathrm{Al}$, fornecendo, no geral, composições pargasíticas ricas em ferro; exibem também maiores quantidades de F (Rêgo, op. cit.).

Os valores de Mg\# dos anfibólios de Venda Nova não são correlacionáveis com os valores das rochas que os contém, sendo eles bem superiores nos minerais. Também não se constata qualquer relação de proporcionalidade entre os teores de $\mathrm{Ca}, \mathrm{Na}$ e $\mathrm{Mn}$ entre mineral e rocha total; já o $\mathrm{K}$ nos anfibólios tende a crescer com o aumento do $\mathrm{K}_{2} \mathrm{O}$ das rochas, com exceção da amostra VN-11.

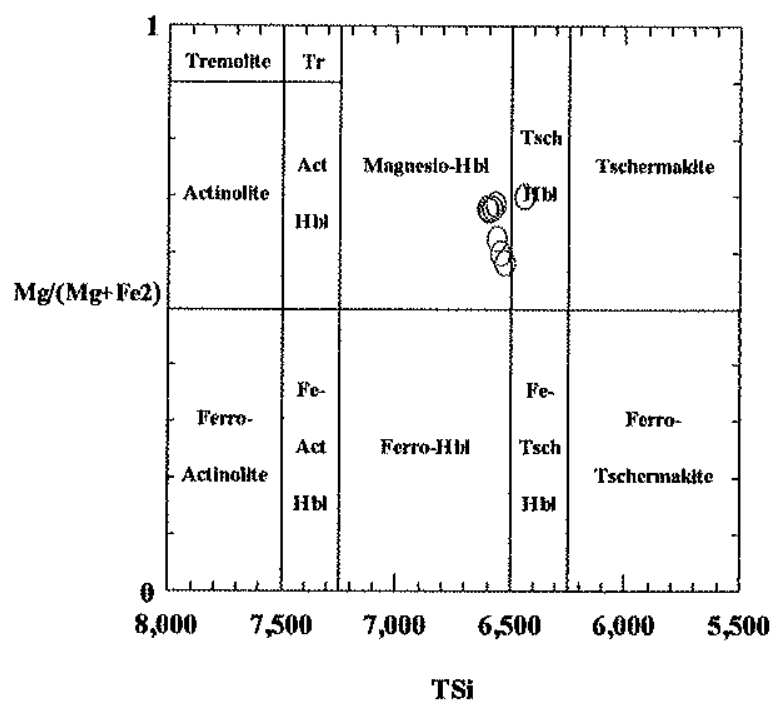

Figura 6.4 - Diagrama TSi x Mg/(Mg+Fe $\left.\mathrm{e}^{+2}\right)$ de classificação de anfibólios cálcicos para as rochas da borda do maciço de Venda Nova 

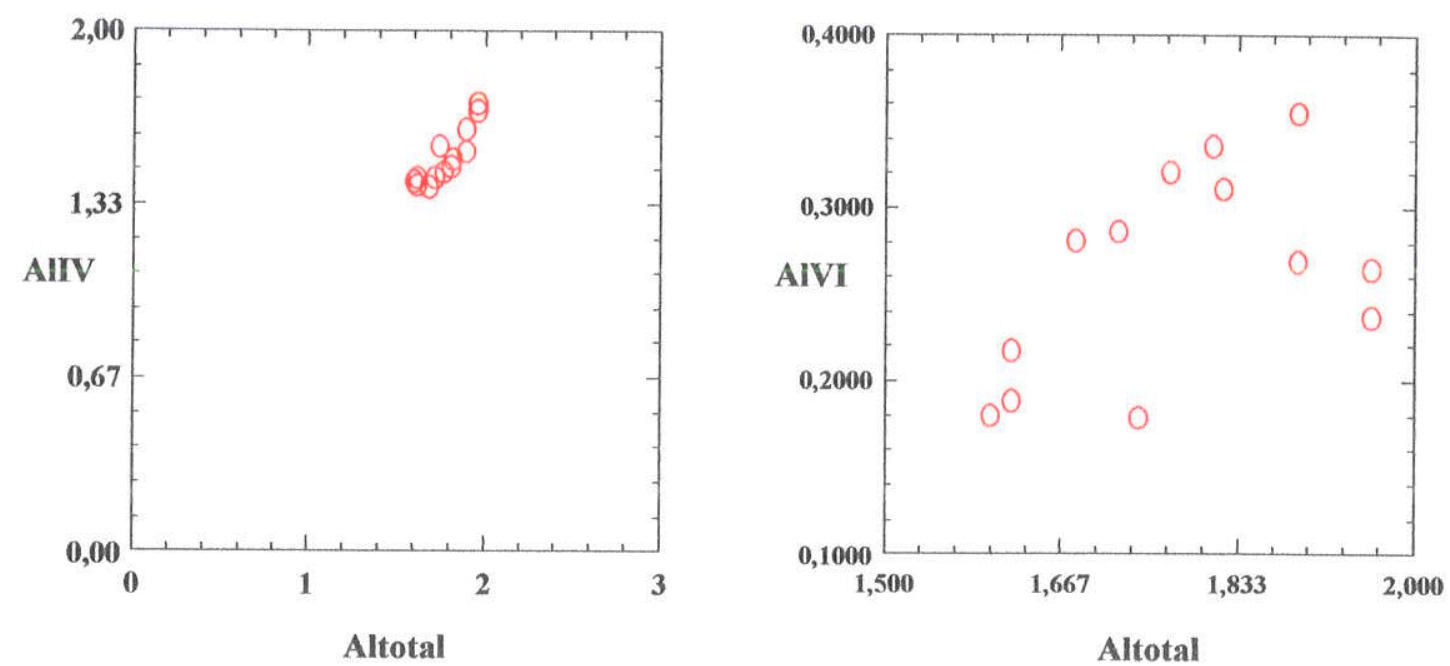

Figuras 6.5 e 6.6 - Diagramas onde estão correlacionados $\mathrm{Al}$ (total) x $\mathrm{Al}^{\mathrm{iv}}$ e $\mathrm{Al}^{\mathrm{vi}}$ para os anfibólios das rochas da borda do maciço de Venda Nova.
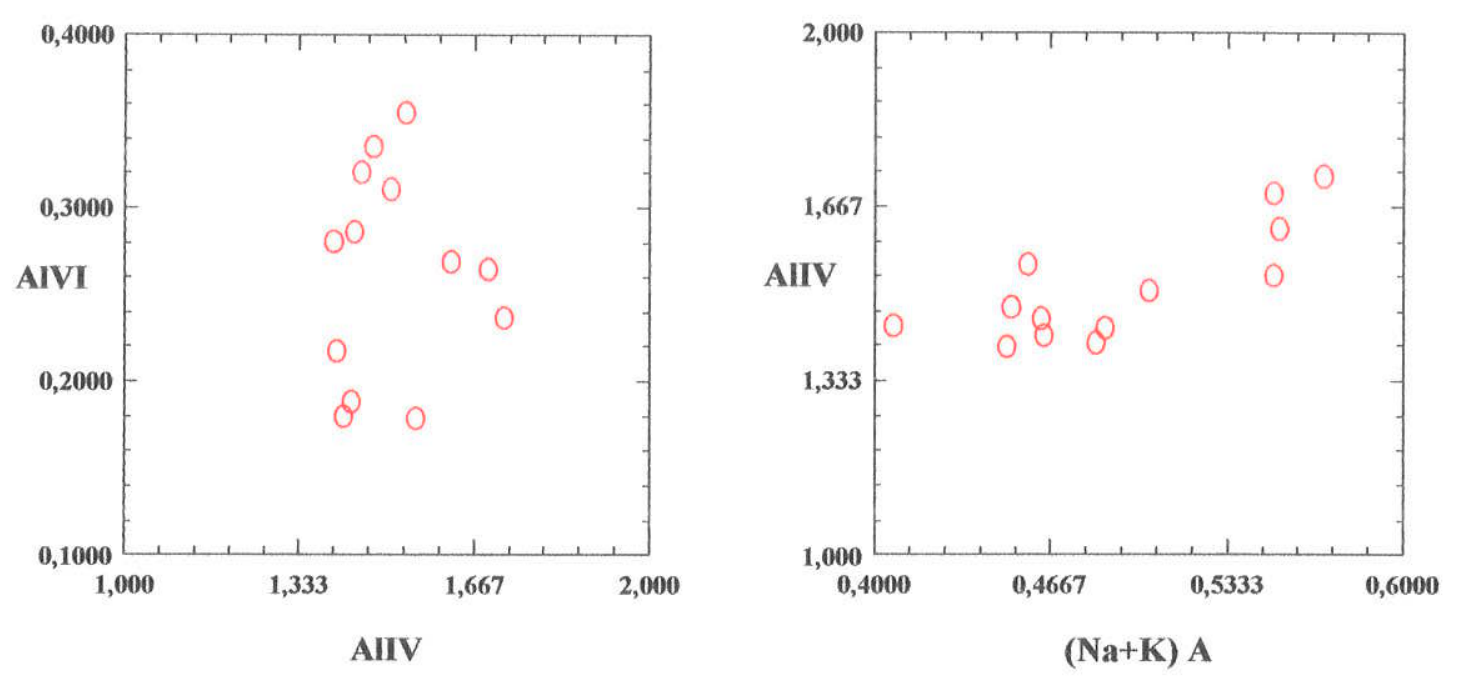

Figuras 6.7 e 6.8 - Diagramas $\mathrm{Al}^{\mathrm{iv}} \times \mathrm{Al}^{\mathrm{vi}}$ e $(\mathrm{Na}+\mathrm{K}) \mathrm{A} \times \mathrm{Al}^{\mathrm{iv}}$ para os anfibólios das rochas da borda do maciço de Venda Nova.

\section{Biotitas}

Foram escolhidas as doze melhores análises de biotita efetuadas em quatro lâminas polidas, sendo uma de norito (VN-11) e o restante de charnoquitóides. Os resultados analíticos estão na tabela 6.4 .

Também para as biotitas a análise petrográfica sugere a existência de mais de uma geração, mas não é possível afirmar com certeza a presença de uma fase primária; por seu lado, as análises químicas destes minerais não mostram variações composicionais dentro da mesma amostra. 
Os Mg\# são muito semelhantes àqueles dos anfibólios para todas as amostras analisadas. São, portanto, maiores para os charnoquitóides, exceto a amostra $\mathrm{VN}-27$, mais rica em Fe. Da mesma forma, não guardam qualquer correspondência com as rochas que as contém. São muito ricas em $\mathrm{Ti}$ (até 0,7 átomos/fórmula) e apresentam insignificantes conteúdos de $\mathrm{Na}, \mathrm{F}$ e $\mathrm{Cl}$. Os teores de álcalis apresentam sutil decréscimo com o aumento das concentrações de Al(total).

As concentrações de Ti e Al(total) possuem uma ligeira tendência a diminuírem com menores valores de $\mathrm{Mg \#} \mathrm{(enriquecimento} \mathrm{em} \mathrm{Fe).} \mathrm{Assim,} \mathrm{a} \mathrm{amostra} \mathrm{VN-27} \mathrm{é} \mathrm{a} \mathrm{que}$ apresenta os menores teores de $\mathrm{Ti}$ e Al. $\mathrm{Na}$ figura 6.9, com os extremos composicionais das micas ferro-magnesianas, é clara a separação de três grupos pelos $\mathrm{Mg}$ \# (que praticamente não oscila em cada grupo): noritos (VN-11), charnoquitóides e VN-27. As principais substituições que ocorrem entre estes membros extremos são em quantidades relativas de $\mathrm{Fe}^{+2}$ e $\mathrm{Mg}$ nas posições octaédricas e Si e Al nas posições tetraédricas. As amostras analisadas situam-se numa região intermediária entre os membros finais flogopita e annita, mas a amostra VN-27 está mais deslocada para o extremo annita. As figuras 6.10 e 6.11 mostram que os conteúdos de Ti e Fe aumentam consideravelmente com pequenos acréscimos do Aliv. O $\mathrm{Cl}$ mostra geralmente correlação negativa com a proporção de $\mathrm{Mg}$ nas posições octaédricas e positiva com o $\mathrm{Fe}^{+2} \mathrm{em}$ biotitas naturais (Valley et al., 1982). Tal situação é bem exemplificada nas biotitas de Venda Nova, como pode ser visto na figura 6.12.

Comparando-se com as biotitas do maciço Bela Joana, constata-se que estas são mais ricas em $\mathrm{Fe}$ e $\mathrm{Al}$ tetraédrico (somente uma amostra possui Al no sítio octaédrico), conferindo composições intermediárias entre annita e siderofilita. Os teores de Ti se eqüivalem ao das biotitas do maciço de Venda Nova e os conteúdos de F são muito superiores. As biotitas das rochas da borda do maciço de Venda Nova são semelhantes àquelas analisadas por Guimarães et al. (1993) para os complexos de afinidade shoshonítica de Bom Jardim e Toritama, $\mathrm{PE}$, sendo mais ricas em Ti e Fe e mais pobres em Mg. No gráfico ternário da Figura 6.13 a localização das biotitas de Venda Nova (menos as de VN-27) é compatível com o posicionamento das biotitas mais ricas em Ti daqueles complexos. Os autores salientam o fato de que os minerais Fe-magnesianos de rochas shoshoníticas são quimicamente similares àqueles de séries Ca-alcalinas. 


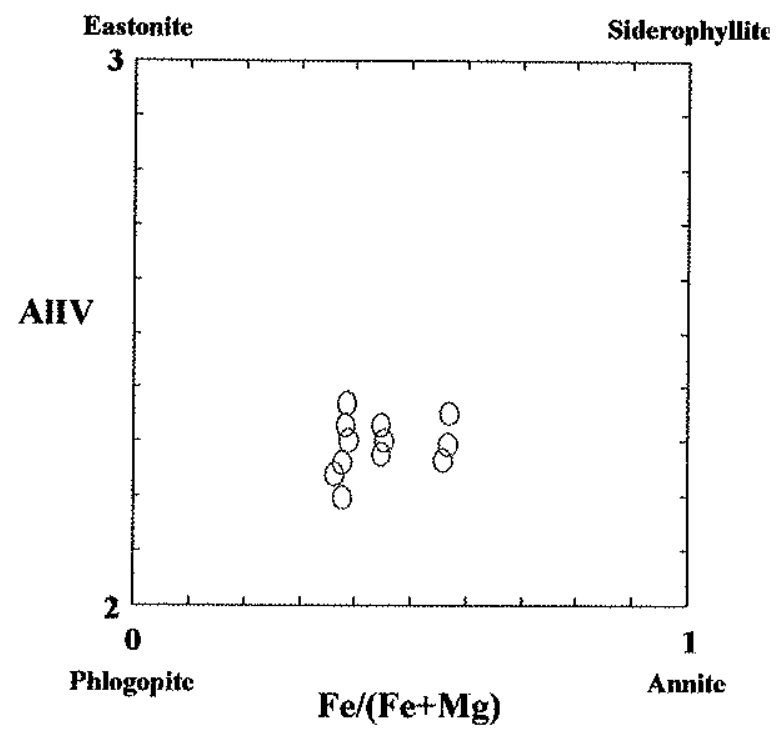

Figura 6.9 - Variação composicional de flogopitas-biotitas para as rochas da borda do maciço de Venda Nova.
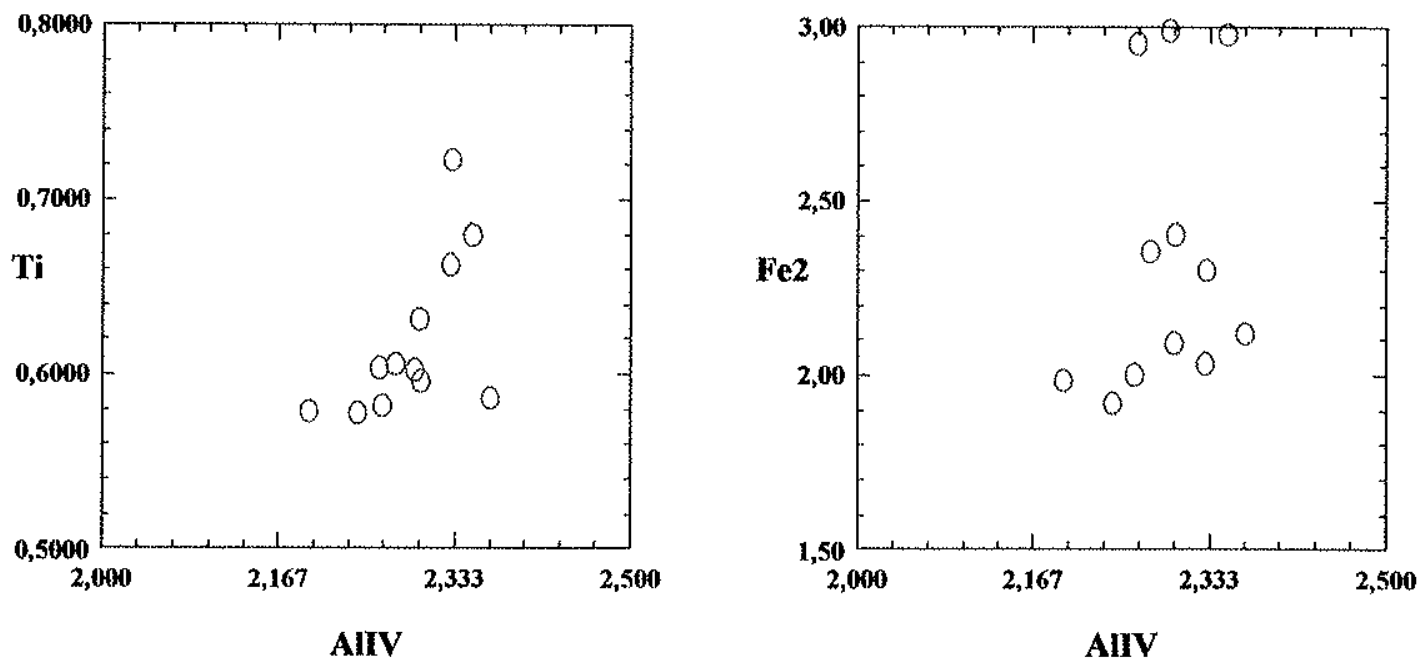

Figuras 6.10 e 6.11 - Diagramas Aliv $\times$ Ti Aliv $\times \mathrm{Fe}^{+2}$ para biotitas das rochas da borda do maciço de Venda Nova. 

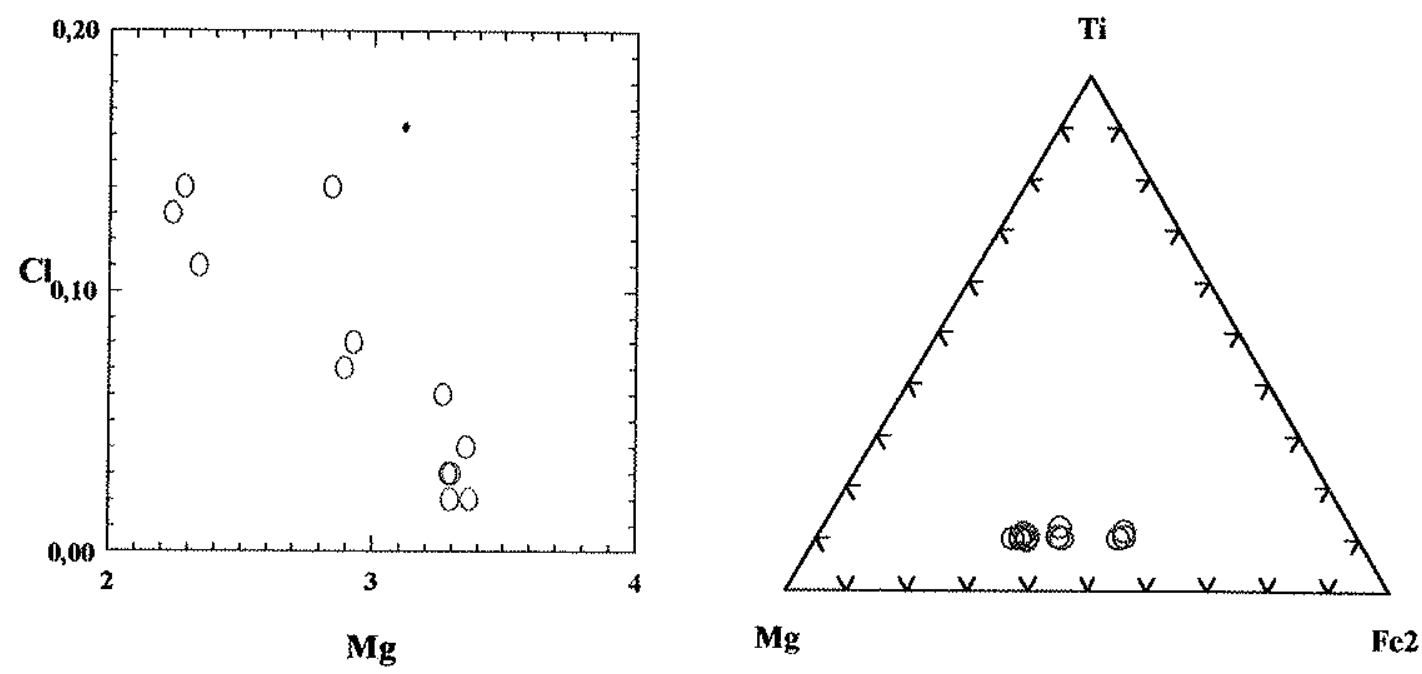

Figuras 6.12 e 6.13 - Diagramas $\mathrm{Mg}$ x Cl e Ti-Mg-Fe (prop. atômica) para biotitas das rochas da borda do maciço de Venda Nova.

\section{Feldspatos}

Foram realizadas análises de plagioclásios em oito lâminas das rochas da borda do maciço de Venda Nova, sendo três delas de noritos e cinco de charnoquitóides, como pode ser visto nas tabelas 6.5 e 6.6. A tabela 6.5 traz os resultados analíticos de microfenocristais dos noritos (9 determinações em 3 amostras) e megacristais dos charnoquitóides ( 15 determinações em cinco amostras) e a tabela 6.6 contém as análises de cristais da matriz dos noritos e dos charnoquitóides.

Nos charnoquitóides a composição dos megacristais e dos plagioclásios da matriz numa mesma amostra é praticamente igual. Estes últimos possuem composição que varia de andesina sódica - Ab67, 1An30,6Or2,3 (amostra $\mathrm{VN}-27$, a de maior teor em álcalis) a andesina cálcica - Ab52An45,60r2,4 (amostra VN-35), enquanto que os megacristais variam entre Ab30,8An66,4Or2,7 (VN-27) a Ab53,3An44,6Or2,1 (VN-35). Ocorrem poucos grãos zonados e destes foram analisados dois na amostra VN-27 (aproximadamente borda An31 - núcleo An39) e um na amostra VN-16 (borda An40 -núcleo An44,6). Nas figuras 6.14 e 6.15 encontram-se os gráficos Or-Ab-An que ilustram as variações composicionais detectadas nos plagioclásios da matriz e megacristais.

Os plagioclásios das rochas da sequuência norítica são muito mais enriquecidos no componente anortita em relação aos charnoquitóides. Praticamente não ocorre diferença composicional entre os cristais da matriz e os microfenocristais; os primeiros são levemente 
mais ricos em Ca. Observa-se considerável variação na composição principalmente em função de grãos zonados. Os zoneamentos detectados são normais e compreendem limites tais como: borda Ab44,8An54Or1,2 - núcleo Ab22,9An76,8Or0,3 (microfenocristal de VN-3); borda Ab37,3An6 1,9Or0,9 - núcleo Ab2 1,2An78,3Or0,5 (cristal da matriz em VN-11). A amostra VN14 mostra os maiores conteúdos de anortita, mostrando em média composição An86 (bytownita cálcica), que deve corresponder ao núcleo do cristal que está corroído. Nas figuras 6.14 e 6.15 estão ilustradas as variações nas composições dos plagioclásios da matriz e dos microfenocristais.

A cristalização de plagioclásio com composições próximas a anortita serve para reforçar a hipótese de que os noritos devam corresponder a uma fase cumulática, cristalizada sob altas temperaturas, comojá aventado no capítulo anterior.

Tanto os plagioclásios dos charnoquitóides como os dos noritos possuem baixas concentrações de K, média de 0,09 cátions/fórmula para os primeiros e 0,025 para os últimos. Os conteúdos de Ba e Sr são negligiveis.

As rochas charnoquitóides do maciço de Venda Nova apresentam pequenas quantidades de feldspato alcalino, observado apenas em poucas amostras mais ácidas, como discorrido no capítulo 4. Alguns cristais de plagioclásio exibem ao microscópio ótico algumas inclusões de uma fase que se assemelha com álcali-feldspato, podendo portanto tratar-se de antipertitas. Infelizmente não foi possível analisar na microssonda essas possíveis lamelas de exsolução.

Foram realizadas análises de feldspato alcalino em três lâminas polidas e os melhores resultados obtidos encontram-se na tabela 6.7 , representados pelas amostras $\mathrm{VN}-27 \mathrm{e}$ VN-16. Observa-se uma grande similaridade nas determinações (variam de Or87,9 a Or92,8), apenas diferindo no componente albita um pouco maior da amostra VN-27. Os conteúdos de $\mathrm{BaO}$ variam bastante, chegando a $1,13 \% \mathrm{em} \mathrm{VN}-16$.

As composições obtidas para os plagioclásios e feldspatos alcalinos dos charnoquitóides de Venda Nova são semelhantes àquelas apresentadas por Rêgo (1989) para o maciço Bela Joana. Os plagioclásios deste corpo oscilam entre An34 e An50 e os álcalifeldspatos variam de Or84 a Or95. 


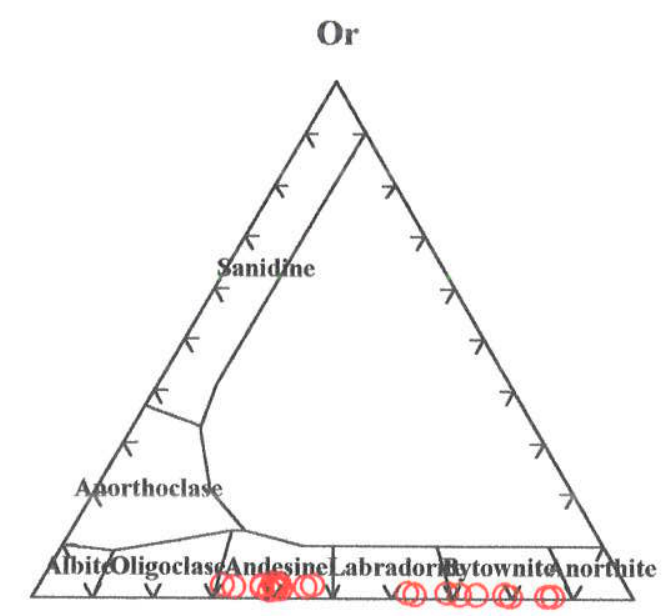

Ab

An

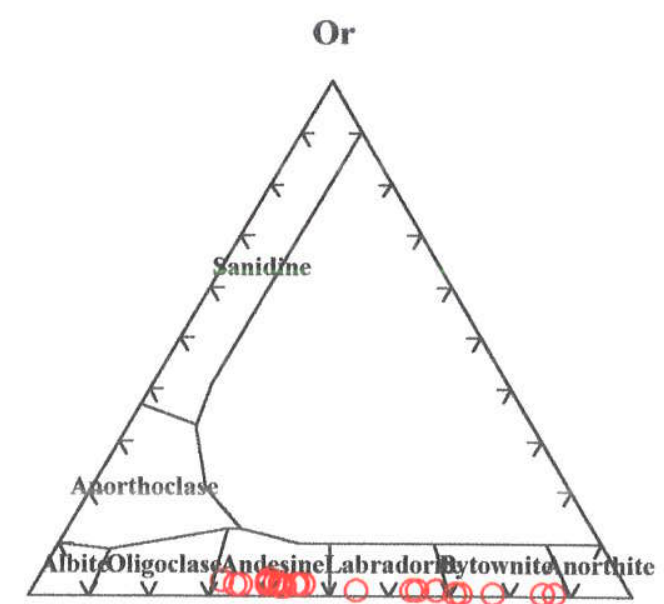

Ab
An

Figuras 6.14 e 6.15 - Diagramas Or-Ab-An exibindo as variações nas composições dos plagioclásios da matriz e megacristais/ microfenocristais, respectivamente, para os charnoquitóides e noritos do maciço de Venda Nova.

\section{Minerais Opacos}

Das fases opacas presentes nas rochas da borda do maciço de Venda Nova foram efetuadas análises em ilmenitas e magnetitas de sete lâminas polidas, sendo quatro de charnoquitóides e três de noritos. Os resultados alcançados, juntamente com as fórmulas estruturais e os membros finais de cada série, estão nas tabelas 6.8 e 6.9. As fórmulas estruturais foram obtidas através do "software" QUILF (Andersen et al., 1993). Algumas amostras não apresentaram um bom fechamento na análise, principalmente entre as magnetitas, o que pareceu estar associado a problemas na superfície da seção (polimento) e a irregularidades no recobrimento. As determinações foram feitas tanto em grãos homogêneos, sem intercrescimento ou lamelas de exsolução, como naqueles onde pôde observar-se tais caracteres.

A determinação dos membros finais foi feita por estequiometria. Para as ilmenitas combinou-se primeiramente $\mathrm{Mn}$ e $\mathrm{Mg}$ com Ti para formar as moléculas $\mathrm{Mg}, \mathrm{Mn}\left(\mathrm{TiO}_{3}\right)$; o $\mathrm{Ti}$ restante foi combinado com o Fe formando a molécula de $\mathrm{FeTiO}_{3}$ (ilmenita). A sobra de $\mathrm{Fe}$ gerou a molécula de hematita. Quanto às magnetitas, combinou-se primeiramente os cátions bivalentes e trivalentes menores para gerar $\mathrm{Mg}, \mathrm{Mn}\left(\mathrm{Al}_{2} \mathrm{O}_{4}\right)$ e a sobra de $\mathrm{Al}$ foi combinada com proporção equivalente de $\mathrm{Fe}^{+2}$ dando $\mathrm{FeAl}_{2} \mathrm{O}_{4}$. Combinou-se então o $\mathrm{Ti}$ com $2 \mathrm{Fe}^{+2}$ para formar a molécula de $\mathrm{Fe}_{2} \mathrm{TiO}_{4}$. O que sobrou de $\mathrm{Fe}^{+2}$ foi somado ao $\mathrm{Fe}^{+3}$ formando enfim a molécula de magnetita $\left(\mathrm{Fe}_{3} \mathrm{O}_{4}\right)$.

Dentre as ilmenitas não ocorrem grandes variações, mas destaca-se a amostra VN16 com os maiores teores de $\mathrm{FeO}$ (ferri-ilmenita) e a amostra $\mathrm{VN}-27$ com quase $5 \%$ de $\mathrm{MnO}$. 
Outras amostras, tais como VN-14, VN-11 e VN-18 também possuem elevadas concentrações de $\mathrm{MnO}$. Os conteúdos de $\mathrm{MgO}$ são altos ( $>1 \%$ ) em quase todas as amostras. As proporções de molécula de hematita são relativamente baixas, mas variam bastante dentro do intervalo $3,1 \%$ a $20,7 \%$; consequentemente tem-se elevadas proporções de ilmenita ( $>80 \%$ na maioria das amostras). Tais porcentagens de molécula de hematita em solução sólida com ilmenita sugerem que o magma se cristalizou sob $\mathrm{fO}_{2}$ relativamente baixas, e que a maior parte da magnetita formada deve estar ligada a transformações tardimagmáticas. Considerações mais aprofundadas quanto ao estado de oxidação do magma quando da cristalização das rochas serão feitas mais adiante.

Os cristais de magnetita correspondem a fases quase puras em $\mathrm{Fe}$, contendo pequenas proporções de $\mathrm{TiO}_{2}(0,18 \%$ em média) e $\mathrm{MgO}$ (média de $0,15 \%)$ e um pouco mais de $\mathrm{Al}_{2} \mathrm{O}_{3}$ (varia de $0,28 \%$ a $1,26 \%$ ). Praticamente todas as amostras apresentam proporções da molécula de $\mathrm{Fe}_{3} \mathrm{O}_{4}$ maiores do que $97 \%$, como pode ser observado na tabela 6.9. Algumas delas mostram maiores porcentagens de ulvoespinélio $(1,1 \%$ em $\mathrm{VN}-3)$ e hercinita $(3,1 \mathrm{e} 1,2 \%$ em $\mathrm{VN}-35)$. 
Tabela 6.1 - Análises químicas de ortopiroxênios das rochas da borda do Maciço de Venda Nova

\begin{tabular}{|c|c|c|c|c|c|c|c|c|}
\hline \multicolumn{9}{|c|}{ Noritos } \\
\hline Amostras & VN 3.1 & $\mathrm{VNN} 3.2$ & VN 3.3 & VN14,1 & VN14.2 & VN 14.3 & VN 11.1 & VN11.2 \\
\hline $\mathrm{SiO} 2$ & 50,73 & 50,06 & 50,15 & 51,51 & 51,73 & 51,61 & 51,88 & 51,70 \\
\hline $\mathrm{TiO} 2$ & 0,08 & 0,09 & 0,10 & 0,08 & 0,11 & 0,00 & 0,00 & 0,05 \\
\hline $\mathrm{Al} 2 \mathrm{O} 3$ & 0,94 & 0,94 & 0,86 & 1,13 & 1,03 & 1,09 & 1,07 & 0,92 \\
\hline $\mathrm{Cr} 2 \mathrm{O} 3$ & 0,04 & 0,00 & 0,00 & 0,03 & 0,00 & 0,02 & 0,09 & 0,06 \\
\hline $\mathrm{FeO}$ & 27,74 & 28,92 & 29,06 & 24,20 & 24,32 & 25,37 & 26,12 & 26,20 \\
\hline $\mathrm{MnO}$ & 0,55 & 0,67 & 0,79 & 0,53 & 0,70 & 0,63 & 0,69 & 0,61 \\
\hline $\mathrm{MgO}$ & 17,73 & 17,63 & 18,65 & 21,11 & 20,35 & 20,48 & 19,24 & 19,03 \\
\hline $\mathrm{NiO}$ & 0,04 & 0,00 & 0,11 & 0,03 & 0,00 & 0,08 & 0,06 & 0,00 \\
\hline $\mathrm{CaO}$ & 0,74 & 0,87 & 0,40 & 0,62 & 0,54 & 0,60 & 0,82 & 1,15 \\
\hline $\mathrm{Na} 2 \mathrm{O}$ & 0,04 & 0,09 & 0,11 & 0,01 & 0,10 & 0,02 & 0,02 & 0,14 \\
\hline $\mathrm{K} 2 \mathrm{O}$ & 0,00 & 0,01 & 0,00 & 0,00 & 0,00 & 0,00 & 0,02 & 0,00 \\
\hline $\mathrm{BaO}$ & 0,14 & 0,00 & 0,00 & 0,02 & 0,00 & 0,00 & 0,04 & 0,00 \\
\hline Total & 98,77 & 99,28 & 100,23 & 99,27 & 98,88 & 99,90 & 100,05 & 99,86 \\
\hline \multicolumn{9}{|c|}{ Número de ions na base de 6 átomos de oxigênio } \\
\hline $\mathrm{TSi}$ & 1,971 & 1,937 & 1,915 & 1,948 & 1,969 & 1,949 & 1,971 & 1,966 \\
\hline TAl & 0,029 & 0,043 & 0,039 & 0,050 & 0,031 & 0,048 & 0,029 & 0,034 \\
\hline TFe3 & 0,000 & 0,020 & 0,046 & 0,002 & 0,000 & 0,003 & 0,000 & 0,000 \\
\hline MIAI & 0,015 & 0,000 & 0,000 & 0,000 & 0,016 & 0,000 & 0,018 & 0,008 \\
\hline MTi & 0,002 & 0,003 & 0,003 & 0,002 & 0,003 & 0,000 & 0,000 & 0,001 \\
\hline MFe3 & 0,011 & 0,065 & 0,087 & 0,047 & 0,016 & 0,052 & 0,011 & 0,032 \\
\hline $\mathrm{M} 1 \mathrm{Fe} 2$ & 0,000 & 0,000 & 0,000 & 0,000 & 0,000 & 0,000 & 0,000 & 0,000 \\
\hline $\mathrm{M} 1 \mathrm{Cr}$ & 0,001 & 0,000 & 0,000 & 0,001 & 0,000 & 0,001 & 0,003 & 0,002 \\
\hline $\mathrm{MiMg}$ & 0,970 & 0,932 & 0,907 & 0,948 & 0,965 & 0,945 & 0,966 & 0,958 \\
\hline $\mathrm{M} \mathbb{N i}$ & 0,001 & 0,000 & 0,003 & 0,001 & 0,000 & 0,002 & 0,002 & 0,000 \\
\hline $\mathrm{M} 2 \mathrm{Mg}$ & 0,057 & 0,085 & 0,155 & 0,241 & 0,190 & 0.208 & 0,123 & 0,121 \\
\hline $\mathrm{M} 2 \mathrm{Fe} 2$ & 0,891 & 0,850 & 0,795 & 0,716 & 0,758 & 0,746 & 0,819 & 0,802 \\
\hline M2Mn & 0,018 & 0,022 & 0,026 & 0,017 & 0,023 & 0,020 & 0,022 & 0,020 \\
\hline $\mathrm{M} 2 \mathrm{Ca}$ & 0,031 & 0,036 & 0,016 & 0,025 & 0,022 & 0,024 & 0,033 & 0,047 \\
\hline $\mathrm{M} 2 \mathrm{Na}$ & 0,003 & 0,007 & 0,008 & 0,001 & 0,007 & 0,001 & 0,001 & 0,010 \\
\hline $\mathrm{M} 2 \mathrm{~K}$ & 0,000 & 0,000 & 0,000 & 0,000 & 0,000 & 0,000 & 0,001 & 0,000 \\
\hline Sumcat & 4,000 & 4,000 & 4,000 & 4,000 & 4,000 & 4,000 & 3,999 & 4,000 \\
\hline WO & 1,560 & 1,790 & 0,810 & 1,26 & 1,12 & 1,21 & 1,690 & 2,37 \\
\hline EN & 51,94 & 50,57 & 52,26 & 59,58 & 58,51 & 57,69 & 55,17 & 54,53 \\
\hline FS & 46,50 & 47,63 & 46,93 & 39,16 & 40,37 & 41,10 & 43,14 & 43,10 \\
\hline $\mathrm{Fe} / \mathrm{Fe}+\mathrm{Mg}$ & 0,468 & 0,479 & 0,466 & 0,392 & 0,401 & 0,410 & 0,433 & 0,436 \\
\hline $\mathrm{Mg} / \mathrm{Mg}+\mathrm{Fe}$ & 0,532 & 0,521 & 0,534 & 0,608 & 0,599 & 0,590 & 0,567 & 0,564 \\
\hline
\end{tabular}


Tabela 6.1 - Continuação

chamoquitóides

\begin{tabular}{|c|c|c|c|c|c|c|c|c|c|c|c|c|c|c|}
\hline \multicolumn{15}{|c|}{ Charnoquitóides } \\
\hline Aaguestitas & VN23.1 & $V_{N} 23.2$ & $V_{N 16.1}$ & VN 16.2 & VN16.3 & VN27.1 & VN27.2 & VN27.3 & VN 35.1 & VN 35.2 & VN 35.3 & VN18.1 & VN 18.2 & VN 18.3 \\
\hline $\mathrm{SiO} 2$ & 51,82 & 52,58 & 53,00 & 52,81 & 52,01 & 49,42 & 50,07 & 48,88 & 50,79 & 52,28 & 52,50 & 51,64 & 52,25 & 51,73 \\
\hline $\mathrm{TiO} 2$ & 0,02 & 0,09 & 0,17 & 0,00 & 0,13 & 0,04 & 0,00 & 0,13 & 0,06 & 0,08 & 0,02 & 0,07 & 0,06 & 0,08 \\
\hline $\mathrm{Al} 2 \mathrm{O} 3$ & 0,95 & 0,93 & 0,90 & 0,93 & 0,84 & 0,65 & 0,64 & 0,63 & 1,01 & 0,96 & 1,01 & 0,91 & 0,86 & 0,83 \\
\hline $\mathrm{Cr}_{2} \mathrm{O} 3$ & 0,07 & 0,00 & 0,02 & 0,04 & 0,03 & 0,00 & 0,03 & 0,03 & 0,00 & 0,09 & 0,04 & 0,00 & 0,03 & 0,00 \\
\hline $\mathrm{FeO}$ & 21,61 & 21,47 & 20,94 & 21,18 & 21,18 & 31,93 & 32,25 & 31,38 & 24,81 & 23,36 & 23,44 & 23,46 & 23,62 & 22,15 \\
\hline $\mathrm{MnO}$ & 1,10 & 1,03 & 0,61 & 0,73 & 0,85 & 2,71 & 2,24 & 2,14 & 0,81 & 0,74 & 0,78 & 1,08 & 1,02 & 0,79 \\
\hline $\mathrm{MgO}$ & 22,35 & 22,62 & 23,44 & 22,68 & 22,48 & 13,90 & 14,06 & 13,68 & 21,44 & 21,18 & 21,56 & 20,72 & 20,77 & 21,61 \\
\hline $\mathrm{NiO}$ & 0,00 & 0,05 & 0,06 & 0,00 & 0,10 & 0,09 & 0,02 & 0,07 & 0,00 & 0,01 & 0,08 & 0,04 & 0,05 & 0,00 \\
\hline $\mathrm{CrO}$ & 1,17 & 1,11 & 1,03 & 1.19 & 0,82 & 0,87 & 0,77 & 1,53 & 0,65 & 1,01 & 0,58 & 0,82 & 0,89 & 1,50 \\
\hline $\mathrm{Na} 2 \mathrm{O}$ & 0,07 & 0,03 & 0,10 & 0,04 & 0,08 & 0,08 & 0,03 & 0,01 & 0,03 & 0,06 & 0,04 & 0,14 & 0,00 & 0,14 \\
\hline $\mathrm{K} 2 \mathrm{O}$ & 0,05 & 0,01 & 0,00 & 0,01 & 0,00 & 0,04 & 0,03 & 0,00 & 0,01 & 0,03 & 0,00 & 0,00 & 0,03 & 0,02 \\
\hline $\mathrm{BaO}$ & 0,00 & 0,11 & 0,00 & 0,00 & 0,00 & 0,00 & 0,00 & 0,00 & 0,23 & 0,00 & 0,00 & 0,00 & 0,25 & 0,04 \\
\hline Total & 99,21 & 100,03 & 100,27 & 99,61 & 98,52 & 99.73 & 100,14 & 98,48 & 99,84 & 99,80 & 100,05 & 98,88 & 99 & 98,89 \\
\hline \multicolumn{15}{|c|}{ Número de ions na base de 6 átomos de oxigênio } \\
\hline $\mathrm{TSi}$ & 1,941 & 1,955 & 1,954 & 1,966 & 1,959 & 1,954 & 1,971 & 1,957 & 1,913 & 1,963 & 1,964 & 1,960 & 1,973 & 1,951 \\
\hline TAl & 0,042 & 0,041 & 0,039 & 0,034 & 0,037 & 0,030 & 0,029 & 0,030 & 0,045 & 0,037 & 0,036 & 0,040 & 0,027 & 0,037 \\
\hline TFe3 & 0,017 & 0,004 & 0,007 & 0,000 & 0,003 & 0,015 & 0,000 & 0,013 & 0,042 & 0,000 & 0,000 & 0,000 & 0,000 & 0,013 \\
\hline $\mathrm{MlAl}$ & 0,000 & 0,000 & 0,000 & 0,007 & 0,000 & 0,000 & 0,001 & 0,000 & 0,000 & 0,006 & 0,009 & 0,001 & 0,011 & 0,000 \\
\hline MITi & 0,001 & 0,003 & 0,005 & 0,000 & 0,004 & 0,001 & 0,000 & 0,004 & 0,002 & 0,002 & 0,001 & 0,002 & 0,002 & 0,002 \\
\hline M1Fe3 & 0,063 & 0,043 & 0,043 & 0,029 & 0,038 & 0,051 & 0,031 & 0,035 & 0,086 & 0,030 & 0,027 & 0,045 & 0,013 & 0,056 \\
\hline $\mathrm{M} 1 \mathrm{Fe} 2$ & 0,000 & 0,000 & 0,000 & 0,000 & 0,000 & 0,125 & 0,142 & 0,141 & 0,000 & 0,000 & 0,000 & 0,000 & 0,000 & 0,000 \\
\hline $\mathrm{M} 1 \mathrm{Cr}$ & 0,002 & 0,000 & 0,001 & 0,001 & 0,001 & 0,000 & 0,001 & 0,001 & 0,000 & 0,003 & 0,001 & 0,000 & 0,001 & 0,000 \\
\hline $\mathrm{M} \mathrm{Mg}$ & 0,934 & 0,953 & 0,949 & 0,963 & 0,954 & 0,819 & 0,825 & 0,817 & 0,912 & 0,959 & 0,960 & 0,951 & 0,972 & 0,942 \\
\hline $\mathrm{MNi}$ & 0,000 & 0,001 & 0,002 & 0,000 & 0,003 & 0,003 & 0,001 & 0,002 & 0,000 & 0,000 & 0,002 & 0,001 & 0,002 & 0,000 \\
\hline $\mathrm{M} 2 \mathrm{Mg}$ & 0,314 & 0,300 & 0,339 & 0,296 & 0,308 & 0,000 & 0,000 & 0,000 & 0,292 & 0,226 & 0,243 & 0,222 & 0,197 & 0,273 \\
\hline $\mathrm{M} 2 \mathrm{Fe} 2$ & 0,597 & 0,620 & 0,595 & 0,630 & 0,626 & 0,864 & 0,899 & 0,861 & 0,654 & 0.704 & 0,706 & 0,700 & 0,732 & 0,630 \\
\hline $\mathrm{M} 2 \mathrm{Mn}$ & 0,035 & 0,032 & 0,019 & 0,023 & 0,027 & 0,091 & 0,075 & 0,073 & 0,026 & 0,024 & 0,025 & 0,035 & 0,033 & 0,025 \\
\hline $\mathrm{M} 2 \mathrm{Ca}$ & 0,047 & 0,044 & 0,041 & 0,047 & 0,033 & 0,037 & 0,032 & 0,066 & 0,026 & 0,041 & 0,023 & 0,033 & 0,036 & 0,061 \\
\hline $\mathrm{M} 2 \mathrm{Na}$ & 0,005 & 0,002 & 0,007 & 0,003 & 0,006 & 0,006 & 0,002 & 0,001 & 0,002 & 0,004 & 0,003 & $0,010^{\circ}$ & 0,000 & 0,010 \\
\hline$M 2 \mathrm{~K}$ & 0,002 & 0,000 & 0,000 & 0,000 & 0,000 & 0,002 & 0,002 & 0,000 & 0,000 & 0,001 & 0,000 & 0,000 & 0,001 & 0,001 \\
\hline Sumeat & 3,998 & 4,000 & 4,000 & 4,000 & 4,000 & 3,998 & 3,998 & 4,000 & 4,000 & 3,999 & 4,000 & 4,000 & 3,999 & 3,999 \\
\hline WO & 2,340 & 2,213 & 2,040 & 2,390 & 1,660 & 1,840 & 1,630 & 3,280 & 1,290 & 2,050 & 1,170 & 1,680 & 1,820 & 3,030 \\
\hline $\mathrm{EN}$ & 62,19 & 62,75 & 64,62 & 63,29 & 63,44 & 40,91 & 41,38 & 40,71 & 59,09 & 59,78 & 60,61 & 59,06 & 58,94 & 60,77 \\
\hline$F S$ & 35,47 & 35,04 & 33,34 & 34,32 & 34,90 & 57,25 & 56,99 & 56,01 & 39,62 & 38,17 & 38,22 & 39,26 & 39,24 & 36,20 \\
\hline $\mathrm{Fe} / \mathrm{Fe}+\mathrm{Mg}$ & 0,352 & 0,347 & 0,334 & 0,344 & 0,346 & 0,563 & 0,565 & 0,562 & 0,394 & 0,382 & 0,379 & 0,388 & 0,389 & 0,365 \\
\hline $\mathrm{Mg} / \mathrm{Mg}+\mathrm{Fe}$ & 0,648 & 0,653 & 0,666 & 0,656 & 0,654 & 0,437 & 0.435 & 0,438 & 0,606 & 0,618 & 0,621 & 0,612 & 0,611 & 0,635 \\
\hline
\end{tabular}


Tabela 6.2 - Análises químicas de clinopiroxênios das rochas da borda do Maciço de Venda Nova

\begin{tabular}{|c|c|c|c|c|c|c|c|c|c|}
\hline \multicolumn{10}{|c|}{ Noritos } \\
\hline Amostras & VN 3.1 & VN 3.2 & VN 3.3 & VN 14.1 & VN 14.2 & VN 14.3 & VN 11.1 & VN 11.3 & VN 11.4 \\
\hline $\mathrm{SiO} 2$ & 50,71 & 50,77 & 51,56 & 51,97 & 51,75 & 51,52 & 51,32 & 51,07 & 51,20 \\
\hline $\mathrm{TiO} 2$ & 0,27 & 0,05 & 0,16 & 0,38 & 0,17 & 0,18 & 0,15 & 0,25 & 0,27 \\
\hline $\mathrm{Al} 2 \mathrm{O} 3$ & 1,57 & 1,53 & 1,56 & 1,57 & 1,41 & 1,56 & 1,69 & 1,50 & 1,33 \\
\hline $\mathrm{Cr} 2 \mathrm{O} 3$ & 0,09 & 0,07 & 0,06 & 0,00 & 0,00 & 0,01 & 0,00 & 0,00 & 0,00 \\
\hline $\mathrm{FeO}$ & 10,06 & 11,55 & 10,83 & 8,99 & 9,45 & 10,03 & 10,08 & 11,73 & 11,97 \\
\hline $\mathrm{MnO}$ & 0,31 & 0,28 & 0,40 & 0,34 & 0,37 & 0,32 & 0,31 & 0,37 & 0,30 \\
\hline $\mathrm{MgO}$ & 12,08 & 12,15 & 12,04 & 13,82 & 12,94 & 14,16 & 12,51 & 12,25 & 13,09 \\
\hline $\mathrm{NiO}$ & 0,04 & 0,11 & 0,00 & 0,00 & 0,00 & 0,00 & 0,09 & 0,11 & 0,05 \\
\hline $\mathrm{CaO}$ & 23,90 & 22,33 & 22,39 & 23,42 & 23,64 & 22,30 & 23,21 & 22,73 & 21,94 \\
\hline $\mathrm{Na} 2 \mathrm{O}$ & 0,31 & 0,39 & 0,24 & 0,23 & 0,30 & 0,26 & 0,33 & 0,23 & 0.24 \\
\hline $\mathrm{K} 2 \mathrm{O}$ & 0,00 & 0,03 & 0,00 & 0,01 & 0,00 & 0,00 & 0,01 & 0,04 & 0,01 \\
\hline $\mathrm{BaO}$ & 0,22 & 0,00 & 0,26 & 0,11 & 0,00 & 0,00 & 0,00 & 0,07 & 0,11 \\
\hline Total & 99,56 & 99.26 & 99,50 & 100,84 & 100,03 & 100,34 & 99,70 & 100,35 & 100,51 \\
\hline \multicolumn{10}{|c|}{ Número de ions na base de 6 átomos de oxigênio } \\
\hline TSi & 1,918 & 1,925 & 1,957 & 1,924 & 1,935 & 1,914 & 1,930 & 1,921 & 1,918 \\
\hline TAl & 0,070 & 0,068 & 0,043 & 0,068 & 0,062 & 0,068 & 0,070 & 0,066 & 0,059 \\
\hline TFe3 & 0,012 & 0,006 & 0,000 & 0,008 & 0,003 & 0,018 & 0,000 & 0,013 & 0,023 \\
\hline $\mathrm{M} 1 \mathrm{Al}$ & 0,000 & 0,000 & 0,027 & 0,000 & 0,000 & 0,000 & 0,005 & 0,000 & 0,000 \\
\hline $\mathrm{M} T \mathrm{Ti}$ & 0,008 & 0,001 & 0,005 & 0,011 & 0,005 & 0,005 & 0,004 & 0,007 & 0,008 \\
\hline$M F \mathrm{~F} 3$ & 0,086 & 0,100 & 0,022 & 0,072 & 0,077 & 0,094 & 0,081 & 0,083 & 0,084 \\
\hline $\mathrm{M} 1 \mathrm{Fe} 2$ & 0,220 & 0,207 & 0,263 & 0,155 & 0,197 & 0,116 & 0,206 & 0,219 & 0,175 \\
\hline $\mathrm{M} 1 \mathrm{C}_{\mathrm{I}}$ & 0,003 & 0,002 & 0,002 & 0,000 & 0,000 & 0,000 & 0,000 & 0,000 & 0,000 \\
\hline $\mathrm{M} \mathbb{M g}$ & 0,681 & 0,687 & 0,681 & 0,763 & 0,721 & 0,784 & 0,701 & 0,687 & 0,731 \\
\hline$M \mathbb{N} i$ & 0,001 & 0,003 & 0,000 & 0,000 & 0,000 & 0,000 & 0,003 & 0,003 & 0,002 \\
\hline $\mathrm{M} 2 \mathrm{Fe} 2$ & 0,000 & 0,054 & 0,059 & 0,044 & 0,019 & 0,084 & 0,030 & 0,054 & 0,092 \\
\hline M2Mn & 0,010 & 0,009 & 0,013 & 0,011 & 0,012 & 0,010 & 0,010 & 0,012 & 0,010 \\
\hline $\mathrm{M} 2 \mathrm{Ca}$ & 0,969 & 0,907 & 0,911 & 0,929 & 0,947 & 0,888 & 0,935 & 0,916 & 0,881 \\
\hline $\mathrm{M} 2 \mathrm{Na}$ & 0,023 & 0,029 & 0,018 & 0,017 & 0,022 & 0,019 & 0,024 & 0,017 & 0,017 \\
\hline $\mathrm{M} 2 \mathrm{~K}$ & 0,000 & 0,001 & 0,000 & 0,000 & 0,000 & 0,000 & 0,000 & 0,002 & 0,000 \\
\hline Sumcat & 4,000 & 3,999 & 4,000 & 4,000 & 4,000 & 4,000 & 4,000 & 3,998 & 4,000 \\
\hline wo & 48,97 & 46,07 & 46,73 & 46,90 & 47,94 & 44,52 & 47,63 & 46,18 & 44,12 \\
\hline EN & 34,44 & 34,88 & 34,97 & 38,50 & 36,51 & 39,34 & 35,72 & 34,63 & 36,62 \\
\hline FS & 16,59 & 19,05 & 18,30 & 14,60 & 15,55 & 16,14 & 16,65 & 19,19 & 19,26 \\
\hline $\mathrm{Fe} / \mathrm{Fe}+\mathrm{Mg}$ & 0,318 & 0,348 & 0,336 & 0,268 & 0,291 & 0,285 & 0,311 & 0,349 & 0,339 \\
\hline $\mathrm{Mg} / \mathrm{Mg}+\mathrm{Fe}$ & 0,682 & 0,652 & 0,664 & 0,732 & 0,709 & 0,715 & 0,689 & 0,651 & 0,661 \\
\hline
\end{tabular}


Tabela 6.2 - Continuação

Charnoguitóides

\begin{tabular}{|c|c|c|c|c|c|c|c|c|c|c|c|c|c|c|}
\hline \multicolumn{15}{|c|}{ Charnoquitóides } \\
\hline Amostras & VN23.1 & VN 23.2 & VN 23.3 & VN 16.1 & VN 16.2 & VN 16.3 & VN 18.1 & VN 18.2 & VN 18.3 & VN 27.1 & VN 27.2 & VN 35.1 & $\mathrm{VNN} 35.2$ & $\mathrm{VN} 35.3 *$ \\
\hline $\mathrm{SiO} 2$ & 51,79 & 51,71 & 51,58 & 52,23 & 52,07 & 51,63 & 52,11 & 51,74 & 51,49 & 49,74 & 50,29 & 51,56 & 51,68 & 51,98 \\
\hline $\mathrm{TiO} 2$ & 0,10 & 0,31 & 0,15 & 0,08 & 0,07 & 0,00 & 0,23 & 0,20 & 0,12 & 0,18 & 0.24 & 0,24 & 0,27 & 0,16 \\
\hline $\mathrm{Al} 2 \mathrm{O} 3$ & 1,52 & 1,59 & 1,41 & 1,37 & 1,55 & 1,53 & 1,59 & 1,43 & 1,58 & 1,23 & 1,28 & 1,59 & 1,57 & 1,60 \\
\hline $\mathrm{Cr} 2 \mathrm{O} 3$ & 0,03 & 0,00 & 0,04 & 0,02 & 0,03 & 0,00 & 0,02 & 0,00 & 0,00 & 0,00 & 0,00 & 0,05 & 0,00 & 0,01 \\
\hline $\mathrm{FeO}$ & 9,25 & 8,92 & 9,55 & 9,15 & 8,92 & 7,86 & 8,78 & 9,42 & 9,94 & 13,93 & 14,25 & 10,89 & 10,87 & 9,13 \\
\hline $\mathrm{MnO}$ & 0,38 & 0,30 & 0,38 & 0,37 & 0,32 & 0,37 & 0,42 & 0,32 & 0,49 & 0,97 & 0,78 & 0,37 & 0,31 & 0.28 \\
\hline $\mathrm{MgO}$ & 14,63 & 14,35 & 14,66 & 14,33 & 13,91 & 13,90 & 13,18 & 13,78 & 13,14 & 10,05 & 10,03 & 12,95 & 12,88 & 13,26 \\
\hline $\mathrm{NiO}$ & 0,14 & 0,00 & 0,10 & 0,06 & 0,10 & 0,00 & 0,06 & 0,02 & 0,00 & 0,05 & 0,15 & 0,00 & 0,00 & 0,01 \\
\hline $\mathrm{CaO}$ & 22,52 & 22,61 & 22,18 & 22,81 & 23,12 & 23,93 & 22,92 & 22,50 & 22,40 & 22,03 & 22,25 & 22,21 & 22,20 & 23,08 \\
\hline $\mathrm{Na} 2 \mathrm{O}$ & 0,29 & 0,47 & 0,29 & 0,29 & 0,35 & 0,29 & 0,24 & 0,36 & 0,27 & 0,36 & 0,31 & 0,29 & 0,19 & 0,31 \\
\hline $\mathrm{K} 2 \mathrm{O}$ & 0,03 & 0,00 & 0,01 & 0,05 & 0,00 & 0,01 & 0,02 & 0,00 & 0,01 & 0,00 & 0,00 & 0,03 & 0,01 & 0,02 \\
\hline $\mathrm{BaO}$ & 0,11 & 0,00 & 0,00 & 0,00 & 0,00 & 0,00 & 0,26 & 0,22 & 0,17 & 0,00 & 0,00 & 0,13 & 0,00 & 0,00 \\
\hline Total & 100,79 & 100,26 & 100,35 & 100,76 & 100,44 & 99,52 & 99,83 & 99,99 & 99,61 & 98,54 & 99,58 & 100,31 & 99,98 & 99,84 \\
\hline \multicolumn{15}{|c|}{ Número de ions na base de 6 atomos de oxigênio } \\
\hline$T S_{i}$ & 1,911 & 1,914 & 1,911 & 1,928 & 1.929 & 1,926 & 1,955 & 1,933 & 1,938 & 1,929 & 1,933 & 1,932 & 1.942 & 1,943 \\
\hline TAl & 0,066 & 0,069 & 0,062 & 0,060 & 0,068 & 0,067 & 0,045 & 0,063 & 0,062 & 0,056 & 0,058 & 0,068 & 0,058 & 0,057 \\
\hline TFe3 & 0,023 & 0,017 & 0,028 & 0,012 & 0,003 & 0,007 & 0,000 & 0,004 & 0,000 & 0,014 & 0,009 & 0,000 & 0,000 & 0,000 \\
\hline $\mathrm{M} \mid \mathrm{Al}$ & 0,000 & 0,000 & 0,000 & 0,000 & 0,000 & 0,000 & 0,025 & 0,000 & 0,008 & 0,000 & 0,000 & 0,002 & 0,011 & 0,014 \\
\hline $\mathrm{M} 1 \mathrm{Ti}$ & 0,003 & 0,009 & 0,004 & 0,002 & 0,002 & 0,000 & 0,006 & 0,006 & 0,003 & 0,005 & 0,007 & 0,007 & 0,008 & 0,004 \\
\hline $\mathrm{MIFe} 3$ & 0,104 & 0,102 & 0,101 & 0,090 & 0,091 & 0,096 & 0,024 & 0,082 & 0,068 & 0,087 & 0,076 & 0,074 & 0,046 & 0,057 \\
\hline $\mathrm{M} F \mathrm{Fe} 2$ & 0,083 & 0,097 & 0,081 & 0,117 & 0,335 & 0,131 & 0,204 & 0,144 & 0,184 & 0.325 & 0,338 & 0,193 & 0,214 & 0,185 \\
\hline $\mathrm{M} 1 \mathrm{Cr}$ & 0,001 & 0,000 & 0,001 & 0,001 & 0,001 & 0,000 & 0,001 & 0,000 & 0,000 & 0,000 & 0,000 & 0,001 & 0,000 & 0,000 \\
\hline $\mathrm{MlMg}$ & 0,805 & 0,792 & 0,810 & 0,789 & 0,768 & 0,773 & 0,737 & 0,767 & 0,737 & 0,581 & 0,575 & 0,723 & 0,721 & 0,739 \\
\hline $\mathrm{MNN}$ & 0,004 & 0,000 & 0,003 & 0,002 & 0,003 & 0,000 & 0,002 & 0,001 & 0,000 & 0,002 & 0,005 & 0,000 & 0,000 & 0,000 \\
\hline $\mathrm{M} 2 \mathrm{Fe} 2$ & 0,076 & 0,060 & 0,086 & 0,063 & 0.047 & 0,011 & 0,047 & 0,063 & 0,061 & 0,025 & 0,035 & 0,074 & 0.082 & 0,043 \\
\hline M2Mn & 0,012 & 0,009 & 0,012 & 0,012 & 0,010 & 0,012 & 0,013 & 0,010 & 0,016 & 0,032 & 0,025 & 0,012 & 0,010 & 0,009 \\
\hline $\mathrm{M} 2 \mathrm{Ca}$ & 0,890 & 0,897 & 0,880 & 0,902 & 0,918 & 0,956 & 0,921 & 0,900 & 0,903 & 0,916 & 0,916 & 0,891 & 0,894 & 0,924 \\
\hline $\mathrm{M} 2 \mathrm{Na}$ & 0,021 & 0,034 & 0,021 & 0,021 & 0,025 & 0,021 & 0,017 & 0,026 & 0,020 & 0,027 & 0,023 & 0,021 & 0,014 & 0,022 \\
\hline M2K & 0,001 & 0,000 & 0,000 & 0,002 & 0,000 & 0,000 & 0,001 & 0,000 & 0,000 & 0,000 & 0,000 & 0,001 & 0,000 & 0,001 \\
\hline Sumcat & 3,999 & 4,000 & 4,000 & 3,998 & 4,000 & 4,000 & 3,999 & 4,000 & 4,000 & 4,000 & 4,000 & 3,999 & 4,000 & 3,999 \\
\hline WO & 44,69 & 45,42 & 44,07 & 45,45 & 46,53 & 48,15 & 47,31 & 45,66 & 45,88 & 46,23 & 46,41 & 45,31 & 45,44 & 47,22 \\
\hline EN & 40,39 & 40,11 & 40,53 & 39,73 & 38,95 & 38,92 & 37,86 & 38,91 & 37,44 & 29,34 & 29,11 & 36,76 & 36,69 & 37,75 \\
\hline FS & 34,92 & 14,47 & 15,40 & 14,82 & 14,52 & 12,93 & 14,83 & 15,43 & 16,68 & 24,43 & 24,48 & 17,93 & 17,87 & 15,03 \\
\hline $\mathrm{Fe} / \mathrm{Fe}+\mathrm{Mg}$ & 0,262 & 0,259 & 0,268 & 0,263 & 0,264 & 0,241 & 0,272 & 0,276 & 0,298 & 0.437 & 0,443 & 0,321 & 0,322 & 0,278 \\
\hline $\mathrm{Mg} / \mathrm{Mg}+\mathrm{Fe}$ & 0,738 & 0,741 & 0,732 & 0,737 & 0,736 & 0,759 & 0,728 & 0,724 & 0,702 & 0,563 & 0,557 & 0,679 & 0,678 & 0,722 \\
\hline
\end{tabular}


Tabela 6.3 - Análises químicas de anfibólios das rochas da borda do Maciço de Venda Nova

\begin{tabular}{|c|c|c|c|c|c|c|c|c|c|c|c|c|c|}
\hline \multirow[b]{2}{*}{ Amostras } & \multicolumn{2}{|c|}{ (4) } & \multicolumn{2}{|c|}{ Noritos } & \multicolumn{2}{|c|}{ > } & \multicolumn{2}{|c|}{ 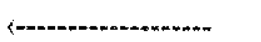 } & \multicolumn{3}{|c|}{ Charnoquitóides } & \multicolumn{2}{|c|}{ 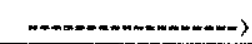 } \\
\hline & VN 3.1* & $\mathrm{VN} 3.3$ & VN 3.3 & VN 11.1 & VN 11.2 & VN 11.3 & VN 35.1 & VN 35.2 & VN 35.3 & VN 18.1 & VN 18.2 & VN 27.1 & VN 27.2 \\
\hline $\mathrm{SiO} 2$ & 43,90 & 44,17 & 44,22 & 42,62 & 43,70 & 43,54 & 45,20 & 43,37 & 44,56 & 44,43 & 45,05 & 41,23 & 41,11 \\
\hline $\mathrm{TiO}_{2}$ & 1,79 & 2,00 & 1,45 & 1,75 & 1,89 & 1,42 & 2,01 & 1,82 & 1,91 & 1,85 & 1,63 & 1,64 & 1,45 \\
\hline $\mathrm{Al} 2 \mathrm{O} 3$ & 10,09 & 10,40 & 9,86 & 10,74 & 10,39 & 10,81 & 9,33 & 9,92 & 9,34 & 9,28 & 9,73 & 10,93 & 10,83 \\
\hline $\mathrm{C} 22 \mathrm{O} 3$ & 0,02 & 0,05 & 0,00 & 0,02 & 0,03 & 0,06 & 0,03 & 0,02 & 0,02 & 0,00 & 0.06 & 0,02 & 0,01 \\
\hline $\mathrm{FeO}$ & 16,14 & 16,77 & 16,29 & 16,18 & 16,20 & 16,37 & 14,53 & 14,16 & 14,03 & 13,98 & 13,93 & 20,95 & 20,39 \\
\hline $\mathrm{MnO}$ & 0,22 & 0,19 & 0,25 & 0,33 & 0,20 & 0,19 & 0,25 & 0,33 & 0,30 & 0,23 & 0,31 & 0,61 & 0,61 \\
\hline $\mathrm{MgO}$ & 11,25 & 10,96 & 11,51 & 11,17 & 11,29 & 11,11 & 13,21 & 12,79 & 13,13 & 12,94 & 12,95 & 8,27 & 8,42 \\
\hline $\mathrm{CaO}$ & 11,63 & 11,66 & 11,93 & 12,13 & 11,69 & 12,08 & 11,86 & 12,32 & 11,94 & 11,88 & 12,17 & 11,60 & 11,45 \\
\hline $\mathrm{Na} 2 \mathrm{O}$ & 1,31 & 1,28 & 1,10 & 1,16 & 1,19 & 1,15 & 1,19 & 0,90 & 1,17 & 1,21 & 1,02 & 1,16 & 1,18 \\
\hline $\mathrm{K} 2 \mathrm{O}$ & 0,84 & 0,89 & 0,77 & 1,29 & 1,24 & 1,38 & 1,12 & 1,36 & 1,14 & 1,03 & 1,11 & 1,47 & 1,34 \\
\hline $\mathrm{F}$ & 0,00 & 0,07 & 0,36 & 0,25 & 0,46 & 0,27 & 0,34 & 0,21 & 0,00 & 0,34 & 0,05 & 0,24 & 0,00 \\
\hline $\mathrm{Cl}$ & 0,07 & 0,11 & 0,06 & 0,15 & 0,10 & 0,10 & 0,05 & 0,01 & 0,04 & 0,00 & 0,05 & 0,12 & 0,13 \\
\hline Total & 97,26 & 98,55 & 97,80 & 97,79 & 98,38 & 98,48 & 99,12 & 97,01 & 97,58 & 97,17 & 98,06 & 98,24 & 96,92 \\
\hline $\mathrm{O}_{-} \mathrm{F}_{-} \mathrm{Cl}$ & 0,02 & 0,05 & 0,17 & 0,14 & 0,22 & 0,14 & 0,15 & 0,09 & 0,01 & 0,14 & 0,03 & 0,13 & 0,03 \\
\hline $\mathrm{O}_{-}^{-} \mathrm{F}$ & 0,00 & 0,03 & 0,15 & 0,11 & 0,19 & 0,11 & 0,14 & 0,09 & 0,00 & 0,14 & 0,02 & 0,10 & 0,00 \\
\hline $\mathrm{O}^{-} \mathrm{C}$ & 0,02 & 0,02 & 0,01 & 0,03 & 0,02 & 0,02 & 0,01 & 0,00 & 0,01 & 0,00 & 0,01 & 0,03 & 0,03 \\
\hline \multicolumn{14}{|c|}{ Número de ions na base de 23 átomos de oxigênio } \\
\hline TSi & 6,548 & 6,525 & 6,563 & 6,377 & 6,493 & 6,465 & 6,580 & 6,433 & 6,567 & 6,595 & 6,601 & 6,277 & 6,308 \\
\hline TAl & 1,452 & 1,475 & 1,437 & 1,623 & 1,507 & 1,535 & 1,420 & 1,577 & 1,433 & 1,405 & 1,399 & 1,723 & 1,692 \\
\hline $\operatorname{Sum} T$ & 8,000 & 8,000 & 8,000 & 8,000 & 8,000 & 8,000 & 8,000 & 8,000 & 8,000 & 8,000 & 8,000 & 8,000 & 8,000 \\
\hline CA1 & 0,320 & 0,335 & 0,286 & 0,269 & 0,311 & 0,355 & 0,180 & 0,179 & 0,188 & 0,217 & 0,281 & 0,237 & 0,265 \\
\hline $\mathrm{CCr}$ & 0,002 & 0,006 & 0,000 & 0,002 & 0,004 & 0,007 & 0,003 & 0,002 & 0,002 & 0,000 & 0,007 & 0,002 & $0,00 \mathrm{I}$ \\
\hline $\mathrm{CFe} 3$ & 0,340 & 0,320 & 0,475 & 0,435 & 0,340 & 0,347 & 0,412 & 0,531 & 0,393 & 0,349 & 0,350 & 0,595 & 0,604 \\
\hline $\mathrm{CTi}$ & 0,201 & 0,222 & 0,162 & 0,197 & 0,211 & 0,159 & 0,220 & 0,203 & 0,212 & 0,207 & 0,180 & 0,188 & 0,167 \\
\hline $\mathrm{CMg}$ & 2,502 & 2,414 & 2,547 & 2,491 & 2,501 & 2,459 & 2,867 & 2,833 & 2,885 & 2,863 & 2,829 & 1,877 & 1,926 \\
\hline $\mathrm{CF}$ 2 & 1,621 & 1,692 & 1,515 & 1,585 & 1,621 & 1,661 & 1,302 & 1,228 & 1,302 & 1,349 & 1,335 & 2,062 & 1,997 \\
\hline $\mathrm{CMn}$ & 0,014 & 0,012 & 0,016 & 0,021 & 0,013 & 0,012 & 0,015 & 0,023 & 0,019 & 0,014 & 0,019 & 0,039 & 0,039 \\
\hline SumC & 5,000 & 5,000 & 5,000 & 5,000 & 5,000 & 5,000 & 5,000 & 5,000 & 5,000 & 5,000 & 5,000 & 5,000 & 5,000 \\
\hline $\mathrm{BFe} 2$ & 0,052 & 0,060 & 0,032 & 0,005 & 0,052 & 0,024 & 0,055 & 0,000 & 0,035 & 0,037 & 0,022 & $0,01\}$ & 0,015 \\
\hline $\mathrm{BMa}$ & 0,014 & 0,012 & 0,016 & 0,021 & 0,013 & 0,012 & 0,015 & 0,018 & 0,019 & 0,015 & 0,019 & 0,039 & 0,040 \\
\hline $\mathrm{CaB}$ & 1,859 & 1,846 & 1,897 & 1,944 & 1,861 & 1,922 & 1,850 & 1,961 & 1,885 & 1,889 & 1,911 & 1,892 & 1,882 \\
\hline $\mathrm{NaB}$ & 0,075 & 0,082 & 0,055 & 0,030 & 0,074 & 0,042 & 0,080 & 0,021 & 0,061 & 0,059 & 0,048 & 0,058 & 0,063 \\
\hline SumB & 2,000 & 2,000 & 2,000 & 2,000 & 2,000 & 2,000 & 2,000 & 2,000 & 2,000 & 2,000 & 2,000 & 2,000 & 2,000 \\
\hline $\mathrm{ANa}$ & 0,303 & 0,284 & 0,262 & 0,307 & 0,269 & 0,289 & 0,256 & 0,238 & 0,273 & 0,289 & 0.242 & 0,285 & 0,288 \\
\hline $\mathrm{AK}$ & 0,160 & 0,168 & 0,146 & 0,246 & 0,235 & 0,261 & 0,208 & 0,220 & 0,214 & 0,195 & 0,208 & 0,286 & 0,262 \\
\hline SumA & 0,463 & 0,452 & 0,407 & 0,553 & 0,504 & 0,551 & 0,464 & 0,458 & 0,487 & 0,484 & 0,450 & 0,570 & 0,551 \\
\hline $\mathrm{CCl}$ & 0,018 & 0,028 & 0,015 & 0,038 & 0,025 & 0,025 & 0,012 & 0,003 & 0,010 & 0,000 & 0,012 & 0,031 & 0,034 \\
\hline$C F$ & 0,000 & 0,033 & 0,169 & 0,118 & 0,216 & 0,127 & 0,157 & 0,099 & 0,000 & 0,160 & 0,023 & 0,116 & 0,000 \\
\hline $\mathrm{Fe} / \mathrm{Fe}+\mathrm{Mg}$ & 0,446 & 0,462 & 0,443 & 0,448 & 0,446 & 0,452 & 0,382 & 0,383 & 0,375 & 0,377 & 0,376 & 0,587 & 0,576 \\
\hline $\mathrm{M}_{g} \mathrm{Mg}_{\mathrm{g}}+\mathrm{Fe}$ & 0,554 & 0,538 & 0,557 & 0,552 & 0,554 & 0,548 & 0,618 & 0,617 & 0,625 & 0,623 & 0,624 & 0,413 & 0,424 \\
\hline
\end{tabular}


Tabela 6.4 - Análises químicas de biotitas das rochas da borda do Maciço de Venda Nova

\begin{tabular}{|c|c|c|c|c|c|c|c|c|c|c|c|c|}
\hline \multirow{3}{*}{ Amostras } & \multirow{3}{*}{$\begin{array}{c}\text { VN } \\
11.1^{*}\end{array}$} & \multirow{3}{*}{$\begin{array}{c}\text { Noritos } \\
\mathrm{VN} \\
11.2 \\
\end{array}$} & \multirow{3}{*}{$\begin{array}{c}\cdots \cdots \\
\mathrm{VN} \\
\mathbf{1 1 . 3}\end{array}$} & \multicolumn{3}{|c|}{ (1)- } & \multicolumn{3}{|c|}{ Charnoquitóides } & \multicolumn{3}{|c|}{ nom } \\
\hline & & & & $\mathbf{V N}$ & $\mathbf{V N}$ & $\mathrm{VN}$ & VN & VN & VN & VN & VN & $\mathbf{V N}$ \\
\hline & & & & 35.1 & 35.2 & 35.3 & 18.1 & $18.2 *$ & 18.3 & 27.1 & 27.2 & $27.3^{*}$ \\
\hline $\mathrm{SiO} 2$ & 35,73 & 36,04 & 36,14 & 36,78 & 35,73 & 36,04 & 36,74 & 36,77 & 37,27 & 35,01 & 34,86 & 35,13 \\
\hline $\mathrm{TiO} 2$ & 6,06 & 5,01 & 5,09 & 5,41 & 4,94 & 5,59 & 5,13 & 4,91 & 4,94 & 4,91 & 5,58 & 4,74 \\
\hline $\mathrm{A} 12 \mathrm{O} 3$ & 14,44 & 14,66 & 14,53 & 14,39 & 14,59 & 14,32 & 14,44 & 14,57 & 14,35 & 14,10 & 14,23 & 14,00 \\
\hline $\mathrm{Cr} 2 \mathrm{O} 3$ & 0,08 & 0,02 & 0,01 & 0,02 & 0,00 & 0,01 & 0,04 & 0,02 & 0,00 & 0,02 & 0,06 & 0,00 \\
\hline $\mathrm{MnO}$ & 0,10 & 0,12 & 0,07 & 0,16 & 0,08 & 0,07 & 0,13 & 0,09 & 0,22 & 0,29 & 0,36 & 0,27 \\
\hline $\mathrm{FeO}$ & 17,36 & 18,17 & 17,78 & 16,13 & 16,09 & 15,44 & 15,33 & 14,66 & 15,26 & 21,94 & 21,96 & 21,63 \\
\hline $\mathrm{MgO}$ & 12,02 & 12,28 & 12,40 & 14,25 & 14,34 & 14,06 & 14,17 & 14,38 & 14,08 & 9,41 & 9,28 & 9,61 \\
\hline $\mathrm{Na}_{2} \mathrm{O}$ & 0,10 & 0,00 & 0,09 & 0,04 & 0,03 & 0,08 & 0,08 & 0,06 & 0,00 & 0,15 & 0,00 & 0,05 \\
\hline $\mathrm{K} 2 \mathrm{O}$ & 9,63 & 9,90 & 9,62 & 9,95 & 9,85 & 9,96 & 9,98 & 9,88 & 10,05 & 9,47 & 9,52 & 9,52 \\
\hline $\bar{F}$ & 0,17 & 0,20 & 0,29 & 0,00 & 0,34 & 0,25 & 0,00 & 0,23 & 0,27 & 0,28 & 0,07 & 0,28 \\
\hline $\mathrm{Cl}$ & 0,14 & 0,07 & 0,08 & 0,03 & 0,02 & 0,02 & 0,03 & 0,04 & 0,06 & 0,14 & 0,13 & 0,11 \\
\hline Total & 95,83 & 96,47 & 96,10 & 97,16 & 96,01 & 95,84 & 96,07 & 95,61 & 96,50 & 95,72 & 96,05 & 95,34 \\
\hline $\mathrm{OFCl}$ & 0,10 & 0,10 & 0,14 & 0,01 & 0,15 & 0,11 & 0,01 & 0,11 & 0,13 & 0,15 & 0,06 & 0,14 \\
\hline \multicolumn{13}{|c|}{ Número de ions na base de 22 átomos de oxigênio } \\
\hline $\mathrm{Si}$ & 5,669 & 5,698 & 5,722 & 5,700 & 5,632 & 5,670 & 5,738 & 5,759 & 5,804 & 5,704 & 5,649 & 5,734 \\
\hline AlIV & 2,331 & 2,302 & 2,278 & 2,300 & 2,368 & 2,330 & 2,262 & 2,241 & 2,196 & 2,296 & 2,351 & 2,266 \\
\hline AlVI & 0,367 & 0,427 & 0,431 & 0,326 & 0,341 & 0,323 & 0,394 & 0,446 & 0,436 & 0,409 & 0,365 & 0,425 \\
\hline $\mathrm{Ti}$ & 0,723 & 0,596 & 0,606 & 0,631 & 0,586 & 0,662 & 0,603 & 0,578 & 0,579 & 0,602 & 0,680 & 0,582 \\
\hline $\mathrm{Fe} 2$ & 2,303 & 2,402 & 2,354 & 2,090 & 2,121 & 2,032 & 2,002 & 1,920 & 1,987 & 2,989 & 2,976 & 2,953 \\
\hline $\mathrm{Cr}$ & 0,010 & 0,002 & 0,001 & 0,002 & 0,000 & 0,001 & 0,005 & 0,002 & 0,000 & 0,003 & 0,008 & 0,000 \\
\hline $\mathrm{Mn}$ & 0,013 & 0,016 & 0,009 & 0,021 & 0,011 & 0,009 & 0,017 & 0,012 & 0,029 & 0,040 & 0,049 & 0,037 \\
\hline $\mathrm{Mg}$ & 2,843 & 2,894 & 2,927 & 3,292 & 3,370 & 3,298 & 3,299 & 3,358 & 3,269 & 2,286 & 2,242 & 2,338 \\
\hline $\mathrm{Na}$ & 0,031 & 0,000 & 0,028 & 0,012 & 0,009 & 0,024 & 0,024 & 0,018 & 0,000 & 0,047 & 0,000 & 0,016 \\
\hline $\mathrm{K}$ & 1,949 & 1,997 & 1,943 & 1,967 & 1,981 & 1,999 & 1,988 & 1,974 & 1,997 & 1,968 & 1,968 & 1,982 \\
\hline $\mathrm{CF}$ & 0,171 & 0,200 & 0,290 & 0,000 & 0,339 & 0,249 & 0,000 & 0,228 & 0,266 & 0,289 & 0,072 & 0,289 \\
\hline $\mathrm{CCl}$ & 0,075 & 0,038 & 0,043 & 0,016 & 0,011 & 0,011 & 0,016 & 0,021 & 0,032 & 0,077 & 0,071 & 0,061 \\
\hline $\mathrm{Fe} / \mathrm{Fe}+\mathrm{Mg}$ & 0,447 & 0,453 & 0,446 & 0,388 & 0,386 & 0,381 & 0,378 & 0,364 & 0,378 & 0,566 & 0,570 & 0,558 \\
\hline $\mathrm{Mg} / \mathrm{Mg}+\mathrm{Fe}$ & 0.552 & 0,546 & 0,554 & 0,612 & 0.614 & 0,619 & 0,622 & 0.636 & 0,622 & 0,434 & 0,430 & 0,442 \\
\hline
\end{tabular}

(*) Corresponde à média de duas análises muito semelhantes 
Tabela 6.5 - Análises químicas de megacristais e microfenocristais de plagioclásio das rochas da borda do Maciço de Venda Nova

\begin{tabular}{|c|c|c|c|c|c|c|c|c|c|c|c|}
\hline \multicolumn{12}{|c|}{ Charnoquitóides } \\
\hline Amostras & $\begin{array}{r}\mathrm{VN} \\
27.1 \mathrm{~b} \\
\end{array}$ & VN 27.2 & $\begin{array}{r}\mathbf{V N} \\
27.3 \mathrm{n} \\
\end{array}$ & $\begin{array}{c}\mathrm{VN} \\
27.4 \mathrm{~b}\end{array}$ & VN23.1 & VN23,2 & VN16.1 & $\mathrm{VN} 16.2$ & VN18.1 & VN18.2 & VN18.3 \\
\hline $\mathrm{SiO} 2$ & 59,12 & 59,28 & 57,91 & 59,46 & 57,33 & 57,71 & 56,51 & 55,90 & 57,38 & 57,62 & 57,61 \\
\hline $\mathrm{Al} 2 \mathrm{O} 3$ & 24,15 & 24,55 & 26,16 & 25,11 & 26,84 & 26,38 & 26,85 & 26,27 & 26,19 & 25,22 & 25,62 \\
\hline $\mathrm{FeO}$ & 0,07 & 0,07 & 0,08 & 0,11 & 0,12 & 0,14 & 0,23 & 0,13 & 0,18 & 0,16 & 0,14 \\
\hline $\mathrm{CaO}$ & 6,84 & 7,39 & 8,60 & 7,71 & 9,16 & 9,02 & 9,70 & 9,16 & 8,63 & 8,22 & 8,45 \\
\hline $\mathrm{Na} 2 \mathrm{O}$ & 8,15 & 7,86 & 7,20 & 7,92 & 7,06 & 6,91 & 6,69 & 6,89 & 6,92 & 6,90 & 7,14 \\
\hline $\mathrm{K} 2 \mathrm{O}$ & 0,51 & 0,41 & 0,36 & 0,42 & 0,32 & 0,31 & 0,37 & 0,33 & 0,47 & 0,60 & 0,49 \\
\hline $\mathrm{BaO}$ & 0,12 & 0,11 & 0,00 & 0,00 & 0,08 & 0,00 & 0,00 & 0,00 & 0,00 & 0,00 & 0,08 \\
\hline $\mathrm{SrO}$ & 0,04 & 0,19 & 0,00 & 0,11 & 0,06 & 0,15 & 0,00 & 0,06 & 0,00 & 0,01 & 0,00 \\
\hline Total & 99,00 & 99,86 & 100,31 & 100,84 & 100,97 & 100,61 & 100,35 & 98,74 & 99,77 & 98,73 & 99,53 \\
\hline \multicolumn{12}{|c|}{ Número de íons na base de 32 átomos de oxigênio } \\
\hline $\mathrm{Si}$ & 10,71 & 10,66 & 10,38 & 10,59 & 10,24 & 10,38 & 10,17 & 10,22 & 10,35 & 10,48 & 10,42 \\
\hline $\mathrm{Al}$ & 5,153 & 5,198 & 5,521 & 5,266 & 5,646 & 5,559 & 5,691 & 5,654 & 5,561 & 5,405 & 5,456 \\
\hline $\mathrm{Fe} 2$ & 0,011 & 0,11 & 0,012 & 0,016 & 0,018 & 0,021 & 0,035 & 0,020 & 0,027 & 0,024 & 0,021 \\
\hline $\mathrm{Ba}$ & 0,009 & 0,008 & 0,000 & 0,000 & 0,006 & 0,000 & 0,000 & 0,000 & 0,000 & 0,000 & 0,006 \\
\hline $\mathrm{Ca}$ & 1,328 & 1,424 & 1,651 & 1,471 & 1,753 & 1,729 & 1,870 & 1,794 & 1,667 & 1,603 & 1,637 \\
\hline $\mathrm{Na}$ & 2,863 & 2,740 & 2,502 & 2,735 & 2,445 & 2,398 & 2,335 & 2,442 & 2,419 & 2,435 & 2,504 \\
\hline $\mathrm{K}$ & 0,118 & 0,094 & 0,082 & 0,095 & 0,073 & 0,071 & 0,085 & 0,077 & 0,108 & 0,139 & 0,113 \\
\hline $\mathrm{Ab}$ & 66,40 & 64,30 & 59,10 & 63,60 & 57,20 & 57,10 & 54,40 & 56,60 & 57,70 & 58,30 & 58,90 \\
\hline An & 30,80 & 33,40 & 39,00 & 34,20 & 41,00 & 41,20 & 43,60 & 41,60 & 39,70 & 38,40 & 38,50 \\
\hline Or & 2,70 & 2,30 & 1,90 & 2,20 & 1,80 & 1,70 & 2,00 & 1,80 & 2,60 & 3,30 & 2,70 \\
\hline
\end{tabular}


Tabela 6.5 - Continuação

\begin{tabular}{|c|c|c|c|c|c|c|c|c|c|c|c|c|c|}
\hline \multirow{3}{*}{ Amostras } & 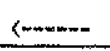 & \multicolumn{2}{|c|}{ Charnoquitóides } & \multirow{3}{*}{$\begin{array}{c}\mathrm{VN} \\
\mathbf{3 5 . 4}\end{array}$} & \multicolumn{3}{|c|}{ sn- } & \multicolumn{3}{|c|}{ Noritos } & \multicolumn{3}{|c|}{ 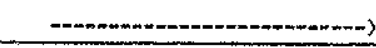 } \\
\hline & $\mathrm{VN}$ & $\mathrm{VN}$ & $\mathrm{VN}$ & & $\mathrm{VN}$ & $\mathrm{VN}$ & $\mathrm{VN}$ & $\mathrm{VN}$ & $\mathrm{VN}$ & VN & $\mathrm{VN}$ & VN & $\mathrm{VN}$ \\
\hline & 35.1 & 35.2 & 35.3 & & 14.1 & 14.2 & $3.1 \mathbf{b}$ & $3.2 \mathrm{~b}$ & $3.3 \mathrm{n}$ & $3.4 \mathrm{n}$ & 11.1 & 11.2 & 11.3 \\
\hline $\mathrm{SiO} 2$ & 57,32 & 58,10 & 56,64 & 56,62 & 45,10 & 45,26 & 50,94 & 52,52 & 48,61 & 47,38 & 51,28 & 49,89 & 50,28 \\
\hline $\mathrm{Al} 2 \mathrm{O} 3$ & 25,63 & 26,01 & 27,05 & 26,87 & 33,37 & 33,47 & 30,33 & 28,40 & 30,90 & 31,89 & 29,76 & 31,33 & 30,60 \\
\hline $\mathrm{FeO}$ & 0,20 & 0,01 & 0,10 & 0,10 & 0,23 & 0,28 & 0,12 & 0,11 & 0,20 & 0,31 & 0,07 & 0,19 & 0,18 \\
\hline $\mathrm{CaO}$ & 8,50 & 8,90 & 9,88 & 9,72 & 18,24 & 18,19 & 13,80 & 11,87 & 15,15 & 16,38 & 13,37 & 15,36 & 14,44 \\
\hline $\mathrm{Na} 2 \mathrm{O}$ & 7,14 & 6,81 & 6,52 & 6,65 & 1,48 & 1,71 & 4,17 & 5,44 & 3,30 & 2,70 & 4,22 & 3,51 & 3,76 \\
\hline $\mathrm{K} 2 \mathrm{O}$ & 0,46 & 0,45 & 0,40 & 0,42 & 0,03 & 0,06 & 0,17 & 0,21 & 0,08 & 0,05 & 0,20 & 0,07 & 0,16 \\
\hline $\mathrm{BaO}$ & 0,04 & 0,08 & 0,03 & 0,04 & 0,12 & 0,05 & 0,00 & 0,09 & 0,09 & 0,00 & 0,00 & 0,12 & 0,00 \\
\hline $\mathrm{SrO}$ & 0,10 & 0,00 & 0,00 & 0,00 & 0,15 & 0,05 & 0,07 & 0,00 & 0,09 & 0,14 & 0,00 & 0,00 & 0,00 \\
\hline Total & 99,39 & 100,36 & 100,62 & 100,43 & 98,72 & 99,07 & 99,60 & 98,64 & 98,42 & 98,85 & 98,90 & 100,47 & 99,42 \\
\hline \multicolumn{14}{|c|}{ Número de íons na base de 32 átomos de oxigêxio } \\
\hline $\mathrm{Si}$ & 10,39 & 10,41 & 10,16 & 10,24 & 8,643 & 8,461 & 9,337 & 9,686 & 9,065 & 8,831 & 9,442 & 9,108 & 9,245 \\
\hline $\mathrm{Al}$ & 5,472 & 5,486 & 5,715 & 5,626 & 7,374 & 7,369 & 6,547 & 6,168 & 6,786 & 7,000 & 6,453 & 6,736 & 6,626 \\
\hline $\mathrm{Fe} 2$ & 0,030 & 0,001 & 0,015 & 0,015 & 0,036 & 0,044 & 0,018 & 0,017 & 0,031 & 0,048 & 0,011 & 0,029 & 0,028 \\
\hline $\mathrm{Ba}$ & 0,003 & 0,006 & 0,002 & 0,003 & 0,009 & 0,004 & 0,000 & 0,007 & 0,007 & 0,000 & 0,000 & 0,009 & 0,000 \\
\hline $\mathrm{Ca}$ & 1,651 & 1,708 & 1,899 & 1,852 & 3,667 & 3,643 & 2,710 & 2,345 & 3,027 & 3,271 & 2,638 & 3,004 & 2,845 \\
\hline $\mathrm{Na}$ & 2,510 & 2,365 & 2,268 & 2,293 & 0,539 & 0,620 & 1,482 & 1,945 & 1,193 & 0,976 & 1,507 & 1,242 & 1,341 \\
\hline $\mathrm{K}$ & 0,106 & 0,103 & 0,092 & 0,095 & 0,007 & 0,014 & 0,040 & 0,049 & 0,019 & 0,012 & 0,047 & 0,016 & 0,038 \\
\hline $\mathrm{Ab}$ & 58,80 & 56,60 & 53,30 & 54,10 & 12,80 & 14,50 & 35,00 & 44,80 & 28,10 & 22,90 & 35,90 & 29,10 & 31,70 \\
\hline An & 38,70 & 40,90 & 44,60 & 43,70 & 87,00 & 85,20 & 64,00 & 54,00 & 71.40 & 76.80 & 62.90 & 70.50 & 67.40 \\
\hline Or & 2.50 & 2.50 & 2.10 & 2.20 & 0.20 & 0.30 & 1.00 & 1.20 & 0.50 & 0.30 & 1.10 & 0.40 & 0.90 \\
\hline
\end{tabular}


Tabela 6.6 - Análises químicas de plagioclásios da matriz das rochas da borda do Maciço de Venda Nova

\begin{tabular}{|c|c|c|c|c|c|c|c|c|c|c|c|c|}
\hline \multicolumn{13}{|c|}{ Charnoquitóides } \\
\hline Amostras & VN27.1b & VN 27.2b & VN 27.3n & VN23.1 & VN23.2 & VN23.3 & VN 16.1b & VN16.2n & VN35.1 & VN 35.2 & VN 18.1 & $\begin{array}{c}\mathrm{VN} \\
18.2\end{array}$ \\
\hline $\mathrm{SiO} 2$ & 59,99 & 59,61 & 57,87 & 57,82 & 56,74 & 57,62 & 58,15 & 56,28 & 57,85 & 56,45 & 58,76 & 57,12 \\
\hline $\mathrm{Al} 2 \mathrm{O} 3$ & 24,49 & 25,13 & 25,87 & 25,81 & 26,21 & 25,62 & 26,07 & 26,45 & 25,74 & 56,83 & 26,07 & 25,84 \\
\hline $\mathrm{FeO}$ & 0,00 & 0,00 & 0,09 & 0,16 & 0,10 & 0,18 & 0,13 & 0,20 & 0,24 & 0,09 & 0,12 & 0,14 \\
\hline $\mathrm{CaO}$ & 6,78 & 7,24 & 8,37 & 8,38 & 8,77 & 8,74 & 8,80 & 9,60 & 8,59 & 9,78 & 8,27 & 8,74 \\
\hline $\mathrm{Na} 2 \mathrm{O}$ & 8,24 & 8,09 & 7,57 & 7,18 & 7,19 & 6,90 & 7,10 & 6,35 & 7,14 & 6,17 & 7,42 & 7,04 \\
\hline $\mathrm{K} 2 \mathrm{O}$ & 0,42 & 0,42 & 0,36 & 0,25 & 0,36 & 0,29 & 0,32 & 0,37 & 0,51 & 0,44 & 0,49 & 0,50 \\
\hline $\mathrm{BaO}$ & 0,00 & 0,00 & 0,00 & 0,08 & 0,00 & 0,12 & 0,01 & 0,07 & 0,00 & 0,16 & 0,00 & 0,00 \\
\hline $\mathrm{SrO}$ & 0,10 & 0,08 & 0,00 & 0,04 & 0,02 & 0,05 & 0,08 & 0,00 & 0,01 & 0,14 & 0,01 & 0,00 \\
\hline Total & 100,02 & 100,57 & 100,13 & 99,72 & 99,39 & 99,52 & 100,66 & 99,32 & 100,08 & 100,06 & 101,14 & 99,38 \\
\hline \multicolumn{13}{|c|}{ Número de ions na base de 32 átomos de oxigênio } \\
\hline $\mathrm{Si}$ & 10,73 & 10,62 & 10,40 & 10,42 & 10,30 & 10,42 & 10,39 & 10,22 & 10,41 & 10,19 & 10,44 & 10,35 \\
\hline $\mathrm{Al}$ & 5,160 & 5,274 & 5,474 & 5,478 & 5,596 & 5,455 & 5,486 & 5,657 & 5,453 & 5,703 & 5,455 & 5,515 \\
\hline $\mathrm{Fe} 2$ & 0,000 & 0,000 & 0,014 & 0,024 & 0,015 & 0,027 & 0,019 & 0,030 & 0,036 & 0,014 & 0,018 & 0,021 \\
\hline $\mathrm{Ba}$ & 0,000 & 0,000 & 0,000 & 0,006 & 0,000 & 0,009 & 0,001 & 0,005 & 0,000 & 0,011 & 0,000 & 0,000 \\
\hline $\mathrm{Ca}$ & 1,300 & 1,382 & 1,611 & 1,618 & 1,703 & 1,693 & 1,685 & 1,868 & 1,656 & 1,891 & 1,574 & 1,697 \\
\hline $\mathrm{Na}$ & 2,858 & 2,795 & 2,637 & 2,509 & 2,527 & 2,419 & 2,460 & 2,236 & 2,491 & 2,159 & 2,556 & 2,474 \\
\hline $\mathrm{K}$ & 0,096 & 0,095 & 0,083 & 0,057 & 0,083 & 0,067 & 0,073 & 0,086 & 0,117 & 0,101 & 0,111 & 0,116 \\
\hline $\mathrm{Ab}$ & 67,20 & 65,40 & 60,90 & 60,00 & 58,60 & 57,90 & 58,30 & 53,40 & 58,40 & 52,00 & 60,30 & 57,70 \\
\hline $\mathrm{An}$ & 30,60 & 32,40 & 37,20 & 38,70 & 39,50 & 40,50 & 39,90 & 44,60 & 38,80 & 45,60 & 37,10 & 39,60 \\
\hline $\mathrm{Or}$ & 2,30 & 2,20 & 1,90 & 1,40 & 1,90 & 1,60 & 1,70 & 2,10 & 2,70 & 2,40 & 2,60 & 270 \\
\hline
\end{tabular}


Tabela 6.6 - Continuação

\begin{tabular}{|c|c|c|c|c|c|c|c|c|c|}
\hline \multicolumn{10}{|c|}{ Noritos } \\
\hline Amostras & $\mathrm{VN} 3.1 \mathrm{~b}$ & VN 3.2 & VN 3.3 & VN 3.4n & VN11.1b & VN 11.2 & VN 11.3n & VN 14.1 & VN 14.2 \\
\hline $\mathrm{SiO} 2$ & 50,56 & 48,16 & 48,83 & 47,25 & 51,38 & 50,44 & 46,88 & 45,27 & 45,78 \\
\hline $\mathrm{Al} 2 \mathrm{O} 3$ & 29,94 & 31,33 & 30,61 & 32,46 & 29,61 & 30,61 & 32,21 & 34,08 & 33,48 \\
\hline $\mathrm{FeO}$ & 0,02 & 0,19 & 0,19 & 0,19 & 0,23 & 0,21 & 0,25 & 0,32 & 0,26 \\
\hline $\mathrm{CaO}$ & 14,11 & 15,78 & 15,36 & 16,79 & 13,41 & 14,69 & 16,62 & 18,37 & 18,23 \\
\hline $\mathrm{Na} 2 \mathrm{O}$ & 4,44 & 3,04 & 3,43 & 2,38 & 4,46 & 3,62 & 2,48 & 1,56 & 1,69 \\
\hline $\mathrm{K} 2 \mathrm{O}$ & 0,13 & 0,10 & 0,10 & 0,05 & 0,16 & 0,16 & 0,09 & 0,04 & 0,05 \\
\hline $\mathrm{BaO}$ & 0,00 & 0,00 & 0,19 & 0,04 & 0,00 & 0,00 & 0,04 & 0,00 & 0,00 \\
\hline $\mathrm{SrO}$ & 0,00 & 0,00 & 0,00 & 0,00 & 0,18 & 0,00 & 0,07 & 0,13 & 0,00 \\
\hline Total & 99,20 & 98,60 & 98,71 & 99,16 & 99,43 & 99,73 & 98,64 & 99,77 & 99,49 \\
\hline \multicolumn{10}{|c|}{ Número de ions na base de 32 átomos de oxigênio } \\
\hline $\mathrm{Si}$ & 9,321 & 8,971 & 9,092 & 8,770 & 9,438 & 9,248 & 8,760 & 8,404 & 8,508 \\
\hline $\mathrm{Al}$ & 6,500 & 6,873 & 6,712 & 7,095 & 6,405 & 6,609 & 7,088 & 7,451 & 7,328 \\
\hline $\mathrm{Fe} 2$ & 0,003 & 0,030 & 0,030 & 0,029 & 0,035 & 0,032 & 0,039 & 0,050 & 0,040 \\
\hline $\mathrm{Ba}$ & 0,000 & 0,000 & 0,014 & 0,003 & 0,000 & 0,000 & 0,003 & 0,000 & 0,000 \\
\hline $\mathrm{Ca}$ & 2,787 & 3,149 & 3,064 & 3,339 & 2,639 & 2,886 & 3,327 & 3,654 & 3,630 \\
\hline $\mathrm{Na}$ & 1,587 & 1,098 & 1,238 & 0,857 & 1,589 & 1,287 & 0,899 & 0,562 & 0,609 \\
\hline $\mathrm{K}$ & 0,031 & 0,024 & 0,024 & 0,012 & 0,037 & 0,037 & 0,021 & 0,009 & 0,012 \\
\hline $\mathrm{Ab}$ & 36,00 & 25,70 & 28,60 & 20,40 & 37,30 & 30,60 & 21,20 & 13,30 & 14,30 \\
\hline An & 63,30 & 73,70 & 70,80 & 79,30 & 61,90 & 68,60 & 78,30 & 86,50 & 85,40 \\
\hline $\mathrm{Or}$ & 0,70 & 0,60 & 0,60 & 0,30 & 0,90 & 0,90 & 0,50 & 0,20 & 0,30 \\
\hline
\end{tabular}


Tabela 6.7 - Análises químicas de feldspatos alcalinos das rochas da borda do Maciço de Venda Nova

\begin{tabular}{lcccccc}
\hline \multicolumn{7}{c}{ Charnoquitóides } \\
\hline Amostras & VN 27.1 & VN 27.2 & VN 27.3 & VN 27.4 & VN 16.1 & VN 16.2 \\
\hline SiO2 & 63,31 & 64,32 & 63,85 & 63,95 & 63,09 & 63,02 \\
$\mathrm{Al} 2 \mathrm{O} 3$ & 18,39 & 18,49 & 18,80 & 18,65 & 18,27 & 18,26 \\
$\mathrm{FeO}$ & 0,09 & 0,09 & 0,01 & 0,01 & 0,00 & 0,08 \\
$\mathrm{Na2O}$ & 1,21 & 1,37 & 1,16 & 1,22 & 0,90 & 0,79 \\
$\mathrm{~K} 2 \mathrm{O}$ & 15,23 & 15,13 & 15,38 & 15,05 & 15,64 & 15,56 \\
$\mathrm{BaO}$ & 0,53 & 0,43 & 0,81 & 0,77 & 0,79 & 1,13 \\
$\mathrm{SrO}$ & 0,08 & 0,00 & 0,02 & 0,04 & 0,00 & 0,00 \\
$\mathrm{Total}$ & 98,84 & 99,83 & 100,03 & 99,69 & 98,69 & 98,84 \\
\hline $\mathrm{Número}$ de ions na base de 32 átomos de oxigênio & & & \\
\hline $\mathrm{Si}$ & 11,892 & 11,928 & 11,864 & 11,898 & 11,901 & 11,896 \\
$\mathrm{Al}$ & 4,068 & 4,038 & 4,114 & 4,086 & 4,059 & 4,059 \\
$\mathrm{Fe} 2$ & 0,014 & 0,014 & 0,002 & 0,002 & 0,000 & 0,013 \\
$\mathrm{Ba}$ & 0,039 & 0,031 & 0,059 & 0,056 & 0,058 & 0,084 \\
$\mathrm{Na}$ & 0,441 & 0,493 & 0,418 & 0,440 & 0,329 & 0,289 \\
$\mathrm{~K}$ & 3,650 & 3,579 & 3,646 & 3,572 & 3,764 & 3,747 \\
$\mathrm{Ab}$ & 10,80 & 12,10 & 10,30 & 11,00 & 8,000 & 7,200 \\
$\mathrm{An}$ & 0,000 & 0,000 & 0,000 & 0,000 & 0,000 & 0,000 \\
$\mathrm{Or}$ & 89,20 & 87,90 & 89,70 & 89,00 & 92,00 & 92,80 \\
\hline
\end{tabular}


Tabela 6.8 - Análises químicas de ilmenitas das rochas da borda do Maciço de Venda Nova

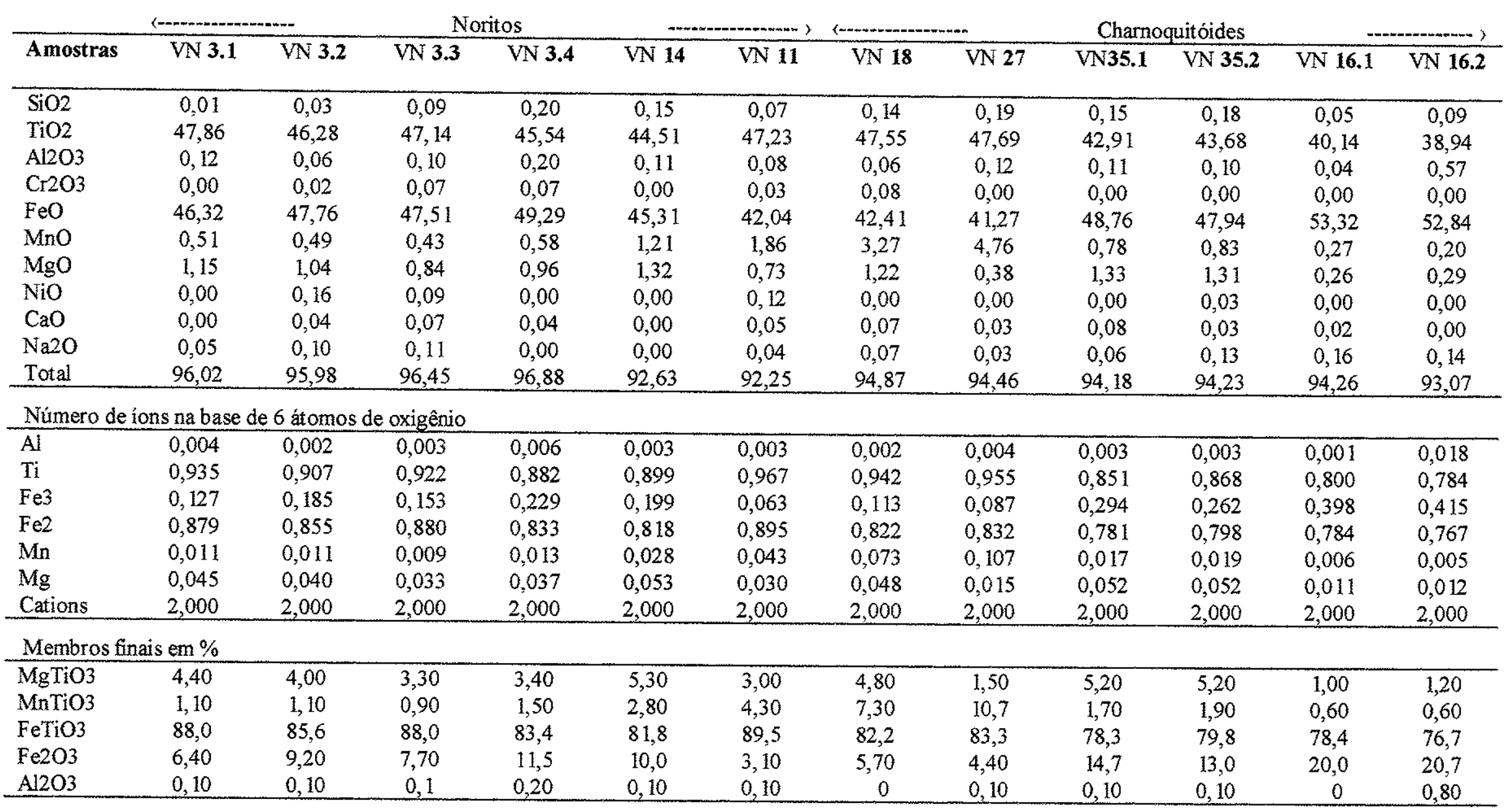


Tabela 6.9 - Análises químicas de magnetitas das rochas da borda do Maciço de Venda Nova

\begin{tabular}{|c|c|c|c|c|c|c|c|c|c|}
\hline \multirow[b]{2}{*}{ Amostras } & \multirow{2}{*}{$\frac{4--\cdot}{\text { VN } 3.1}$} & \multirow{2}{*}{$\frac{\text { Noritos }}{\text { VN } 3.2}$} & \multirow{2}{*}{$\frac{-\cdot-->}{\text { VN } 3.3}$} & \multicolumn{2}{|c|}{ 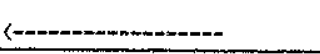 } & \multicolumn{2}{|c|}{ Charnoquitóides } & \multicolumn{2}{|c|}{-..n- > } \\
\hline & & & & VN 18 & VN 27.1 & VN 27.2 & VN 35.1 & VN 35.2 & VN 16.1 \\
\hline $\mathrm{SiO} 2$ & 0,09 & 0,23 & 0,20 & 0,07 & 0,20 & 0,08 & 0,15 & 0,17 & 0,24 \\
\hline $\mathrm{TiO} 2$ & 0,18 & 0,39 & 0,38 & 0,31 & 0,03 & 0,27 & 0,26 & 0,00 & 0,09 \\
\hline $\mathrm{Al} 2 \mathrm{O} 3$ & 0,42 & 0,39 & 0,46 & 0,31 & 0,39 & 0,61 & 1,26 & 0,41 & 0,28 \\
\hline $\mathrm{Cr} 2 \mathrm{O} 3$ & 0,09 & 0,09 & 0,03 & 0,14 & 0,00 & 0,11 & 0,13 & 0,11 & 0,06 \\
\hline $\mathrm{FeO}$ & 93,04 & 91,67 & 92,68 & 91,09 & 91,25 & 91,25 & 91,71 & 95,31 & 90,33 \\
\hline $\mathrm{MnO}$ & 0,04 & 0,10 & 0,08 & 0,14 & 0,00 & 0,12 & 0,00 & 0,00 & 0,00 \\
\hline $\mathrm{MgO}$ & 0,12 & 0,14 & 0,21 & 0,14 & 0,08 & 0,21 & 0,20 & 0,00 & 0,14 \\
\hline $\mathrm{NiO}$ & 0,00 & 0,02 & 0,00 & 0,00 & 0,07 & 0,00 & 0,04 & 0,00 & 0,02 \\
\hline $\mathrm{CaO}$ & 0,09 & 0,09 & 0,09 & 0,07 & 0,02 & 0,00 & 0,05 & 0,07 & 0,02 \\
\hline Total & 94,07 & 93,12 & 94,13 & 92,30 & 92,04 & 92,65 & 93,80 & 96,07 & 91,18 \\
\hline \multicolumn{10}{|c|}{ Número de íons na base de 4 átomos de oxigênio } \\
\hline $\mathrm{Al}$ & 0,019 & 0,018 & 0,021 & 0,014 & 0,018 & 0,028 & 0,057 & 0,018 & 0,013 \\
\hline $\mathrm{Ti}$ & 0,005 & 0,011 & 0,011 & 0,009 & 0,001 & 0,008 & 0,007 & 0,000 & 0,003 \\
\hline Fe3 & 1,971 & 1,960 & 1,958 & 1,968 & 1,980 & 1,957 & 1,928 & 1,982 & 1,982 \\
\hline $\mathrm{Fe} 2$ & 0,997 & 1,000 & 0,996 & 0,996 & 0,996 & 0,992 & 0,996 & 1,000 & 0,994 \\
\hline $\mathrm{Mn}$ & 0,001 & 0,003 & 0,003 & 0,005 & 0,000 & 0,004 & 0,000 & 0,000 & 0,000 \\
\hline $\mathrm{Mg}$ & 0,007 & 0,008 & 0,012 & 0,008 & 0,005 & 0,012 & 0,011 & 0,000 & 0,008 \\
\hline Cations & 3,000 & 3,000 & 3,000 & 3,000 & 3,000 & 3,000 & 3,000 & 3,000 & 3,000 \\
\hline \multicolumn{10}{|c|}{ Membros finais em $\%$} \\
\hline $\mathrm{MgA} 12 \mathrm{O} 4$ & 0,47 & 0,53 & 0,80 & 0,53 & 0,33 & 0,80 & 0,70 & 0 & 0,53 \\
\hline $\mathrm{MnAl} 2 \mathrm{O} 4$ & 0,10 & 0,20 & 0,20 & 0,33 & 0 & 0,30 & 0 & 0 & 0 \\
\hline $\mathrm{FeAl} 2 \mathrm{O} 4$ & 0,73 & 0,47 & 0,40 & 0,07 & 0,87 & 0,80 & 3,10 & 1,20 & 0,35 \\
\hline Fe2TiO4 & 0,50 & 1,10 & 1,10 & 0,90 & 0,10 & 0,80 & 0,70 & 0 & 0,32 \\
\hline $\mathrm{Fe} 3 \mathrm{O} 4$ & 98,2 & 97,7 & 97,5 & 98,2 & 98,7 & 97,3 & 95,5 & 98,80 & 98,8 \\
\hline
\end{tabular}




\subsection{MACIÇO DE VÁRZEA ALEGRE}

\section{Piroxênios}

A tabela 6.10 contém os resultados analíticos de ortopiroxênios dos charnoquitóides de Várzea Alegre. Estão apresentadas 16 análises efetuadas em seis lâminas polidas. A maioria das análises não tiveram um fechamento satisfatório em função do considerável grau de alteração de grande parte dos cristais, comojá foi abordado no capítulo 4 . Apesar disto, constata-se que a variação na composição é muito pequena, e somente a amostra VA-252 afasta-se das demais devido ao seu maior conteúdo de Fe. A figura 6.16 ilustra o restrito intervalo composicional, que oscila de Wo 1,57 a Wo2,49, En30,42 a En4 1, 18 e Fs56,99 a Fs67,43. Dentre os outros elementos detectados, não ocorrem significativas variações nos teores, com exceção do $\mathrm{Ca}$ que mostra concentrações entre $0,55 \%$ e 1,14\%. As diferenças observadas nos conteúdos de $\mathrm{Mn}$ são uma resposta às oscilações dos teores de Fe.

Os Mg\# dos piroxênios (média de 0,40) são maiores que os das rochas que os contêm, que possuem média de 0,28 . As concentrações de Ca, Mn e Al também não apresentam uma relação de proporcionalidade com os teores encontrados na rocha total, com exceção da amostra VA-261 que exibe os maiores teores de Ca no mineral e na rocha.

Os ortopiroxênios dos charnoquitóides de Várzea Alegre são bem mais pobres em Fe e Mn e enriquecidos em Mg e Al quando comparados aos OPX das rochas mangeríticas e charnoquíticas dos maciços de São Pedro de Caldas, MG e Hopen, Noruega (Janasi, 1992 e Ormaasen, 1977), que possuem $\mathrm{Mg \#} \mathrm{em} \mathrm{torno} \mathrm{de} \mathrm{0,2.} \mathrm{Os} \mathrm{teores} \mathrm{de} \mathrm{Ca} \mathrm{são} \mathrm{equivalentes} \mathrm{aos}$ primeiros e superiores aos dos litotipos da Noruega. Análises de OPX de gabros do domínio interno do maciço de Várzea Alegre revelaram composições mais ricas em $\mathrm{Mg}$, com extremos composicionais variando de En46 a En60 e Fs40 a Fs52 (cf. Medeiros, 1993).

Da mesma forma que as rochas da borda do maciço de Venda Nova, os OPX dos charnoquitóides de Várzea Alegre posicionam-se na zona de transição entre piroxênios ígneos e metamórficos no diagrama $\mathrm{Al}_{2} \mathrm{O}_{3} \times \mathrm{MgO}+\mathrm{FeO}+\mathrm{Fe}_{2} \mathrm{O}_{3}$ de Rietmeijer (1983), como se verifica na Figura 6.17. 


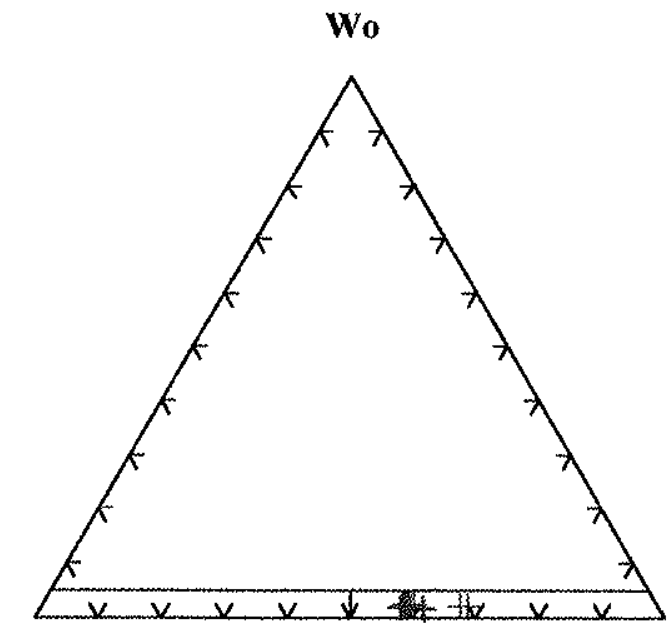

En

Fs

Figura 6.16 - Diagrama Wo-En-Fs para os ortopiroxênios dos charnoquitóides de Várzea Alegre

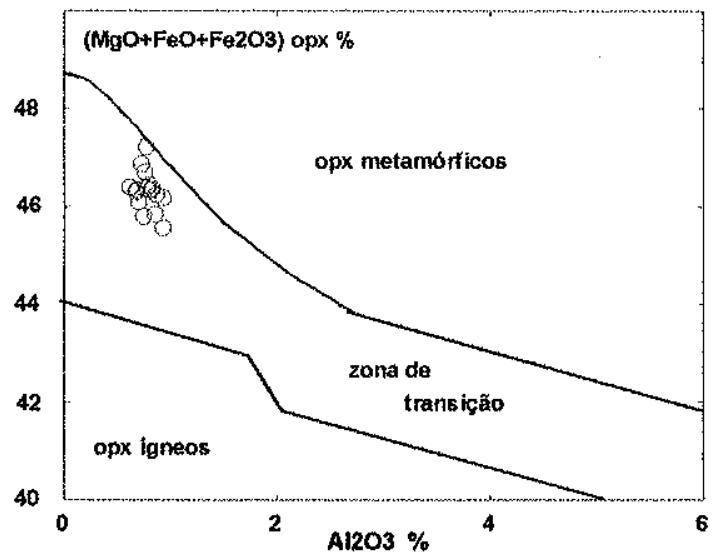

Figura 6.17 - Diagrama $\mathrm{Al}_{2} \mathrm{O}_{3} \times \mathrm{MgO}+\mathrm{FeO}+\mathrm{Fe}_{2} \mathrm{O}_{3}$ para os ortopiroxênios dos charnoquitóides de Várzea Alegre

\section{Anfibólios}

As rochas da borda do maciço de Várzea Alegre possuem pequenas quantidades de anfibólio. Das determinações efetuadas apenas sete análises puderam ser aproveitadas, e elas estão apresentadas na tabela 6.11. Para o cálculo da fórmula estrutural o teor de ferro adotado foi o ponto médio entre o máximo e o mínimo possível de $\mathrm{Fe}^{+3}$.

As composições obtidas são muito homogêneas, resultando em Mg-hastingsitas e hastingsitas magnesianas, com $\mathrm{Si}=6,21$ a 6,37 átomos/fórmula, conforme se encontra na Figura 6.18. Os Mg\# são de 0,38 em média, maiores que os das rochas correspondentes. Praticamente não há variação dos teores de $\mathrm{Al}\left(\right.$ total) e de $\mathrm{Al}{ }^{\mathrm{iv}}$, o que está ilustrado na Figura 6.19. Por outro lado, ocorre maior variação nas concentrações de Alvi relativamente ao Aliv, como se vê na 
Figura 6.20. Nas Figuras 6.21 e 6.22 observa-se uma correlação positiva entre os conteúdos de Aliv e de $\mathrm{Ti}$, o mesmo se dando com relação a ocupação do sítio $\mathrm{A}$. O posicionamento é típico de composições hastingsíticas, que resultam de substituições edeníticas e tschermackíticas.

Os anfibólios das rochas mangeríticas e charnoquíticas do maciço de São Pedro

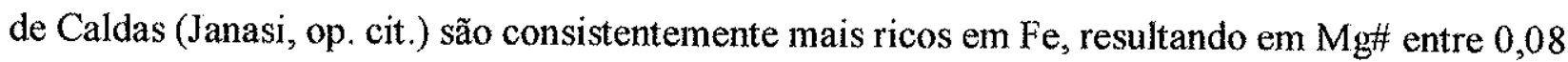
a 0,3. Possuem menores conteúdos de $\mathrm{Ca}$ e $\mathrm{Al}$ e maiores de $\mathrm{Na}$ que os anfibólios dos charnoquitóides de Várzea Alegre. Por seu lado, os anfibólios das rochas do domínio interno do maciço de Várzea Alegre (Medeiros, op. cit.) são bem mais ricos em $\mathrm{Mg}$ e Si e mais pobres em $\mathrm{Fe}, \mathrm{Al}$, Ti e K.

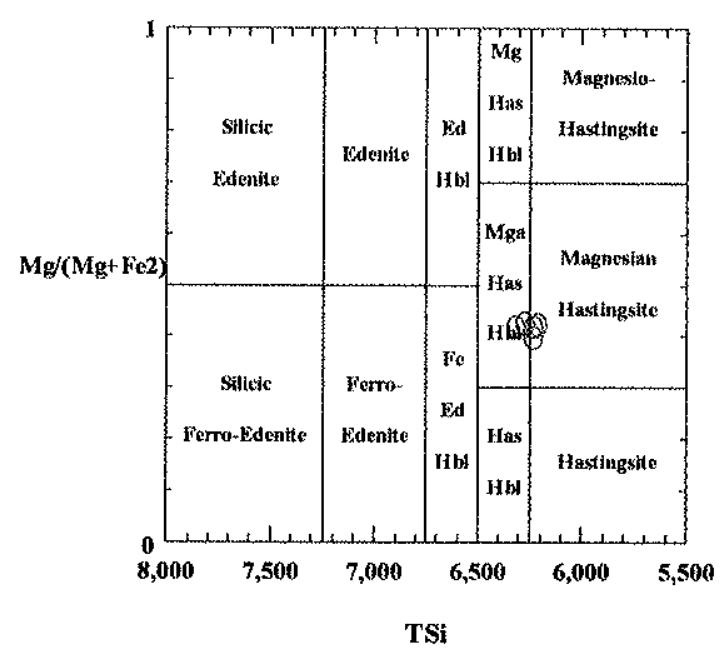

Figura 6.18 - Diagrama para classificação de anfibólios cálcicos (Leake, 1978) para os charnoquitóides de Várzea Alegre.
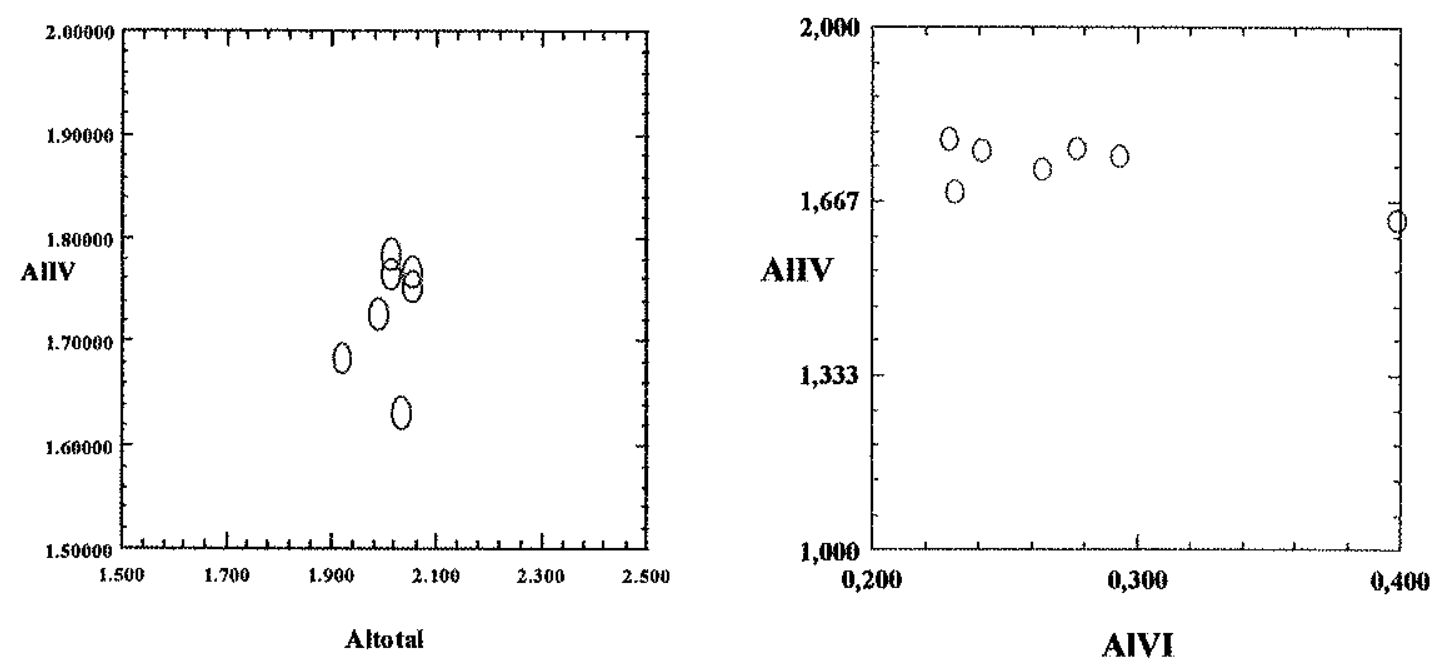

Figuras 6.19 e 6.20 - Diagramas Altotal $\times \mathrm{Al}^{\mathrm{iv}}$ e $\mathrm{Al}^{\mathrm{Vi}} \times \mathrm{Al}^{\mathrm{iv}}$ para os anfibólios dos charnoquitóides do maciço de Várzea Alegre. 

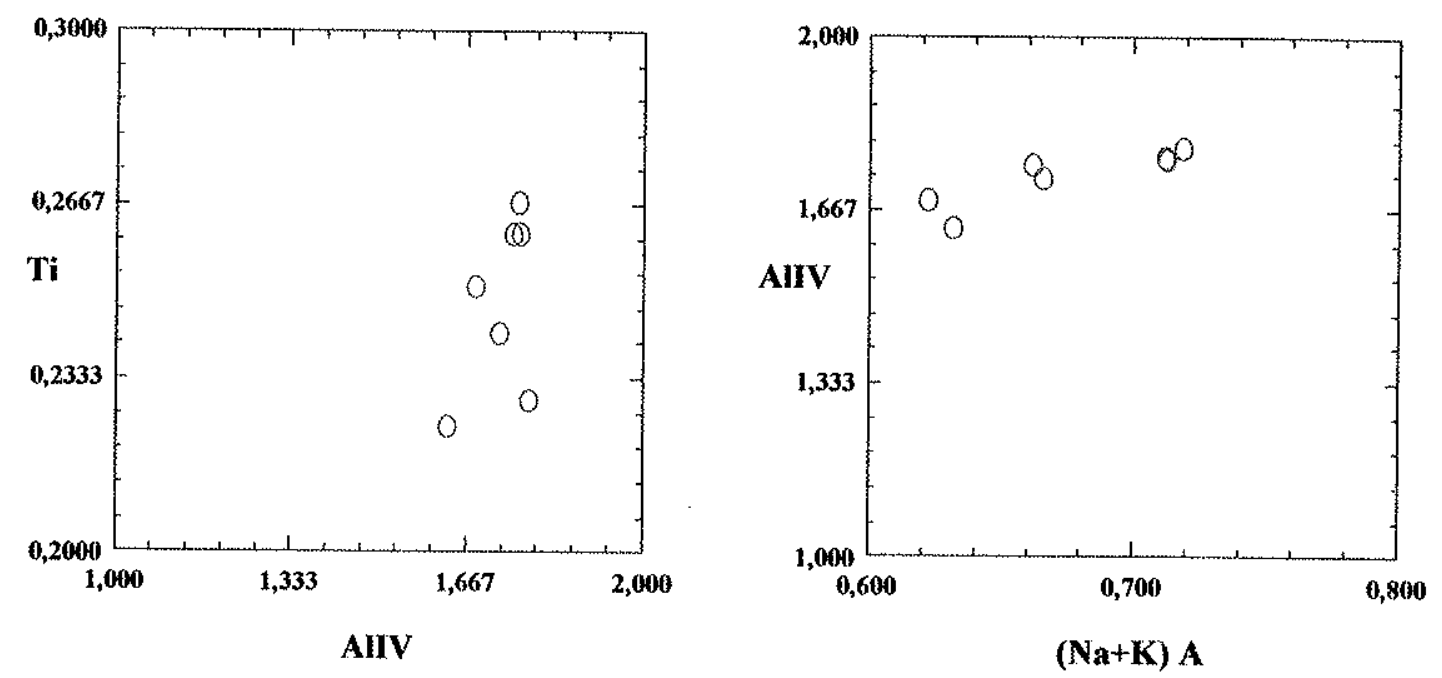

Figuras 6.21 e 6.22 - Diagramas $A l^{i v} \times$ Ti e $(\mathrm{Na}+\mathrm{K}) \mathrm{A} \times \mathrm{Al}^{\mathrm{iv}}$ para os anfibólios dos charnoquitóides do maciço de Várzea Alegre.

\section{Biotitas}

Excetuando a amostra VA-263, as composições das biotitas variam muito pouco, como está apresentado na tabela 6.12, onde estão as dez análises selecionadas de quatro lâminas polidas (três delas são médias). Na Figura 6.23 tem-se o gráfico com os membros extremos das micas Fe-magnesianas, e nele observa-se que as biotitas de Várzea Alegre estão deslocadas em direção ao membro annita, principalmente aquelas da amostra VA-263 em função dos seus maiores Fe\#.

Apresentam, no geral, $\mathrm{Mg \#} \mathrm{superiores} \mathrm{aos} \mathrm{dos} \mathrm{anfibólios} \mathrm{e} \mathrm{das} \mathrm{rochas}$ correlacionadas. Os conteúdos de $\mathrm{Al}^{\mathrm{iv}}$ não mostram qualquer razão de proporcionalidade com os Mg\#, como se observa na Figura 6.23. Os altos teores de Ti (de 0,63 a 0,73 átomos por fórmula) tendem a aumentar com maiores concentrações de $\mathrm{Fe}$, decrescendo portanto com maiores $\mathrm{Mg \#}$ (Figura 6.24). Como pode ser observado na Figura 6.25, o Ti também exibe correlação negativa com o Alvi, contrário ao comportamento do $\mathrm{F}$, que tende a aumentar com a elevação dos teores de Alvi (Figura 6.26). Os álcalis possuem, como um todo, tendência a aumentar com maiores concentrações de Al(total).

Biotitas do maciço São Pedro de Caldas analisadas por Janasi (op. cit.) forneceram considerável variação composicional, com $\mathrm{Mg} \#$ variando entre 0,03 e 0,38 , mas com predomínio dos termos mais ricos em Fe. Elas possuem menores teores de $\mathrm{Ti}$ e $\mathrm{Cl}$ e maiores concentrações de $\mathrm{F}$ que as biotitas dos charnoquitóides de Várzea Alegre. Assim como se observa entre os anfibólios, as biotitas das rochas do domínio interno do maciço de Várzea 
Alegre são mais ricas em $\mathrm{Mg}$ e $\mathrm{Si}$ e bem mais pobres em $\mathrm{Fe}$; os conteúdos de $\mathrm{Ti}, \mathrm{Al}, \mathrm{F}$ e $\mathrm{Cl}$ se eqüivalem e as análises de $\mathrm{BaO}$ de Medeiros (op. cit.) resultaram em valores entre $0,45 \%$ e $0,8 \%$ (duas análises de biotita dos charnoquitóides, da amostra VA-16, efetuadas por C. Wiedemann na Holanda, forneceram conteúdos de $\mathrm{BaO}$ de $0,73 \%$ e $0,58 \%$ ).
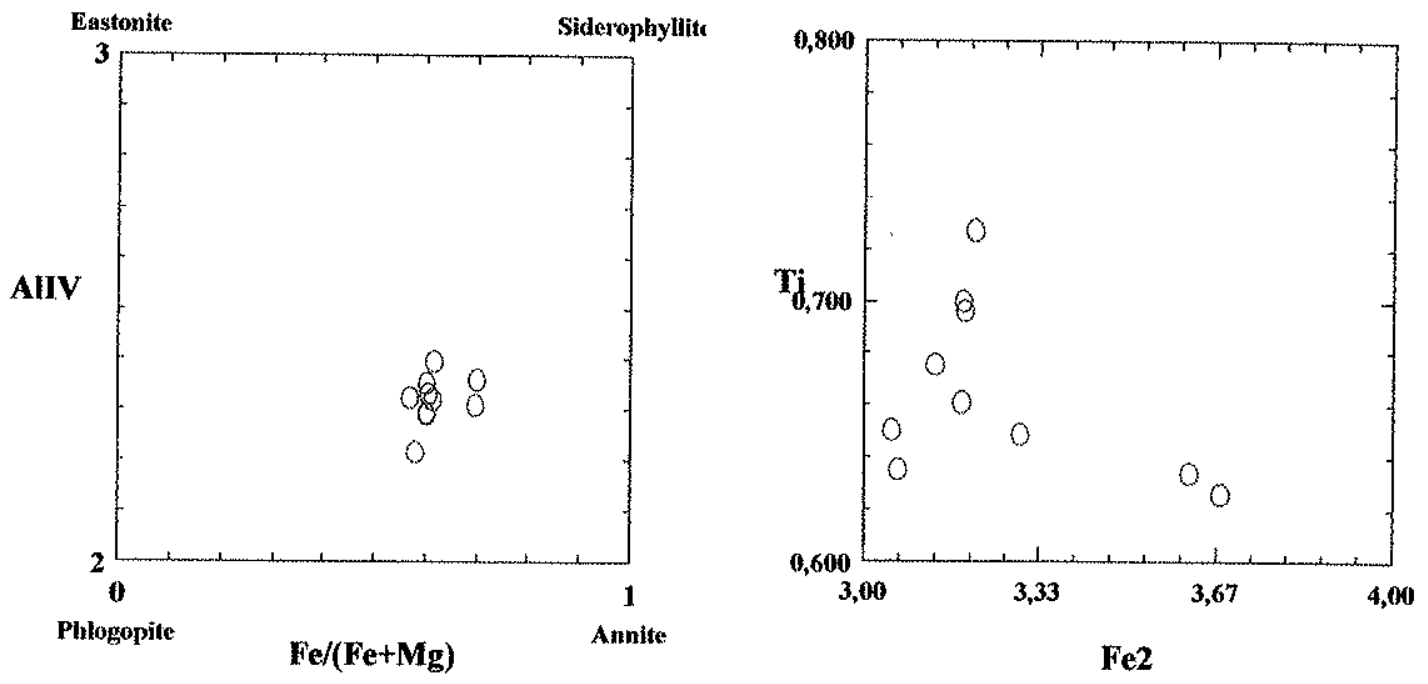

Figuras 6.23 e 6.24 - Diagramas $\mathrm{Fe} /(\mathrm{Fe}+\mathrm{Mg}) \times \mathrm{Al}^{\mathrm{iv}} \mathrm{e} \mathrm{Fe} 2 \times \mathrm{Ti}$ para as biotitas dos charnoquitóides de Várzea Alegre
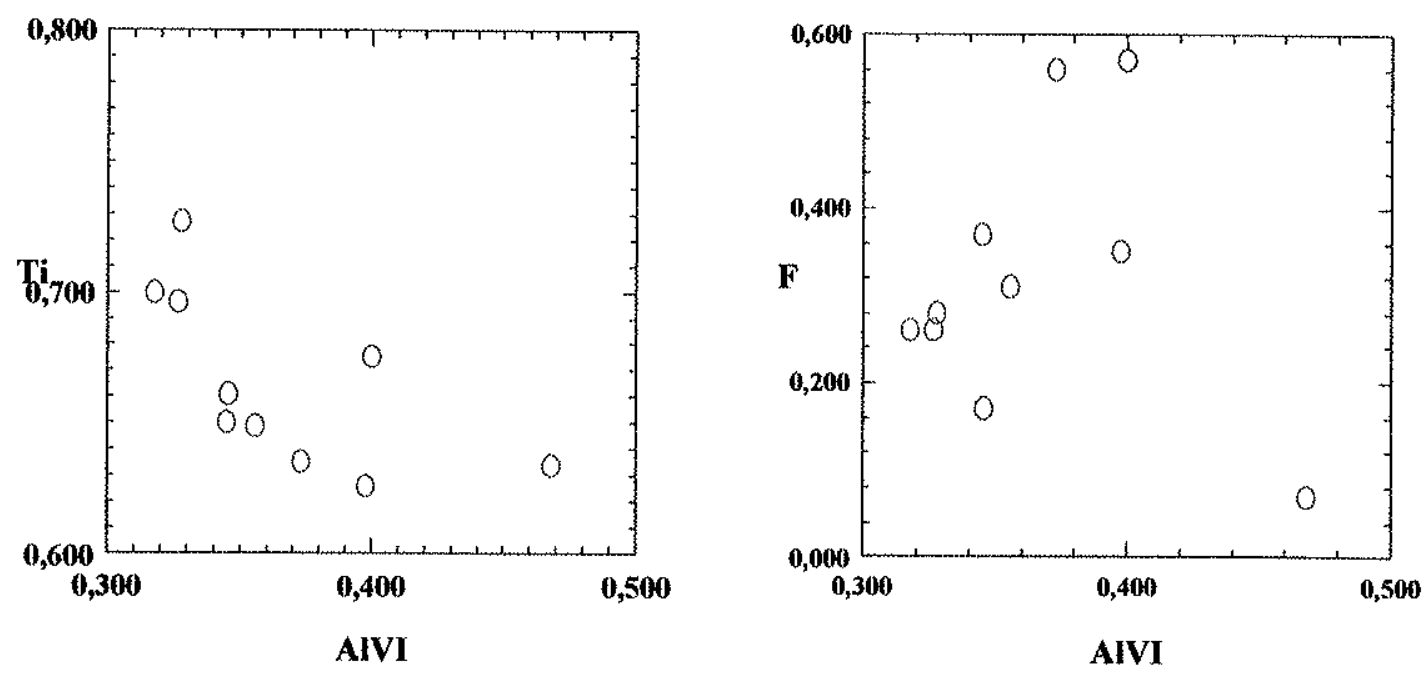

Figuras 6.25 e 6.26 - Diagramas Alvi $\times$ Ti e Alvi $x$ F para as biotitas dos charnoquitóides de Várzea Alegre.

\section{Feldspatos}

Foram efetuadas várias análises de feldspatos em sete amostras dos charnoquitóides do maciço de Várzea Alegre. As determinações foram tanto nos megacristais como nos cristais da matriz. 
Nas tabelas 6.13 e 6.14 estão apresentados os resultados analíticos dos plagioclásios, megacristais e da matriz respectivamente. Pode-se observar que não ocorre grande diferença composicional entre eles, e que a variação dentro de uma mesma amostra é mínima, não tendo sido detectados portanto cristais com zoneamentos significativos. A composição é andesina, variando de Ab65An32 a Ab57An40, sendo que as composições mais cálcicas correspondem aos plagioclásios dos quartzo-dioritos. O componente ortoclásio oscila entre 1,1 a $4,3 \%$, com os menores teores correspondendo aos quartzo-dioritos. Os conteúdos de Ba e Sr são muito baixos, da ordem de 0,01 átomos/fórmula. As Figuras 6.27 e 6.28 exibem as variações nas composições dos plagioclásios dos charnoquitóides.

As determinações realizadas nos feldspatos alcalinos foram feitas tanto em cristais com pequenas quantidades de lamelas pertíticas quanto em outros densamente pertíticos, megacristais e da matriz. Em vista disto, as variações composicionais observadas devem ser um reflexo da exsolução desigual do componente sódico. Infelizmente não foi possível regular a largura do feixe da microssonda eletrônica, pois um feixe largo possibilitaria a análise de uma área maior, que seria ideal para os grãos mais exsolvidos.

As tabelas 6.15 e 6.16 trazem os resultados obtidos para os megacristais (tabela 6.15) e para os cristais da matriz (tabela 6.16). Não ocorrem diferenças entre eles, apenas alguns pontos com maior proporção da molécula albítica, associados a maior e/ou desigual exsolução do componente sódico. Em função disto, os extremos composicionais obtidos foram de Or89 a Or68, sendo que das amostras analisadas somente VA-257 e VA-263 exibiram maiores variações na composição.

É digno de nota a ausência do componente anortita nos álcali-feldspatos de todas as amostras analisadas ( $\mathrm{Ca}$ foi detectado somente em um ponto), contrastando com proporções de albita que variam de 11 a $31 \%$, predominando valores em torno de $15 \%$. Por outro lado, os teores de Ba são altos, alcançando até 0,17 átomos/fórmula $(4,2 \%$ do componente celsiana, contrapondo-se ao menor valor de $1,1 \%$ de molécula celsiana na amostra VA-263) e apresentam, a grosso modo, uma relação inversa com os conteúdos de $\mathrm{Na}$. As variações composicionais dos feldspatos alcalinos estão ilustradas nas Figuras 6.29 e 6.30 .

As altas proporções modais de feldspato alcalino com lamelas pertíticas, juntamente com a presença de megacristais de mesopertita, sugerem que essas rochas possam ter se cristalizado sob condições "hipersolvus", relacionado a um sistema inicialmente com baixa PH2O (que eleva a temperatura do solidus), cristalizando inicialmente um único feldspato 
pertítico, que com a diminuição da temperatura se desmisturou no estado sólido. No entanto, os conteúdos relativamente altos de anortita normativa dessas rochas (até $25 \%$ ), as composições dos plagioclásios (andesinas sódicas a intermediárias) e aspectos texturais mostrando nítida substituição de plagioclásio por feldspato alcalino (restos de cristais plagioclásio, evidenciando que eles foram os primeiros a se cristalizar) não confirmam a hipótese aventada.

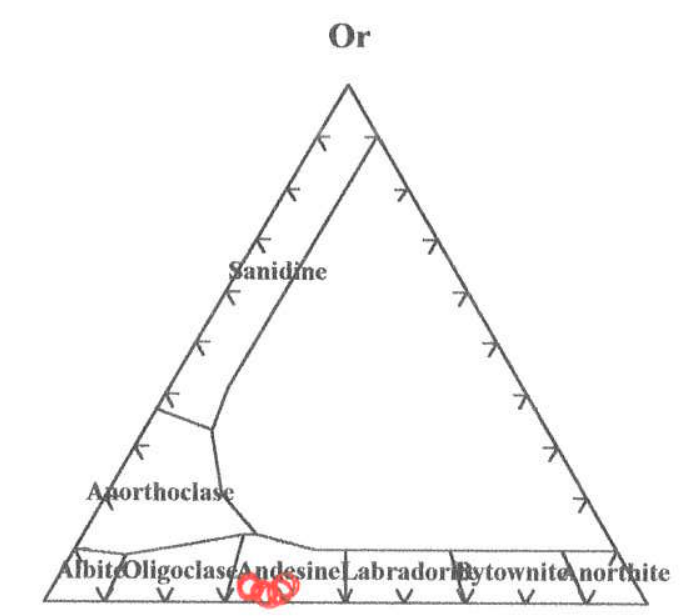

Ab

An

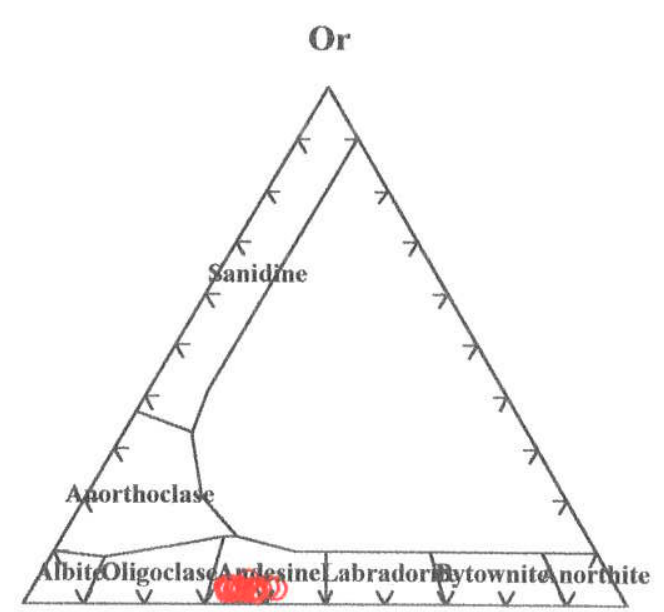

Ab

An

Figuras 6.27 e 6.28 - Composição dos plagioclásios da matriz e megacristais, respectivamente, dos charnoquitóides de Várzea Alegre.

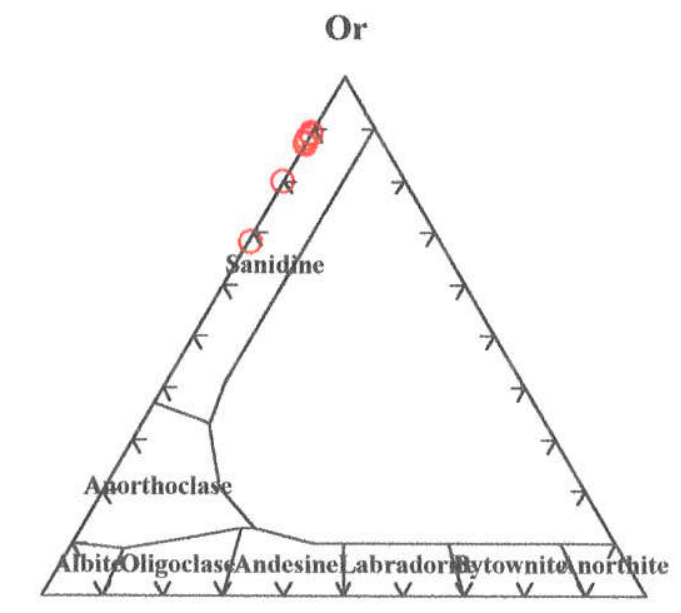

Ab
An

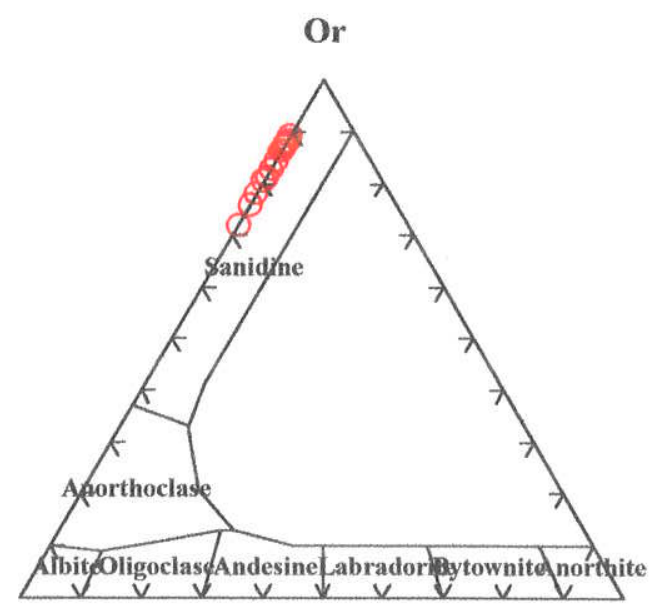

Ab
An

Figuras 6.29 e 6.30 - Composição dos feldspatos alcalinos da matriz e megacristais, respectivamente, dos charnoquitóides de Várzea Alegre.

\section{Minerais Opacos}

Nos charnoquitóides do maciço intrusivo de Várzea Alegre foram identificadas as seguintes fases opacas: ilmenita com poucas lamelas de exsolução de hematita, magnetita, 
localmente intercrescida ou nitidamente substituindo a ilmenita e pirita. Foram realizadas análises por microssonda em cristais de ilmenita e magnetita, e os melhores resultados encontram-se nas tabelas 6.17 e 6.18 , juntamente com as fórmulas estruturais e os membros finais das soluções sólidas.

As ilmenitas representam soluções sólidas ricas em moléculas de $\mathrm{FeTiO}_{3}$, com proporções variando entre $84 \%$ e $90 \%$. As porcentagens de molécula de hematita não ultrapassam $12,8 \%$, o que indica cristalização em condições predominantemente redutoras, e confirma o caráter secundário da maior parte dos cristais de magnetita. Os conteúdos de $\mathrm{Mg}$ são baixos (no máximo 0,66\% MgO) e os de $\mathrm{Mn}$ variam bastante, entre 0,48 e 1,59\% $\mathrm{MnO}$.

Apenas cinco análises de magnetita, de duas amostras, foram consideradas satisfatórias ( apesar de não apresentarem um fechamento a contento ) e encontram-se na tabela 6.18. Verifica-se que são minerais quase puros em $\mathrm{Fe}$, com a proporção da molécula de $\mathrm{Fe}_{3} \mathrm{O}_{4}$ oscilando de 95,8 a 98,7\%. Adicionalmente foram detectados pequenos teores de $\mathrm{Si}$, $\mathrm{Ti}$, $\mathrm{Cr}$ e $\mathrm{Mg}$; são desprovidas de $\mathrm{Mn}$ e as concentrações de $\mathrm{Al}_{2} \mathrm{O}_{3}$ atingem até 1,05\%, propiciando a formação de $2,6 \%$ de molécula de $\mathrm{FeAl}_{2} \mathrm{O}_{4}$ (hercinita) na amostra VA-56. A porcentagem máxima da molécula de ulvoespinélio é de $1,1 \%$. 
Tabela 6.10 - Análises químicas de ortopiroxênios das rochas charnoquitóides do Maciço de Várzea Alegre

\begin{tabular}{|c|c|c|c|c|c|c|c|}
\hline \multicolumn{8}{|c|}{ OPX-quartzo-dioritos } \\
\hline Amostras & VA261.1 & VA261.2* & VA 261.3 & VA 261.4 & VA 182.1 & VA 182.2 & VA 182.3 \\
\hline $\mathrm{SiO}_{2}$ & 49,01 & 49,56 & 49,34 & 49,64 & 48,80 & 49,49 & 49,44 \\
\hline $\mathrm{TiO} 2$ & 0,08 & 0,09 & 0,04 & 0,17 & 0,11 & 0,00 & 0,00 \\
\hline $\mathrm{A} 12 \mathrm{O} 3$ & 0,76 & 0,83 & 0,93 & 0,87 & 0,75 & 0,77 & 0,73 \\
\hline $\mathrm{Cr} 2 \mathrm{O} 3$ & 0,02 & 0,02 & 0,05 & 0,02 & 0,03 & 0,01 & 0,02 \\
\hline $\mathrm{FeO}$ & 33,69 & 33,64 & 33,58 & 33,12 & 32,62 & 33,58 & 33,58 \\
\hline $\mathrm{MnO}$ & 0,92 & 0,80 & 0,87 & 0,99 & 0,97 & 0,87 & 0,85 \\
\hline $\mathrm{MgO}$ & 13,01 & 12,71 & 12,60 & 13,12 & 13,17 & 13,64 & 13,29 \\
\hline $\mathrm{NiO}$ & 0,03 & 0,01 & 0,02 & 0,00 & 0,00 & 0,11 & 0,04 \\
\hline $\mathrm{CaO}$ & 0,98 & 1,14 & 0,90 & 1,07 & 1,06 & 0,99 & 1,05 \\
\hline $\mathrm{Na} 2 \mathrm{O}$ & 0,13 & 0,04 & 0,05 & 0,14 & 0,13 & 0,07 & 0,00 \\
\hline $\mathrm{K} 2 \mathrm{O}$ & 0,02 & 0,01 & 0,03 & 0,00 & 0,02 & 0,00 & 0,00 \\
\hline $\mathrm{BaO}$ & 0,17 & 0,11 & 0,15 & 0,10 & 0,10 & 0,00 & 0,00 \\
\hline Total & 98,82 & 98,96 & 98,56 & 99,24 & 97,76 & 99,53 & 99,00 \\
\hline \multicolumn{8}{|c|}{ Número de íns na base de 6 átomos de oxigênio } \\
\hline $\mathrm{TSi}$ & 1,967 & 1,988 & 1,989 & 1,979 & 1,973 & 1,963 & 1,976 \\
\hline TAl & 0,033 & 0,012 & 0,011 & 0,021 & 0,027 & 0,036 & 0,024 \\
\hline $\mathrm{M} \mid \mathrm{Al}$ & 0,003 & 0,028 & 0,033 & 0,020 & 0,009 & 0,000 & 0,010 \\
\hline M 1Ti & 0,002 & 0,003 & 0,001 & 0,005 & 0,003 & 0,000 & 0,000 \\
\hline MuFe3 & 0,036 & 0,000 & 0,000 & 0,001 & 0,022 & 0,042 & 0,013 \\
\hline M. IFe2 & 0,179 & 0,209 & 0,206 & 0,194 & 0,171 & 0,148 & 0,183 \\
\hline $\mathrm{MlCr}$ & 0,001 & 0,001 & 0,002 & 0,001 & 0,001 & 0,000 & 0,001 \\
\hline $\mathrm{MlMg}$ & 0,778 & 0,760 & 0,757 & 0,780 & 0,794 & 0,807 & 0,792 \\
\hline $\mathrm{MNi}$ & 0,001 & 0,000 & 0,001 & 0,000 & 0,000 & 0,004 & 0,001 \\
\hline $\mathrm{M} 2 \mathrm{Mg}$ & 0,000 & 0,000 & 0,000 & 0,000 & 0,000 & 0,000 & 0,000 \\
\hline $\mathrm{M} 2 \mathrm{Fe} 2$ & 0,915 & 0,920 & 0,926 & 0,910 & 0,910 & 0,923 & 0,926 \\
\hline $\mathrm{M} 2 \mathrm{Mn}$ & 0,031 & 0,027 & 0,030 & 0,033 & 0,033 & 0,029 & 0,029 \\
\hline $\mathrm{M} 2 \mathrm{Ca}$ & 0,042 & 0,049 & 0,039 & 0,046 & 0,046 & 0,042 & 0,045 \\
\hline $\mathrm{M} 2 \mathrm{Na}$ & 0,010 & 0,003 & 0,004 & 0,011 & 0,010 & 0,005 & 0,000 \\
\hline M2K & 0,001 & 0,001 & 0,002 & 0,000 & 0,001 & 0,000 & 0,000 \\
\hline Sumcat & 3,999 & 3,999 & 3,998 & 4,000 & 3,999 & 4,000 & 4,000 \\
\hline WO & 2,130 & 2,490 & 1,990 & 2,330 & 2,330 & 2,110 & 2,260 \\
\hline $\mathrm{EN}$ & 39,26 & 38,68 & 38,67 & 39,72 & 40,17 & 40,49 & 39,83 \\
\hline $\mathrm{FS}$ & 58,61 & 58,82 & 59,34 & 57,95 & 57,50 & 57,40 & 57,91 \\
\hline $\mathrm{Fe} / \mathrm{Fe}+\mathrm{Mg}$ & 0,592 & 0,598 & 0,599 & 0,586 & 0,581 & 0,580 & 0,586 \\
\hline $\mathrm{Mg} / \mathrm{Mg}+\mathrm{Fe}$ & 0,408 & 0,402 & 0,401 & 0,414 & 0,419 & 0,420 & 0,414 \\
\hline
\end{tabular}


Tabela 6.10 - Continuação

\begin{tabular}{|c|c|c|c|c|c|c|c|c|c|}
\hline \multirow[b]{2}{*}{ Amostras } & \multicolumn{2}{|c|}{ Opdalitos } & \multicolumn{2}{|c|}{ (1- } & \multicolumn{3}{|c|}{ Jotunitos } & \multicolumn{2}{|c|}{ (ב-.......... } \\
\hline & VA 252.1 & VA 252.2 & VA 253.1 & VA 253.2 & $\begin{array}{l}\mathrm{VA} \\
56.1\end{array}$ & $\begin{array}{c}\mathrm{VA} \\
56.2\end{array}$ & $\begin{array}{c}\text { VA } \\
56.3\end{array}$ & $\begin{array}{c}\mathrm{VA} \\
257.1\end{array}$ & $\begin{array}{c}\text { VA } \\
257.2\end{array}$ \\
\hline $\mathrm{SiO} 2$ & 48,49 & 48,08 & 48,82 & 49,08 & 49,01 & 49,03 & 48.70 & 49,64 & 49,46 \\
\hline $\mathrm{TiO} 2$ & 0,05 & 0,00 & 0,11 & 0,12 & 0,12 & 0,06 & 0,10 & 0,11 & 0,09 \\
\hline $\mathrm{Al} 2 \mathrm{O} 3$ & 0,62 & 0,67 & 0,80 & 0,93 & 0,70 & 0,86 & 0,82 & 0,69 & 0,78 \\
\hline $\mathrm{Cr} 2 \mathrm{O} 3$ & 0,00 & 0,05 & 0,00 & 0,00 & 0,00 & 0,00 & 0,08 & 0,00 & 0,02 \\
\hline $\mathrm{FeO}$ & 36,33 & 36,66 & 34,23 & 33,49 & 32,73 & 32,38 & 32,84 & 32,95 & 33,20 \\
\hline $\mathrm{MnO}$ & 1,33 & 1,41 & 1,07 & 1,05 & 0,88 & 0,81 & 0,88 & 0,87 & 0,85 \\
\hline $\mathrm{MgO}$ & 10,06 & 9,64 & 12,20 & 12,07 & 13,36 & 13,46 & 13,50 & 13,38 & 13,17 \\
\hline $\mathrm{NiO}$ & 0,00 & 0,00 & 0,15 & 0,03 & 0,07 & 0,08 & 0,02 & 0,00 & 0,01 \\
\hline $\mathrm{CaO}$ & 0,88 & 0,95 & 0,55 & 0,70 & 0,85 & 0,83 & 0,81 & 0,90 & 0,92 \\
\hline $\mathrm{Na} 2 \mathrm{O}$ & 0,06 & 0,04 & 0,00 & 0,12 & 0,08 & 0,15 & 0,02 & 0,04 & 0,09 \\
\hline $\mathrm{K} 2 \mathrm{O}$ & 0,01 & 0,00 & 0,02 & 0,01 & 0,00 & 0,05 & 0,00 & 0,00 & 0,01 \\
\hline $\mathrm{BaO}$ & 0,07 & 0,00 & 0,00 & 0,31 & 0,00 & 0,00 & 0,10 & 0,00 & 0,00 \\
\hline Total & 97,90 & 97,50 & 97,95 & 97,91 & 97,80 & 97,71 & 97,87 & 98,58 & 98,60 \\
\hline \multicolumn{10}{|c|}{ Número de ions na base de 6 átomos de oxigênio } \\
\hline $\mathrm{TSi}$ & 2,003 & 1,999 & 1,987 & 2,000 & 1,979 & 1,976 & 1,966 & 1,989 & 1,983 \\
\hline TAl & 0,000 & 0,001 & 0,013 & 0,000 & 0,021 & 0,024 & 0,034 & 0,011 & 0,017 \\
\hline TFe3 & 0,000 & 0,000 & 0,000 & 0,000 & 0,000 & 0,000 & 0,000 & 0,000 & 0,000 \\
\hline $\mathrm{MIAl}$ & 0,030 & 0,031 & 0,025 & 0,044 & 0,012 & 0,017 & 0,005 & 0,022 & 0,020 \\
\hline MTi & 0,002 & 0,000 & 0,003 & 0,004 & 0,004 & 0,002 & 0,003 & 0,003 & 0,003 \\
\hline $\mathrm{M} \mathrm{Fe} 3$ & 0,000 & 0,000 & 0,000 & 0,000 & 0,008 & 0,017 & 0,021 & 0,000 & 0,000 \\
\hline $\mathrm{MFe} 2$ & 0,349 & 0,370 & 0,227 & 0,218 & 0,370 & 0,153 & 0,155 & 0,176 & 0,189 \\
\hline $\mathrm{MICr}$ & 0,000 & 0,002 & 0,000 & 0,000 & 0,000 & 0,000 & 0,003 & 0,000 & 0,001 \\
\hline $\mathrm{MlMg}$ & 0,619 & 0,597 & 0,740 & 0,733 & 0,804 & 0,809 & 0,813 & 0,799 & 0,787 \\
\hline $\mathrm{MNi}$ & 0,000 & 0,000 & 0,005 & 0,001 & 0,002 & 0,003 & 0,001 & 0,000 & 0,000 \\
\hline $\mathrm{M} 2 \mathrm{Fe} 2$ & 0,906 & 0,905 & 0,938 & 0,923 & 0,927 & 0,922 & 0,933 & 0,929 & 0,924 \\
\hline $\mathrm{M} 2 \mathrm{Mn}$ & 0,047 & 0,050 & 0,037 & 0,036 & 0,030 & 0,028 & 0,030 & 0,030 & 0,029 \\
\hline $\mathrm{M} 2 \mathrm{Ca}$ & 0,039 & 0,042 & 0,024 & 0,031 & 0,037 & 0,036 & 0,035 & 0,039 & 0,040 \\
\hline $\mathrm{M} 2 \mathrm{Na}$ & 0,005 & 0,003 & 0,000 & 0,009 & 0,006 & 0,012 & 0,002 & 0,003 & 0,007 \\
\hline M2K & 0,001 & 0,000 & 0,001 & 0,001 & 0,000 & 0,003 & 0,000 & 0,000 & 0,001 \\
\hline Sumcat & 3,999 & 4,000 & 3,999 & 3,999 & 4,000 & 3,997 & 4,000 & 4,000 & 3,999 \\
\hline WO & 1,990 & 2,150 & 1,220 & 1,570 & 1,860 & 1,830 & 1,770 & 1,960 & 2,010 \\
\hline EN & 31,61 & 30,42 & 37,65 & 37,77 & 40,69 & 41,18 & 40,91 & 40,54 & 39,98 \\
\hline FS & 66,40 & 67,43 & 61,13 & 60,66 & 57,45 & 56,99 & 57,33 & 57,50 & 58,01 \\
\hline $\mathrm{Fe} / \mathrm{Fe}+1$ & 0,670 & 0,681 & 0,611 & 0,609 & 0,579 & 0,574 & 0,577 & 0,580 & 0,586 \\
\hline $\mathrm{Mg} / \mathrm{Mg}+\mathrm{Fe}$ & 0,330 & 0,319 & 0,389 & 0,391 & 0,421 & 0,426 & 0,423 & 0,420 & 0,414 \\
\hline
\end{tabular}


Tabela 6.11 - Análises químicas de anfibólios das rochas charnoquitóides do Maciço de Várzea Alegre

\begin{tabular}{|c|c|c|c|c|c|c|c|}
\hline \multirow[b]{2}{*}{ Amostras } & \multirow{2}{*}{ VA 257.1 } & \multirow{2}{*}{$\frac{\text { Jotunitos }}{\text { VA } 257.2}$} & \multirow{2}{*}{ VA 257.3} & \multirow{2}{*}{ VA 182.1 } & \multicolumn{2}{|c|}{ OPX-quartzo-dioritos } & \multirow{2}{*}{ VA 261.2} \\
\hline & & & & & VA 182.2 & VA 261.1 & \\
\hline $\mathrm{SiO} 2$ & 40,87 & 40,45 & 40,19 & 41,77 & 41,25 & 40,02 & 40,54 \\
\hline TiO2 & 2,10 & 1,98 & 2,29 & 1,95 & 2,18 & 2,22 & 2,26 \\
\hline $\mathrm{Al} 2 \mathrm{O} 3$ & 11,02 & 11,13 & 10,98 & 11,30 & 10,62 & 11,13 & 11,30 \\
\hline $\mathrm{C}+2 \mathrm{O} 3$ & 0,03 & 0,06 & 0,03 & 0,00 & 0,02 & 0,00 & 0,04 \\
\hline $\mathrm{FeO}$ & 21,36 & 21,88 & 21,02 & 21,57 & 21,93 & 21,11 & 21,84 \\
\hline $\mathrm{MnO}$ & 0,29 & 0,15 & 0,29 & 0.26 & 0,15 & 0,28 & 0,24 \\
\hline $\mathrm{MgO}$ & 7,73 & 7,62 & 7,60 & 7,22 & 7,63 & 7,14 & 7,24 \\
\hline $\mathrm{CaO}$ & 11,41 & 11,60 & 11,58 & 11,61 & 11,49 & 11,86 & 11,60 \\
\hline $\mathrm{Na} 2 \mathrm{O}$ & 1,33 & 1,47 & 1,40 & 1,18 & 1,27 & 1,11 & 1,37 \\
\hline $\mathrm{K} 2 \mathrm{O}$ & 1,72 & 1,68 & 1,68 & 1,74 & 1,57 & 1,68 & 1,79 \\
\hline $\mathrm{F}$ & 0,16 & 0,16 & 0,29 & 0,20 & 0,24 & 0,30 & 0,18 \\
\hline $\mathrm{Cl}$ & 0,11 & 0,13 & 0,12 & 0,14 & 0,07 & 0,08 & 0,10 \\
\hline Total & 98,13 & 98,31 & 97,47 & 98,94 & 98,42 & 96,93 & 98,50 \\
\hline O_F_Cl & 0,090 & 0,100 & 0,150 & 0,120 & 0,120 & 0,140 & 0,100 \\
\hline $\mathrm{OF}$ & 0,070 & 0,070 & 0,120 & 0,080 & 0,100 & 0,130 & 0,080 \\
\hline $\mathrm{O} \mathrm{Cl}$ & 0,020 & 0,030 & 0.030 & 0,030 & 0,020 & 0,020 & 0,020 \\
\hline \multicolumn{8}{|c|}{ Número de ions na base de 23 átomos de oxigênio } \\
\hline TS & 6,272 & 6,215 & 6,235 & 6,369 & 6,316 & 6,247 & 6,232 \\
\hline TAl & 1,728 & 1,785 & 1,765 & 1,631 & 1,684 & 1,753 & 1,768 \\
\hline SumT & 8,000 & 8,000 & 8,000 & 8,000 & 8,000 & 8,000 & 8,000 \\
\hline $\mathrm{CAl}$ & 0,264 & 0,229 & 0,241 & 0,399 & 0,231 & 0,293 & 0,277 \\
\hline $\mathrm{CCr}_{\mathrm{r}}$ & 0,004 & 0,007 & 0,004 & 0,000 & 0,002 & 0,000 & 0,005 \\
\hline $\mathrm{CFe} 3$ & 0,375 & 0,420 & 0,312 & 0,207 & 0,388 & 0,286 & 0,299 \\
\hline $\mathrm{CTi}$ & 0,242 & 0,229 & 0,267 & 0,224 & 0,251 & 0,261 & 0,261 \\
\hline $\mathrm{CMg}$ & 1,769 & 1,745 & 1,758 & 1,641 & 1,742 & 1,661 & 1,659 \\
\hline $\mathrm{CFe} 2$ & 2,328 & 2,360 & 2,399 & 2,512 & 2,377 & 2,470 & 2,482 \\
\hline $\mathrm{CMn}$ & 0,019 & 0,010 & 0,019 & 0,017 & 0,010 & 0,029 & 0,016 \\
\hline SumC & 5,000 & 5,000 & 5,000 & 5,000 & 5,000 & 5,000 & 5,000 \\
\hline $\mathrm{BFe} 2$ & 0,039 & 0,032 & 0,016 & 0,031 & 0,044 & 0,000 & 0,026 \\
\hline $\mathrm{BMn}$ & 0,019 & 0,010 & 0,019 & 0,017 & 0,010 & 0,008 & 0,016 \\
\hline $\mathrm{CaB}$ & 1,876 & 1,910 & 1,925 & 1,897 & 1,855 & 1,983 & 1,911 \\
\hline $\mathrm{NaB}$ & 0,066 & 0,048 & 0,040 & 0,055 & 0,061 & 0,009 & 0,048 \\
\hline SumB & 2,000 & 2,000 & 2,000 & 2,000 & 2,000 & 2,000 & 2,000 \\
\hline $\mathrm{ANa}$ & 0,330 & 0,390 & 0,381 & 0,294 & 0,316 & 0,327 & 0,361 \\
\hline AK & 0,337 & 0,329 & 0,333 & 0,338 & 0,307 & 0,335 & 0,351 \\
\hline SumA & 0,666 & 0,719 & 0,713 & 0,632 & 0,622 & 0,662 & 0,712 \\
\hline $\mathrm{CCl}$ & 0,029 & $0,0,34$ & 0,032 & 0,036 & 0,018 & 0,021 & 0,026 \\
\hline CF & 0,078 & 0,078 & 0.142 & 0,096 & 0,116 & 0,148 & 0,088 \\
\hline $\mathrm{Fe} / \mathrm{Fe}+\mathrm{Mg}$ & 0,608 & 0,617 & 0,608 & 0,626 & 0,617 & 0,624 & 0,628 \\
\hline $\mathrm{Mg} / \mathrm{Mg}+\mathrm{Fe}$ & 0,392 & 0,383 & 0,392 & 0,374 & 0,383 & 0,376 & 0,372 \\
\hline
\end{tabular}


Tabela 6.12 - Análises químicas de biotitas das rochas chamoquitóides do Maciço de Várzea Alegre

\begin{tabular}{|c|c|c|c|c|c|c|c|c|c|c|}
\hline \multirow[b]{2}{*}{ Amostras } & \multirow{2}{*}{ VA 257.1 } & \multirow{2}{*}{$\frac{\text { Jotunitos }}{\text { VA } \mathbf{2 5 7 . 2}}$} & \multirow{2}{*}{$\frac{\text { VA257.3* }}{\ldots-\cdots}$} & \multicolumn{2}{|c|}{ Qtzo-mangeritos } & \multicolumn{2}{|c|}{ (................... } & \multicolumn{2}{|c|}{ OPX-quartzo-dioritos } & (2) \\
\hline & & & & VA263.1* & VA 263.2 & VA182.1* & VA 182.2 & VA 182.3 & VA 261.1 & VA 261.2 \\
\hline $\mathrm{SiO} 2$ & 35,39 & 35,77 & 35,32 & 34,04 & 35,05 & 34,91 & 34,40 & 35,47 & 35,21 & 34,23 \\
\hline $\mathrm{TiO} 2$ & 5,39 & 5,22 & 5,55 & 5,02 & 5,19 & 5,70 & 5,67 & 5,46 & 5,99 & 5,27 \\
\hline $\mathrm{A} 12 \mathrm{O} 3$ & 14,13 & 13,58 & 14,15 & 14,11 & 14,52 & 13,89 & 13,81 & 13,92 & 13,93 & 14,26 \\
\hline $\mathrm{Cr} 2 \mathrm{O} 3$ & 0,00 & 0,01 & 0,03 & 0,09 & 0,00 & 0,06 & 0,00 & 0,04 & 0,00 & 0,04 \\
\hline $\mathrm{FeO}$ & 22,76 & 22,65 & 23,19 & 26,52 & 26,63 & 23,48 & 23,21 & 23,65 & 23,78 & 24,06 \\
\hline $\mathrm{MnO}$ & 0,10 & 0,11 & 0,11 & 0,14 & 0,12 & 0,09 & 0,07 & 0,14 & 0,10 & 0,01 \\
\hline $\mathrm{MgO}$ & 9,65 & 9,19 & 8,54 & 6,34 & 6,45 & 8,52 & 8,55 & 8,76 & 8,33 & 8,34 \\
\hline $\mathrm{Na} 2 \mathrm{O}$ & 0,03 & 0,08 & 0,06 & 0,20 & 0,04 & 0,14 & 0,05 & 0,15 & 0,00 & 0,16 \\
\hline $\mathrm{K} 2 \mathrm{O}$ & 9,40 & 9,35 & 9,44 & 9,59 & 9,47 & 9,46 & 9,53 & 9,40 & 9,54 & 9,52 \\
\hline$F$ & 0,37 & 0,56 & 0,57 & 0,35 & 0,07 & 0,26 & 0,26 & 0,17 & 0,28 & 0,31 \\
\hline $\mathrm{Cl}$ & 0,16 & 0,13 & 0,14 & 0,12 & 0,01 & 0,10 & 0,13 & 0,14 & 0,12 & 0,15 \\
\hline Total & 97,38 & 96,65 & 97,10 & 96,52 & 97,55 & 96,61 & 95,68 & 97,30 & 97,28 & 96,35 \\
\hline $\mathrm{O} \mathrm{FCl}$ & 0,19 & 0,27 & 0,27 & 0,17 & 0,03 & 0,13 & 0,14 & 0,10 & 0,14 & 0,16 \\
\hline \multicolumn{11}{|c|}{ Número de íns na base de 22 átomos de oxigênio } \\
\hline $\mathrm{Si}$ & 5,676 & 5,786 & 5,707 & 5,643 & 5,691 & 5,670 & 5,648 & 5,708 & 5,681 & 5,606 \\
\hline AlIV & 2,324 & 2,214 & 2,293 & 2,357 & 2,309 & 2,330 & 2,352 & 2,292 & 2,319 & 2,394 \\
\hline AIVI & 0,345 & 0,373 & 0,400 & 0,398 & 0,468 & 0,327 & 0,318 & 0,346 & 0,328 & 0,356 \\
\hline $\mathrm{Ti}$ & 0,650 & 0,635 & 0,675 & 0,626 & 0,634 & 0,696 & 0,700 & 0,661 & 0,727 & 0,649 \\
\hline $\mathrm{Fe} 2$ & 3,053 & 3,064 & 3,134 & 3,676 & 3,616 & 3,189 & 3,187 & 3,183 & 3,209 & 3,295 \\
\hline $\mathrm{Cr}$ & 0,000 & 0,001 & 0,004 & 0,012 & 0,000 & 0,008 & 0,000 & 0,005 & 0,000 & 0,005 \\
\hline $\mathrm{Mn}$ & 0,014 & 0,015 & 0,015 & 0,020 & 0,017 & 0,012 & 0,010 & 0,019 & 0,014 & 0,001 \\
\hline $\mathrm{Mg}$ & 2,307 & 2,216 & 2,057 & 1,567 & 1,561 & 2,063 & 2,093 & 2,102 & 2,004 & 2,036 \\
\hline $\mathrm{Na}$ & 0,009 & 0,025 & 0,019 & 0,064 & 0,013 & 0,044 & 0,016 & 0,047 & 0,000 & 0,051 \\
\hline $\mathrm{K}$ & 1,923 & 1,929 & 1,946 & 2,028 & 1,962 & 1,960 & 1,996 & 1,930 & 1,964 & 1,989 \\
\hline $\mathrm{CF}$ & 0,375 & 0,573 & 0,583 & 0,367 & 0,072 & 0,267 & 0.270 & 0,173 & 0,286 & 0,321 \\
\hline $\mathrm{CCl}$ & 0,087 & 0,071 & 0,077 & 0,067 & 0,006 & 0,055 & 0.072 & 0,076 & 0,066 & 0,083 \\
\hline $\mathrm{Fe} / \mathrm{Fe}+\mathrm{Mg}$ & 0,569 & 0,580 & 0,604 & 0,701 & 0,698 & 0,607 & 0,603 & 0,602 & 0,616 & 0,618 \\
\hline $\mathrm{Mg} / \mathrm{Mg}+\mathrm{Fe}$ & 0.431 & 0,420 & 0,396 & 0,299 & 0,302 & 0,393 & 0,397 & 0,398 & 0,384 & 0,382 \\
\hline
\end{tabular}

(*) Corresponde à média de duas análises muito semelhantes 
Tabela 6.13 - Análises químicas de megacristais de plagioclásio das rochas charnoquitóides do Maciço de Várzea Alegre

\begin{tabular}{|c|c|c|c|c|c|c|c|c|c|c|c|c|c|c|c|c|c|c|c|}
\hline \multirow{3}{*}{ Amostras } & \multicolumn{2}{|c|}{ 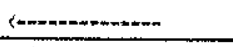 } & \multirow{2}{*}{$\frac{\text { Jotunitos }}{\text { VA }}$} & \multicolumn{2}{|c|}{$\ldots$} & \multirow{2}{*}{$\frac{1}{\mathrm{VA}}$} & \multicolumn{3}{|c|}{ OPX-quartzo-dioritos } & \multirow{3}{*}{$\frac{\mathrm{VA}_{2}}{261.3}$} & \multicolumn{3}{|c|}{ (-) Quartzo-mangeritos - - $)$} & \multicolumn{2}{|c|}{ 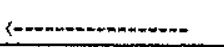 } & \multicolumn{2}{|c|}{ Opdalitos } & \multicolumn{2}{|c|}{ - } \\
\hline & VA & VA & & VA & VA & & VA & VA & VA & & VA & VA & VA & $\overline{\mathrm{VA}}$ & VA & $\mathrm{VA}$ & VA & VA & VA \\
\hline & 257.1 & 257.2 & 257.3 & 56.1 & 56.2 & 182.1 & 182.2 & 261.1 & 261.2 & & 263.1 & 263.2 & 263.3 & 252.1 & 252.2 & 252.3 & 244.1 & 244.2 & 244.3 \\
\hline $\mathrm{SiO} 2$ & 58,60 & 59,79 & 58,08 & 57,77 & 57,20 & 57,59 & 58,52 & 57,75 & 57,61 & 56,58 & 59,86 & 58,77 & 59,68 & 59,27 & 58,88 & 58,47 & 59,23 & 59,44 & 59,28 \\
\hline $\mathrm{A} 12 \mathrm{O} 3$ & 25,31 & 25,25 & 25,01 & 25,59 & 25,50 & 25,22 & 25,74 & 25,74 & 25,91 & 25,09 & 24,84 & 25,25 & 25,02 & 24,84 & 25,24 & 24,92 & 24,80 & 25,04 & 24,41 \\
\hline $\mathrm{FeO}$ & 0,09 & 0,16 & 0,18 & 0,07 & 0,07 & 0,06 & 0,12 & 0,19 & 0,16 & 0,12 & 0,09 & 0,07 & 0,07 & 0,14 & 0,11 & 0,10 & 0,21 & 0,05 & 0,17 \\
\hline $\mathrm{CaO}$ & 7,75 & 7,80 & 7,75 & 8,11 & 8,26 & 8,07 & 8,23 & 8,63 & 8,70 & 8,45 & 7,34 & 7,56 & 7,33 & 7,47 & 7,74 & 7,54 & 7,18 & 7,60 & 7,06 \\
\hline $\mathrm{Na}$ & 7,58 & 7,68 & 7,38 & 7,38 & 7,29 & 7,42 & 7,37 & 7,09 & 6,80 & 7,35 & 8,12 & 7,69 & 7,99 & 8,10 & 7,61 & 7,83 & 7,84 & 7,75 & 7,93 \\
\hline $\mathrm{K} 2 \mathrm{O}$ & 0,46 & 0,55 & 0,79 & 0,54 & 0,34 & 0,46 & 0,53 & 0,58 & 0,53 & 0,50 & 0,57 & 0,57 & 0,57 & 0,48 & 0,51 & 0,42 & 0,45 & 0,53 & 0,56 \\
\hline $\mathrm{BaO}$ & 0,00 & 0,00 & 0,04 & 0,00 & 0,12 & 0,00 & 0,04 & 0,16 & 0,00 & 0,08 & 0,17 & 0,00 & 0,00 & 0,00 & 0,00 & 0,00 & 0,16 & 0,07 & 0,04 \\
\hline $\mathrm{SrO}$ & 0,14 & 0,10 & 0,00 & 0,13 & 0,00 & 0,00 & 0,10 & 0,00 & 0,10 & 0,12 & 0,03 & 0,00 & 0,18 & 0,16 & 0,05 & 0,00 & 0,00 & 0,00 & 0,00 \\
\hline Total & 99,93 & 101,33 & 99,23 & 99,59 & 98,78 & 98,82 & 100,64 & 100,14 & 99,81 & 98,29 & 101,02 & 99,91 & 100,84 & 100,46 & 100,14 & 99,28 & 99,87 & 100,48 & 99,45 \\
\hline
\end{tabular}

Número de íns na base de 32 átomos de oxigênio

\begin{tabular}{|c|c|c|c|c|c|c|c|c|c|c|c|c|c|c|c|c|c|c|c|}
\hline $\mathrm{Si}$ & 10,53 & 10,60 & 10,53 & 10,44 & 10,42 & 10,47 & 10,46 & 10,40 & 10,39 & 10,46 & 10,65 & 10,56 & 10,27 & 10,61 & 10,56 & 10,57 & 10,64 & 10,61 & 10,69 \\
\hline $\mathrm{Al}$ & 5,357 & 5,270 & 5,340 & 5,445 & 5,468 & 5,401 & 5,418 & 5,458 & 5,502 & 5,365 & 5,203 & 5,341 & 5,246 & 5,234 & 5,328 & 5,305 & 5,247 & 5,265 & 5,183 \\
\hline $\mathrm{Fe} 2$ & 0,014 & 0,024 & 0,027 & 0,011 & 0,011 & 0,009 & 0,018 & 0,029 & 0,024 & 0,018 & 0,013 & 0,011 & 0,010 & 0,021 & 0,016 & 0,015 & 0,032 & 0,007 & 0,026 \\
\hline $\mathrm{Ba}$ & 0,000 & 0,000 & 0,003 & 0,000 & 0,009 & 0,000 & 0,003 & 0,011 & 0,000 & 0,006 & 0,012 & 0,000 & 0,000 & 0,000 & 0,000 & 0,000 & 0,011 & 0,005 & 0,003 \\
\hline $\mathrm{Ca}$ & 1,492 & 1,481 & 1,505 & 1,570 & 1,612 & 1,572 & 1,576 & 1,665 & 1,681 & 1,644 & 1,399 & 1,455 & 1,398 & 1,432 & 1,487 & 1,460 & 1,382 & 1,454 & 1,364 \\
\hline $\mathrm{Na}$ & 2,641 & 2,639 & 2,594 & 2,585 & 2,574 & 2,617 & 2,554 & 2,475 & 2,377 & 2,588 & 2,801 & 2,678 & 2,758 & 2,810 & 2,645 & 2,744 & 2,731 & 2,683 & 2,772 \\
\hline $\mathrm{K}$ & 0,105 & 0,124 & 0,183 & 0,124 & 0,079 & 0,107 & 0,121 & 0,133 & 0,122 & 0,116 & 0,129 & 0,131 & 0,129 & 0,110 & 0,117 & 0,097 & 0,103 & 0,121 & 0,129 \\
\hline $\mathrm{Ab}$ & 62,30 & 62,20 & 60,60 & 60,40 & 60,40 & 60,90 & 60,10 & 57,90 & 56,90 & 59,50 & 64,70 & 62,80 & 64,60 & 64,60 & 62,20 & 63,80 & 64,80 & 63,00 & 65,00 \\
\hline An & 35,20 & 34,90 & 35,10 & 36,70 & 37,80 & 36,60 & 37,10 & 39,00 & 40,20 & 37,80 & 32,30 & 34,10 & 32,60 & 32,90 & 35,00 & 33,90 & 32,80 & 34,10 & 32,00 \\
\hline Or & 2,50 & 2,90 & 4,30 & 2,90 & 1,80 & 2,50 & 2,80 & 3,10 & 2,90 & 2,70 & 3,00 & 3,10 & 2,80 & 2,50 & 2,80 & 2,30 & 2,40 & 2,90 & 3,00 \\
\hline
\end{tabular}


Tabela 6.14 - Análises químicas de plagioclásios da matriz das rochas charnoquitóides do Maciço de Várzea Alegre

\begin{tabular}{|c|c|c|c|c|c|c|c|c|c|c|c|c|}
\hline \multirow{3}{*}{ Amostras } & \multicolumn{2}{|c|}{ 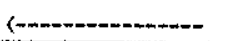 } & \multicolumn{2}{|c|}{ OPX-quartzo-dioritos } & $-\cdots-\cdots$ & \multicolumn{2}{|c|}{ Jotunitos } & \multicolumn{2}{|c|}{ Qtzo-mangeritos } & \multirow{2}{*}{ VA } & \multirow{3}{*}{$\begin{array}{c}\text { Opdalitos } \\
\text { VA } \\
252.2\end{array}$} & \multirow{3}{*}{ VA 244} \\
\hline & VA & VA & VA & VA & VA & $\overline{V A}$ & VA & $\mathrm{VA}$ & VA & & & \\
\hline & 261.1 & 261.2 & 182.1 & 182.2 & 182.3 & 56.1 & 56.2 & 263.1 & 263.2 & 252.1 & & \\
\hline $\mathrm{SiO} 2$ & 58,39 & 57,52 & 59,02 & 58,85 & 58,47 & 57,16 & 57,40 & 59,30 & 58,12 & 58,67 & 58,25 & 58,14 \\
\hline $\mathrm{Al} 2 \mathrm{O} 3$ & 25,35 & 25,75 & 25,45 & 25,14 & 25,63 & 25,66 & 25,45 & 24,93 & 24,50 & 24,74 & 24,35 & 24,31 \\
\hline $\mathrm{FeO}$ & 0,14 & 0,08 & 0,08 & 0,13 & 0,11 & 0,17 & 0,13 & 0,09 & 0,09 & 0,07 & 0,23 & 0,09 \\
\hline $\mathrm{CaO}$ & 8,53 & 8,53 & 8,03 & 7,87 & 8,21 & 8,35 & 8,30 & 7,26 & 7,32 & 7,27 & 7,06 & 7,13 \\
\hline $\mathrm{Na} 2 \mathrm{O}$ & 7,18 & 7,01 & 7,69 & 7,74 & 7,53 & 7,26 & 7,21 & 7,82 & 7,91 & 7,80 & 7,66 & 7,77 \\
\hline $\mathrm{K} 2 \mathrm{O}$ & 0,56 & 0,54 & 0,27 & 0,32 & 0,21 & 0,31 & 0,35 & 0,52 & 0,56 & 0,45 & 0,45 & 0,55 \\
\hline $\mathrm{BaO}$ & 0,04 & 0,08 & 0,08 & 0,16 & 0,12 & 0,00 & 0,00 & 0,00 & 0,02 & 0,16 & 0,00 & 0,00 \\
\hline $\mathrm{SrO}$ & 0,00 & 0,00 & 0,01 & 0,10 & 0,04 & 0,11 & 0,07 & 0,00 & 0,01 & 0,00 & 0,10 & 0,09 \\
\hline Total & 100,19 & 99,51 & 100,63 & 100,31 & 100,32 & 99,02 & 98,91 & 99,92 & 98,53 & 99,16 & 98,10 & 98,08 \\
\hline \multicolumn{13}{|c|}{ Número de íons na base de 32 átomos de oxigênio } \\
\hline $\mathrm{Si}$ & 10,49 & 10,40 & 10,53 & 10,55 & 10,47 & 10,39 & 10,43 & 10,63 & 10,60 & 10,62 & 10,65 & 10,64 \\
\hline $\mathrm{Al}$ & 5,361 & 5,484 & 5,347 & 5,307 & 5,406 & 5,492 & 5,448 & 5,265 & 5,260 & 5,272 & 5,241 & 5,237 \\
\hline $\mathrm{Fe} 2$ & 0,021 & 0,012 & 0,012 & 0,019 & 0,016 & 0,026 & 0,020 & 0,013 & 0,014 & 0,011 & 0,035 & 0,014 \\
\hline $\mathrm{Ba}$ & 0,003 & 0,006 & 0,006 & 0,011 & 0,008 & 0,000 & 0,000 & 0,000 & 0,001 & 0,011 & 0,000 & 0,000 \\
\hline $\mathrm{Ca}$ & 1,641 & 1,653 & 1,535 & 1,511 & 1,576 & 1,626 & 1,616 & 1,395 & 1,430 & 1,409 & 1,383 & 1,398 \\
\hline $\mathrm{Na}$ & 2,500 & 2,458 & 2,660 & 2,690 & 2,615 & 2,558 & 2,541 & 2,719 & 2,796 & 2,737 & 2,715 & 2,756 \\
\hline $\mathrm{K}$ & 0,128 & 0,125 & 0,061 & 0,073 & 0,048 & 0,072 & 0,081 & 0,119 & 0,130 & 0,104 & 0,105 & 0,128 \\
\hline $\mathrm{Ab}$ & 58,60 & 58,00 & 62,50 & 62,90 & 61,70 & 60,10 & 60,00 & 64,20 & 64,20 & 64,40 & 64,60 & 64,40 \\
\hline An & 38,40 & 39,00 & 36,10 & 35,40 & 37,20 & 38,20 & 38,10 & 33,00 & 32,80 & 33,20 & 32,90 & 32,60 \\
\hline $\mathrm{Or}$ & 3,00 & 3,00 & 2,40 & 1,70 & 1,10 & 1,70 & 1,90 & 2,80 & 3,00 & 2,40 & 2,50 & 3,00 \\
\hline
\end{tabular}


Tabela 6.15 - Análises químicas de megacristais de feldspato potássico das rochas charnoquitóides do Maciço de Várzea Alegre

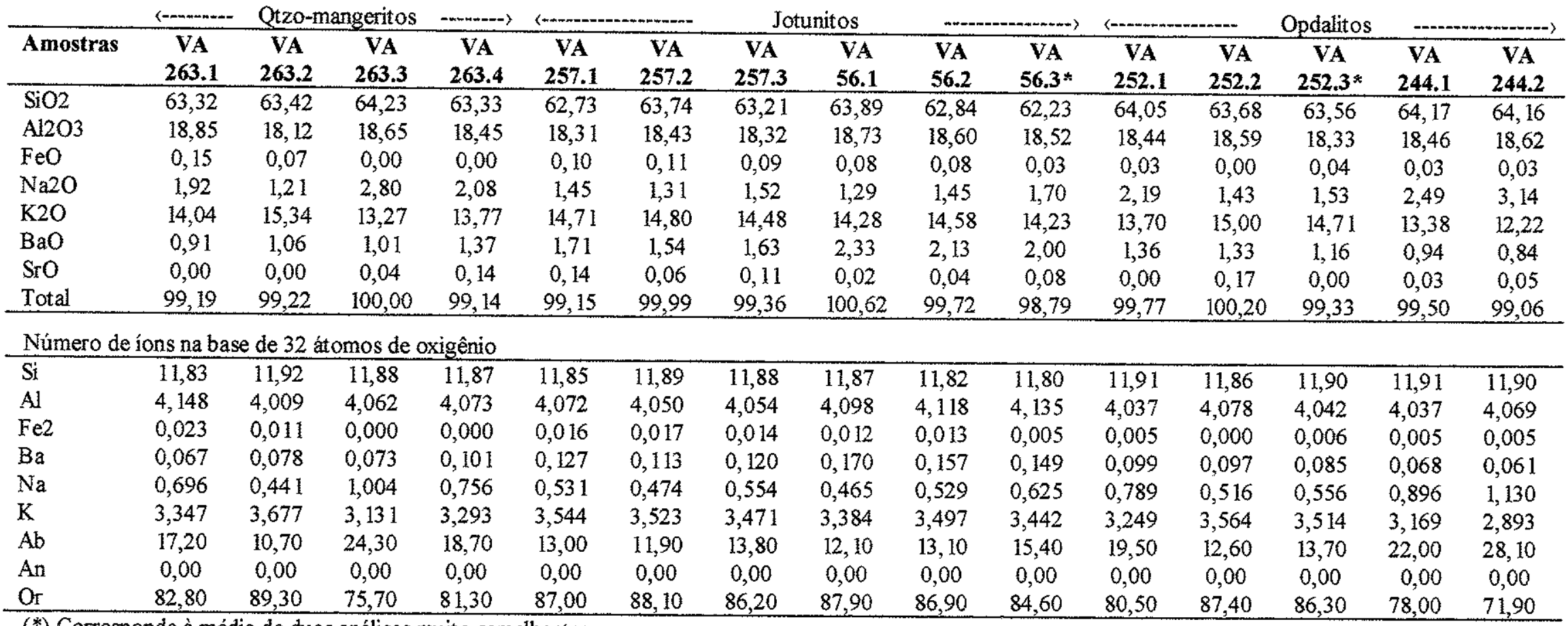

(*) Corresponde à média de duas análises muito semelhantes 
Tabela 6.16 - Análises químicas de feldspato potássico da matriz das rochas charnoquitóides do Maciço de Várzea Alegre

\begin{tabular}{|c|c|c|c|c|c|c|c|}
\hline \multirow[b]{2}{*}{ Amostras } & \multirow{2}{*}{$\begin{array}{c}\mathrm{VA} \\
261.1\end{array}$} & \multicolumn{2}{|c|}{ OPX-quartzo-dioritos } & \multirow{2}{*}{$\begin{array}{c}\mathrm{VA} \\
182.2\end{array}$} & \multicolumn{2}{|c|}{ Jotunitos } & \multirow{2}{*}{$\frac{\text { Qtz-mang }}{\text { VA } 263}$} \\
\hline & & $\begin{array}{c}\mathrm{VA} \\
261.2 \\
\end{array}$ & $\begin{array}{c}\text { VA } \\
182.1 \\
\end{array}$ & & VA 56 & VA 257 & \\
\hline $\mathrm{SiO} 2$ & 61,69 & 63,14 & 62,91 & 63,38 & 63,67 & 63,47 & 64,07 \\
\hline $\mathrm{Al} 2 \mathrm{O} 3$ & 18,44 & 18,58 & 18,85 & 18,35 & 18,70 & 18,40 & 18,66 \\
\hline $\mathrm{FeO}$ & 0,09 & 0,09 & 0,10 & 0,00 & 0,08 & 0,05 & 0,92 \\
\hline $\mathrm{CaO}$ & 0,00 & 0,00 & 0,00 & 0,00 & 0,00 & 0,00 & 0,07 \\
\hline $\mathrm{Na} 2 \mathrm{O}$ & 1,23 & 1,33 & 1,20 & 1,45 & 1,37 & 2,29 & 3,57 \\
\hline $\mathrm{K} 2 \mathrm{O}$ & 14,88 & 14,79 & 15,08 & 14,76 & 14,46 & 13,70 & 11,87 \\
\hline $\mathrm{BaO}$ & 2,01 & 2,05 & 1,75 & 1,97 & 2,19 & 1,36 & 0,62 \\
\hline $\mathrm{SrO}$ & 0,17 & 0,00 & 0,00 & 0,05 & 0,14 & 0,13 & 0,08 \\
\hline Total & 98,51 & 99,98 & 99,89 & 99,96 & 100,61 & 99,40 & 99,86 \\
\hline \multicolumn{8}{|c|}{ Número de íons na base de 32 átomos de oxigênio } \\
\hline $\mathrm{Si}$ & 11,826 & 11,834 & 11,793 & 11,872 & 11,848 & 11,872 & 11,830 \\
\hline $\mathrm{Al}$ & 4,097 & 4,101 & 4,161 & 4,048 & 4,098 & 4,053 & 4,058 \\
\hline $\mathrm{Fe} 2$ & 0,014 & 0,014 & 0,016 & 0,000 & 0,012 & 0,008 & 0,142 \\
\hline $\mathrm{Ba}$ & 0,149 & 0,151 & 0,129 & 0,145 & 0,160 & 0,100 & 0,045 \\
\hline $\mathrm{Ca}$ & 0,000 & 0,000 & 0,000 & 0,000 & 0,000 & 0,000 & 0,014 \\
\hline $\mathrm{Na}$ & 0,450 & 0,483 & 0,436 & 0,527 & 0,494 & 0,831 & 1,278 \\
\hline K & 3,581 & 3,536 & 3,606 & 3,527 & 3,433 & 3,269 & 2,796 \\
\hline $\mathrm{Ab}$ & 11,20 & 12,00 & 10,80 & 13,00 & 12,60 & 20,30 & 31,30 \\
\hline An & 0,000 & 0,000 & 0,000 & 0,000 & 0,000 & 0,000 & 0,300 \\
\hline Or & 88,80 & 88,00 & 89,20 & 87,00 & 87,40 & 79,70 & 68,40 \\
\hline
\end{tabular}


Tabela 6.17 - Análises químicas de ilmenitas das rochas charnoquitóides do Maciço de Várzea Alegre

\begin{tabular}{|c|c|c|c|c|c|c|c|}
\hline & $(\cdots)$ & -gtzo-di & $\operatorname{los} \quad-\cdots$ & 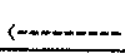 & Jotunitos & -……-- & Opdalito \\
\hline \multirow{2}{*}{ Amostras } & VA & $\mathrm{VA}$ & VA 182 & VA & VA & $\mathrm{VA}$ & VA 252 \\
\hline & 261.1 & 261.2 & & 56.1 & 257.1 & 257.2 & \\
\hline $\mathrm{SiO} 2$ & 0,11 & 0,04 & 0,08 & 0,11 & 0,02 & 0,09 & 0,19 \\
\hline $\mathrm{TiO} 2$ & 43,73 & 43,53 & 44,21 & 45,04 & 45,22 & 45,76 & 45,95 \\
\hline $\mathrm{Al} 2 \mathrm{O} 3$ & 0,09 & 0,13 & 0,06 & 0,06 & 0,14 & 0,07 & 0,07 \\
\hline $\mathrm{Cr} 2 \mathrm{O} 3$ & 0,07 & 0,07 & 0,02 & 0,06 & 0,00 & 0,05 & 0,00 \\
\hline $\mathrm{FeO}$ & 49,55 & 48,99 & 46,13 & 46,57 & 44,91 & 45,13 & 44,50 \\
\hline $\mathrm{MnO}$ & 0,49 & 0,48 & 0,74 & 0,84 & 0,79 & 0,66 & 1,59 \\
\hline $\mathrm{MgO}$ & 0,47 & 0,57 & 0,66 & 0,54 & 0,46 & 0,37 & 0,17 \\
\hline $\mathrm{NiO}$ & 0,06 & 0,11 & 0,03 & 0,00 & 0,00 & 0,00 & 0,01 \\
\hline $\mathrm{CaO}$ & 0,06 & 0,03 & 0,08 & 0,06 & 0,03 & 0,04 & 0,07 \\
\hline $\mathrm{Na} 2 \mathrm{O}$ & 0,21 & 0,00 & 0,04 & 0,25 & 0,05 & 0,06 & 0,08 \\
\hline Total & 94,84 & 93,95 & 92,05 & 93,53 & 91,62 & 92,23 & 92,63 \\
\hline \multicolumn{8}{|c|}{ Número de íons na base de 6 átomos de oxigênio } \\
\hline $\mathrm{Al}$ & 0,003 & 0,004 & 0,002 & 0,002 & 0,005 & 0,002 & 0,002 \\
\hline $\mathrm{Ti}$ & 0,871 & 0,872 & 0,905 & 0,910 & 0,931 & 0,938 & 0,941 \\
\hline $\mathrm{Fe} 3$ & 0,256 & 0,253 & 0,189 & 0,177 & 0,134 & 0,121 & 0,116 \\
\hline $\mathrm{Fe} 2$ & 0,841 & 0,838 & 0,861 & 0,870 & 0,894 & 0,908 & 0,897 \\
\hline $\mathrm{Mn}$ & 0,011 & 0,011 & 0,017 & 0,019 & 0,018 & 0,015 & 0,037 \\
\hline $\mathrm{Mg}$ & 0,019 & 0,023 & 0,027 & 0,022 & 0,019 & 0,015 & 0,007 \\
\hline Cations & 2,000 & 2,000 & 2,000 & 2,000 & 2,000 & 2,000 & 2,000 \\
\hline \multicolumn{8}{|c|}{ Membros finais em $\%$} \\
\hline $\mathrm{MgTiO} 3$ & 1,9 & 2,3 & 2,7 & 2,2 & 1,9 & 1,5 & 0,7 \\
\hline MnTiO3 & 1,1 & 1,1 & 1,8 & 1,9 & 1,8 & 1,5 & 3,7 \\
\hline FeTiO3 & 84,1 & 83,7 & 86,0 & 86,9 & 89,3 & 90,8 & 89,7 \\
\hline $\mathrm{Fe} 2 \mathrm{O} 3$ & 12,8 & 12,7 & 9,4 & 8,9 & 6,8 & 6,1 & 5,8 \\
\hline $\mathrm{Al} 2 \mathrm{O} 3$ & 0,1 & 0,2 & 0,1 & 0,1 & 0,2 & 0,1 & 0,1 \\
\hline
\end{tabular}


Tabela 6.18 - Análises químicas de magnetitas das rochas charnoquitóides do Maciço de Várzea Alegre

\begin{tabular}{|c|c|c|c|c|c|}
\hline \multirow{3}{*}{ Amostras } & s--:-an & \multicolumn{2}{|c|}{ Jotunitos } & \multirow{3}{*}{$\begin{array}{c}\text { VA } \\
257.2\end{array}$} & \multirow{3}{*}{$\frac{\text { Opdalito }}{\text { VA } 252}$} \\
\hline & VA & VA & $\mathrm{VA}$ & & \\
\hline & 56.1 & 56.2 & 257.1 & & \\
\hline $\mathrm{SiO} 2$ & 0,19 & 0,25 & 0,18 & 0,10 & 0,21 \\
\hline $\mathrm{TiO} 2$ & 0,12 & 0,29 & 0,37 & 0,05 & 0,33 \\
\hline $\mathrm{Al} 2 \mathrm{O} 3$ & 0,36 & 1,05 & 0,41 & 0,36 & 1,01 \\
\hline $\mathrm{Cr} 2 \mathrm{O} 3$ & 0,13 & 0,11 & 0,04 & 0,06 & 0,07 \\
\hline $\mathrm{FeO}$ & 90,86 & 90,72 & 89,02 & 90,07 & 89,07 \\
\hline $\mathrm{MnO}$ & 0,00 & 0,00 & 0,07 & 0,00 & 0,00 \\
\hline $\mathrm{MgO}$ & 0,19 & 0,15 & 0,07 & 0,11 & 0,11 \\
\hline $\mathrm{NiO}$ & 0,04 & 0,00 & 0,09 & 0,05 & 0,09 \\
\hline $\mathrm{CaO}$ & 0,08 & 0,00 & 0,01 & 0,00 & 0,00 \\
\hline $\mathrm{Na} 2 \mathrm{O}$ & 0,15 & 0,08 & 0,27 & 0,11 & 0,07 \\
\hline Total & 92,12 & 92,65 & 90,53 & 90,91 & 90,96 \\
\hline \multicolumn{6}{|c|}{ Número de íons na base de 4 átomos de oxigênio } \\
\hline Al & 0,017 & 0,048 & 0,019 & 0,017 & 0,047 \\
\hline $\mathrm{Ti}$ & 0,004 & 0,008 & 0,011 & 0,001 & 0,010 \\
\hline $\mathrm{Fe} 3$ & 1,976 & 1,935 & 1,959 & 1,980 & 1,934 \\
\hline $\mathrm{Fe} 2$ & 0,992 & 1,000 & 1,005 & 0,995 & 1,003 \\
\hline $\mathrm{Mn}$ & 0,000 & 0,000 & 0,002 & 0,000 & 0,000 \\
\hline $\mathrm{Mg}$ & 0,011 & 0,009 & 0,004 & 0,006 & 0,006 \\
\hline Cations & 3,000 & 3,000 & 3,000 & 3,000 & 3,000 \\
\hline \multicolumn{6}{|c|}{ Membros finais em $\%$} \\
\hline $\mathrm{MgAl} 2 \mathrm{O} 4$ & 0,70 & 0,60 & 0,30 & 0,40 & 0,40 \\
\hline $\mathrm{MnAl} 2 \mathrm{O} 4$ & 0 & 0 & 0,15 & 0 & 0 \\
\hline $\mathrm{FeAl204}$ & 0,40 & 2,60 & 0,90 & 0,75 & 2,73 \\
\hline $\mathrm{Fe} 2 \mathrm{TiO} 4$ & 0,40 & 0,80 & 1,10 & 0,10 & 1,00 \\
\hline $\mathrm{Fe} 3 \mathrm{O} 4$ & 98,50 & 96,00 & 97,55 & 98,75 & 95,87 \\
\hline
\end{tabular}




\section{CAPítulo 7}

\section{PETROGÊNESE DOS MACIÇOS DE VENDA NOVA E VÁRZEA ALEGRE}

\subsection{MACICO DE VENDA NOVA}

\section{Condições de cristalização das rochas $\left(\mathrm{PH}_{2} \mathrm{O}, \mathrm{T}, \mathbf{P}, \mathrm{f} \mathrm{O}_{2}\right)$}

A paragênese seguramente primária dos noritos e charnoquitóides de Venda Nova (plagioclásio $+\mathrm{OPX}+\mathrm{CPX}+\mathrm{ilmenita+quartzo)} \mathrm{sugere} \mathrm{que} \mathrm{os} \mathrm{magmas} \mathrm{progenitores} \mathrm{cristalizaram-}$ se sob condições anidras $\left(\mathrm{PCO}_{2}>>\mathrm{PH}_{2} \mathrm{O}\right)$ e de altas temperaturas. No entanto, alguns autores advogam que apesar da cristalização de paragênese condizente com um sistema anidro, pequenas quantidades de $\mathrm{H}_{2} \mathrm{O}$ na composição inicial de um magma são suficientes para estabilizar minerais hidratados, sobretudo flogopita-biotita. Wendlandt (1981) assinala que tal situação faz com que a flogopita se estabilize como fase solidus a pressões acima de 0,5 Kbar. Martignole (1979) salienta que apesar das condições predominantemente anidras na cristalização dos charnoquitos, algumas ocorrências têm apresentado saturação em $\mathrm{H}_{2} \mathrm{O}$ nos estágios tardimagmáticos. Ainda a este respeito, estudos experimentais têm comprovado que com suficiente atividade da água e concentração significativa de $\mathrm{K}_{2} \mathrm{O}$, magmas com atividade de $\mathrm{MgO}$ superior a $0,2 \%$ propiciariam a cristalização de flogopita nos estágios iniciais (Hewitt \& Wones, 1984). Portanto é possível, do ponto de vista físico-químico, a existência de biotitas primárias nos charnoquitóides de Venda Nova, mas se tal fenômeno efetivamente ocorreu os baixos teores de $\mathrm{K}_{2} \mathrm{O}$ detectados nas rochas não apontam para uma cristalização precoce das mesmas.

Segundo Naney (1983) a biotita pode se formar em condições mais secas do que as requeridas para a estabilidade da hornblenda. Os valores de $\mathrm{KdF}$ e-Mg para hornblendas e biotitas pode ser usado como aspecto distintivo entre biotitas transformadas da hornblenda e aquelas cristalizadas diretamente do magma. Saxena (1968) obteve valores próximos de 1,0 para hornblendas e biotitas em equilibrio de charnoquitos da Suécia, mesmo resultado alcançado por Mason (1985) para biotitas formadas a partir de hornblendas em granitóides do batólito costeiro do Peru; Kds de cerca de 1,6 foram obtidos por este autor para cristais tidos como primários. Os Kds para biotitas e anfibólios de Venda Nova são também iguais a 1,0, sugerindo portanto equilibrio entre estas fases provavelmente em subsolidus; deve-se ressaltar que os cristais 
analisados não mostram necessariamente contatos entre si, e que muitos dos anfibólios e das biotitas dessas rochas estão substituindo piroxênios.

Foram utilizados alguns pares de piroxênios coexistentes nas rochas da borda do maciço de Venda Nova para se estimar as temperaturas de equilíbrio, através da partição entre Fe e Mg, durante a cristalização magmática desses minerais. Por intermédio do "software" QUILF (Andersen et al., 1993), que permite o cálculo das condições de equilíbrio de diversas associações de minerais (piroxênios, óxidos de Fe-Ti-Mg, olivina e quartzo), tais temperaturas foram obtidas e encontram-se na tabela 7.1. Observa-se que para os noritos obteve-se uma média de $915 \pm 25^{\circ} \mathrm{C}$, inferior àquela calculada para os charnoquitóides, de $967 \pm 50^{\circ} \mathrm{C}$. Na mesma tabela estão os resultados geotermométricos alcançados através do método desenvolvido por Wood \& Banno (1973), que forneceram resultados ligeiramente inferiores, da ordem de $908^{\circ} \mathrm{C}$ para os noritos e de $958^{\circ} \mathrm{C}$ para os charnoquitóides (a amostra VN-27 foi descartada). Devemse destacar que os valores alcançados por tal método estão diminuídos de $60^{\circ} \mathrm{C}$, conforme recomendação de alguns autores. A amostra VN-27 é a que fornece as menores temperaturas. Estimativas através da calibração gráfica de Kretz (1963) resultaram em temperaturas de aproximadamente 840 e $980^{\circ} \mathrm{C}$, respectivamente.

Foi possível a obtenção das prováveis temperaturas de reequilibro mineral no estado subsolidus usando-se, no "software" QUILF, a opção do equilibrio entre magnetitailmenita. As temperaturas deram em torno de 580 a $600^{\circ} \mathrm{C}$, associadas a valores de $\log \mathrm{O}_{2}$ da

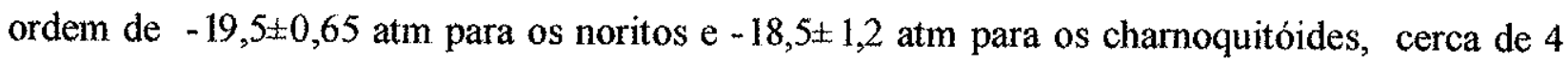
unidades log abaixo do tampão FMQ para as mesmas P e T. Tal resultado corrobora com as condições predominantemente redutoras já aventadas anteriormente (a partir das baixas proporções de molécula de hematita em solução sólida com ilmenita), apesar dos Mg\# relativamente altos dos minerais máficos sugerirem um estado de oxidação mais avançado na gênese dessas rochas.

Através do geotermômetro de Blundy \& Holland (1990), baseado nas trocas químicas entre plagioclásio e anfibólio, tencionou-se conseguir as temperaturas de reequilibro para estas duas fases. No entanto, as temperaturas calculadas para todas as amostras com análise de anfibólio variam de 920 a $970^{\circ} \mathrm{C}\left( \pm 75^{\circ} \mathrm{C}\right)$, utilizando-se diversos $\mathrm{X}_{\mathrm{ab}}$ e pressões calculadas pela equação proposta por Schmidt (1992). Apesar de tais valores corresponderem àqueles alcançados por meio do par OPX-CPX, eles não devem refletir o equilíbrio primário entre plagioclásio e hornblenda, uma vez que os anfibólios são secundários em sua grande maioria. 
Portanto, trata-se provavelmente de pura coincidência numérica, e não deve ter havido uma troca química global entre plagioclásios e anfibólios no estado subsolidus.

O grau de solubilidade de elementos traços constituintes de minerais acessórios em magmas granitóides é um indicador da temperatura desses magmas. Watson e Harrison (1983 e 1984) realizaram experiências neste sentido e propuseram gráficos onde associam o grau de saturação em $\mathrm{P}_{2} \mathrm{O}_{5}$ do magma ao conteúdo de $\mathrm{SiO}_{2}$ do mesmo para três intervalos térmicos, e a saturação em $\mathrm{Zr}$ com a razão $(\mathrm{Na}+\mathrm{K}+2 \mathrm{Ca}) /(\mathrm{Si} \times \mathrm{Al})$ para cinco diferentes temperaturas do magma (para ilustração, tais gráficos encontram-se nas figuras 7.2 e 7.3, mas com as amostras do maciço de Várzea Alegre).

Os baixos teores de $\mathrm{P}_{2} \mathrm{O}_{5}$ e $\mathrm{Zr}$ dos charnoquitóides de Venda Nova fazem com que as amostras fiquem concentradas nesses gráfícos abaixo das curvas de $800^{\circ} \mathrm{C}$. Temperaturas desta ordem são bem inferiores àquelas obtidas para o par OPX/CPX, e talvez indiquem a saturação nesses elementos (uma vez que ocorrem inclusões de apatita e zircão nos piroxênios, a saturação deve ter ocorrido em algum ponto). Provavelmente os conteúdos de $\mathrm{P}$ e $\mathrm{Zr}$ dessas rochas sejam o reflexo de uma fontejá empobrecida nestes elementos.

Diversos autores propuseram calibrações geobarométricas baseadas no conteúdo de Al dos anfibólios, a partir de dados analíticos/experimentais. Com a ressalva de que elas foram definidas para rochas com uma determinada paragênese (hornblenda-biotita-plagioclásioortoclásio-quartzo-titanita-opacos) e com anfíbólios primários, elas serão aqui utilizadas com o intuito de se estimar o intervalo de pressão no qual se deu o final de cristalização do magma (os anfibólios de Venda Nova foram, em sua maioria, formados no estado subsolidus). Os resultados obtidos através das equações de Hammarstrom \& Zen (1986), Hollister et al. (1987), Johnson \& Rutherford (1989) e Schmidt (1992) estão apresentados na tabela 7.2 (ver também Figura 6.5 no Cap. 6).

Verifica-se que os valores oscilam consideravelmente dentre os métodos, e que a calibração de Johnson \& Rutherford fornece as menores pressões, contrapondo-se aos maiores valores alcançados pelo barômetro de Schmidt. Blundy \& Holland (op. cit.) atentaram para o fato de que as variações nas concentrações de Aliv dos anfibólios estão estritamente relacionadas a temperatura, e em vista disto consideraram o barômetro de Johnson \& Rutherford mais confiável pois foi definido a partir de experiências com temperaturas fixas. Posteriormente, Schmidt (op. cit.) obteve dados experimentais em condições isotérmicas (por meio de solução 
tampão adequada) e propôs sua equação para o cálculo da pressão. Ele salienta que desta forma as oscilações dos teores de Al dos anfibólios ficam atreladas somente a variações da pressão.

Portanto, a pressão estimada para a consolidação final das rochas da borda do maciço de Venda Nova corresponde ao valor médio calculado pelo método de Schmidt, de cerca de $5,5 \pm 0,6 \mathrm{~Kb}$ para os noritos e charnoquitóides, abaixo dos valores de 7 a $8 \mathrm{~Kb}$ obtidos para o metamorfismo dos gnaisses de alto grau da região (Fritzer, 1991; Geiger, 1993 e Seindensticker \& Wiedemann, 1993).

Tabela 7.1 - Temperaturas de equilíbrio obtidas para pares de minerais dos noritos e charnoquitóides de Venda Nova

\begin{tabular}{|c|c|c|}
\hline \multicolumn{3}{|c|}{ OPX/CPX - Noritos } \\
\hline & QUILF & Wood \& Banno \\
\hline $\mathrm{VN}-3$ & $930 \pm 25^{\circ} \mathrm{C}$ & $925^{\circ} \mathrm{C}$ \\
\hline $\mathrm{VN}-14$ & $890 \pm 25^{\circ} \mathrm{C}$ & $905^{\circ} \mathrm{C}$ \\
\hline $\mathrm{VN}-11$ & $920 \pm 25^{\circ} \mathrm{C}$ & $895^{\circ} \mathrm{C}$ \\
\hline
\end{tabular}

OPX/CPX - Charnoquitóides

\begin{tabular}{|c|c|c|}
\hline $\mathrm{VN}-16$ & $1037 \pm 45^{\circ} \mathrm{C}$ & $959^{\circ} \mathrm{C}$ \\
\hline $\mathrm{VN}-23$ & $1028 \pm 75^{\circ} \mathrm{C}$ & $998^{\circ} \mathrm{C}$ \\
\hline $\mathrm{VN}-18$ & $970 \pm 62^{\circ} \mathrm{C}$ & $918^{\circ} \mathrm{C}$ \\
\hline $\mathrm{VN}-35$ & $925 \pm 22^{\circ} \mathrm{C}$ & $957^{\circ} \mathrm{C}$ \\
\hline $\mathrm{VN}-27$ & $874 \pm 22^{\circ} \mathrm{C}$ & $828^{\circ} \mathrm{C}$ \\
\hline
\end{tabular}

Imenita/magnetita (QUILF)
\begin{tabular}{|c|c|}
\hline $\mathrm{VN}-3$ & $585 \pm 62^{\circ} \mathrm{C}$ \\
\hline $\mathrm{VN}-16$ & $560 \pm 80^{\circ} \mathrm{C}$ \\
\hline $\mathrm{VN}-18$ & $576 \pm 34^{\circ} \mathrm{C}$ \\
\hline $\mathrm{VN}-35$ & $612 \pm 26^{\circ} \mathrm{C}$ \\
\hline $\mathrm{VN}-27$ & $552 \pm 76^{\circ} \mathrm{C}$ \\
\hline
\end{tabular}


Tabela 7.2 - Determinações geobarométricas para anfibólios das rochas da borda do Maciço de Venda Nova

\begin{tabular}{|c|c|c|c|c|}
\hline & H\&Z & Holl. et al. & J\& R & Schmidt \\
\hline $\mathrm{VN}-3$ & $5,0 \pm 3 \mathrm{~Kb}$ & $5,2 \pm 1 \mathrm{~Kb}$ & $4,0 \pm 0,5 \mathrm{~Kb}$ & $5,4 \pm 0,6 \mathrm{~Kb}$ \\
\hline $\mathrm{VN}-11$ & $5,4 \pm 3 \mathrm{~Kb}$ & $5,6 \pm 1 \mathrm{~Kb}$ & $4,4 \pm 0,5 \mathrm{~Kb}$ & $5,8 \pm 0,6 \mathrm{~Kb}$ \\
\hline $\mathrm{VN}-35$ & $4,6 \pm 3 \mathrm{~Kb}$ & $4,8 \pm 1 \mathrm{~Kb}$ & $3,6 \pm 0,5 \mathrm{~Kb}$ & $5,0 \pm 0,6 \mathrm{~Kb}$ \\
\hline $\mathrm{VN}-18$ & $4,5 \pm 3 \mathrm{~Kb}$ & $4,7 \pm 1 \mathrm{~Kb}$ & $3,7 \pm 0,5 \mathrm{~Kb}$ & $5,0 \pm 0,6 \mathrm{~Kb}$ \\
\hline $\mathrm{VN}-27$ & $5,9 \pm 3 \mathrm{~Kb}$ & $6,3 \pm 1 \mathrm{~Kb}$ & $4,8 \pm 0,5 \mathrm{~Kb}$ & $6,3 \pm 0,6 \mathrm{~Kb}$ \\
\hline
\end{tabular}

\section{Modelamentos geoquímicos e o estabelecimento do processo de diferenciação}

No capítulo 5 foi brevemente discutida uma possível ordem evolutiva para as rochas da borda do maciço de Venda Nova. A abordagem se deu com base nos diagramas de variação $\mathrm{SiO}_{2}$ versus óxidos e elementos traços. Nem sempre esses diagramas convencionais são eficazes para a caracterização de um processo magmático. Visando uma melhor definição do que a obtida com aqueles gráficos, vários outros diagramas foram confeccionados mas nenhum forneceu respostas coerentes. Nem mesmo diagramas de elementos incompativeis versus elementos compatíveis mostraram-se esclarecedores; a maior parte deles separa as amostras dos charnoquitóides em grupos, mas tais grupos não se repetem nos diversos gráficos, impossibilitando qualquer correlação.

Para exemplificar, a figura 7.1 exibe dois desses diagramas, onde estão posicionados $\mathrm{K}_{2} \mathrm{O} \times \mathrm{V}$ e $\mathrm{Zr} \times \mathrm{MgO}$. Nota-se que os noritos apresentam um maior espalhamento, delineando um "trend", com relação ao seu comportamento nos diagramas de variação convencionais. Isto implica que os cumulatos podem espelhar uma parcela da evolução do magma parental. Na seqüência intermediária pode-se sugerir mais de um "trend" em ambos os gráficos, mas tais tendências são conferidas por amostras diferentes. Em vista disto, o modelo que envolve cristalização fracionada e/ou mistura de magmas, como aventado no capítulo 5, parece ser o mais coerente para estas rochas.

Com o intuito de testar quantitativamente a hipótese de evolução por cristalização fracionada, foi realizado um modelamento geoquímico para óxidos de elementos maiores, a partir do programa XLFRAC (Stormer \& Nicholls, 1978, modificado por M.S.M. Mantovani), cuj os resultados são apresentados abaixo. Com base nos "trends" lineares obtidos nos diagramas de Harker, foi inferida a composição de um possivel magma parental, e o mesmo é referenciado 
como M.P. Apesar das composições das rochas analisadas não corresponderem a liquidus, para efeito do modelamento efetuado M.P. foi tido como magma progenitor e o "trend" definido considerado como "liquid line of descent". A partir de M.P. foi feito o modelamento para a obtenção de um magma com a composição da amostra VN-35; depois disto, tomando-se VN-35 como magma inicial modelou-se para chegar a VN-23 e assim sucessivamente até as amostras mais evoluídas.
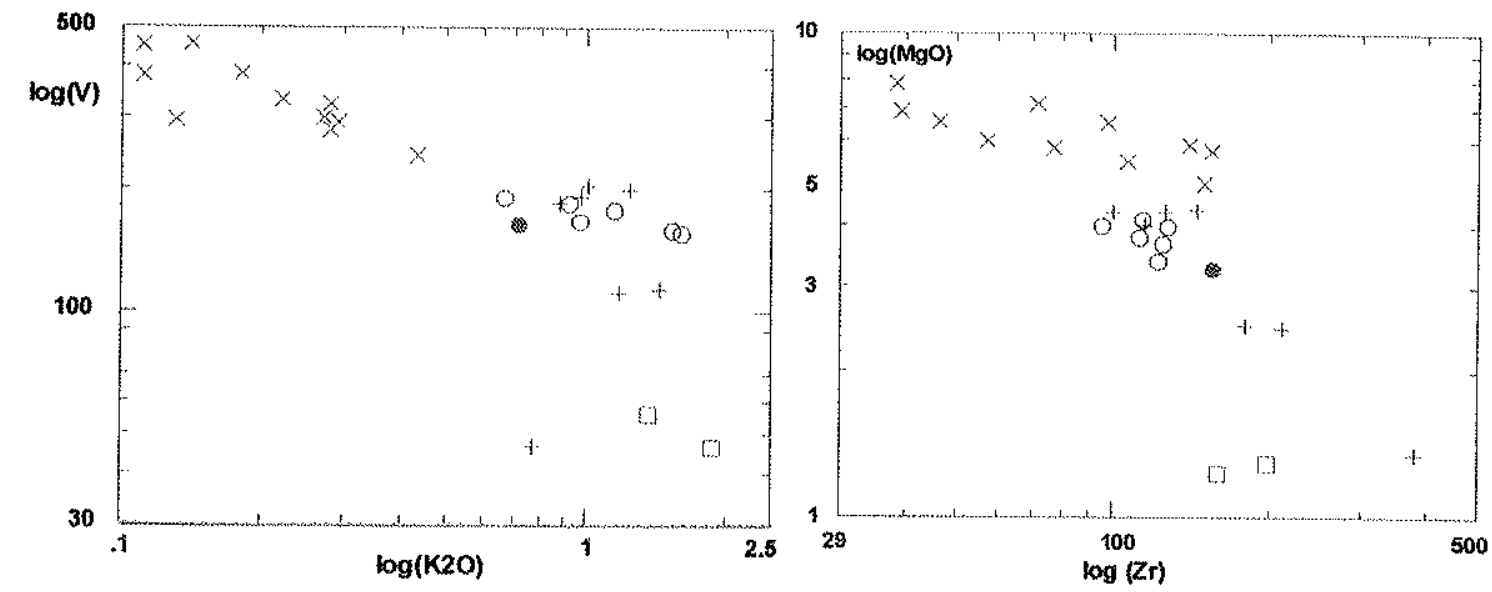

Figura 7.1 - Diagramas $\log \left(\mathrm{K}_{2} \mathrm{O}\right) \times \log (\mathrm{V})$ e $\log (\mathrm{Zr}) \times \log (\mathrm{MgO})$ para os charnoquitóides de Venda Nova Símbolos: $x$ Noritos; 1 Opdalitos; O OPX-Quartzo-dioritos; Enderbitos; Quartzo-mangerito

As tabelas $7.3,7.4,7.5$ e 7.6 contêm as composiçôes químicas das rochas utilizadas, dos minerais fracionados, dos extratos obtidos e das proporções das fases extraídas no modelamento para elementos maiores. As etapas de (1) a (6) correspondem a evolução teórica presumida (por cristalização fracionada) para a sequência charnoquitóide a partir de um magma parental (M.P.). Os minerais fracionados para todas as etapas foram os mesmos: plagioclásio, OPX, CPX e ilmenita. O não fracionamento de uma destas fases, em várias combinações possíveis, piora consideravelmente os resultados. $\mathrm{O} \mathrm{K}_{2} \mathrm{O}$ não foi incluído nas composições das rochas e dos minerais usados porque sua proporção é muito pequena e a sua inclusão implica em piores resultados.

A etapa (1) compreende o fracionamento de M.P. para VN-35, tendo se utilizado os minerais da amostra $\mathrm{VN}-11$. Esta etapa resultou num valor bem alto para a soma dos quadrados dos resíduos e cerca de $44 \%$ de fases extraídas (valores de $S Q R$ até 1 são considerados bons pelos autores do programa). Isto pode indicar que a composição adotada não está próxima do magma parental ou então que a composição dos minerais fracionados não é 
coerente com o mesmo. Ao se usar os minerais da amostra VN-35 a SQR cresce demasiadamente; pequenas variações na composição de M.P. foram efetuadas e testadas, mas também causaram acréscimo da SQR.

Os valores alcançados para a SQR nas outras etapas são considerados matematicamente bons e viabilizam o modelo. Apenas a etapa (4), fracionamento da amostra VN-16 para a amostra VN-24 fornece um valor alto para a SQR $(0,9413)$. A cristalização fracionada de um magma com a composição da amostra VN-24, a partir da extração de plagioclásio, OPX, CPX e ilmenita, pode resultar tanto na amostra VN-31 quanto na VN-27, só que para esta última tem-se o menor valor da SQR $(0,4773)$. Os minerais utilizados nas duas últimas etapas foram os da amostra VN-16. É interessante observar que a proporção total das fases extraídas é semelhante a partir da etapa (2), apesar das variações das proporções de minerais fracionados. Há uma grande predominância de fracionamento de plagioclásio nas várias etapas, sobretudo na (2), que envolve a extração de $72 \%$ deste mineral; as menores proporções correspondem a extração de ilmenita (varia de cerca de 4 a $7 \%$ ).

Ao se confrontar o que foi obtido com as oscilações dos teores dos elementos maiores e traços da seqüência charnoquitóide verifica-se que há coerência. Isto é, as variações que ocorrem nos conteúdos de $\mathrm{Ca}, \mathrm{Sr}, \mathrm{Fe}, \mathrm{Mg}, \mathrm{V}$ e Ti podem ser explicadas por cristalização fracionada envolvendo a extração das fases mencionadas. No entanto, as altas proporções de plagioclásio envolvidas deveriam resultar em menores teores de Eu e, por conseqüência, em anomalias negativas acentuadas deste elemento nos padrões de terras raras.

Para checar se os resultados do modelamento para elementos maiores são confirmados pelos elementos traços, foi realizado um modelamento para elementos terras raras e alguns traços $(\mathrm{Rb}, \mathrm{Ba}, \mathrm{Sr}, \mathrm{Ni}$ e $\mathrm{V}$ ) através da opção Newmelt do programa NEWPET (Clarke, 1993). Os valores alcançados para as opções de equilíbrio total (TEQ) e seqüencial (SEQ) são muito próximos, mas os melhores resultados são os da opção SEQ e eles serão aqui utilizados. Os coeficientes de partição usados, para rochas félsicas, intermediárias e básicas, são aqueles do programa e estão na tabela 7.7. Para a ilmenita foram usados valores de $\mathrm{Kd}$ de magnetita (na literatura são escassos os Kds para ilmenita).

A tabela 7.8 apresenta os resultados obtidos para as várias etapas: uso de Kds para rochas félsicas, intermediárias e básicas nas etapas (2), (3) e (4) (2a,2b,2c;3a,3b,3c;4a,4b,4c) e só para rochas félsicas e intermediárias nas etapas (5) e (6) $(5 \mathrm{a}, 5 \mathrm{~b} ; 6 \mathrm{a}, 6 \mathrm{~b})$. As concentrações dos elementos são calculadas da seguinte maneira: a partir dos teores dos elementos traços (daqueles 
escolhidos) da amostra tida como magma inicial (no caso, VN-35, 23, 16 e 24) o programa calcula os teores esperados para o magma final através de cristalização fracionada envolvendo extração das proporções dos minerais e do total fracionado (Tsub) obtidos anteriormente, para as etapas de (2) a (6), pelo "software" XLFRAC.

Com relação aos elementos terras raras, os valores obtidos são praticamente os mesmos para os diferentes Kds, com exceção do Eu que apresenta teores significativamente maiores, e mais próximos da realidade, com os $\mathrm{Kds}$ para rochas básicas.

A etapa (2) - (2a,2b,2c) - corresponde ao fracionamento da amostra $\mathrm{VN}-35$ para VN-23; os teores de ETR usados para VN-35 foram os da amostra VN-17. Observa-se que os valores calculados são um pouco inferiores, mas bem próximos aos teores dosados em VN-23. As razões $(\mathrm{Ce} / \mathrm{Yb})_{\mathrm{N}}$ e $(\mathrm{Dy} / \mathrm{Yb})_{\mathrm{N}}$ são similares. Os padrões que se obtêm nesta etapa estão na figura 7.2, onde se verifica que eles são coerentes e que ao se usar os Kds para rochas básicas a forte anomalia negativa de Eu desaparece.

O fracionamento de $\mathrm{VN}-23$ para $\mathrm{VN}-16$, correspondente a etapa (3) - $(3 \mathrm{a}, 3 \mathrm{~b}, 3 \mathrm{c})$ resulta em teores superiores para todos os ETR, mas principalmente os leves. Isto fica constatado nas maiores razões $(\mathrm{Ce} / \mathrm{Yb})_{\mathrm{N}}$ calculadas (média de 9,5, enquanto na amostra $\mathrm{VN}-16$ ela é de 6,0) e nas razões (Dy/Yb) $)_{\mathrm{N}}$ próximas (calculada é de 1,28 e a de $\mathrm{VN}-16$ é de 1,21). Os padrões associados a essa etapa encontram-se na figura 7.3, onde se vê que quando se usa Kds para rochas básicas o padrão fica mais parecido ao da amostra VN-16, em função da pequena anomalia de $\mathrm{Eu}\left(\mathrm{Eu} / \mathrm{Eu}^{*} \mathrm{~N}\right.$ de $\mathrm{VN}-16$ é igual a 0,73 e o calculado é de 0,72$)$.

Os resultados da etapa (4) - $(4 \mathrm{a}, 4 \mathrm{~b}, 4 \mathrm{c})$, fracionamento de VN-16 para VN-24, utilizando-se os teores de ETR da amostra VN-13 para a amostra VN-24, são superiores aos de VN-13, sobretudo os terras raras pesados. Os ETRP desta amostra são muito baixos e diferem do restante da seqüência (pode ser por problemas analíticos, uma vez que ela possui um quimismo compativel com as outras rochas, inclusive de ETR leves e intermediários). Isto resulta numa significativa diferença entre as razões $(\mathrm{Ce} / \mathrm{Yb})_{\mathrm{N}}$ e $(\mathrm{Dy} / \mathrm{Yb})_{\mathrm{N}}$ teóricas e as calculadas para VN13. Os padrões desta etapa estão na figura 7.4, onde fica bem nítido o contraste entre os traçados esperados e o da amostra VN-13. Enquanto VN-13 não exibe anomalia de Eu, todas as possibilidades de fracionamento resultam em anomalias negativas, que são menores para $\mathrm{Kds}$ de rochas básicas. 
Tabela 7.3 - Composições químicas de rochas utilizadas nos modelamentos de fracionamento para elementos maiores, para os charnoquitóides do Maciço de Venda Nova

\begin{tabular}{lccccccc}
\hline Amostras & M. P. & VN-35 & VN-23 & VN-16 & VN-24 & VN-31 & VN-27 \\
\hline $\mathrm{SiO} 2$ & 53,33 & 56,75 & 58,74 & 61,28 & 64,36 & 69,68 & 68,42 \\
$\mathrm{TiO} 2$ & 1,03 & 0,90 & 0,92 & 0,80 & 0,78 & 0,52 & 0,55 \\
$\mathrm{Al} 2 \mathrm{O} 3$ & 18,36 & 18,06 & 16,84 & 17,21 & 16,68 & 16,08 & 16,16 \\
$\mathrm{FeO}$ & 10,15 & 8,54 & 8,23 & 7,00 & 6,37 & 4,49 & 4,84 \\
$\mathrm{MgO}$ & 4,82 & 4,37 & 4,36 & 3,47 & 2,55 & 1,27 & 1,32 \\
$\mathrm{CaO}$ & 9,74 & 8,00 & 7,79 & 7,06 & 5,51 & 3,93 & 4,62 \\
$\mathrm{Na2O}$ & 2,56 & 3,39 & 3,12 & 3,18 & 3,75 & 4,03 & 4,09 \\
\hline
\end{tabular}

As composições químicas estão recalculadas para $100 \%$ e Fetotal $=\mathrm{FeO}$

M.P. = composição de um possivel magma parental, inferida a partir dos diagramas de variação

Tabela 7.4 - Composições químicas de minerais utilizados nos modelamentos de fracionamento para elementos maiores, para os charnoquitóides do Maciço de Venda Nova

\section{OPX-11 CPX-11 PLAG-11 NME-11 OPX-35 CPX-35 PLAG-35 ILME-35 OPX-23 CPX-23 PLAG-23 OPX-16 CPX-16 PLAG-16 ILME-16}

\begin{tabular}{|c|c|c|c|c|c|c|c|c|c|c|c|c|c|c|c|}
\hline $\mathrm{SiO} 2$ & 52,12 & 51,18 & 49,75 & 0,08 & 52,95 & 52,23 & 56,64 & 0,19 & 53,20 & 51,73 & 58,16 & 53,22 & 52,08 & 56,50 & 0,05 \\
\hline $\mathrm{TiO}_{2}$ & 0,05 & 0,27 & 0 & 52,34 & 0 & 0,16 & 0 & 46,78 & 0,09 & 0,31 & 0 & 0,17 & 0 & 0 & 42,74 \\
\hline $\mathrm{Al} 2 \mathrm{O} 3$ & 0,93 & 1,33 & 31,24 & 0,09 & 1,02 & 1,61 & 26,88 & 0,11 & 0,94 & 1,59 & 25,86 & 0,90 & 1,54 & 26,85 & 0,04 \\
\hline $\mathrm{FeO}$ & 26,41 & 11,97 & 0,20 & 46,59 & 23,64 & 9,17 & 0,11 & 51,34 & 21,72 & 8,92 & 0,20 & 21,03 & 7,93 & 0,26 & 56,69 \\
\hline $\mathrm{MgO}$ & 19,19 & 13,08 & 0 & 0,81 & 21,74 & 13,32 & 0 & 1,40 & 22,89 & 14,36 & 0 & 23,54 & 14,02 & 0 & 0,28 \\
\hline $\mathrm{CaO}$ & 1,16 & 21,93 & 15,32 & 0,06 & 0,58 & 23,19 & 9,72 & 0,03 & 1,12 & 22,62 & 8,82 & 1,03 & 24,14 & 9,70 & 0,02 \\
\hline $\mathrm{Na} 2 \mathrm{O}$ & 0,14 & 0,24 & 3,50 & 0,04 & 0,04 & 0,31 & 6,65 & 0,14 & 0,03 & 0,47 & 6,96 & 0,10 & 0,29 & 6,69 & 0,17 \\
\hline
\end{tabular}

As composições químicas estão recalculadas para $100 \%$ e Fetotal=FeO 
Tabela 7.5 - Composição dos extratos obtidos no modelamento para elementos maiores para as rochas de Venda Nova

\begin{tabular}{lcccccc}
\hline & (1) & (2) & (3) & (4) & (5) & (6) \\
\hline SiO2 & 48,70 & 53,00 & 52,13 & 55,82 & 51,68 & 51,98 \\
TiO2 & 2,01 & 2,31 & 3,19 & 1,84 & 2,86 & 2,68 \\
A12O3 & 18,51 & 19,61 & 14,67 & 17,27 & 17,31 & 19,35 \\
FeO & 10,63 & 7,70 & 9,70 & 7,23 & 9,06 & 9,42 \\
MgO & 6,80 & 4,88 & 7,43 & 6,12 & 6,25 & 6,72 \\
CaO & 11,26 & 7,69 & 8,96 & 10,44 & 8,55 & 7,56 \\
Na2O & 2,09 & 4,81 & 3,92 & 4,27 & 4,29 & 4,30 \\
\hline
\end{tabular}

Tabela 7.6 - Proporção das fases extraídas no modelamento para elementos maiores para os charnoquitóides de Venda Nova

\begin{tabular}{|c|c|c|c|c|c|c|}
\hline & (1) & (2) & (3) & (4) & (5) & (6) \\
\hline$\overline{O P X}$ & 28,95 & 20,64 & 21,32 & 15,61 & 21,03 & 25,65 \\
\hline $\mathrm{CPX}$ & 9,31 & 2,42 & 17,13 & 17,35 & 9,10 & 4,71 \\
\hline PLAG & 57,97 & 72,02 & 54,88 & 62,79 & 63,25 & 63,48 \\
\hline ILME & 3,76 & 4,91 & 6,67 & 4,25 & 6,62 & 6,16 \\
\hline SQR & 1,1826 & 0,7387 & 0,7682 & 0,9413 & 0,7152 & 0,4773 \\
\hline Tsub & 43,88 & 32,69 & 26,58 & 27,21 & 29,94 & 25,08 \\
\hline
\end{tabular}

\section{Os extratos correspondem a:}
(1) $=\mathrm{MP} \cdot$ para $\mathrm{VN}-35$
(2) $=\mathrm{VN}-35$ para $\mathrm{VN}-23$
(3) $=\mathrm{VN}-23$ para VN-16
(4) $=\mathrm{VN}-16$ para $\mathrm{VN}-24$
(5) $=\mathrm{VN}-24$ para $\mathrm{VN}-31$
(6) $=\mathrm{VN}-24$ para $\mathrm{VN}-27$ 
Ao se fracionar a amostra VN-24 para VN-31 (foram usados os conteúdos de ETR da amostra VN-13 para VN-24 e de VN-27 para VN-31) obtém-se os padrões da figura 7.5 e os resultados são os da etapa (5) - (5a,5b). Observa-se que não existe qualquer diferença ao se utilizar Kds para rochas ácidas ou intermediárias. Os valores calculados são ligeiramente superiores aos da amostra VN-27 para os terras raras leves e intermediários, mas são inferiores aos conteúdos de ETRP, implicando numa mudança do padrão e em maiores razões $(\mathrm{Ce} / \mathrm{Yb})_{\mathrm{N}} \mathrm{e}$ $(\mathrm{Dy} / \mathrm{Yb})_{\mathrm{N}}$ comparados a $\mathrm{VN}-27$. As razões $\left(\mathrm{Eu} / \mathrm{Eu}^{*}\right)_{\mathrm{N}}$ são menores e conferem anomalias negativas mais pronunciadas que a de $\mathrm{VN}-27$.

Finalmente, a etapa $(6)$ - $(6 a, 6 b)$ - corresponde ao fracionamento da amostra VN24 (com os teores de ETR de VN-13) para VN-27. Os resultados calculados são praticamente idênticos ao da etapa anterior, como se observa na tabela 7.8 e nos padrões apresentados na figura 7.6. As similaridades das duas etapas são totais, inclusive das razões calculadas.

Quanto aos outros elementos traços modelados, os resultados estão na tabela $7.8 \mathrm{e}$ são resumidos nos parágrafos abaixo.

$\mathrm{Na}$ etapa (2) os conteúdos de Rb calculados são superiores ao da amostra VN-23, os teores de $\mathrm{Sr}$ só mostram coerência quando se utiliza $\mathrm{Kds}$ para rochas intermediárias e o $\mathrm{Ba}$ fornece valores levemente maiores do que o de $\mathrm{VN}-23$; o Ni calculado a partir dos Kds de rochas félsicas é o que mais se aproxima do teor real e para o $\mathrm{V}$ o melhor resultado é com os Kds de rochas intermediárias.

No fracionamento de $\mathrm{VN}-23$ para $\mathrm{VN}-16$ (etapa (3)) os valores calculados para $\mathrm{Rb}$ são bem inferiores ao teor da amostra VN-16, o conteúdo de Sr que mais se aproxima é o obtido por Kds de rochas intermediárias e os teores de Ba são um pouco superiores; o Ni apresenta melhor resultado com $\mathrm{Kds}$ para rochas básicas e o $\mathrm{V}$ com $\mathrm{Kds}$ de rochas intermediárias.

A etapa (4) resulta em péssimos resultados para $\mathrm{Rb}$ e excelentes para $\mathrm{Ba}$; novamente o teor de $\mathrm{Sr}$ com $\mathrm{Kds}$ de rochas intermediárias é o que mais se aproxima da amostra final, que no caso é VN-24. Somente com Kds de rochas básicas os valores de V se distanciam do teor real e para o $\mathrm{Ni}$ o resultado mais coerente é com $\mathrm{Kds}$ de rochas básicas.

Para a etapa (5) os resultados são no geral razoáveis, sendo que os valores de $\mathrm{Ba}$, Ni e V melhor ajustados são os obtidos com Kds de rochas félsicas e o teor de Sr que mais se aproxima do conteúdo da amostra VN-31 é o calculado com $\mathrm{Kds}$ de rochas intermediárias.

$\mathrm{Na}$ etapa (6) os teores de Rb calculados coincidem com os da amostra VN-27 e os de Ni estão abaixo. Para $\mathrm{Ba}$ e $\mathrm{Sr}$ os valores alcançados com Kds de rochas intermediárias são os 
mais adequados e o $\mathrm{V}$ se aproxima mais do conteúdo da amostra $\mathrm{VN}-27$ com $\mathrm{Kds}$ de rochas félsicas.

Tendo em mente algumas limitações no modelamento para elementos traços, tais como o uso de teores de elementos terras raras de amostras que não estão sendo modeladas (particularmente da amostra $\mathrm{VN}-13$ ) e a utilização de coeficientes de partição que foram definidos para magmas com composições específicas, conclui-se que os resultados alcançados são razoáveis e de maneira geral corroboram com o modelo aventado e testado anteriormente para elementos maiores. Algumas incoerências são visíveis, dentre elas os resultados melhor aj ustados para o $\mathrm{Sr}$ com $\mathrm{Kds}$ de rochas intermediárias contrastando com melhores teores para Eu com o uso de Kds para rochas básicas. Com relação ao comportamento do Eu, não somente o coeficiente de partição deve ser levado em conta, mas também é importante o estado de oxidação do magma, além das possiveis combinações de anomalias positivas e negativas das fases fracionadas (anomalias positivas causadas por extração de alguns minerais podem vir a anular as anomalias negativas derivadas da extração de plagioclásio).

Desta maneira, a hipótese de que as rochas charnoquitóides do maciço de Venda Nova evoluíram por cristalização fracionada, controlada por maiores extrações de plagioclásio seguida por ortopiroxênio, clinopiroxênio e ilmenita, a partir de um magma básico/intermediário de natureza Ca-alcalina parece bem embasada. Os resultados numéricos ratificam, como um todo, esse modelo e o comportamento da maior parte dos elementos analisados também é coerente. A possibilidade de mistura de magmas pode também ser aventada, mas a ausência de afloramentos com termos extremos ácidos-básicos e principalmente os baixos teores de elementos incompatíveis nos charnoquitóides (sobretudo $\mathrm{K}$ e $\mathrm{Rb}$ ) indicam que tal mecanismo não foi preponderante, i.e., se houve mistura não deve ter sido em grande escala. Uma evolução por fusão parcial de rocha básicas é outra possibilidade, mas não parece muito provável em função do predomínio de composições intermediárias; tal hipótese torna-se de difícil explicação se os noritos forem rochas cumuláticas derivadas do líquido que deu origem aos charnoquitóides.

Os cumulatos noríticos podem tanto ser produtos do mesmo magma cálciom alcalino que originou os charnoquitóides quanto de um magma toleítico. A primeira possibilidade parece ser mais adequada em função da íntima relação dos litotipos no campo, de similares aspectos mineralógicos e texturais e das características geoquímicas gerais das duas seqüências (enriquecimento em Al, Ca e Fe e baixos conteúdos de elementos LIL). Entretanto, 
os menores valores de $\mathrm{Mg \#}$ dos minerais máficos dos noritos e o comportamento do Ni e do $\mathrm{Sr}$ nos diagramas de variação (já enfatizado no Cap.5) são os empecilhos existentes para esta teoria.

\section{A discussão a respeito do magma parental}

São complexos os processos para a geração de magmas cálcio-alcalinos. Cristalização fracionada ou fusão parcial de magmas básicos derivados diretamente do manto são mecanismos desde há muito aventados para a geração de rochas com tal afinidade. No entanto, ao se levar em conta somente a atuação de tais mecanismos, algumas questões ficam sem resposta. Dentre elas pode-se destacar: qual seria a explicação para o enriquecimento em elementos LL apresentado por muitas suítes Ca-alcalinas? Ao se admitir a participação exclusiva de tais processos de diferenciação, obrigatoriamente deveriam ocorrer associados grandes volumes de diferenciados ultramáficos (em superfície ou em subsuperfície), o que muitas vezes não ocorre, como é o caso do batólito de Serra Nevada, onde dados geofísicos não apontam a existência de extensos corpos ultramáficos na crosta subj acente (Best, 1982).

Tendo em vista tais fatores limitantes, atualmente a formação de magmas cálcioalcalinos é estritamente relacionada a movimentação das placas litosféricas, mais especificamente aos arcos magmáticos desenvolvidos nas zonas de subducção modernas ou antigas (arcos de ilhas ou continentais). Desta maneira, o envolvimento direto ou indireto de crosta oceânica ou continental subductada é de suma importância para a caracterização do processo de formação e da assinatura geoquímica desses magmas.

Dentro deste contexto, as hipóteses para a geração de magmas Ca-alcalinos envolvem uma série de fenômenos que incluem: desidratação e/ou fusão parcial da crosta subductada; fusão parcial da porção mantélica sobrejacente (cunha do manto) provocada pelos fluidos provenientes da mencionada desidratação ou fusão do "slab" de crosta (Pearce, 1984; Brown et al., 1984; Martin, 1987); fusão parcial de crosta inferior induzida pela residência do magma básico (provindo da fusão da cunha do manto) na base da mesma; mistura de magmas básicos e ácidos nessa porção crustal; fracionamento do magma básico trapeado ou de subprodutos intermediários e, finalmente, contaminação crustal quando da subida do diápiro.

Portanto, são muitas as alternativas para a produção de líquidos cálcio-alcalinos: fusão parcial de crosta subductada anfibolítica ou eclogítica, fusão parcial hidratada de manto peridotítico e posterior ascensão e fracionamento na base da crosta; fusão parcial e fracionamento de crosta inferior anfibolítica; mistura de magmas e contaminação (Hall, 1987). 
Vários autores apregoam a importância do fracionamento de anfibólio, em magmas básicos hidratados, na assinatura química de rochas Ca-alcalinas. Mas, por outro lado, Gill (1981) ressalta a formação de magmas andesíticos a partir da cristalização fracionada de basaltos controlada por plagioclásio, OPX e/ou olivina, augita e magnetita.

Uma vez que não existem dados isotópicos para as rochas da borda do maciço de Venda Nova, não é possível estimar o grau de contaminação crustal que as mesmas apresentam. Mas, levando-se em conta a sua composição, com teores moderados de elementos incompatíveis, parece pouco provável que tal contaminação tenha sido intensa. Uma vez que essas rochas fazem parte de um arco magmático de idade brasiliana, sua formação é diretamente relacionada ao desenvolvimento do mesmo.

Considerando-se a sua mineralogia e a química de rochas e de minerais, os charnoquitóides de Venda Nova podem ter se formado a partir da cristalização fracionada, em condições anidras e redutoras e sob pressões moderadas, de um magma basáltico cálcionalcalino trapeado na base da crosta. O fracionamento foi conduzido principalmente por maiores proporções de plagioclásio, seguido de OPX, CPX e ilmenita. Ao mesmo tempo ocorreu fusão parcial da crosta inferior, induzida pelo calor do magma básico, que pode ter adicionado algum outro componente ao sistema (incipiente mistura de magmas?). Este magma derivou-se de uma porção do manto que não sofreu um acentuado enriquecimento prévio em elementos incompatíveis (manto normal), quando da desidratação ou fusão de provável "slab" de crosta continental.

Os noritos talvez representem cumulatos separados do mesmo magma básico que gerou os charnoquitóides. Esta hipótese parece provável mas, no entanto, existem empecilhos, relacionados ao seu quimismo, que foram discutidos no item anterior. Uma outra possibilidade seria a sua geração a partir da acumulação de cristais de um magma toleiítico, representando portanto um outro magmatismo.

Os teores relativamente baixos de ETR pesados das rochas da borda do maciço de Venda Nova sugerem que granada deve ter sido fase residual quando da fusão parcial da fonte mantélica. 
Tabela 7.7 - Coeficientes de partição (Kds) utilizados nos modelamentos para elementos terras raras e alguns outros traços

\begin{tabular}{|c|c|c|c|c|c|c|c|c|c|c|c|}
\hline & \multicolumn{4}{|c|}{ Rochas intermediárias } & \multicolumn{4}{|c|}{ Rochas félsicas } & \multicolumn{3}{|c|}{ Rochas básicas } \\
\hline & CPX & OPX & PLAG & MAGN & CPX & OPX & PLAG & MAGN & CPX & OPX & PLAG \\
\hline $\mathrm{La}$ & 0,250 & 0,028 & 0,350 & 0,098 & 0,320 & 0,220 & 0,320 & 0,530 & 0,288 & 0,026 & 0,180 \\
\hline $\mathrm{Ce}$ & 0,300 & 0,038 & 0,240 & 0,110 & 0,500 & 0,150 & 0,270 & 0,610 & 0,303 & 0,032 & 0,120 \\
\hline $\mathrm{Nd}$ & 0,490 & 0,058 & 0,170 & 0,130 & 1,110 & 0,220 & 0,210 & 0,880 & 0,379 & 0,051 & 0,081 \\
\hline $\mathrm{Sm}$ & 0,700 & 0,100 & 0,130 & 0,150 & 1,670 & 0,270 & 0,130 & 0,930 & 0,476 & 0,079 & 0,067 \\
\hline $\mathrm{Eu}$ & 0,870 & 0,079 & 2,110 & 0,100 & 1,560 & 0,170 & 2,150 & 0,580 & 0,354 & 0,099 & 0,340 \\
\hline Gd & 0,960 & 0,171 & 0,090 & 0,120 & 1,850 & 0,340 & 0,097 & 0,700 & 0,561 & 0,126 & 0,063 \\
\hline Dy & 1,200 & 0,293 & 0,086 & 0,140 & 1,930 & 0,460 & 0,064 & 0,800 & 0,663 & 0,197 & 0,055 \\
\hline $\mathrm{Er}$ & 1,200 & 0,460 & 0,084 & 0,155 & 1,660 & 0,650 & 0,055 & 0,800 & 0,706 & 0,355 & 0,063 \\
\hline $\mathrm{Yb}$ & 0,900 & 0,670 & 0,077 & 0,170 & 1,580 & 0,860 & 0,049 & 0,800 & 0,719 & 0,470 & 0,067 \\
\hline $\mathrm{Lu}$ & 0,800 & 0,840 & 0,062 & 0,190 & 1,540 & 0,900 & 0,046 & 0,400 & 0,719 & 0,590 & 0,060 \\
\hline K & 0,037 & 0,002 & 0,100 & 0,000 & 0,037 & 0,002 & 0,100 & 0,000 & 0,027 & 0,006 & 0,360 \\
\hline $\mathrm{Rb}$ & 0,020 & 0,020 & 0,070 & 0,000 & 0,032 & 0,003 & 0,041 & 0,000 & 0,030 & 0,003 & 0,200 \\
\hline $\mathrm{Ba}$ & 0,020 & 0,020 & 0,160 & 0,000 & 0,131 & 0,003 & 4,400 & 0,000 & 0,025 & 0,040 & 0,460 \\
\hline $\mathrm{Sr}$ & 0,080 & 0,020 & 1,800 & 0,000 & 0,516 & 0,085 & 0,310 & 0,000 & 0,300 & 0,050 & 3,600 \\
\hline $\mathrm{Ni}$ & 6,000 & 9,000 & 0,040 & 12,00 & - & - & - & - & 4,400 & 5,000 & 0,040 \\
\hline $\mathrm{V}$ & 1,100 & 1,100 & 0,000 & 30,000 & 0,000 & 7,000 & 0,000 & 20,000 & 1,000 & 0,500 & 0,080 \\
\hline
\end{tabular}


Tabela 7.8 - Resultados dos modelamentos para elementos terras raras e alguns outros traços para as rochas charnoquitóides do Maciço de Venda Nova, utilizando-se Kds para rochas básicas, intermediárias e félsicas

\begin{tabular}{|c|c|c|c|c|c|c|c|c|c|c|c|c|c|}
\hline & (2a) & (2b) & (2c) & (3a) & (3b) & $(3 c)$ & (4a) & $(4 b)$ & (4c) & $(5 a)$ & $(5 b)$ & (6a) & (6b) \\
\hline $\mathrm{La}$ & 26,67 & 22,03 & 22,94 & 36,11 & 36,86 & 37,55 & 23,84 & 24,16 & 24,79 & 20,52 & 20,94 & 19,60 & 39,94 \\
\hline $\mathrm{Ce}$ & 52,60 & 54,19 & 55,57 & 86,95 & 89,95 & 90,90 & 56,54 & 58,20 & 59,21 & 45,27 & 46,81 & 43,31 & 44,42 \\
\hline $\mathrm{Nd}$ & 26,07 & 27,29 & 27,64 & 36,27 & 38,78 & 39,01 & 25,66 & 27,24 & 27,62 & 21,04 & 22,32 & 20,35 & 21,20 \\
\hline $\mathrm{Sm}$ & 4,92 & 5,11 & 5,15 & 6,18 & 6,69 & 6,75 & 5,06 & 5,44 & 5,52 & 4,24 & 4,52 & 4,14 & 4,30 \\
\hline $\mathrm{Eu}$ & 0,73 & 0,75 & 1,24 & 0,96 & 1,02 & 1,41 & 0,75 & 0,80 & 1,15 & 0,81 & 0,85 & 0,85 & 0,88 \\
\hline $\mathrm{Gd}$ & 3,71 & 3,84 & 3,86 & 4,43 & 4,76 & 4,84 & 3,98 & 4,25 & 4,34 & 3,34 & 3,54 & 3,26 & 3,38 \\
\hline Dy & 3,79 & 3,89 & 3,93 & 4,60 & 4,89 & 5,02 & 4,30 & 4,53 & 4,67 & 2,71 & 2,84 & 2,64 & 2,72 \\
\hline$E_{r}$ & 2,00 & 2,04 & 2,06 & 2,58 & 2,70 & 2,77 & 2,60 & 2,70 & 2,77 & 1,16 & 1,21 & 1,13 & 1,16 \\
\hline $\mathrm{Yb}$ & 1,75 & 1,80 & 1,82 & 2,34 & 2,48 & 2,51 & 2,31 & 2,43 & 2,46 & 0,83 & 0,87 & 0,80 & 0,83 \\
\hline $\mathrm{Lu}$ & 0,24 & 0,24 & 0,25 & 0,29 & 0,31 & 0,31 & 0,30 & 0,31 & 0,31 & 0,14 & 0,14 & 0,13 & 0,13 \\
\hline $\begin{array}{l}\mathrm{Ce} / \mathrm{YbN} \\
\text { Dy/YbN } \\
\mathrm{Eu} / \mathrm{Eu} \text { *N }\end{array}$ & $\begin{array}{l}7,77 \\
1,41 \\
0,50 \\
\end{array}$ & $\begin{array}{l}7,79 \\
1,40 \\
0,50 \\
\end{array}$ & $\begin{array}{l}7,90 \\
1,40 \\
0,82 \\
\end{array}$ & $\begin{array}{l}9,61 \\
1,28 \\
0,54 \\
\end{array}$ & $\begin{array}{l}9,38 \\
1,28 \\
0,53 \\
\end{array}$ & $\begin{array}{l}9,37 \\
1,30 \\
0,72 \\
\end{array}$ & $\begin{array}{l}6,33 \\
1,21 \\
0,49 \\
\end{array}$ & $\begin{array}{l}6,19 \\
1,21 \\
0,49 \\
\end{array}$ & $\begin{array}{l}6,22 \\
1,23 \\
0,69 \\
\end{array}$ & $\begin{array}{l}14,10 \\
2,12 \\
0,64 \\
\end{array}$ & $\begin{array}{l}13,92 \\
2,12 \\
0,68\end{array}$ & $\begin{array}{l}14,00 \\
2,12 \\
0,68 \\
\end{array}$ & $\begin{array}{l}13,84 \\
2,13 \\
0,68 \\
\end{array}$ \\
\hline $\begin{array}{l}\mathrm{Rb} \\
\mathrm{Ba} \\
\mathrm{Sr} \\
\mathrm{Ni} \\
\mathrm{V} \\
\end{array}$ & $\begin{array}{c}43 \\
521 \\
190 \\
40 \\
112 \\
\end{array}$ & $\begin{array}{c}42 \\
543 \\
407 \\
14 \\
146 \\
\end{array}$ & $\begin{array}{c}41 \\
497 \\
241 \\
25 \\
274 \\
\end{array}$ & $\begin{array}{c}35 \\
552 \\
307 \\
47 \\
106 \\
\end{array}$ & $\begin{array}{c}35 \\
569 \\
494 \\
14 \\
120 \\
\end{array}$ & $\begin{array}{c}34 \\
539 \\
357 \\
26 \\
234 \\
\end{array}$ & $\begin{array}{c}84 \\
569 \\
242 \\
38 \\
114 \\
\end{array}$ & $\begin{array}{c}84 \\
589 \\
416 \\
15 \\
125 \\
\end{array}$ & $\begin{array}{c}81 \\
555 \\
288 \\
23 \\
192 \\
\end{array}$ & $\begin{array}{c}35 \\
770 \\
197 \\
30 \\
58 \\
\end{array}$ & $\begin{array}{c}35 \\
799 \\
360 \\
9.4 \\
68 \\
\end{array}$ & $\begin{array}{c}33 \\
731 \\
224 \\
28 \\
61 \\
\end{array}$ & $\begin{array}{c}33 \\
751 \\
364 \\
11 \\
77 \\
\end{array}$ \\
\hline $\begin{array}{l}\text { Tsub } \\
\text { F }\end{array}$ & $\begin{array}{c}33 \\
0,67\end{array}$ & $\begin{array}{c}33 \\
0,67 \\
\end{array}$ & $\begin{array}{c}33 \\
0.67 \\
\end{array}$ & $\begin{array}{c}27 \\
0,73 \\
\end{array}$ & $\begin{array}{r}27 \\
0.73 \\
\end{array}$ & $\begin{array}{c}27 \\
0,73 \\
\end{array}$ & $\begin{array}{c}27 \\
0.73 \\
\end{array}$ & $\begin{array}{c}27 \\
0,73 \\
\end{array}$ & $\begin{array}{c}27 \\
0.73 \\
\end{array}$ & $\begin{array}{r}30 \\
0.70 \\
\end{array}$ & $\begin{array}{c}30 \\
0,70 \\
\end{array}$ & $\begin{array}{c}25 \\
0.75 \\
\end{array}$ & $\begin{array}{c}25 \\
0,75 \\
\end{array}$ \\
\hline
\end{tabular}

Tsub=proporção aproximada de fases extraídas do magma inicial; $F=$ fração total aproximada de magma restante

\section{Resultados:}

(2a) fracionamento de VN-35 para VA-23 utilizando-se Kds para rochas félsicas.

(2b) fracionamento de VN-35 para VN-23 utilizando-se Kds para rochas intermediárias

(2c) fracionamento de VA-35 para VA-23 utilizando-se Kds para rochas básicas.

(3a) fracionamento de $\mathrm{VN}-23$ para $\mathrm{VN}-16$ utilizando-se $\mathrm{Kds}$ para rochas félsicas.

(3b) fracionamento de $\mathrm{VN}-23$ para $\mathrm{VN}-16$ utilizando-se Kds para rochas intermediárias.

(3c) fracionamento de $\mathrm{VN}-23$ para $\mathrm{VN}-16$ utilizando-se $\mathrm{Kds}$ para rochas básicas. (4a) fracionamento de $\mathrm{VN}-16$ para $\mathrm{VN}-24$ utilizando-se $\mathrm{K}$ ds para rochas félsicas.

(4b) fracionamento de $\mathrm{VN}-16$ para $\mathrm{VN}-24$ utilizando-se $\mathrm{Kds}$ para rochas intermediárias.

(4c) fracionamento de $\mathrm{VN}-16$ para $\mathrm{VN}-24$ utilizando-se Kds para rochas básicas.

(5a) fracionamento de $\mathrm{VN}-24$ para VN-3 1 utilizando-se $\mathrm{Kds}$ para rochas félsicas.

(5b) fracionamento de $\mathrm{VN}-24$ para $\mathrm{VN}-31$ utilizando-se $\mathrm{Kds}$ para rochas intermediárias.

(6a) fracionamento de $\mathrm{VN}-24$ para VN-27 utilizardo-se Kds para rochas félsicas.

(6b) fracionamento de VN-24 para VN-27 utilizando-se Kds para rochas intermediárias 


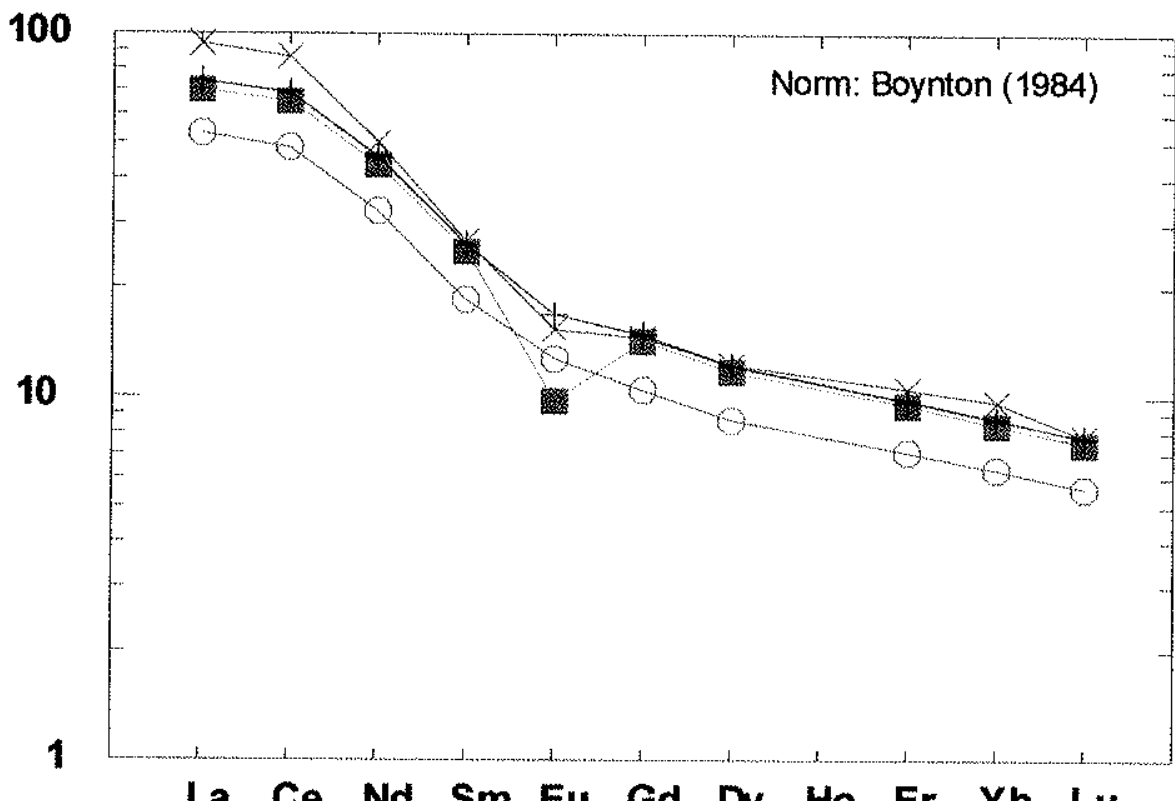

Figura 7.2 - Padróes de elementos terras raras para o fracionamento da amostra VN-35 para a amostra VN-23, utilizando-se os teores de ETR da amostra VN-17 para a amostra VN-35.

Símbolos: $\mathrm{OVN}-17, \mathrm{X}$ VN-23; fracionamento de OPX, CPX, plagioclásio e ilmenita: Kds para rochas fêl sicas, Kds para rochas intermediárias, $+\mathrm{Kds}$ para rochas básicas.

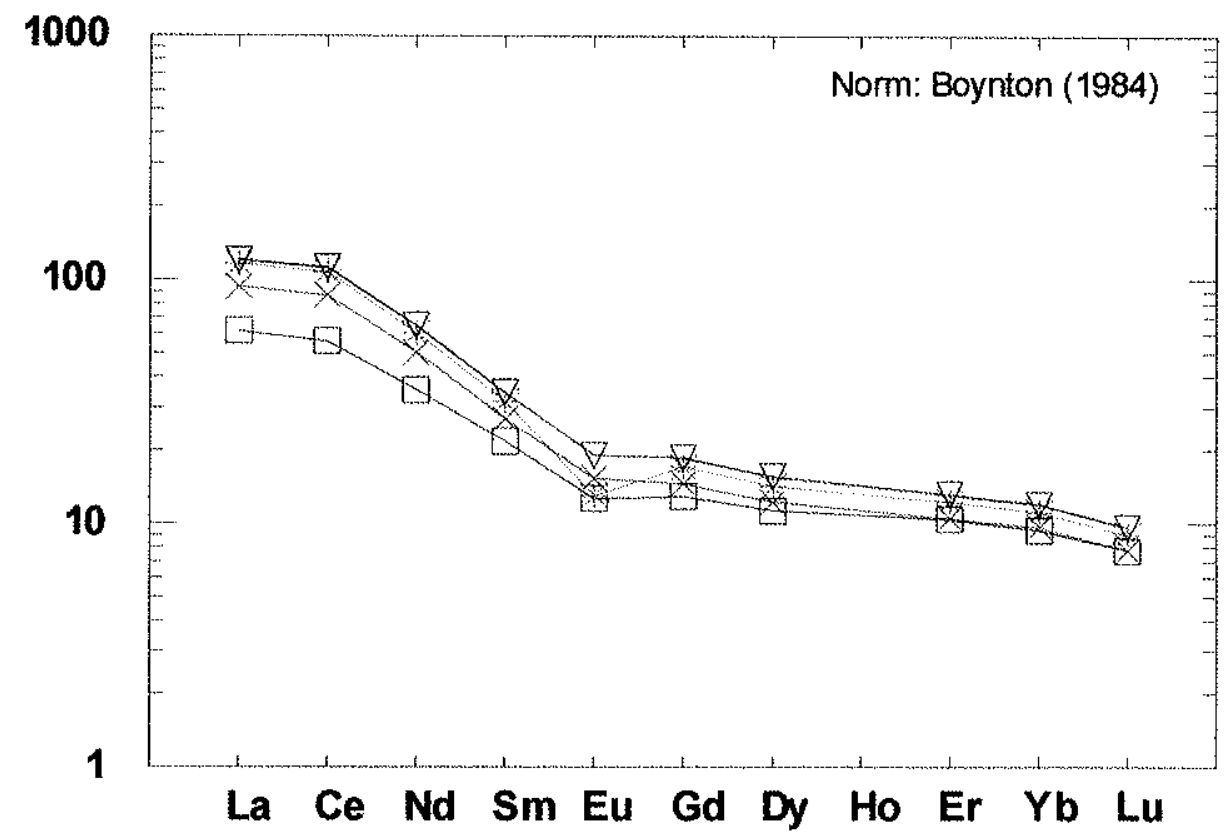

Figura 7.3 - Padrões de elementos terras raras para o fracionamento da amostra VN-23 para a amostra VN-16. Símbolos: X VN-23, I VN-16; fracionamento de OPX, CPX, plagioclásio e ilmenita: * Kds para rochas fẻlsicas,

$\checkmark \mathrm{Kds}$ para rochas intermediárias, $\nabla \mathrm{Kds}$ para rochas básicas. 


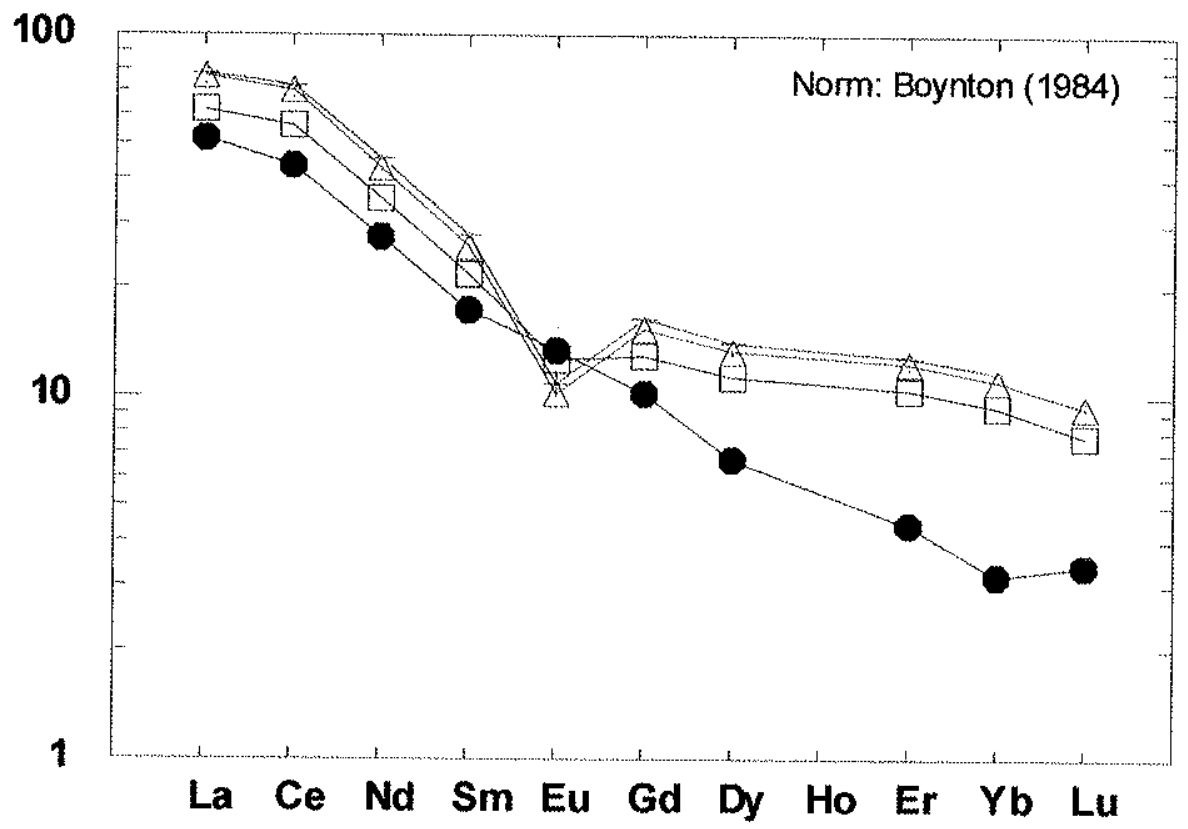

Figura 7.4 - Padrões de elementos terras raras para o fracionamento da amostra VN-16 para a amostra VN-24, utilizando-se os teores de ETR da amostra VN-13 para a amostra VN-24.

Símbolos: $\square$ VN $-16,-V N-13$; fracionamento de OPX, CPX, plagioclásio e ilmenita: $\triangle \mathrm{Kds}$ para rochas fëlsicas, + Kds para rochas intermediárias, Kd para rochas básicas.

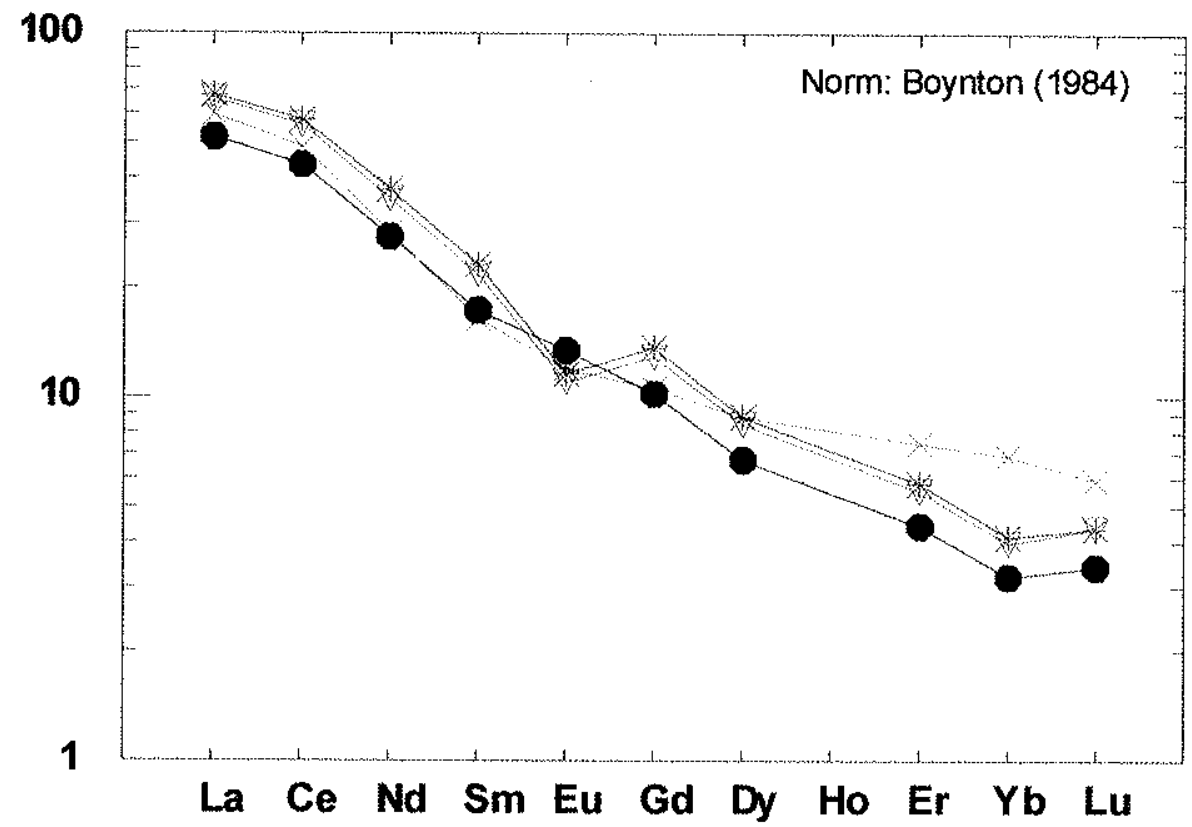

Figura 7.5 - Padrões de elementos terras raras para o fracionamento da amostra VN-24 para a amostra VN-31, utilizando-se os teores de ETR das amostras VN-13 e VN-27 para as amostras VN-24 e VN-31, respectivamente. Símbolos: - VN-13, X VN-27; fracionamento de OPX, CPX, plagioclásio e ilmenita: $\nabla$ Kds para rochas fëlsicas, * Kds para rochas intermediárias. 


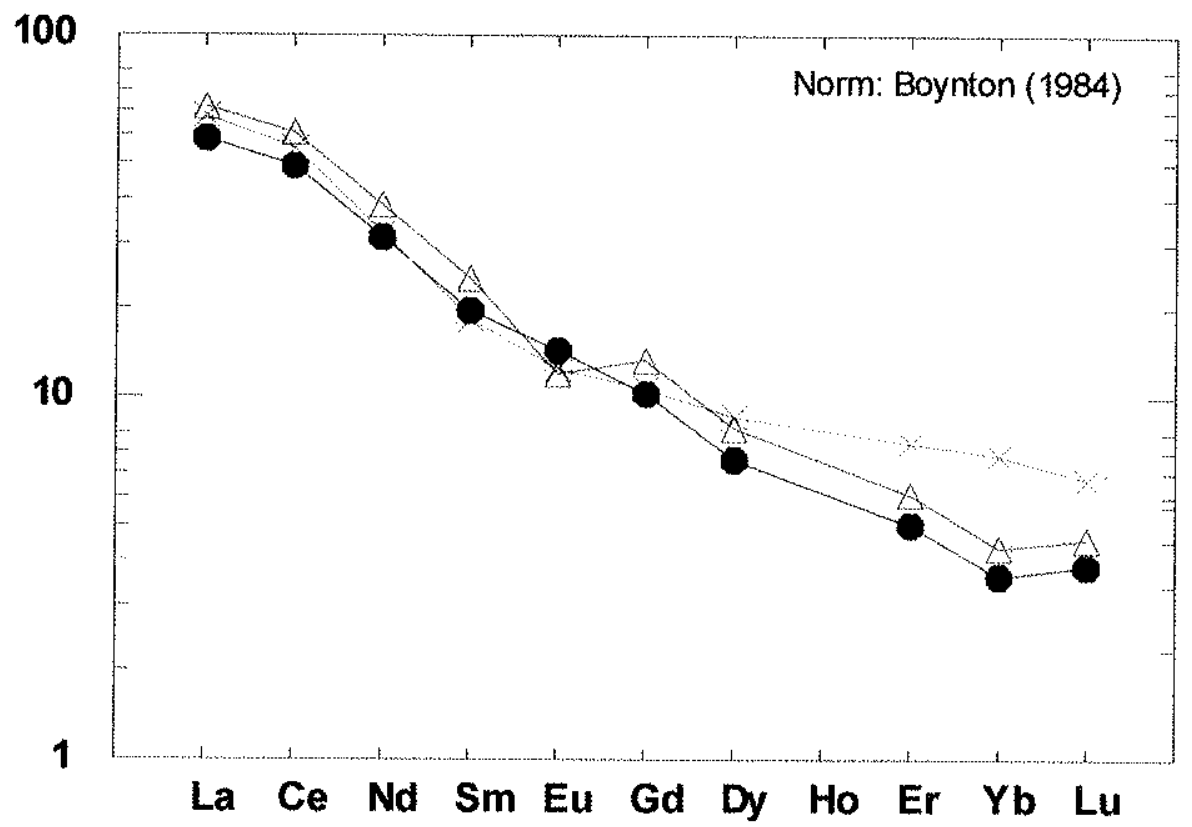

Figura 7.6 - Padrões de elementos terras raras para o fracionamento da amostra VN-24 para a amostra VN-27, utilizando-se os teores de ETR da amostra VN-13 para a amostra VN-24.

Símbolos: $\bullet V N-13, X V N-27$; fracionamento de OPX, CPX, plagioclásio e ilmenita: $\triangle \mathrm{Kds}$ para rochas fèlsicas, $\mathrm{Kds}$ para rochas intermediárias.

\subsection{MACIÇO DE VÁRZEA ALEGRE}

\section{Condições de cristalização das rochas $\left(\mathrm{PH}_{2} \mathrm{O}, \mathrm{T}, \mathbf{P}, \mathrm{f} \mathrm{O}_{2}\right)$}

Assim como as rochas da borda do maciço de Venda Nova, os charnoquitóides do maciço intrusivo de Várzea Alegre formaram-se sob condições anidras, com $\mathrm{PCO}_{2}>\mathrm{P}_{\mathrm{H} 2} \mathrm{O}$, resultando como paragênese primária essencial plagioclásio, OPX, ilmenita, quartzo e ortoclásio/mesopertita. A possibilidade da ocorrência de biotita primária foi aventada no capítulo 4 e fica reforçada pelos teores de cerca de $2,2 \%$ de $\mathrm{K}_{2} \mathrm{O}$ das rochas menos evoluídas da seqüência, cujas composições devem ser próximas às do magma parental. As pequenas quantidades de anfibólio modal e a falta de consistentes evidências petrográficas para a existência de cristais primários, juntamente com as texturas de substituição observadas, sugerem que os anfibólios das rochas da borda do maciço de Várzea Alegre se originaram principalmente a partir de reequilibrios químicos tardi-magmáticos. Os $\mathrm{KdsF}$ e-Mg para biotitas e anfibólios de Várzea Alegre resultam em valores entre 0,87 e 0,97, indicando equilíbrio entre as fases, valendo lembrar que estes minerais freqüentemente substituem OPX. 
A aplicação dos gráficos elaborados a partir do nivel de saturação de elementos traços dos minerais acessórios, notadamente $\mathrm{Zr}$ e $\mathrm{P}$, para se estimar a temperatura de cristalização de magmas granitóides (Watson \& Harrison, op. cit.) tem dado bons resultados e fornecido intervalos de temperatura bem coerentes. Nas figuras 7.7 e 7.8 encontram-se algumas amostras das rochas da borda do maciço de Várzea Alegre posicionadas em tais gráficos. Observa-se que tanto amostras que possuem composições próximas às do magma parental (OPX-quartzo-dioritos VA-26 l e VA-182) quanto as mais evoluídas encontram-se saturadas em $\mathrm{P}_{2} \mathrm{O}_{5}$ e $\mathrm{Zr}$. Ambos os gráficos indicam que o magma necessitava estar a temperaturas superiores a $900^{\circ} \mathrm{C}$ (entre 950 e $1000^{\circ} \mathrm{C}$ ) para manter em solução as elevadas concentrações medidas para estes elementos. No entanto, a possível acumulação de uma fase mineral nas rochas charnoquitóides de Várzea Alegre (sobretudo feldspatos) pode ser um fator limitador para os resultados obtidos pelo geotermômetro.

A presença de ilmenita com baixas proporções de molécula de hematita em solução sólida como óxido primário nos charnoquitóides de Várzea Alegre sugere que eles tenham sido gerados num ambiente redutor. A aplicação do geotermômetro ilmenita-magnetita (através do "software" QUILF) para três amostras de charnoquitóides resultou nos valores que estão na tabela 7.9. A temperatura média obtida é de $543 \pm 45^{\circ} \mathrm{C}$, correspondendo certamente ao reequilibro ocorrido em condições subsolidus, quando provavelmente deu-se a formação da magnetita. $\mathrm{O}$ cálculo da $\mathrm{fO}_{2}$ a partir deste par forneceu valores para log $\mathrm{fO}_{2}$ de aproximadamente $-21,50 \pm 1,25 \mathrm{~atm}$, cerca de 6 unidades log abaixo dos valores calculados para o tampão FMQ nas mesmas condições de $\mathrm{P}$ e $\mathrm{T}$, o que comprova a origem em ambiente

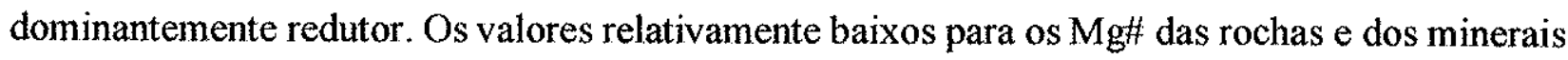
máficos corroboram com tal assertiva, mas o não desenvolvimento de anomalias negativas de $\mathrm{Eu}$ nos termos mais diferenciados vem a ser o único fator contraditório.

As temperaturas de subsolidus encontradas se repetem quando se utiliza o termômetro plagioclásio-feldspato alcalino de Fuhrman \& Lindsley (1986). As temperaturas médias obtidas para as equaçôes de atividade de feldspatos de várias amostras (i.e., $a(A b, p l a g)=a(A b$,falc $) ; a(A n, p l a g)=a(A n, f a l c)$ e $a(O r, p l a g)=a(O r$, falc $))$ foram de $630^{\circ} \mathrm{C}$, portanto um pouco superiores do que aquelas calculadas para o par ilmenita-magnetita. Isto indica que os feldspatos se reequilibraram quando do resfriamento do magma, e algumas texturas de substituição de plagioclásio por álcali-feldspato observadas podem estar associadas a esse fenômeno. 
Assim como ocorre para as rochas do maciço de Venda Nova, a aplicação do termômetro plagioclásio-anfibólio de Blundy \& Holland (op. cit.) para os charnoquitóides de Várzea Alegre fornece temperaturas de equilíbrio elevadas, de cerca de $950 \pm 75^{\circ} \mathrm{C}$. Apesar deste intervalo térmico ser compatível com a temperatura de cristalização do magma inferida pela saturação de $\mathrm{P}_{2} \mathrm{O}_{5} \mathrm{e} \mathrm{Zr}$, ele não deve refletir o equilíbrio primário entre as fases, uma vez que os anfibólios são predominantemente secundários, indicando assim que se trata de mera coincidência numérica.

A estimativa da pressão de cristalização dessas rochas através do geobarômetro que a correlaciona ao conteúdo de Al dos anfibólios fornece os resultados expostos na tabela 7.9. Verifica-se que os valores calculados são um pouco maiores do que aqueles encontrados para as rochas da borda do maciço de Venda Nova. Isto mostra coerência com as rochas encaixantes de mais alto grau metamórfico (anfibolito alto a granulito) do maciço de Várzea Alegre (na região de Venda Nova as faixas regionais encontram-se metamorfoseadas no grau anfibolito a anfibolito alto).

Levando-se em conta as restrições para o uso do geobarômetro, já descritas quando do cálculo para os charnoquitóides de Venda Nova (quanto à paragênese das rochas e origem dos anfibólios), observa-se que os valores alcançados pela calibração de Jonhson \& Rutherford são os menores (média de 4,9 $\pm 0,5 \mathrm{~Kb}$ ) e os de Schimidt e Hollister et al. os maiores $(6,4 \pm 0,6 \mathrm{~Kb})$. É provável enfim que as rochas da borda do maciço de Várzea Alegre tenham se consolidado sob pressões da ordem de $6,5 \mathrm{~Kb}$. Apesar de não haver determinações para os gnaisses encaixantes, comparando-se com os dados obtidos mais ao sul do Espírito Santo conclui-se que os mesmos sofreram metamorfismo a pressões mínimas de $8 \mathrm{~Kb}$. 
Tabela 7.9 - Determinações termobarométricas para os charnoquitóides do maciço de Várzea Alegre

\section{IImenita/magnetita (QUILF)}

\begin{tabular}{|l|l|}
\hline VA-56.1 & $546 \pm 52^{\circ} \mathrm{C}$ \\
\hline VA-56.2 & $602 \pm 41^{\circ} \mathrm{C}$ \\
\hline VA-257.1 & $603 \pm 19^{\circ} \mathrm{C}$ \\
\hline VA-257.2 & $482 \pm 47^{\circ} \mathrm{C}$ \\
\hline VA-252 & $480 \pm 66^{\circ} \mathrm{C}$ \\
\hline
\end{tabular}

\section{Anfibólios}

\begin{tabular}{lcccc}
\hline & H\&Z & Holl. et al. & J \& R & Schmidt \\
\hline VA-257.1 & $6,1 \pm 3 \mathrm{~Kb}$ & $6,5 \pm 1 \mathrm{~Kb}$ & $5,0 \pm 0,5 \mathrm{~Kb}$ & $6,5 \pm 0,6 \mathrm{~Kb}$ \\
VA-257.2 & $6,2 \pm 3 \mathrm{~Kb}$ & $6,6 \pm 1 \mathrm{~Kb}$ & $5,1 \pm 0,5 \mathrm{~Kb}$ & $6,6 \pm 0,6 \mathrm{~Kb}$ \\
VA-182.1 & $6,3 \pm 3 \mathrm{~Kb}$ & $6,7 \pm 1 \mathrm{~Kb}$ & $5,1 \pm 0,5 \mathrm{~Kb}$ & $6,6 \pm 0,6 \mathrm{~Kb}$ \\
VA-182.2 & $5,7 \pm 3 \mathrm{~Kb}$ & $6,0 \pm 1 \mathrm{~Kb}$ & $4,6 \pm 0,5 \mathrm{~Kb}$ & $6,1 \pm 0,6 \mathrm{~Kb}$ \\
VA-261.1 & $6,4 \pm 3 \mathrm{~Kb}$ & $6,8 \pm 1 \mathrm{~Kb}$ & $5,2 \pm 0,5 \mathrm{~Kb}$ & $6,7 \pm 0,6 \mathrm{~Kb}$ \\
\hline
\end{tabular}

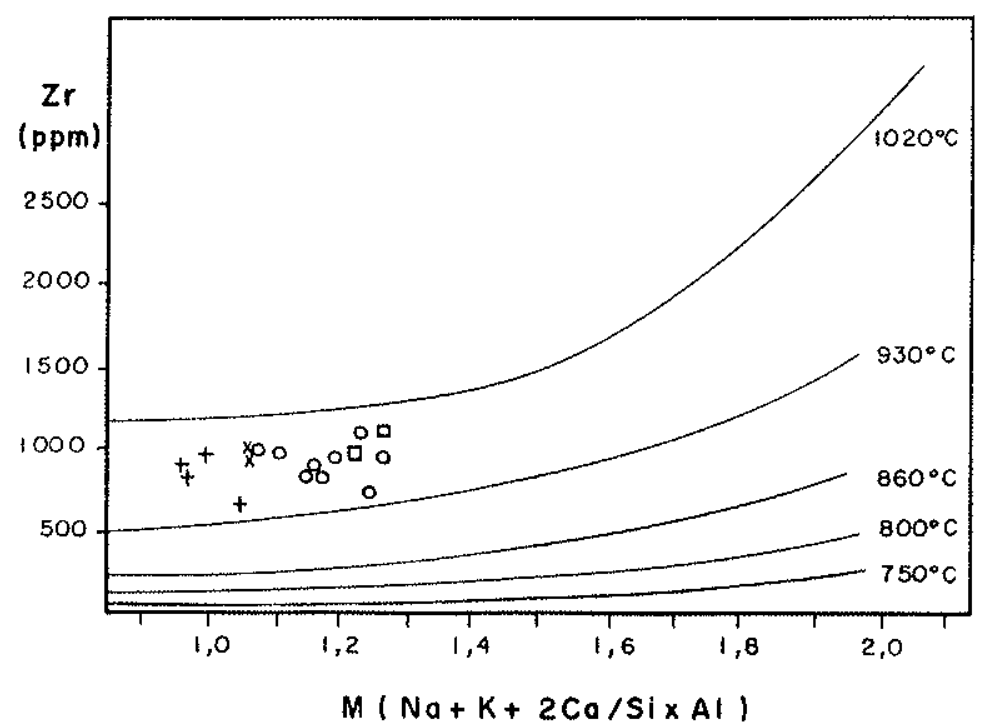

Figura 7.7 - Gráfico $\mathrm{M}(\mathrm{Na}+\mathrm{K}+2 \mathrm{Ca} / \mathrm{Si} \times \mathrm{Al})$ versus $\mathrm{Zr}$ para as rochas charnoquitóides do maciço de Várzea Alegre. As curvas foram determinadas experinentalmente por Watson \& Harrison (1983) e representam o grau de saturação em $\mathrm{Zr}$ para as temperaturas indicadas.

Símbolos: † OPX-quartzo-dioritos; O Jotunitos; + Opdalitos. 


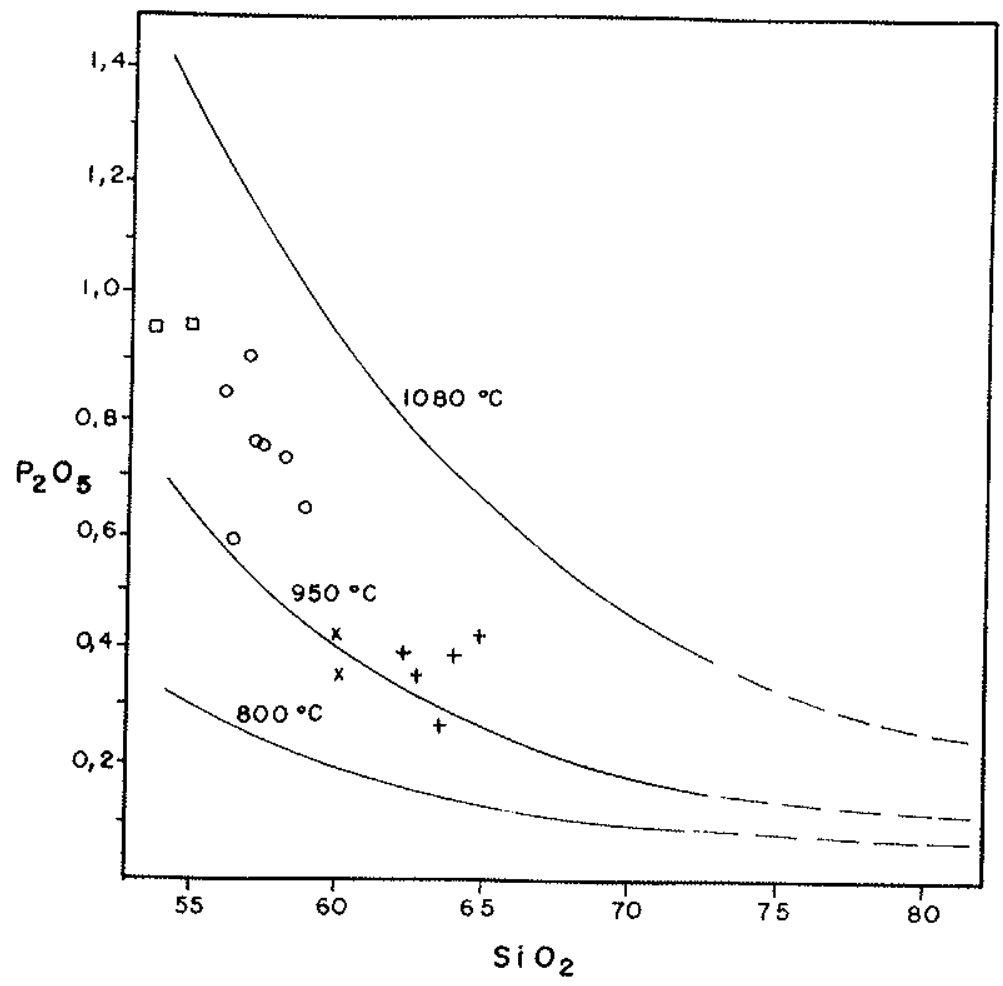

Figura 7.8 - Gráfico $\mathrm{SiO}_{2} \times \mathrm{P}_{2} \mathrm{O}_{5}$ para as rochas charnoquitóides do maciço de Várzea Alegre. As curvas foram determinadas experimentalmente por Watson \& Harrison (1984) e representam o grau de saturação em $\mathrm{P}_{2} \mathrm{O}_{5}$ para as temperaturas indicadas.

Símbolos: D OPX-quartzo-dioritos; O Jotunitos; + Opdalitos.

\section{Processos evolutivos e modelamentos geoquímicos}

No capitulo 5 foi apontada a ineficiência dos diagramas de variação tradicionais $\left(\mathrm{SiO}_{2} \times\right.$ óxidos e elementos traços) para uma melhor definição dos processos ígneos responsáveis pela diversidade litológica dentre os charnoquitóides de Várzea Alegre. Em vista disto, a utilização de gráficos que correlacionam elementos incompatíveis com elementos compativeis é mais uma tentativa para a proposição dos mecanismos atuantes. Tal expediente foi utilizado com sucesso por Martin (1987) na separação de fenômenos de cristalização fracionada e fusão parcial em seqüências TTG do leste da Finlândia.

Nos diagramas da figura 7.9 estão plotados elementos muito a pouco incompatíveis ( $\mathrm{Rb}, \mathrm{Zr}$ e $\mathrm{Sr}$ ) versus elementos muito a pouco compatíveis ( $\mathrm{V}, \mathrm{Mg}$ e Ti). A título de ilustração e para um melhor entendimento, em quase todos os gráficos estão colocados os números de várias das amostras junto aos símbolos correspondentes. Observa-se que nesses diagramas pode-se separar dois conjuntos distintos, com considerável repetibilidade das amostras para todos os gráficos. Os grupos que se separam são: 1-amostras VA-56, 249, 252, $262,260,42,250,164$, e 263 ( \pm 16 e 125); 2-amostras VA-182, 257, 253, 246, 242, 237, 264, 
241, 244 e MP-161 ( $\pm 16,90$ e 125). As amostras MP-173, 128, 718 e HR-29 colocam-se aleatoriamente, deslocadas dos grupos (coincidentemente são análises de outro laboratório).

Observa-se que a amostra VA-261 situa-se no extremo menos evoluído dos dois "trends" definidos, o que indica que ela representa a composição mais próxima do magma parental para ambos os conj untos. Os dois grupos possuem comportamento geoquímico distinto que pode ser explicado da seguinte maneira: as amostras do grupo 1 evoluem para os termos mais diferenciados com acentuado decréscimo dos teores dos elementos compatíveis ( $\mathrm{V}, \mathrm{Mg} \mathrm{e}$ $\mathrm{Ti}$ ), um considerável aumento de $\mathrm{Rb}$, pequenas variações nos teores de $\mathrm{Zr}$ e menores concentraç̃̃es de $\mathrm{Sr}$; por outro lado, os conteúdos de elementos compatíveis das amostras do grupo 2 praticamente não oscilam em direção aos termos mais ácidos (ou exibem pequena variação, como no caso do Ti) e os elementos incompatíveis comportam-se de modo similar ao grupo 1, excetuando o $\mathrm{Zr}$ que diminui mais intensamente. Isto significa que o $\mathrm{Kd}$ mineral/líquido para os elementos compativeis é bem diferente de um grupo para o outro, mostrando-se quase constante no grupo $2(\mathrm{D} \cong 1)$ e maior no grupo 1 .

A tendência observada para as amostras do conjunto 1 pode ser explicada por processos de diferenciação por cristalização fracionada (com fracionamento de plagioclásio, OPX, ilmenita e talvez feldspato alcalino) a partir de um magma com composição próxima àquela da amostra VA-261. A discreta dispersão observada na porção terminal, mais evoluída do "trend", talvez seja associada a mecanismos de acumulação de cristais (como já aventado no capítulo 5, as amostras VA-250 e VA-263 podem estar relacionadas a acumulação de feldspato alcalino). Já a tendência delineada pelas amostras do conjunto 2 poderia ser explicada por processos de mistura magmática atuando isoladamente ou em conjunto com fenômenos de cristalização fracionada.

Com $o$ intuito de testar as possibilidades genéticas sugeridas acima foram realizados modelamentos para processos de cristalização fracionada em ambos os grupos. Tal análise quantitativa foi feita para óxidos de elementos maiores a partir do programa XLFRAC (Stormer \& Nicholls, op. cit., modificado por M.S.M. Mantovani). Apesar das composições das rochas analisadas não corresponderem a liquidus, para efeito do modelamento efetuado a amostra VA-261, a menos evoluída delas, foi utilizada como representante do magma progenitor, e os "trends" definidos considerados como "liquid line of descent".

No conj unto 1 as seguintes amostras foram utilizadas: VA-261, VA-56, VA-249, VA-252 e VA-42; para o conjunto 2 várias opções foram testadas e nenhuma delas forneceu 
resultados muito satisfatórios, mas os melhores foram aqueles com as amostras VA-261, VA-253 e VA-16.
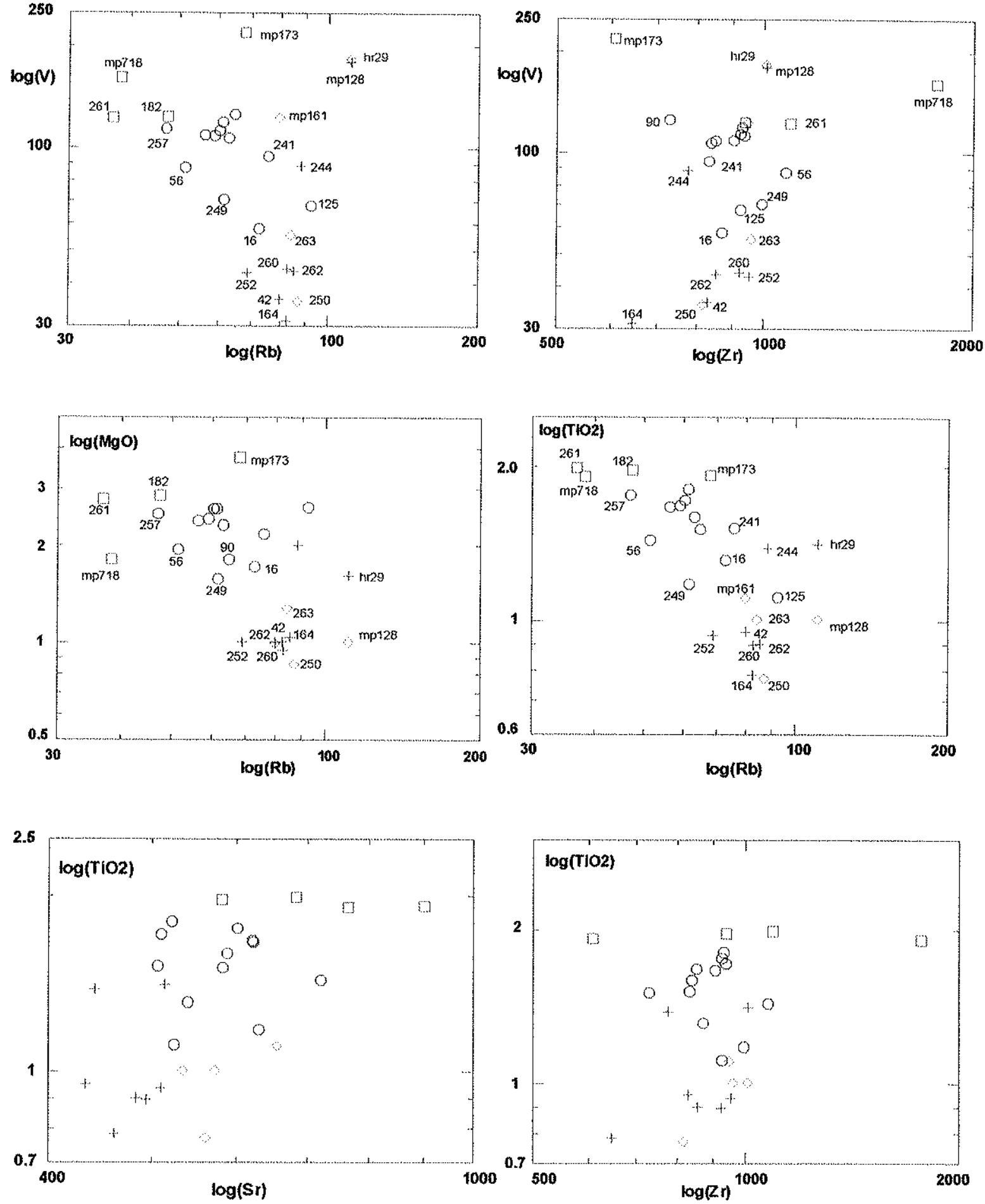

Figura 7.9 - Diagramas de variação que permitem a separação de dois grupos de rochas nos charnoquitóides da borda do Maciço de Várzea Alegre.

Símbolos: $U$ OPX-Quartzo-dioritos; O Jotunitos; + Opdalitos; $\ominus$ Quartzo-mangeritos 
Nas tabelas 7.10 e 7.11 encontram-se as composições das rochas e dos minerais, recalculadas para 100\%, utilizadas nos modelamentos efetuados. Os resultados obtidos encontram-se nas tabelas 7.12 (composição dos extratos das várias etapas) e 7.13 (proporção de fases extraídas). Para as etapas (4) e (5), VA-249 para VA-252 e (10), VA-253 para VA-16, os minerais utilizados foram os da amostra VA-56 e nas etapas (6) e (7), VA-252 para VA-42, a composição da ilmenita utilizada foi a de VA-56.

Verifica-se que para quase todos os passos foram obtidos valores aceitáveis para a soma dos quadrados dos resíduos (menores que 1, com exceção da etapa (2)), com variadas proporções de extração do magma tido como inicial. Isto implica que os resultados são matematicamente aceitáveis e o modelo é viável para quase todas as etapas. $O$ fracionamento de feldspato alcalino fornece os menores valores da SQR, refletindo também uma maior proporção de fases extraídas. $O$ envolvimento de feldspato alcalino na etapa (1) resulta em adição de pequenas proporções do mesmo, e isto não parece provável em função da composição das rochas.

Para as rochas do grupo 1 parece bem satisfatório o modelo de cristalização fracionada dominada pela extração de plagioclásio (com proporções variando de aproximadamente $75 \%$ a $50 \%$, dependendo do fracionamento de feldspato alcalino), ortopiroxênio (18 a 30\%), ilmenita ( 3 a $6 \%$ ) e possivelmente álcali-feldspato, haj a visto os bons resultados obtidos quando ele é extraído (proporções variando de 13 a $21 \%$ ). Concomitantemente ao fracionamento dessas fases essenciais provavelmente ocorreu extração de apatita, em função do comportamento do $\mathrm{P}_{2} \mathrm{O}_{5}$ nos diagramas de variação; pode também ter havido uma discreta extração de zircão.

Ao se comparar com a química dos elementos maiores e traços observa-se uma boa coerência nesta proposição, espelhada, por exemplo, na diminuição dos teores de $\mathrm{Ca}, \mathrm{Sr}, \mathrm{Fe}$, $\mathrm{Mg}$, Ti, $\mathrm{P}, \mathrm{V}$ e Ba nas rochas do conj unto. Mas, a considerável extração de plagioclásio deveria ser responsável por anomalias negativas de Eu e uma maior redução dos conteúdos de $\mathrm{Sr}$, o que não ocorre (isto será enfatizado logo mais adiante); a extração de fedspato alcalino deveria, por sua vez, causar o decréscimo ou a estabilização dos teores de $\mathrm{K}_{2} \mathrm{O}$ e $\mathrm{Rb}$ das rochas envolvidas, e eles tendem a aumentar. Deve ser levado em conta que essas rochas possuem considerável quantidade de biotita modal, predominantemente secundária, e sua presença afeta bastante os conteúdos desses últimos elementos. 
Com relaçấo aos componentes do grupo 2, os altos valores para a $\mathrm{SQR}$ calculados nas etapas (8), (9) e (10) sugerem que a cristalização fracionada não foi unicamente responsável pela sua evolução, ratificando assim uma provável participação de mecanismos de mistura de magmas.

Vale ressaltar que algumas outras possibilidades foram testadas, para os dois conjuntos: a extração de CPX com 18\% de $\mathrm{FeO}$ e $8 \%$ de $\mathrm{MgO}$ resulta numa diminuição dos valores da SQR com pequenas porcentagens de CPX fracionado, mas a proporção total de fases extraídas praticamente não altera; diferentemente, a inclusão de olivina rica em ferro como fase fracionada, o não fracionamento de feldspatos e o não fracionamento de ilmenita implica em resultados muito ruins.

Com o intuito de averiguar se os resultados obtidos acima seriam confirmados pelos elementos traços, foi realizado um modelamento para elementos terras raras e alguns outros traços (Rb, Sr, Ba, V e Zr) a partir da opção Newmelt do "software" NEWPET (Clarke, op. cit.). Os coeficientes de partição para rochas intermediárias (média de andesitos) e félsicas utilizados são aqueles encontrados no programa e estão na tabela 7.14. 
Tabela 7.10 - Composições químicas de rochas utilizadas nos modelamentos de cristalização fracionada para rochas charnoquitóides do Maciço de Várzea Alegre

\begin{tabular}{lccccccc}
\hline & VA-261 & VA-56 & VA-249 & VA-252 & VA-42 & VA-253 & VA-16 \\
\hline $\mathrm{SiO} 2$ & 55,04 & 58,36 & 60,74 & 64,18 & 66,08 & 56,58 & 62,07 \\
$\mathrm{TiO} 2$ & 2,01 & 1,45 & 1,18 & 0,94 & 0,96 & 1,69 & 1,32 \\
$\mathrm{~A} 2 \mathrm{O} 3$ & 16,90 & 16,92 & 17,12 & 16,25 & 15,38 & 16,05 & 16,38 \\
$\mathrm{Fe} 2 \mathrm{O} 3$ & 11,50 & 8,71 & 7,53 & 6,41 & 5,67 & 9,97 & 7,20 \\
$\mathrm{MgO}$ & 2,81 & 1,96 & 1,58 & 1,01 & 1,01 & 2,41 & 1,73 \\
$\mathrm{CaO}$ & 6,34 & 5,46 & 5,02 & 4,14 & 3,67 & 5,30 & 4,58 \\
$\mathrm{Na2O}$ & 3,34 & 3,52 & 3,52 & 3,40 & 3,56 & 3,16 & 3,56 \\
$\mathrm{~K} 2 \mathrm{O}$ & 2,06 & 3,61 & 3,30 & 3,66 & 3,67 & 2,84 & 3,15 \\
\hline
\end{tabular}

As composições químicas estão recalculadas para $100 \%$ e Fetotal $=\mathrm{Fe}_{2} \mathrm{O}_{3}$

芩 Tabela 7.11 - Composiçôes químicas de minerais utilizados nos modelamentos de cristalização fracionada para rochas charnoquitóides do Maciço de Várzea Alegre

\begin{tabular}{|c|c|c|c|c|c|c|c|c|c|c|c|}
\hline & OPX-261 & PLAG-261 & FALC-261 & ILME-261 & OPX-56 & PLAG-56 & FALC-56 & ILME-56 & $0 \mathrm{PX}-252$ & PLAG-252 & FALC-252 \\
\hline $\mathrm{SiO}_{2}$ & 48,69 & 57,76 & 64,46 & 0,11 & 48,48 & 58,08 & 64,42 & 0,11 & 48,42 & 59,26 & 64,52 \\
\hline $\mathrm{TiO} 2$ & 0,09 & 0 & 0 & 43,99 & 0,10 & 0 & 0 & 46,05 & 0,11 & 0 & 0 \\
\hline $\mathrm{A} 12 \mathrm{O} 3$ & 0,81 & 25,98 & 18,97 & 0,09 & 0,82 & 25,73 & 19,07 & 0,06 & 0,80 & 24,99 & $18 ; 83$ \\
\hline $\mathrm{Fe} 2 \mathrm{O} 3$ & 36,74 & 0,19 & 0,11 & 55,04 & 36,33 & 0,07 & 0,08 & 52,92 & 37,98 & 0,07 & 0 \\
\hline $\mathrm{MgO}$ & 12,49 & 0 & 0 & 0,47 & 13,44 & 0 & 0 & 0,54 & 12,12 & 0 & 0 \\
\hline $\mathrm{CaO}$ & 1,12 & 8,72 & 0 & 0,06 & 0,81 & 8,15 & 0 & 0,06 & 0,55 & 7,34 & 0 \\
\hline $\mathrm{Na} 2 \mathrm{O}$ & 0,04 & 6,82 & 1,36 & $0,2,1$ & 0,02 & 7,42 & 1,49 & 0,25 & 0 & 7,88 & 1,45 \\
\hline $\mathrm{K} 2 \mathrm{O}$ & 0,01 & 0,53 & 15,10 & 0,03 & 0 & 0,54 & 14,95 & 0,01 & 0,02 & 0,45 & 15,20 \\
\hline
\end{tabular}

As composiçôes químicas estão recalculadas para $100 \%$ e Fetotal $=\mathrm{Fe}_{2} \mathrm{O}_{3}$ 
Tabela 7.12 - Composição dos extratos obtidos no modelamento para elementos maiores

\begin{tabular}{lcccccccccc}
\hline & $\mathbf{( 1 )}$ & $\mathbf{( 2 )}$ & $\mathbf{( 3 )}$ & $\mathbf{( 4 )}$ & $\mathbf{( 5 )}$ & $\mathbf{( 6 )}$ & $\mathbf{( 7 )}$ & $\mathbf{( 8 )}$ & $\mathbf{( 9 )}$ & $(\mathbf{1 0})$ \\
\hline $\mathrm{SiO} 2$ & 51,56 & 49,27 & 53,94 & 52,96 & 54,78 & 54,36 & 56,88 & 51,72 & 52,24 & 51,93 \\
$\mathrm{TiO} 2$ & 2,69 & 5,03 & 2,62 & 2,48 & 1,77 & 2,27 & 1,20 & 2,84 & 2,63 & 2,88 \\
$\mathrm{~A} 203$ & 16,89 & 16,43 & 17,19 & 19,10 & 18,76 & 19,27 & 18,64 & 17,80 & 17,72 & 15,44 \\
$\mathrm{Fe} 203$ & 14,44 & 15,29 & 11,36 & 10,55 & 9,50 & 9,71 & 8,33 & 13,17 & 12,85 & 15,14 \\
$\mathrm{MgO}$ & 3,76 & 3,57 & 3,11 & 2,87 & 2,77 & 2,28 & 2,23 & 3,27 & 3,25 & 4,41 \\
$\mathrm{CaO}$ & 5,93 & 5,36 & 4,31 & 6,17 & 5,25 & 5,72 & 4,37 & 6,20 & 5,96 & 4,54 \\
$\mathrm{Na2O}$ & 4,39 & 4,71 & 4,08 & 5,47 & 4,83 & 6,04 & 4,89 & 4,64 & 4,50 & 4,04 \\
$\mathrm{~K} 2 \mathrm{O}$ & 0,35 & 0,34 & 3,39 & 0,40 & 2,35 & 0,35 & 3,47 & 0,36 & 0,86 & 1,61 \\
\hline
\end{tabular}

Tabela 7.13 - Proporção das fases extraídas no modelamento para elementos maiores

\begin{tabular}{|c|c|c|c|c|c|c|c|c|c|c|}
\hline & (1) & (2) & (3) & (4) & (5) & (6) & (7) & (8) & (9) & (10) \\
\hline OPX & 29,89 & 26,12 & 22,91 & 21,12 & 20,47 & 18,63 & 18,27 & 25,90 & 25,77 & 32,56 \\
\hline PLAG & 64,04 & 63,01 & 50,59 & 73,54 & 62,26 & 76,50 & 58,11 & 67,70 & 64,96 & 52,42 \\
\hline FALC & - & - & 20,87 & - & 13,48 & - & 21,07 & - & 3,35 & 8,84 \\
\hline ILME & 6,07 & 10,87 & 5,63 & 5,34 & 3,79 & 4,88 & 2,55 & 6,40 & 5,92 & 6,18 \\
\hline SQR & 0,7957 & 1,2057 & 0,6925 & 0,7436 & 0,4132 & 0,7519 & 0,4389 & 0,9319 & 0,8950 & 0,9869 \\
\hline Tsub & 48,31 & 16,98 & 32,29 & 28,61 & 36,10 & 15,09 & 21,08 & 48,31 & 53,19 & 33,70 \\
\hline
\end{tabular}

Os extratos correspondem a:

(1) $=$ VA-261 para VA-56

(2) e (3) = VA-56 para VA-249

(4) $\mathrm{e}(5)=\mathrm{VA}-249$ para VA-252

(6) e (7) $=$ VA-252 para VA-42

(8) e (9) =VA-261 para VA-253

$(10)=$ VA-253 para VA-16 
A partir das proporções das fases extraídas, calculadas anteriormente pelo programa XLFRAC nas diversas etapas evolutivas de ambos os conj untos, o modelamento para elementos traços resultou nos valores expostos na tabela 7.15, com os diferentes Kds utilizados. Eles foram calculados a partir do modelo de fracionamento de equilibrio total (TEQ), que forneceu valores quase que idênticos aos do modelo de fracionamento seqüencial (SEQ). Como algumas das amostras não têm determinações de elementos terras raras, foram utilizados os teores de amostras de composição muito semelhante; é o caso das amostras VA-249 (foram usados os ETR de MP-128), VA-252 (usados os ETR de VA-262) e VA-253 (foram usados os ETR de VA-264).

Ao se fracionar os minerais da amostra VA-261 para VA-56 (etapa (1)) os teores de elementos terras raras calculados são bem superiores aos de ambas as amostras (amostras "pai e filho"), com exceção do Eu que resultou num valor inferior. No entanto, o padrão, que está na figura 7.10 é muito semelhante (paralelo), só que com acentuada anomalia negativa de Eu para $\mathrm{Kds}$ de rochas intermediárias e ácidas. Ao se utilizar $\mathrm{Kds}$ de rochas básicas o padrão se mantém, ligeiramente mais enriquecido mas sem anomalia negativa de Eu (os dados com esses Kds não estão tabelados). Nesta figura está também representada a possibilidade de fracionamento de álcali-feldspato, que não provoca mudança no padrão.

Quando se modela o fracionamento de minerais da amostra VA-56 para a amostra VA-249 (etapas (2) e (3) - cf. Figura 7.11), as concentrações calculadas são superiores para os ETRL e se assemelham para os outros elementos da amostra MP-128. O fracionamento envolvendo álcali-feldspato implica num melhor resultado final, como pode ser visto no padrão da figura 7.11, que é ligeiramente mais fracionado que o da amostra MP-128(razão $(\mathrm{Ce} / \mathrm{Yb})_{\mathrm{N}}$ de 21,5). As anomalias levemente positivas de Eu são quase idênticas (razões Eu/Eu*N bem próximas).

A passagem da amostra VA-249 para VA-252 (etapas (4) e (5)) resulta em maiores teores de ETR intermediários e pesados do que os da amostra VA-262, não importando as fases fracionadas. $O$ fracionamento de feldspato alcalino não provoca qualquer mudança no padrão, como pode-se verificar na figura 7.12, e eles não são paralelos ao da amostra VA-262. Esta possui razão $(\mathrm{Ce} / \mathrm{Yb})_{\mathrm{N}}$ de 22,18 , contrastando com as razões de 13,15 obtidas através do modelamento. Apesar dos conteúdos de Eu serem praticamente os mesmos, o padrão da amostra VA-262 mostra pequena anomalia positiva $\left(\mathrm{Eu} / \mathrm{Eu}^{*} \mathrm{~N}\right.$ de 1,18$)$ contrastando com a anomalia negativa conferida pelo modelamento $\left(\mathrm{Eu}^{\mathrm{E}} \mathrm{Eu}^{*} \mathrm{~N}\right.$ de cerca de 0,80$)$. Tais diferenças podem ocorrer pelo fato dos teores de ETR usados não serem os das amostras modeladas.

Uma avaliação ampla das etapas (6) e (7), fracionamento de minerais da amostra VA-252 para VA-42, é prej udicada pela análise incompleta do espectro de ETR da amostra VA42. Entretanto, observamse que a extração de feldspato alcalino não implica em mudança dos teores, fornecendo idêntico padrão de ETR (cf. Figura 7.13). Ao se comparar com a amostra VA42, observa-se que as concentrações de ETRL são maiores e as de ETRP são menores, 
implicando num padrão ligeiramente diferente (razões $(\mathrm{Ce} / \mathrm{Yb})_{\mathrm{N}}$ de 22,24 , contrastando com razão de 13,11 para a amostra VA-42). Não há o desenvolvimento de anomalias de Eu, enquanto que para a amostra VA-42 tem-se a impressão que ocorre uma discreta anomalia positiva.

Com relação às amostras do grupo 2, o modelamento para ETR de VA-261 para VA-253 (etapas (8) e (9)) fornece resultado quase idêntico ao obtido para o fracionamento de minerais da amostra VA-261 para VA-56. As concentrações calculadas para todos os elementos são bem superiores aos da amostra VA-264, exceto o Eu, e o padrão obtido é paralelo ao de VA264 e 261, só que com uma conspícua anomalia negativa de Eu (cf. Figura 7.14). Utilizando-se $\mathrm{Kds}$ de rochas básicas tal anomalia praticamente desaparece e o padrão se mantém. A extração de feldspato alcalino não interfere nos conteúdos de terras raras. Há que se destacar que as amostras VA-261 e VA-264 possuem concentrações de ETR quase idênticas.

A última etapa testada, VA-253 para VA-16, é também prejudicada pela análise incompleta da amostra VA-16. Só foi levado em conta o fracionamento de todas as fases envolvidas (plagioclásio, OPX, álcali-feldspato e ilmenita), já que a não extração de álcalifeldspato implica num péssimo resultado no modelamento para elementos maiores. As concentrações calculadas para os elementos são superiores a quase todas as da amostra VA-16, com exceção dos teores de Lu. O padrão obtido, representado na figura 7.15 é paralelo ao de VA-16 na porção em que se tem análise desta amostra, mas exibe anomalia negativa de Eu, o que não se observa em VA-16.

Levando-se em conta que algumas das amostras não possuem determinação de elementos terras raras e os teores usados são de outras rochas, limitando a confiabilidade do modelamento, de maneira geral os resultados calculados são razoáveis, aproximando-se grosseiramente dos padrões das amostras consideradas. A inclusão de CPX como fase extraída não resulta em mudanças significativas nos conteúdos calculados, mantendo-se os mesmos padrões e as relações inter elementos.

A falta de anomalia negativa de Eu (as anomalias são suavemente positivas), esperada pelo fracionamento preponderante de plagioclásio se justificaria caso o magma tivesse se cristalizado sob condições oxidantes, e desta forma o $\mathrm{Eu}^{+3}$ não entraria na estrutura do plagioclásio. Como concluído anteriormente, o ambiente de geração das rochas foi fortemente redutor e desta forma o estado estrutural do Eu era sobretudo bivalente, possibilitando assim sua alocação na estrutura do plagioclásio. Então, o não desenvolvimento de tais anomalias deve estar associado a processos de acumulação de plagioclásio e/ou ao efeito da extração conjunta de minerais com valores de $\mathrm{Kd}$ para $\mathrm{Eu}$ bem distintos, fazendo com que houvesse uma compensação de anomalias negativas e positivas. Deve-se considerar também que ao se utilizar menores valores de $\mathrm{Kd}(\mathrm{Eu})$ para o plagioclásio (p.e. $\mathrm{Kd}$ para rochas básicas), no modelamento realizado, as anomalias tornam-se menos acentuadas.

A seguinte avaliação poder ser feita para os outros elementos traços considerados nos modelamentos: os conteúdos de Sr calculados são ligeiramente inferiores aos das amostras 
consideradas como magma final, sendo no geral mais próximos da realidade quando não se extrai feldspato alcalino; os teores de $\mathrm{Rb}$ são um pouco superiores mas mostram boa correlação com os das rochas consideradas, e, da mesma forma que para o $\mathrm{Sr}$, são melhores quando não ocorre extração de feldspato alcalino; os teores de Ba calculados são nitidamente superiores aos das amostras, sendo mais próximos quando há o fracionamento de álcali-feldspato (com exceção das etapas (4) e (5)); as concentrações de V, controladas pela extração de ilmenita e \pm OPX, são bastante coerentes com as composições dos "resíduos", menos para as etapas (8) e (9); finalmente, observa-se que os teores de $\mathrm{Zr}$ são totalmente irreais, o que é facilmente explicado pelo fato de que as fases extraídas não influem no comportamento deste elemento (é só observar na tabela 7.14 os Kds muito baixos para o Zr), sendo ele controlado somente pelo zircão.

A partir das possibilidades vislumbradas pelos diagramas de elementos incompatíveis versus elementos compatíveis e pelos modelamentos realizados e discutidos acima, a seguinte hipótese evolutiva deve ser considerada: as rochas charnoquitóides de Várzea Alegre evoluíram a partir de um magma de composição intermediária que sofreu cristalização fracionada e originou um conj unto rochoso (denominado grupo 1) por extração de plagioclásio, OPX, ilmenita \pm feldspato alcalino e apatita, não descartando aí pequenas parcelas de mistura de magma (que pode ter causado a elevação dos teores de $\mathrm{K}_{2} \mathrm{O}$ ). $\mathrm{O}$ fracionamento de $\mathrm{CPX}$ é plausível como fase retirada precocemente, uma vez que não ocorre nenhum vestígio deste mineral nas rochas de Várzea Alegre; deste modo se o magma progenitor cristalizou pequenas quantidades de CPX, o mesmo foi totalmente fracionado e/ou substituído. Concomitantemente, a preponderância de processos de mistura magmática sobre cristalização fracionada deve ter sido responsável pela evolução das rochas do grupo 2 , implicando em variações bem estreitas dos conteúdos de elementos compativeis.

O provável fracionamento de apatita não provocou mudanças sensíveis nos conteúdos de terras raras intermediárias; do mesmo modo, se houve extração de zircão ela deve ter sido em proporções mínimas, haj a visto as concentrações uniformes de ETRP. Hanson (1978) aponta o forte controle exercido pelo comportamento destes minerais nas terras raras intermediárias e pesadas. 
Tabela 7.14 - Coeficientes de partição (Kds) utilizados nos modelamentos para elementos terras raras e alguns outros traços

\begin{tabular}{|c|c|c|c|c|c|c|c|}
\hline & \multicolumn{3}{|c|}{ Rochas intermediárias } & \multicolumn{4}{|c|}{ Rochas Félsicas } \\
\hline & OPX & PLAG & MAGN & OPX & PLAG & FALC & $\overline{\mathrm{MAGN}}$ \\
\hline $\mathrm{La}$ & 0.028 & 0.350 & 0.098 & 0.220 & 0.320 & 0.050 & 0.530 \\
\hline $\mathrm{Ce}$ & 0.038 & 0.240 & 0.110 & 0.150 & 0.270 & 0.044 & 0.610 \\
\hline $\mathrm{Nd}$ & 0.058 & 0.170 & 0.130 & 0.220 & 0.210 & 0.025 & 0.880 \\
\hline $\mathrm{Sm}$ & 0.100 & 0.130 & 0.150 & 0.270 & 0.130 & 0.018 & 0.930 \\
\hline $\mathrm{Eu}$ & 0.079 & 2.110 & 0.100 & 0.170 & 2.150 & 1.130 & 0.580 \\
\hline $\mathrm{Gd}$ & 0.171 & 0.090 & 0.120 & 0.340 & 0.097 & 0.011 & 0.700 \\
\hline Dy & 0.293 & 0.086 & 0.140 & 0.460 & 0.064 & 0.006 & 0.800 \\
\hline $\mathrm{Er}$ & 0.460 & 0.084 & 0.155 & 0.650 & 0.055 & 0.006 & 0.800 \\
\hline $\mathrm{Yb}$ & 0.670 & 0.077 & 0.170 & 0.860 & 0.049 & 0.012 & 0.800 \\
\hline $\mathrm{Lu}$ & 0.840 & 0.062 & 0.190 & 0.900 & 0.046 & 0.006 & 0.400 \\
\hline $\mathrm{Rb}$ & 0.020 & 0.070 & 0.000 & 0.003 & 0.041 & 0.366 & 0.000 \\
\hline $\mathrm{Ba}$ & 0.020 & 0.160 & 0.000 & 0.003 & 4.400 & 9.400 & 0.000 \\
\hline $\mathrm{Sr}$ & 0.020 & 1.800 & 0.000 & 0.085 & 0.310 & 6.120 & 0.000 \\
\hline $\mathrm{Zr}$ & 0.080 & 0.100 & 0.300 & 0.150 & 0.100 & 0.000 & 0.400 \\
\hline V & 1.100 & 0.000 & 30.000 & 7.000 & 0.000 & 0.000 & 20.000 \\
\hline
\end{tabular}

OPX=ortopiroxênio; PLAG=plagioclásio; FALC=feldspato alcalino; MAGN=magnetita. 
Tabela 7.15 - Resultados dos modelamentos para elementos terras raras e alguns outros traços para as rochas charnoquitóides do Maciço de Várzea Alegre, utilizando-se Kds para rochas intermediárias e félsicas

\begin{tabular}{|c|c|c|c|c|c|c|c|c|c|c|}
\hline & (1) & (2) & (3) & (4) & (5) & (6) & (7) & (8) & (9) & (10) \\
\hline$\overline{\mathrm{La}}$ & 110,93 & 67,13 & 76,81 & 62,71 & 66,99 & 63,01 & 66,68 & 109,93 & 112,12 & 89,05 \\
\hline $\mathrm{Ce}$ & 265,09 & 146,84 & 168,57 & 126,07 & 133,61 & 144,30 & 152,17 & 263,50 & 264,68 & 207,07 \\
\hline Nd & 141,38 & 75,71 & 86,40 & 77,73 & 81,56 & 66,13 & 69,49 & 140,86 & 137,59 & 106,91 \\
\hline $\mathrm{Sm}$ & 24,33 & 12,61 & 14,52 & 14,61 & 15,51 & 12,08 & 12,77 & 24,31 & 24,23 & 19,23 \\
\hline Eu & 2,92 & 4,05 & 3,82 & 3,51 & 3,42 & 3,23 & 3,18 & 2,84 & 2,72 & 3,36 \\
\hline $\mathrm{Gd}$ & 16,80 & 8,43 & 9,75 & 10,82 & 11,51 & 8,33 & 8,80 & 16,84 & 16,91 & 13,36 \\
\hline Dy & 11,42 & 5,93 & 6,86 & 6,61 & 7,08 & 5,78 & 6,15 & 11,50 & 11,67 & 9,40 \\
\hline Er & 4,92 & 2,53 & 2,90 & 3,32 & 3,54 & 2,53 & 2,67 & 4.97 & 5,03 & 4,24 \\
\hline $\mathrm{Yb}$ & 3,32 & 1,77 & 2,01 & 2,48 & 2,63 & 1,68 & 1,77 & 3,38 & 3,40 & 2,92 \\
\hline $\mathrm{Lu}$ & 0,44 & 0,23 & 0,26 & 0,33 & 0,36 & 0,21 & 0,23 & 0,45 & 0.47 & 0,35 \\
\hline $\begin{array}{l}\mathrm{Ce} / \mathrm{YbN} \\
\mathrm{Dy} / \mathrm{YbN} \\
\mathrm{Eu} / \mathrm{Eu}^{* N}\end{array}$ & $\begin{array}{c}20,65 \\
2,23 \\
0,42 \\
\end{array}$ & $\begin{array}{r}21,46 \\
2,17 \\
1,13 \\
\end{array}$ & $\begin{array}{c}21,69 \\
2,21 \\
0.93 \\
\end{array}$ & $\begin{array}{c}13,15 \\
1,73 \\
0,82 \\
\end{array}$ & $\begin{array}{c}13,14 \\
1,75 \\
0,75 \\
\end{array}$ & $\begin{array}{c}22,22 \\
2,23 \\
0,93 \\
\end{array}$ & $\begin{array}{c}22,24 \\
2,25 \\
0,87 \\
\end{array}$ & $\begin{array}{c}20,16 \\
2,21 \\
0.41 \\
\end{array}$ & $\begin{array}{c}20,14 \\
2,23 \\
0,39 \\
\end{array}$ & $\begin{array}{l}18,34 \\
2,09 \\
0,61 \\
\end{array}$ \\
\hline $\begin{array}{c}\mathrm{Rb} \\
\mathrm{Ba} \\
\mathrm{Sr} \\
\mathrm{Zr} \\
\mathrm{V}\end{array}$ & $\begin{array}{c}66 \\
3052 \\
629 \\
1973 \\
77 \\
\end{array}$ & $\begin{array}{c}60 \\
3996 \\
648\end{array}$ & $\begin{array}{c}70 \\
2975 \\
346 \\
1468 \\
55 \\
\end{array}$ & $\begin{array}{c}91 \\
2509 \\
297 \\
1444 \\
48 \\
\end{array}$ & $\begin{array}{c}84 \\
3389 \\
567 \\
1350 \\
55 \\
\end{array}$ & $\begin{array}{c}79 \\
2853 \\
474 \\
1092 \\
38 \\
\end{array}$ & $\begin{array}{c}84 \\
2256 \\
287 \\
1157 \\
36 \\
\end{array}$ & $\begin{array}{c}66 \\
3039 \\
611 \\
1975 \\
76 \\
\end{array}$ & $\begin{array}{c}73 \\
2546 \\
313 \\
2017 \\
59 \\
\end{array}$ & $\begin{array}{c}82 \\
2375 \\
354 \\
1272 \\
58 \\
\end{array}$ \\
\hline $\begin{array}{c}\text { Tsub } \\
F\end{array}$ & $\begin{array}{c}48 \\
0,52 \\
\end{array}$ & $\begin{array}{c}17 \\
0.83 \\
\end{array}$ & $\begin{array}{c}32 \\
0,68\end{array}$ & $\begin{array}{c}29 \\
0,71 \\
\end{array}$ & $\begin{array}{c}36 \\
0.64\end{array}$ & $\begin{array}{c}15 \\
0.85\end{array}$ & $\begin{array}{c}21 \\
0.79\end{array}$ & $\begin{array}{c}48 \\
0,52\end{array}$ & $\begin{array}{c}53 \\
0,47 \\
\end{array}$ & $\begin{array}{c}34 \\
0,66 \\
\end{array}$ \\
\hline
\end{tabular}

\section{Resultados:}

(1) fracionamento de VA-261 para VA-56 utilizando-se Kds para rochas intermediárias.

(2) fracionamento de VA-56 para VA-249 utilizando-se Kds para rochas intermediárias.

(3) fracionamento de VA-56 para VA-249 utilizando-se Kds para rochas fél sicas.

(4)fracionamento de VA-249 para VA-252 utilizando-se Kơs para rochas intermediárias.

(5) fracionamento de VA-249 para VA-252 utilizando-se Kds para rochas félsicas.
(6) fracionamento de VA-252 para VA-42 utilizando-se Kds para rochas intermediárias. (7) fracionamento de VA-252 para VA-42 utilizando-se Kds para rochas félsicas.

(8)fracionamento de VA-261 para VA-253 utilizando-se Kds para rochas intermediárias. (9) fracionamento de VA-26l para VA-253 utilizando-se Kds para rochas félsicas. (10) fracionamento de VA-253 para VA-16 utilizando-se Kds para rochas félsicas. 


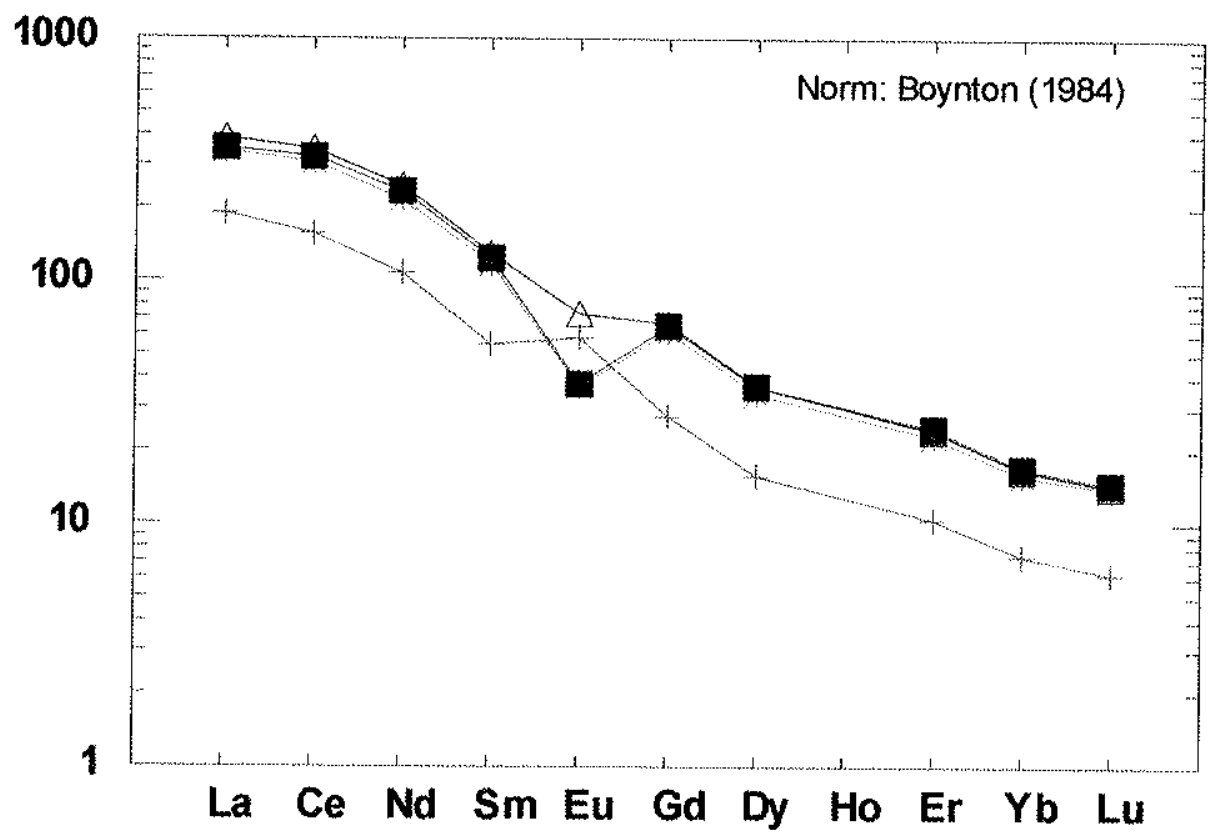

Figura 7.10 - Padrões de elementos terras raras para o fracionamento da amostra VA-26I para a amostra VA-56.

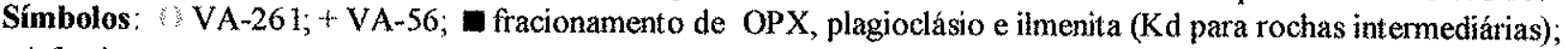
$\Delta$ fracionamento de OPX, plagioclásio e ilmenita ( $\mathrm{Kd}$ para rochas básicas); * fracionamento de OPX, plagioclásio, ilmenita e álcali-feldspato (Kd para rochas félsicas).

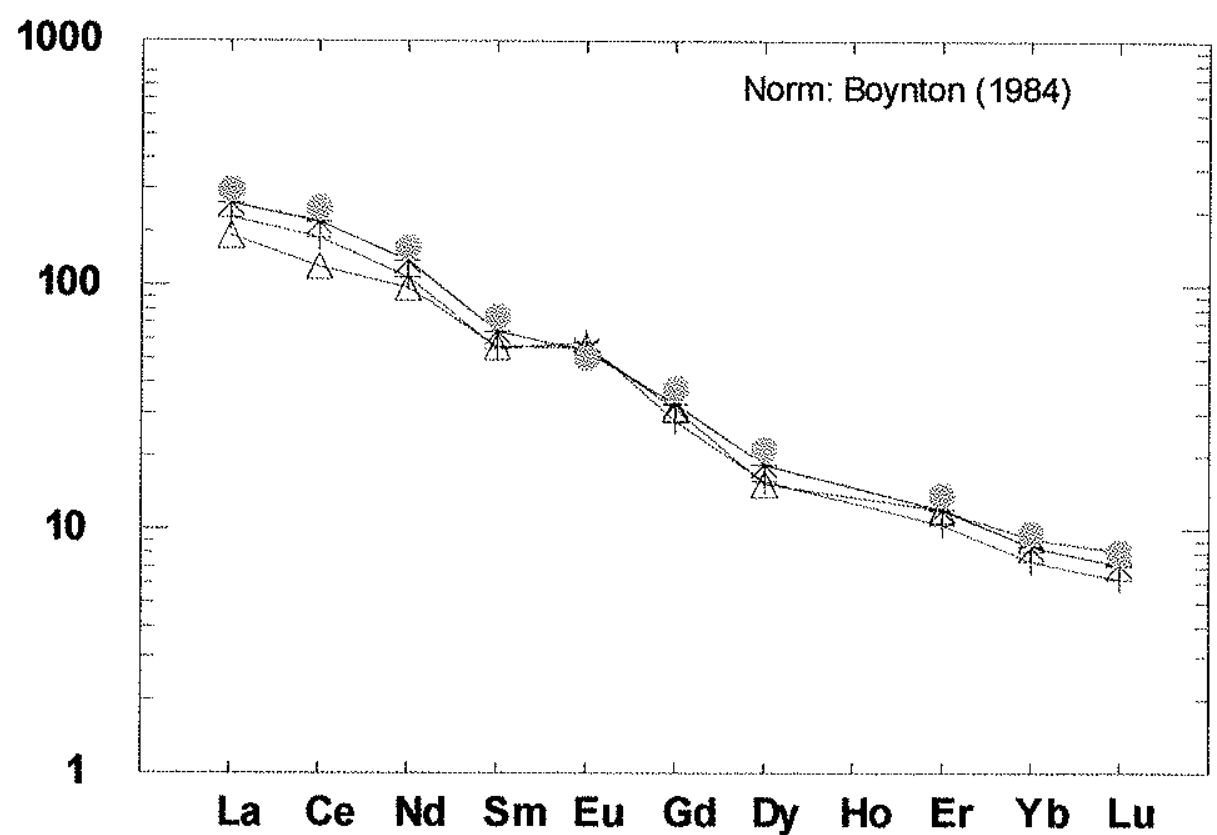

Figura 7.11 - Padrões de elementos terras raras para o fracionamento da amostra VA- 56 para a amostra VA-249, usando-se para esta última amostra as concentrações de elementos terras raras da amostra MP- 128 .

Símbolos: + VA-56; $\triangle$ MP- 128 (VA-249); * fracionamento de OPX, plagioclásio e ilmenita (Kds para rochas intermediárias); : fracionamento de OPX, plagioclásio, ilmenita e álcali-feldspato (Kds para rochas félsicas). 


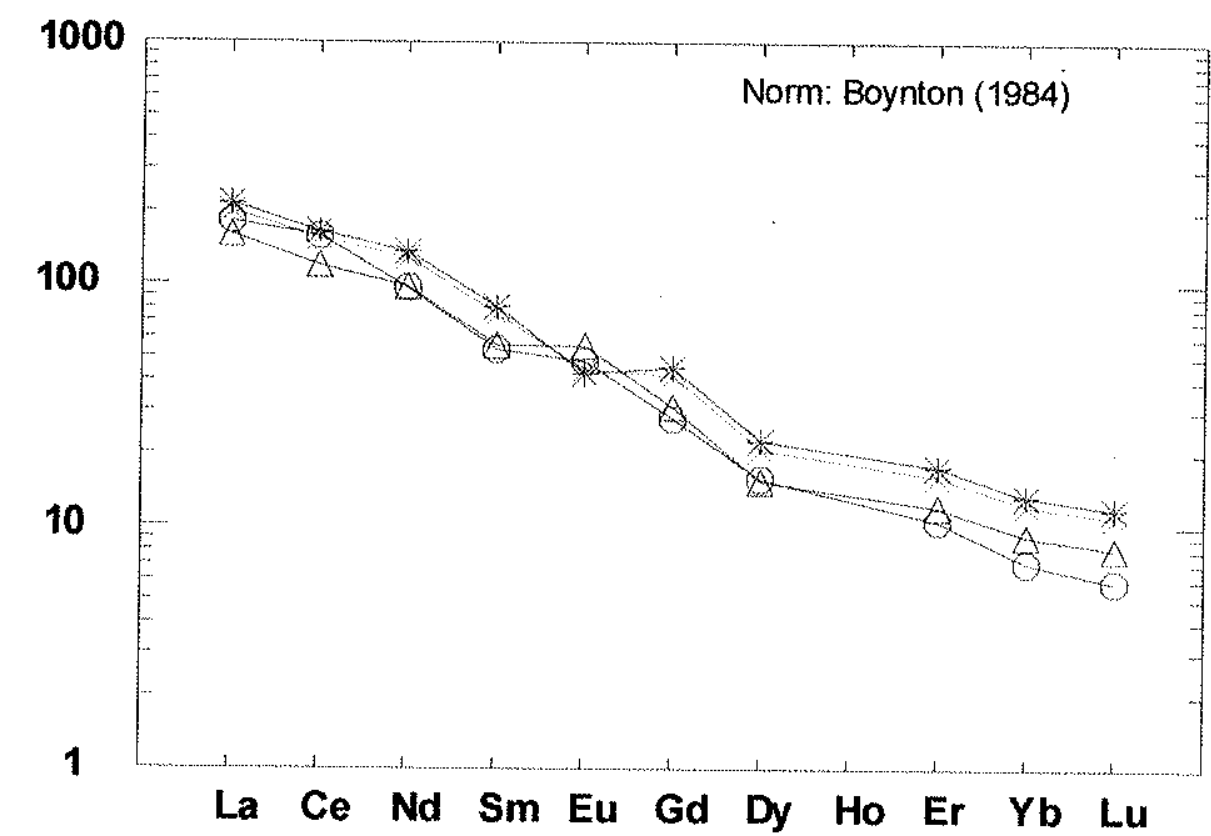

Figura 7.12 - Padrões de elementos terras raras para o fracionamento da amostra VA-249 para a amostra VA-252, usando-se as concentrações de elementos terras raras das amostras MP- 128 e VA-262 para VA-249 e VA-252, respectivamente.

Símbolos: $\triangle$ MP- 128 (VA-249); O VA-262 (VA-2 \$2); X fracionamento de OPX, plagioclásio e ilmenita (Kds para rochas intermediárias); * fracionamento de OPX, plagioclásio, ilmenita e álcali-feldspato (Kds para rochas félsicas).

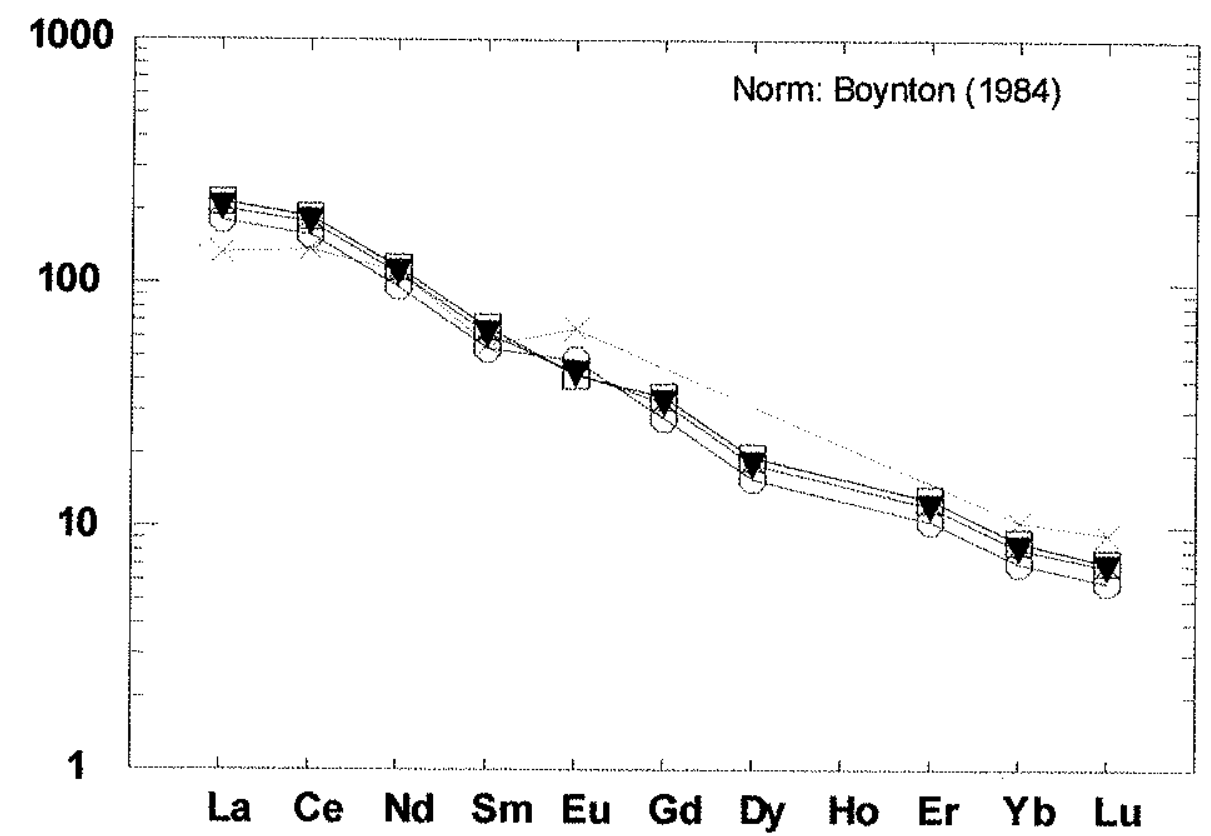

Figura 7.13 - Padrões de elementos terras raras para o fracionamento da amostra VA-252 para a amostra VA-42, usando-se as concentrações de elementos terras raras da amostra VA-262 para VA-252.

Símbolos: O VA-262 (VA-252); X VA-42; fracionamento de OPX, plagiociásio e ilmenita (Kds para rochas intermediárias); 1$]$ fracionamento de OPX, plagioclásio, ilmenita e álcali-feldspato (Kds para rochas félsicas). 


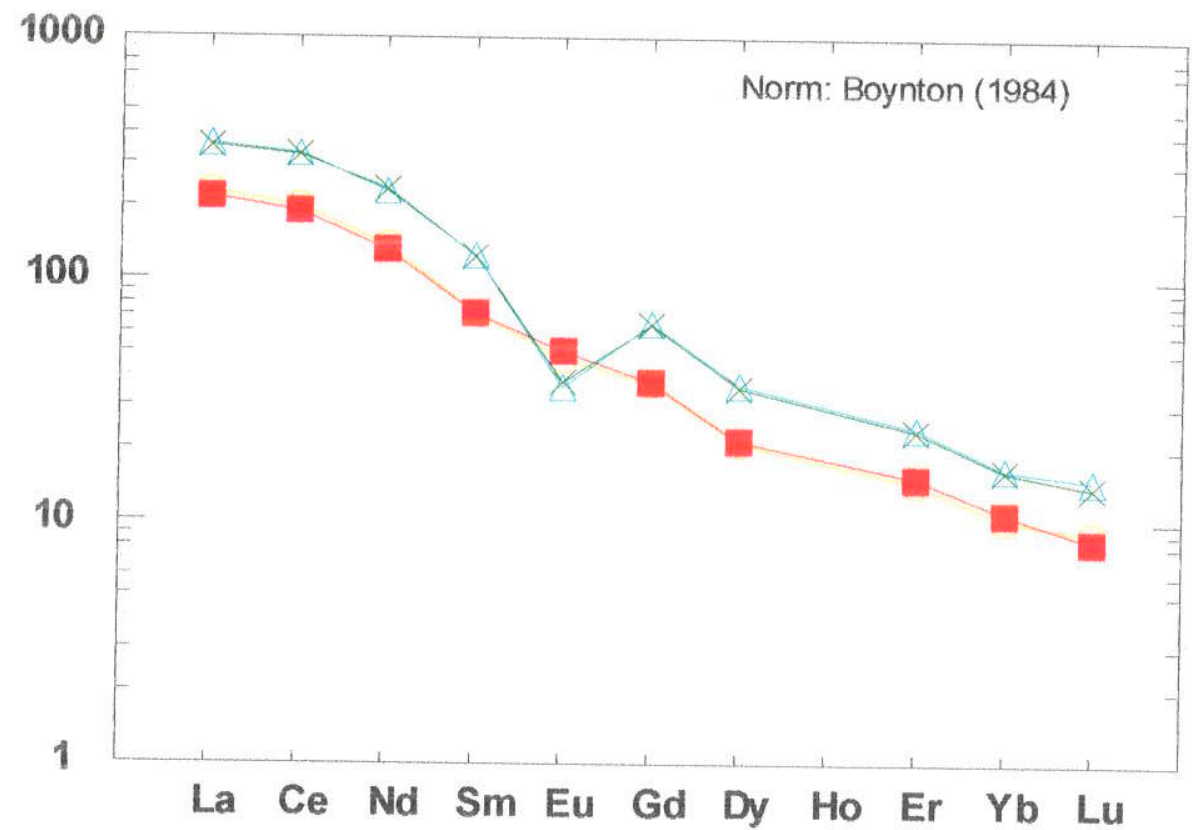

Figura 7.14 - Padrões de elementos terras raras para o fracionamento da amostra VA-261 para a amostra VA-253, usando-se as concentrações de elementos terras raras da amostra VA-264 para a amostra VA-253.

Símbolos: VA-261; VA-264 (VA-253); X fracionamento de OPX, plagioclásio e ilmenita (Kds para rochas intermediárias); $\triangle$ fracionamento de OPX, plagioclásio, ilmenita e álcali-feldspato (Kds para rochas félsicas).

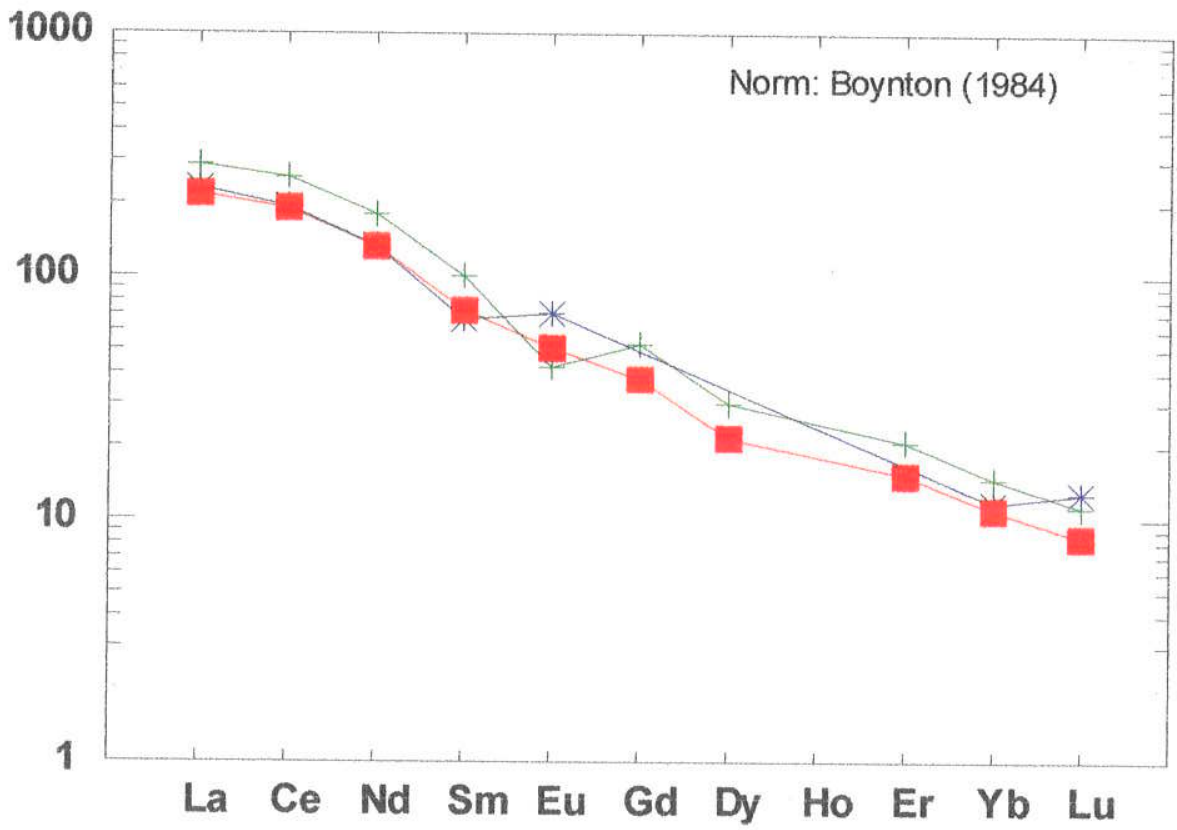

Figura 7.15 - Padrões de elementos terras raras para o fracionamento da amostra VA-253 para a amostra VA-16, usando-se as concentrações de elementos terras raras da amostra VA-264 para a amostra VA-253.

Símbolos: VA-264 (VA-253); *VA-16; + fracionamento de OPX, plagioclásio, ilmenita e álcali-feldspato (Kds para rochas félsicas). 


\section{Considerações a respeito do magma parental}

A geração de magmas Ca-alcalinos/álcali-cálcicos enriquecidos em elementos incompatíveis, como é o exemplo dos charnoquitóides de Várzea Alegre, tem sido comumente associada ao fenômeno de contaminação das rochas da cunha do manto por desidratação ou fusão parcial da placa litosférica subductada, em zonas de subducção de diferentes idades (Pearce, 1983, Wilson, 1991 , McCulloch \& Gamble, 1991). Magmas derivados ou que sofreram contribuição desta porção enriquecida do manto apresentariam portanto uma assinatura geoquímica característica, marcada por teores elevados de elementos incompatíveis, sobretudo os de íon grande (LLLE), acompanhados por relativa deficiência de elementos de alto potencial iônico (HFSE). A ascensão desses magmas previamente enriquecidos através de uma crosta continental espessa (caso da região estudada nesta tese) provocaria diferentes graus de fusão parcial na mesma e, segundo Wilson (op. cit.), a contaminação crustal seria inevitável, com a subsequente evolução geoquímica dos magmas sendo dominada por processos de assimilaçãocristalização fracionada (AFC; De Paolo, 1981).

Como não se dispõe, até o momento, de um volume consistente de dados isotópicos para as rochas do maciço de Várzea Alegre, torna-se dificil avaliar o grau de contaminação crustal presente nas mesmas. No entanto, as razões iniciais ${ }^{87} \mathrm{Sr} /{ }^{86} \mathrm{Sr}$ de 0,708 mencionadas por Siga Jr et al. (1989) para os charnoquitóides de Itarana, e posteriormente confirmadas por S.R. Medeiros e A.C. Fonseca (comunicação verbal) não deixam dúvidas quanto a existência de tal contaminação. A concreta possibilidade da atuação de processos de mistura magmática, discutida no item anterior, pode também ter favorecido o enriquecimento em elementos de íon grande. Por seu turno, os teores moderados a altos de alguns elementos HFS destas rochas ( $\mathrm{Ti}, \mathrm{Zr}, \mathrm{Nb}, \mathrm{Ce}$ e $\mathrm{Y}$ ) não seriam adequados para o ambiente em que elas foram geradas, pois assim ocorre um aumento na esperada baixa relação LILE/HFSE. Rochas ricas em elementos HFS têm sua geração comumente associada a magmatismo intra-placa, sendo tais anomalias portanto uma característica do manto precursor (McCulloch \& Gamble, op. cit.). Pode-se então admitir, a partir destes dados, que houve contribuição de um manto parcialmente enriquecido em elementos HFS, além de elementos LIL, na formação dos litotipos da borda do maciço de Várzea Alegre. Eles são análogos, portanto, aos granitóides álcalicálcicos maduros, de arco magmático, enriquecidos em elementos LIL e HFS e com razões HFS/LILE mais altas (Brown et al., 1984).

Partindo-se da concreta possibilidade de participação de rochas mantélicas na geração dos charnoquitóides de Várzea Alegre, algumas teorias para a formação de magmas intermediários envolvendo fusões mantélicas devem ser destacadas.

A geração de magmas andesíticos diretamente por fusão parcial de peridotitos é muito restrita em função das razões $\mathrm{H}_{2} \mathrm{O} / \mathrm{CO}_{2}$. Fusões anidras resultam em magmas basálticos, enquanto que fusões hidratadas podem resultar em composições intermediárias só sob condições muito especiais; pequenas quantidades de $\mathrm{CO}_{2}$ adicionado pode resultar em composições 
próximas de andesitos, mas quando o conteúdo de $\mathrm{CO}_{2}$ iguala ou excede o de $\mathrm{H}_{2} \mathrm{O}$ o líquido torna-se alcalino (Hall, 1987). Além do que, os baixos conteúdos de $\mathrm{Cr}$ e $\mathrm{Ni}$ dos charnoquitóides de Várzea Alegre não são compatíveis com uma origem direta do manto.

Líquidos intermediários podem se formar a partir de fracionamento de fenocristais de magmas basálticos sob baixas pressões (Gill, 1981) (envolvendo plagioclásio, piroxênio, olivina e magnetita em condições secas, e mais anfibólio na presença de água) ou em altas pressões envolvendo granada e piroxênio. Não deve ter havido extração de granada na formação do magma parental de Várzea Alegre, uma vez que os padrões de ETR das rochas não são muito fracionados e elas não são empobrecidas em terras raras pesadas.

Eichelberger (1978) concluiu, a partir de evidências petrográficas, geoquímicas e petrológicas, que magmas de composição intermediária (andesíticos especificamente) se originam a partir da mistura de líquidos básicos, formados por fusão de material ultramáfico do manto, com líquidos ácidos oriundos de fusão parcial de crosta inferior. Tal mistura é favorecida em zonas de compressão e a formação do magma riolítico é viabilizada pela presença de crosta continental. Segundo ele, o vulcanismo andesítico envolve portanto adição de material na crosta e fracionamento de crosta pré-existente.

$\mathrm{Na}$ literatura encontram-se vários outros modelos para geração de magmas intermediários, como por exemplo a participação de fontes anfibolíticas da crosta inferior, a fusão de crosta oceânica eclogítica ou anfibolítica e a contaminação de magmas basálticos por material crustal ácido.

Portanto, são muitas as possibilidades para a gênese de magmas intermediários. Contudo, tendo em vista as características petrográficas e geoquímicas das rochas da borda do maciço de Várzea Alegre, o modelo abaixo, bastante simplificado, pode ser sugerido para a formação e posterior evolução do magma parental.

Um líquido basáltico, derivado por fusão parcial de manto peridotítico ou piroxenítico enriquecido em elementos incompatíveis, ascendeu até a base da crosta e ficou trapeado ("underplating"). Tal período de permanência crustal possibilitou que o mesmo sofresse fracionamento e desse origem a magmas intermediários, ao mesmo tempo que promovia fusão parcial da crosta inferior. Sob condições anidras e redutoras, e pressões moderadas, ocorreu a cristalização e fracionamento continuado, num resfriamento lento, combinado com mecanismos de mistura magmática desses líquidos básicos/intermediários com líquidos ácidos provindos da fusão crustal. Transformações tardimagmáticas provocaram alguns desequilíbrios químicos: ortopiroxênios foram substituídos por biotitas e anfibólios, exsolvendo magnetita, que por sua vez substitui ilmenita, e plagioclásios foram transformados em feldspatos alcalinos. Provavelmente em meio a este complexo processo houve a formação de cumulatos dominados por feldspatos, possivelmente por "filter pressing" ou por flotação.

Os litotipos hoje aflorantes correspondem a uma amostragem do que resultou desta possível ordem evolutiva, mas deve-se levar em conta que a grande complexidade do 
sistema como um todo não envolve modelos estanques, e aspectos físicos como a dinâmica da câmara magmática combinada a esforços da subida diapírica podem exercer grande influência nos mecanismos de diferenciação de magmas. 


\section{CAPÍtulo 8 \\ CONCLUSÕES}

A formação de rochas com paragênese anidra é na maioria das vezes associada a atuação de metamorfismo de fácies granulito. No entanto, a ocorrência de maciços ígneos charnoquitóides, que se cristalizaram sob condições secas $\left(\mathrm{PCO}_{2}>\mathrm{PH}_{2} \mathrm{O}\right)$, é relatada em vários locais. Wendlandt (1981) considerou que a geração de charnoquitos pode ocorrer por cinco diferentes processos: 1- intrusão de magma subsaturado em água em crosta anidra durante metamorfismo granulítico; 2- anatexia "in situ" durante metamorfismo granulítico; 3charnoquitos são os resíduos após extração de fusões graníticas; 4- charnoquitos são cumulatos separados nos fracionamentos ígneos; 5- metamorfismo granulítico com fase volátil rica em $\mathrm{CO}_{2}$ ocorrendo em altos níveis crustais.

As bordas dos maciços de Venda Nova e Várzea Alegre são típicos exemplos de rochas com características ígneas bem preservadas cristalizadas em condições anidras, exibindo portanto ortopiroxênio, feldspato e quartzo na sua associação mineral primária. Dentre os processos cogitados por Wendlandt (op. cit.), é provável que apenas o quarto deles deva ter exercido um papel importante na geração das rochas estudadas nesta tese.

A porção atualmente aflorante nos maciços de Venda Nova e Várzea Alegre corresponde a raiz dos plutons, tendo em vista o volume de rochas básicas aflorantes, a estruturação interna e a foliação da borda mergulhando para o interior do pluton e as rochas encaixantes de alto grau metamórfico. Será feito, adiante, um apanhado conclusivo dos aspectos abordados neste trabalho para as rochas da borda de ambos os maciços. A tabela 8.1 traz um resumo comparativo com as principais características identificadas nos dois corpos. 
Tabela 8.1 - Comparação entre as rochas da borda dos maciços de Venda Nova e Várzea Alegre

\begin{tabular}{|c|c|c|}
\hline Características & Borda do maciço de Venda Nova & Borda do maciço de Várzea Alegre \\
\hline Área total & cerca de $10 \mathrm{Km}^{2}$ & cerca de $70 \mathrm{Km}^{2}$ \\
\hline Tipos litológicos & $\begin{array}{l}\text { predominam OPX-quartzo-dioritos, } \\
\text { enderbitos e noritos }\end{array}$ & $\begin{array}{l}\text { OPX-qtzo-dioritos, jotunitos, } \\
\text { opdalitos e quartzo-mangeritos }\end{array}$ \\
\hline Forma de ocorrência & $\begin{array}{l}\text { maioria em blocos; afloramentos são } \\
\text { escassos }\end{array}$ & amplos afloramentos; formam serras \\
\hline Foliação das rochas & discreta orientação mineral & é acentuada nos contatos \\
\hline Deformação apresentada & incipiente & $\begin{array}{l}\text { também incipiente, mas é maior que } \\
\text { nas rochas de VN }\end{array}$ \\
\hline Rochas encaixantes & $\begin{array}{l}\text { gnaisses de grau anfibolito a anfibolito } \\
\text { alto }\end{array}$ & $\begin{array}{l}\text { gnaisses de grau anfibolito alto a } \\
\text { granulito }\end{array}$ \\
\hline Granulação e textura & $\begin{array}{l}\text { noritos: finos com textura granular } \\
\text { hipidiomórfica a intergranular; } \\
\text { charnoquitóides: grã média com textura } \\
\text { granular hipidiomórfica }\end{array}$ & $\begin{array}{l}\text { são rochas porfiríticas a } \\
\text { megaporfiríticas, com megacristais de } \\
\text { feldspatos e quartzo; matriz média a } \\
\text { grossa }\end{array}$ \\
\hline $\begin{array}{l}\text { Paragênese essencial } \\
\text { primária }\end{array}$ & $\begin{array}{l}\text { feldspatos, ilmenita, quartzo, OPX, CPX } \\
\text { (biotita/anfibolio?) }\end{array}$ & $\begin{array}{l}\text { feldspatos, OPX, ilmenita e quartzo } \\
\text { (biotita?) }\end{array}$ \\
\hline Paragênese secundária & $\begin{array}{l}\text { biotita, anfibólio e magnetita que } \\
\text { substituem piroxênios e ilmenita }\end{array}$ & ídem \\
\hline $\begin{array}{l}\text { Composição dos minerais } \\
\text { máficos }\end{array}$ & $\begin{array}{l}\text { possuem Mg\# superiores aos dos } \\
\text { minerais de VA; nos noritos eles têm } \\
\text { maiores teores de Fe. Biotitas com altos } \\
\text { teores de Ti }\end{array}$ & $\begin{array}{l}\text { são ricos em } \mathrm{Fe} \text {; OPX chegam a } \\
\text { atingir Fs } 67 \text {. Biotitas com altos teores } \\
\text { de Ti e anfibólios com maiores } \\
\text { conteúdos de Al que VN }\end{array}$ \\
\hline $\begin{array}{l}\text { Quimismo dos litotipos } \\
\text { internos }\end{array}$ & rochas com tendência alcalina & cálcio-alcalino \\
\hline Assinatura química & $\begin{array}{l}\text { noritos: toleítica; charnoquitóides: } \mathrm{Ca}- \\
\text { alcalina. Ricas em } \mathrm{Ca}, \mathrm{Fe} \text { e } \mathrm{Al} \text {; }\end{array}$ & $\begin{array}{l}\text { cálcio alcalina de alto } \mathrm{K} / a ́ l c a l i \text {-cálcica. } \\
\text { Ricas em } \mathrm{K}, \mathrm{Ba}, \mathrm{Zr} \text { e Fe; } \\
\end{array}$ \\
\hline Conteúdos de LILE & $\begin{array}{l}\text { moderados a baixos teores; anomalia } \\
\text { positiva de Ba e negativa de K }\end{array}$ & $\begin{array}{l}\text { altos teores; anomalias positivas de } \\
\text { Ba e K }\end{array}$ \\
\hline Conteúdos de HFSE & $\begin{array}{l}\text { baixos; anomalias negativas de } \mathrm{Ti}, \mathrm{Pe} \\
\mathrm{Nb}\end{array}$ & $\begin{array}{l}\text { moderados a altos; anomalia positiva } \\
\text { de } \mathrm{Zr} \text { e negativa de Ti e P }\end{array}$ \\
\hline Padrões de ETR & $\begin{array}{l}\text { moderadamente fracionados, com } \\
\text { discretas anomalias negativas de } \mathrm{Eu}\end{array}$ & $\begin{array}{l}\text { bem fracionados, com discretas } \\
\text { anomalias positivas de } \mathrm{Eu}\end{array}$ \\
\hline Acumulação de cristais & os noritos são rochas cumuláticas & provável acumulação de feldspato \\
\hline Condiçốes de cristalizaçấo & $\begin{array}{l}\text { Anidras e redutoras. } \mathrm{T} \text { : cerca de } 920^{\circ} \mathrm{C} \\
\text { para os noritos e } 970^{\circ} \mathrm{C} \text { para os } \\
\text { charnoquitóides; } \mathrm{P}: 5,5 \mathrm{a} 6 \mathrm{~Kb} \text {. }\end{array}$ & $\begin{array}{l}\text { Anidras e fortemente redutoras } \\
\text { T: cerca de } 950^{\circ} \mathrm{C} ; \mathrm{P}: 6,5 \text { a } 7 \mathrm{~Kb} \text {. }\end{array}$ \\
\hline Temperaturas subsolidus & aproximadamente $600^{\circ} \mathrm{C}$ & entre $550^{\circ} \mathrm{C} \mathrm{e} 630^{\circ} \mathrm{C}$ \\
\hline $\begin{array}{l}\text { Mecanismos de } \\
\text { diferenciação }\end{array}$ & $\begin{array}{l}\text { forte predomínio de cristalização } \\
\text { fracionada de basalto Ca-alcalino } \\
\text { controlada por plagioclásio, OPX, CPX e } \\
\text { ilmenita. Noritos são cumulatos do } \\
\text { mesmo basalto ou de um toleítico }\end{array}$ & $\begin{array}{l}\text { cristalização fracionada (extração de } \\
\text { plag, OPX, ilme e falc) de magma } \\
\text { intermediário, combinada a processos } \\
\text { de mistura de magmas }\end{array}$ \\
\hline Ambiente tectônico & $\begin{array}{l}\text { transpressivo; granitóides de arco } \\
\text { magmático } \\
\end{array}$ & ídern \\
\hline Contribuição mantélica & manto normal ou empobrecido & manto enriquecido \\
\hline
\end{tabular}




\subsection{MACIÇO DE VENDA NOVA}

O maciço intrusivo de Venda Nova, de idade Brasiliana, situa-se na região centrosul do Estado do Espírito Santo, exibindo forma circunscrita e tendo como rochas encaixantes gnaisses orto e paraderivados de grau metamórfico anfibolito a anfibolito alto. $\mathrm{Na}$ sua porção mais interna encontram-se gabros e monzogabros que estão totalmente envolvidos por um significativo volume de sienomonzonitos e monzonitos. Um estreito e irregular anel de rochas noríticas e charnoquitóides circunda todo o conjunto nos seus bordos oeste, sul e sudeste. Pequenos stocks graníticos foram delimitados em diferentes pontos do corpo intrusivo, além dos granitos aparecerem como diques e veios cortando os demais litotipos. $\mathrm{Na}$ região de contato entre os gabros e os sienomonzonitos desenvolveu-se uma zona mista, com estruturas tipo "pillow", onde os dois litotipos se interagem e mostram relações que sugerem um provável intrusionamento simultâneo. Localmente também são observadas discretas zonas de interação entre rochas enderbíticas e sieníticas, onde pequenas porções de sienomonzonito porfirítico estão irregularmente associadas com o material enderbítico, como veios sin-intrusivos ou estruturas tipo "schlieren".

São bastante escassos os afloramentos dos noritos e dos charnoquitóides, sendo estas rochas encontradas principalmente na forma de blocos de tamanhos variados. Quando afloram, o fazem em pequenos lajedos nas encostas. São rochas de estrutura maciça e homogênea, mas localmente possuem foliação de fluxo mais desenvolvida; nos charnoquitóides ocorrem discretas zonas de cisalhamento dúctil, associadas a penetração de veios e diques pegmatóides. Quando mostram orientação, a direção da foliação é paralela aos contatos com as rochas encaixantes e com os domínios internos. Além disto, exibem enclaves microgranulares básicos arredondados e lenticulares, posicionados paralelamente ou fazendo pequenos ângulos com a foliação. Nos charnoquitóides são vistos também veios máficos sin-intrusivos, possivelmente de noritos, o que sugere um posicionamento simultâneo para os dois conj untos.

Os noritos correspondem a rochas cumuláticas que possuem granulação fina e exibem texturas que variam de hipidiomórfica granular a intergranular, sendo isoladamente microporfiríticos. Os microfenocristais de plagioclásio possuem bordas corroídas e os minerais máficos se associam normalmente em glomérulos. Classificam-se em hornblenda-noritos e hornblenda-CPX-noritos e sua mineralogia é plagioclásio (An54 a An85), anfibólio (Mghornblenda, Mg-hornblenda hastingsítica e Fe-hornblenda pargasítica), OPX (Wo0,81 a Wo2,37, 
En50,57 a En59,58 e Fs39, 16 a Fs47,63), CPX (Wo44, 12 a Wo48,97, En34,44 a En39,34 e Fs 14,60 a Fs 19,26), ilmenita, magnetita, apatita, zircão e rara biotita. O anfibólio e a magnetita são predominantemente secundários e a orientação da rocha, quando presente, é conferida pelos minerais máficos e pelos microfenocristais de plagioclásio.

Os charnoquitóides são modalmente classificados em enderbitos, OPX-quartzodioritos, opdalitos e jotunitos. São rochas de granulação média, leucocráticas a mesocráticas e que possuem textura granular/inequigranular hipidiomórfica a porfirítica, com megacristais de plagioclásio e raros de piroxênio e quartzo com até $1 \mathrm{~cm}$ de tamanho. Compõem mse de plagioclásio (An30 a An45), quartzo, biotita, OPX (Wo 1,17 a Wo3,28, En58,94 a En64,62 e Fs33,34 a Fs39,62), CPX (Wo44,07 a Wo48, 15, En29, 11 a En40,53 e Fs 12,93 a Fs24,48), anfibólio (Mg-hornblenda/Mg-hornblenda hastingsítica e Fe-hornblenda pargasítica), feldspato alcalino, ilmenita, magnetita, pirita, apatita e zircão, estes últimos principalmente na forma de inclusões nos outros minerais. Os megacristais de plagioclásio não possuem diferenças na composição com relação aos cristais da matriz. São freqüentes os glomérulos máficos com apatita associada. Vários cristais de plagioclásio possuem intercrescimento de uma fase incolor, que é provavelmente álcali-feldspato.

Zoneamentos mais significativos foram detectados nos plagioclásios dos noritos (núcleos An77 e An70 e bordos An54 e An63 respectivamente), mas também ocorrem nos charnoquitóides (núcleos An39 e An45 e bordo An30 e An39).

Texturas de instabilidade mineral geradas em estado subsolidus foram identificadas nos noritos e nos charnoquitóides. Os piroxênios são substituídos por anfibólios e biotitas, exsolvendo minerais opacos, e magnetita substitui ilmenita e piroxênios. Discreta recristalização da matriz (sobretudo dos plagioclásios), extinção ondulante em quartzo e lamelas de geminação de plagioclásio e traços de clivagem de biotita recurvadas são feições de deformação incipiente no estado dúctil observadas.

Os piroxênios dos noritos e dos charnoquitóides exibem íntima relação e alguns pares coexistentes analisados por microssonda evidenciam cristalização em equilíbrio no diagrama Wo-En-Fs. Os $\mathrm{KdsMg-Fe} \mathrm{fornecem} \mathrm{valores} \mathrm{típicos} \mathrm{de} \mathrm{piroxênios} \mathrm{ígneos} \mathrm{para} \mathrm{os}$ charnoquitóides e de piroxênios metamórficos para os noritos e para a amostra VN-27. Os baixos $\mathrm{Kds}$ dos noritos se justificam pela sua origem cumulática, que pode causar desequilibrios nas trocas químicas, enquanto na amostra VN-27 eles devem refletir reequilibrios químicos posteriores. 
Os Mg\# dos minerais máficos dos noritos são inferiores aos dos charnoquitóides, ao contrário dos valores obtidos para as rochas, que mostram Mg\# na mesma ordem de grandeza para as duas seqüências, apesar deles serem bem menores que os dos minerais.

As análises dos anfibólios e biotitas não apontaram expressivas variações composicionais, dificultando assim a identificação de possíveis cristais primários. Os $\mathrm{KdsF}$ e-Mg para esses minerais forneceram valores próximos de 1 , indicando cristalização em equilíbrio. Apenas a amostra VN-27 apresenta composições um pouco diferente, mais rica em Fe, mas esta amostra possui também piroxênios com menores $\mathrm{Mg \# ,} \mathrm{refletindo} \mathrm{provavelmente} \mathrm{reequilibrios}$ posteriores.

Os anfibólios mostram correlação positiva entre $\mathrm{Al}($ total), $\mathrm{Al}$ iv e Alvi, o mesmo se dando com a ocupação do sítio A. Maiores teores de Al(total) implicam em Mg\# menores, o que significa que os anfibólios dos noritos tendem a apresentar maiores conteúdos de Al. As biotitas são muito ricas em Ti (até 0,7 átomos/fórmula), seus conteúdos de Ti e Fe aumentam consideravelmente com pequenos acréscimos do Alvi e seus teores de $\mathrm{F}$ e $\mathrm{Cl}$ são insignificantes. Suas composições são intermediárias entre os membros finnais annita e flogopita, que, da mesma forma que a composição dos anfibólios, são típicas de granitóides Ca-alcalinos.

A utilização do geotermômetro OPX-CPX forneceu temperaturas da ordem de $915 \pm 25^{\circ} \mathrm{C}$ para os noritos e de $967 \pm 50^{\circ} \mathrm{C}$ para os charnoquitóides, calculadas pelo "software" QUILF, e de $908^{\circ} \mathrm{C}$ para os noritos e $958^{\circ} \mathrm{C}$ para os charnoquitóides através do método desenvolvido por Wood \& Banno. Portanto, o magma se encontrava em altas temperaturas quando da cristalização dos primeiros minerais dessas rochas.

As prováveis temperaturas de reequilíbrio subsolidus foram calculadas por meio do par ilmenita-magnetita, também com o "software" QULLF. Os valores obtidos foram em torno de $600^{\circ} \mathrm{C}$ e o $\log \mathrm{O}_{2}$ calculado foi da ordem de -19 atm, abaixo do tampão FMQ para iguais condições de $\mathrm{P}$ e $\mathrm{T}$. Valores desta ordem são compatíveis com um ambiente redutor quando da geração dessas rochas, como pode-se inferir pelas baixas proporções de molécula de hematita em solução sólida com ilmenita, contrastando com o Mg\# relativamente alto dos minerais máficos que as constituem.

Por meio de geobarômetros baseados nas variações do teor de Al em anfibólios, as pressões obtidas para o final da cristalização das rochas da borda do maciço de Venda Nova se situam em torno de 5,5 a $6 \mathrm{~Kb}$, inferiores às pressões calculadas para o metamorfismo dos gnaisses regionais, de cerca de $8 \mathrm{~Kb}$. 
A química de rocha total separa duas seqüências: uma básica, com características toleí́ticas, que corresponde aos cumulatos noríticos e outra intermediária, Ca-alcalina de médio $\mathrm{K}$, compreendendo os charnoquitóides. Diferem completamente do quimismo apresentado pelas rochas da porção interna do maciço de Venda Nova, que possem tendência alcalina.

$\mathrm{Na}$ maioria dos diagramas classificatórios utilizados a classificação química das rochas mostrou uma boa correlação com a classificação modal adotada.

Apesar de estarem nitidamente separadas em quase todos os diagramas discriminantes, as duas seqüências apresentam características gerais similares: caráter metaluminoso, enriquecimento em $\mathrm{Ca}, \mathrm{Fe}$ e $\mathrm{Al}$ e valores moderados a baixos de elementos incompatíveis, $\mathrm{Mg \#} \mathrm{com} \mathrm{a} \mathrm{mesma} \mathrm{ordem} \mathrm{de} \mathrm{grandeza} \mathrm{(excetuando} \mathrm{as} \mathrm{amostras} \mathrm{mais} \mathrm{ácidas} \mathrm{dos}$ charnoquitóides) e semelhança nos padrões de terras raras. Os seus teores de elementos incompatíveis as diferenciam dos vários corpos intrusivos estudados no Espírito Santo, identificando-se algumas similaridades com as rochas intrusivas do maciço Bela Joana, no norte do Rio de Janeiro, como também com gnaisses charnoquíticos do norte da China.

A norma dos charnoquitóides reflete também um comportamento Ca-alcalino para a seqüência: são rochas supersaturadas em sílica, com hiperstênio normativo que diminui com o aumento do índice de diferenciação e que contêm raríssimo corindon normativo. Os noritos concentram-se no diagrama AFM junto ao lado FM do triângulo, com maior enriquecimento em $\mathrm{Fe}$, mas não possuem composições que evoluem para termos extremos ricos em Mg ou em álcalis, não delineando um "trend" típico.

Os teores de elementos terras raras das duas seqüências são moderados e os padrões são pouco fracionados. As rochas charnoquitóides possuem conteúdos um pouco mais elevados de ETRL. Os teores de Eu tendem a diminuir com a diferenciação.

Os "spidergrams" das duas seqüências revelam um relativo enriquecimento em $\mathrm{Ba}$ e acentuadas anomalias negativas de $\mathrm{Nb}, \mathrm{P}$ e $\mathrm{Ti}$ nos charnoquitóides e de $\mathrm{K}$ e $\mathrm{Zr}$ nos noritos, que também exibem discretas anomalias negativas de $\mathrm{Nb}$ e $\mathrm{Ti}$. A presença de tais anomalias de elementos HFS ( $\mathrm{Nb}, \mathrm{P}$, Ti e $\mathrm{Zr}$ ) comprovam que a origem das rochas está associada a processos de subduccão, como tem sido apontado por vários autores. Diagramas de discriminação tectônica confirmam uma formação vinculada ao desenvolvimento de arco magmático, num estágio tardi a pós-orogênico.

Nos diagramas de variação convencionais observa-se que as amostras dos charnoquitóides exibem uma tendência linear, para a maioria dos óxidos e elementos traços. Os 
noritos concentram-se em tais gráficos no extremo dos "trends" traçados, exceto nos diagramas $\mathrm{SiO}_{2} \times \mathrm{Sr}$ e Ni, sugerindo que eles podem ser cumulatos do líquido que evoluiu para os litotipos da seqüência Ca-alcalina.

Os "trends" sugerem que as rochas charnoquitóides formaram-se a partir de cristalização fracionada controlada por plagioclásio, OPX, CPX e ilmenita, de um magma básico/intermediário com 50 a $52 \% \mathrm{SiO}_{2}$. Os modelamentos para elementos maiores e traços ( $\mathrm{ETR}, \mathrm{Rb}, \mathrm{Ba}, \mathrm{Sr}, \mathrm{Ni}$ e V) efetuados forneceram resultados que são coerentes, como um todo, com esta hipótese. Não parece provável ter havido contribuição significativa de mistura de magmas na evolução das rochas. A possibilidade de origem direta por fusão parcial (de crosta inferior ou de manto) é remota e dificilmente explicada se os noritos forem cumulatos do mesmo magma parental. Quanto a eles, uma outra possibilidade seria corresponderem a cumulatos de um magma basáltico de afinidade toleíitica.

Uma plausível evolução teórica para os charnoquitóides de Venda Nova é então sugerida: as rochas formaram-se a partir da cristalização fracionada de um magma basáltico cálcio-alcalino trapeado na base da crosta, em condições anidras e redutoras e sob pressões moderadas. As principais fases fracionadas foram, em ordem decrescente de proporção, plagioclásio, OPX, CPX e ilmenita. Ao mesmo tempo ocorreu fusão parcial da crosta inferior, induzida pelo calor do magma básico, o que pode ter adicionado algum outro componente ao sistema (incipiente mistura de magmas?). Este magma derivou-se de uma porção do manto que não sofreu um acentuado enriquecimento prévio em elementos incompatíveis (manto normal ou empobrecido). Granada deve ter sido fase residual quando da fusão parcial desta fonte mantélica, em função dos teores relativamente baixos de ETRP das rochas da borda do maciço de Venda Nova.

\subsection{MACIÇO DE VÁRZEA ALEGRE}

O maciço intrusivo de Várzea Alegre, situado na porção central do Espírito Santo, corresponde a um corpo diapírico tardi a pós-tectônico, inversamente zonado, com gabros no centro topograficamente arrasado, envolvidos por rochas dioríticas/quartzo-dioríticasmonzodioríticas e granitos megaporfiríticos. Granito a titanita ocorre como um pequeno stock próximo dos gabros e também na forma de diques que cortam os demais litotipos. Todo este conj unto é circundado por uma extensa e irregular auréola de rochas charnoquitóides, que estão 
representadas num grande número de afloramentos. Enquanto nos bordos sul e oeste esse anel é estreito, com algumas centenas de metros, a leste e a norte ele chega a ter até quase $4 \mathrm{Km}$ de largura, formando serras de cotas elevadas com amplos laj edos e encostas. Essas rochas estão encaixadas em orto e paragnaisses metamorfoseados no fácies anfibolito alto a granulito.

Uma característica marcante das rochas do domínio central é a intensa mistura mecânica entre os dioritos e gabros e os granitos megaporfiríticos, originando grandes estruturas em rede onde se observa toda a sorte de feições típicas de mistura de magmas, além de litotipos com composições intermediárias (quartzo-dioritos e quartzo-monzodioritos).

Os charnoquitóides são rochas megaporfiríticas, de cor verde escura, que exibem foliação bem desenvolvida próximo aos contatos e uma estrutura maciça quando distante dos mesmos. Via de regra as foliaçôes nas bordas e nas rochas encaixantes mergulham para dentro do corpo. Quando afloram, os contatos com os gnaisses são bruscos e paralelos à foliação, enquanto que com os litotipos do domínio interno eles são normalmente interdigitados, associados com discreta a intensa interação mecânica entre as rochas.

Apesar de aparentarem grande homogeneidade, eles exibem heterogeneidades tais como: variação na quantidade de megacristais, às vezes num mesmo afloramento; presença de diques de provável composição diorítica (raramente granítica) e de enclaves microgranulares básicos com ou sem xenocristais de feldspato; veios pegmatóides que provocam descharnoquitização localizada e xenólitos das rochas encaixantes variavelmente assimilados, sobrando às vezes restitos contendo granada.

A composição mineralógica dos charnoquitóides é: plagiclásio (An32 a An40), ortoclásio pertítico/mesopertita, OPX (Wo1,57 a Wo2,49, En30,42 a En41,18 e Fs56,99 a Fs67,43), biotita, anfibólio (hornblenda pargasítica e Mg-hastingsita), ilmenita, magnetita, pirita, apatita, zircão e rara allanita. A textura é porfirítica, com megacristais de feldspato alcalino, plagioclásio e quartzo, que podem atingir até $6 \mathrm{~cm}$ de tamanho e a matriz tem granulação média a grossa, e quando está apertada entre os megacristais é mais fina e parcialmente recristalizada. Efeitos de deformação incipiente no estado dúctil são também observados em grãos de quartzo e feldspato com extinção ondulante e nas lamelas de geminação de plagioclásio e traços do plano de clivagem de biotita recurvados.

Os cristais de OPX encontram-se parcialmente substituídos por biotita, anfibólio e minerais opacos e alteram-se freqüentemente para clorita e um material de cor ocre. Biotitas e anfibólios primários podem ocorrer, sendo quimicamente possível a existência de biotita 
cristalizada precocemente. Entretanto, a análise por microssonda não detectou variações nas suas composições e os $\mathrm{KdsF}$ e-Mg para essas fases resultam em valores próximos de 1 , indicando equilíbrio entre elas. São observados cristais de feldspato alcalino substituindo plagioclásio e consideráveis variações nas concentrações de lamelas pertíticas. Muitos cristais de plagioclásio exibem intercrescimento de mineral incolor, provavelmente álcali-feldspato. Apatita e zircão ocorrem tanto como inclusð̃es nos outros minerais quanto como grãos isolados ou associados aos minerais máficos. Observamse um predomínio de ilmenita com relação a magnetita; elas se apresentam intercrescidas ou a magnetita substitui a ilmenita, evidenciando seu caráter secundário.

Os OPX são bem ricos em Fe, apresentando pequena variação na sua composição, mas possuindo $\mathrm{Mg \#} \mathrm{superior} \mathrm{aos} \mathrm{das} \mathrm{rochas} \mathrm{que} \mathrm{os} \mathrm{contém,} \mathrm{o} \mathrm{que} \mathrm{também} \mathrm{foi} \mathrm{constatado} \mathrm{para} \mathrm{os}$ anfibólios e biotitas. Ocorre pequena variação nos teores de Al(total) dos anfíbólios; os conteúdos de Alvi exibem correlação positiva com o Ti e com a ocupação do sítio A. As biotitas possuem altas concentrações de Ti (de 0,63 a 0,73 átomos/fórmula), que por sua vez são inversamente proporcionais ao Mg\# ; os álcalis tendem a aumentar com maiores concentrações de $\mathrm{Al}($ total) e os conteúdos de $\mathrm{Ba}$ são relativamente altos. As composições das biotitas se aproximam do membro extremo annita.

Não ocorre grande diferença composicional entre os plagioclásios e feldspatos alcalinos megacristais e da matriz, não existindo também zoneamentos significativos. A molécula Or nos plagioclásios não ultrapassa $4,3 \%$, enquanto que os feldspatos alcalinos possuem considerável variação da molécula $\mathrm{Ab}$ (composições variando entre Or89 a Or68), o que está relacionado às desiguais concentrações de lamelas pertíticas. Por outro lado, os teores de Ba são altos, alcançando até 0,17 átomos/fórmula (4,2\% do componente celsiana).

Estimativas da temperatura de cristalização do magma através da saturação de $\mathrm{Zr}$ e $\mathrm{P}_{2} \mathrm{O}_{5}$ resultou em valores da ordem de $950^{\circ} \mathrm{C}$. No entanto, a provável existência de rochas cumuláticas pode limitar a confiabilidade do método, apesar de temperaturas desta ordem serem compatíveis com as características químico/mineralógicas das rochas estudadas.

Foram calculadas temperaturas de reequilibro subsolidus através dos termômetros ilmenita-magnetita e plagioclásio-feldspato alcalino. Os valores obtidos foram de $543 \pm 45^{\circ} \mathrm{C}$ para o primeiro par e de $630^{\circ} \mathrm{C}$ para os feldspatos. Fica claro, portanto, que os feldspatos se reequilibraram quando do resfriamento do magma, e algumas texturas de substituição de plagioclásio por álcali-feldspato observadas podem estar associadas a esse fenômeno. 
A presença de baixas proporções de molécula de hematita em solução sólida com ilmenita indicam condições redutoras na cristalização do magma. $\mathrm{O}$ cálculo do $\log \mathrm{fO}_{2}$ através do par ilmenita-magnetita resultou num valor de $-21,5 \pm 1,25 \mathrm{~atm}$, abaixo dos valores calculados para o tampão FMQ nas mesmas condições de $P$ e $T$, o que confirma que as rochas se formaram num ambiente fortemente redutor. Os baixos $\mathrm{Mg} \#$ das rochas corroboram com tal conclusão.

O cálculo das pressões de consolidação das rochas da borda de Várzea Alegre, através dos teores de $\mathrm{Al}$ nos anfibólios, resultou em valores de 6,5 a $7 \mathrm{~Kb}$, contrastando com estimativas para os gnaisses encaixantes de valores superiores a $8 \mathrm{~Kb}$.

A análise química de rocha total possibilitou classificar os charnoquitóides de Várzea Alegre em OPX-quartzo-dioritos, opdalitos, jotunitos e quartzo-mangeritos, uma vez que a análise modal não apresentou resultados satisfatórios, em função do tamanho dos megacristais.

São rochas ricas em elementos incompatíveis, inclusive terras raras e elementos HFS, como Nb e Zr. Os padrões de ETR são bem fracionados e exibem pequenas anomalias positivas de Eu. Não se verifica uma relação direta dos teores de Eu com a diferenciação, o que pode ser um reflexo da acumulação de cristais de plagioclásio.

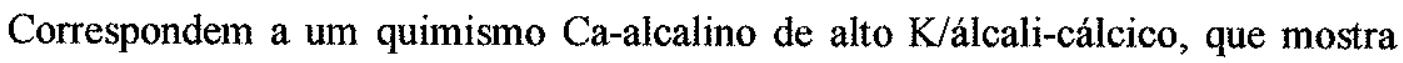
semelhanças tanto com as rochas da série cálcio-alcalina normal quanto com as da série Caalcalina de alto $\mathrm{K} /$ alcalinas definidas por Wiedemann (1993) para o Espírito Santo. Apesar de apresentarem similaridades com rochas da suíte mangerítica, aí não se incluem devido a seus maiores teores de $\mathrm{Ca}$ e $\mathrm{Sr}$ e menores de $\mathrm{K}$ e $\mathrm{Rb}$ e $\mathrm{Mg \#} \mathrm{um} \mathrm{pouco} \mathrm{superiores.}$

Com relação aos litotipos do domínio interno, cujas rochas possuem uma assinatura química tipicamente Ca-alcalina, a geoquímica dos charnoquitóides se assemelha com os granitos a titanita, enquanto que os padrões de ETR são similares aos dos gabros e dioritos. A investigação de um possível parentesco entre as rochas charnoquitóides e aquelas do domínio interno só poderá ser realizada a contento com um maior volume de dados analíticos para as últimas, aliado a dados isotópicos, o que está sendo conduzido por Medeiros (em preparação) na sua tese de doutoramento.

Os litotipos da borda do maciço de Várzea Alegre são metaluminosos, super saturados em sílica e com consideráveis conteúdos de anortita normativa, sugerindo afinidade Ca-alcalina, o que é contrariado pelo comportamento aleatório do diopsídio e do hiperstênio normativos com relação a diferenciação. $O$ aranhograma dessas rochas evidencia o enriquecimento em LILE e $\mathrm{Zr}$, ao mesmo tempo que apresenta as típicas anomalias negativas de 
Ti e P (componentes de subducção). Pode-se concluir que elas possuem comportamento geoquímico compatível com granitóides álcali-cálcicos maduros, de arco magmático, enriquecidos em Fe, elementos LIL e HFS e com razões HFS/LILE mais altas.

$\mathrm{Na}$ busca do(s) processo(s) responsável(is) pela diversidade litológica encontrada, os diagramas de variação convencionais não forneceram resultados satisfatórios para as rochas charnoquitóides de Várzea Alegre. A partir deles foi possível apenas identificar algumas amostras que devem corresponder a cumulatos e verificar que ocorre uma boa correlação de quase todos os óxidos e elementos com a sílica.

Em função disto, foram utilizados gráficos correlacionando-se elementos compatíveis versus elementos incompatíveis, e através deles foi possível separar dois conjuntos de amostras que evoluíram por processos diferentes, a partir de um mesmo magma parental de composição química intermediária. Para um desses conjuntos predominaram mecanismos de cristalização fracionada e para o outro a mistura de magmas deve ter sido preponderante (grupos 1 e 2 , respectivamente).

Os modelamentos para cristalização fracionada efetuados para testar o modelo acima, usando-se óxidos de elementos maiores e elementos traços (ETR, $\mathrm{Rb}, \mathrm{Ba}, \mathrm{Sr}, \mathrm{Zr}$ e V), forneceram resultados mais coerentes para as amostras do grupo 1 e menos coerentes para o grupo 2, corroborando portanto com a hipótese de origem dominada por mistura de magmas para as rochas do último grupo.

A seguinte evolução é então proposta para as rochas da borda do maciço de Várzea Alegre: um magma basáltico proveniente da fusão parcial de um manto enriquecido ascendeu até a base da crosta e sofreu "underplating". Foi fracionado, gerando líquidos intermediários, e o seu calor possibilitou a fusão parcial da crosta inferior sobrẹjacente. Sob altas temperaturas, condições anidras e redutoras, e pressões moderadas, ocorreu a cristalização e fracionamento continuado, num resfriamento lento, combinado com mecanismos de mistura magmática desses líquidos básicos/intermediários com líquidos ácidos provindos da fusão crustal. Transformações tardimagmáticas provocaram desequilíbrios químicos e originaram uma paragênese secundária. 


\section{REFERÊNCIAS BIBLIOGRÁFICAS}

ABREU, S.F. 1943. Feições morfológicas e demográficas do litoral do Espírito Santo. Rev. Bras. Geogr., 5 (2): 215-234.

ALLEN, P.; CONDIE, K. NARAYANA, B.L. 1985. The geochemistry of prograde and retrograde charnockite-gneiss reaction in southern India. Geoch. and Cosmoch. Acta, 49: 326-336.

ALMEIDA, F.F.M. 1967. Origem e evolução da plataforma brasileira. DNPM/DGM, Rio de Janeiro. Boletim 241,36p.

ALMEIDA, F.F.M; AMARAL, G.; CORDANI, U.G. \& KAWASHITA, K. 1973. The precambrian evolution of the south american cratonic margin, south of the Amazon river. In: A.E.M. Nair and F.G. Stehll (eds.), The ocean basins and margins. New York, Plenum Publ. Co., v. 1: 411-446.

ANDERSEN, D.; LINDSLEY, D.H. \& DAVIDSON, P.M. 1993. QUILF: A PASCAL program to assess equilibria among Fe-Mg-Ti oxides, pyroxenes, olivine and quartz. Computers \& Geosciences, 19 (9): 1333-1350.

BARBEY, P. \& CUNEY, M. 1982. K, Rb, Sr, U and Th geochemistry of the Lapland granulites (Fennoscandia). LILE fractionation controlling factors. Contrib. Mineral. Petrol., 81: 304316.

BARBOSA, A. L. \& GROSSI SAD, J. H. 1983. Reinterpretação das "Séries" Juiz de Fora e Paraiba, em Minas Gerais e Rio de Janeiro. In: $2^{\circ}$ Simp. Geol. Minas Gerais. Anais...:1-15.

BATISTA, J. J. 1984. Caracterização dos processos geológicos-evolutivos do Pré-Cambriano da região de São Fidélis, norte do Estado do Rio de Janeiro. Tese de Doutoramento, IG/USP, $123 \mathrm{p}$.

BATCHELOR, R.A. \& BOWDEN, P. 1985. Petrogenetic interpretations of granitoid rocks series using multicationic parameters. Chemical Geology, 48: 43-55.

BAYER, P. 1987. Strukturgeologische Untersuchungen im brasilianischen Küsten Mobile Belt, südliches Espírito Santo, unter besorender Berücksichtigung der Brasiliano Intrusionen. Münchener Geologische Hefte, B/2, 144p. München.

BAYER, P.; HORN, H.; LAMMERER,B.; SCHMIDT-THOME, R.; WEBER-DIEFENBACH,K.; WIEDEMANN, C. 1986. The Brasiliano Mobile Belt in Southern Espírito Santo (Brazil) and Its Igneous Intrusions. Zbl.Geol.Paleont., I, 9/ 10: 1429-1439.

BEST, M.G. 1982. Igneous and metamorphic petrology. W.H. Freeman and Company, New York. 630p.

BHATTACHARYYA, C. 1971. An evaluation of the chemical distinctions between igneous and metamorphic orthopyroxenes. The American Mineralogist, 56: 499-506.

BLUNDY, J.D. \& HOLLAND,T.J.B. 1990. Calcic amphibole equilibria and a new amphiboleplagioclase geothermometer. Contr. Miner. Petrol., 104: 208-224.

BOSUM, W. 1973. O levantamento aeromagnético de Minas Gerais e Espírito Santo e sua seqüência quanto a estrutura geológica. Rev. Bras. Geoc., 3: 149-163. 
BOYNTON, W.V. 1984. Cosmochemistry of the rare earth element: meteorite studies. In: HENDERSON, P. ed. Rare Earth Element Geochemistry Amsterdan. Elsevier, p. 63-114.

BRAJNIKOV, B. 1955. Matériaux pour servir a la carte géologique de Êtat d'Espírito Santo. Imprensa Oficial, Vitória.

BROWN, G.M. 1961. Co-existing pyroxenes in igneous assemblages: a re-evaluation of the existing data on tie-line orientations. Geological Magazine, 98 (4): 333-343.

BROWN, G.C. 1982. Calc-alkaline intrusive rocks: their diversity, evolution and relation to volcanic arcs. In: R.S. Thorpe (ed.), Andesites. John Wiley \& Sons, p. 437-461.

BROWN, G.C.; THORPE, R.S. \& WEBB, P.C. 1984. The geochemical characteristics of granitoids in contrasting arcs and comments on magma sources. J. Geol Soc. London, 141: $413-426$

CAMPOS NETO, M.C. \& FIGUEIREDO, M.C.H. 1990. Evolução geológica dos terrenos Costeiro, Paraíba do Sul e Juiz de Fora (RJ-MG-ES). In: $36^{\circ}$ Congr. Bras. Geol., Natal-RN. Anais...v. 6: 263 1-2648.

CAMPOS NETO, M.C. \& FIGUEIREDO, M.C.H. 1992. A orogênese Rio Doce.In: $37^{\circ}$ Cong. Bras. Geol., São Paulo. Bol. Res. Expand...v. 1: 276-277.

CAMPOS NETO, M.C. \& FIGUEIREDO, M.C.H. 1995. The Rio Doce Orogeny, Southeastern Brazil. Journal of South Amer. Earth Sciences, 8 (2): 143-162.

CAMPOS NETO, M.C.; FIGUEIREDO, M.C.H.; JANASI, V.A.; BASEI, M.A.S. \& FRYER, B.J. 1988. The São José do Rio Pardo mangeritic-granitic suite, southeastern Brazil. Geochimica Brasiliensis, 2: 185-189.

CHAYES, F. 1949. A simple point counter for thin-section analysis. Amer. Miner., 34: 1-11.

CLARKE, D. 1993. NEWPET. A petrological program. Department of Earth Sciences. Memorial University of Newfoundland, Canada.

CONDIE, K.C.; ALLEN, P. \& NARAYANA, B.L. 1982. Geochemistry of the Archean low-to high grade transition zone, southern India. Contributions to Mineralogy and Petrology, 81: 157-167.

CORDANI, U. G. 1971. Síntese da geocronologia Pré-Cambriana da região costeira atlântica meridional da América do Sul. In: $25^{\circ}$ Cong. Bras. Geol., São Paulo. Boletim de Resumos...179-180.

CORDANI, U. G. \& BRITO NEVES, B. B. 1982. The geologic evolution of South America during the Archean and Early Proterozoic. Rev. Bras. Geoc., 12 (1-3): 78-88.

CORDANI, U.G.; DELHAL, J. et LEDENT, D. 1973. Orogéneses superposées dans la précambrien du Brésil Sud-oriental (Etats de Rio de Janeiro et Minas Gerais ). Rev. Bras. Geoc., 3: 1-22.

COX, K.G.; BELL, J.D. \& PANKHURST, R.J. 1979. The interpretation of igneuos rocks. Unwin Hyman Ltd., London. 450p.

CULLERS, R.L. \& GRAF, J,L 1984. Rare earth elements in igneous rocks of the continental crust: intermediate and silicic rocks - ore petrogenesis. In: HENDERSON, P. (ed.), Rare earth element geochemistry. Amsterdam, Elsevier. p. 275-3 16. 
CZAMANSKE, G.K.; ISHIHARA, S. \& ATKIN, S.A. 1981. Chemistry of rock forming minerals of the Cretaceous-Paleocene batholith in southwestern Japan and implications for magma genesis. Journal of Geophysical Research, 86: 10470- 10488.

DE PAOLO, D.J. 1981. Trace element and isotopic effects of combined wall rock assimilation and fractional crystallisation. Earth Planet. Sci. Letters, 53 : 189-202

DEBON, F. \& LE FORT, P. 1983. A chemicalmineralogical classification of common plutonic rocks and associations. Transactions of the Royal Society of Edinburgh Earth Sciences, 73 : 135- 149.

DIDIER, I. 1987. Contribution of enclave studies to the understanding of origin and evolution of granitic magmas. Geologishe Rundschau, 76/1: $41-50$.

DEER, W.A.; HOWIE, R.A. \& ZUSSMAN, J. 1966. An introduction to the rock forming minerals. Longmans, Green and Co., Ltd. London.558 p.

DRURY, S. A. 1973. The geochemistry of Precambrian granulites facies rocks from the Lewisian complex of Tiree, Inner Hebrides, Scotland. Chemical Geology, 11: 167-188;

DUTRA, C.V. 1984. Método para determinação de traços e subtraços de terras-raras em rochas por espectrometria de plasma (ICP) - aplicação em petrogênese. In: $33^{\circ}$ Cong. Bras. Geol., Rio de Janeiro. Anais...v. 10: 4792-4805.

DUTRA, C.V.; GROSSI SAD, J.H. \& PEDROSA SOARES, A.C. 1986. Terras raras em litogeoquímica - I. exemplo de esquemas de distribuição em rochas graníticas. Rev. Bras. Geoc., 16 (2): 224-228.

EBERT, H. 1955. Pesquisas na parte sudeste do Estado de Minas Gerais. Relatório Anual do Diretor, DNPM/DGM pp. 62-81.

EBERT, H. 1967. A estrutura pré-cambriana do sudeste de Minas Gerais e áreas adjacentes. Bol. Paran. Geoc., 26: 42-45.

EICHELBERGER, J.C. 1978. Andesitic volcanism and crustal evolution. Nature, 275 (7): 2 1-27.

EL BOUSEILY, A.M. \& EL SOKKARY, A.A. 1975. The relation between Rb, Ba and Sr in granitic rocks. Chemical Geology, 16:207-2 19.

EMSLIE, R.F. 1991. Granitoids of rapakivi granite-anorthosite and related associations. Precambrian Research, 51: 1173-1192.

FIELD, D.; DRURY, S.A. \& COOPER, D.C. 1980. Rare-earth and LIL element fractionation in high-grade charnockitic gneisses, south Norway. Lithos, $13: 281-289$.

FIGUEIREDO, M. C. H. 1982. Geochemistry of high-grade complexes of Bahia State, Brazil. Rev. Bras. Geoc., 12 (1,2,3): 307-3 12.

FIGUEIREDO, M.C., CAMPOS NETO, M. \& BARROS, E.J. 1992. Geoquímica dos charnoquitóides Serra do Valentim (ES). In: $37^{\circ}$ Cong. Bras. Geol., São Paulo. Boletim de Resumos Expandidos...v. 1: 383-384.

FIGUEIREDO, M.C. \& CAMPOS NETO, M. 1993. Geochemistry of the Rio Doce magmatic arc, southeastern Brazil. An. Ac..bras.Ci.., 65 (1): 63-81.

FIGUEIREDO, M.C.H; CAMPOS NETO, M.C. \& RÊGO, I.T.S.F. 1989. Geoquímica dos terrenos Juiz de Fora, Paraíba do Sul e Costeiro nos Estados do Rio de Janeiro e Espírito 
Santo. In: Workshop Geoquímica Isotópica, Geocronologia. e Litogeoquímica das regiões sul e sudeste do Brasil, Bol. Res. Exp., SBGq-IG/USP: 4 1-45.

FONSECA, A. C. 1986. Geocronologia das rochas graníticas e suas encaixantes na Cidade do Rio de Janeiro. Dissertação de Mestrado, IG/UFRJ.

FONSECA, M. J. G.; DA SILVA, Z. C. G.; CAMPOS, D. A. \& TOSATTO, P. 1979. Folhas Rio de Janeiro/Vitória/Iguape SF 23, SF 24, SG 23. Texto Explicativo. In: Schobbenhaus Filho (coord.), Carta Geológica do Brasil ao Milionésimo. Brasilia, DNPM, 240p.

FREY, F.A. 1984. Rare Earth Element Abundances in Upper Mantle Rocks. In: Henderson, P. ed. Rare Earth Element Geochemistry Amsterdan. Elsevier, p. 63-114.

FRITZER, T. 1991. Das Guaçuí Lineament und die orogene Entwicklung des Zentralen Ribeira Belt (Espírito Santo, Brasilien). Münch. Hef., 2, 196p.

GASPARINI, P. \& MANTOVANI, M.S.M. 1979. Geochemistry of charnockites from São Paulo State, Brazil. Earth and Planetary Science Letters, 42:311-320.

GEIGER, A. (1993) - Die Geologie des Steinbruchreviers von Cachoeiro de Itapemirim Südliches Espírito Santo, Brasilien).Münc. Geol. Hef. ,11, $217 \mathrm{p}$.

GILL, J.B. 1981. Orogenic andesites and plate tectonics. Springer Verlag, Berlin, 390 pp.

GUIMARÃES, D. 1956. Os charnoquitos do Espírito Santo. Bol. Inst. Tecn. Ind., Belo Horizonte, $n^{\circ} 23,30 p$.

GUIMARÃES, I.P.; SILVA FILHO, A; NOLAN, J. \& WILLIAMS, T. 1993. The mineral chemistry of the Brasiliano age Bom Jardim and Toritama Shoshonitic complexes, State of Pernambuco, northeast Brazil. An. Acad. Bras. Ci., 65 (1): 83- 106.

HALL, A. 1987. Igneous petrology. Longman Group UK Limited, England, 573 pp.

HAMMARSTROM, J.M. \& ZEN, E-an 1986. Aluminium in hornblend: an empirical igneous geobarometer. American Mineralogist, 71: 1297-1313.

HANSON, G.N. 1978. The application of trace elements to the petrogenesis of igneous rocks of granitic compositions. Earth and Planetary Science Letters, 38: 26-43.

HEWITT, D.A. \& WONES, D.R. 1984. Experimental phase relations of the micas. In: S.W. Bailey (ed.), Micas. Mineral. Soc. Amer., Reviews in Mineralogy, 13 : 201 1-297.

HORN, H. A. \& WEBER-DIEFENBACH, K. 1987. Geochemical and genetic studies of three inversely zoned intrusive bodies of both alkaline and subalkaline composition in the Ribeira Mobile Belt (Espírito Santo, Brazil). Rev. Bras. Geoc., 17 (4): 488-497.

HUBBARD, F.H. \& WHITLEY, J.E. 1979. REE in charnockite and associated rocks, southwest Sweden. Lithos, 12: 1-11.

IRVINE, T.N. \& BARAGAR, W.R. 1971. A guide to chemical classification of the common volcanic rocks. Can. J. Earth Sci, 8: 523-548.

JANASI, V.A. 1992. Rochas sieníticas e mangerítico-charnoquíticas neoproterozóicas da região entre Caldas e Campestre (MG): aspectos petrológicos. Tese de Doutoramento, IGEO/USP. $298 \mathrm{p}$.

KAIYI, W.; YUEHUA, Y.; RUIYING, Y. \& YIFEI, C. 1985. REE geochemistry of early precambrian charnockites and tonalitic-granodioritic gneisses of the Qianan region, eastern Hebei, north China. Precambrian Research, 27: 63-84. 
KRETZ, R. 1961. Some applications of thermodynamics to coexisting minerals of variable composition. Examples: orthopyroxene-clinopyroxene and orthopyroxene-garnet. The Journal of Geology, 69 (4): 36 1-387.

KRETZ, R. 1963. Distribution of magnesium and iron between orthopyroxene and calcic pyroxene in natural mineral assemblages. Journal of Geology, 71: 773-785.

LAMEGO, A.R. 1949. A faixa costeira de Vitória. DNPM/DGM, Rio de Janeiro. Boletim $\mathbf{n}^{\circ}$ $168,68 \mathrm{p}$.

LAMEYRE, J. \& BOWDEN, P. 1982. Plutonic rock type series: discrimination of various granitoids series and related rocks. J. Volcanol. Geotherm. Res., 14: 169-186.

LAMMERER, B. 1987. Short notes in a structural section through the Ribeira Mobile Belt (Minas Gerais and Espírito Santo, Brazil). Zbl. Geol. Paläont., Teil I (7/8): 7 19-728.

LE MAITRE, R.W. 1989. A classification of igneous rocks and glossary of terms. Blackwell, Oxford, 193p.

LINDSLEY, D.H. 1983. Pyroxene thermometry. American Mineralogist, 68: 477-493.

MANIAR, P. D. \& PICCOLI, P.M. 1989. Tectonic discrimination of granitoids. Geological Society of America Bulletin, 101: 635-643.

MASON, G.H. 1985. The mineralogy and textures of the coastal batholith, Peru. The Peruvian Andes. John Wiley \& Sons, New York, 328p.

MARTIGNOLE, J. 1979. Charnockite genesis and the proterozoic crust. Precambrian Research, 9: $303-310$.

MARTIN, H. (1987). Petrogenesis of Archaean trondhj emites, tonalites, and granodiorites from eastern Finland: maj or and trace element geochemistry. Journal of Petrology, 28 (5): 921 953.

McCULLOCH, M.T. \& GAMBLE, J.A. 1991. Geochemical and geodynamical constraints on subduction zone magmatism. Earth and Planetary Science Letters, 102: 358-374.

MEDEIROS, S. R. 1993. Geologia, petrologia e geoquímica do Complexo Intrusivo de Várzea Alegre, ES. Tese de Mestrado, IGEO/UFRJ. 143p.

MEDEIROS, S. R. Mineralogia, petrologia-geoquímica do domínio interno do Complexo intrusivo de Várzea Alegre. Tese de Doutoramento, IGEO/UFRJ (em preparação).

MEDEIROS, S.R., MENDES, J.C. \& WIEDEMANN, C.M. 1994. Feições diagnosticas do complexo intrusivo de Várzea Alegre, ES. In: $38^{\circ}$ Congr. Bras. Geol., Balneário Camboriu, S C. Boletim de resumos expandidos...vol. 1: 140-14 1 .

MENDES, J.C.; WIEDEMANN, C.M. \& FIGUEIREDO, M.C.H 1994. Enderbitos e hiperstênio-gabros do maciço de Venda Nova-ES: considerações petrográficas e geoquímicas. In: $38^{\circ}$ Congr. Bras. Geol., Balneário Camboriu, S C. Boletim de resumos expandidos...vol. 1: 133-134.

MENESES, P. R. \& PARADELLA, W. R. 1978. Síntese geológica preliminar da parte sul do Estado do Espírito Santo. In: Simp. Bras. Sensor. Remoto, S. J. Campos, SP, INPE/CNPq. Anais...479-499;

MIDDLEMOST, E.A.K. 1985. Magmas and magmatic rocks. Longman Group Limited, Essex. 
NANEY, M.T. 1983. Phase equilibria of rock-forming ferromagnesian silicates in granitic systems. Amer. Journal of Sciences, 283: 993-1033.

NOCKOLDS, S.R.; KNOX, R.W.O.B. \& CHINNER, G.A. 1978. Petrology for students. Cambridge University Press, $432 \mathrm{p}$.

ORMAASEN, D.E. 1977. Petrology of the Hopen mangerite-charnockite intrusion, Lofoten, north Norway. Lithos, 10: 291-310.

PEACOCK, M.A. 1931. Classification of igneous rock series. Journal of Geology, 39: 54-67.

PEARCE, J.A. 1983. Role of the sub-continental lithosphere in magma genesis at active continental margins. In: C.J. Hawkesworth e M.J. Norry (eds.), Continental basalts and mantle xenoliths. Shiva, Nantwich. pp. 230-249.

PEARCE, J.A.; HARRIS, N.B.W. \& TINDLE, A.G. 1984. Trace element discrimination diagrams for the tectonic interpretation of granitic rocks. Journal of Petrology, 25(4): 956983.

PETERSEN, J.S. 1980. Rare-earth element fractionation and petrogenetic modelling in charnockitic rocks, southwest Norway. Contrib. Mineral. Petrol., 73: 161-172.

PETRICK, F. 1987. Der Venda Nova Pluton im südlichen Espírito Santo, Brasilien. Geologish Kartierung des nordöstlichen Teilgebietes sowie geochemisch-petrographische Bearbeitung der Mischgesteinszone von Syenomonzonit und Gabbro. Relatório de Graduação, Univ. Munique, $79 \mathrm{p}$.

PETRO, W.L.; VOGEL, R.A. \& WILBAND, J.T. 1979. Maj or-element chemistry of plutonic rock suites from compressional and extensional plate boundaries. Chemical Geology, 26: 217-235.

PHILPOTTS, A.R. 1966. Origin of the anorthosite-mangerite rocks in southern Quebec. Journal of Petrology, 7 : 1-64.

PINHEIRO, J.C.F.; BIONDI, J.C. \& PINHEIRO, J.C. 1978. Granulitos e/ou charnoquitos do Cinturão Granulítico Atlântico, Maciços de Aimorés, Itapina, Itaguaçu e Itanhomi. In: $30^{\circ}$ Cong. Bras. Geol., Recife. Anais...v. 3: 1288-1302.

PITCHER, W.S. 1982. Granite type and tectonic environment. In: K. J. Hsü (Ed.), Mountain Building Processes. Academic Press, London, p. 19-40.

PROJETO RADAMBRASIL 1983. Folhas SF 23/24, Rio de Janeiro/Vitória, Levantamento de Recursos Naturais. Vol. 32. MME/Rio de Janeiro.

PROJETO RADAMBRASIL 1987. Folha SE 24, Rio Doce, Levantamento de Recursos Naturais. Vol. 32. IBGE/Rio de Janeiro.

RÊGO, I. T.S.F. 1989. Petrologia e geoquímica da unidade charnoquítica Bela Joana, São Fidélis, RJ. Tese de Doutoramento IG/USP, São Paulo. 348p.

RICHARD, L. L. 1995. MINPET Geological Software - mineralogical and petrological data processing system.

RIETMEIJER, F.J.M. 1983. Chemical distinction between igneous and metamorphic orthopyroxenes especially those coexisting with Ca-rich clinopyroxenes: a re-evaluation. Mineralogical Magazine, 47: 143-151. 
ROLLINSON, H. 1993. Using geochemical data: evaluation, presentation, interpretation. Longman Group UK Limited. 352p.

ROSIER, G.F. 1957. A geologia da Serra do Mar entre os picos de Maria Comprida e do Desengano. DNPM/DGM, Rio de Janeiro. Boletim nº 166.

ROSIER, G.F. 1965. Pesquisas geológicas na parte oriental do Estado do Rio de Janeiro e na parte vizinha do Estado de Minas Gerais. DNPM/DGM, Rio de Janeiro. Boletim $\mathbf{n}^{\circ} 122$. $4 \mathrm{lp}$.

SAXENA, S.K. 1968. Chemical study of phase equilibria in charnockites, Varberg, Sweeden. The Amer. Mineral., 53 : 1674-1695.

SEIDENSTICKER, U. \& WIEDEMANN, C. 1993. Geochemistry and Origin of lower crustal granulite facies rocks in the Serra do Caparaó region, Esp.Santo/Minas Gerais, Brazil. J. South Am. Earth Sc., 6 (4): 289-298.

SIAL, A.N. \& McREATH, I. 1984. Petrologia Ígnea. SBG; CNPq; BUREAU, Salvador. Vol. 1, $180 \mathrm{p}$.

SIGA JR., O.; TASSINARI, C.G. \& VAN SCHMUS, W.R. 1989. Caracterização geocronológica de maciços charnoquíticos do sudeste brasileiro. In: Simp. Geol. Sudeste, I, Rio de Janeiro. Bol. Resumos...: 90-91.

SIGA JR., O.; TEIXEIRA, W. CORDANI, U. G.; KAWASHITA, K. \& DELHAL, J. 1982. O padrão geológico-geocronológico das rochas de alto grau da parte setentrional da Faixa Ribeira, a norte do Rio de Janeiro, Brasil. In: Cong. Latinoamericano de Geologia, V, Argentina. Actas...I: 349-370.

SIGNORELLI, N. 1993. Texto Explicativo da Folha SF.24-V-A-II, Afonso Cláudio. In: N. Signorelli (org.) Programa Levantamentos Geológicos Básicos do Brasil, DNPM/CPRM, Brasília. 153pp.

SILVA, J. N. \& FERRARI, P. G. 1976. Projeto Espírito Santo, relatório final. s/ed. (relatório inédito) - DNPM/CPRM - Belo Horizonte, $285 \mathrm{p}$.

SLUITNER, Z. \& WEBER-DIEFENBACH, K. 1989. Geochemistry of Chamoenderbitic Granulites and Associeted Amphibolitic Gneeisses in the Coast Region of Espírito Santo, Brazil. Zbl. Geol. Palaont. Teil I, H. 5/6:9 17-931.

SÖLLNER, F.; LAMMERER, B. \& WEBER-DIEFENBACH, K. 1991. Die Krustenentwicklung in der Küstenregion nördlich von Rio de Janeiro/Brasilien. Münchner Geologische Hefte, 4 , 100pp.

SÖLLNER, F.; WEBER-DIEFENBACH, K \& LAMMERER, B. 1987. The Brasiliano Orogenesis: age determinations ( $\mathrm{Rb}-\mathrm{Sr}$ and $\mathrm{U}-\mathrm{Pb})$ in the coastal mountain region of Espírito Santo, Brazil. Zbl. Geol. Paläont. I, H 7/8: 729-741.

SÖLLNER, F.; WEBER-DIEFENBACH, K \& LAMMERER, B., 1989. Brasiliano age of a charnoenderbitic rock suite in the Complexo Costeiro (Ribeira Mobile Belt), Espirito Santo, Brazil: evidence from U-Pb geochronology on zircons. Zbl. Geol. Paläont. I, H 5/6: 933-945.

STORMER, J.C. \& NICHOLLS, J. 1978. XLFRAC: a program for the interactive testing of magmatic differentiation models. Computers \& Geosciences, 4: 143-159. 
STRECKEISEN, A. 1976. To each plutonic rock its proper name. Earth Science Reviews, 12: 133.

SUN, S.-s. \& McDONOUGH, W.F. 1989. Chemical and isotopic systematic of oceanic basalts: implications for mantle composition and processes. In: Magmatism in the Ocean Basins. Geol. Soc. Sp. Pub., 42: 313-345.

TARNEY, J. \& WEAVER, B. L. 1987. Geochemistry of the Scourian complex: petrogenesis and tectonic models. In: PARK, R. G. \& TARNEY, J. (eds), Evolution of the Lewisian and comparable Precambrian high grade terrains. Geological Society Special Publications, 27: 45-56.

TÖPFNER, C. 1987. Der Venda Nova Pluton im südlichen Espírito Santo, Brasilien. Geologische Kartierung des südöstlichen Teilgebietes sowie geochemisch-petrographische Bearbeitung des charnockitischen gesteinsgürtels. Relatório de Graduação, Univ. Munique, $13 \mathrm{lp}$.

TULLER, M.P. 1993. Texto Explicativo da Folha SE.24-Y-C-VI, Colatina. In: M.P. Tuller(org.) Programa Levantamentos Geológicos Básicos do Brasil, DNPM/CPRM Brasília. 163pp.

VALLEY, J.W.; PETERSEN, E.U.; ESSENE, E.J. \& BOWMAN, J.R. 1982. Fluorphlogopite and fluor-tremolite in Adirondack marbles and calculate C-O-H-F-fluid compositions. Amer. Mineral., 67: 545-557.

VIEIRA, V.S. 1993. Texto Explicativo da Folha SE.24-Y-C-V, Baixo Guandu. In: V.S. Vieira (org.) Programa Levantamentos Geológicos Básicos do Brasil, DNPM/CPRM, Brasília.

VIEIRA, V.S.; RAPOSO, F.O. \& DELGADO, I.M. 1993. A granitogênese Brasiliana na evolução do cinturão móvel Costeiro (cinturão móvel Ribeira) em áreas dos Estados do Espírito Santo e Minas Gerais. In: Workshop Mag. Gran. e Miner. Assoc. Res. Exp. e Roteiro de Excursão, Publ.Esp. Acad. bras. Ci.: 83-86.

WATSON, E.B. \& HARRISON, T.M. 1983. Zircon saturation revisited: temperature and composition effects in a variety of crustal magma types. Earth and Planetary Science Letters, 64 : 295-304.

WATSON, E.B. \& HARRISON, T.M. 1984. Accessory minerals and the geochemical evolution of crustal magmatic systems: a summary and prospectus of experimental approaches. Physics of the Earth and Planetary Interiors, 35: 19-30.

WEAVER, B.L. 1980. Rare-Earth element geochemistry of Madras granulites. Contrib. Mineral. Petrol., 71: 271-279.

WEAVER, B.L. \& TARNEY, J. 1983. Elemental depletion in Archean granulite facies rocks. In: M.P. Atherton \& C.D. Gribble (eds.), Migmatites, melting and metamorphism. Shiva Publ. Co., Cheshire, UK. p. 250-263.

WENDLANT, R.F. 1981. Influence of $\mathrm{CO}_{2}$ on melting of model granulite facies assemblages: a model for the genesis of charnockites. American Mineralogist, 66: 1164-1174.

WIEDEMANN, C.M. 1992. Evolução magmática Brasiliana do Cinturão Móvel Ribeira no Estado do Espírito Santo. In: $37^{\circ}$ Congr. Bras. Geol., São Paulo - Brasil. Bol. Res. Expand., p. 376-377. 
WIEDEMANN, C. 1993. The evolution of the early paleozoic, late- to post-collisional magmatic arc of the coastal mobile belt in the state of Espírito Santo, Eastern Brazil. An. Ac.bras.Ci.., 65 (1): 163-181.

WIEDEMANN, C.; BAYER, P.; HORN, H.; LAMMERER; B.; LUDKA, I.P.; SCHMIDTTHOMÉ, R. \& WEBER-DIEFENBACH, K. 1986. Maciços intrusivos do Espírito Santo e seu contexto regional. Rev. Bras. Geoc., 16 (1): 24-37.

WIEDEMANN, C.; LAMMERER; B.; MENDES, J.C. \& LUDKA, 1.P. 1995. The Evolution of the Brasiliano/Panafrican Mobile Belt along the central part of the Brazilian coast (Espirito santo). In: Centennial Geocongress, Johannesburg. South Africa. Extended Abstracts.

WIEDEMANN, C.M.; MEDEIROS, S.R. \& MENDES, J.C. 1994. Diversidade geoquímica do polidiapirismo tardi-brasiliano no Cinturão Móvel Atlântico. Exemplo do complexo intrusivo de Várzea Alegre - ES. In: $38^{\circ}$ Congr. Bras. Geol., Balneário Camboriu, S C. Boletim de resumos expandidos...vol. 1: 129-131.

WIEDEMANN, C. \& MENDES, J.C. 1993. Field evidence of magma mixing in the late Brasiliano magmatic arc of Espírito Santo, Eastern Brazil. In: Workshop Mag. Gran. e Miner. Assoc. Res. Exp. e Roteiro de Excursão, Publ.Esp. Acad bras. Ci. : 91-116.

WIEDEMANN, C.; PENHA, H. \& SCHMIDT-THOMÉ 1987. Granitoids of Espírito Santo and Rio de Janeiro States. Rev. Bras. Geoc., 17 (4): 674-689.

WILSON, M. 1991. Igneous Petrogenesis, Harper Collins Acad., 466 p.

WINCHESTER, J.A. \& FLOYD, P.A. 1977. Geochemical discrimination of different magma series and their differentiation products using immobile elements. Chemical Geology, 20: 325-343.

WOOD, B.J. \& BANNO, S. 1973. Garnet, orthopyroxene and orthopyroxene-clinopyroxene relationships in simple and complex systems. Contrib. Miner. Petrol., 42: 109- 124. 


$$
-
$$



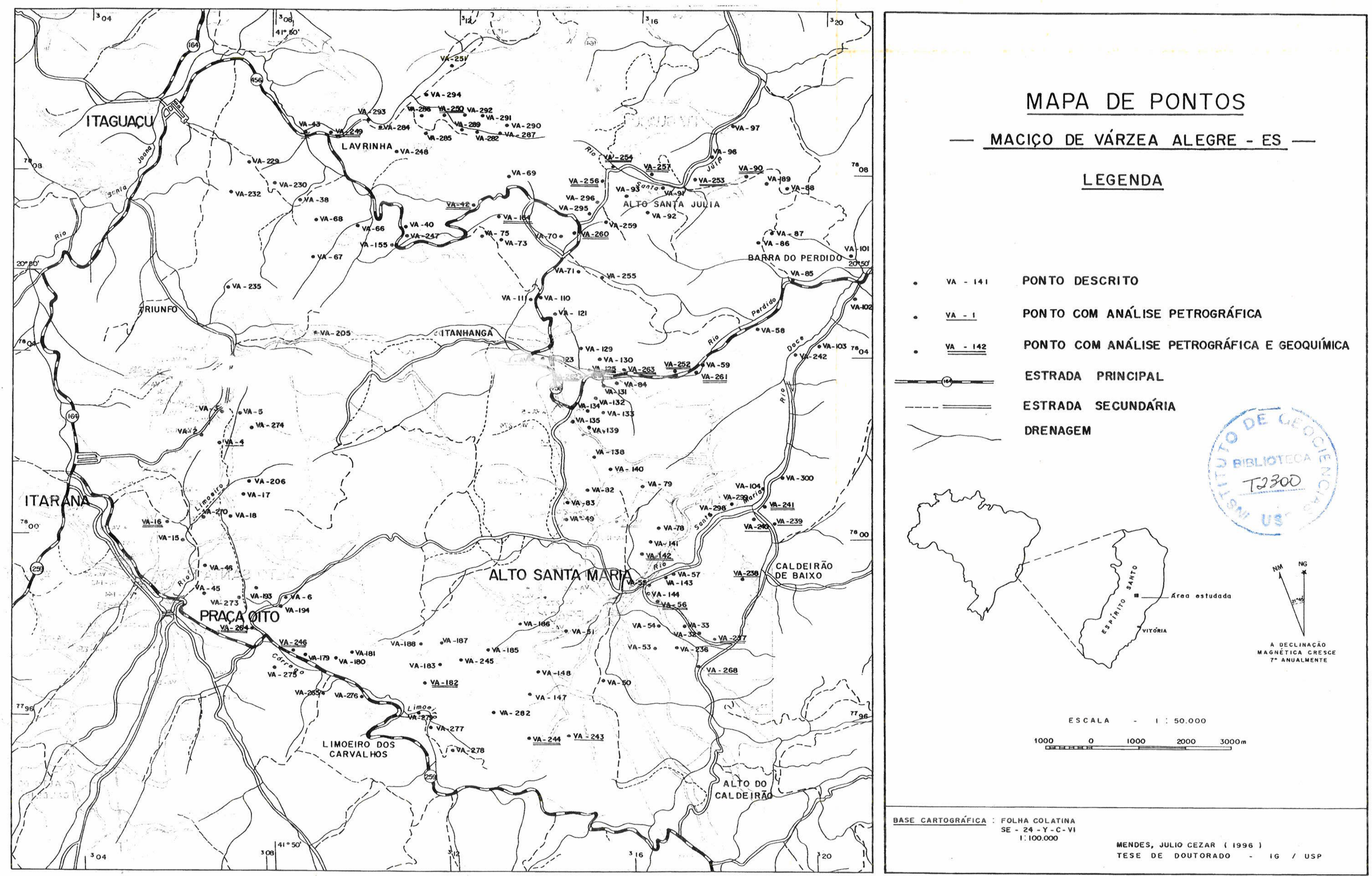